\title{
ENVIRONMENTAL ASPECTS
} of the TRANSURANICS

A Selected, Annotated Bibliography

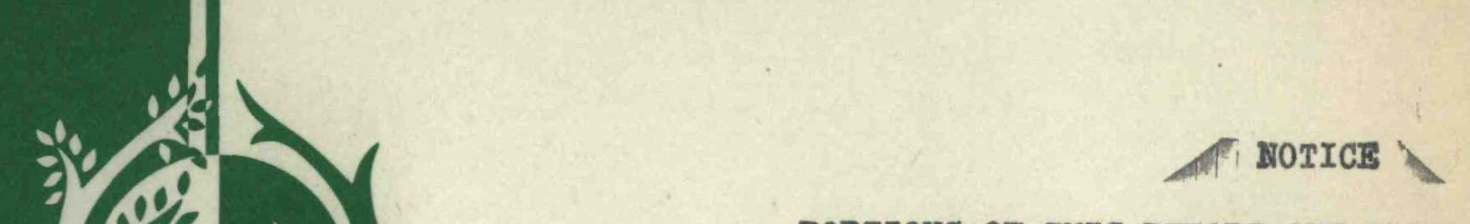

PORTIONS OF THIS REPORT ARE IILEGIBLE. It has been reproduced from the best available copy to permit the broadest possible availability.

\section{Sponsored by}

NEVADA APPLIED ECOLOGY GROUP Nevada Operations Office

\section{OAK RIDGE NATIONAL LABORATORY}

OPERATED BY UNION CARBIDE CORPORATION FOR THE ENERGY RESEARCH AND DEVELOPMENT ADMINISTRATION 


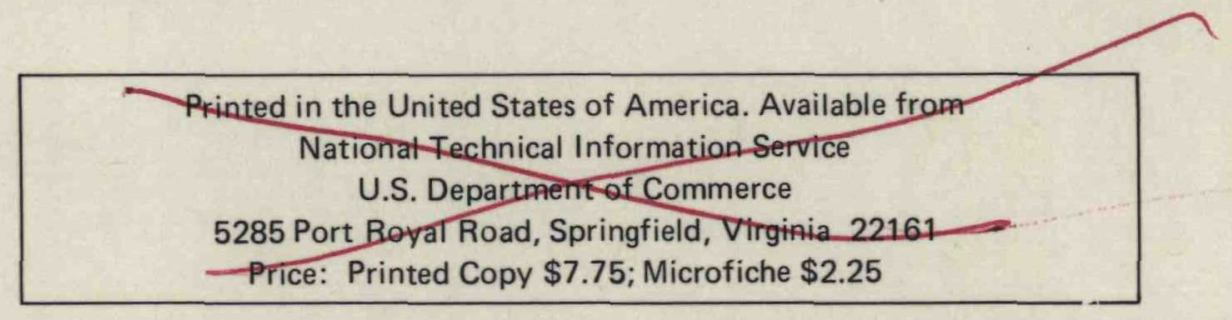

This report was prepared as an account of work sponsored by the United States Government. Neither the United States nor the Energy Research and Development Administration/United States Nuclear Regulatory Commission, nor any of their employees, nor any of their contractors, subcontractors, or their employees, makes any warranty, express or implied, or assumes any legal liability or responsibility for the accuracy, completeness or usefulness of any information, apparatus, product or process disclosed, or represents that its use would not infringe privately owned rights. 


\section{DISCLAIMER}

This report was prepared as an account of work sponsored by an agency of the United States Government. Neither the United States Government nor any agency Thereof, nor any of their employees, makes any warranty, express or implied, or assumes any legal liability or responsibility for the accuracy, completeness, or usefulness of any information, apparatus, product, or process disclosed, or represents that its use would not infringe privately owned rights. Reference herein to any specific commercial product, process, or service by trade name, trademark, manufacturer, or otherwise does not necessarily constitute or imply its endorsement, recommendation, or favoring by the United States Government or any agency thereof. The views and opinions of authors expressed herein do not necessarily state or reflect those of the United States Government or any agency thereof. 


\section{DISCLAIMER}

Portions of this document may be illegible in electronic image products. Images are produced from the best available original document. 
Contract No. W-7405-eng-26

\title{
ENVIRONMENTAL ASPECTS OF THE TRANSURANICS
}

\section{A SELECTED, ANNOTATED BIBLIOGRAPHY}

\author{
Compiled and Edited by \\ C. S. Fore \\ F. M. Martin \\ R. A. Faust \\ Nevada Applied Ecology Information Center \\ Ecological Sciences Information Center \\ Information Center Compless \\ Information Division
}

\section{JULY 1976}

Thus report was prepared as an account of work sponsored by the Unuted States Government Neather the United States sor the United States Fnergy ther subcontraplayees nor any of their conerractors, warranty express ot umpled, or assues ans ant

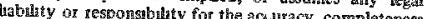
or usefulness of any informa tion, apparatur, profuct or process disclosed, or represents that its use weald or infringe privatelly owned nghts
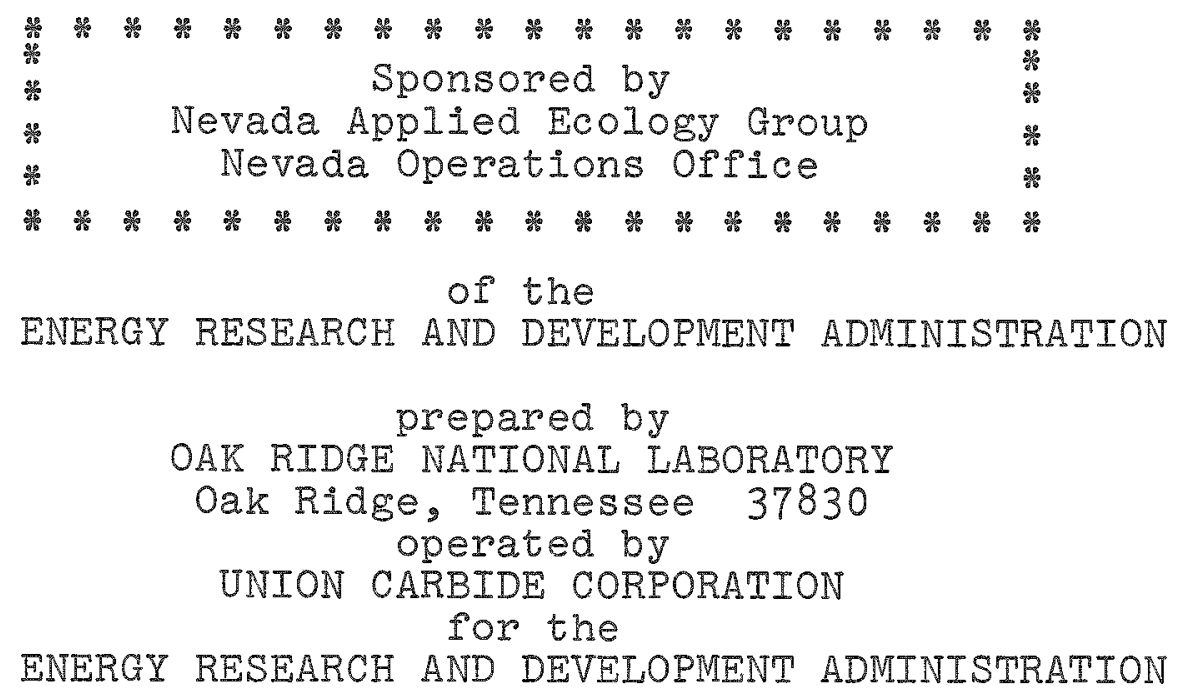
-<smiles>O</smiles> 
TABLE OF CONTENTS

Page

ABSTRACT. . . . . . . . . . . . $V$

PREFACE . . . . . . . . . . . . . . Vii-x

SAMPLE REFERENCE. . . . . . . . . . . X Xi

\section{BIBLIOGRAPHIC REFEREICES}

Biological Aspects, Animals....... 1-69

Biological Aspects, Plants...... . 70-71

Chemical Aspects . . . . . . . . 72-76

Ecological Aspects . . . . . . . . 77-81

Energy . . . . . . . . . . . 82-83

Environmental Assessment . . . . . . 84-87

Instrumentation. . . . . . . . . . 88-89

Medical Aspects. . . . . . . . . 90-102

Monitoring, Measurement and Analysis... .103-112

Physical Aspects . . . . . . . . . . . 113

Production ..............114-115

Radiation Safety and Control ...... . 116-121

Waste Disposal and Management. . . . . .122-124

\section{INDEXES}

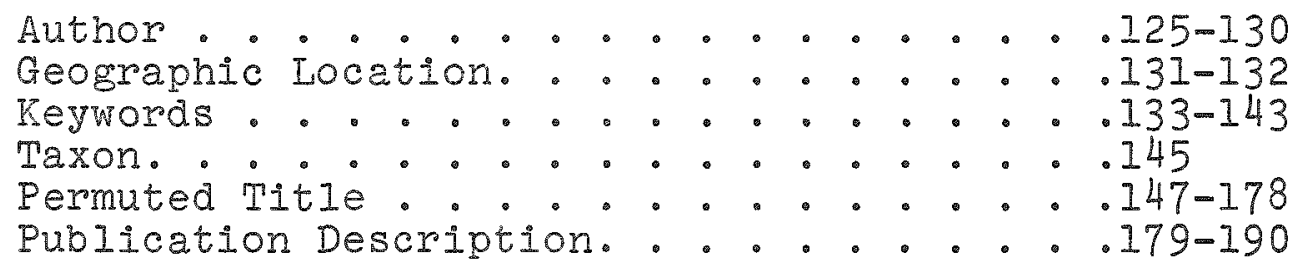

DISTRIBUTION. . . . . . . . . . . . . 191-198 

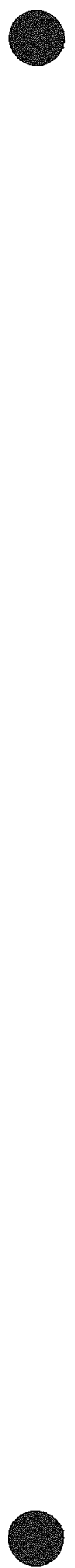


\section{ABSTRACT}

This seventh published bibliography of 500 references is compiled from the Data Base on the Environmental Aspects of the Transuranics built to provide information support to the Nevada Applied Ecology Group (NAEG) of ERDA's Nevada Operations Office. The general scope is environmental aspects of uranium and the transuranic elements, with emphasis on plutonium. Laboratory and field studies dealing with the effects of plutonium 239 on animals are highlighted in this bibliography. Supporting information on ecology of the Nevada Test Site and reviews on the effects of other radionuclides upon man and his environment has been included at the request of the NAEG. The references are arranged by subject category with first authors appearing alphabetically in each category. Indexes are given for author, geographic location, keywords, taxons, permuted title and publication description. 
○

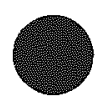


VII

PREFACE

This publication of 500 references is the seventh in a series of bibliographies published by the Nevada Applied Ecology Information Center to provide information support to the Nevada Applied Ecology Group (NAEG) of ERDA's Nevada Operations office. The scope is centered on the environmental aspects of plutonium, but has been expanded to include uranium and the transuranics. Studies on the ecology of the Nevada Test Site, redistribution and resuspension, low-level radiation effects, and reviews and bibliographies on other radionuclides have been included at the request of the NAEG. The subject category, Biological Aspects, is subdivided to separately list the plant and animal studies. A majority of the references deal with several subject areas requiring multiple categories; however, each entry is chosen to be categorized according to the main subject area described. Laboratory and field studies dealing with the biological effects of plutonium 239 on animals are emphasized in this bibliography. Current and pre-1962 domestic Iiterature as well as foreign literature is actively sought. This bibliography contains literature dating back to May, 1944.

Indexing for the Data Base on the Environmental Aspects of the Transuranics conforms with the definitions of concentration ratio, inventory ratio and transfer coefficient by the Plant Uptake Panel at the ERDA/DBER Workshop on Environmental Research for the Transuranium Elements held in Seattle, Washington, November 11-14, 1975. These definitions are as follows:

- Concentration Ratio $=\mathrm{CR}$ (unitless)

$$
C R=\frac{\text { Activity/Unit Dry wt. Product iaterial }}{\text { Activity/Unit Dry wt. Reference Material }}
$$

Examples:

Uptake; $C R($ Plant/Soil $)=\frac{\mathrm{dpm} / \mathrm{g} \text { Dry Plant }}{\mathrm{dpm} / \mathrm{g} \text { Dry Soil }}$

Translocation; $C R($ Seed/Leaf $)=\frac{\mathrm{pCI/g} \text { Dry Seed }}{\mathrm{pCI/g} \text { Dry Leaf }}$ 
- Inventory Ratio = IR

(unitless)

$I R=\frac{\text { Activity/Unit Area in Product Material }}{\text { Activity/Unit Area in Rererence Naterial }}$

Examples:

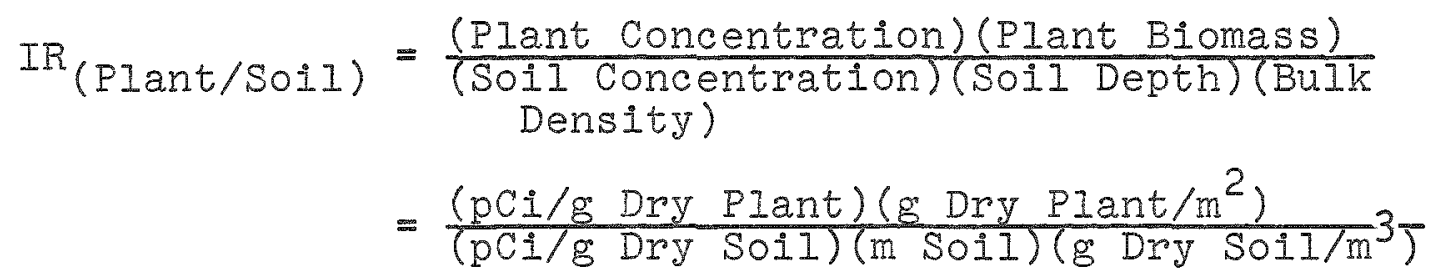

- Transfer Coefficient $=\mathrm{K}=$ Fraction/Unit Time

Example:

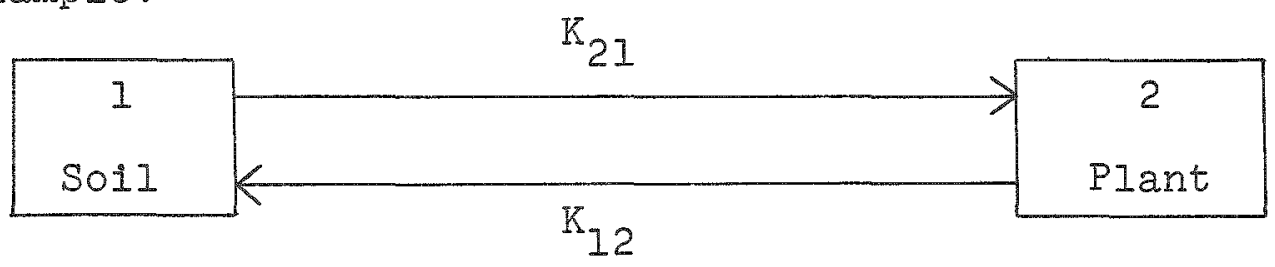

All the published literature references are contained In the Data Base on the Environmental Aspects of the Transuranics and are available for searching upon submission of specific requests.

Citation Form

The references are arranged by subject category with first authors appearing alphabetically within each category.

As a result of computer limitations in indicating superscripts and subscripts in the standard manner, certain conventions have been established in the bibliography:

1.) $X$ sub $t$ ( $X$ being a variable) means $X_{t}$ or $X$ subscript $t$.

2.) In chemical compounds and elements, NaIO3 (for example) means $\mathrm{NaIO}_{3}$.

3.) $10(E+3)$ or $X(E-3)$ ( $E$ denoting exponent) means $10^{3}$ or $X^{-3}$, respectively.

4.) For units of measurement, such as centimeters, meters, feet, etc., $X 3$ means $X^{3}$. 
Indexes

Indexes are provided for: 1.) authors, 2.) geographic location, 3.) keywords, 4.) taxons, 5.) permuted title and 6.) publication description.

\section{ACKNOWLEDGEMENTS}

P. B. Dunaway, Director of the Bioenvironmental Sciences Division, Nevada Operations Office and $M$. G. White, Scientific Director of the Nevada Applied Ecology Group, Nevada Operations Office, have closely guided the Nevada Applied Ecology Information Center in selection of material for this project.

Appreciation is due to the many researchers who have contributed their publications for inclusion in this bibliography. R. G. Shreckhise, Pacific-Northwest Laboratories, assisted in the explanations of the indexing terms. G. R. Eisele of the Comparative Animal Research Laboratory, Oak Ridge, has collaborated with the information center in collecting and indexing documents on the biomedical aspects of plutonium in man and animals.

Ruth SIusher of the Computer Sciences Division, ORNL, and Faye Fletcher and staff of the Information Storage and Retricval Processing Section of the Information Center Complex, ORNI, have managed the computer production of this document.

Nevada Applied Ecology Information Center Ecological Sciences Information Center Building 2029

P. O. Box X

Oak Ridge, Tennessee 37830

Telephone: 16151483-8611, Ext. 3-6524 or $3-6915$

FTS $850-6524$ or $850-6915$ 
Bibliographies previously issued by the Nevada Applied Ecology Information Center are as follows:

Report Number

ORNL-EIS-72-2I

(NVO-AEIC-72-21)

ORNL-EIS-73-21 (Supp1. 1) (NVO-AEIC-73-21)

ORNL-EIS-74-21 (Supp1.2) (NVO-AEIC-74-2I)

ORNL-EIS-74-21 (SuppI. 3) (NVO-AEIC-74-2IA)

ORNL-EIS-75-2I-NO. 5 (NVO-AEIC-75-I)

ORNL-EIS-75-2I-NO . 6

(NVO-AEIC-75-2)
Title

"Environmental Aspects of Plutonium-A Selected, Annotated Bibliography", Environmental Plutonium Data Base Group (September, 1972)

"Environmental Aspects of Plutonium and Other Elements -A Selected, Annotated Bibliography", Environmental Plutonium Data Base Group (August, 1973)

"Environmental Aspects of Plutonium and Other Elements - -A Selected, Annotated Bibliography", Environmental Plutonium Data Base Group (February, 1974)

"Environmental Aspects of the Transuranics--A Selected, Annotated Bibliography", F. M. Martin, C. T. Sanders and S. S. Talmage (December, 1974)

"Environmental Aspects of the Transuranics--A Selected, Annotated Bibliography", R. A. Faust, F.M. Martin, C. T. Sanders and S. S. Talmage (June, 1975)

"Environmental Aspects of the Transuranics--A Selected, Annotated Bibliography", F. M. Martin, R. A. Faust and C. T. Sanders (July, 1975) 
This is an example of the format for the descriptive fields used in this bibliography:

$$
\begin{gathered}
1 \text { - Subject Category } \\
2 \text { - Record Number } \\
\text { (Sequential Number } \\
\text { of Reference) } \\
3 \text { - Author } \\
4 \text { - Corporate Author } \\
5 \text { - Publication Date }
\end{gathered}
$$

$$
\begin{aligned}
& 6 \text { - Document Title } \\
& 7 \text { - Publication Description } \\
& 8 \text { - Abstract } \\
& 9 \text { - Abstractor's Initials } \\
& 10 \text { - Comments } \\
& \text { (Pertinent Numerical } \\
& \text { Data) }
\end{aligned}
$$

2

$3000>$

Dagle, G.D., R.D. Phemister, J.I. Lebel, R. Jaenke, and R.L. Watters, Battelle Memorial Institute, Pacific Northwest Laboratories, Richland, WA; U. S. Atomic Energy Commission, Division of Biomedical and Environmental Research, Washington, DC. ${ }^{5} 1975$

${ }_{7}^{6}$ Plutonium-Induced Popliteal Lymphadenitis in Beagles. Radiation Research, 6I, 239-250; BNWL-SA-5119; 14 .

\section{8} implanted with 10.6 to 39.4 uCi of high-fired Pu 239 Puo2 with a mass median diameter of about 0.7 um into the left hind paws. The Pu particles accumulated in the popliteal lymoh nodes. Histopathologic changes in these lymph nodes were characterized primarily by reticular cell hyperplasia, increased numbers of macrophages, necrosis, and fibroplasia. Eventually the Pu particles became sequestered by scar tissue that often replaced the normal architecture of the lymph node. Light-microscopic autoradiographs of the popliteal lymph nodes showed a timerelated increase in number of alpha tracks per Pu source. Electron microscopy showed that Pu particles were aggregated in phagolysosomes of macrophages. $($ RAF)

10 Four electron micrographs of Pu particles in popliteal lymph nodes are given. 
BTOLCGRCAI BSERCR

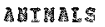

$<13$

Abrans, H. Niversty of chicago, chicagc. II. 1945 .

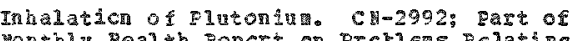

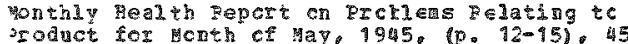

All update ef data from a frevious study of inhalation of Du is presented fer the Arc aeroscl studies and trace intubation studies. hndyses are still incolalete on the grcur of rats ezcesed to a racer aeresel consisting of a ixture of 9 (4) and 65 ala cons lating of a lixture of difficult. The rate of elimination was about the sale, with 25 leaving the lung sonewhat caster. parteta an the luag was about days foz 23 and 13 day cor vo. Tissue analyses rave been completed for intubation a fortheoming orogress report. Iung

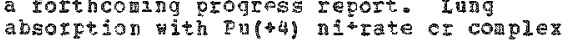
occurred pery rasilily uring the firse days then suksided te a rate characteristic cs $\mathrm{Pu}(+4)$. With $\mathrm{Pu}(+4)$ nitrate absorption was slow and incmplete. Majer sites of derositon were the 1 iner and sheleton. Aadition of citrate caused Iapid absorticn from ele lumgs. Calgen acts auch like citrate but seered to be a poorer colloying agent. (EEM)

<2>

Arderson, E.C., G.A. Drake, … Holdand, J.E.

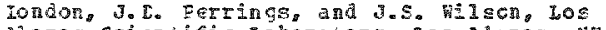
Alamos sctentific Laboratory. IOs Alamos, w 1973. tarch

The Hot Earticle Propect. Exrosure of Animals. LA-5227-FE; Dart of pichocnd, C. Z a ad ioelz,

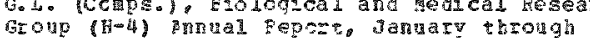

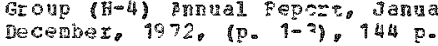

Sere of the experinental condterers tor an on-gcing rict study dealing uith posaible carcinogenesis resulting from lecalized

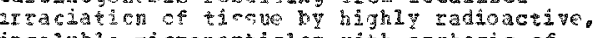
jasoluble micropartioles guoz is + le lung are given. Tncluded is a casular revien of the pu content ef 10

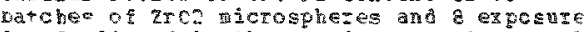
leve is if sted in the previous year's annual renort. The experínents Here planner as an expleratory survey covering a vide aynagic Iange using co gclden hasters per grcup

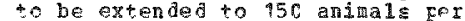
groug. Due to an unapected low biological response be range of experinents vas extended with a nce modest number of aninals. cre adilo icnal great of animals was anjected with 6000 spheres 10.22 pcistoperel. the toral lung murder of Ahese anjmals as 1.3 nch in ordet to give exposures re wuch larger guars of gmaller and meremokile Earticles, anditional groups of 30 animal wete injected with total lung burdens 0 about 160 nc: one grou recelved from 1, COC,000 to $2.000,000$ speres/animal 10.07 pilsficed, and the cther fecetved $2,000,000$ spiesesfariat 10.42 pci/spherel. These two group y? 11 he cerpares the the coservatien that 0.1 nci lung burden =esuted En a survival tile of enly 1 yr in ratso Thenty-four animals received co 57 lakeled spheres by sntrattacheal insufflation te study gessitle diffezences in fereign-bedy zespcrise te carticies on opposide sines of the alleolar-capillazy wi1. A small auber

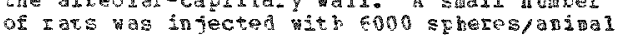
(4. 3 cristhere) to deternine is this spectes which has nore natural lung isease shomeda higher incidence of Iadation da age scssibity as a result of sylergistic expocts.

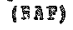

33

Argold, 8.S. and laberatory. Lemont. IL; Dniversity of 0tah. college of Medicine, Radiobiology pivision. Departaent of anatong. Salt lake cityo vT.

Arerfican Journal of Anateny, 109, 367-417.

Ycung fenale $1960 \mathrm{gr}$ rats were given uCi/kg of plutonin (t4) citrate intzavinously and seriali 147 dags Gross ard detailed raticautcoran of undecalcifiea sections of the lumbar

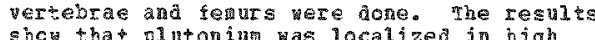
sher tha plutonian was localized in high concentrat ch at endosten surfaces and to a lesser dearee at pericsteal and endosecal ミuffaces of vascular chanvelso wc apcarent selective deposition vas cherved with respect to the presence or osteoclastic or csteoblasejc acejuley. Fe bone which was depositel after injection overlayed the strata of initially defesited plutonilu. nI cot-injection bone was readily identified by its diffuge labeling. Where resorption occurred, glatchin derived from tre sesorked bene progregsively concentrated in the osteoclasts. The giu onin of the csteoclases was later ransferred to racesphages. ahe a bove chroustances uniquly feronstrated both the Exrative and

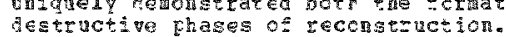
Flutomu concentration in ostenclasts was

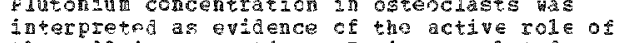
tre cell in resorpton. It is apeculated That the csteoklase acts as $1+5$ surface fragent the bone and then ajgerts the ingeated bone taxticles in tos cytoplasm, there 2 t concentzates the liherated

gliptonin. The lccalization of plutoning if the and tie reticulcendchelial systen. tegethet whth its lack of aiffusiballay. suggests that it is a collcil. The inteversible nature of its devosition suggesss collodial adsorficn as leing the

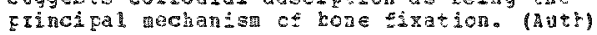

《的〉

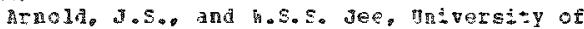
liar, College of Hedicine, Fadiobsolcgy Divisich, Department of Anatony. Salt Lake city.

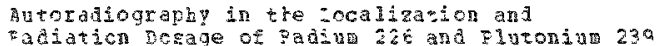

in the Bones of pogs. Laboraton Investigatici.

in the $194-204$.

Yeung adul beagles $114-20$ months of agel bere given sufficient radun chloride in 2 eitrate intravenousiy to produce the

fcllowing gives levels of retaired body vurieg: (1) $0143,(2) \cdot 086,(3) 0.27,(4)$ - eq and (5) 2.5 uci/ta of body weight. Three \$6garate autoratiograchic aproactes were undertaken to evaluate the gross and Micioscopic distribution cs the elemente and

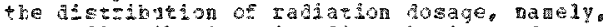
gross distributicn nicrodistrutston and guant $a+i v e$ autoradiograng. PCr the gross as atration, the over-all pat eIn of eu and

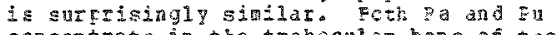
cencentrate in the +rabecular bone of the B6:aphoses of long tones and an tlat bones tot they are aeposited in very ach lower concentration in the trabecular bene

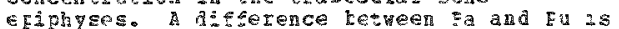


3TOLOSICAL ASEECES

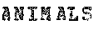

<4> CC $\mathrm{BT}$.

seen in coxtical boge, wrereas a small

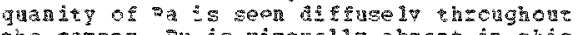

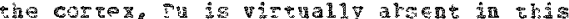

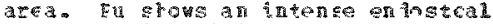
concentration $11 n$ ing the rednliar cavies of the shat and to a leser extert, at the pericseal surace. Por morolistribation.

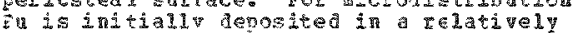

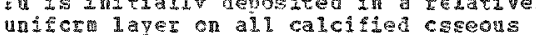
surfaces which have blcod supply or are is suriaces which have blcod sopply az are in contace wh he linint ce the nazzor staecs. der ssited Fu concentrates in the cyconiase dersited concentates in the cytonlase the csteoclasts. The contract ketween the absence of activity in all bone that existed prior te injecion and the datefuse labeling of a d bone aeposither after inyection lakes - $\mathrm{x}$ possible to tollow the sequence of bone rodeling. The radiation efects ca Fenodelirg are noten. yarked ditferunces are apparent in the concentratich and diseribution of the activiti fret cne dese level te ancthor. In the anitals bighest bugen of 3 , beth the qesorptive and formative phases of temodeling of trabecular cone are arroged. The dose ta to sof to som cicsue at 10 micro for the rafioactive cone sis cace vas calculated te be 45 rads/ar for Buad $900 \mathrm{rads} / \mathrm{a}$ cor $\mathrm{g}$. The actual

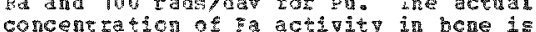
creater than that of $\mathrm{Eu}$ ly a factor of 2.5.

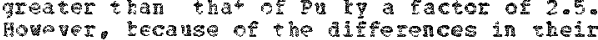
Howner. tecanse of the alferences in their

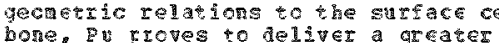

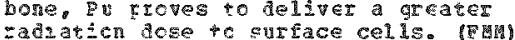

$<5$

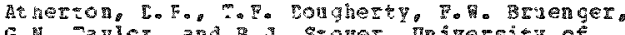
G. H. Zaylez, and R.d. Q⿻一𠃋十 Jiah, cellege of Melicine. Padok olcgy D2visien. Defartant of anatery. Salt take city.

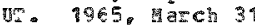

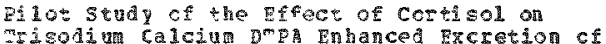
plutcosu 334 in the geage coo-119-232: Fart of sougherty. T.

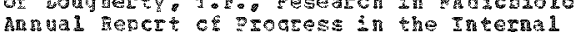

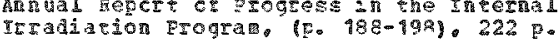

A $\operatorname{dog} 688$ dags old was injected ulth 2.72 uci Pu $239 / \mathrm{kg}$. Frine and feces vere latex coliected and analyzed fer pu 239 to deterine the pretreatrent excretion cater. I wo rassive doses of certisol vefe given mobilize Eu 239 to kake it available Eor chela icr by 6rcreticr. ho cracizcally significant znceease in excretion was observed, and there vas DC g

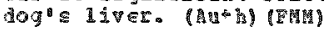

$\langle 6\rangle$

Atherton, D.F., E.J. Stover, H.S.S. Jee, W.

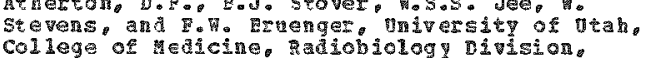

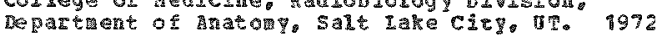

skeletal Pesention and Distribution of Bolyertc and Womeric Flutonin 239 in Beagies. Eadiaticn Fesearch, 59,538 .

gu $239(44)$ was given intravenously to beaglea Ln: (1) the Fu-transferrin complex (Pu-TElo (2) 0.02 citrate buffer (Pu-

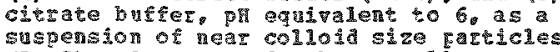

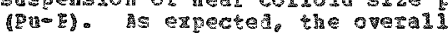
distribution of the polymeric for of

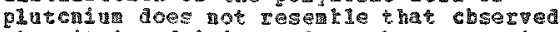
wen it is and nistered as the wonomeric complex with citrate or transferrin. The

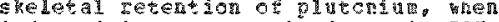

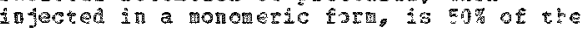

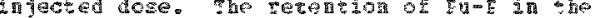
sheleten vas less than $1 / 20$ that seen in $\vec{E}$ uc. 9 -

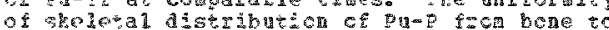

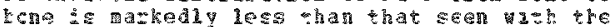
tho monomere form. peanced speleral retention in anala injected vith pu- nay acchang in animal injected wi polvesic acchanism in animal injected wi holye

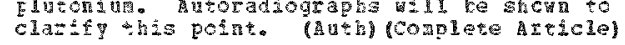

$\langle 7\rangle$

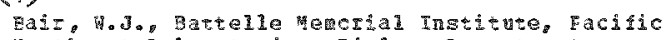
Borthest Latoratories, B3olcy. Department.

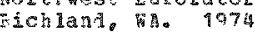

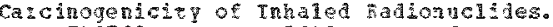

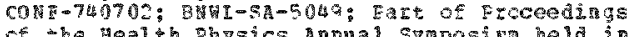

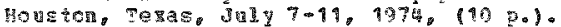

the carcinogendictiv of inhaled a tha teta-ganta emoting rabicnuelides has been dewotrated in a nuber of anial species. dewingtrated in a numet of anial stecies. iradequate to assess

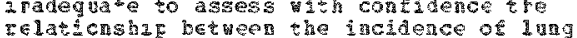
camcer and he tadition dose. These dat cancer and the zadition dose. The

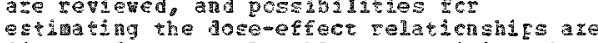
discused. Eeveral tables sumarizing the

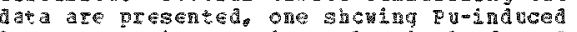

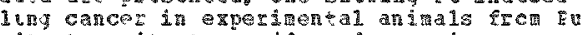
citrate, mitrate, oxide and amonim Elvenju pent carbonate. and plutenyl traetate. 1 graph shering the relations if and the cusvival time in dogs is shown as

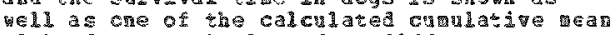
aIfha dose to the 1 ung frel ditrerent $\mathrm{Eu}$ ccrosuts admintstered to several experimental anitals. Scre or tre problens experzental andals associated apereriate cse value that lelates to cathcet anciden

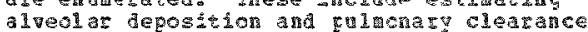
a iveol as deposition and fulmonary clearance

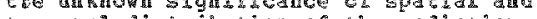
terbetal distribution of tre zadiation dose crom the radionuclide ihat is dercsited. and

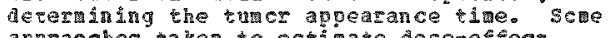
appraoches takn to estinat dose-erect relaticnship are gentioned such as the legarithmic protit curve and athemateal cdels. Because of the andegract of the a vallable data, altarnatives are needed to agtisapolate the results frcen and

e reximencs to man por partoses of develoring radiation protection standards.

possibility suggested is a tozicological

atproch in which the aptropriace radiaticn

dese nodels needed to describe cancer

induction are of secondary inportance. (Fm

<क

Ear. HoJ., and J.F. Eark, Ratelle Hencrial 7nstinte Pacific vorthwest iaboratories. Pichland. Wa. 1967, JuL

Comarative Disposition of Fur Tyges of

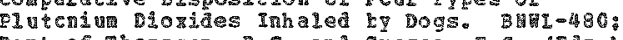

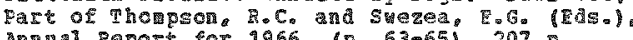
Annal neport for 1966 , (5. 63-65), 207 .

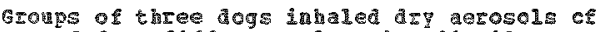
cre of four differen plutcrin ajozides. To osldes were propared ty calcining the oralate at 1000 c or at $35 \mathrm{C}$; ancher was retal at 450 degrees and another by the slch oxidacion of the pure metal at 123 degrees. 
BIOLCGTCAL BSETCE

A

《e> $\cos \mathrm{i}$

The particle size charateristics of the four

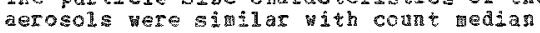
diatreres of about 9.5 m. The lung retention hall-tive of oralate calcthed at $350 \mathrm{C}$ wa abous cne year. hal of that of the other
oxides tested. The greater lung clearance oxides tested. The greater lung clearan this oxide as acconpanted ky qIeaer accurulatien of plutonium in the lypp Translocation of plutoridu to ussues outside of the lung ate lypph nodes was least vinary excretion of plutoning as well as transiccaticn appearea tc be greatest for the oxalace calcineat at 350 C. (2.

$\langle$ ¿ो Ba:*. Exoducts Cferarion, Fichland, *h. 1961, March

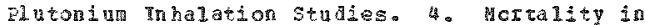
Dogs after In halaticn of luterivis $239 \mathrm{pu} 2$.

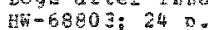

In 2 teagle dogs depositing 1 to $930 \mathrm{uCi}$ of plutenin dicside of Farticl sise $0.50-0.6$ i by intalaticn, deaths due to zespratory insufficienct occurad two lonth to a year after expesure. Iungs contained 95 pez cen and the bronchial lyogh ncdes 4 per cont of the toral plutonium content. cildodeal syntco included increased respiratory rates. 20 per cent weight los and marked Iy ghepenta. Historathelegic effects were confined to Iungs and benchial lyph nedes. It was concluded that intital derosition of

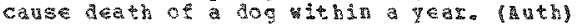

Sec also Fadiation Fesearch, $16,819-829$ (1962).

$<10\rangle$

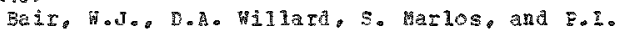
Bair, we D.A. Hillar, So farlos and E. Laboratcies. 3iolegy operation, ichand wa 1960

Yxelininary crservations on the pharmacodpades and Biological fifects of Thhaled Bluton jug oxide in yegs. paddition pesearch, $12,419$.

Innediately atter an thalation exposure of dogs to a plutoniun oxide aercsel 60 \% of the deposited fiutonium has in the Iung and the renainder was distributed between the uger respiratory passages and the gastrointestinal cract. Hith two weeks after eycosure. about 5 co of the jeposited clistoralu was excreted in the feces an ${ }^{2}$ less than one in

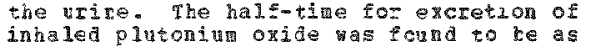
great as 9500 days in 40 weok studies. Caly saal 1 quantities of plutcring (1ess than ene W ot the decsited dosel were translocated fren the lug te other tissues whthe excepticn of the tracheorronchial lym nodes. The concentration of el utongun in

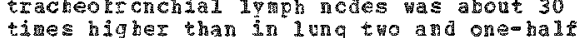
years atter pulachery deccition of plutoni

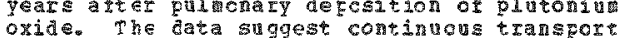
of lutcriuf fro ung to log mode with a of 1 utchivin from lung to 1 grach mode with a

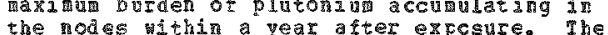
the nodes within a year after expcsure.
bistcrathelegy of trachechronchil 1 iy nodes and lung was descriked. No naglignat neoplas ${ }^{2}$ have been observed in dogs following inalation of plutonid oxide. Dogs depositing between 50 and 100 uch $\hat{z}$ plateni um died within the to four month with Rassive gioss lung changes. Blccd Iy ahocyte inhalation exposure (Auth) (Coplete hrticlel
<11?

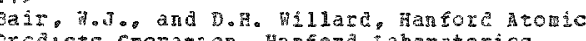
rcduces creratzon, Hanfo=d Iaboratories operation, Eiology sabcratcry. ichland, wa

Dutenzat Inhalation sevaies.4. Mercality in Dogs aster Inhalation of Elutoniu 39 prot. padation Research. $10,911-921$.

Eeagle dogs were exposed to ou $23^{\circ}$ enoz aerosols: at a concentration of $10(-3-3)$ uCi of Fu 23902 per thl of atr. the medal Partucle diateter ranged from $0.50-0.65$ u. A range in the quantity of $F$ a depositea $11 \mathrm{k}$ 950 uCi) in the acgs was obtained by varying tre aration of the expesure time. Tho aogs were alive 21 month after esposure. All deaths cccurred 2 te 14 months after exposure and were due to restratory insufficiency. Iugs contained gef and the bronchisl 1 yte ncdes 4 of of the dotal plutonium content. clinical symotom included increased

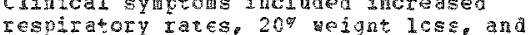

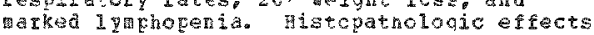

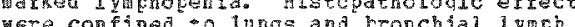
a ere con tred lun and bronchal lyag

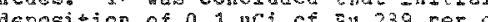
deposition of 0.1 uct of lu 239 per gran of ling wold razely cause death of dog witio $a$ year. (Buth)

See also 1 H-63803, $245 .(1961)$.

$<q<>$

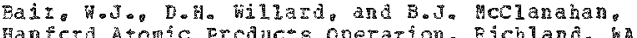
faracra Atonic Eroducts Operazion, Buchland, wa.

Exeretion ana Fanslccation of plutoniur 239

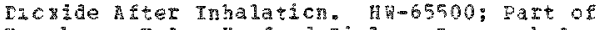

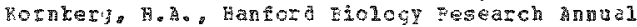
Feport for 9959 (5. $116-12 \%$. $208 \mathrm{~g}$.

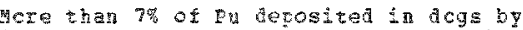

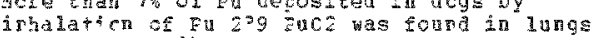
intalarely atter expogure me halforime

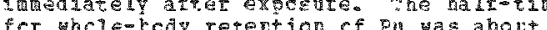

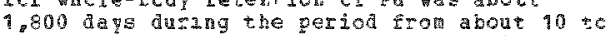
ur week after eqcosures. F wrom lung to tracheobroncial ingh nodes y a majoI pumonary clearance crecess. was a nor pumonary clearance crecess. unine and feces were denchistated (Auth)

<13>

Ballew, Jor.o General ilectic Company, hanfor Iaccracories, Elolegy Iaboratory, Qichland, 1962. उam uary-

Feroval of Deposzted Flutenin by Triethylenetetranime hexaceric Acid. Hature. $193(4822), 1301-9304$.

The effectiveness of triethylenetetsonine hexacetric acid, (TrHh) was conpared with DFE in rencuing deposited Fu. Adult fenalo Sprague-5aley rats averaging aboue $220 \%$ cere injected intraveroush with

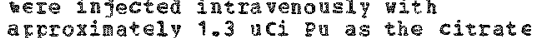

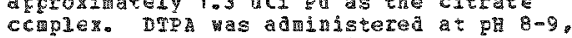

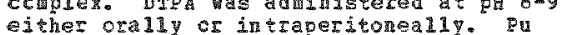
ccrtert as deter ined in excreta, liver, ccrtent vas deteringed in excreta, liver, terar and cotal ges idual carcas a The Iesuls sho that oromet intraperitoneal acministration of pho resuled in greater
removal of Dis from bone than was accomplished with oquivalent Drf treatrent. ITEA was hewever, wore effective ib reducing liver aeposition, DIF and ITt were equaly elfective in promoting en excreticn when giver intraceriotonealdy 1 days atter the 
BIOLOGICAE ASEECIS

ALI请等S

$\langle 13\rangle \cos T$.

rabinuclade injection. The ertectiveness of the chelating agents was wapedly decreased wh delayed treatment. The oral administration of 6 a/kg DTPA or TTH Ifduced bone deposaticn to about the same exten as a -fold lower ineraperitoneal dose. The rit treatment as somewat ore dose The hat tratrent was soberat are

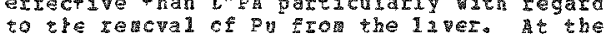
lower oral dosage level of 2.8 . lower oral desage level of 2.8 . superiority of drath of one animal. $\mathrm{At}$ a higher dosage of

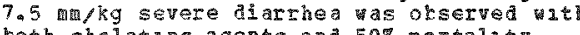
both chelating agents and 50\% moztality occurted in the mptandals by the 4 th day. THA is the fxrst substance to show promee of a practacal degree of oral etectiveness

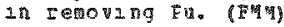

Table sheus comparat ave effectueness of DTQA and $T$ ry in retoval of $\bar{P} u$.

14>

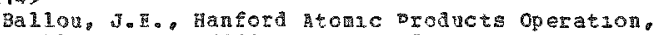
F2chiand. 1962, January 15

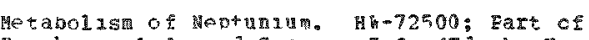

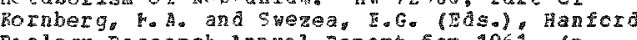
Ficlcgy Pesearch anual report Eor 196\%. (P. $41-43), 980$.

Dust samples were obtaned fren union carbide and Nuclear company. Daducah, kentucky fer - valuatior as a pctential health hazara. Pad lochen zcal andises of the paducas dust 1ndicated gross alpha contamination of 0.26 uCi/g; $00 \mathrm{E} \in \mathrm{I}$ cen a due $t c$ lip 237 and the zerainder from anan iscopes. The dust was adinasered eather acutely $c r$ chronically to rats co determine gut absolption and tokzcitv. of venty-feur hour absorption and tonicitv quenty-ficur hour to a bu $q$ per cent of the admastered dcse. to diou per cent of the adminater che dust was fed as a vater suspension

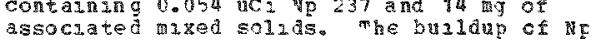
assoclated rate fad a diet contaming 4.4 per

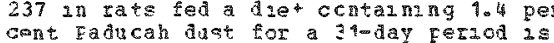
srown. $\bar{F}$ cod consunetion and wejght gan appeared normal on this duet which provided an ayerage dcse of 9.042 uCl po $37 /$ aro Fre body burden of un 237 attarned after 31 days feedings was 2.5 per cent of the dany acse or less than 0.1 ras cent of the total amount angested. Intest anal abserption cf hegtunu cytrate scluticns anked according to ralence

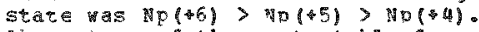
Absorption of the mest stable for was acout 1 per cent of the adminzstered

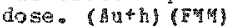

$\langle 15\rangle$

Eallov, Jo I. and J.I. Palotay, Eattelle

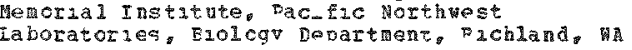

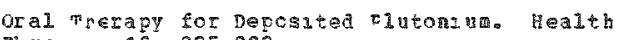
Eryacs, $12,895-899$.

Young adul fenale rats velghing 250 g were admistered chelating agents (DrEA and relared compounds) ky gavage 1 hr after Firecnua catrate in pection and at daly intervals thereefeer. DTr and Tha itruethylenetetranine herace $1 \mathrm{c}$ acidi vere

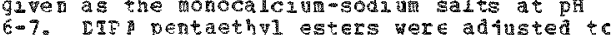
6-7. Lre pertaethol esters were adjusted pH 4o Effective cral theragy for glutensum m-moles/kgadingtered hr after plutoniug

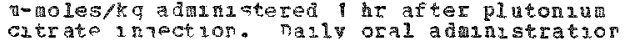

of a 1.5 moles/kg dose, inltated 4 hr after Slutonu anjecticn and contrued for 9 days, was only rarginally effective. heasuremegt of the entanced excretan of Fiutonau in the bile aurang perfusan at different atestanal segunts wh chelatiog agents indicated that the agent axe absored on oral therapy are discusced. (PAF)

$\langle 16\rangle$

Barrch, E.S.G., Unzersity of Chycago, chicago, II. 1945, 19

Dhosthollpid Turnover in Product Folsoned An1als, ch-2992; Part of honthy Health Feport cn Ercblens Felarang tc Product for Month of qav, 1945, (0. $5-11), 45 \mathrm{~g}$. (Leclassified Jan ขอบ 4,9058$\}$

An experment was devised to check the validity of the observations that Pu treated rats developed a fatty a ferrang liver. hetabolism of prospholipids in the rats gave an indication of deranged fat metabolism resulting in the grcos pathological plctur

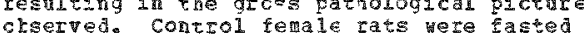
fer to hours then trjected nto the stomach w $0.5 \mathrm{cc} / 200 \mathrm{~g}$ of $0.62 \mathrm{ag} / \mathrm{cc}$ inorganze Fhosphate followed by a cc. of cod liver oll.

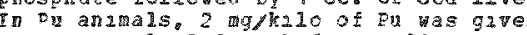
intravenousiy 5 days before $=32$ adrinyetration. Fiood was aken fron the Fu andals for whate count, non-protein natrgen and cholesterol estimaticns. Animis from berh grcurs wese sacrificied at $3,6,9,15$. $3 C, 60$, and 102 bours atcar mital feedug ct the prosphate. The entre

Jastrontestinal uract and feces collected were ashed to deter mane the extent of absorption, and the 19ver was analyzed. The ansine is in the on serzes showed nore Indvidual vardations that 1 in the control setwes, but this dad not exceed $0-15 \%$. Ire setwes, but this did not exceed o-15\% ingased by the amoun of ou hagher than an

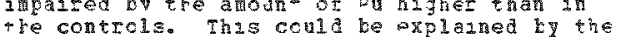
antial gatts of the curves $(0-9 \mathrm{hrg})$ were stmilar showing transport of to the 11 me and renewal of $\mathrm{P}$ an proschollsad molecules was not affected by for poisoning. The rea of the curye as festponed to 95 hrs $2 \pi$ ou aruals as conparad to 9 hrs $n$ the controls. "has a dafficult tc explan as ore livers dsd no appeas fatty. The white count was lcwe nenrotezn natrogen (Non) and

$\langle 17\rangle$

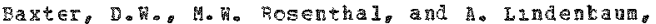
Argone Hat jonal abcratory Davisicn of Biolcgical and medical wesearch, Argenne, IL. 9973 . Jul

t1 urcman Decorporation by 61 ucan and zelated

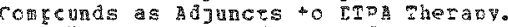
coll-730439: Part of Eroceedang of the $21 \mathrm{st}$

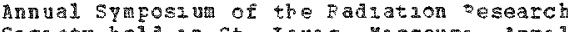
Society held an St, Louzs, Fissounz, April 29-4ay 3, 1973. Fubliohed In Fadsacien Fescarch, $=(3), 596$.

DTEA, chrentiy the treatient of chorce tar

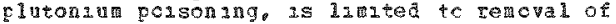
extracellular plutonam recause $2 t$ is essert lally unakle to penetrate cell Meniranes. The effectiveness of veast glucan, giver as an adjuct 0 LzE theraf has been demonstrated in remova sed ad tricnal hepatic cluromium previously una vallable fer chelation by ter. To Qlucidate the thechanis of alucan action other substance

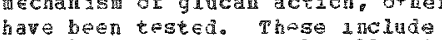

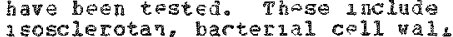


BIOLOGTCAI ASEERTS

AUIARES

<17〉 CONT.

Folysaccharides, a pyran copolymer, poly I/C

1339. Dac compournd

was adanistered, in conjunction weth DTs.

to race in iected inerav colymerze plutonum five days previously. Four of the tested substances removed significant addituonal platona fron the liver oy f reeks. Of these, the most effectuve (pyran copolyasr) and leas effective (Tilarone) are soluble interieron-zaucers. Adational studies uth pyran have show that il another gyran cogolyar is a iso effective $3 n$ removal of bout one week, and 3) henatic purton a removed by pyran is not translocated to bone 3 in the absence of DrgA as is that removed by glucan. The two compounds wh internedute effectuvans tere glucan and 1 soscleroten. These are ansoluble, morphologically

different but chemicaliy simiare

glucopoly saccharide construants of yeast and fungal celi valis, cespectively.

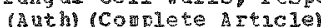

$\langle 18\rangle$

Belyaev, Yu.A., 1964

Relative effaciency of Certan complex compounds in the Perowal of Plutonin 239 frow the

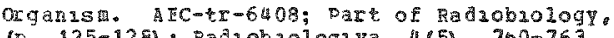

(p. $125-126) ; 7$ alloblologiva, $4(5), 700-763$.

Dlutonum in the for of the citrate was injected intraperitoneally in to rats in doses of $0.8-1.0$ ucfrat. The folloving chelating

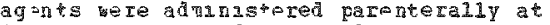
A1 fferent 1 mes after Pu admanstratson: i) ca va salt of

triethy lenetetraamneheracetuc acud (Tith). 2) Ca tra salt of

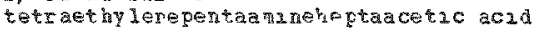
(TPHAl. 3) Ca va salt of

(TPHA) 3) Ca va salt of acia $(m 5)$, ani 4 ra $\mathrm{ra}$ as salt of

dzethyenetramanepentamethy - Fhosphnzc

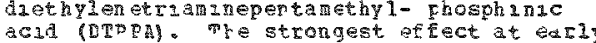

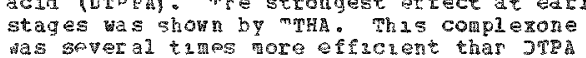
was Several thes wore efinerent thar JTR vhach was taken as the standard for the eftaciency of the other complexonos. The effect of PPis vas somewht veaker than tha of Trith but still stronger than DETA. The no interest for further research. DTPQA was effective for the removal of plutonz soft tisgues and spoleton although on the whole 3 ts efficuerey was less sha that of

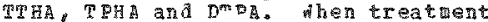
Complexcnos was started 30 days after the ingection of plutongum the efficiency of TTHA did rot differ fron that of TPHA and OPQA. (GR

Tatbes are given of pu content 1 n rat organs (1) vex, kI a i eys, soleen, skeleton 3 , 6 and 45 deys ater a ansistration of complexons.

$$
\text { <19> }
$$

Bolvaev, Yu.A. Not quven. 1964

plutonbu Beroval in Pats Given some Complexons by louth. AEc-tr-7590; Part of Moskalev, tu.T. (Ed.). D15tribution, Blological Fifects, and Accelerated Ercretion of Padroactive Isotopes.

(p. $356-360), 405$ p.

Fxperanents vere conducted on wase rats, thing 220-270 grans, alven solution 01 plutoniam natrate intraperstoneal1y, pH 6.5 , at a concentration of 0.65 to $1.01 \mathrm{uc} / \mathrm{s}$ a The coplexons were quen by mouta using a

\begin{abstract}
gastrac catheter at different tam folloung tne Pu 1 joection. organs anazyzed for Pa content vere kidneys, spleen, liver and

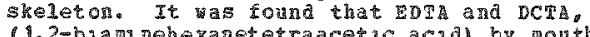
(1,2-bianneneranecetraceric acid) by mouth was meffective, even at rhe early stages, with respect to pu rewoval sron the sheletcr or luter Doph was effective only 2 or 6 hours after the 20 angect 10 . Multaple adminztratzon of adanistration of pu lovered the pu level
coth the liver $11.6-$ fold decreasel and tots the laver $(1.6-f 0$ d decrease) and
cheleton (65\% of the conerol): however. when

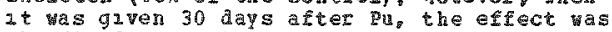
chiefiy due to the pulevel in the liver (2-fold decrease). The best response was ottanned wh DTPA when diming sed $\mathrm{Pu}$ content of the liver and sicleton regardess of time of adrinistration. When this agent Has given 30 days after $\mathrm{Pu}$, there was a 4.5 fold decrease in its level in the liver and a $1.6-101 d$ decline in the skeletor $(61 \%$ of the Control). (RAE)
\end{abstract}

Tabular data gave pu 239 levels in rat skebetcr and liver 7 ays after ingestion or complexon. in rat organs on the $16 \mathrm{th}$ day, and on the $83 \mathrm{tb}$ day oth late admistration of complexions.

$<20>$

Belyaer, Yu.A.e and V.K. Lexcerg, Not glven.
1964

Elfectreness of Duethylenetrian negentacet

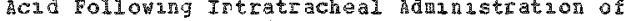
PI teniur. ABC-tr-7590; Part of moskalev, Yu.T. (Ed.). Distrabuton, B101093cal tefects, and Accelerated Excretion of Radractive Isotopes. (p. 36 (-366), 405 p.

Experzents tere conducted on 86 histax rats

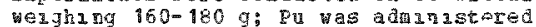
bitratracheliy as the nutrato, $\mathrm{FH} 2$, and the 13tratracheally as the nutrats, $\mathrm{F}^{2} \mathrm{a}_{\mathrm{s}}$ and the

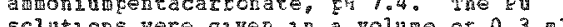

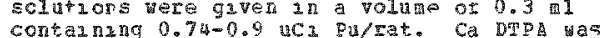
concal ning

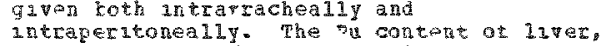
whole lungs and fenur was analyzod. The

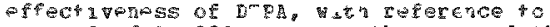
removal of gu 239 given an the rorm of the nutrate or carrorate complex antratracheally fron the lungs, has Beglaglole, even at the early stages of treatrent. Intratracheal admastration as somevhat more effectupe than 2 ntrapertoneal. Fu-pentacarbonte of antonlat, when given 2 ntravenously was $80 \%$ Fetalnod in tne 1iver. The Mean excretson of Pu 2392 in urane was 0.13 and $2 \mathrm{r}$ teces $12 \%$

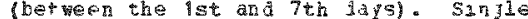
intraperitoneal adninstration of DTPA (24 heurs after intravenous admantration of a par-carbonate complex) lowered the pis 239 conent of the livex bs $23 \%$. (रRF)

$\langle 2\rangle$

Berdjas, C.C. (fid.). Armed Forces Tnstutute of

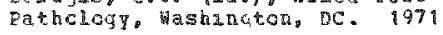

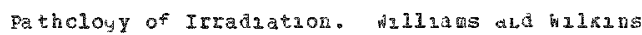
compay, paltumore, Nariand, $710 \mathrm{p}$.

The book presents the curtath fromlease of the effects of radiation on man and arials ani revievs the latest laterature avalab on the subject. Atterpts have been ade to correlate the structural ad ot tor the ultras ructural features of tissue reaction to *radation th the the clinachl

b3ophysaological, genetse and functional a spects as they ar mandested luring and after arradiarzon. The probleng or extrapolating anial date to Ran are 
BIOLOGICAL ASPECTS

AHIVALS

$\langle 21\rangle \cos T$

discussed. Two chapters, one dealing wrth bone-seek rng radionucludes, such as ou 239 . Ra 226, E 228 , Th 228 and $S E 90$, and the other wth togucity a spects of internally deposited $\mathrm{Pu} 239$ have been abstracted

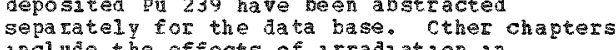

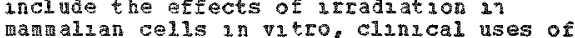
radiossotopes. radition carcinogenes s, the eflects of radiation on skin, the nervous syter, salivary glands. gastrountestinal tract, II ver. cardiovascular syster. endocrine glands, hematogoletic system. lymatic svsten, thvans, pulmonary syste gendtours nary tract, kud neys and organs of special senses. The effects of acute wradiation in man are described as well as treatuent for the restoration of the hemetpori etic syster, such as by transfusars ef cempatible autologous or Isogenic bone arcow. (F)

$\langle 22\rangle$

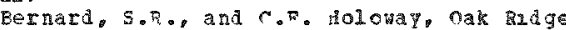
National Laboratory, oak Rudge, Th. 1965. october

Estzate for Fluorine 1 for Plutoni us Compounds.

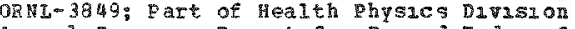
An rual Frogress Report for peruod Endlag July 31, 196 $,(0.212-213), 257 \mathrm{E}$.

Experimental data on rats are reviewed whch peralt some fluorine i estimates to be of some $D_{u}$ compounds. Particular reference is ade to stulies by reeks, et al, and Ballou. For the present it is suggested that fluorine 1 equals $2 \times 10(E-2)$ for ingestion of monemer $1 C$ Pu and 2 \& $10 / E-5 \%$ for ingestion of Pu as an aged collo1d. No data are avalable for the estatiation of aanaged collordal solut ions of Pu (\$4). (RAF)

<23>

Bland, M.R., J.F. Loutet, and 3. H. Sansom, gedical kesearch council, Padoblology pit. Ha wel1, England. 1974

Hz stochemcal phosphatases and metachromasia in surine Tuars Induced by Bone seeking Radionuclides. British Journal of cancer. 29. $206-221$.

Tunors induced an mite, ether CBA normal and chuararal, or C3H, by SE 90 or Ra 226 or

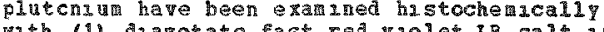
wth (1) diarotate fast red violet tB salt 1 naphthol AS-ph phosphate buferer at ph 8.6 and 5.2. (2) 1.9 dzmethyl methylene blue (Taylor). It is concluaed that the duagnosas of ostecsarcoma is faclil tated yith Taylor's Blue whych staun osteoud getachromaticalsy. cells of csteosarcoma II ke nor al

osteoblasts, contain alkaline phosphatase but this may ve lost by atation alther in the original turer of subsequently on passage of

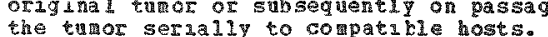
the triar serlaliy to co patidie hosts. corms. bi zarre tumor cells and csteoclasts: toras, bu zarre tumor cells and csteo osteosarconata un 1 ch rotarn the 15 osteora on serial passage have fen colls contanning acid phosphatases. Prqut Ive aesenchyal cell tabors of angiomatous form ray ccert, it the bone marrcw is Irradiated, e.g. by Sr 90- 90 and Pa. These tumors lack osteold and celis Hinergretahle as asteoblasts or osteoclasts (though ther destror bone). Tumours classifuable as fibrosarcoma cccur rarely. and way be crul

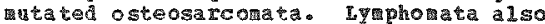

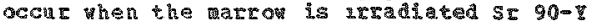

90 and Pul. They way be generalizea, when thele cells may contain alkabne Fhosphatase or lack tt. The 7 ay be localized to akdomal vascera, the retaculo-sarcoatous fcrin in which case the cells lack al aline chosphatase. (Auth)

$\langle 24\rangle$

Bleaney, B., Churchill Hospatal, Medzcal Research Council. Eore-Seekng Isotopes zesearch urit, Oxford, England. 1967

Radıatron Dose- Wates Near Bone Surfaces n Pabbits after an injection of plutonam.

Fhysics in Medicine and Brology, 13(1), $145-160$.

Rabbits 6 weeks old given sugle sntravencus injections of 1.25 we/kg of plutomum nitrate were killed at dufferent trises after

injection. Undecalcisied sections of remurs and ertebrae were prepared, and the dose rates determined by track counting on autoradlographs. In trabecular bone, 24 hours ater anjection, the ratio of andum to man dose rates to stem cells outside the endosteal surface is about $3: 1$. all the trabecular bone surfaces have a depost of pu trabecular bone surfaces have a deposit of pu

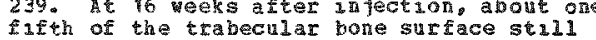
bas a significant dcse rate, and cnly a for bas a sagnacant dcse rate. and cnly a degosit, even though nearly all the trabecular bone has been formed sunce injection. Since most of the endosteal bone surface is trabecular bone, a large polune of stem cells and marrow cells is urraduated by these deposits. There is also a significant dcse rate cue to plutonal in the rarrov. (Buth) (RAF)

Tabular date are given on dose rates in trabecular bone in fenurs and vertebrae. The astribution of dose rates is shown in graphic form.

$<25$

Boecker, B.B., R.G. Cudahy, F.F. Hahn, and Meclellan, Lovelace Foundation for Heatcal Education and Research, Inhalation Tcxicolog. Research Institute. 1 buquerque, No. 1974. Decenber

A Seven-Pear Study of the Pulmonary Fetentao and clearance of cesiu 137 Inhaled in Fused Alumasilicate garticles by the Beagle Dog.
LF-49; Part of Eoeker. B.B. and Ruppecht. F.C. (Eds), anual peport of the Inhalation Toricolog 7 Research Institute, October 1.1973 through septerber $30,1974(0.48-52), 384 \mathrm{~g}$.

Iong-ter pulanony retention and clearance pere studied using 30 beagle a ags given sagigle, 15- 1 n minalation exposures to cs 137 labeled fused aluminosincate particles $(A M D=1.5$ to 1.7 ua, sagma $\$ 0 b=1.6$ to 1.8$)$. An average of about $60 \%$ of the initial boly burden vas excreted rapdaly pramasily in the feces; the readider was retane for the

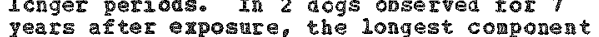
years a ter exposure, the longest conponent

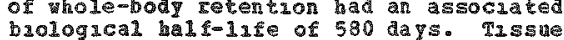
hological hal 112 of 380 days. TISSue to 7 dyears for dogs sacrufuced an pans tetention in the lung. tramsfer of significan quantities to the tracheobronchal lyph nodes and sone sort tissue accululatron of releasea $\mathrm{Cs} 137$. Results have been incorporated anto knekc medel to study the relative sapontance of varuons lung clearance mechanisns. These data on long-tern 1 ung retention and transocaton to tracheobronchyd lyph nodes 
BIOLOGICAL ASFEMS ANT THLS

<25> CCAT.

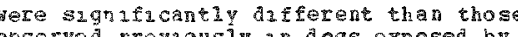
observed revzousiy an ags exposed by una lation to ou 239 Pa O2. (Auth)

<26>

Boyatov, I.t.., and \%.T. Kalmylova, 1961

Ir vestugation of the Functional state of the Blood Systen in Dogs in the Long-Terd Ferlods after chrome Influonee of Ionzang Radation.

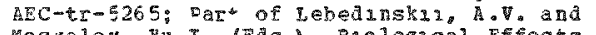
Moskalev, Yu.I. (5dso), Blologzcal Effects of Faduation and Eroblens of Ralioect Ive Isotope. Distributzor Translated row a pablication of the state Eublishing House of II terature 1 th the

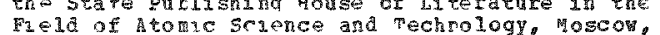
USSP. (F. 32-42), 187 .

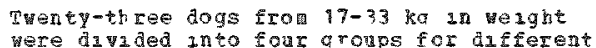
were divided into four grougs for different
treatments. Tne is grou recelved chronac

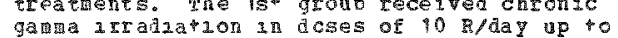
gama Irratiation in deses of 90 R/day up

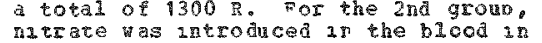

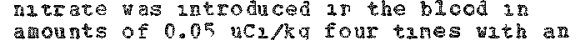

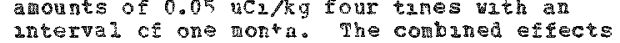

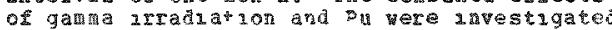
in the $3 r d$ group and the uh grougs recenved

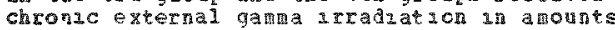
of 18 palay uF to a total dose of 945 in. There was also a control group. Cestain rassive or repeated 3100 dettings and the 15tramiscular antroduction of defattea mik fid adrenalin. The results show that 1 all logs. both experimental and cortrols, the reacticn of the peripheral blood to the mitroluc hor of milt was monotypac and

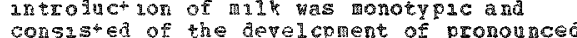
consis ed of the develcphent of pron

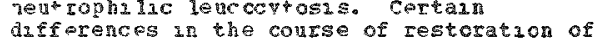
differences in the collige of restoration tho bosd after maselve blood loss wer

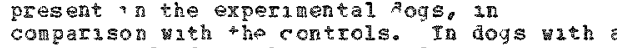
Lor 3 period after chronic arradiation lgroup 4). reger eration of the perboheral blood occurrea mere rapialy than in the controls. $T_{n}$ al the ambals 12 th teveated blond to thing fhe amounts of eryehrocytes and heloq lown decreased after repeated blood losses. During the period of plocaletting. the rumors of retuculocytes uncreased five to seter tzas. WOMnobolization of the erythrocvte content in all dogs occurred 2 ? days after cessation of the bloodleting. wh the except"on of the anial is an group 2

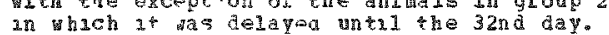

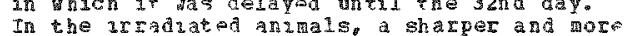
prolcnged deceloracion of the blood clotting prodcnged deceloracon of the blood clotting in the controls. B though whe controls in the controls. Athough 3 in the controls the clotting tio inceased from seven-eight

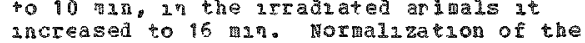
increased to 15 1日2. Normalization clotting occurred after a day in the controls, and atcer several hay in the experimental dogs. The changes revea led in
some of the osperinental dogs andacete that somplete restoration of the functiona actu1ty of the hemopozetic syster and the organs 5 as a thole a ces not recur in all cases and depends largely on the periods after chronac irradition anfugence. (Fun)

〈27》

BorIsow, V.F., Not gIVPn. 1964

Changes In Cortelatuon Between Isotopes in a Mzture of products of Uraning Fisson with Re sorption Thereof fros the Drgestave Tract. REC-tr-7590; Part of loskalev, Yu.I. (EA.). on stribution. Bologreal Refects, and
Accelerated Excretion of Radzoactive Isotopes (1). $99-102), 405 \mathrm{p}$.

An aged solution of fission fraguents 12 years ela) contaning $91 \%$ rare earth elements (Ce 144, SI 90, Yttriul 90 and $2 \mathrm{x} 95$ ) tas admustered through a tha catheter into the rat's stonach in large doses (75 uci $/ \mathrm{kg}$ ) to frovae adeguate concentration $1 n$ nternal organs and tisines after resorption. The rats vere sacrificed on the 3 ta day. tissues and organs were geasud radsonetrucally. Strortum, Zterium, and, ipart, zarconat, were 90-96\% concentrated in bone tussue. 4cre than 50 of the ce 144 accumulated the skin. The percentrle of strontulu in the inver tas lower than in the injtial soluticn. The alstribution of isotopes in bones. ascles. Ilver and skin were $96.70,0.75$. 0.04 and $2.51 \%$, respectuvely. for strontiun: $96.0,0.91 \% 0.05,2.44 \%$ for yetrium: 23.5 . $15.02,2.38$ and 59 . 1 for cersu and 90.7

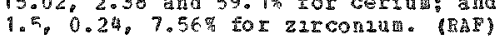

Tabular data are given on the characteristucs of Solutil ons used for radiochen 1 cal analysis, raluocheracal composition of $172 t z a l$ solutions and lumedra, curulative acturty in organs. concaratze xadometrc and radiochenzcal data and distrabution of iscropes in organs.

$\langle 28\rangle$

Borisov, W.P., and R.S. Kravchenkova, hot given. 1064

Acculeration of Excretzon of Radioactive Isotopes, Evaluation of Some Inmediate Heasures Agannt Injury iq Radioactrve Substances.

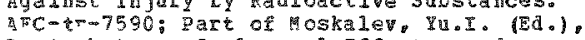
Afc-tr-7590: Part or loskalev, Yu.I. Distributione elological Effects, and (p. 303-311), 405 p.

Several agents were tested as emergency care Ecllowing intake of $y 238$. Po 210 . Ce 14 th and Sr 90 an the argestrye tract. Albino rats weughng 200-250 g were adunstersd radiol sotopes intra peritonea $11 y$ or 3ntragastracally an doses of $10-15 \mathrm{uCl} / \mathrm{kg}$. Drags were given anedicely after intake of the radzolsotope: the rats tere sacrifuced after 3-5 days. Folonsun, Ce and Sr tissue and organ levels we estuated radionetrically, o by fluorescence. 51 rall taneous intake of $y$ and sodiu bicarbonate in the gastrontestinal eract, of y and heavy metal antadote. cermula and comolemons increased deposition of radionacides in tissues and organ. radion ucl ides in tissues and organs. Tetivated charcoal did not prevent borption of the radionulides tested. d decrease of ce 144 penetratea ce lut penetrated into the digestive tract as compad to its astectiveness wher cer given Intrapertonealiy. The re are contraindications aganst the ase
complexons for gastric lavage or complexons for gastric lavage or recontanuation of the routh. sance experiwents EROved that with penetratson of complesons $2 \pi$ the stomach, in cases of oral Ce 94 polsoning there vas a sharp lncrease in level of depositzon or the radionsotoge (decreased daposatch an the kadneys) was oltanged in experiments involving adminstration of 238 to amals wath the use of phospheres. It was denonstrated that antrotum retalorad and "ary hydrogen sultade" (hydrogunone sulfhydate) were effective aganst poloma un the storiach, carective againt polon strontula 90 possonjing, an

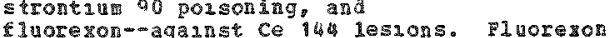

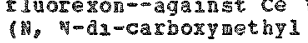


$<28>$

BIOLOGICAL ASPECTS A HTMALS

$\langle 28\rangle$ cons.

anincmethylifuroescein) dimished deposition of Ce 144 in the skeleton and $1 \geq \mathrm{ver}$

concurrent1y, (RAF)

$<20\rangle$

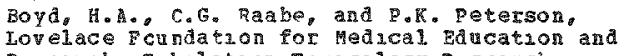
hesearch. Trhalation Toxicology Research Institute, A Ibuguerque, NH. 1974 , Decenber

Froduction of Monodisperse Respurable Aerosols of anericiua 241 Dioxide and valuation of In Vitro Dissolution. I, 49 ; Part of Boecker, B. and Rupprecht, F.C. (Fas.). Annual Report of the Inhalaticn Toricology Research Institute.

october 1,1973 through septembes 30 , 1974, ip.
1-7). 384 F.

4 Rethod is descrubed for the production of

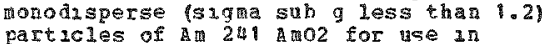

nhalat $10 \mathrm{n}$ experiments ith dog and rodents.

The effects of physical and chemical factors

on the frcauction of polydusperse aerosols of

Am 241 H 22 mere studed and evaluated. The

best aerosol was achieved when a suspension

of americiu hy hroxide wh 2.5 ag hulal at

pH=7.3 was aerosolized and passed through two

pH=7.3 was aerosolized and passed through two

300 degrees $C$ and the second at 1050 degrees

C. The particies were roughl sperical and

C. The particles were roughl syerical and

had dersities rear 9 m/cm 3 the aerosol

and sigaa sub g were about 1.5 u and 1.7.

respectively.

separated and collected with the Lopelace
Aerosol particle separator (LAES) and

Aerosol particle separator (LARS) and
subsequently suspended in deionized water

with pH adjusted to 10.2 with vip 3 for

nebulizat ion to produce mondisperse rerosols

for snhalation excosures. Part 1cles

collected on filters aring inhalation

experinerts were used for evalutuon of in

vitro alssolution rates th two systers and

various forms of a lung fluId sioulant. The

inportant role of phosphate zons in such

issciutucn systems was demonstrated,

suggesting the potontial for the equaly

suggesting the potont 1 al for the equally
3nportan

3aportan role of free phosphate an retarding
dussolution of ano 2 partucles in the lung.

(a)

$\langle 30\rangle$

Brooks. A.I., R.J. LaBauve, R.o. Mcclellan, anc D.A. Jensen, Lovelace Foundation for led 1 cal Education and esearch. Inhalaticn pox ze zology Research Instztute, Albuquerque, of. 1974 . Decerber

Chromosome Aberration Frequency in Blood Lyphocytes of Ansals weth Plac on Iu $239 \mathrm{Lung}$ Burdens. LF-49; Part of Boecker, F. and Rupprecht. F.C. (Eds.). Annual Repct of the Inhalation Torvcology Research Institute october 1,1973 through september $30,1974,(p$. $165-(69), 324$.

Other investagators have suggested a causal telationsh $1 \mathrm{p}$ between accident $\mathrm{Pu} 239$ exposures in an and the presence of chromosone aberrations in blood lymphocytes. To assess this relationship experimentally. To a ssess this relationshlp experimentally

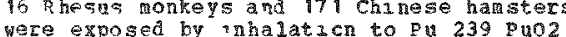
were exposed by inhlatzcn to p 239 puo2 aroscls and an addutional 5 hamsters
injocted with pal 230 chtrate and the Irequency of aberrations in blood lyophocytes determined. Lung burdens in the hansters were estiated by serial sacrifice and radican layeis. Ater an injtal fapa clearance phase, the pu 239 vas retarned in the acrkey lung with a long effectrve half-11fe $>500$ days. At 30 days acter

2 whalation, $99 \%$ of the sacrifice body burden was in the lungs of both speczes. The ranges of cundative radiation dose to the hamster lungs 30 days after minalation we calculated to be $80-170,220-540$ and $830-2120$ rads for antial lung burden levels of 10-30 $30-70$ and $180-260 \mathrm{nCa} / \mathrm{g}$ respectively 120 day a 120 days these doses vere calculated to be 40-350 500-710 and 1440-2770 rads. Hasiste 1th the highest lung burdens had a medin survival in any of the cther treated hamsters or ronkeys by 250 days atter Pa 239

inhation. Hasters sacraficed at 30 days 1nhalation. Hansers sacraficed at 30 days
shoved an increase in chromosone aberration shoved an increase in chromosome aberration 0.0 .014 and 0.089 aberrations/cell 2 is the controls, $80-120,220-540$ and $830-2120$ Ead groups, respectively. By 120 days after Inhation, the aberration frequency an the controls was 0.012 . The frequency in and mals with doses that produced significant infe shortening 11440-2970 radis had decreased to 0.018 and 0.032 aberrations/Cell an anams with lung doses of 500-710 rads. At 380 days after injection of $50 \mathrm{nc}$ Pu 239 citrate/g o hamster 1 ymphocytes had an aberration

frequency of 0.048 aberrations/cell Frequency of 0.048 aberrations/cell. The
level of chromosome damage $3 n$ the 24239 fuor inhalation was at different than observed in controls. (Auth)

$\langle 31\rangle$

arooks, A.d...R. B. Peters, and J.C. Retherford, Lovelace Foundation for Medical Education ana Research, Inhalation Toxicologi Research Tristutute. Albuquerque, MH. 1974, Decenber

The liffect of licrodose Dastribution on Chrcosone aberatuons Brequency an haver cells of the Chinese Hamster Follcung Exposure to D1 utonial 239 Fuo2 ar ELutonzun 238 PuO2 Partzcles. IF 49 ; Part of Boecker, R. B. and Rupprecht, F.C. (Eds.), An alal keport of the Tnhalation Toxicology Research Institute, octoker 1.1973 through septemer $30,1974 \mathrm{fg}$. $174-178,394 \mathrm{p}$.

Chunese hamsters were anjected antravenously 1th Pu 239 Qu 02 or Pal 238 pu 02 particles of knowa size or with $\mathrm{P}_{4} 238$ catcate to determine the effect of particle size and specifac activity on the frequency and distribution of chromosone danage an the 11ver. Three partiele sizes were used in the

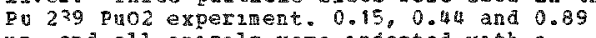
ud and all animals vere injected wath a constant activity. $5 \mathrm{x} 10(\mathrm{E}-4)$ uC 1 Pu $239 / 9$ th body weight. The pu 238 puo2 was injected in three particle sizes, $0.17,0.41$ and 1.1 un and at three actinty legels. The $\mathrm{Du} 238$ cutrate yas injected at 5 \& $10(\bar{E}-3)$ uCI $P u$ $238 / 9$ m body weight. Hameters injected wh Ev 239 Puo2 were sacrificed at 15,42 and 122 days after injection and those injected with e1ther Fu 238 Euo2 or Eu 238 catrate vere sacrificed 12 days after injection. The acproxinate sizes and distribution of particles were determined by autoradiogaphic nethods. The number of alpha tracks/staI increased as a function of the particle size injected. A change an particle size witn 1njected. a change an particle size wat aggregated into larger ones by the phagocyt aggregated 2 into larger ones by the phagocytic action of $\mathrm{k} u \mathrm{p}$ fer cells. Injection of pu 239 Quo2 and Pu 238 QuO2 produced a distribution of chronosone danage which was non-por nature. Plutonu 239 puO2 produced increased damage 1 th 1 ncreasing average dose wth some cells contanang a lasge auber of
bersations, but there was relatively little part2cle size effect. conversely. aberration

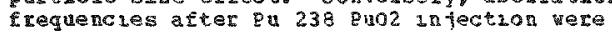


〈3i> cont.

1nverselp selated to particle size and no cells wex seen w1th large amounts or damage. The pu 238 citrate produced $6 \times$ vo(E-3) aberrations/cel1/rad which was a hagher rate than obserwed for pa 238 particles. This for Pu 239 illar to that observed previously for Pu $23 \%$ citrate. Risk for the production

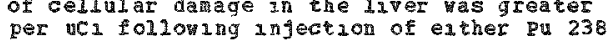
per uC 1 following injection of elther Pu 238
of pu 239 eitrate than at was following deposition of the same a mount of $\mathrm{Pu} 239 \mathrm{PuO} 2$ or Pu 238 puoz particles. (Auth)

<32>

Bruenge $r_{e}$ F. W. D. R. Atherton and B.J. Stover. University of 0 tah college of ledicime. radroblology Division. Departant of anatony.
Salt iake City. VT. 9963 . Parch 31

studies of the oxpation states of Plutonati 239 in Injectien solutions. c00-225: Part of Doughorty, T.F., pesearch in Radioblology. Annual Report of hork in progress on the chronac Toxicity erogram, $(p \cdot 62-72), 136$.

a study was made to determine what spontaneous changes occur an the Pu 239 injection solutzons durzing the 1 nterval $(1-3$ days) between preparation of the solution and injecticn of the dog. By a comblation of precipitation and spectrophotometric methods it has been shown that the plutoniua injected into the dogs is abont $98 \%$ pu(t4) and $2 \%$

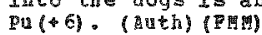

$\langle 33\rangle$

Bruenger, F.H., H. Stevens, D. Atherton, Gop. Taylor and B.J. Stover, Unzversity of Utah, Depatment of Anatomy, Salt Iake city. UT. 1972

The Effect of the physical-chem 2 cal state of Plutomiun on Its Earit Distribution $2 n$ the Inver. Radiation Resparch, 51, F39.

The early depostion and subcliular dastrabution of $\mathrm{Pu}(44) 239$ in carne 12ver followng admingtration of exther strictly monomerie $p u(+4)$ as a transferrin complex ( $P u-T f)$, non-polymeric $\mathrm{pu}(+4)$ in c1trate buffer pr 3.5 ( $\mathrm{Pu}-\mathrm{Bg}$ ) or largely colynerac Pus 4 in citrate buffer of 6 (Pu-P) has been stud led. Large duferences an the quantaties deposited and the intraorgan astribution patterr in the liver vere observed. IIver depositions ranged from $25 \%$ of tatal dose for the structly monowerze $(2 u-m f)$ an average of $32 \%$ for $D_{u}-1$, to ergalvalent to $70 \%$ for the largely pclyneric material. autoraajographs show that in 1 trally pull is deposited unformit and diffusely in hepatic cells whereas $2 u-P$ was found largely in rando clusters in reticuloendothelial cells. Cellular arstribntion patterns of pu-Tf ana Pu in irected dogs vere quite simlar. Inver nomogenates of e pu-h in jected aog and the andial unjected with Pu-t also were studied by diferemtal and sop scric sucrose density gradient crocedures. monomer po plutoniu In1tially assocated hth soluble liver protens, 1. Po ferriting and was found at

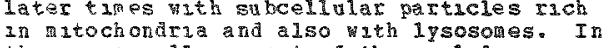
these organelles, most of the nuclide uas elther for in ane bound or possibiy associated wath beavy granular material. In homogenates of liver cbtaned from dogs ingected wh Pu-D nost of the nuclide sedinested wth nucler er mitochondria. Ho association of $\mathrm{Fu} \sim \mathrm{D}$ wath soluble protens could be domonstrated even at very short tapes after injecticn. (Auth) (romplete srticle) $\langle 34\rangle$

Bruenger, F.H., Stevens, B. Stover, and D.I. Beriner, University of utah, college of Anatomy, salt lake city, UT. 9964 september 30

Chemical state of Plutonum (4) c coo-119-231; Part of Dougherty, T.F., Research in Radioblology, Annul peport of work in progress on the chromic Toxicity programo (p.99-109) $173 \mathrm{p}$.

The method of gel-filtratzon was uged to study $1 n$ vitro the binding and the alstribution of Pu( +4$)$ in $\mathrm{aOg}$ plasta. It was found that the daln portion of pu was bound by albuin. OnIy a stall amount of plutonu was associated luth high aclecular weight protenns. The redua veight globuins of type 75 and -55 were essentraily free of plutoniug. (Aath)

$\langle 35\rangle$

Bruenger, F. B.J. Stover, B. Stevens, and D.R. Atherton, Unzversty of Jtah, college of medicine Radrobrology D2vision. Departient of Anatcay, Salt take City. UT. 1968, harch 31

rote on the Exchange of Plutorun 239 Between Tranfertin and Fertatin an Vitro. coo-119-237. Part of Dougherty. $x^{2}$. . Research in Radicbiology, Annual leport of vork an progress In the Internal Irradiation Progran ( $P$.

153-157!. 168 .

The transfer of $\mathrm{Bu} 239(+4)$ from trasferrad which is the transport prctein for 1 rong te ferritin, hich is a storage orotedi for

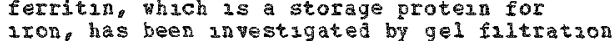
and gel electrophoresis. Jsing blood serua and ged electrophoresis. using blood sera Irow a bealie and equine ferri Iesults show that the reaction Fv $(+4)$-transferrin teritin-transferrin that under the specsfic conditions of thas exverinent the ferritin complex is more stable than the transferrin complex. (Auth)

$\langle 36\rangle$

EI uenger, F. h. B.J. Stover, and h. Stevens, Und 1 ersity of utah, college of medicine, salt

On the Bandng of Ameracium 441 in the canine Liver. Coo-119-240, Part of Doughertye T.F." Research in Radroblology, Annual Regcrt of Hork (2. $139-161), 279$ g.

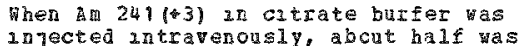
deposited in the liver of the beagle. The luver was separated into five fractions are connective tissue nuclei and debris, soluble material. The concentration of an s49 The solutie fraction as separatea according The solutie fraction was separatea accord tc molecular velght, and min 241 was foun with the raterial of highest weight

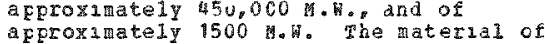
apprormately 1500 H. ho The materia associated 12 pofuscan. The materal of 450,000 \%. Wh. Was Turzfred and identified as ferritin. Tre association of A 241 wath fercitan 35 or high statility. The materal of

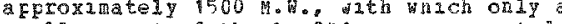
small amout of the An 241 was associated was not identified. Analysis of a digest of 
$\langle 36\rangle$ CONT.

the Incrosomal fraction showed an 241 bound to ferritin and to an undentified taterial of high velght. The reaction Am $(* 3)-t r$ ansferrin + fercitin results $1 n$ transferran + A $(+3)$ - ferratan was shown to occur in vitro as is the case wath gu (t) Linated results show the Pu 239 may also be strongly bound by ferritin an the laver of the living dog.

〈37〉

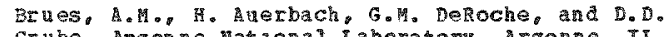
1965 . Decono

Hechanisms of Carcinogenis. Bis-7278. Part of Biological and Hedical pesearch DIvision Anzual Biological and iedical Research Di
Re port, $1966,(p, 132-134), 324 \mathrm{p}$.

This progress report dea ds yth the study and defintion of conditions under phren tumors are induced by local irradiation. special emohasis on the skin and 1 medrately underlyina tassues. Findings suggest that mouse artalt ty desends strongly on the portion of body irradated. After irradiating a somewhat snaller portion of the body surface $\left(50-60^{\circ}\right)$ than in previons study 1 it 7200 rads external beta radiation. mice survived Hellofr 6 months. Ho twors appeared after 7200 or 5000 rads (16 and 11 and Iymprocytes vas observed in the first week, followad by a rapkd recovery to moral valus. Studies on strin sections or harless mace treated ith $5000 \mathrm{rads}$ surface dose wich were grien tritiated thymald before sacrifuce showed that DHa synthesis was markedy reduced for one or to days after arkedi reduced for one or to als arter exceed the control. Stadres on the exceed the control. Stades on the

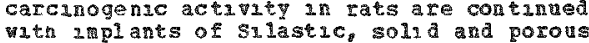
Teflcr cellophane, porous fiberglass Teflcn, cellophane, porous fiberglass
prefilters, solid alscs of reactor grade graphite, and illipore filters of 6 graded pore szzes. our attempt is mate to relate the grosth rates of beng an and alignat mannary tumors in rats to the histologic character istics of these turors, to the age of the anjals and to thenz exposure to x-rays or to alpha radiation from injected particula te pu 239. Mylar inplants contalning 5,10 or 15 uCl 5 r $90-190$ placer subcutanecusiy an ferale rats vere observed for one year and compared to anıals wh

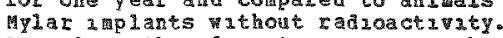

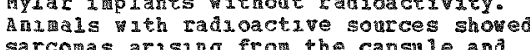
arcomas arising fror the capsil 1 an pndings fo experiments an weh particulate randings to experinents an he Iu intramacularly into rats vere as sol rats retaned, at about $1 / 2-2$ yrs.
folloulng 1 ingecton $25-45 \%$ of he dose at

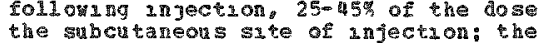
the subcutameons site of anjection: the I- $2 \%$ vas found in the laver and $0.2-0.3 \% 2 n$ spleen. A comparison of wce injected subertaneousip yth paxtaculate ou 239 (1.33 ug) and 2 on 16 Pu 239 (1.20 vg) shosed that vith the former, $48 \%$ remangea at the injection ste ant $11 \%$ appeared in the skel eton; with the latter, $3 \%$ remalned at the site and $26 \%$ was deposined in bone. (RAF)

$\langle 38\rangle$

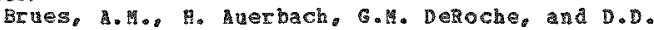
Grube, Argon ae pational Iaboratorv. Argonne. IL. 1965. December

Mechanisns of carcinoqenesis. ลm-7136, Part of
B.0logrca and Medical Research D1Viszon AnmuI Pepore, 1965, (p. (64- 466$), 333 \mathrm{p}$.

sprague-Dawley ferale rats each recenved 8 s1 tul tareous gubcutaneous un jectsons totaling 9.9 .2 .2 . or 1.3 ug o polyeric. partaculate pu 239. D1so, because of the unown high incudence of hamary tamors in intact females and cr an apparent uncreased higher dose levelis were admastered to castrated females. in adultonal group recented a single 2 inection of $1.3 \mathrm{ug}$ antranscularly 1 sto the raght thigh ascles. In mace, single subcutaneous injection of $1.3 \mathrm{ug}$ of polymerze particulate gu 239 yas given and 1 ts effect was compared with that

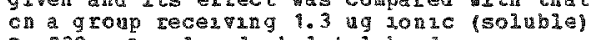
pu 239 . Local and streletal burdens were Pu 239 . Local and skeletal burdens were wasured as a function of time, and tumor
were examped histologncally. Tro years after subcutaneous anjection of particulate Pu 239 about 35 of the anjectea amonnt remarned 2 the area of injection. rotal remaned 2 the area of 1 njection. Total
sheletal burdens in excess of 1 ug appeared after the hagholevel injections, and bone twiors appeared in these rats after 360 days. where the total zinjectrons were below 2.6 ug, skeletal burdens were less than $0.2 \mathrm{ug}$ and no bone turors appeared. The castrate group showed somewhat hagher sheletal burdens than the correspondang antact animis. Sas wonths after intrarascular ingection ther vas a retention of about $80 \%$ in the in jected - iscle. Injection-site sarconas Iil rats began to appear in the hagh-dose groups at 360 days, the sale tine as the begining of appearance of bone tumors. In ace injected ith particulate pu 239 the first bone tur appeared at 328 days: in those 2 nected yt come naterial at the sane dose land rath

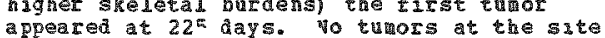
of 1 inection appeared in wice. hem

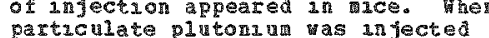
subcutancusly, autorad 10 ra phs showed "starst subcut ancusly, autoradiographs showed sta in the area of local injection inacatug were seen in the skeleton, liver, spleen, and in locally roduced sarcomes manceting that transfer froa the site of pritar deposition occurred following depolyserization or sclubildzation. (FM

<39>

Brues. A. H. H. Auerbach, G. D. Deroche, and Io Bllarski. Argone vationa l taboratory. Argonne. II. 1964, Decerber

Vechansms of carcinogenesus. MHL-6971: pert of

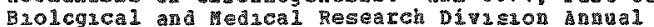
Report, 1964, (p. 47-48), 223 p.

The carcinogencity of loca11y 2 glected $Q u$ 239 was exalned comparatively li specses of giferent size. Local zlectuons of particulate suspensuns of plutonum vere given to rats and lace and a series of fenale rats was ovarzectcused before injection in order to prevent the ordunarily high ncidence of amary tuross. Lasger animals (rabites and doge) 11 be 2 meluaed in later experanents. \$3 plutonila 13 revoved from the injectson 31 te (as ntha led plutonim particles are from the Iung) andi through incorgorat 10 n 2 ito lacroprages experiments were carried out using suspensions of plutoniu 239 particles o deter mine thest effects on macrophages an tissue culture. The fate or cells wh ingest these aipham eatung particles 121 be

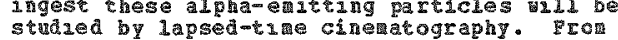
the results it aprears that particulat liton iu ls a satisfactor pre paration for 
BIOLOGICAT BSPECTS

BUIHALS

<39 $\operatorname{con} \mathrm{T}$.

Inducing subcutaneous tumors since $100 a l$

tamors were beginnang to occur in rats given 2njecticns of 1.0 and 0.4 uCh. (FH)

$<40\rangle$

Bukhtoyarova, z.M., V.K. Lemkerg, and 5.5 . Freisinger (Transiator). ncadery of medical sciences, uss?. 1959

Tuars Develcping in ats after Intraperitoneal Ingection of Plutoniun Nitrate (Platoniu 239). Voprosy onkologin, 5(8), 140-148; Probleas of oncology.

white rats weaghing $110-130$ g were alanistered plutoniu nitrate as a sangle intraperitoneal injection at po 2 in ases of $6.3 \times 10(\mathrm{E}-3) .4 .0 \times 10(\mathrm{E}-3), 1.89 \times 10(\mathrm{E}-3)$. $0.3 \times 10(\mathrm{E}-3)$ and $0.315 \times 10(2-3)$ ac $2 \%$. Sury 3 val $(2-3)$ and

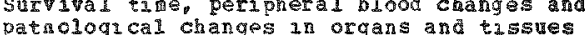
patiological changes in organs and tissues were stud sed. The average surva val tal we Pr doses of $6.3 \mathrm{x}$ 10 $(\mathrm{E}-3) .4 .0 \mathrm{X} 10(\mathrm{E}-3)$ shorter than that of the controls. Finangs suggest that developpent of osteogenc sarccuas teoresent the mcst 1 mportant late conseguences of accumulation of $\mathrm{Qu} 239$ in the body. All fuve doses caused appearance of osteogenic sarcomas and of various soft tyssue turors (mamary gland, endocrine gland. Fitustary turors) in the rat. The dose of $1.89 \times 10(E-3)$ u $(1 / \mathrm{kg}$ of $\mathrm{Fu}$ istrate represented the optital sarcomogenac dose. ostoggenuc sarcomas were characterized by multicent ric growth and by poly morphous structure. soft tzssue tuinors shoted greater $v$ araty and were less differontuted than in the control anilals. (RA

Doses and rumber of anmals bearing tumors, and localuzaricn and type of soft tisue turors are given in 2 tables. The relation between the developient of osteosarcoma and dose and ture 15 given in graphe form.

$<41\rangle$

Buldakov, I.A., R.A. Frokhng, and A.P. H Ifacov, handstry of Health, Instutute of Baphysics, Mo scom? USSR. 1968

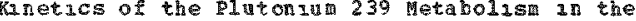
Case of prolonged Peroral Admzistratzon. AEC-tr-7013: Part of Padioblology, (p. 16/-171). 232 . : Radioblologiya, $8(6), 900-907$.

The distribution in the Internal organs. resorption an the gastrontestani tract, atd solution of plutonum adrinistered pesoraldy solution of plutonum adinstered perorald dally at doses from o.01 to lo uci per day were investigated in experiments on 337 rat the isotope in the intestires does not depend the asotope in the intestrnes does not

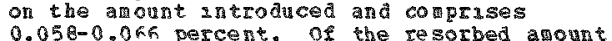
0.058-0.0h percent. of the resorbed amount 1a the skeleton, $71-83$ percent is retained I the skeleton, $10.4-20$ percent in the liver.
$2.5-6.5$ percent 27 the kidneys, and $2.2-7.6$ percent in the lungs. The alstrabution of the 150 to ne in the internal organs a diffuse, whle in the lumen of the gastrontestanal ract $2 t$ is affuse and in the forl of "stars" frol the tracks of al ma partucles corresponding to fragnents of plant cells of food masses. The sites of the "stars" are situated on the surface of the nucous menbrane of the GI tract. In areas of erosion and deep uleers in the $G I$ tract. erosion and deep ulcers in the GI tract,

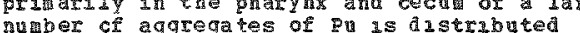
nuaber cf aggregates of pu is distribute accumulation of piutonsum in the internal organs is descraked by an exponential function and for tre sheloton takes the form $\mathrm{R}=0.0478 \mathrm{x}+(\mathrm{E}-0.878)$. Whale the sadiation dcse rate increases during the entire lire of the anumal. In the large nitestines, the dese rate is practlcally unchanged during the ferzod from tie furst to 600th day. (Auth) (Fin)

<2>

Bulakov, I.A., E.G. B112ppova, and G.V. Rhalturin, Manstry of Health. Institute of

The rate of Plutoniul 239 in the case of Subcutaneous Injection

The behavior and rerodistrabuticn of Eluton 1 um 239. injected subcutaneously. in the hexa and the tetravalent polymer form vere studied an experiments on gunea pigs. it mas shown that $T$ sub of or plutoniu $3 \pi$ the hexa and tetravalent monor rorms and tetravalent polymer for for the s10xyy exchanged fractions 1586,80 , and 1220 days, respectrvely. The aan site of deposition of the absorbed platonza is the ilver and skeleton. A decrease $3 \pi$ tre act 31 ty of beza anä tetravalent monerer clutona in the I2ver occurs with sub off 39.5 and 79.5 ays, respectively, whic for plutonus of the tetravalent polyer for it occurs w th $T$ $\$$ ob of $f=240$ days. The activity of the Lsotope in the skeleton decreases period of 134 ays. The microdistribution of the introduced plutenum compouds in the skeleton is monotypac: in the liver the hexapalent and tetravalent ho diver the astributed difusely, while the polymer

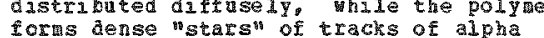
partacies. (Auth) (complete text)

Thas nanuscrapt as degcsuted an VIPITI as No. 3639-71 Dep from octooner 26,1971 .

643>

BuIdakov, E.A., E.R. Lyubchansk11, Yu.I.

Moskalev, A.P. Mratov, A.A. Horvath

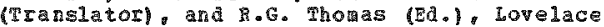
Foundation for Medical Education and Research. Inhalation Toxicologi Research Instztute. A1buguergue, 19. 1970, June

Problens of Plutonulu Toxicology. I. $P-t x-41,225$ .

Thas book contalus a sumarazation, systematization and analysis of the Fublashed data selating to the toxacaty of plutoniun. The principal areas assussed are physucal and chemeal propertzes of Pa 239. alstribution of Pu 239 in tho body a ferer varzous routes of adninstration, b201093cal effects of Pu followng varzous roukes of adunistration and the basis for setting the Daxinut permissible 110its of Pu 239 in the human body. as and water. Four-humded and then references are listed. (RAP)

《44\$

Buldakov, L.A. Yu. I. Moskalew, and V. H.

Strel'tsova, 1961, December: 1961, Hovewher

Observations on the 81ological Action of

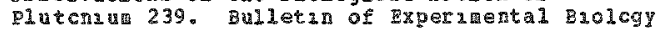
an tenc

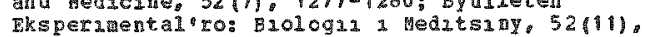
Eks per
$57-61$.

Whute rats weighng $182 \mathrm{~g}$ were given 
BTOLOGTCAL BECRS

A I I HALS

<44> conT.

2ntraperitoneal injectsons of plutonu

citrate at pa 5 in mounts of 0.00125 .

$0.0025,0.005,0.01,0.02$ and 0.08 acs/9.

The effects of plutonam 239 on the life

span. velght and peripheral blood as well as

on the development of bone tumors was

invesergated. Thmemerfect and dose-effect

curves vere traced and their relatsonsh

wath the IIfe spar, body weight, erythrocyte

and leucocyte count vas established.

According to the life span craterion, the

action of $\mathrm{Pu}$

The naximal noneffectave dose of Pu vas equal

to 0.0025 uc $/ / 9$. Thth the admins stration of

Pul in a dose of $0.0025-0.005 \mathrm{uC}_{2} / 9$ a bries erythroctrosis vas found subseguenty Eollowed by stabilization of the nulaber of was given in higher doses an anemia lad was given in higher doses an anema leading toth-30th day of the mperament. Leak kopena $14 t h-30$ th day of the experament. Leakropena occurring as a resule of pa adninistra was irreversible. The 1 Incidence of
osteosarconas $3.1-27.2 \%$, and was about the sare in lales and in females. (RAF)

tabular data are given on mean survival tue of rats and on the 1 neldence of osteosareomas. changes 3 the nuaber of lencocytes and exythrocytes at difforent tue intervals after Pu znjection are shown graphrcally.

《us

sustad, I.K., R.A. Strtzel, E.R. Haro, and ho Goloman Iniversty of Cali forna Radrobjology to boratory. Davisg CA. 1972

The Chorce of the Beagle for Padroblologic Studas, patt ef Stover, B.J. and jee, (FdS.). Taduobrology of Plutonuta. J. Press. valt lake Cityo otah, (p. $203-212), 552 \mathrm{p}$.

organally choser for waspread experizental use on the basis of caretaking, anatomic, and physologic considerations, the beagle has proven to bo an excellent model for sytento studzes phose results way be applied to nan. There are wumerous parallels among the late systemic efocts of intermally deposited ensters and of external radiat ion to the beagle and van, and the breed is aking vortnirile contributzons in several areas: in radionuclade toxicity, as a model in the scaling of the effects of alkaln ne eath radionsclides on hone and bone merrow and blood, $2 n$ respratory thysiology as a model
for the pulmonary affects of inhaled raduonuc $c^{2}$ as; $3 n$ reproductions where it 35

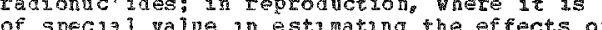
of 3 pecia value in estinating the extects of fetaland baceline data acgur red orer the past 20 yea should enable userul extrapolations to be avelve processes 1 nvolved sin 3 ging as rell as on radiation-induced alterations, particulardy oncodenesia. atablished corollaries betwen cann he and human ages provade a userul terplate for the scaling of dose-response over tye esstntial to gantrealang the effects of low-1evel, longoterm exposure to radiation and to oviluatia possible risas to human copulatzons. (Auth)

$<463$

Cable, Joh. V.G. Horstman, and Lok. Bustad, lanford Atom oroducts operat $10 \mathrm{n}_{\mathrm{g}}$ Rzehland,

-ffects of Irtradertal Injections of Plutonum. ज标-72500; "art of Kornberg. R.A. and Swezea. E. $G($ (de.), Panford Brology Pesearch Anna E. G (Eds), fantord Brology Reseren
Fight blond lumature sune, sux being held for lifetrae observations, pere injected 2atraderally w plutonaunatrate at various sites on the lateral thoraczco-abalonal regron. The quantaty of plutonu detected by external montoring of the sites in lected with the three highest dose levels varied from 98 per cent at one day to less than 2 per cent after 565 days. A consaderable variatron an the degree and duration of the gross pathology. e.g.. inflaration and $\$ 1 z$ of ulcer. occurred between similar sites a vong animals. (Auth)

$\langle 47\rangle$

Catsch. A., Nuclear Research Center. Instatute or Radioblology. Karlsrinf. German Federal

Raducactive Metal Hoblization. Federation proceedings, 20, 206-219.

The nechansm of action and effectrveness of various chelating agents is described. Dimercaptopropanol (BAL) vas ineffective aganst radionetals of practical interest.

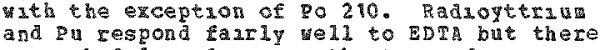
1s maked dependeace on the tare of admistration. The significance of relatzve chelate stability is pointed out as in the case of $1,2-d i a n$ nocyclohera ne tetraacetic acad (CDTA) wheh has substanteliy hagher stability constants than EDT for most aetal lcns, bat only slightiy different relative lcns but only slightiy different relative
stabilities. Its brological effectiveness 25 thus comparable to EDTh and not superor in thus conparable to Evil and not sup fadorttria. Results frotexperiments wh 5adoyttrian. Results fro experiments wit rats show the considerable differences 1 . -ifectiveness beteen EDT and DTho the

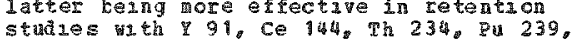
$\mathrm{Fe}_{\mathrm{g}} \mathrm{Cr}, \mathrm{Co}, \mathrm{z} \mathrm{n}$, qn and $\mathrm{y}$. The higher hemologue of DTPA, tenwatere

triethylenetetranuneharacetic acia (TTHA). when admistered early, nublots depositack of radiocerrum, and radroyterium in the skeleton tuch wore than DrPA. In experimonts on the unfluence of chelating agents in the

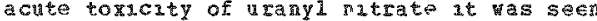
that when a single acse of the chelating agent was administered earby the ID 50 of 0 was dncreased from $6.7 \mathrm{mg} / \mathrm{kg}$ to $12.4 \mathrm{~kg} / \mathrm{kg}$ by EDTA and to $16.2 \mathrm{ag} / \mathrm{kg}$ by DTPA. However, the tomicity of TTHA Was $100 \%$ lethal to U injectea anals witha cme hour of adrunstration. In the case of

\section{Fadiostrontzun, DTP proved to pe just as} Iadiostrontzun, DTP proved to de just as in radiostrontiula deposition an the skeletca in radiostrontiu deposition an the skeletcn
has been ortained ith Diagond ast Blue bat sance this dyestuff in effectio doses has proved strongly toxic ant sometimes lethal, it has no prectacal importarce. The tole of the kidneys in the effectveness of chelat agenes $2 \mathrm{~s}$ dsedssed and experinents th causes a arked increase of radictiotal

excretion an the fetus also, especially in the case of those, which like raliocerium, are deposited to a large extent in the liver. The differences an the extent to wach the Eadronetal in the 1ryor and skeleton can be depleted by DTPR vere shown for Eu. dasly admuntration of DTPA over 2 veeks reduce the pu content of the liver to 3 of of the control, while that of the sheleton fell tc 50\%. It 35 suggested that the extectiveness t Dipa as aue to its penetration anto the intraceliular space particularig in the 
BTOLOGIC AL ASEECTS ABI

<47> cont $\mathrm{T}$.

process were intensified, there would be a correspon aing increase in effectiveness. The guestion of DrPA toxicity is discussed

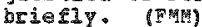

Table I shows effect of CaMa3-DTPA and

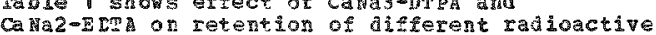

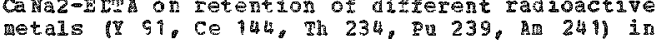
aetals Table 2 shows effect of sodiug rats. Table 2 shows effect of sodiug 14 and colyphosphate

<483

Catsch, A. Muclear Pesearch center, Institute of Radicbiclcy. Rarlsruhe, German Federal kepublic. 1963

Toxicology: Padioactive Metals. Annul Revier of Pharmacology, 3, 243-266.

a reviev is given of the toxicity of interrally deposited radioactiye metals. The behavior of a given radiometal in the organis can uitimately be explained by certain chemical, particularly cortain chencals particularl processes. An exact mathematical for pecesses. An exact rathematical for an lation of retention and excretion of a radionaclide is of great practichl importance in so far as it is a requisite for the calculation of MPC values. The temporal astribution of the radiation dose zeens to have difference importamee for radiations wh ifferent IF. a guantit ative analysis of rads otomicity reguires a aeteraination of the radiation aoses administration of given amount of radionucides. In this, knowledge of the retention functions as vell as the wicrcscopic distributicn in the organ is needed. Fossibilities of therapeutic treatment are mentioned, the most promising

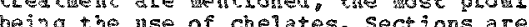
devoted to indivianal radionetals incluang tho transuric olements. the rame eaths and vterim, thoring poloni un the alkaline parths, andiscellaenous metal a (II 192, Ca

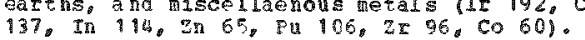
For the transuranic, the getabolic behovior of A 241 in rats is comparea with pu 239 . fhere is saster Ienovil of Ar 241 from the 13ver and reduced initial deposition in the skeleton. Several experimental results are cited. Dolt $20 \%$ or an inhaled pu 239 Fuc2 aerosol wth a mean particle size of 0.2 u was retained by lung of mice. ysing experinental data the MPC for nan is computed as $1.6 \times 10(\mathrm{E}-90)$ uci/lal air compared to the Walue of $4 \mathrm{~g} 10(\bar{r}-14) \mathrm{uCi} / \mathrm{l}$ l recomended by the ICRE. Concerring the dependence of pu 23 toxicity por the dose rate, it is reported that single coses are significantly rore effective than fractionated ones in the inducticn of he ratological reactions, and the reducticn of the liffospan in rats. The reducticn of the lichon in rats. The man following contanination by E 239 is man fcllowing cont

$\langle 49\rangle$

Catsch, A. Mclear Feserch center, Institute ot Radíbiology. Rarlsruhe, Gernan Federal Repubic. 1952

principles and Treds in Therapeut ic Reroval of Interna 1ly Deposited Radionueliaes. Health Elysics, $8,725-730$

The general principlos governing the therapertical removal of radionetals oy

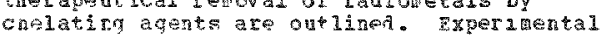
chelatirn agents are outher deperdence of chelate effectiveness on the number and the fature of ligand ators as vell a $z$ on the molecular configuration of the ligand. Inglications derived frot

experinental data and sor the - viticorpartmental nature of a body orgat for wcrking out an optinal dosage schedule are

discussed. Several experimental results are discus sed. several experimental results ar discussed, for exalule, those dealing with the effectiveness of chelating agents (EDTA, DTFA, THA and THA on retention of $Y$. 144 and Th 234 in rats when treatwent is early or delayed. The effectiveness of nuliple chelate doses if also discussed and experiments cited, anong then studies on the removal of aonoweric Pu 239 by aultiple DTEA doses $(500 \mathrm{mg} / \mathrm{kg})$ from liver and skeleton of the wouse. whe effect of esterified Eclyaninoacids is also briefiy discussed. (Auth) (F)M

Figure 6 shows removal of monomeric Pu 239 by Duitiple DTPA doses $(500 \mathrm{mg} / \mathrm{kg})$ from organs of the Douse: Figure 1 shows effect of EDTA. DTPA TTH, and TPH on the retertion or radiometals (T) $91, \mathrm{Ce} 944$ and Th 234 ) by orgars of the rat. The calciun chelares $(250$ an/rat) vere

aduinistered a rew minutes cost-jajection fearly aduinistered a rew Binutes cost-jajection treatremt.

$<50\rangle$

Chipperfiela, A. A., and D.H. Taylor, Institute of Cancer Pesercin, Department of Bicpnysics. suttcr, surrey. England. 1970

The Binding of Americiul ard plutoniug to bone Glyceproteins. European Joural of

Biochenistry, 17, 58 !-585.

Ey ileans of a gel filtration techngue it is shown that plutonin and americiu aifer in their mese of oinding to two glycoproteins isclated from bovine cortial bone. Elutonias binds more serongly than agericiun.

Flutoniun bunding is maxial at on 6 and

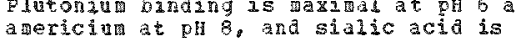
involved in the biraing of plutonium but not involved in the birding of plutonim but elements bind to glycoproteins in vitro are aiscussea. (Auth)

〈द 1 >

Chriztensen, 以.R., 特.S.S. Jee, G. H. Taylor, and N. Nebeker, "uiversity of Utan, college of Medicine, Fadiobjology Division, Departant of Anatcry, Salt Lake city, JT. 1972

Distribution of Internal Radiation-Induced ostecgenic Sarcoma in Varions species. Part of

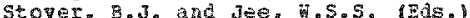

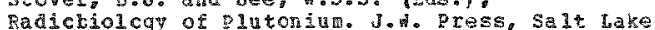
city, ytah, (p. (95-202)。 $5 \mathrm{k} 2 \mathrm{p}$.

The localiation of ostecgenic sarcosa varies markediy from species to species, whether occurring as a "scontanesus tumor" or as a result of an internally-decosited,

bcre-seeking radionucilde. In humars the scontaneous tumors shoved an unusua? Fredilection for the reyson os the knee jeint. Fa $22 b-i n d u c e d$ tuors in hamas are 1 ccatea pribarily in the appendicular skeleton $(90 \%)$, rat there are relatively fev at the phe foint. The most comon site is the pelvis. In dog $60 \%$ of the

radiation-1nduced tumors were found in the

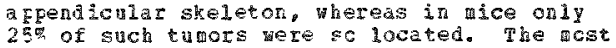
ccomon site in the jouse is the vertearal ccium. Tn the case or hoth dons andice the distributions of $\mathrm{Pu} 239$ and Ra

226-induced ostogenic sarcoma vere quite 
$<51\rangle$

ETOLOGICAL ASEECTS

AMTARSOS

(a) conto

1assinilar. (Auth)

Table and Table 2 give the distribution of spontanecas esteogenic sarcomas in argans. Table 4.5 and f give the distribution of osteogenic sarcoma in agso Tabie 7 and 8 give the distribution of osteogenic sarcomas in mice.

S2)

Clarke, J., and

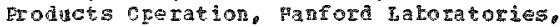

Eachland,

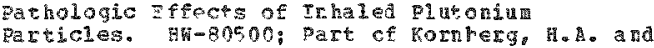
Swegea. E. Go Eds. panford Biology Research

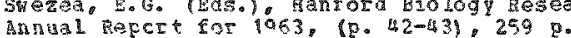

Inhalation of $P$ r 239 puoz particles by beagle

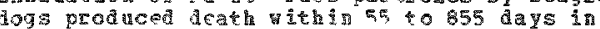
anials having lung buedens of 2 to 27 aci. heaths were preceder by a progressive ipphoperia and respirat ory listress. beposition of the particles in the lungs was tolloved by substatial translocation to the bronchial and mediastinal lyaph modes. Pulachary lesions consisted primarily of severe filrosis followed ty metaplasia. althouh primary Ing carcinoma had not been observed, mant of the changes that hat oceurred were $a$ int lar to those found in those Reoplas

Table 1 shcus time of death and body burdes data in beagles inhaling pu 239 puor rertieles

$<53\rangle$

clarke, w.J. J.Z. Mckenney. V.G. Herstran, L.J. seigreur. J.I. Terry, and I.R. Bustad, Fanford Atomic Froducts operation, Richland, 1959. January 5

Flutoni uetabolisa in minature suine. EW-59500: Eaz of Davis. J.3. (EA.) thanfora Bioloyy Research Annial Report for i958, (p. $54-60), 156 \mathrm{~F}$.

The bloca uptak, tissue concentration, boty burden and excretion pattern of plutoning varbously adnistered, vere studied in tourteen vearling ainiture swine of the hormel strain. inteilly areraging $70 \mathrm{~kg}$ in body weight. By the intravenous coute, 5 uCi of Pu 239 vere ad (t) cit cite at pH 6.0, by the intratracheal route. the dose was $30^{\circ}$ uci as pulthi vitrate at pH 2.5. and by the intragast It route. 600 uci pere arainistered as (Pultu) aitrate at pH 2.0. It was shovethat the percentage of adrinistered ase of pu 239 recined by the dal $\mathrm{min}$ iatures sine at 600 days adul 20 in iature smine at 600 days as about after intragastric adainistration. The afte intragatric adanisticton. Tie plutcnin showed a higher concentration in 1itre than in bone, regaraless of path of entry. The eli was dependent on coute of adrinistration beigg 510 w

Table 3 show concentration of er 239 in liver and bone at 30 and 500 days after administration.

$\langle 54\rangle$

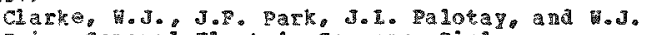
Bair. Generd Electric Compar Biology

Bronchiclo- Iveclar Tugars of the cantre fung Fol loring Tr hal tion of glutcnium Carticles. Fol lowing In halation of Plutcnin Rarticles. 
BIU] JGICA R BSFCPS RNIMALS

<50 CONT.

project heals vith the blologac action of $x$ and gamma rays on mice, gurnea pigs and

rabbats. Pathopogral and henatological fundags are gaver. (Pan)

$\langle 57\rangle$

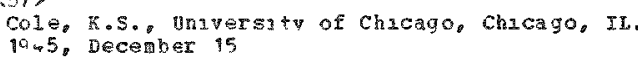

B1ologlcal Research section. Cri-3358; part of Jacobson, I, Co ot al, Report of Health

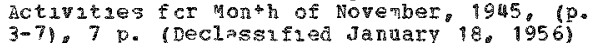

The absorption of angested pu was straled in G2x rats that were ven

g3ver plutongu bo stomach tube as the plus a nutrate at a concentration of a hout 0.5 mg

Fer 1 and at a pH of about 2. The actual

were sacrificeat antervals foilowang

ingestion and to fem

the rats were ashed and aralyzed. The fewuts

the rats were ashed and aralyzed. She tenuz

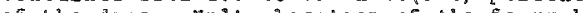

of the ilose. Multiplication of the fenur by

cron 8.7 to $25 \mathrm{x} 19(\mathrm{~m}-4)$ percent of the dose.

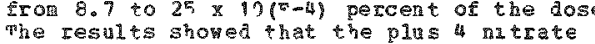

given crally to rats at a level of 4.7

Mlcrograms per gran was absorbed from the

gastrointestinal tract in an awount not over

$3 \times 10$ (5-3) percont. In another epernant the hematological effects of Pu were studied an $A B C$ zale mace that were given 0.25 microgran/g of plutoniua. The hemoglobin level shoved moderate, progressive reducticn that reached its lowest pornt at 25 weeks. Erythrocyto counts shoved a 10 to 12 percent reduction that persistod throughout the 40 wells of the experzinent. The

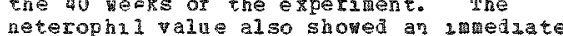
reducticn that Ieached 3 t\$ at 8 veeks. Recovery folloned repidy after at 8 veess. hecovery folioned rapialy

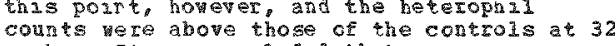
Heeks. It was concluded that recover occurref in the heterophil count in spite of cont 2 mus a a radiation, but that no recovery occurred in the red cell and lymphocyte

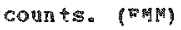

Taple I shcws absorption of orally admandsteren Qu by rats.

$\langle 58\rangle$

Cole, K.S., J.J. Hacksen, and J.G. Hamzlton, Ur iversity of chicago, tete linrgical Laboratory. ch 3 cago, II. 1944, fugust 17

Honthly zeport on Problems Relating to Product for persoéc Ending Julv $31,1944, \mathrm{CH}-1990: 6 \mathrm{p}$ (Deciassifued Janury 2,1952

The wonthy grogress report updates work being perforied at the litetalurg $\$$ cal Iaboratory and oniversity of Califorma Fadi ation laboratory. vork in the blological research section is continung wh studies

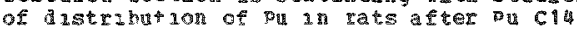
aerosol inhalation oxcretion and toxicl ty of 2u cl4 in rabbsts. Eats, and ace, and radu exgerzats. The ladical Industral mazard Section reported an surveys of personnel and facilitieg for radiat lon contaminatson. cont anution of studies by the onatersity of call fornia Radiation Laboratore are resorted on radioautographzc studies. tracer studies. and decontanimation studies. (BBH)

$<59$

Cole, K.S., J.J. N.cksor, and J.G. Hamlton,
Unaversity of chacago, Chacago, IL. 1944, JuLy

Monthly Health Feport or Dronlens Relating to Procuct for Feriod fidang Jupe $30,1944$.

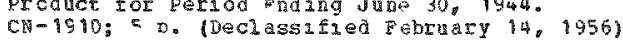

The monthly health reports fron Clintor Laboratory updates vork in progress at the vetallurgical laboratory and the buversity of Callforna fadiation Laboratory. The kiological research section covers zork beng acne or aerosol production, Pu Cl4 aerosol exposure studies on rats, and analytical recovery of the product frot tussues. The Medical Industrial hazar section reported or surveys of radiation and contamination of fachlities and personnel. Reports on metabolic studies of plutonum are updated fer radioautographic studzes and tracer studies on anzals. (BBM)

$<60\rangle$

Crasg, D.R., R.I. Buschbon, and JoP. Herring,

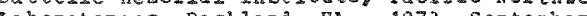

Relationsaps Between the saze Distratuch of Pluterana 239 Buoz Aerosols. serosol

Concentration, and Nebulizer suspensto

concentration. Bind-1650 (Past 11: 2art of Thempson, R.C. (EQ.). Anual Report for 1971

(p. $178-189), 313 \mathrm{~F}$.

In a study of low level effects of inhaled $p$ 239 Puo2 in beagle dogs, alveolar burdens over the 1500-10ld range from $2 \mathrm{BCl}$ to $3 \mathrm{uCs}$ vere deposited inuanesthetazel dogs by aerosol 2 halation. Aercsols vere generated by nebluzing magrietrcally stared suspensions of pu 239 puot particles 1 is vater: the aerosol concentration (Conc) being varied, pramarily, by changing the pu

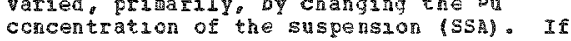
cricentration of the suspension (SSA) If the ass concentration of the suspension was good corredatzon $(R=0.827$ for $n=64)$ wa $\$$

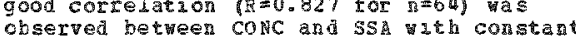
ar flow through the excoure cramer. 3 m values from 1 to 600 uCl/al gave coflc values in the range 1.5 to about $3000 \mathrm{nC}_{3 / 1}$ however, the aerodynamc egumvient $s_{3}$ dastribution also varied signaficanty wh conc. The activity median aerodynamic dianeter (AMAD) increased from and 1.5 to 3

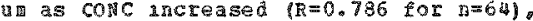
whle the geometric stardard dewation (GST) decreased $(R=0.576$ versus $A M D)$. These otseryations help te explain the large variation observed in the percentage alveolar

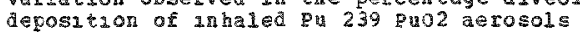
from less than $1 \%$ to nearly $50 \%$ in 64 dogs from less than lo to change in AMAD from 1.54 un (GSD 2.61) to 2.77 un (GSD 1.61 ) decreased the percentage of Pu 239 activity al cartucles having of Pu 239 activity al Fartacles havag aerodynamic equialeat dianeters less ul from 32.63 to 9.62 . This effect on
farticle $\$ 21$ is the najor factor deterning percentage alveolar degosition. (Auth)

$\langle 61\rangle$

Crotley, J., H. Iang, K. Scott, and J.G. Hallon, University of Chicago, Chqcago, II. 1946 , May 31

A Comparison of the vetabolas of Patony (p1utondu 238) in man and the Rat. Ch-3589:16 p. (Declassified Hovenber 21, 1956)

The fate of plutonan angected 1 ntravenousi iato a huran subject and a beo rats yas followe in parailel studies. The 
BROLOGICAL AS PECTS ARIMRLS

<61> CONT.

distribution of plutony anong the eqsines of the body and the average darly rate of excretion of this elevent vere compared in wan and rats. Tn genera1, the results of these experiments showed a high degree of prolonged retention of plutoniu in the body. kith selectrve deposition in the skeleton. especially an the region ad facent to the bone marrow in the end esteus and trabecular bone. The ellar mation of plutonau frol the body occurs at higher rates in rats than in man. During the course of these studies, rats elamated $50 \%$ of the plutomin admistered. elininated 5om or the plutomin admistered ondy about $5 \%$ as excreted. phe limination of plutorivi as primarily in the feces in rats and in man the rajor ellinintan of rats, and in man the rajor elliminaton of
platony occurred va the urine. (A uth)

<628

Dagle, G.Z., Colorado state ynuersity. Fort Collins. Co. 1973. August

ly ah Node clearance of plutoniun from Subcutaneous wounds in Beagle. Coo-1787-18; $\mathrm{Ph} \cdot \mathrm{D}$. Thesis, Colorado state unutersuty; 127 p.

The Iymph node clearance of plutonumaxude from subcutaneous implants mas studied in adul beagles to siaulate accidental contamation of hand wounds. External in sit scintillation da ta vere collected from the poplitial 1 inoh nodes of each dog after the poplitwal 1yph nodes of each dog subcutanoously 1 mplanted into the left or subcutano ously anplanted into the left or right hind pars. The left hind paw was amputated theeks after inplantation to prevent continued aeposition of plutoniul oxlde particles in the left poplateal Iyaph node. Groups of 3 dogs were sacraficed 8 , for histopathologie, electron mucroscogic. and rad lochemical analysis of regiona 1 Iyph nodes. An additional grcup of ags recelved treatment with the chelating agent alethlenetriannepentaacetic acid (DPTA). plutonz un raplalw accugulated $2 \pi$ the popliteal lymph noles after subcutaneous 1njection into the hand Fat, and $1 \%$ to $10 \%$ of the laplant dose was present in the popliteal lyaph nodes at the trae ct necropsy.

HIstopathologic changes in the poplitea 1 loapn neder wath Flutenum farticles were characterized primarilv by reticilar ceil

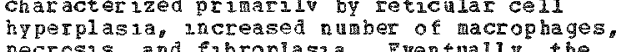
necrosis, and fibroplasia. Fventually, the pluton un particles became seruestered by scar tissue that often replaced the ent architecture of the Iyth node. light macroscoolc altoradiographs of the popliteal lyaph nodes showed a time-relatea increase in number of alpha tracks per plutonam source. -1actron 1 icroscopy showed that the plutoniu partucies were aggregated in phagclysosones of macrophages. of plutchulu from the poplateal lyaph nodes of dogs non tored for 32 weeks. The clearance of plutonum particles from the popliteal Iymph nodes was ascociated with necrosis of macrophages. The external 11200 lynph notes contalned fever plutonum particles than the popliteal lyaph nodes an histcpathologac changes were less severe. The superficial lagural. ly mph nodes of one dog contaned appreciable amounts of olutconul. Treatment with DTPA did not have a measurabie effect on the clearance of clutcnum frci the popliteal ivaph nodes. plutcna

$<63>$

Debols, J.M., Samt Rapha1l unquersity Clunc,
Iounan, Belg1u. 1966

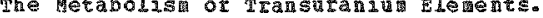
Bulletin d'Information de I'Assocjation Belge

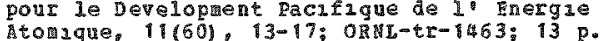

A reviev is given of the toxicyey and general characteristics of the ecabolism of the

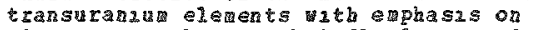
plutomia. Elements brieriy alscussed are americiug, curium and californu. The detailed discussion of plutonu deals with general tharacteristics, perussible body burden, absorption, 2rhajation, injuries findings in wa and long-ter particularly 1 is the skel eton. emposure to transuranics are mentioned. (RAF)

<4\$

Debriyn。 P.P.

Lyph wode and Intestinal Iy phat 10 Tussue. PaIt of Bloon, (Ed.). Hastopathology of Irradiation fros External and Internal sources, Chapter 8. McGIav Hall Book Company. Inc.s New York Hew rork, (p. 348-445), 808 p.

The damage in the lymph node of anmals exposed to $x^{-r a y s}$ is correlated 1 th the anount of raciation. This correlation is seen $3 n$ the amount of debris resultang from seen an the amount of debiss resulting
the destruction of lymphocytes, but is the destruction of ly phocytes, but is partacularly marked in the changes of the
lyohatic nodules. In rabolts, doses of 800 and 500 completely destroy the great and 500 completely destroy the great "ajority of nodules resulting in a after treatment. at which time new nodules begin to forl. Since the LD $50 / 30$ days of $x$-rays for rabbst, rat, and gumea pqg are afproxsmately 800,500 , and $175 \mathrm{R}$,

respectively. it appears that the intensity of damage is relatively independent of the $u$ $50 / 30$ days value. Both fast and slow neutrons groduce histologically the same changes in the lymph node as do 8 -rays. The changes produced in the lyaph node by

internaliy andnastered radioactave waterlals are histologically the same as those produced by extertally applied radiations admuntered to rats 1 m doses of 23 and 33 uci/g br arvage, completely destroyed the

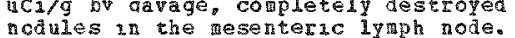
ncalues in the mesenteric lyph node.
Stront 1 a 89 danistered intraperitoneally Strontiua 89 admintered intraperitone teticular cells after $3.6 \mathrm{uCa} / \mathrm{g}$. $\mathrm{A}$ dose of reticular cals after 3.6 ucs/g. A dose of 14.5 uci/9 caused conplete destruct
ncdules. sodiun 24 adinastered

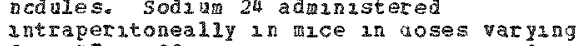
from 47 to 83 macrocuries gram caused ccaplete destruction of the nodules of the $1 y$ mph node. No nodules were found in the lyph nodes of rats 1 mjected intracardially with zirconum 93-n zoblut 93 in acses rangang intraperstoneally with raduan in doses rangeng from 0.02 to 0.5 ucl $/ g$, there was after two to sis months a corrolation between the rumber of 1ymph nodes whth nodules and the dose. The intravenous injection of 0.08 uci/g of plutonum. or the intramuscular injection of $0.1 \mathrm{uCs} / \mathrm{g}$ produced $3 \mathrm{n}$ the $1 \mathrm{yghh}$ ncdes of mice only moderate nuclear and cytoplasm $2 \mathrm{c}$ damage to 1 yghocytes. typhopolesis wes not affected. Plutonu injected intravenously into rats in doses of

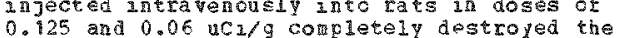
iyphatac nodules. hath the exception of

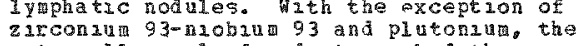
internaliy applied radiations had the same effect in the intestinal lymphatic essue as 
BTOLOGICAD ASPECTS

AHIREES

$\langle 64\rangle \cos \mathrm{T}$.

In the 1yop nole. Follcking these two

agents there vere mor guantitative

alferones in the react ion of the tuo

tissues. (Auth) (柴阿)

Nugerous histologecal sections are shown.

〈65)

Dedrick, M.. M. F. Sakov, and D.D. Mahlum, Battelle Memoral Institute. Pacific Morthwest Laboratorzes, Buology Departaent, Buchland, ma. 1973,3429

Distribution and pifect of qutom un 238 in the Fetoplacental vnut of the Rat. CoNF-730431; Part of preceedrngs of the $213 t$ Annual Sypoosum of the Radiation Research socret held in st.

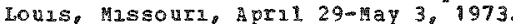
Published in Raduation Research, $55(3), 515$.

The asstribution of heavy metals wathin the fetoplacental unit (PPV) of the rat shovs a typlcal pattern, altnough aiferences relating to the specific gaterial. phys Icocherucal otate, and stage of gestation are apparent. noses of pu 239 as low as $34 \mathrm{Cl}$ to the dan have a pronounced embryocidal effect when adimistered at 9 days of gestation, although 50 un $\mathrm{Cl}_{1}$ not lethal at is or 19 days. Fhe present study $2 t h$ pu 238 was undertaken to evaluate the effect of specifac activity on the asstrabution and toricipy of clutonin in the prenatal rat. Dregnant rats were intravenously anjected with graded doses of eitrated $\mathrm{B}$ i 238 solution after 9 days of gestation and killed 5 days later. The components of the FPo vere weighed, examed, and subjected to radu oanalysis and autoradrography. Mortaly ty was an the sane range as found wh $p$ u 239 , being $40 \%$ after a dose of 6 uch to the dar wh th further ancrease at doses of 7.5 uCi and above. other animal vere injected with and above. other and 238 atter 15 or 19 davs of gestation, hilea 24 hours later, and the distribution of activty determined. The pattern of relative concentrations wa pateern of relative concentrations was

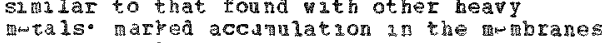
(particularly the yolk sac). less in the placenta, and least in the conceptus. suggesting that specific actrvity does not influence paxtition. (Auth) (complete Article)

$\langle 60\rangle$

Dockung H. I., and w.S.S. Jee, Unaversaty of vtan, College of nedscine, salt zake city, UT. 1966. March 51

iffect of [ally Injections of plutonum 239 on Rat Bones. COO-199-234; Part of Dougherty. T.F. Feserach in Padioblology. An wal Report of Work 3 in rogress in the Internal Irradiaton Work in rogress in the Interna
programs (p. $180-190) .326$.

Rats were adrinutered 0.5 acl of gu 239 lintrapertonea 117 dal 17 fer $7,6,5,4$, and 3 days followed hy from to 5 days rest. 3-thyma ne was adinustered 13traporztoneally to sonw of the groups one nour priot to sacrifice at 8 days. Another gron recelved 7 intraperatonoalit anjections of $\mathrm{Pu} 239$ and after 9 g aditional days admastered 1 3-thymalne one hour prat to sacrifice. Control anilals vere given fi 3-thymalne at the same time, nately at 65 days. The parancters investigated included total osteoblasts per unit area, traoecular berineter, ostenclasts and osteoblasts per allineter of trabeculas surface. Followind Pu 239 adminutration it ras folnd wesenchytal cell population tended to fator the formation of osteoclasts rather than osteoblasts in both the short-tera and long-ter expermental answals when they were centrols for the sare time perıod. (Auth)

<67>

Dougherty, J.H., Unuersuty of Jtah Radicbiology Laboratory. Salt lake cuty. UI.
1950

Comparison of fifects of Lethal Body Burdens of

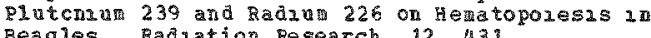
Beagles. Radration Research, 12, $43 \%$.

The blood pucture was followed at monthly intervals in ten adult beagles given a $51 n g l 0$
intravenous injection of an average of 10.4 micro $\mathrm{Cl} / \mathrm{kg}$ of Ba-226 and nane dogs glven an a verage of 2.88 micro $\mathrm{C} / \mathrm{kg}$ of $\mathrm{pu}-23 \mathrm{~g}$ a verage of 2.88 micro cl/kg of py-23 1mtranous 1 . Compacisons vere similar ata mo thent four control amimals are approxiately 2.5 tides that to the

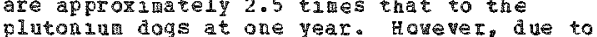
dufferences ar the radionucilde astrabuticr difierences 1 ho the radionucilde astrabuticr in bone this does nct accurately reflect Dcse marrow dose. The average survival take was 1046 days for radum ingected dogs and 133
days for the plutoniun group. There were elght bone tumors in the radun group and three hone tumors in the plutonam group. The detaled hetatolog $3 \mathrm{cal}$ findungs for all gromps 111 be presented. Ho tumors of hematopoletzc origin were foumd. Despate differences in radionuciade astribution. tumor Incidence, survaval tame and amount and distribution of skeletal darage between the tho grougs of dogs, the degree and tare sequence of depression an blood cell elements and hematological findings at time of death

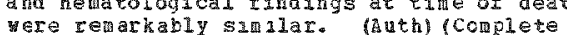
Article)

$\langle 68\rangle$

Dougherty, J.H., Unaversity of vtah, college of hedicire, Badiobrolohy Division, Department of Anatcoy, Salt Lake City, UT. 1972

The fenatologyc Changes Induced by plutonzar 239 in Beagles. Part of stover. B.J. and Jee, H.S.S. (Eds.). Radiobsclogy of Plutonzul. J.k. press. Salt lake cuty, utah, (0. 75-86), $552 \mathrm{~F}$.

The hematologic changes following a single utravenous gnjection or a wade range of doses of Pu $239(0.016-2.8 \mathrm{acz} / \mathrm{kg})$ in poung adult beagles have been followel cver the 13fespan of the antrals. Thrs study has been underyay for 20 years. All of the aogs in the original 12 injection groups have died. the nasn cause of death benng osteosarcona. Blood cells alterations were found in dogs recelving the four highest dase levels. The changes mere doserdependent and were most acked 1ir granular leukocytes which we maximally depressed at 2 to 3 veeks post-injection. A sustained IY rphogena occurred at the two haghest dose Ievels. A transient early thrombocytopen 1 and anemia were also found y higher devel acgs. A Iicderate anema reappeared as the an
kecame tormanal. There was myelojd metaplasia in spleens and livers of dogs at autopsy. The hematologic changes tound after Pu 239 injection were corpared to several other internal entters (Ba 226, In 228, Ba 699 and Th 228, were found to be the wcst damging to the heratoporetic system. (Auth)

Table 1 gives peripheral blood findung on 5-1evel Pu dogs. Table 2 gives bone bartch 
3TOLOGTCAL ASPFCTS

ABT $M$ RIS

$\langle 68\rangle \mathrm{CON} T$.

ratios in a-1evol pa dogs.

<69>

Dougherty, J.H., J.\%. Sowers, R.C. Bay, and 2.

keyanonda, university of utah, college of

Medicine. Kadiobiology Division, Salt iake city.

vT. 1955, Ju1 y-Decenher

Comparison of Hematologic Effects of Internaly

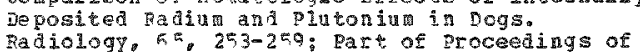

Radiology, ${ }^{2}, 25-259$ Part of proceedings of

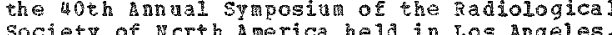

Society of pcrth america hela in Los Angeles.
California, Decenber 5-10, $1954,(7 \mathrm{pol}$.

Young adult male and female beagle dogs vere injected intravenously five dose levels of $R$ 226 and Pu 239 in the citrate form. The are levels vere estimated on petained basis as $2.5,0.81,0.27 \mathrm{ant} 0.086$ and $0.014 \mathrm{uCs} / \mathrm{kg}$. Retained zurden was estimated by total gagma counting, breath radon weasurements, and urine ard focal assays. The hematologic deterainations included herog lobin, yolume of packed red blood cells, tea cell count, cellular indices, white cell count, direct eosinophi count, platelet count. sedimentation rate reticulocyte comt, and icteric nder. wo sighicant hembologic icteric indeg. fisst yeat in anials feceiving 0.085 of First yeat in animals Eeceiving 0.085 or leukopenia developea in dogs wich retained

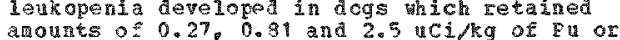
anowes of 0.27 . 0.81 and 2.5 uCing of Ra. Ther was no significant hifference
leuchte depression between pu and animals at comprable dose levels. Leukocyte rambers tell at all dose levels at 21 to 30 days, then increased auring the next 30 to 60 days to reach a subnormal platean. A

depression in granular leukocytes was seen in the 0.27 ucifog dogs with 1 yrphocyte values remainirg within normal linits during the pear of ouservation. A depression of

Iyphocytes was sean in andials receiving the two hiohest dose levels. I variable but significat deprossion in erythrocyte values significat deprossion in erythrocyte values dose of $\mathrm{PH}$ (

The dose-tine relationsh ips of leukocyte heterophi. Inghocyte and platelet Eesponse to Fu and Ra ate given in graphic for

\section{$<70>$}

Dougherty, T.F. I IIversity of vtah, college of

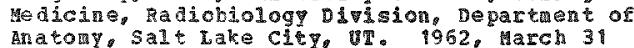

Fe search on Faulobiology, Annal Report of mork in progress cn the chronic Toxicity rogram. coo-225: $135 \mathrm{p}$.

Injection tables are given and esplained for the chronic toxicity seudies on dogs using the radionuclides Ra 226, Pu 239 , Th 228, Th 228 and 5 r 90 . several related studies are reported and 8 of these have been abstracted separately for inclusion in the data base. separateiy for inelusion in the data base. of radiation-induce fractires in beagles an electrophoretic stody of serin protein eloctrophoretic stady of serin protein dogs. fraction in Ra 225 and Pu 239 injected doga pathologie and normal bone rewodelligg as of $\mathrm{g}$, the long-ferm effects of $\mathrm{za} 239$ in aduit beagles and comparative toxicity of 2 226, gu 239 , and $\mathrm{Sr} 90$ in adult beagles. (ㅍำ $\langle 7\rangle$

poughery, Tor oniversity of utah, college of vedicine, Radiobiology division, Department of An atcay, Salt Lake City, BT, 1960, darch 31

Fesearch an Radiobiology, A A Annal pepot of mork in progress on the chronic Toxicity Drograta $C 00-220: 225 \%$

Progress is reported for the vrrious sections of the chronic toricity progra. The project is designed co obtain information on the influences of internally deposited infitences or internaly deposited radialsotopes on certain tunctions hich occur during aging. Injection tabies ise used in the study ith 226, Pu 239, Ra 228, Th 228 and $5 \mathrm{~S} 90$. Theven pagers have been abstracted separetely for inclusion in - be data base. These inclade the distibution of the radionuclides in dog teeth and the histopathologic changes in teath containing $\mathrm{Pu}$, the effect of internaly deposited radionuclides on the blood vessels or cortical bone, the localized distributica of $2 u 239$ in the lubar vertebral centra of 5-level dogs and a case of bone tur arising from the texporal bone. (FMm)

$<72$

Dougherty, m. Finiversity of itah, college of medicine. Radiobiology Divisicn. Department of Anatcry. salt lake city. UT. 1960. Septeaker 30

Fesearch in Radobiology. Semiannal heport of work in Progress on the chronic roxicity

Progran. coo-222: 140 $\mathrm{p}$.

Progress is reported for the chronic toxicit progra involving dogs injected ith 226 . Eu 239 , Ra 228 , Th 228 or SE 90 . The injection tabies are shota in tabular for and give the age and veight of the animals. injected dose, date injected and dose to the skeletcn. Reports are included on 15 test radiun dogs and on soft tissue tumor incidence in beales with long-tern internal radionuclide burdens. (Fis)

$<73>$

Jitrbing, P. . Lavrence Radiation Laboratory, Division of Medieal Ehysics, Eerkeley, CA. 1960

Metabolic characteristics within a chemicel Fanily. Health Phics, $2,225-238$.

The a wallable date hate been sevieded for the biological behavior in rate of high specicic-activity radioisotopes of seventy velents. Tracer quantieies vere adrinistered in single intramscular injections. troups of rats vere autopsied at various intervals, atd were a ssayed for radioactivity. Distribation dat 2 ere arranged according to the grouping of the periodic table of the elements. The anions (incluaing the halogens). the oxpgenated or hatogenated ions of Groups 4, 5 and 6 , and the eransition tetals vere rapidiy eliainated by the kidneg. The capidilent alk i tals were distributed monovient alkald atals were distribut

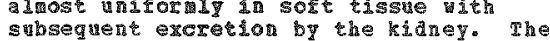
subsequent excrecton by the kidney. The

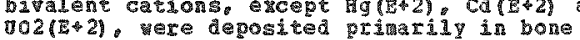

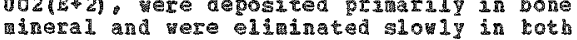
urine and reces. Fhe tripowitive elements of 6 roup 3 , the lanthandes, and the actinides vere deposited in liver and bone. The diver Eraction was excreted ya the bile vithout recisculation, while that deposited in bone was turned orex at a rate slower than that of

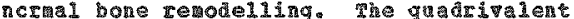


BIO LOGICAD ASPECTS

An

$\langle 7.5\rangle \operatorname{col} T$

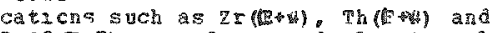

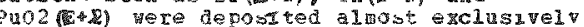

$2 \pi$ bone and vere bond more strongly than the

rroul 3 elemonts. The propert deternzie 310 logical behavior ars: (d) the oxzation state stakle at body $\mathrm{pH}$, (b) the oldiblaty of the steble state, (c) the rendency to be 17 corporated into organs compounds, and (d) the tendenco
witn specifie proteins. (Anth)

$\langle 74\rangle$

thier, h.G.. and w. Schwartz, Dortmua

ur lverosty, portmund, Germany. 1073, october

Irvestigations on the Bacterial Lachung of uranau ores. Frzmota1z, 26 (10),

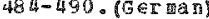

Basic pruncuples of the process of bacterual ladehria are copered. Experz nents whth uranlug ores from deposits in the Federal Republic of Germanv, using varieties of the thiobaciling are descrited. results and oponization of leachang contutions are discussed. Arother rethod comaning cham cal and microblological deachirg is descr bed. $\left(6^{\circ}\right)$

$\langle 75\rangle$

Elisua, I.。 Mot given. 1963

Enosphatase Actryqt and contert of calcun

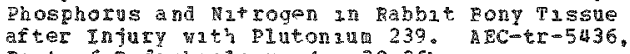

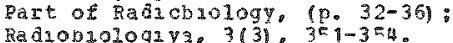

Rabbits aged $190-240$ days, wezhag $2.5-3.0$

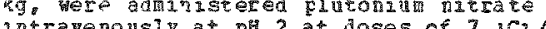
274 ravenousIv at ph 2 at doses of $73 \mathrm{Ci} / \mathrm{ka}$ asd 2 aci $/ \mathrm{kg}$. The rabbits wore sacrifaced 3. $7,14,90,135$ and 180 daws after the 7 wC $3 /$ hand 135,980 and 360 ady after the 2 uCifkg tu injection. Bony t2ssue vas analyzed for ca $\mathrm{F}_{p}$ ard phosohatase activity. Separate intestigations at daplisical ar epinhsical portions of phosphatase activity in rabbit bony tissue at phosphatase activity in rabbit bony tas epiphysis and diaphysis. At doses of 2 eplphysis and diaphys is. at doses of 2 uciphg Fu, the decrease of enzy activit calcan phosphorus and tora matrogen an of calcan, phosphorus and toha matrogen an sandicanty from the control. (RAS)

$\langle 76\rangle$

El 125, I.C.. and D.I. Berliner, state Un 1 versity。 Lepartment of zoology, Logan, vis, Unzversity of btan college of hedzche. Padiobiology Jivision, Departrent of anatony. Salt Lake Clty, 19T. 1966

Internaliy Deposited Radionucludes and the Subsequent $\mathrm{Altatat}$ on of Androger Basythesas by Canne Testacular Tissue. Comp-60212: Part

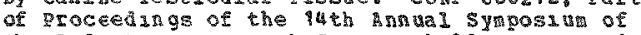
the Rad ation Research Socretr held un coronado. Californa, Februar 13-16. 1966. qubished in Radiatuan Researes, 27,549 .

The data fresented in this report were obtanse from adult beagl dogs wheh vere schedule. These rise is pere part of the comparative stuay on the lological effects of some radionuclides in the basıe progran of the Reasologieal Division of the Departint of Ratcay. Braversaty of gitah. The dogs were 1 ngected wath the various radionuclades according to the project outine. Five anzals were $2 \pi j e w t e$ with 3.2 aC2/9 of Ra

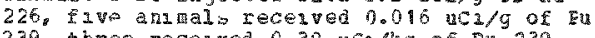
$23 \%$ three recelved C.30 ucl/kg or Pa $239 s$ Elvir animals recelved $0.015-3.30$ un $2 / 9$ of 2

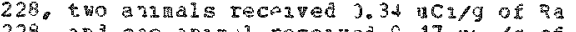

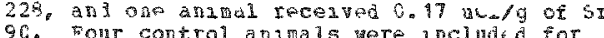
96. Wour control andmals aere dneduded for comparatrve parposes Traefrately arrer the anmals vere sacrificed, one-gram aluquets of the tostos were ariced ard incuoated unt 5-pregnenol ooe-7 al phe-H 3 and

progesterone-i $=\mathrm{C}$ 14. Isolation an.

guan-ification of the stercid

antarrojatesshoved that s-pregrerolone ya converted Into 17 a lpha-ngarozytoresterone. ardrostenedione, and testcoteron raster than was progesterore, as las beer demonstrated by cther workers. The convereion of the two androgen precursors $3 n$ to androstertane iestosterone, and tetal androgens was arikedis reduced for a 11 of the 1 njected arzma 1s. Thus, trese data saos that artals damish androgen busythesis 2 in vitro as

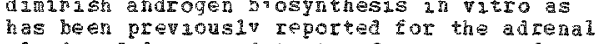
has ben previous 1ands of dons and testes from 10 ce and rat of irrallatson. (3uth)

$\langle 77\rangle$

Elxis, L.C.e And D.L. Merliset, Ur a Versity o vtah, College of Hedacine. Radicbuology

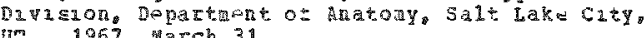
y

The Efrects of Ionzarg Radzations on Endocrane Celis. 6. Alterations in inarogen Biosynthesi by canne pesticiar Tisse after the Internal Devositzon of Some Rad loticluzes. CoO-119-2s6. Fart of Dougherty. T ... pesearch ir Dadicklology. Annual teport of Wor at Projress

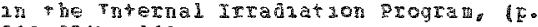
$218-2511,268 p$

male beagle dogs were ir jected brtaturousiy

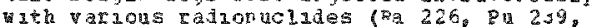

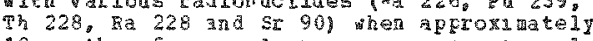
if pons of age. ar varsons ine intervals the tostes vere temoved from the animals. ara

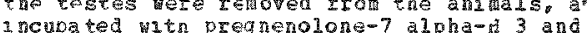
progesterone-4-C 14 . The resulting sterioc intermedates vere iso3ated by paper chromatograpy and derivative formetion. The chtonatography and derivative formatson. arhways observed or the synthess of androgens were essentially the same as those otserved from perfusion studies by othes

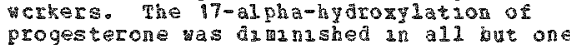
andal, whech had receaved $3 \mathrm{r} 90$. Sumlatiy less arrostenedone testosterone and total androgens were froduced by the tassues fral the treated animals as compared to the control group. Pregnanedione wa isolated from the incubations of at least elght dogs. The occurrence of this conpoun wath respect to ferers in treated andmals was discussed. when a MADPH-generating systom as added to 3rubation of tassues frow both groups of anials, there vas an increase in steriod b3otransornatzons bor both grougs Hitboug the 3 ricrease in mucles of testorerone and androstonedione production vas grater for he control group after the and ston of the cofactor-generatang syster othe percent and totel androgen production ras greater for the treated group. (auth)

$\langle 98\rangle$

Freksova. T.. and israel progra for Scientific Traniations. 
BIOLOGICAL ASPECTS AMITALS

<78> COHI.

Jerusaler. Israel. 1969

Distrabution of Plutonil 239 in the Andal Organssis. AEC-tr-5982: Part of Erleksova the Anial organis polonu 210 , Fadobhor 226. plutom u 239 , and Stronerat 901. Atlas. (p. 112-144), 169 p.

wor a study of the nature of Pu 239 distribution in the organsm and its localization in tissues and organs, raterial was obtan ned from 286 white rats and 20 whyte arce for cadroautographic exarnation. Pu 239 nitrate 10.91 ca 3 solutions at $\mathrm{pH} 6.49$ was administered intraperitoneal1y. Activities of solut lons were $0.15,0.08$,
$0.04,0.02,0.04,0.005$, and $0.0025 \mathrm{mcl} / \mathrm{kg}$. Trent ty ce received $0.15 \mathrm{acz} k$ subcutaneously. Anumals were sacruced and organs and tissues vere exama ned ron 5 alnutes to 578 days. Framation was made on the injection szte, lungs, wocardin hellotopietrc organs. sex organs, bones, and in some anilals, the nervous systea. Acute radition sickness develcyed wi th 0.15 to 0.08 国 $1 / \mathrm{kg}$, the subacute for appeared with 0.04 to 0.02 ach $/ \mathrm{kg}$ : and a $a$ iter date. osteogenic sarconas developed ath 0.01 . 0 steogenic sarcomas developed uth o. disappeared from the organs of all sy sters disappeared from the organs of all sy sters comparatively raps. dy eten from the laver, With the exception of the skeletor where it

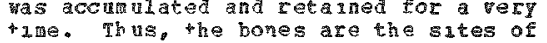
development of the most severe pathological processes and tumors, such as osteogenic sarccma, associated with the directeffect of an alpha enter. (Bsh)

$\langle 79\rangle$

Erokhin, R.A.D. A. Roshurnikova, E.R. LYubchanstar, A.P. N ifatov, and G. R. Resetov,

Levels ana icredustribution of plutenum 239 in the rat Eungs and L1vir, and morphologieal Changes in these irgans zollowng Intratrachea 1 Adninistration of the Isotopes. AEC-tr-7590;

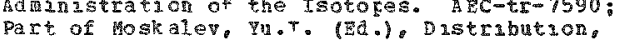
part of Moskalev pu. Radroactive Tsotopes. (p. 42-h2), $405 \mathrm{p}$.

Dlutcna un 23 yas adenustered lutratracheally to fistar rats of both sexes weignang $140-160$ grams in a dasage of 7 uci/kg as the nitrate (pH 2) and the sodium plutonyl trqacetate (pH 5.5). The arlmals vere sacrificed after 20 minutes, $1,6,12$ ho.rs, $1,3,4,9,16$ days and $1,3,4,6$ and gronths. The behavior of plutonum an the lungs fol lownd intracheal adranistratzon of different salts thereof was determined prinarziy by the physicochenucal form of the compound admistered a) the flutonum content of the lungs was 5-10 tines higher after adninistration of nierate than sodium plutonv1 tracetate, b) elimation of plutcnu vas subject to an exponentzal law: however, there has faster elimnation or the rase of schin olutonil triacerate. A lasge quantity of putonam vas transported by guantity of ol utont wa transported by macrophage from the lungs to the regional 1ymphode. There was slaver accumatar of plutorism in the liver at th
$(20$ mandes to 23 honrs) after (20 whutes to 23 年 homrs) after

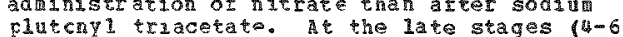
plutcryl tracetate. At the late stages $(4-6$ wonths), the plutonin level in the rat liver becae the same following adminatration nitrate an sollun plutonil triacetate. constatut $2 n g$ o.9-0.56 and $0.95-0.57 \%$
respectude of the quven dose. The merodistrabutson of plutenian in the rat 11 wer was primarily diffuse followang ntrateacheal adinistration of the isotope in the form of natrat and sodum putury triacetate. The histological changes in the 1 ung of plutongu and they develoned primarily in Ecci of acculintaton of the The se versty of the pathological changes and the of their appearance were related to the changes conststed of dystrophy and changes consisted of dystrcphy and desquation of bronchal and alveolat Thereafter. chronic infla ar ion developed. Thereafter. chronic inflamation developed, the pathological prccess resulted in development of preunoscelerosis. The sclerotic process usually developed indirectly, on the basis of proliferation of comective tassue cellular elementa wleh coration of fabrous structures. No significant morphological changes in the rat liver follow ing intratrached a dusnistraticn of plutonum mitrate and scalum plutongl triacetate an a dosage of $7 \mathrm{uCz} / \mathrm{kg}$ were observed. (RAF)

$<80\rangle$

Ershov, E.B., and D. D. Osanov, 1970, December

0ustrbation of Platonat 239 in Intact skin in Its Surface Contamination. Meditsinskaya
Padiologiya, $15(12), 44-46$. (Pussian)

The penetration of $F u 239$ through the epueras (up to 150 ul thrck) during sperfical contarination was studued using 22 arglets whose norphological skn structure $2 \mathrm{~s}$ sidnat to hum shin. The results of the specufic actirity into the depth of the epldermas at variou perzods of tige of contact wh Eu 239 are given in graphic

fora. It was found that at the beginning the specific activity as very rabldiy increased at an fured depth and after 12 hr of contact the teroo aecreased and becane balaros. that the acunt of the abcrbed and radroactive preparation was equal. (RVI)

$<81>$

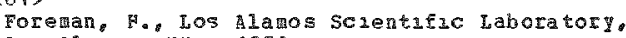
Los Hamos, 1958

Dlutonum Buning by Bore. Radation Research. $9(1) .115$

Previous studues have shown that, when plutonin is shaken vin various powdered tone fractions, the fracticns from which a 12 of the organze materzal has been removed have the greatest uptake and the fraction from which all of the calcium has been removed has the least. other studies strongly induat that the mode of combnation is 51 mole adsorptzon to the surface of the kone powder. These findings suggested the possibllity that plutonum is taken up un the skeleton on the surface of bone mineral, rather than by combation with some orgaric taterial as gas previonsiy believed. The study as previously believed. The stuy is a fcllow-up of the prelilinary fandings. ethylenedianinetetrabetic acid to gemove calciun and after carefil washing vas shaxen calcum ard after careful washing was

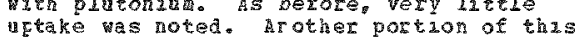
actake was noted. prother portion of this

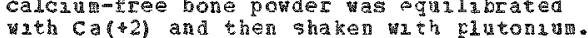

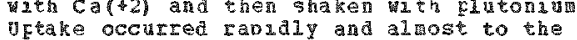
ertent of untreated powdered bone.

Autorad lographs of bongs of rat fetuses

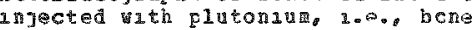


BTOLOG ICAL BSP FCTS

AMTY MES

$\langle 81\rangle \mathrm{CON}$

containing both calcified and precalcified

areas, shoved that plutorium uptake is

1initad ntrely to the calcitied portions of

the bone. Buss rron young rats rendered

rachitic ip diet were calcified in vitro by

standard calcification technigues and ther

shaken with plutonina. Considerabie

plutoniul was taken up. Sĭmia bone treated

in the same fashion, except that $\mathrm{ca}(+2)$ was

let on ef the calcification solution.

slowed matkedly less glutoni na uptake. These

finaings further ind ate that the uptake of

plutenium by the skeleton is by combination

with the hone gineral. (Auth) (Complete Text)

《82 \

Foreman .

Minnesota, inneapolis, y. 1958

pephrotoxicity of chelating hants.

Conf-670521: ponographs on Wuclear wedicine and Biclogy. HC. 2: part of Rornberg. H.A. and

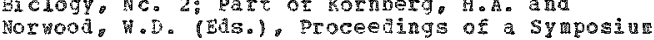
on the Diagncsis and Teatuent of Deposited Satouclides hela in richland, hashington, May 15-17, 1967, (0. 419-423), 680 p.

The role of manganese $(+2)$ in remal lesion develoment following the atumistration of ca chelat $6 \mathrm{~s}$ of ethy le redaminetoracetic acid (EDT and dothyleretrat nepentaacetic acid (STPA) was investigated. The crelater vere admisterec intraperitonealiy to rat and the lethality ratio was determined. It a 3 3houn thas the toricity of gn IDPa vas geasured by lethality was significant ly lcver aeasured th the ca chelate. The effect

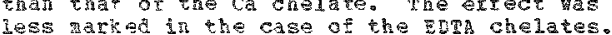
Litanise the toxicity of the Mr chelates using renal tubngar finding as the end point using renal tubilar hays as the end point was men lonter than the ca chelates. given along ath the ca Dis did not

influence the toxicity of ca bron 1 it is a transiont depletion of

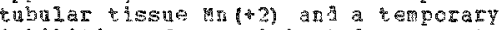
inhibition of nacitivated enzyme that is involvea that cansot be replenished or rectifien by concurrate alminstration of

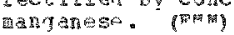

$\langle 83\rangle$

Forendn, tho Jo Dost, and C. Finnegan, Los hamos scien tific Laboratory. Los allamos, Wh.

The Staect of Irradiation in the Absorption of

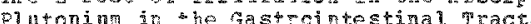
Raluation pearch, $7,257-259$.

Male adult $3=0$ g Sprague Dawley ras were $x$ irradiated ofth $250.500,1000$ and 2000 a a ratio of $<$ s/min. To days aftes irradiation, each enimal was given 5 to $5 x$ $10(n+5)$ counts/ain of pu(4) in $0.5 \%$ sodiug cirrate sclution by stomach tuhe. both fed ani fasted qroups of and als were tested. And yses were done on gastrointestinal tract, lurg sing liver, skeleton a marcass. phe results show that $x$ irradiation, ewen in high

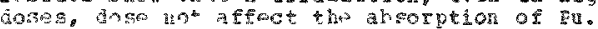

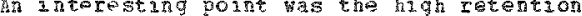
of $\mathrm{P}$. the controls and irratiated. This is grobably reliatal to the larger amount of cinte in the intestines of the fed animals. Tre extra intestinal contents probandy crovias nechaical serubbing action unich proates ranser of the pu into the secal stratr. The relatively high lues of Fu stroara. The relativing high values of Ft the tis.s es -0 . 2 to $9.3 \%$ in 211 the

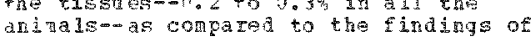

others of 0.05 to $0.1 \%$, are probably due to

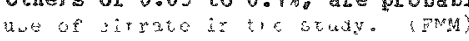

Table 1 shows effect of $z$-irradiation on ajstribution of pu aduinistered by nouth.

<84

Fried, J. givision of Biological and Hedical pesearch. RIgome, II. 1961

Influence of Physical state on the Rewoval of Hyarolyzat 1 Radiolements by Chelation. ANL-6637; Paxt of Proceedings of the 7 th Annwal Sypesiur on Eloassay and Anatytical Creoistry held in Argone, Iilincie, october 12-13, 1961 $(p .5-8), 100$ p.

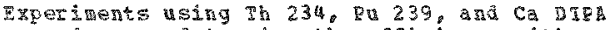
were done to deteraine the efficiency with which an extracellular agen coula remove intracellular relatively insoluble deposits of radionctive motals. In one experiment mice vere injected intravenously with tho forms of pu (ionic and colloidal) at a jeves of 3.3 uci/ge for the icaic and of 2.6 uCi/kg for the colloidal. Drpa therapy, began 3 days later, consisted of twelve daily IP injections at $500 \mathrm{mg} / \mathrm{kg}$ each. It was sean that the ionic pu vas divided almost eveniy Ietween liver and bone wheres the arount of cclloidal pu in the liter yas over twice that in the bone. In the anzals receiving DTt therapy. iond pu was almost condetely renoved from the liver in 3 days whereas in those receiving colloidal Pu, the liver still retained alnost two-thiras of its inatial curden ater the entre treatnent period was over. In $s$ wadry the total reruction of tody hurder brouthe about oy DFPA therapy nas considerably greacer in those anma

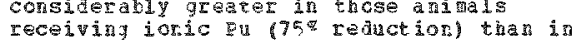
those receiving the colicidal for $(40 \%$ reaction). (Eut)

$<85\rangle$

Galising, G.9., Not Jiven. 1974, June

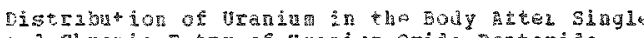
and chronic Entry of urania oxide-gentouide. Gigiene i sanitariya, 6, 37-w0. (Russian, Engijsh Sumaxt

The coefficierts of araiu retention an the bcdy in cose of single introduction by oral and respiratory routes of $0308 \quad(0.1$ and $25 \%$ rospectiveinl were determined in ax (x) respective-y were deterained in ax iajelingintion of urania from the skeleton haje 1 ind

initially rotained isotope vas aimatad at initidily rotined isotope was alimated at

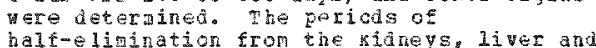
sfleen ain not excoed 16 to 32 days In

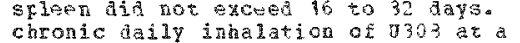
concentration of 1 na/s $(\mathrm{E}+3)(0.8$

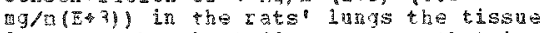
doses nay be absut 30 rea/year, thet is twc times hijher than the recomended aximal perassible levels. (Ata)

$\langle 86\rangle$

Goldthorpe, H.C., And S. Bennett, Iniversty ct utah, college of medicine, Rabiobiolcyy

Divisior, Salt Late Caty, ur, 1959, March 31

Fiochemstry group. CCo-218; Part of Stover. C. N.. Jr, (Ed.), Annua 1 Eregress peport, 1959 P. $72-24), 224 \mathrm{p}$.

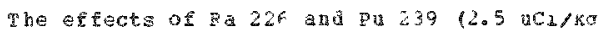


$\langle 86\rangle$ Cont.

retaned tosel on the levels of varuous serur constituents in dogs are reported and

conpared tc nornal palnes.

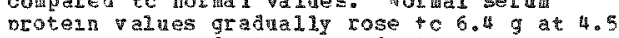

veotein vales gradually rose

yedrs and then declired graduali ser

proten in pu and ls decreased atter

protenns at 7 yrs of age. Pe 226 injection

was folloved by a aroo in total proten

values. Trere was then an ancrease untal 3.3

YFS foliowed by a decrease to $5.8 \mathrm{~g}$ at 4.8

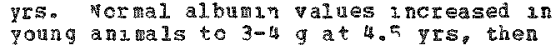

decreased to 3.0 at $6.5 \mathrm{yr}$ ev or going below

the globuin ralues. In animals injected

with $\mathrm{Pu}$, album decreased quickl $y_{0}$ Ieaching

$2.3 \mathrm{~g}$ at time of sacrifice. Globulan values decreased after 1 nqection, but at 2.7 yrs. started to rise Feaching 2.7 at tale of sacriface. other serum constituents reported

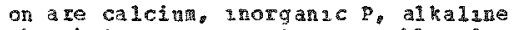
Fhoschatase, area nutrogen, chlorddes and carbon doxide. The effect of enviromental temperature un blood serut values vas also

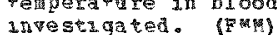

<87>

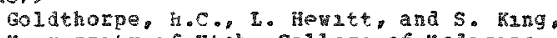
unuversity of prab. College of heacune. Radiobrclogw Division, Departient ce Anatory. Salt lake City, wh. io62, gach 39 An Electrogkcretic Study of Serum Proten
Fractions in padum 226 and Plutoniu 239 In jected Doge. roo-225; Daft of Dougherty. m. "Research in Radiobiology. Arnual Report of work in prcqress on the chronic Tozacity progran, $(0.49-58), 135 \mathrm{p}$.

Dogs were infected whth 3.00 ncs la $226 / \mathrm{kg}$ of $2.77 \mathrm{uCs}_{3}$ Fu $239 \mathrm{~kg}$. The serum crotean fractions vere determined

electrothoreticaliy. The results showed that

serm albun 1 alues tended to stay farly

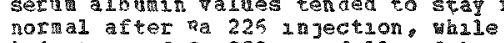

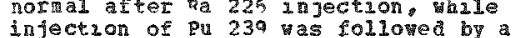

lonerang of the serum lavan values. The

lonering of the serum lavin values.
alpha 2 fractron vas greatly affected.

alpha 2 raction vas greatiy affected.

Plutonin 239 had the greater erfect, but the
values returned to the normal level after 125

days. Elatonum 230 mpjectuon as also

followed by an Increase of values of the beta

1 iraction. Radum 226 nnjection appeared to

ankzbot gara globulin production at seven

days, but sxos there on up to fifty days

there ws increased production followed by

decreased prcucen lastrag up to 125 days.

After that tume, values followed the norkal

curve. Plutoniu 239 seemed at first to

Inhbrt gara globulin production. movever

at 290 days there seemed to be stimlation of

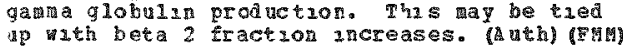

Figure 2 shows the effect of Ra 226 and $\mathrm{Ru} 239$ on albugin and globulin in serum of dogs as compared te noral controls.

$<88\rangle$

ta alton. J.6. argonne Hatzonal Labotatory. Argonne. Il 194 , Vay 2

Techncal Progress Reoort on the letabolic Stuales of ission Products: MDDC-1061: 2 p.

A serzes of tracer experzants vith rats have been minertaken wh product 17 all 3 of 1 is valence states in the form of a solution. Proulution was given at a dose of 15

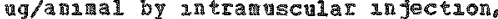

interpulmonary admassteation and antubatzon. Eesult 5 indicate that less than $0.05 \%$ was absorbed fron the digest3ve tract $2 \pi$ any of the 3 valence states. Following intranuscular injection the plas a product was poorly absorbed roa the ingection site.

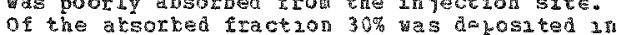
the skeleton and such smaller anounts in liver and kidnevs. Sisteen disy after liver and kldnevs Sixteen duys after interpulmonary admistration

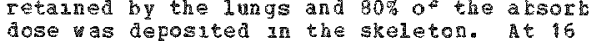
dose as deposited in the skeleton. At is days foslowing 1 mtramsucular anjection of
plus 3 and plus 6 product the sheleton retalned $55 \%$ of the absorbed dose. Following intrapulmonary admisustration $50 \%$ of the glus 3 product and $32 \%$ of the plus 5 croduct wa retanned by the lungs and over 30 \% of atsorbed plus 3 and almost 90 of of asorbed DIus 5 product was in the skeletor. (RAE)

$\langle 89\rangle$

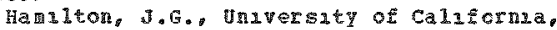

Berkeley, CA: University of Calmfornia, San Francisco. CA. 1949. Januar $\rightarrow$ Jne

whe Hetabolisn of the radzoactive Elements Created by vuclear $\bar{F} 13510 n$. The pev 3 nglant Journal of hedzerne, $240(22), 863-870$.

Signur 2 cant etabolic characterastics of the fission products and of $\mathrm{up}$ and $\mathrm{Pu}$ are listed It 25 show that ip and gu re not absorbed tc any signiflcant degree by the way of the agestive tract. After parenteral admistration oper halt the fussion-product groug, as well as neptunsum and plutonum. a re accumiated by the skelecon and ellanated from this organ very slowiy. The rates of elimination from time sheleton of neptuna and plutons are gute slow. The dall ercretion of plutonum in the rat falls tc 0.01 vercent of the a wount remaning in the body a year atter the intranuscalar adnustration of this radicectue element. Radioathographac studies were adad of the distribution of the radioactive isotopes of

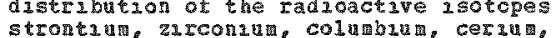

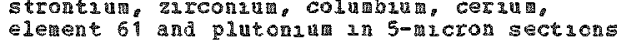
element 61 and plutoma in 5-micton secticns that most of the pu 18 apparent dy deposated that nost of the pu as apparenty deposated

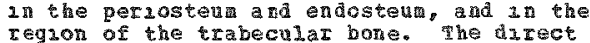

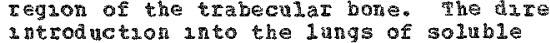
compounds of the cartier-free fission products, and neptuniu and piutomum. demonstrated that the radioelements that were nct absorbed fron the algrestive tract were retanded by the lungs to a considerable degree for a prolongea anterval. Eight wonths fter exposure to a plutongua oxide aterosol. vhich is an insoluble compound of inhalef sti in remanned in the lungs. ccoparable alues vere observed wth plutony 1 nutrate. a soluble corgound of the ele and with the long-1ived fission-product arture. There vas vexy Ittie absorptson asture. There vas very lith absorptom tho sheleton. after inhagent of the the skeleton, after inhalation of the pitan ansoluble for

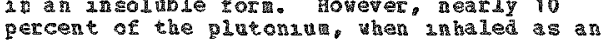
percent of the plutonutu when anhled an aerosol of the soluble plutony i nitrate, was atsorbed throagh the lungs in the risst hrs and deposated in the sirelezon. The property of accusulating in the regions 1medately adjcent to the bone marrov gives

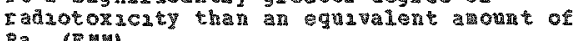
Ra. (F)

Table 1 shows a sumary of the metabolush of the PEInGIpal hembers of the long-12ved fission 
BIC 36 TCAL BSE

ANI늘 슨 5

<8y> copr.

products, $\mathrm{AP}$ ank $\mathrm{P}_{\mathrm{M}}$ in the rat after parenteral and ora 1 a dm ans

$<90\rangle$

Hamilon, Jac, nnaversaty of Chacago, pealth Division, Chicago, TL. 1945

Technical Ireqress Peport on the pletabolic

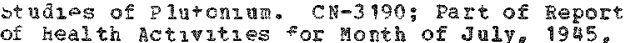
$(p \cdot 10-17)$. 17 p. (reclassified Decerber 15 ,

A table 19 presented showng experimental urine and fecal excretron data of a nuan subject who recelved 5 ug of pa 238 intravenously. The average level of dasly rates of axcretion vas about .008\%/day of the adninstered dose and the das iv rate of

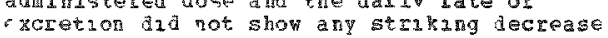
beteventhe $20+h$ and the 37 th day. The fecal beteretion was about one-fourth the The fec urcretion ves about one- pourt hat of the urinary excretion. Assay of all samples were lore by tho lanthand fluoride and
क. T.A. ftho phenyltrifluoroacetonel toethods. The T.T.A. pethod are described in detal. ather stadies antioned are: i) radioautograrhic stadier on noral, reachztsc and ca dufuchent tats given $P u_{2}, 21$ assays of bone tror anials sabjected to the calcufrcation cycle, and 31 pgpergents to

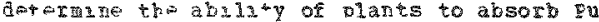
fron day suspensans and fron solutrons. Desilts s jalcate that Pu 25 mose a valable to olants 13 the sto sta and least avalable in the +3 state. (RAm)

49

Hesblon, Jo6., Hot given, 1045, pay 9

Techncal Frogress Report on the petabol 10 Studies of reduet. CN-2905; part of monthly Hea th Repcrt on problens selatang to product

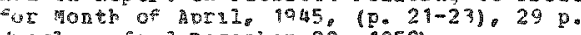

(worlassifiea Docerner 22,952$)$

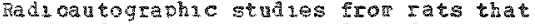

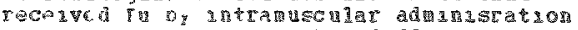
showed that no perceptiole astrerences

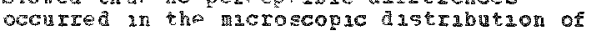
Pu in bone between the three principal valence states of Pa. The two principal regions of deposition of pu in the bome vere in the rovion of the endosteun and the in the region of tho endosceun and the periaster almost nvariably contaned man

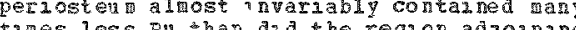
the endcsteu. Regult are reporten for rats he endcsteum. hesules are reported for rats that wer exposen to pura aezosols produced by burgurg nelytion arradiated pu metal which contaned fissior products. The distribution of $u$ and fission products $2 \pi$ lungs, liver runey, scleen, head, skeleton, urs ne and feces is giver. The uptake by the skeleto of the fassion froducts as considerably greater than that for u. The sort tassues had a lon content of both pu and fission

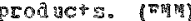

$\langle 92\rangle$

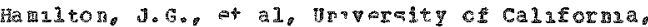
Fadiation laboratory. Berkeley, CA. 1944. JuIy

Techncal progress Revort on the Metabol $2 \mathrm{c}$

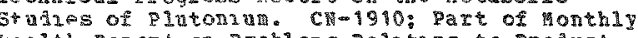
Health Regort on Rroblors selating to Product

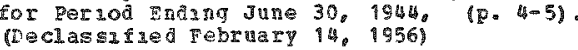

Pour-day antravenous animal studses yth pu
In 113 yalence states showed a sullaraty of alatribition as seen an the intramusula adringtration of Pu wh the exception of ats astribution in the liver. Flutonam in the laver canged from $28 \%$ wh 9 is plus 6 $36.5 \%$ with Ru plus 3 and $71.5 \%$ weth pil 4. Prelmanary 6a-day studes of animals given Paby intramscular ard intrapulmonary admistration showed that the retention at the site of injacticn for pa plus 3 plus and plus 6 Qu vas $42 \%, 69 \%$ and $36 \%$ (RA)

$<93$

Fe11er, 14. Wot given, 1948

The Testes. Dart of Bloom, W. (BA.).

ph Internal Sources, chapter 12. Mogram 111 Bcck

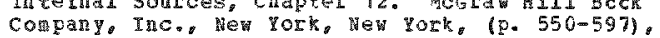
$808 \mathrm{p}$.

The effects on the testrs of rabout, rat, mouse and gun tea plo of externaly apolied beta, gamara ard total-body rays and fast neutrons and of lnternaly adanistered ranioactye lsotofes lis rabit, rat and mouse are descrined. The cranges appeared to be quantutatuvely simiar, but there were aratsed Ifferences in the aegree of darade at the ID $50 / 30$ days lovel. The sten celis were the mest radiosensutive elements. DCses as lcu as 8.8 per alay of garaa rays from an exterral source had curulative effects, resulting in complete elinination of sperratogeresis from the guirea pig testas. Falowng fast neutrons and $x-r a y s$ at the $I$ $50 / 30$ davs level recovery was usul, jathex

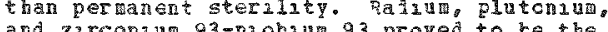

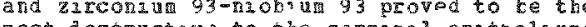

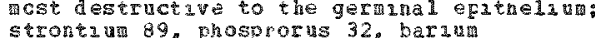

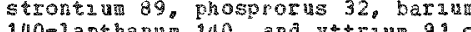

140-Lanchand 14p and yetrium 91 cased comaratively mider damage. not enough an1 15 were treated whth the other isotopes to permat definte statedents as to theis ectrots. In mice changes in the testis wer morf severe after a dCse of 0.08 ucu/g of wu atravenousiy adminstered than after 0.1

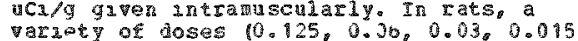
a nd 0.008 uCI/J was adu2tastered and extersave injury resuled. The observed dane consusted of the nearly ccinlete assaprearance of all spermatogenacelis by 120 days after 0.06 uCa/go Less extensive destruction was noted at 64 days after 0.0 veldg and at 150 days after $0.015 \mathrm{aCl} / \mathrm{g}$. Halt-life of an agent, tyce of enssion. ox pattern of autoradographic astribution ccula not be correlated consistently with a arage. Except in a fer anjals in the

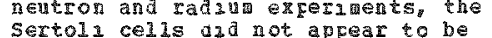

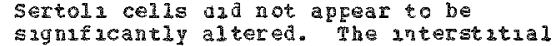
cells were extretely radoresistant. (A)

《94

geliex, ho, Not gaver. 1946

Bone. Fart of Bloon, W. (EA.), Hastopathology of Irradiation from Erternal and Interdal Sources, Chapter 5. McGrav-Hall Bock Confang. Inc.. Hev York, we York, (p. 70-16\%), $808 \mathrm{p}$.

The processes of cessation and resuption of grovth of the ferur and thisa after treatment wh varzous externally and 3nternally admastered radiat 10 as were descrabed. There were some sillarites between the effects of cadiations fron external and internal sources. Bone reacted in a simat fashion to the several internaliz 
<94〉

<94> CONI.

adrinistered isotopes, (ST 99, Ba 140-Ia 140 P 32, Y 91, 2a 24, Fa, Pu, EIssion-products

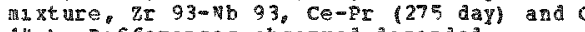
14.) Differences observad de pended principally on age, species, dose, node of admistration, and interval. In rats injected wth radiun or plutomu, bone growth was resumd despate the long half-life of the agent. After an initial cessation of growth following injection of strontzum 89 into young rats a resumption of growth occurred, which was follcwed by a second and perqanent stunting. Fhis is considered as prewature oplohseal closure. The rey bone that for ed betreen the "cla" song the epuphyseal cartilage was oractically free the epuphyseal cartilage was oractically of radicactivity. The deposition of most ferum and promal end of the tabia. the areas of 0 ax? areas of laxi rab growth of these bones. young rat treated nith strontin 89 ,
fractures occurred near or lin the areas of bone devitalized by the deposition of the isotope. one very early osteogenic sarcoma was observed in the tibu of a SI 89 treated rat. Several other ostecgensc sarconas vere noted after treatment with this agent. Brief references vere made to depostion of carbon 14 in bone, to the fact that alizarin and plutoniul irfected at the sane tige are deposited in the same places in the bone, and to the a stribution in pageon bones of

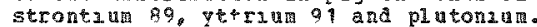
$(A)+h)$

<5>

nobbs, C.

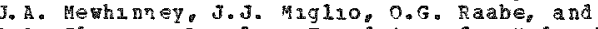
D.O. Slauscr, Lovelace Foundation for medical zacation ard Research. Inhalaticr Texicology Research Irstatute, 1 buguerque, vil. 1974 . Decerber

Foxzcity of Trhaled Alpha-Emating Radionuclides-An Experimental spproach. IF-49, Part of Boerker, B.F. and Rupprecht, F.C. (Eds.). Anrual pepore of the Inhalatron Toxicology pesearch Institute, October 1, 1973 through seftember 30,1974, (p. 136-139), 384 e. studres in which bearle dogs and Syrian hamsters vere exposed to aerosols of hansters vere exposed to gerosols of described. The characteristics of described. The characteristics of arollodi perse aerosols of pu 230, Pu 238 , An relative to their use in studies to determine relative to their use in studies to deterin the relat 17e laportance of such factors as the local aose around the particle, the specustc acitivty of the particle and the aze and numer of particles inhaled phe hot particle guestion on the resultzng nological effects. other factors such as the alewe ntal characteristics nd the chem rcal for of the material and the age of the animal at the tine of malation which bay influence the toxicity of these

Ealiorucludes was studied. The purpose of the studies was to determine the basic relationships between the radiatzon dose patern and the resultig bialoqical effects. (Ant $\mathrm{B}$ )

Table 2 shcta local and smeared dose estrates for beagle aog 1 nng local ara average ing dose estumtes for $\mathrm{Pu} 23$ PuC 2 beagle acg aose-response stud (AD=1.5 na).

<96

Hobbs, C.H., J.A. Homhriney, D.A. Slazson, R.O. Mcclelian, an J.J. Mglio, Lovelace zoundation
For medical Education and Research. Inhalatu Toxicology Research Institute, Al buguergue, Nh. 1974. Decem be

Toxlcrty of Inhaled Diutonam 239 Dioszde in I w ture, Toung dult and ged Syrian Hamsters. 2.. LF-49, Part of Boecker, B. B. and Rupprecht, F.C. (Eds.). Annual Report of the Inhalation Toxicology Research Institute, october 1, 1973
through september $30,1974,(0.150-155), 3840$

syraan hamsters have been exposed at elther 28 (1 arature), 84 (young adult) or 340 (aged) days of age to polvdzsperse aerosols of pu 239 por to better desane pcpulation with a vide range of ages such as pould te tne case whth a humen population would to the case with a humen population
followng a catestropha nuclear acciaent. following a catestrophac nuclear acciaent. Animals exe exposed to obtain 1 mitzal lung
burdens of $240,60,15,3.8,0.95,0.25$, and burdens of $240,60,15,3.8,0.95 \% 0.25$ and andmals and $240,60,15$, and $3.8 \mathrm{nCI}$ for the animals and 240,60 , 15 , and 3.8 nCa for the both for serial sacriflce to deterane the radzation dose pattern for lung and other tissues and for lifespar cbservacica to deterisne ase- cesponse relationsh 1 ps. At the present iae, only andmals with in ital Iung burden (ILB) of about $200 \mathrm{nCl}$ cr hagher aposed at enther 1 mature, youg adult or aged aninals have shoun increa sed mortality young adult or aged andala have ghown incteased motaliey as compared to controls. at thas time the young adult 3 mature and aced animas are 68,73 and 27 meeks aged aninas are 68 , 73 and 27 geer $\$$. The post-inhalation exposure respectively. The animals that died in the higher I I group had radiation preumonitis and pulanary fibrosis along with atyplcal pulaonary
exthelial hyperplasia. Hzstopatholog acal eqthe lial byperplasia. Hzstopathologacal

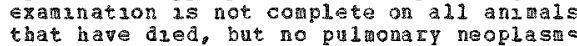
have boen observed to dite. (Anth)

$\langle 97\rangle$

Hol11ns, J.G., H.C. Stcri, and A. Duratrovic, vatucnal Research Council, ottava, Ontarlo, Canaod. 1974, Fobruary

The Iffect of Natural Physalogical stresses and reticicial pormonal stresses on the Retention of arerarium and Plutoms by Rat Bore.

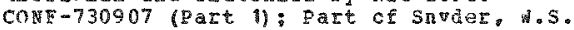
(Bd.). Proceedings of the 3 rd International Congress of the IRPA held in washington, D.C.,

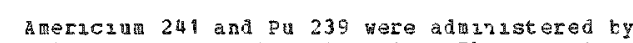
intravenous injection to rats. The injection vclume of $0.1 \mathrm{ml}$ obtarned $50 \mathrm{nCl}_{2}$ of 241 or Py 239. It as cound that the retentron of a merzciua and plutoniu by rat bone vazies with age and sex, and arring pregnancy and lactation. Whale the calciut cotrent of bone was substantially reduced by lactationg the scarcely affected. When the food consurption of lactating rats was restricted to that of control virgia rats fed ad libitum, the retention of atericlua by the pone of the lactatung nothers was greater than rhat of the controls. The effect of parenteral adurnatration of parathyold hormone and a adinistration of parathyrold hormon increased the retention of arericaulat a trae hen bone calciun was reduced. In tame hen bone calcium was teduced. In contrast, the retention of americiula by rat bone durang the lntense anabolic geriod of mcther andedately after lactation us less
than that of the controls. the retention of ameraciun and platonum by bone as also reduced arter ezthor a serzes of 
BIOLOGICAL ASPRCTS ARIMALS

$\langle 97\rangle \operatorname{CON} \mathrm{T}$.

intraperitoneal injections of calciun gluconate or parathvroudectomy. (Auth) (PM) (CTS)

Table 1 shows retention of an and $\mathrm{Pu}$ by rats 7 days after 1 njection.

$<98>$

Huffmans F.N., and J.C. Norman, Thermo Electron Corporation, kalthal, MA; Cardiovascular Surgical Research Iaboratorjes, Texas Heart
Institute, Heuston, Tr. 1973

Study of the Effects of additional Endogenous Heat. PH-43-66-982-7; DB-212-952; $240 \mathrm{p}$.

The feasiblinty of implantable circulatory support $s$ ytems depends on the absity of the body to dissipate the reject heat rrow the pover source dring the klood pump. If the energy source is a radionsotope, the body must also tolerate chronic intracorporeal radiation. Fhe object 1 tre of the endogenons heat program is to characterize the effects of antracorporeal nuclear radition and additional thermal load on malmands. The program is contanuation of initial canine program is contanution of lnitial canine subseguent friorts ut $132 \mathrm{z}$ ing heat exchangers subseguent feforts ut 123 zing heat

(plutonu 238) capsules. More recenty, the effects of RES (radiation equivalent sourcel -24 capsules wheh sialate the reatron and gama radiation envi ronment from 24 -watt Pu 238 heat sonrce have been ovaluated in mongrel dogs. Within the past reporting period, the two priary focl have becn: (1) the implantation of simulated thermal systems (STS) in calves for evaluating the effects of a 50-watt hat load using a functioning left ventricular assist puap as a blood-cooled heat exchanger: and (2) tne inplantation in primatos of p $5-50$ capsules which nodel the shape and densaty of
a balf-scale pover source for draving a blood panp. The long-tern survivals ingood pup. The long-tern survivals 1 good
condition of both pul 238 and pes saplanted condition of both pu 238 and Bes 1 aplan dogs and primatos, as 11 as the sts anticipated reject heat and dose rate levels anticlpated reject heat and dose rate levels aay be permissibie. (auth)

〈99>

IIy 2 , L.A.s Institute of Blophyszcs, Moscow, USSR. 1974. February

Regularities in Metabolist of Radioactive Isotopes fpon Incidence on the $5 \mathrm{kn}$. COVF-730907 (PART 2); Dart of Snqder. H.S. (Dd.). Proceedings, of the $3 r d$ Internatzonal septerber 9-14, 19\%, (p. 1371-1376), 1475 p.

The report, based on experimental data and calculated-dosinetric estmates preserts alculated-dosinetric est inates presefts a radionnclides of the elements of varions

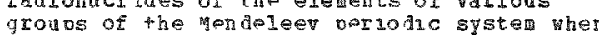
qroubs of the findeleev portodic systers treir sclut ons are aplled to the sta Data are analyzed for the levels of accumiation, the mode of intercutaneous distribution and elinination from the skin of

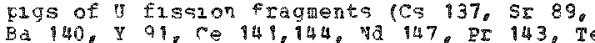
132. จ० 94, I 131, as ขอ 11 as 00210 and transuraniur elenents Pu 239 and an 241 . Comon features an the distribatzon of these agerts in he skan urrespectu we of their chen 1 cal or $191 n$ have been astablushed. Esental differpnces in the accumulation levels of radioactzve subetances $2 n$ the $\$ k 2 I$ and an the level of percutaneous resorbtion have been found, Wramus, Th, tranguram un and transplutonu lements, Te and Po, were classifued as raduonucluaes wh th low leye? of percutaneous reserption. while those w th a hagh level of percutaneous resorption 1ncluaed radionuclides of the alkaline elesents, the chroniul subgroups, and groups elegents, the chron 3 un sugroups, and groups that transfollicular route is the lin show of radionuclide penetzation anto the body
through the smin. (Auth) (Fmil)

Table 3 shows kinetics of elmunation from the skin of some racioactive substances $(\mathrm{H} 3 \mathrm{C}$ 137. Pu 239 . Do 210.1

\section{$<100\rangle$}

Ivannikov, A.T. L.M. Rarbitnaya, and D.D. Strolan, 1964

Effect of $N_{0} N_{0}, N_{0},-T e t r a c e t 30$

2, $2^{\prime}-01 a$ ingodiethyisulfiae on Dxcretzon of uranyl nutrate and course of uran un Intoxication in Rats. AEC-tr-7590; Fart of Moskalev, Y.I. (Fe.), Dastribation, Blological Radicactive Isotopes, $(\mathrm{p} .375-380), 405 \mathrm{p}$.

Male albino rats vezhnng $140-180$ grams were adran 2 stered subcutaneously $5 \mathrm{mg} / \mathrm{kg}$ uranyl nitrate for acute intoxication. one laur 1 ater DDSTA (N, N, 粗, $2.2^{\circ}-d$ a minodiethylsulfidel in the form of the aqueous calcium asodiun salt solution in a cosage of 50 unoles/100 grams rat aght was given intraperitoneally for the risst 5 days. Drandur content was deterinined fluoronetricaliy in bones, kidneys and liver. gyperinental results were assessea according to survital. change 13 body zelght, and clinical signs of lesions. DDST was found be an effective complexing agent for uranyl

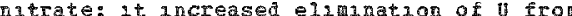
the organisq when given at both the early stages after v and at the jater stages. wnen deposition of $\mathrm{d}$ has already occurfed. The complez compound of $u$ and DDSTA was excreted complez congound of data pertannato residual i levels in the rat organsa were andcative of a significant decrease an the adicatze of a significan docrease in the accula lation of is particularly lis the skele
(FAP)

$\langle 101\rangle$

Jacokson, I, O., Unztersity of Chrcago, chucago, Il. 1945, Jure 95

The Hetabolisw of Tussues of Rats ireated with Plutcruum $(46)$ vitrate. CN-2992; Part of Barron, E. S.6., et ald, Monthly Health Report cn Problems Relating to product for Month of ay 1945, (F $37-47$ ) 47 D. (Declassifzed Januegy $H_{0}$ 1956)

Rats were injected intravenously Eu(t6) nitrate and sacrificed at afferent nitervals of the from 2 davs to 10 days after injection. The netaboly $s$ of the followng tzssues was studied: laver, katwey, scleen, heart, subraxllary gland adrenals, and thy reduced in size up of $\mathrm{pu}$. Six days later. however, it went donn consiaerably so that it becane only one half or ever a third of the ncrial size. The oxyger consuption of the spleen slicks decreased tc about haif ot the normal value by the tharj day. Ea produced some damage to the liver as shown by a andushea glycolysas, a \$light di nantion or inhubizon an tae utilizatich of Eluvate. 
〈101>

B IOLOGECAL ASPECTS

ANI傮BLS

$\langle 101\rangle$ CON⿴囗十

In the kidney. Pu produced slight danage as shown by a diminished oxidaticn of batyrate and of glutamate. phe respiration of heart ilices and the oxidation of acetate vere not influence $b y$ the injection of $\mathrm{P}$ to rats in lethal doses. All the anirals showed the characteristic leukopenta produced by $P u$ injecticn. (prin)

$\langle 192\rangle$

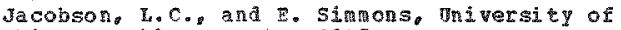
chicago. Chicago. II. 1945, hay

Acute Effects of plutonilla on the Peripheral Blood of thala mals. CM-2992; Part of Monthly Health Report on Problens Relating to Product for Month of may, 1945, (0.15-48), 45 p.

The effects of intravenoushy adninistered $\mathrm{Qu}$ (45) nitrate on the constituents of peripheral blood of the rat hawe been
studied. Doses of $0.0,0.25,0.50$ and 1.0 ugfom vere given to is grougs of 9 rats. hea gra were given to 4 giougs of 9 rats. hean tall veine at intervals through 167 days are sumarized. level of erythrocyree doses teaced the wean belon control levels by a days. In rats infected with $0.25 \mathrm{ag} / \mathrm{g}$ a reduction of $30 \%$ is aprarent, and greater than for the dose of 1.0 ug/gr. At 167 hays, recovery had not yet occurrea, though values vere higher thar the 135 day sagpling. A 10-20\% reduction in wean hemoglobin in 211 experimental grosps tas noted at 33 days. This Forsisted through 167  dats. Ag ain the sharpest 5eduction was noted in anials receiving 0.25 mean leucocyze per wa foll ost precipitously y.th the highest ase, but was comparable by 7 days and all grcups remajned
low. Heterophis per min 3 were reduced $50 \%$ in 10w. Heterophis per an 3 vere reduced $50 \%$ recovery in 135 days. A sidilar experinert is in progress using 0.5 ug/gat and 2.0 ug/go of + 6 citrate plutomi un. Sinilar 'results were obtained ith 0.5 ug/gm, but death
supervened ith the iagger dose. (BBu)

\section{<103>}

Jee, .. S.S., University of thah, college of

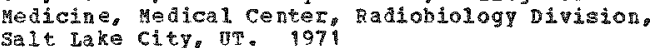

Bone-Seeking Radionuclides and Bones. Part of Berdjis, C.C. (EA.), Pathologr of Irradiation. Chapter 11. Willians and Tilkins company. Batimore, aryland, $\left[p_{0}, 186-212\right), 710$.

The chapter is divided into four sections: deposition of radionuclides, radiologicall detected changes, histologically detected changes, and induction of malignancy in bone. A sumary is given of the deposition of $B$ 239. $\mathrm{Ea} 226 . \mathrm{Pa} 228$. Th 228 and $\mathrm{Sr} 90$ in bores. The calein-1ike radionvelides falkaline earths) are called volume seekers and deposit in sites identical to ca in bone. In contrast to this pattern, both $\mathrm{Pu} 239$ and Th 228 are deposited on bone surfaces and are cal1ed surface-seekers. lowever radiothori. has a greater variety for reticuloendothelial cells and approtictely 25 of the pu cieposites in 1iver. Sove of bone changes occuring in beagles following I injection of $\mathrm{Ra} 226$, PU 239 , Be 228 and Th 228 are structirai changes in the mandible. destructive chages in the terthe pathologic eractur with and without healing. distortio of corter of long bones, distrubance of of corter of long bones, aistrubance retaghisical trabeculation osteolyc necrosis and tur formation. The radioinduced histolcgic lesions in bones of ceagles intected wh $\mathrm{Pu} 239$ are described and a histopathologic bypothesis of alpha irradiation induced bone dysplasia is presented. Some of the factors which influence the effectiveness of a given nuclide in the induction cf bone ralignancy are sumarized. It is pointed out that the bone surface-seeking alpha-enitcers are bore tcric than the bone volume seekers because nere of their energy is absorbed in cells and less is absorbed in aineral. The critical or sensitive tissue in the inatuction cf bone turors and squamous carcinona is probably the osteoprogentor cells and basal layers of the sgua mous epithellum near bone surface. There is tentative agreemert, that the current tuar data on man suport the threshola dcse-response hypothesis. on the contrary. dcse-response hypothesis. on the contrary, non-threshold dose-response hypothesis. (29M)

Table 11.3 shows the incidence of asteosarcomas and carcinota following deposition of bone seeking radionuclides in man.

$\langle 104\rangle$

Jee W.S.S.e vinuersity of vtah, college of hedicine, Radiobiology Divisien, pecartment of natcry, Salt Lake City, UT, 197

PI utonina 239 in Bones as Visualized by Photcgraphic and leutron-Induced

Antoradiography. Part of stcver, B.J. and Jee,

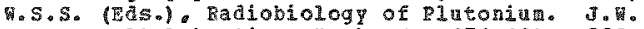
Press, salt Lake city, otah, (p. 171-19k), 552

Detailed autoradiographic studies found 1pton 239 to be: 231 a bone surface seeker, (2) non-unifor on bone surfaces, (3) buried by difusely labeled post-injection bcre, f(t) Ienoved Erom bone by osteeclastic activity. (5) concentrated in osteoclasts and macrophages, (6) teropea finom bone wut face by 6 monehs post-injection in dogs injected with $0.015 \mathrm{uCi}$ of $\mathrm{pu} 239 / \mathrm{kg}$ (7) concentrated in wacrophages with hemosiderin, and (8) accurulated in macrophages of bone warron at death. The accumplation of labeled

acrophages is an indicator of altered kinetics of both macrophages and bone cells. Labeled macrophages are chserved in $2.7,0.9 \%$ $0.3,0.09$ and 0.05 uci/kg bue not in 0.015 uCi Pu $239 / \mathrm{kg}$ injected dogs. An inproved a 239 is ascribed, in whoh fission tragment tracks and bone irage in Leran plastic filis frow bones containing $\mathrm{Pu} 239$ vere produced when irradiated by thermal neatrons (dectiled neutran autoradiography Prelininary

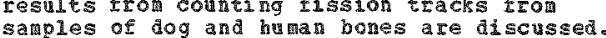
satolea

able 1 gives percentage of $\mathrm{P}$ il 239 associated with sites vithin lumbar vertebral bodies. as studied by autoradiography. Table 2 gives average skeletal retention and distributicn for four 3-1evel $\mathrm{Pu}$ beagles 40 to 560 days after injection. Table 3 gives skelecal retention and distributon for 11 i-level pu heagles 35 to 769 days in injection.

$\langle 105\rangle$

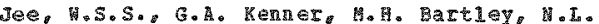
Jocku, H. Sah, H. ueller, and $k$. Scherfrahn, vaiversity of Utah College of medicine. Radiobiology Division Degartent of Anatong. Badiobiology Division Departhent of

Preliminary Report: Changes in yascularty of Cortical Bones Induced by bone seeking 
BTOLCGISA ASFFCTS

A

(105) CCNT.

Fedzonaclides. Coo-119-236: Bart cf Dougherty,

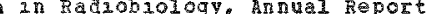
Work in Erogress in the Internal Irradmation program, (c. $97-125), 268$ p.

A technique of India ink-gelatin ingected vessel hits per unat area of netatarsal shaft was used to determine the alterarion 21 vascularity induced by graded, single intravenously injected dose of $\mathrm{Du} 239$. Sa 226. Th 228, Ra 228 or SI 90 in adult beagles. Percent of cross sectional area of bone th vascular chanels was 11.4 plus or minus 1.4 g 2 an 529 to 3896 day old controls. The reduction an vascularity was dose and tat dependent. Sagnificant reduction in vascalarity occurred at: 1.1 uci of radum $225 / \mathrm{kg}$ after 1900 days and $2300 \mathrm{rads}, 0.096$ $n \mathrm{Cl}$ of plutonum $23^{\circ} / \mathrm{kg}$ after 2200 days ano 350 Iads, 0.17 aCl of mesothorzu $228 / \mathrm{kg}$ after 2 .00 days and 000 rads, 0.032 uCI of ragiothor 130 radjothor 2um $228 / \mathrm{kg}$ ater 1900 days and 250 days and 8000 rads. The values for estruates days and 8000 rads. The values for estruate the accutulated ase necessary for thenselves are as follows: 0.06 uCs of radu $226 / \mathrm{kg}$ and $260 \mathrm{rads} 0.016 \mathrm{uC}$ ? $\mathrm{pluton} 2 \mathrm{q}$ $239 / \mathrm{kg}$ and 100 rads. 0.00162 ucs of $239 / \mathrm{kg}$ and 100 rads, 0.00162 ucs of to 100 radiothorlum $228 / \mathrm{kg}$ and $10 \mathrm{rads} 32$ to 100
aCl of stronem 90 and 7000 rads. (Auth)

Th gure 5 showe effect of graded doses of pu 239 on percent vascularity of bones of dogs as a Eunction of accuminter dose.

$\langle 100\rangle$

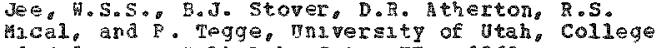
of Meiscine, Salt lake city. WT. 1962.

The Long-Tera Effects of plutonam 239 in adult Beagles. coo-225: Part of Dougherty. T. F. Research in Fadobiology. Semanmal peport of Mork in progress on the chronic ramucity Eroqua, (p. 95-127), $135 \mathrm{p}$

The progress of natie years of work que to october, 1962 to determine the tomalty of plutcnum 239 an the ske leton of acult

beagles 35 sumarized. Tntravenous 3njoctions of $2.8,0.90,0.30$, and 0.096 uci/kg flutonam (t) citrate induced $7 / 9$, $12 / 12,12 / 12$, and $7 / 8$ bone cancers. The average accunulaten rads to the skeleton varied from 326 plus or minus 70 to 6470 plus of inus 1590 rais. Systeratic radsographic and histo $\log _{2} \mathrm{c}$ search for bone tuars revealed wuztup prinary osteosarconas and the atratom tcal astributicn for each dose

level. The anatomical a Istribution of osteosarccias differed for each dose level.

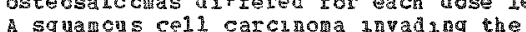
frontal bone was detecte in the 0.096 wh/th frontal bone was detected in the

group. The skoleton exhabited radiographucally and histolog $1 \mathrm{cally}$ extensive gross tasue dama in the higher dose levels, wile isolated engty lacune and a slight anout of resorpt son occurred in the trabeculae of 0.096 kC1/kg dogs. In contrast to the an Imal darage of the spcngiosa of the 0.096 uca/kg groug. The trbial compact of the same skeletor exhlusted a high jncadence of canal flugs and loss ef osteocytes in ostocns. Tho dzstribution and redistrabution of plutoncum are revreved to eaphasize the non-uniforasty of the radunuclide nin osseous tissue. Detazled radrocher lcal analy ses of bone saplos of four beagles injected wth 2.8 ucalkg Pu 239 also Ievealed paryation in the concentration of plutonu in the san bone of several dogs and 1 varous bones of a guven dog. The amoung of activity in the Bandinle and shaft of the humerus was fally icw. correspondingly, the tunt mankib were restricted to the higher dose ievels. Highest concentration of the tertebral column was the sacrum and thoracic vertebrae, but wast of the turors arose in the cervical and lumbar reghons. The concentrations of lutoniut in ribs, scapulae, and pelves were in the same Iange as the vertebrae, but more pelvic tumors were detected. The addston of lower dose levels. when the andals and space are avalable to insure a safety factor in the exgerinent 1 s announced. (Auth)

The incudence of osteogenic sarcosas in beagle dog $2 n j e c t e d$ win $2 u 239$, the dastrabutzen of Pu 239 in the skeleton, the varsation of average weletal dose and numbers and sites of osteogenic sarcomas are given in tabular corm.

<107>

Johnson, I.J., R.I. Watters, J.I. Lebel, C.R.

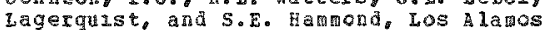
ScientiflC Laboratory, LOS Alamos, NM, Colorado State University, Fort Collas, Co; Don Chemacal
Conpany, Rocky piats Division, Boulder, Co. 1972

The Istrabution of Rlutonan and smericiua: Subcutameous Rumintration of plutonilu Diomate and the Effect of chelation Therapy. Part of Stover, B.J. and Jee, H.S.S. (Eas.).

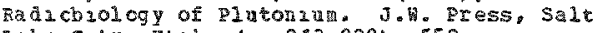
lake City, utah, (p. 213-220), 552 p.

Translocation data obtanned following subcutaneous a plants ô Fuo2 1 dogs, sinulatung pu contannated vouds wach have been experienced in plutonan banding facilities, are presented. Trssue

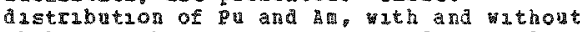
chelation therapy, are presented. Results otserved include apparent tissue pu and $\mathrm{A}$ concentration equalibriun uithan the flist theray da not alter the pu concentration in theray dad not alter tre pu concentration the thsses, but signicicantiv reduced the average A concentration $1 \mathrm{n}$ the skeleton
lyver. The inportance of rapld reaval. were feasibie, of imbedied Pu is re-erphasized by these findings. The use ce DTPA therapy for the oxade form of pal in a contarinated yound appears to be cf linted value. (Auth)

Table gaves percent of 2 aplanted Pu $2 \pi$ tlssuesss. Table 2 gives percent of Implanted Ala 1 tsssue.

<108>

Ralistratova, V.S.. I.S. Katsepov, and V.I. Trifonov, Not giver. lighs pebruary

R 10logical Effects observed ath combined Fposure to adsatsons. Con -730907 (Fart 1), Part of Styder. W.S. IEA.l, proceedings of the 3rd International congress cf the IRPA held I

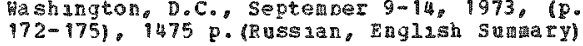

The combined efrects of I 131, An 249 , HTO and of externd radiatzon sources were studied in why rats. The results obtayed adacate that combuning of radionuclade and whole-body external gama irraduation in

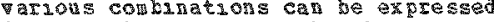
different $1,1 . e$. elther by sumation of the effects or by their 1 increase or decrease. (Auth) 
BTOLOGICAL ASEECTS

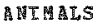

$\langle 109\rangle$

Kallfelz, E.A., C.I. Conar, P. F. Crasg, and A. P. Casaret, cornell inzersiey, Ves York state vetermary college, Department of Piysical BI Ology, Ithaca, vi. 1972

Blologacal Fifects of Radution fron sulutat Plutoni un 238 Pover Sources in Dogs.

Cov $\mathrm{F}-720108 ; \operatorname{co0-3167-28;}$ Part of Proceedangs of a Symosian on pesearch kninals in hedictne held II) Washangton, D.C., January $28-30,1972,(14$ p.).

The entuled Iadiation sources used $2 \pi$ thas experiment consist of a combination of cf 252 (to provide the nentron component of a 30 wate pu 238 source) and $5 r$ s0-X 90

Bremsitralung fo provide the adiztional photon tiun needed?. The sources. placed into a stanless steel canule. were inplanted into Iabraior pertievers delsuerng $1,5,15$, or 70 times the radiatzon dose expected from a 30 wate w 238 poner source. and dose rates to various organs were deterante. I tatal of us dog have been 1.mplanted to date inth a raximu total acrumlated aose in a sigle dog of 37,000 rad at 1 co from the surface of the inplate. post-morten aramatzon of somo dogs revealed a complete cessat zon of spernatogeness ame a complete cessat ion of spernatogeness and

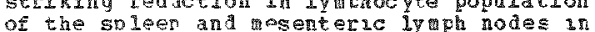
of the spleen and esenteric ly the nodes the 70 arimals. Simlar, though less severe lesions were observed bin the $15 \mathrm{R}$ dogs. In adarion, one $90 \mathrm{~d}$ dog aeveloced a mast cell sarcon at the mplant sute and the th and $70 x$ dogs knlled fter one vear showed a
reduction in nubers of megakaryocytes and atythroponet $3 c$ elements 2 in the bone alrows in the picsmaty of the inplant. Ho functzona 1 changes vere sem 28 ix or $5 x$ anclals. $(\mathrm{A} u+h)(\mathrm{RA})$

$\langle 10\rangle$

Fa lingova, Z.T., Mn+stry of Health, Instrtute of Honhysics, "loscow, USSP. 1960

State of the ped Blood celle and remotymacs in

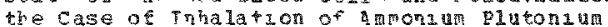
pentacarborat by Rets. AFC-tT-8013: Part of Radiobiclogy, (p. 204-2ns) $232 \mathrm{pe}$; Red 100301092 ya, $8(6), 925-927$.

It was shoun on 317 rets of the wastar 12 ne $(130-160 \mathrm{~g}$ i verght) that in the case of a

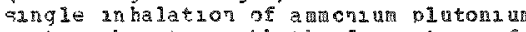
pentacarhonate, with the deposit 10 on of $0.024-0.032$ u 1 of 01 utonan 239 in the lungs, hyporsma, erconvaned by hvervolenua and accel eration of b100a Elon. periodically arises, 1 is the case of chronge inhalatuon. during the late perpods, $18-20$ percent erythrocytes with an snrreased ack

tesistance acpeared in the blcod. (Auth)

$\langle 11\rangle$

Kotz, J.. ". H Weers, and

Flectruc compan, Hanford atcmic Droducts of ration, zichiand, 角

FCssible Thompertic gents for Rariatzon Darage. kith-27588, nart of kesearch and Levalopint Activi ans guartarly Dogreas Repor rot January-March, 19\%3, (p. 16i.

Glacuronolactone, a conpound not previously

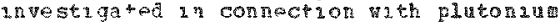
therapy, was snow to affect signifucanty

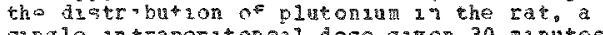

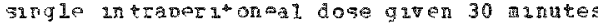
after piutorium administration decreases

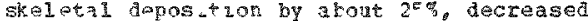
sofe tissue deposition by about $40 \%$ and increased later deposztion approxamateiy five-fold. (Ath) (comlete Text)

$<112\rangle$

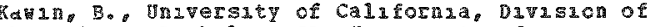
Thysiology, Berkeley, CA: 0nuersuty of Ca litornia, crocker tiadlation Laboratory. Berkeley, $\mathrm{CA}$. 1953

ffects of zuconum Citrato on warly Fenur Uptake and Uernary Excretion of Radionsotopes.

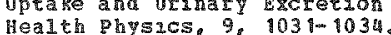

Effects of single antraperatoneal

adrantratuon of nonadioactive zuIconsu cutrate on ferming mptake and urinary excretion

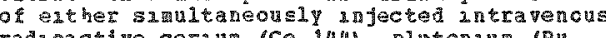
radioactive ceriug (Ce 144$)$, plutongu (Pu

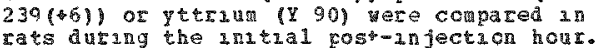
In the experiment niety ycung adut female Ieng-Evans rats (average th. 175 g) zere

atratenousiy injected ath Ce 144 . Pu 239 or T 90 in dosages of $5,0.5$ and $40 \mathrm{nC} 1 / \mathrm{ar}$ mal.

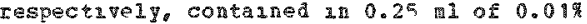
sodium citrate, pri 8 . lithin 30 seconds fcllowng injection of radrousotope.

forty-ine of the anmals aere intraperitoneally anjected wth a non-radioactive zirconiu citrate soluticn, in dose of 40 然 per amalial. The results wath increased plas a disaguearance of pu

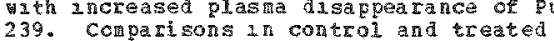
anials indacate tha zaccondu citrate treatment has no effect to alter rates of fear deposation for the earin time interval studied, and that it emanres urinaty excretion of $\mathrm{Ce} 144$ and $Y 90$, with crily a very small effect on $P$ il 239 excrepron. (Auth) (t)

$\langle 113\rangle$

Rayn. B.. Veterans Adanustrataon pesplal,

Efects of Zirconam on Early Femar uptake and vrinary Excretion of Radionsctopes. dadation nesearch, $16(4), 583$

Injection of anamal wh zarconalu catrate sclutions ts krown to alter markediy the dastribution and excrecion of radiossotopes. Iffects of prombe zirconsu cutrate

antactions on early plasta dusappearace. uftake by femur, and armary excretion or - ntravenously adunstered raoroactive cerrum (ce 144) plutonzug (Pu 239 (6)) and yetrzat (190) vere studied 2 rats. Folionizg treatient the vlasa conceatrations of tia Iadionsotopes vere vroportronal to tap plasma concentrations of zarcontua labelied veth $\mathrm{zr}$ 95 . Thas effect decreased an the order ce iat $>90>P$ 239. GraphICal aralysis of the inta shoved that fenur urtake coula be related by a constant CE provortionality related br a constat ce provortionally

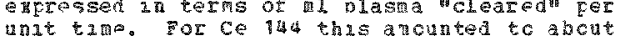
f.018 $\mathrm{wl} / \mathrm{in}$ the correspondang values for rols aldin The corresponding values for

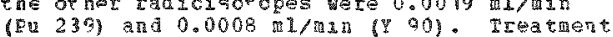

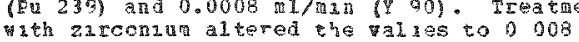

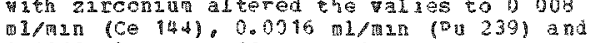

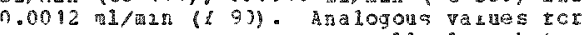
urdnary oxerstion were gaver llit low, but were dncreased markedl by the 2 reomun treatrent. The corpol valus amounted to

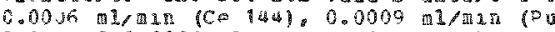

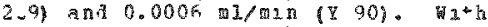
zacondut trearment these constants anounted

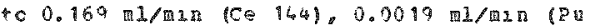

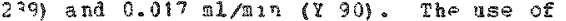
the ge proportiopalities as measures of 
BICIOG ICAL ASPTCTS

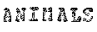

$\langle 113\rangle \mathrm{COHT}$.

effectiveness of zircoridu treatrent is

di scussea. (Auth) (Complete Article)

<114>

Kanin, B., and D. H. Copp, nniversity of Brysology, Berkeley, CA; vinersity of California, crocker Radiation Iaboratory Berkeley. CA. 1953

Effect of 2,3-Dstiercaptopropanol (BAL) I pon Distribution and Fxcretion of Platonin. Distributicn and scretion of Platomino Biology and Medicine, $84,576-538$.

Young adult fomale rat: weighing 200 to $240 \mathrm{~g}$ were injected intzamsculariy with 15 ug of hexavalent $\mathrm{p}$ 239 as the chloride. Some arizals received 9 injections of 10 ag. 2, 3-dimercaptopropa nol (BAL) $3 n 0.1$ al peanut oil antranuscularly, at is hr istervals following the injection of $p_{\text {ul }}$ while others

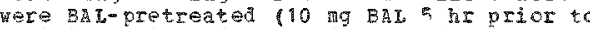

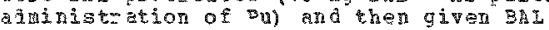
after the 2u injection. 9rithe and feces were collected at 2 days and 8 days following injection of Pu. At the end of 8 days, the rats were acrificed and liver, kidmeys, right fetur, right foreleg. Ieft foreleg and carcass were a ssaved. The results snow that intratoscular injection of intrata scular injection of ases therapertically effective in arsenic and therapertically effective in arsenie and Mexcusy poisoning had no effect on the dist ribum (heravalent, whether giter prior to or following the adinistration of the metal. (Auth) (F)

wable 1 shows the effects of BAL upon aistribution (in iner. bidaeys. ferur, carcass) ard excretion of intramscularly injected $2 u$.

$\langle 115\rangle$

Kenrer, G. H. aga W.S.S. Jees priversity of Utah, college of hedicine, Salt lake coty. UT. 1967, "areh 31

Efects of Age and sono-Secking Radionuclides on the vasculartiy of Rones from alult Beagles. con-19-235; Part of jougherty, T.F. Research

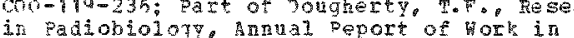
progress in the Internal Intadiation progran, (r. $126-143), 269 \%$.

Celloinir sections of the diaphyis of iaetatarsal hones injected with Traja ink-gelatin from adult beagles vere studie to deternia the effect of aging and internal irradiation on the negree of pascularty and sone index of bose remodeling. The experimental dog vere injected with 2.7 . $0.9,0.3,9.05$ or 0.315 aci of plutoniun 239 citrate/sg or $10,{ }^{3}$ or 1 uci of radiem 226 uztrate/kg. The degree of vaseularity uas atserrined hy the onserved atios of the numer oz haversian canals cortaining India

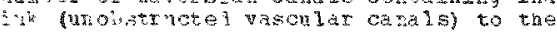
tot 1 num of haversian canals. Bone

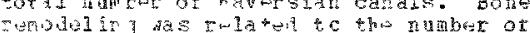
corring optons. The only change observed

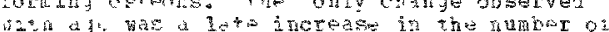

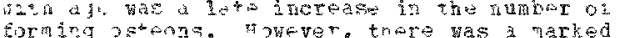
dachease in vascilarity foerased porcert dock ase in vascilarity fecrabed percent

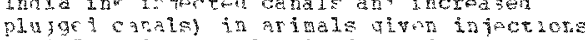

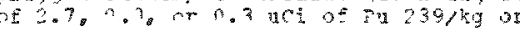

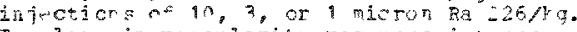
rars lose in vachlarity was nowe intense ar.

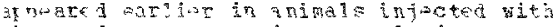

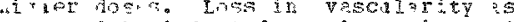
Ty
2. lower accumbated rads than pluggea cands. Increased mubers of foring csteon occurred at higher doses of plitoniun and
radiura. (Auth)

<116>

Rhodyreva, M.A. Hor given. 1965

The Fenetration of 210 toniu 239 through the Skin. Meditsinskaya Radiologiya, 10, 42-46. (Russian, English Sumary)

Experi trental studies vere manertaken to detertine the possiblity of plutcaiu nitrate venetrating the intact skin of rabbits. plutonina 239 Fenetration through the intact skin was assessed by the ancunt of activity in blood and interali organs of the anmals. Blood radioactivity was measured by alpha-track photograpiy on thick-2ayer plates of the $A-2-50$ type. plutoniug nitrate applied in the forn of a solution in a dore of 0.4 and a uci/ch (E) 2$)$ of skin sarface aksorbed through the skin of and als. A relaticnshif was estabitshed between the $P u$ 239 content in the blood and the quantity applied on the skin. In the epicutaneous rcute of absorption the greastest amount was founa in bone tissue. on the 1 ath day uf to $70 \%$ of the absorbed guantity as found in the rabbit sieleton. At the end of the

observation tine about $0.15 \%$ remalned on the skin. BRA

〈117>

Konstantirova, V.V., Mot given. 1963:1964

Deoxyribonuclease Reitivity in Rabit liver Affected by Plutonian. AEC-tz-5417; Part of Radiobiology, (p. 19-22); Badiobiolcaiya, 3 , $501-503$.

Nabbits of both seres veigning 3.0 to $3.5 \mathrm{~kg}$ were intravenously admisistered a solution of plutonim nitrate in a single dose of 7 uci/kg: Atres 1, 3, 7, and 15 days, and afer $\%, 3,4,5$ ma $F$ months, the anilabs vere sacriticen anc the activity of was determined in the liver. The activity of IMase 2 consuderably increased alrady within morta after priming an reacned its waximut value $(3.8-$ fold increase $4 / / 2$ in aximu value $(3.8-1010$ increase radioelenent. (RAF)

$<118$

Ronstantinova, V.V., end R. E. Jibinzon, Not given. 10ag, January-Feoruary

The Iffect of platonium on the content and Fonewal of Nucleic Acids in sond pabit Tissues. Biochemstizy, 24(1), 897-903.

Fabtists of both sezes aged b-7 mortas were injected intravenously wh a solution of Flatonfar aitrate in the amour of 7 uci/kg

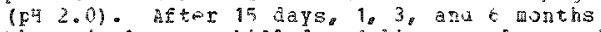

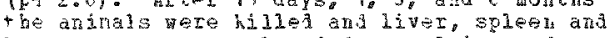

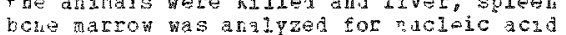
content. For the leteraindtan cr Iate of content. Fot he leteraliation ct rate

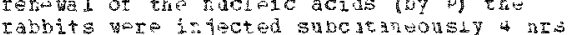

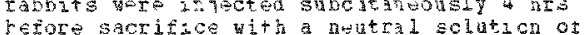
va 293204 is 32 ka

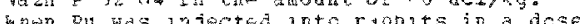
of 7 uciso

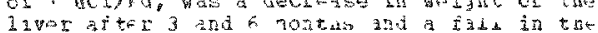

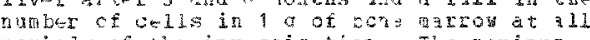
perions of the invistindton. The raxdina Aढct

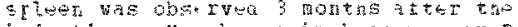

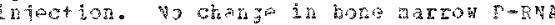




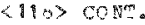

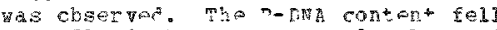
markedy in hone martow and spleen atter 3

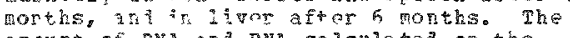

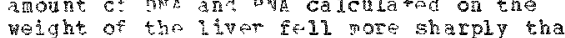
weight of the iner fell wor sharply than Whon calculated on he basis of anit weight of organ. The amont of Point inall the

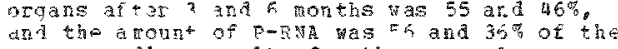
corresponding rasults for the conerol animals. The goecific activity of EA ircteased $1.5-2$ times in all tho tissues in nost of the reriods of study. The greatest ancrease in No sfocific activity pas it the liver. The activity of bone matrow le volyger ases 5 months after it iecting

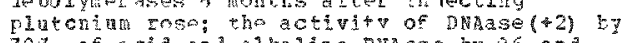
$70 \%$ of acid anl alkaliue prase ky 05 and

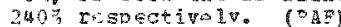

Teples are qives on vequt of organs anount of Pu ionzation abse. and content of total and it ranbit tisues ater pu admintration, of content and specific activity of nucleic acid ard of amount of nucleic acis a an intensity of wetak of $\mathrm{I} 32$ in hne marrow ce? $\mathrm{s}$.

$\langle 119\rangle$

Rormberg. H. A., Hanfor Atomic Droducts Feration piologe Section. pichiand. 1956. Biology Research, Amnal Feport, 1955. Bat $-4900 ; 188$.

The research activites of the Biology section were sumarized for the year 175.5. The reports fall into the following categories: effectivenass of isotopic diluticn, studies on radicactive narticlos, stuies in plants on radicactive paticlos stuies in plants and animals including ficrobial stidies, and rats fish and plats. Sevora studies of $I$

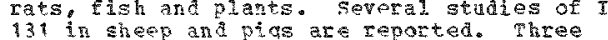
131 in shep and pigs are reparted. Thtee papers Erom the

$\langle 120\rangle$

Kozaberg, H.A., and J.J. Navis (EA,), lanford Atomic Eroducts operation. Bialogy operation.

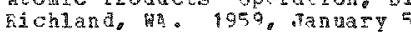

Hanford Biclen desearch annal feport for 1958. Hik $-59500 ; 15,6$.

The subjocts discussed in this andul regort incluce: uptake and metabolis of strontu and calciur in plants and animals, the retention and elinination of plutonin following differer rontes of edinistration. synergism of plutonita and external

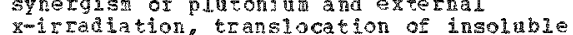

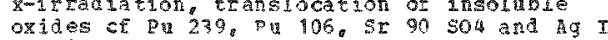

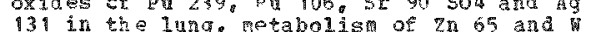
185, intestinal tract ir raliation by 190 , 185, intestinal tract irradiation by 90 and effects ci procoss efrluents on th
biota. Three papers tere abstracted separatel $Y$ for the data base. (fip)

$\langle 121\rangle$

Kornberg, Ho An and D. Warner (Ed.), Hanford Atonic Products aperation, Pichland, ha. 1960. de 1 a

Hanfora Biology Research nual Report for 1959. WW -65500 : $208 \mathrm{p}$.

The 38 papers in this 1959 prograss report deal with some aspects of internal enitter metablis and toxirity, and relate some metaolis and toricity and relate some aternal radiation. Seven papers vere iscractod stonratoly for the data tase. areas studied include an investiation of st-Ca relaticnships and their rateation in st-ca redaticrships and their rateition in the aninal body and in plants; and $k$, Cs 137 and aiso alsoussed ane aspets of st conleity in miniature swire and he ccmparative toxicity of St 90 , Ra 226 and bu 239 in suine. other large animal research deals with

efect jeness tegting of selectea radiation protfotion procedures; the biological effects of ${ }^{2} 131$ in sheep and solues and its removal frot leaves. The wetabolise of $\mathrm{F} 32$ and $\mathrm{zn}$ 65 was investigated tn fish, mice, rats, abd rans. A gethod for measuring in vive $\mathrm{E} 32$ by breisstrahlung was developen Radioactive carticles stidies irolude the effects of $\mathrm{St}$ 905 so 4 inhalation on mice; excretion and teansiccatior of pil 239 Fuoz afrer

inhalaticn: distrivution and toxicity of inkaled Pu 239 Palo and biologtcal effects of

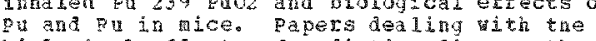
biological efects of radiation discuss the effects of gastrobutestinal irradiation on effects of gastrolitestinal irradition glucose abscrpton; poivinglpurrclidine

excretion as an indicatos of radiation damage in the intestine; the effects of comined E and $x^{-i}$ - rradiation in cats: and cytological aspects of irradiated yeasts. A technique was established for measuring the rovebent of radionacidies across oili meabranes. Reports are given on the radioactive contannation of widife for 1959; chirook silton spawaing near inaford; $2 \mathrm{n} 65$ in 2 arine wollusks near the columba piver touth; mutaticn and tenperature effects in chcndFococcus COLUm APIS; and on the participation in the onvirondental progran of eroject chariot. (1)

$\langle 122\rangle$

Koghurnikova, H. A.. and $V_{0}$ Z. Leinberg, not given. 1954

Sffects of Aseptic Inflatation on Long-Tert Sequelae ia Rats Given Plutoniu 239. Aac-tr-7590; Part of loskalev, Yu. I. (Ed.) jistribution, Biological Eftects, and Acceletated Excretion of Radioative Isotopes. (p. $258-256\}$, $405 \mathrm{p}$.

Experiments vere conducted on 264 mistar rats of both sexes, with an inital weight of $100-200 \mathrm{~g}$. The rats were divided into fom groups. Plutomiun aitrate soluticns (E 2 ) vere given once. intraperitonealig in a dosage of $0.63 \mathrm{uci} / \mathrm{kg}$ to the anials in the first group. Turpentine was given to the rats in the $2 n$ a groun is days aftor atsinistration of the same dosage of $q u$. anly turpentine was given to the 3ra groug of only traentine was given to the 3ragroug of rats, The bth group sertid as biological control. 2 weeks for 3 months, subcutaneously in the thigh to induce asertic inflantetion. the thigh, to induce aseptic inflato The experiments shored that aseptic inflamation combined hat sua 11 doses

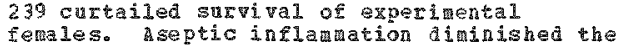
incidence of bone and hematopoietic tissue turots in rats of both sexes. multiple injections of turpentine. adinistration of stedi doses of Pu 239 , as vell as the combination of these tro factors, induced scre rise in incidence of neoplas endocrine glands. (RAE)

Tabular ata are giten of localization and incidence of tumors and of worbidity in experifertal and control groups of animals. 
BTOLCGICAI ASDERT

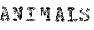

$493\rangle$

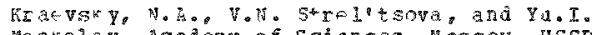
fosklev, ncadery o cciences, oscoun, ussp. 1904

sore sesults of sturying the Blastomogenic

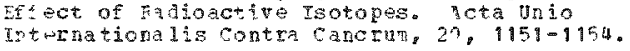

Tumors inducel in rats bu deposited

radicactive fiscion products of uraniug were studied : doses from 10 to fin 00 times above tha maximan perrissible level. A $20-30 \%$ turot inciacres vas onserved. Several types of tunors were afferentiatel according to their mecharisna of development as a function ot the isotop as listribut ion in tissiles. radiatier lose and ase rate. one type of thar fosteoszacozas, iver and gastrointostinal tumors) resulted from a direct exposure of tissu to jondzing radiaticn. Anothor tvpo (tumor of the nypothysis), induce by all the sotopes irrespective of their distibistion ia tissues, doyeloper by indirect influences as well as by ditoct rajition exposure. The well as by dzoct raniation prosuse The thid group of neplasis (lencoses, tumors of

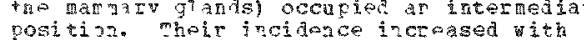

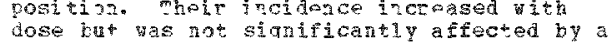
dose but vas not significant
change of dose rate. (RAF)

<1243

Brivolutski:, A.L., A.L. Tikhositrov, V.A. Turchantroca, and \%errard (Transiator) Institute for volutionary Morphology a d

Changes in structure of Animal populations (Torrestrial ard soi. Invertekrates) Due to soiz

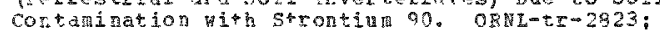
f D.: Pedoki ologia, $12,374-380$.

a study vas caricad out on the action of 35 90 contarinated soi on the structure of an sr $9 \mathrm{C}$ by varions species of land and soil invertebrates. Birch-pine forest plots were

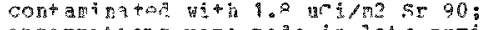
onservations were pale in late spaing. IIfierent aninal arcups racted aifferenty to soli contamination. The population density of tho soil-dweling ajerorauna was markediy decreasen in srocontaminatel soil. sacrophytes, rainworms, and diplopods nere especially sensitive: no fect was observer in flying insects fripter, Staphyliniale. siateridael or on mombidias and nernithidae. Effects of radiation on over invertebrates in theis active and reproductive perion. The sol 1 invertebrate population decroased considerably during population decreased consideraby during 耳azin aruance in $\mathrm{sr}$ contaminated soil. tio pattern could be found of the amount of accunulation of $\mathrm{s} z$ oo in different species: wale variation was observed. Snalls accumblated relatively ore $5 x 90$ than did rainworms. (RAE)

$\langle 125\rangle$

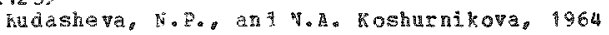

Eifects of aditional Pathological Factors on Eeripheral 1 cod of Rats Given Plutonim 239. AEC-tr-7590; Dart of Moskalev, Pu.I. (EA.), istribution, Fiological Effects. and Ascelerated Frretion of Fadioactive Isotopes, (p. $230-237), 405 \mathrm{p}$.

Data are given pertaining to the geripheral blood of rats when relatively snall aoses of
Fu Were comolnea vith andiple nloodetring and turpentive indaced aseptie intaration. Experinents were confucted on wistar rats cet

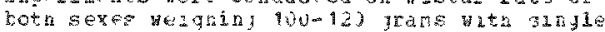
intraperitoreal itjections or y lutorian intrate (ph 2) in a dosage of jof aci/kg.

changes ing body weight dnd survival time ver Changes in body weight dnd survival time ver month. Single adrinstration of pu resulted montho Sirgle adninstration of pu result ir a decrease of survival tiga to

nuitiple bloodlettra and aseptis inflamation did not alter the response.

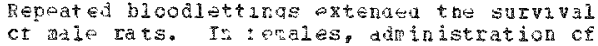
Fu alone as vell as a comination af the two other factors, dia not alter tag man surviva? tial Blood leteing and aseptic inflamation did not result in any apprectable changes ise the rum der ot erythrocptea, he gogloban cr ret He significart changes in erythroroles is was obsarved. The chatges reterabla to witie lood coils, manifested by a gratual decrasta is total rumper of leacocytes and lyphocytes with ar increase in neutrophis were atributed to age. Aseptic intamaticn ata attributed to a pe. Aseptic intlamat depression of leukocyte besponsu. same increase in thrombocte ruber ias roce after the ist and zid blcodetting. (RE)

(126)

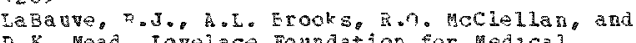
D.K. Mead, Lovelace Foundation for Medscal Education and Research. Inhadation Toxicology Pesearch Institute, Aibuguerque, Na. 1974, December

Petfation, Distribution and Freretion of Plutcrium 239 pioxide Farticlus babeled wth Wterbion 169 in the phesus Monkey After a Single Acute Inhdation Exposure. LF-49; Part

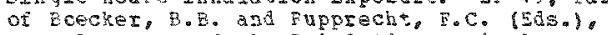
Aneval seport of the Imadation poxicology gesparch Institute october 1,1973 tarowgh septetiver 30, 1974, (p. 170-173), 384 p.

Sizteen shesus workeys wero exposca to a figh fired 239 Puol abrosol labeled wish 169, and Ietention, distribution and excretion patterns were deterained. After an edriy rapia clearance phase, which nad a hale-1ife of less than one day, the reating plutoniur was retained in the lungs with a half-life that apporea to be greater than 500 days. $3 y 30$ days after exposure, $99 \%$ of the $\mathrm{Pa} 239$ in the body was in the lungs. At this time, 6 to $10 \%$ of the Y3 169 burden ras in the carcass and skeleton suggasting that the particles. The Jemaining Yo 169 activity was in the lungs. There was little Pu 239 il the liver, bone or lyzph nodes. The particulate naterial was cleared rapidy frow the gastrointestina and upper respiratory tracts and appeared in feces over the first four days. The jevel of 23239 in feces returned to bacirground by six days, JIinary excretion of $\mathrm{pu} 239$ reached a peak by 8 to 10 days and then renained at a constant rate throughont the remajnder of the experiment These data are useful in calculating radiation dose to a variety of ordans and relating tis a ase to the appearance of late effects frol inhaled aipha-enitting Farticles. (Auth)

《127》

Iikbtarev, I.A.. G.V. Arkhangelskaya, A.I. Dobroskok, T.A. Zvonova, H. F. Korelina, G.P.

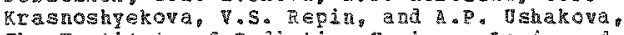
The Institute of tadiation Hyglene, Hentrgrad, us\$. 1974, February 
$\langle 127\rangle$

MOIOGICAL ASPECTS

A RTIMISS

〈127〉 CONT.

Use of a Specialized Aralog computer for the Modil of the perabolism of some Radionuclides. ConF-730907 (Part 2); Paxt of snyder. (E).). Froce edings of the 3 ed International Congerse of the TRPA hald in washingtono D.C. September s-14, 1973, (p. 1358-1363). (4475 g.

The arplication of andog complers in the The aplication of andog complers in the (EOllowing Pu injection and of iodine (Eollowing pu injection and of iodine metabelisin, and of an age-related model of serontim ard calcium thetabolis in an is
lescribel. The fechnigues involved in the lescribel. The technigues involved in the solution of the problems are examined and
suitable structural schenes to be analyzed on analon conputers a re sugge sted. The blotaned prelictions are in good aqreenent with scre experinental findings, which give every reason to consider the suggested nodels to be adeduate. mus, the analog conputer nodellina provides an effective means for the quantitative analysis of the sufficiently complicated non-linoa 5 problems of

cadionuclite transport in the iving

orgasisa. (Auth) (F⿳M卄日)

<128>

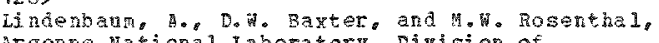
Argonne Naticnal Labotatory, Division of Eiological and palical pasearch, Argonse. IL. 1972

Conparison of Flood clearance and six-day Tissue Distribution of ponomeric ard polymeric Plutonivi 22 in the teagle. Radiation Sespreh, $51,540-541$.

No cceparative metabolic studies of monoteric and colymeric plutoni un he been male in the dog. althould the aistribution getention. and therapentic nomoval of different

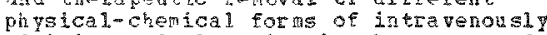

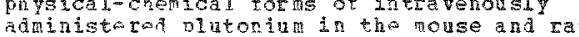
adrinist ron olutorim

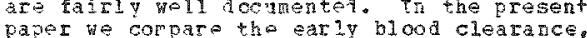
paper ve compare the ear y blood clearance

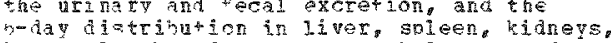
luags, lvmph nodes, testes, skeleton, and

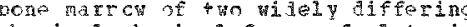
ohysical-chotical forms of plutoriun in the beatle tog. To-year-old male Argone-bred be agler wese exgh qjen a single intravenou infection of 3.2 uci (about 3.3 uci/kg) of withes mogomeric plutoniug aistate labout $00 \%$ ulerafilterahl or highly polvperice

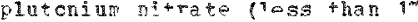

ultrafilerable). Pesults to date frdicate a note rapid hlood cloarance and a high marrow concentration of the polynerice as compred tc the monomeric pilutonia. For interspecies conarisons the plutonin preparations used for the logs voro also injected into nice. in both epecies the contert of polyneric piutonium ir. tho matrou of tho long bones $a^{+}$ plutoniall ir the matros of tho long bones monsario nreparation. The 6-ay 3ist ribut ion of monomeric piutoning in the dog tisgus yill provide baseline values for ostametrat the conbired effect of DTPA and tre yast cell wall polysaccharide gacan.

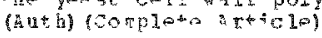

$\langle 120\rangle$

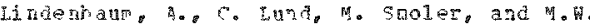

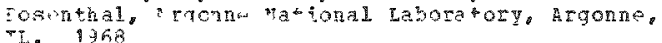

Drwartion, rharacterization and Distrubition In Souse minges of Graded Polymerie an

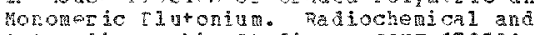

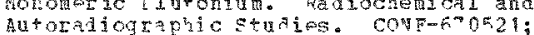

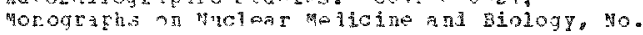

2; Part of Rornberg, H.A. and Norwood, W. D. (Eds.) Proceedings of a Symgosius on the Diagnosis and Treatient ot Deposited Radionaclides held in Richlana, washington, Haq $15-17,1967,(2.56-64), 680 \mathrm{p}$.

Solutions of plutoniu(ta) nitrate, adjusted te $p H$ F. 5-6.0 and stabilized with citrate. ve eractionated ith isfrect to particle size by passage through sephadex columa. Three graded solutions of narrow particle Three graded solutions of narrow parti
size range thus obtained, in which the sraction of plutoniun ultrafilterable through fraction of plutonium ultrafilterable through
cellophane meabranes was less than $1 \%, 30 \%$ and $100 \%$ respectively, were injected intravenousiy into nice. st sacrifice, five days later, livers, spieens, femurs and tibial shafts the latter separated into hard bone and aarrov fractions were removed for plutoniug a increasing ultrafilterability, less plutonium was decosited in $11 \mathrm{ver}$, spleen and arrow. while rore was deposited in bone. Injecticn of the graded solution containing $30 \%$ ultrafilterable plutoniug, from which both larger and sabller particles had been different organ distribution of platonilu as compared ith previously used angraded. sclutions of the sabe ultrifiterabity. ith the graded solutions, the greatest differences in tissue deposition vere found tetieen the wost polymerized glutcniul and the two less polyteric forms. The pattern of degosition in molse tissues thus agpears to depend on aggregation of plutonium-containing particulates to some critucal particle size. Filtration of platonina solutions through calibrated 国lifpore filters indicates tha this critical size is below 0.5 u and well. a hove 0.01 u in diameter. puantitative autoradiography of livers from aice given graded polymeric plutonia showed differences in deposition between parencyal and littcral cells (60\% v. $40 \%$ respectiven $)$ ine ratio cells $60 \%$ vo $40 \%$ respectiven : the rat

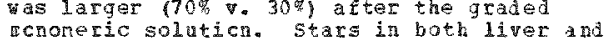
scleer vere seen on 3 after the nost sclefr vere seen on
polymeric solution. (auth)

$\langle 130\rangle$

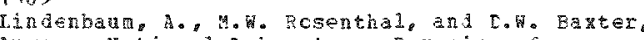
Argonne National Isaboratory. Buvisicn of pological ard gedical Resparch, Arqonne, IL. 1973

Fffect of DTPA a Monomeric plutoniun in the perale sea. CONF-730431; Part of Proceediags of the 2 ist Annul Svaposiun of the Fadiation pesearch Socisty hela in Sto Louis, Missouri, Aptil 29-May 1973 . published in tadiation pasearch, 5 a (3), $51 x_{0}$

The long biological half-tine of ronomers Fuleniug 239 observed in the 11 ver of the beagle dog following intravenous injection is generally interpreted to be the resule of cellular incororation. andogous to the known intracelinias hepatic retertion of celyteric plutonium in the motse. DTPa (diethylaretrianfnepentacetic acial is nnes to be aneffective against intracellula deposited pu because of poor aeturane permeability. least glucan, however, has beerly deronstrated in this laboratory to ke ptective, in tice, in rearing hegatic rlutoniu not robilized by DrFa. To test the usefulthess of these two sucstances in anorber species, the dog, treathent ulturpa, eithex a lon or in conjunction uith glucang vas begun 6 days after intravenous injection of 0.32 aci/kg of mononeric platoniute Beagle

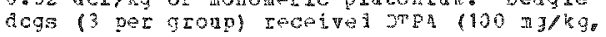


BIOLOGCAL ASPERT

ABTHAS

<130> CONT.

thise weeky) etther alone or in addition tc glucan 13 injection of 15 mang at 4 -reek intervalsl. By 3 months prpa ejther with or

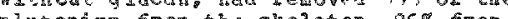

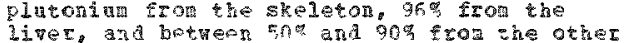
sive and botween mo and $90 \%$ from in sort tissues, as comparad to untreated
controls. Glucan along ith DPP renoved no controls. Glucan along vith DPPA renoved no of Imph, with no adaltional plutonim removed by glucam, suggests that the long retention of monomeric pintoniug in the dog iner is provably not tho to intracellula:

incorporation. (Anth) (Complete Article)

<131>

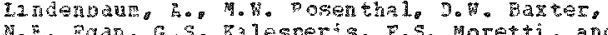

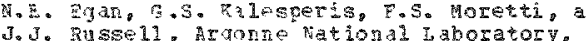
Argonne, II. 1972, recember

Metabolic ara gherapentic stuales ef pluton:

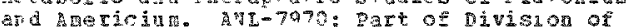
AJd $1572,(\mathrm{c}, 121-125), 23 \mathrm{~F}$.

The pogzag aims to bevelop nev actoaches to the thera of poisenina by rafioactive and nonracíactive potals. Previous vork bas denonstrated the effectivoress of chelating agents such as IPP; sttontion is aisected toward cther therapentic aproaches ained at removal of the portion of $\mathrm{pl}$ atot readily

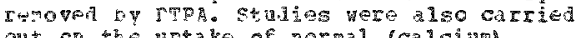

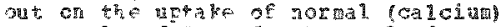

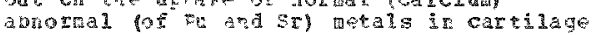
ard bon. A vrontose zant is giver.

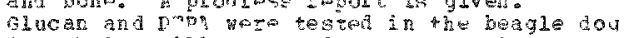

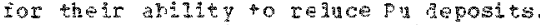

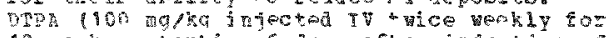

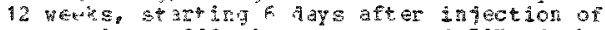

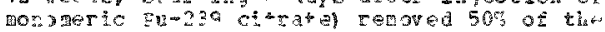
bont bueder, his of the lige burdene and

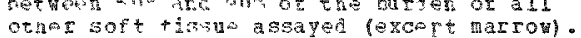

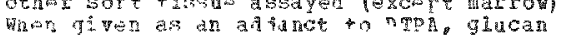

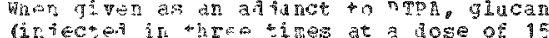

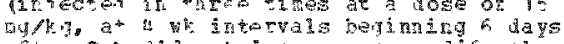
a

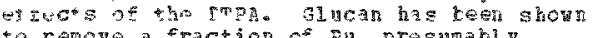
to renove a fraction co Pu, oresumably intraceli dar the is not available for

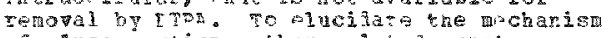
of 31 lucar action, other telated substances wer rested at" these, the most effuctive (pyran corolvger) ard lens aftectur (allaromol are soluhle interferon-inducess. Further work has shan that ant the pyran copolyger is alsn of ecetive ia removal of

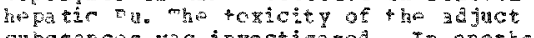
whostrese was irvestigaped. In another pojort z Drinying antoraciogsaty, two nev

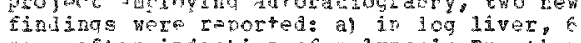
days aftor intoction of polpriatic Pu, ther. vas a torna incerase of the cuntrilotar concentition of pu as cripares to the

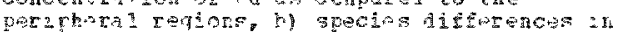
12. Wer furction vore indiceton ky a liver concentrition of nononer ic and polvare pa associated vith liver varenchyal cells of the dor, compars with thos of the mouse.

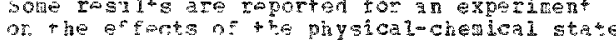
or the erfacts of the physical-chemleal sea aice. Microeconic atulies of hones are beine con to correlate hore tumer ircidence with sisietal loge and to contra

historetiogonica saqueiar in bone as

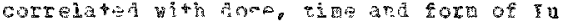

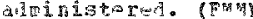

$\langle 132\rangle$

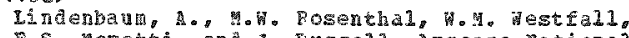
2.5. Motett and J. Hussell. Argonne hational Labratory, argorne. TL. 19. A, Decener

Theragy of poisonith oy gad cactive and Tonradioactive meta1s. Ami-6971: Part of B iological ana pepore, 1964, (p. 212-214), $230 \mathrm{p}$.

A trongasis report is given or zeveral experinents conducted. Tn cae experinent. the atrerential distribution of Eu in the marrow and or the bone surface of the tibial shate, following admintration to gice of 3 Eu solutions of varying collojal properties, was geasure. The colloidal properties of the plutonid solutions vere measured by the MItratitration techniat and bo the

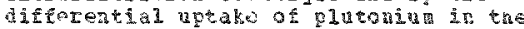
tissue of the mouse. The plutonium andyses of tissues from mice hilled at 6 ays showed a difrerent patern or degerition fer each of the three solntions. Fnjection of $a$ nighi collozial zolution (Eu 183

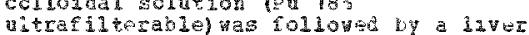
deposition of pos of thw injecsed dose (I.D.)

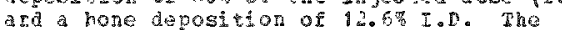
intermatiate colloidal plutonia solution (Pu $30 \%$ ultafiterablel zas fellowed oy a

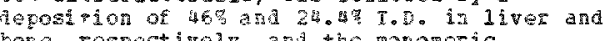
bore, papectively, and the motomeris sclution (Fu gog kltrafilterable) Dy $28 \%$ aru 4. $2.4 \%$ T. D. Another experiment showed that the femr is the bost recresentitive bon 3 teras of uptake of El. The quats

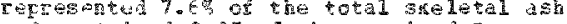
and contained $8.3^{\text {to }}$ or the zerained $\mathrm{Pa}$. 2 the case of the contal aice dn $7.8 \%$ id the case of ITP-treated wee. Experiments on the 1 cng - twra efects of ITEA showe. that the

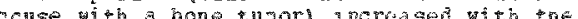
ment of Pa menowa by

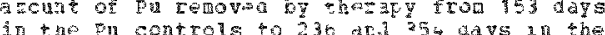
he the

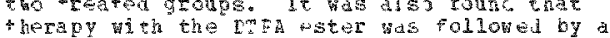

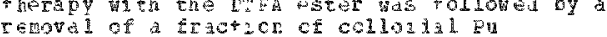

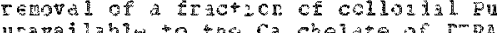

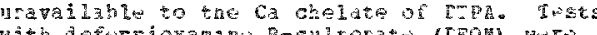
with defer

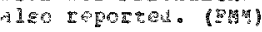

$<133$

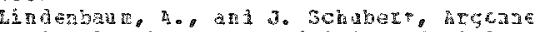
Jational Laboratery, Divisica of jologleal ar.

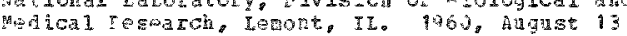

Eustainted action of Tnjected Chelating Ayeres.

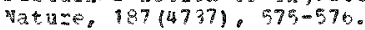

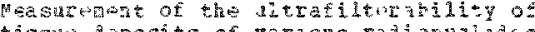

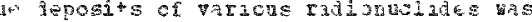

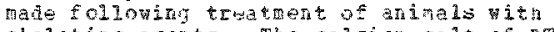
chelating agents. The calcian sed of DTs (335 mgnplign body to as the acha form) or

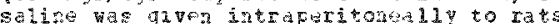

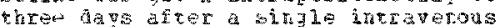
intection of a soluticn contanan 35 u $239: n 1$ perceat os a

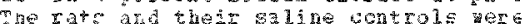
killea at intervals of $1,2,3$ and 7 jay

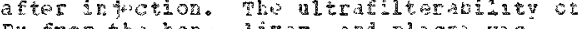
Pal frob the bone, ingr, and plasta vas 0.

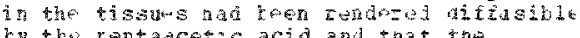

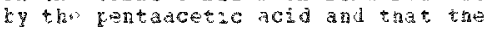
afferability reman ned ten or tore tiats greatw that that of the coneroh knials los

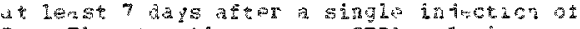

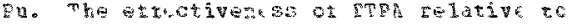

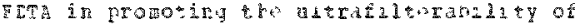

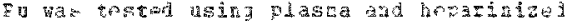
wole blook. The pu

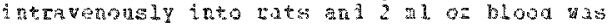


(13)

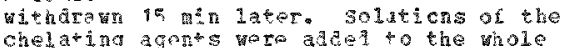

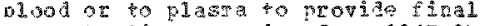

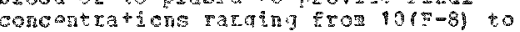

$\left.10(2-)^{2}\right)$ \% Fhe super

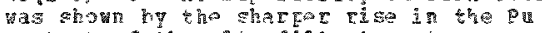

contert of tha untationaterat

concentrations of chelating agert in the

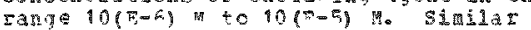

wheriments yose made

234 as a tracos. simidar sageriority of

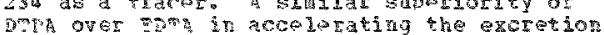

of $3 h$ from rass as anonstrated. (FH)

《134\$

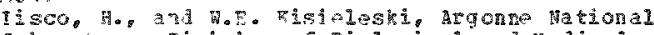

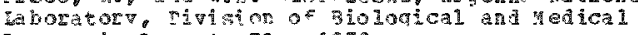

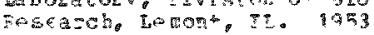

The Fate and Dathologic Effacts of 21 lutomiul Fetal Inglanteal Into pabbits and Pats. American Jourtal of Pathology. $29,305-329$.

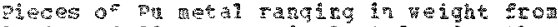
0.01 to 1.80 ne were i gis lantea undar the shin or 2 ta rabits and 3 te

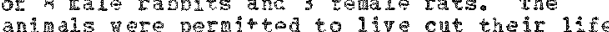
aninals are besaittad to live cut the ir lite com and wer sacticed on

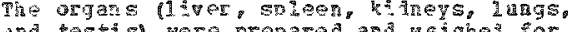

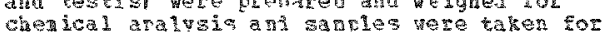
if

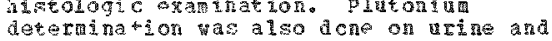

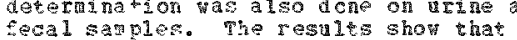
Plit

sebcuta novaly into rabbits and rats.

Aisinegrared into mang sall fragmen soon

after in roduction into the tssines. the

pieces we coun to be relatively inert

lowaly, and or 1 y sal1 anounts of plutontum

we absorbed fror the implanes during an

observation poriod extendiag to 1048 days.

the inclatition sis became heavily

calcified in all anisals. Retertion and

organ distributen studieg gave eridence that

rabists atsorbed considerably wore plutoni a

ander these conditions that rats. The

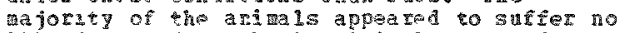

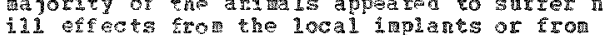

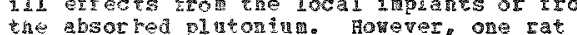

dipt wh an ostogenic seroma of the spine

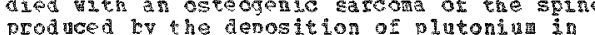
the ske de tal tissues. The dati indicate that the ske detal tissues. The data indic goth species can harbor considerable in the

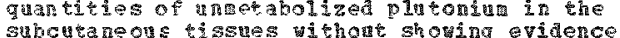

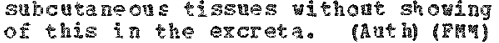

<135>

II C

Morphological Charges of Bone rissue in acute and Subacute fefection with plutonilu

Me itsinskay a viologiya, 4(5), 69-72. (Eussiar.

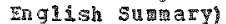

Experiments vere conducted on 70 whte rats Who received intraper it oned1I plutonim 239. Conziderakle changes were seen in the bone tissue upen aduinistration of $0.15,0.08$. 0.04 and 0.02 ci/g body weight. The changes were most pronomea in the long bones and had a definite seguence of develogrent. In the course of the eqrse days following the

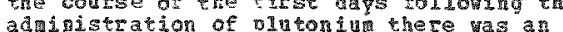
admisistion of plutoniun there vas a of collular-fibrous tassu, containing large trantity of osteonlasts. After the second

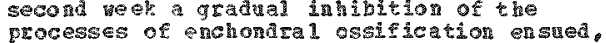
uth reconstuction of the bone and a drog of the arout of osteoblasts. At the height of affection (3- weeksi total indibition of the Frocesses of ostroyeresis with death of osteognnic tissue as observet. In aniale recejving lutonium with specitic activity of 0.04 and 0.02 uci/g body weight the

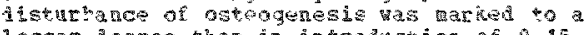
lesser aegree thas in intrabucton of 0.15 and 0.08 ucs $\mathrm{s}$ in the cover of the second anth the growh of botes vas restored to certain extent. She formation $G$ a large cetrain extan. The formation st darge

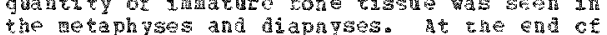
the thin month prenature cossis

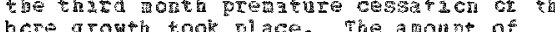
bcre growth took flack. The ach of skeleton increased. (Auth)

〈36)

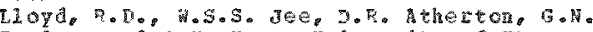
Taylet, and $C \cdot$. college of Hedicine. Radiobiology Division copartment of tratony, salt iake cter, UT. 1972

Americiu 24 in Beagles: Bloleqiea 1 Etrects and SFeletal Distributiona PaEt of Stover, Sa

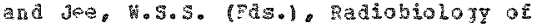

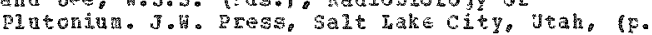
$141-1481,552 \mathrm{p}$.

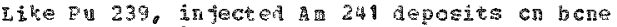
surfaces vithin the sheleton. No iaportant

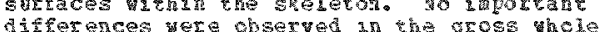
hore distribution of 1 in 241 corpared ith Eu b39. in beagles injected with

239 in beagles injected wh

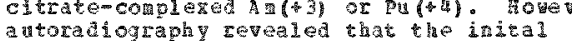

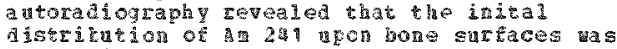

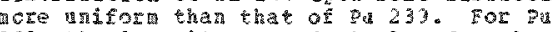
239 , the deposite on endosteal and crabecular surfaces were about 2 to 4 tines greater tha on the pertosteal artaces. For An 241 , they were only about 1.5 to 2 tives reater than the periosteal deposits. Biolozical dange fron A 241 in beagles has been ofserved in all tissues of bighest activity cencentrations: Hiver thyrold, sieleton and hadney. (Auth)

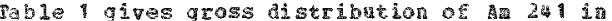
beagle skelfon compared with that of pu 239. mives reintive aistribntion of an 24

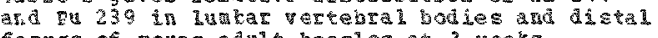
fearurs of yourg adult bearlon atr 3 weers postinjection.

<37\%

Llota, R.D., C.V. Neys, W. Fishar, and R. Hentze, thiversity of ptah Collego of hedicines Badicbiology bivision, Departiene of Anareny. salt lare cieg. $8 \mathrm{~T}$. 1962 , farch 31

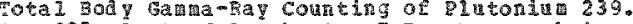
Co0-225; Part of Dougherty. T.R. Fesearch in Fa d obiology, Annal Report of hork in Frogress on the Chronic Toticity Erogra, (p, 76-83), 136 p.

The infreguem game rays groduced in the radicective decay of Fu 239 have beer used to assa the plutonium content of living dogs each given a silule intravenous injection of Pu 239 ranging in activity from 16 ucs to 35

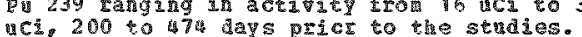
uci. 200 to b7a days pricr to the studies. unlike the more abadant 7 kg $\mathrm{z}$ rays wiph animal's body. the gama rays at 100 hev and animal body. the gama zays at 100 iev ad 213 239 in the sholoton. Bagles containing

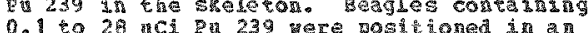
1. to 33 aci 23 .

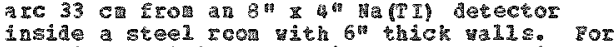
ccanting periods of 30 minutes, accaracies of 0.6 ic1 pu 239 at 100 kev and 2.1 taci pu 239 
STOE $3 G^{\circ} \times A T$ ASPRCTS

ANI

$\langle 137\rangle$ comp

at 390 keV wore obtained. (Auth) (PMn)

《13\%र

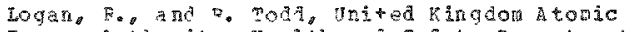
Exexgy Authority, Fealth and Safety Department,

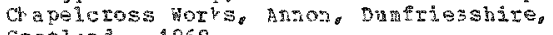
Scotland 19G0

解ole sody counting of plutenium in frats. Tr.ternational Journal of Applied nadiation asd

A method for the doteraination of the Qu-burjen of an unanastherized arima 1 using olatonim 237 as lakel for ol at on iak 239 is described the platoniut sol ution was

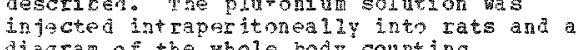

aiagram of the whole body connting

described backrouma was about 500 coune per

described background as about 500 counts per

ginute and a tat bardaned with 75 nci gu 237

gave 15,900 counts ver ninute. The countish

perion was 200 soc in all caseso prelininary

experimente shoved that the count rates son

varad by up to 20 per cento + thas

thereforo not possible te apply the sate

calibraticn factor to each rat. In an lo rat

experinen tho average diftarence bet wew the

sigast and lonest values of the calibration

factor for each rat was $5.6 \%$ and the worst

difference vas 10,4\%. The nan advantage of

the phola body counting nethot is its

simplicity and spoed. no roulesome excreta

collection was itivolved rexcept during the

anig al on (Fin)

Thle 2 contares the 31237 any 1 hy whole body couratiag it in that recoveted at autopsy in iiver. skeleton, and gther tissies of rats.

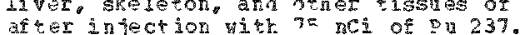

<139>

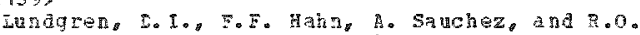
hecle11an, Ls ctelace Fondation for thedical Fugation and Fesearch, Thasation Tojicology Resarch Institute. Mlbugrergue, m. $197 \%$. Deceriner

AR tqbody sesporees a na pulmcnary lesions After

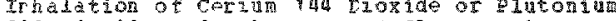
239 horite and subseguente Influenga varus

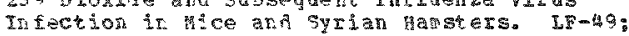
Fart of Boecket, 9.R. and Fupprecht, F.C (Fdsa) Andual Peport of the Trhalation Toxicolody neseareh Institute gctober i, 1973 through September 30, 1974, (p, 214-274), $334 \mathrm{k}$.

Fende mice 8 to in weeks or age were exposed by inhalation to ce 144 ceo2 or pu 239 tuc2 and $3 y r i$ a hanstars 12 veess of age vere exposea by inhalation to co lut ceo2. The activity inedian aerodyna ce particles ranged from 1.2 to 1.5 un and ce particles ranged from 1.2 to 1.5 un and for the particles, it was 1.0 to 1.6 un. The curat at ice and hasters and the cumiative lungs of wice and hansters and the cumulation thar irhalea pu pas calculated froma

3-component curve fit to the retention of the radion clide in the lungs. Nitrals mere jufected viti influenza virus 7 days of 3.6. of 12 month after inhalation esposiar sacrifice or if egpan observation. Serially sacrisiced animas vere kled to obtain sera for serclegical confirmation of influenza virus infectior. Syrian hasters induculated

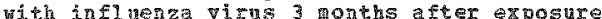

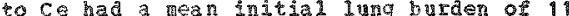

uci $(20,900$ rans to the lungs) and those innoculated 6 months lad a tedin TLS of 12 uci $(28,090$ rads to the langs). In the mince

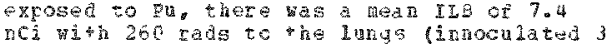
acrehs atter exposurel and 340 rads (inoculated tronths a pter exposura). There

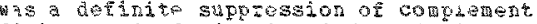

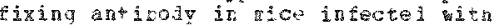

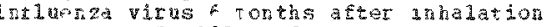
exposire to pu 230 puoz. Frevalo chservations of sevtre metaflasia yitn sguanous cel? differentiation in race exposed

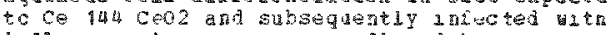
influera virus was rot confirmad hy observations of atritals examitu to date.

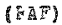

$\langle 140\rangle$

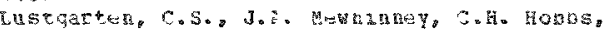

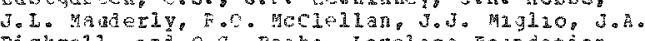

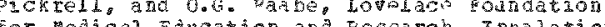

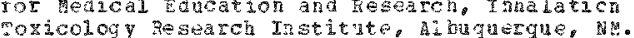

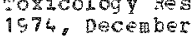

Toxicity of Irhated Elutonsun 238 Dicxide in

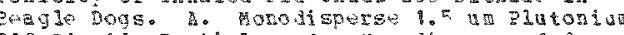

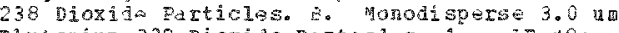
Pl patt of Boecker, B.B. and papptecht, F.C.

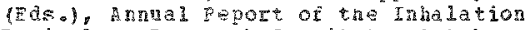
soxicology Reserach Institute. Otober 1,1973 thargh septerber 30.1974 (p. 140-144), 384 p.

Studies on the wetatolisto dosinetsy axu biogical effects of inhaled $\mathrm{P}$. 238 particles have beon initiated in beagle degs. Tc obtain escential ineormation on the

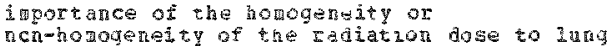
the hot particle question. dogs have peer the hot perticle guesticn. dogs ha ve pee

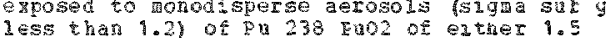
an or 3.0 un aerodynatic alaneter (AD). By an or 3.0 un aerodvnatic alaneter (AD) usin monodicperse farticies of these two
sizes the average bose to ing is hela ccrstant for a givor initial lang wuden

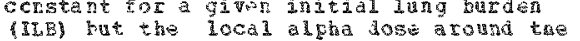
two sizes of partiches varies by a factor ct about 10. To date. 48 logs have been exposed to each of the two particle sizes of Eu 238 Qun2 (total of 96 dojs) resulting in graded ILES which range frog 0.009 to $2.2 \mathrm{wCi} / \mathrm{kg}$ of hody veight. Sixten dogs exposed to a diluent aerosol are sexvinjas controls. of the total actarity inheled, the dogs oxposed

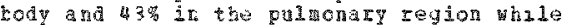
corresponding depostion values $\mathrm{f}$ in the doas exposed to 3.0 u $A D$ aerosols were $73 \%$ and 45. Ali the acas are surviving with ne detectaklo abroralities at from 10 to 293 ays post-inhalation exposure. It is aticipated that an adational a dogs $12 \mathrm{a}$ for each particle sizel and $\mathrm{B}$ conrols will for each particle sizel and controls will te addea to these dase resconse studies ovet the negt fer worths In aditions a sacrifice stady oill be initiated to resulting from inhalation of these wodisperse mizes CE Pu 236 PuO2. (Auth)

<14 1)

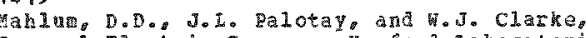
General Biectric Corpany, Hanford taboratories,

Effect of Internal Enitces on Iiver Turors Inducen by Dimethyiainoarobenrence. Hature, $205(4987), 945-946$

Fenale rats were injected intraverous 3 with 
(B⿱ 1) CONT.

$$
\begin{aligned}
& \text { a beta-eniteter ce } 144-\mathrm{Pr} 144 \text { or } 20 \\
& \text { uci/rat). os an alpha-entter, एu } 238 \text { (2 } \\
& \text { uci/rat): The rats were fed a det high in } \\
& \text { Iibofiavin and protein to mich } 0.06 \% \text { DMAB }
\end{aligned}
$$

MarkIay, J.T. Argosne pational Laboratory. Division of Fiologica! an 1 gàcal sesearch.

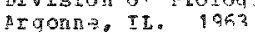

Deroval of nelymeric plutonim from mice by comine Therapy ith the calciut chelate and

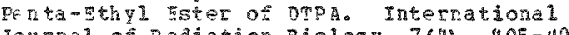
Journal of atiation piology, 7 (4), 405-407.

CF No. 1 femal o los, 70 days ola, wejghng $21-23$ t tere each givan 0.292 aci gu 239 in 0.2 intratenons?. various arouss gere given a series of intraperitoneal injections once a day for 19 days of $9.2 \mathrm{~m} 1$ of bither saline (ccntrols), smpa ester at 75 mg/kg. Ca

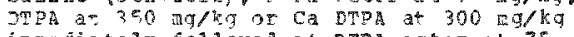
imaediatey followel at Dron aster at 75 go/kg. I ipers, staen an fenurs wo re analyzed fro sil. Tt as seen that depositior was bigh in livet and spleeth and lot in the skeleton. Treatmont it it oithor Ca DTEA or TPA ester a lone singis icantly lowered the $P$ u cont ent of the linat by about the sane anount in each case (28\% peduction). Treatuent

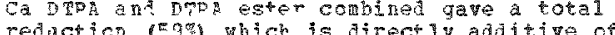
redactier (In) which is ditacely adaitive of

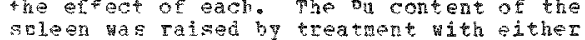
agent siraly, indicating that rome of the ru ramoved stom the liver was redepositad in the spluen. How wor, when combinet treatment was piven, this incroasw was oreverted; morecter the level in the spluen was loweret

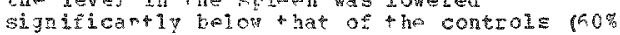
reducticnl. The $p$ a content of tone was reduced hy treatrent with Ca TT vas unaffecter by tho DTEA ester, and the

affect of the combined treatmen cn vone was the sane as that of the Ca DTPA alone. (Fom)

A table shows the effect of treatment with DTP

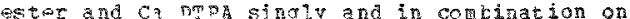
the distribution of polvmetic Pu in aice

\section{<143>}

Matveev, V.I., Trstitate of Biophysics, Moscow,

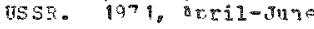

A Vechnague for Dosed Adninistration of Fadioctive Aerosols to Doas. Fyoiene and Santetion, 3r. 254-25a.

\footnotetext{
A methot is lescribel for a one-time losed
}

bifect intratracheal adanistration of acrosols to dogs winch prevent substances from entering the gastrointestinal tract by licking aerosels of their body surfaces or from passing from the nascpharye into the gastrointestinal tract. Dogs inhaled atrosols generated from selutions of plutonin nitrates and plutonitu citrates with activities ranging ect 2 to 23.8 wcilnt. The matational activity from the lungs to the internal organ was aeterained ty radiometric analysis of lungs, liver. blcod and Lent. Retention of isotope determinea to be about $24 \%$ or the inhaled isotope. (ARE)

A table is given with calculations of che arount of isotope retained in the dog' $\mathrm{S}$ body after inhatation of pu 239 aerosols.

\section{$\langle 144\rangle$}

Mys, C. B... B. Stover, B. H. Glad, and D.R. Athexton, uni versity of biah, college of pedcine, Radiobiology Rivision, Salt Lake city。 un. 1959, March 31

Skeletal Dosimetry ig teah Beagles. coo-218; Fart of stover. Col. Jr. (Ed.), Angul Drogress peport, 19a9, (p. 12i-145), 22 is.

Values for the sikeletgl retertion of $P$ rabiothoriug and stronsiog in beagles vere obeined aguationg were deweloged cor the averave skeletal radiation wyosere at any averave skeletal radiation hyosuge at any rads, and rad-days. Vlues were lcter for rads, and rad-days. values re plot.

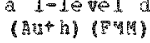

\section{<145>}

Beclellan, F.o., B.B. Beecker, F.F. Hahn, Collo

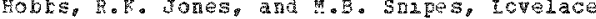
Fourdation for Medical Eucation ar Tesearch

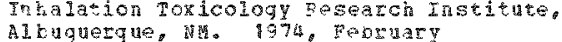

Comparatye Toxicity of Juhaled Aeta-Lnitting Fadicnucildes in Beagie rogs. con-730907 laat

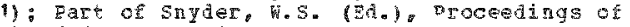

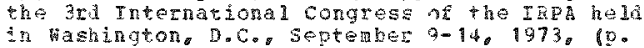
$208-213), 1475 \mathrm{p}$.

Four lifesfan studies are being conducted in which teagle dogs have been exposel ya irhalation to aerosols of fusod clay particles containing $\$ 90, Y 91, \mathrm{Ce}$ 14 $\mathrm{Y}$ or $\mathrm{St}$ 90 sesulting in graded initid lurg burtens of ralioactivity. With ail four aerosols. the labeled particles aze temaciousiy reained in the lung with efsetive retention halt-times of 2.6 .53 .178 and 400 days respectivel\%. with the 7 90, ce lut and $5 \mathrm{I}$ 30 in fused clay, the physica halt-iife is sufticientiv long to allow translecaton of sall cantities of radioactivity. presumbly in particulate form te tracheobrcnchial

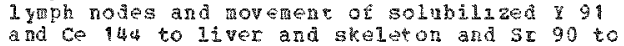
skeleton. With the highest initial luny burdens, deaths related to radition prounonitis and pulmonar fibrosis were

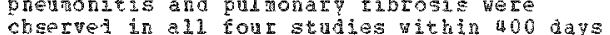
oost inhelation exposme. Tne radiaticn acse post inhalation expesure. The radiaticn dese required to produce early deatns was loues ter Y and highest fot de 144 and se besng related to the ling retention hal-- lides land rate or dectenses of radation dose ratel. Later deaths foreater than 640 days) related to pritary pulatary henagiosaxconas have been observed in dog

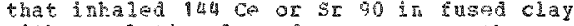
with cund lative lung aros grentex than 
BUOLOGTCRT ASPICTS AMTMAIS

$\langle 145\rangle$ COHT.

20.000 rads. The current status of the studies to 1800 days post-inhalation exposure) is liscussed and compared with similar studies conducted with pu 239 Puoz at Battelle-Northwest. of special interest is the develofment of primary pultanary henangiosarcomas fendothelial tumors) vith chronic a trat irradiation from plutonium. (Auth)

$\langle 166\rangle$

Heclellan, P.0., H. W. Casey, J.H. Cable, and to K. Bustad, Hanford Atomic products operation, Fichland F⿱ $^{2}, 9962$, January 15

ransfer of Heav padionuclizes to nilk. HW- 72500 ; Fart cf kornberg. H. A. and Swezea E. G. (Eas.), Hanford B lology Research annal peport for 1961, (E. $44-49$ ). 180 p.

Mature puregred suffolk sheep in their secont to fourth month of lacation were injected intravenousy ith $\mathrm{Ce} 144, \mathrm{PT} 144, \mathrm{~Np} 23 \%$, pu 339 , and 241 in the following anounts and forms: Ce 144-PI 144 at a dose of 1000 uci in the form of tho chlorides 237 at a dose of
150 wci, as the nitrate, pas 239 at a dose of $150 \mathrm{uCi}$ as the nitrate and $\mathrm{n} 241$ at a dose of 150 uci in the cor of chloride. nill and blood samples for radioanalysis were coliected at Erequent interyals for up to 10 cays post-irfection and the plasta and gilk concentration of the nuclides vere expressed as per cent of intocted dose and plotred aqainst tine post-intection. Both Ce 144-FI 144 and $\mathrm{a} 241$ disappared rapidy from the plasma as vere concentrated in min, whereas pip 23 and pa 239 both disapeared sion from plas a and tha mils concertrations alver less than those found in plasna whe dverag milk-o-plasta ratios vere: Ce 14 is-p

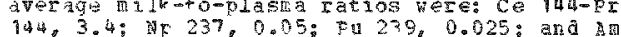
241. 2.3. From the ata avilable, it would not appezr that any of these hoavy radionclides wculd Fepresent a significant hazath to man via ingestion of mili fron animals grazing on contaninated forage. (FMn)

$<147\rangle$

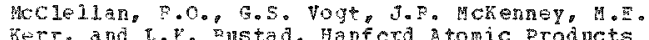

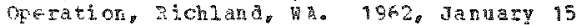

Compartive moxicity of Strontium 90, Radiun

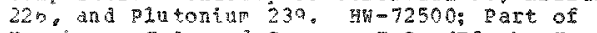

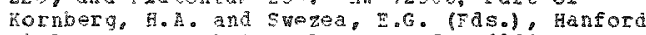
Biology kesearch Annul peport for 195 i. (E. $30=401,180 \mathrm{~F}$.

Finen-y for injected intravenonsly with SI 90 , ga 226 , or Pu 239 in doses of 44 uCi 3 ag/kg, 6.4 bCi Ra $226 /$ ta, or 1.3 uCs 8 o $239 / \mathrm{kg}$. Severe reducticn in lenkecyto numbers were see Auring the first three months after radonclite infection. veutrophils showed a Iroter depression than the cell types. The most 8 w y $x$ re change was erident in the groups administered bu 239 . Hine male animals intected 18 mox ths previous ly and the ir controls were kactiticed to provide specia nistocherical changos. (Duth) (FM)

C148)

gentingey, 3.A., J.4, Miglio, C. H. Hobbs, and -0. "CCle1la Lovelace Fountation for tedica adoation ara Pegearch, Inhalation roxicology

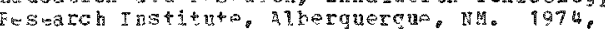
De cosine re
Short-Tern Hetabolisi of Three Stzes of Monodisperse Plutonium 238 Puo2 Aerosols in Beagle Dogs. IT-49: Part af Boecker. B.B. and Rupprecht, R.C. (Eds.), Anwual Report of the inhalation Toricology Research Institute. october 1973 through septeaber 30.1974 p.
$37-39$. 384 .

Inhalation exposures of 30 beagle dogs were conducted using monodisperse and polydisperse aerosols of Pu 238 Fuo2 to measure the initial puimonary deposition and short tern transiccation of pu 238 to other tissue.

Three sizes of ronodisterse zerosols 10.7 $1.5,3.0$ an $A D$ ) were compared with a single polyaisperse size (1.5 un $A M A D)$ in this study. Animals vere sacrificed at 0,8 and 32 days after inhalation exposure and tissues analyzed for pu 238 content radiociemically. Initial pul wonary deposition decreased as monodisperse particle size increased and the pclydisperse aerosol closely resenbled the saller monolisperse size in injtial

aeposition. upper respiratory clearance was nearly complete at 8 days after inhalaticn. Hinimal translocation of fin 230 to tissues was founat at 8 and 32 a ays post-inhalation exposure. Transport of $\mathrm{Pu} 238$ Puc2 particles to tracheobronchial iyph nodes appearea to be particle size dependent at 32 days after

inhalation. (Auth)

$\langle 149\rangle$

Moskalev, Yu.I. (Ed.), 1971

Rercte aftereffects of Radiation Damage. A.CC-tr-7387;574 F.

The collection of 68 articles presents the cot recent data or tunorous and nontumorous ferms of renote aftereffects arising with darage by external sounces of ionizing radiation and necrorated radoactioe isotopes. Two articles have ben abstract
spearately for the data base. Materials include new data on the spontaneous freyuency ot tanors in animals, on remote arterefiects following exposure to high-energy protons. mixed gama-neutron and external beta ictadiation, and also patonius 239, poloniu 210 , a mericium 24 , protactintum 233 . tritiun oxide and aranian, the effect of radiation on offsping, on the preventicn of remote aftereffects, and also information on the relationshif betweer the grimary dechnisss of the action of radiaticnan remote afteteffects. Extensive data have peen used in convingingly aremstrating the incentionaliy high blastomogen ic activity of $144, \mathrm{~Pa} 233 . \mathrm{Pu} 239, \mathrm{Ag} 2411 . \mathrm{Pu} 239$ has $\mathrm{an}$ exceotionaliy high blastomogenic activity. In the case of damace by this radicactive elenent turors of the bones and lungs ani element rubrs ot the bones and lungs and a so sclerotic processes in the pustonary tissue and sucutancous celluar tissue arise With the accuralation of vert insiga
doses. Facts are being accumate. indicating deperdence of the csteosarcomogenic effect of Pu 239 or the path and rnythof adninistration. It mas found that the osteosarcomogenis activity of Pu 239 in the case of inhalation and chronic Feroral adninistration is freater tha in the case of a single istravenous adminiatration. Tre lesser (in cosparison with ev 239)

bjological and osteosarcompteric

effectiveness of ancther transuraning

element, Aa 241 , was sonewhat anezpected. As

tevealed by the latest data, this is atributable to peculiarities in the attributable to peculiarities in the considerei eniters in the bone tiscue. In ccntrast to $P u 230$, the relatively great 
$\langle 49\rangle$

BIOLOGTCAL AS RECTS

AUTMALS

CTUOS CORT.

quartities of $\mathrm{m} 241$ in the bone tissue are

bound ith gineral structures, whereas

protein structures (staloproteins.

transferrin hold considerably greater

quartities of Pu 239 . For the first tive

lata are presented on the blastowogen ic

effects of $\mathrm{St} 90$ on the glial elements of the

central nervous system ard on the biochenical

changes in the lungs after inhaling pu 239

ard Am 24\%. Ore hundred five tables, 208

ficures ana bibliography of 1.026 iters are

included. (Fing )

<150)

Moskalev, Yu.T., and T.F.S. Gradley

fransiatorl 1958

Pornarities in the Distribution and Toxicity of

padiolements. Riofizika, 3(5),725-731.

some regularities in the distributions and

biological exfects of radioisotopes are

discussed. The elements in any one group of

the periodic system beha ve very similariy.

The types of aistription alstinguished are

the skeletal, the inver, the uniform and the

kidney. Complexing agents, carriers and

alter the distribution types found with

produce no effect $s$ ith elements giving

most ly soluhie compornds. Toricities should

not be evaluated in terus of activity alone,

since the radiation dose is the primary

parapeter, and not the decar rate. The

paratectiveness of any eniter depends on its

physica larameters (energy, exission type.

physical parame ters (energy emission type:

(distribution type rate of elimiation,

legree of absorption from depots). The dat

indicate that some elements ( $\mathrm{S}, \mathrm{Ba}, \mathrm{Zas}_{\mathrm{s}} \mathrm{Z}$.

Ir, Pal are osteophilice while others (Ia

Ce, Ea, Pr. Am, Cal are selectively depos

muscle $(R, C s, R b)$, whereas others tend $t$

prefer the reticuloendothelial systen (Nh.

Rat, Te, Pol. (Auth) (FMm)

Table 2 shows tine doses produced in organs (skeleton 1 iver, kinney spleen, bone marrow) after injecting is $50 / 30$ amounts of emitters (includirg Cs 137, Sr 90, 1 o1, PR 147, Pu 239 , ij 233)。

$\langle 159\rangle$

Moskalev, Yu. I., J.A. Fuldakov, and V. Ho

Strolitsova. 1961 , Decerber 8

Bependence of the 3 iological Action of Plutonin Jpon the Rhythri of Its Fntry Into the organism JPRS-11522; Fart of Radioblology, (p. 297-315)

453 p.: Nadioblologiva, $1(2), 25 c-256$.

Ma le and female rats weighing 170-200 g were administered intraperitonea 11 plutin citrate solutions (pll 6$)$ in a single or
Eracticnal woses of $0.00125,0.005,0.02$ or 0.08 ucj. 9 of rat weight. The prects on duration of life, body eight, ceripheral blood and cecurrence or turors

investigated. Fhe lifespan of rats given $P u$ depended not on $1 y$ on the dose but also on the risthm of the isotope ineroduction. At doses of 0.00125 uCi/g the life span did change and vas not dependent on the ruyth of intake. an hot dependent on the rhytha of in take In coses or $0.005-0.03$ cilg, Eractionel adnistration prolonged the life of Anis als LD 50 alues incteased with bod weight and hemetological values were first less pronounced than at later periods first less pronouned than at later periods

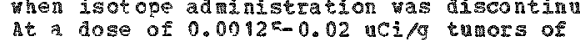
bcdy tissues developed both in singla and
fractionated Pu introduction. (RBF)

$\langle 152\rangle$

gostalev, Yu.I.A E.J. Rudnitskaya, L.A.

3ulakov, A. P. Nifatov, and $\mathrm{L}_{0}$ G. Filippora, Not given. 1974, Fektuary

Remote Aftereffects Associated HIth Danage oy Transuraniu Elements. Conf-730907 (Rart ll: 3rd Intermational congress of the InpA held in hasington, D.C., Septenber 9-14, 1973, (P.

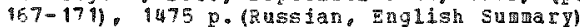

In experiments on rats and dogs the late effects of maignant and reomalignant developient after the intake of varions ccupounds of Du $239, \mathrm{Am} 241$ and Np 237 vere studied. It has been shown that dogs and rats after the intake of transuranium elements develop osteosarcomas, leucosis, tumors of lungs, lives, $k$ indeys and othe organs, sclerotic processes contracted 1iver, sephrosclerosis, preumosclerosis) at the sites of deposition or transition of the isotope and septical processes of various localization. After the intake cf Eu 239 the wind an esteosarcomogenic dose is within 5 rad and after $\mathrm{A}$ 241-17 rad. The makim frequency of osteosarcome developement after the intake of 241 is $33 \%$ in rats ard $100 \%$ in dogs. With the decrease of dose accuniated in the bone tissue the relative osteosarcomogenic efficiency is increased in dcgs as conpared to rats from 3 to 30 times. When the doses are clcse to ainimu ef fective When the doses are clcse to minimum efiective is ive-fold that of All $24 \%$. The developant is ive-fold that of Al $24 \%$. The develogant elenents occurs more often and at earijer periods relative to control animals. The Feriods relative to control aninals. The waxinu yield of kidney turors $(2-4,5 \%)$ is ofserved theh Al 24 when the doses ased are scluble compounds of 241 the trequency cf preumosclerosis and lung tumor developont is 1 cwer as compared to $\mathrm{Pu} 239$. The routes of AE 24 and Fu 239 intake into the body do not affect the values of carcinogenic doses for the particular tissue. The 四inum osteosarcomogenic and levcomogenic dose for nitrate of $\mathrm{g} 237$ arter intravenous injection Is below $0.1 \mathrm{ci} / \mathrm{kg}$. (Auth)

153>

Moskalev, Tu. I. V. H. Strel tsova, and V.R.

Letberg, not given. 9969

Rerote Seguelae of Radiation Damage.

REC-tr-7195: part of Moskalev, Yu.T. (Bd.) Radicactive Isotopes and the Body. (2. $439-456)$, $458 \mathrm{p}$.

The remote effects of radiation danage are grouped into tumorous and nontumorous forms of injury. Both forms of injury are experinentally documented; included are pertinent literature findings. The nonturorous forms are pathological processes such as nephroscierosin, cirrhosis of the

liver, pneumosclerosis, different versions of Yascil lar pathology and endocrine

disturbances. These pathological processes are deternine by the region a nd form of irradition, the dose, the biological properties of the irradited substrate etc. Exeriments on white rats, after a single tctal irradiation tith protons and neutrons tctal irradiation inth protons and neutrons of 90 or so 210 , shoved cirhosis of the 1 iver

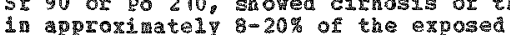

andils. Alpha-eritters exhibited greater 
BHOLOGICAE ASEECPS

Aำ $1 A=5$

$\langle 1,3\rangle \cos \mathrm{N}^{\mathrm{T}}$

cincrotic affuct than betawenitters.

wephrogcherosis arose in $6-180$ or rats irradiat, a once tiv protons or neutrons. Irradiation ky ainha particles of incorrorted Do 210 caused a rise in rephroscl rosis in about 40 \% trequency of the disease reached 2 raximat (B1\% in melem, 100\% in temales! for a dose of $0.0048 \mathrm{~m} / \mathrm{fa}$. Preimosclerosis aeveloped preferent daliy incases of inhalation ot intratracheal intake of foorly resorbing radionuclides. Froeriments intratrachea 1 Pu 230 puNo 34 adinistratior to rats in a guatity of 7 uci, 9 shomed that the develog nt of pneumosierosis cccurred in several stags characterized by a clear correlation hetween the dose and the reactica of the perenchya. Endocrine a sturbances of the rerenchys ondocrine asturbances Experimental das on the tumorons forms of Experimental data on the tumorons forms of renote segaelae were obtalned yth a sing irradisticn of white rats by orotons and mutonim 239 was injected intraperitonealy into rats and rahkits in doses of 0.00001 to 0.006 wi/g and on 210 vas in inected intraperitonolly into rats at doses of 0.0003 to 0.02 ucifg. The beta-elituters were $5 \mathrm{r} 90, \mathrm{Sr} 80, \mathrm{Ba}$ l40, $\mathrm{Y} 90, \mathrm{Y}$ a $, \mathrm{Ca} 45, \mathrm{P}$ 33, Ce $144, \mathrm{P}_{\mathrm{I}} 447, \mathrm{ta} 140, \mathrm{~kb} 95$, Cs 137 and Ru 146. yajignant and henign new growths of different tissies fosteosarcomas leakoses, tumars of the gastreintostinal tract, 1iver. kideys, lungs, soxial organs, internal secretion glanas, etc.) developed or the

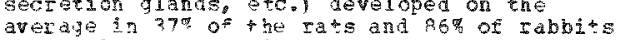
tested in the chronic phase of radiation thing caused by 1 inh or beta enitters. injury caused by alpha or beta enitters.

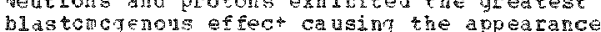
biastotegenous effect causing the apearanc females. females. multicertric groweh of tanors va observed poth inder extermal ne utron and proton irraatation and in cases of radicruclia incorporation. Radations with a high iorization fonsity exhibited a ingher carcinogenic activity than radiations ich lover ionization density. The possiolitey of

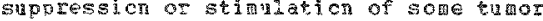
forng is fresented with a disensston and with some exporinental data on tissur aitotic activity。 (?AD)

रा5 4 >

moskajev, Yu.I., and v.n. Streltsova, grot given。 1665

Radiaticn Cancerogenesis and the Problen of kestoration. Mentitsinskeqa Badiologiva. 10. 40-47. (Russianl

The frequency of occurrence of osteosarconas and lentenia in rats was invest igated afser successive injections of $\mathrm{Sr} 9 \mathrm{O}_{0}, \mathrm{Ce} 144$ and $\mathrm{ku}$ 239 over various time periods varying from a daily injection to an injection each 4 mortis. out of a total of 526 rats. osteosarconas were found in 99 rats, and

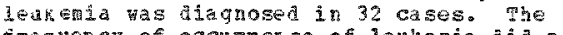
irequency of occurerce of leulenia did not change mith incredsed time of administration of a given anout of activity. On the other han the frequency of occurrence or osteosarcanas decreased with increasing time osteosarcaras decreased wh increasing tim total of 102 uct of ce lus into a rat in five shot once a wek, once each 2 veks, and shots once a week, once each 2 veeks, and once each four weeks, the percentage osteosarcomas vere fó, 40 and 31 .
respectively. Hith the shots the percentages were $45 \%, 33^{\circ}$ and $0 \%$ respectively. similar cesults vere obtained with $\mathrm{S} 90$. With the alph a eriter Bu 239 fractionation of the acse $r$ sulted in an increase in the requercy ct ocurrence ct osteosarcomas. Thus, a

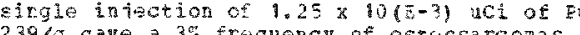
$230 / 9$ gave a srequency of ostecsatcomas.

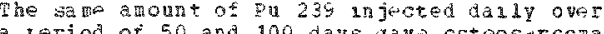

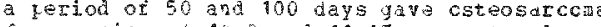
frequencies of 14.2 dnd 11.17 respectively. bith weekly intervals betreen shots this trequency increased to $2 \% .4 \%$ The nore diffurentiated tamor forms we foud in vas 10u. (TTT)

$\langle 155\rangle$

Moskalev, Iu.I., V.F. Zhuraviev, A. B. Istorina, T.K. Petrovich, and D. A. Razkekova, Institute of Biophyice, moscow viss. 1971

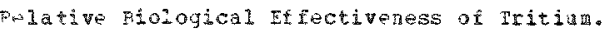
CONF-710809; EaIt of Moghissi, A.A. and Carter. \%. (pis.). Proceedings of a sprposing on

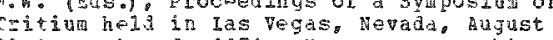

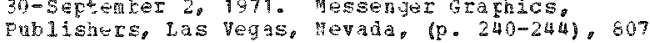
p.

The effects of beta radition from tritian vere ccrpared with the gasala radiation frcto Cs 137 in order to determine the $\mathrm{Bi}$.

crperiments were perorget using 587 rats.

Tritiated vater vas qiven to animals in quantities of $3.0,2.0,1.0,0.6,0.3,0.15$ mila rody wight. other rate gero continaonsly exposed gana radiation of $\mathrm{Cs}$ 437 in speial instellation at the same incident ase rate as was calculated tor tne trtiu. The PaE of tritian mes measured in tibia of the following indices: survival rate. perpheral hlood response, and thymic rato peripheral hoo respons, ard thym and splente sel Iht responses. The dose causing death of cneralt ct the rits

the first four days was 1.86 and 3.72
silorads for tritiut and jama radiatzon, respecively. Hance. the Rz of tritsu oxide is equal to two. On the basis of mertality rates with varicus doses of tritium oride and exteral gana radiation, doses vere calculated uhich caused death of $50 \%$ cf rats by ays 12 and 30. In the case of gawa radiation of $\mathrm{Cs} 137$, the 10 $50 / 12$ vas 1820 fius or minus 134 rads, and in the case of

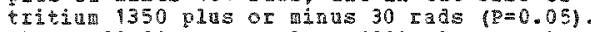
The ID $50 / 30$ was equa to 1290 Flus or tinus 42 and 895 plus or ainus 53 rads, respecively. These results show that the
BE of tritiun is equal to 1.35 and 1.34 .

BEE of tritiul is equal to 1.35 and 1.34 .

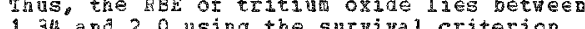
1.34 and 2.0 using the survival criterion. when hed in acutely efrective ases 13.0 to $0.5 \mathrm{mci} / 9$ body weight or 3000 to $690 \mathrm{tads}$ tritiur and gata radiation ied to strongly marke leukopenia in the rets. The degree of leakopenia following exposure to equal dos was greater vith tritiun than with gama
radiation. The dose casing $50 \%$ decrease in levcocyte count was 22 rads for tritiun and 26 rads for gama radiacion. The dose causing in tworold decrease in lyophogyte count, one day after exposure, was 270 rads for tritium and 390 for gama ratiation. Ite Bag of tritiua is thus 1.45. Analysis of the results bas shown that, fudging from the responses of peripheral blood and thyle and sflenic ights. the fre of tritium oride

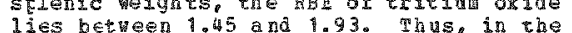
case of acutel effective doses, trition beta case of acutel effctive doses, tritiu beta radiation is biologicaliy nore eftect the garna radiation of Cs $13 \%$. The relatively greater biological efectiveness it develops 10 to 30 times as great ionization density per unit tissue volume as s or gam a radiation. (F) 
BIOLOGTCAL AS EECTS

A

$\langle 856\rangle$

muggenbueg, E.A., J.A. Mewhinney, J.J. Miglio, D.0. Slauscri, and P. noclellan, Lovelace Foudation for medical Education and Research, Inhalaticn Texicology se search Institute. Al buquergue. $\$$ \%. 1974 , Decerher

Bronchopulmory Lavage and DTPk Treatment for the Semoval of Inhaled Plutoniun 239 of Varied Solubility in Beagle nogs. 2.. LF-49: Part of Mcclellan. F.C. and Ruppzecht, F.C. (Eds.). Inhalaticn Texicology ie search Inseltute Annual Report, octorer 9 , 973 through septenber 30 .

1974. (F. 259-277), 342 o.

The efficacy of bronchopulmonary lavage and che efteacy of bronetopulnonary lavage and chelation herapy as deterained for removing Fu 239 fron hoagle dogs after inhalat
pu 239 aerosols of differing in vivo sulubility. The four aerosols used Solubilizy. The four aerosols used bre
nebulized froma solution of pu 239 puclu and nebulized from a solution of pu 239 puciu and hent treated at temperatures of $325,600,900$ and 1150 degrees $C_{0}$ respectivel . Sig dogs were exposed to each of the four a
3 dogs in each groun were treated subsequentiy by lavage and intravenou diethylenetriarinepentaacetic acid (DTPA) three dogs served as untreated controls. Tissue accuritation of $P$ u $23^{\circ}$ in the untreated control logs at sacrifice 56 days post-exposure, expressed as a percentage of the initial lung burden (TIB), was $6 \%$ in liver and $a \%$ in sketeton for the 325 legrees C geroscl group, in liver and $2 \%$ in the skeleton for the 600 aegrees $r$ group. and less than $0.6 \%$ in these tissues for the 900 degrees an 1150 degrees c aerosol groups.

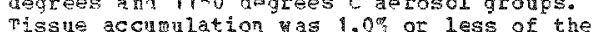
IL for $A 11$ orvans in the troated groups of IL for all organs in the troated groups of increasen in the treated dogs compared to the increasen it the treated dogs compared to the and 600 degrees c aerosols and as low in all dogs exporad to the abo degrees and 1150

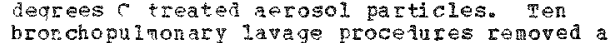

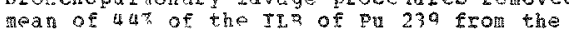
langs. The Aerosol temperature and resultirg difterences in solubility of the farticles did not influence the ficacy of the lavage procedure. An in vitro solubility of the particles aid not influence the efficacy of the lavage proceluro. An in vitzo solubility test prealctad the celative in vino solubility of the 4 aerosols. These results are discussed in relation to the choice of therapy and its timing. (Auth)

<157>

Mrggenturg, FoA.. J.A. yewhinney, J.J. Miglio, and N.0. Sla uson, love lace Founda ton for Medical Education and Rosearch Thbalation
Toricology peseareh Institute. Minuquerque. wh 4, $5 \in \cos \mathrm{gh}=\mathrm{r}$

Fenoval of Inhaled anoricing 249 from the Eeagle Dog by lung I avage: a bilot study. LF-49; Part

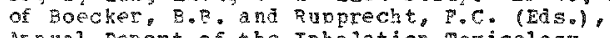
Arnual Report of the Thalation poxicology Besearch Tnstitute, nctober 1, 197 through september $30,1074,10.274-2749.384 \mathrm{p}$.

The purpose of his pilot stury vas to obtain information on the relative effectiveness of lung lavage an? intravenous chelation therapy on the removal of 1 m 241 from the dog. Six Beagle dogs were divided irto 2 equal groups; the first aroup tas evposed hy ithalation to

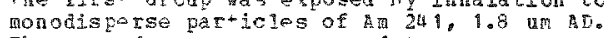
monodiserse par le les of are rolydisperse aprosol. Two logs in each gronp pere treetod bu lung larage on days 2 and post mexcosure and

dzothylenetrianinegentacetic acia (DTEA) on days 1, 2, 3, 4, 7 atd 9. Lung lavage treatment removed $24 \%$ of the initial 1 ung kurden of 3 m 241 and DTEE increased urinary escretion to tore than $15 \%$ of the initial lung burden (TLB) during tne 16 days of the study. Translocation of $A$ a 241 to liver 2 mo skeleton occurred in the control dogs, 6 to to these organs in the treated dogs. (Auth)

$\langle 958\rangle$

Murtay, Ro, H. Lisco, M. Bloom, and Heller, wot giver. 1945, Wareh 14

Effects of product Administration

Intramscularly to mice. Cl-2740; Part of sonthly Health Report on proilens Relating to Fontuly foa Reriod Ending Febrary 15,1945 , $5=71$.

Plutoniun nitrate was administered

intra nuscularly, intravenousiy ant

succutaneously to male aice at doe levels of

1.5 and $4.5 \mathrm{ag} / 9$. Preliminary results

indicate that intravenous fu caused certain

systemic lesions in the liver and spleen.

The redian lethal dose was between 0.6 and

19/9. with gedian survival of $2-3$ veeks.

Intramscular Pu showed no acute toxicity in acses up to $4.5 \mathrm{ug} / \mathrm{g}$. Subcutaneous pu cansed systemic lesions, with the median lethal dose Frobably belor 4.5 ug/9. Local lestons rere olservea ith subcutaneous and intranuscul ar doses down to 1.5 ug/g. The histclcoical effects of $\mathrm{Eu}$ in soleen and iy

aiscussed. (RAF)

$\langle 150\rangle$

purIay, R.G.. Not givon, 1948

The Thymus. Part of Bloom. W. (Eà.).

fistcpathology of Irradiation from External and Interral Sources, Chapter 9. Hegrav Hill Beck coming, rnc.. Hew york, Wew Tork, (p. 446-501) $808 \mathrm{~F}$.

The thymuses of great numbers of rabbits. rats, mice, guinea figs, and chickens inere histologicaly examined following treataent

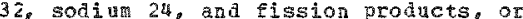
externally uith gast or slou neutrons beta rays, gama rays, and $x$ rays Single and
repeated doses yere given. Comparale damage was done to the thyms in a variet of species ly a similar numer of $\mathrm{s}$ of single-troatment totai-body $x-5$ ays single-troatment total-body $\begin{aligned} & -r a y s \\ & \text { irrespective of the pariations in } 50,30\end{aligned}$ davs for these species. ifice had stall but days for these species. hice had swall but many as 20 daily go-R total body doses of many a -rays, although severe depletion occurred -rays, although severe depleticn occurre ater 350 given $i n$ a single dose and slight danage after a single $80-$ exposure. $^{2}$

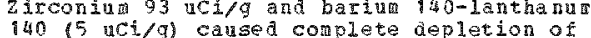
$140(5,10 i / 9)$ cansed conplete the rat thyms within 2 weoks. chosphorus 32 in mice did not deplete the thymas. A dose of 50 to $80 \mathrm{uCi}$ a of sodium 24 causea rapid and severe depletion withcut substential recotery in 4 days, in a manez similar to that following a single dcse of tectal-body irradiation vith an external asource. Intraperitoneal injecticn of 1.0 uCi/g of radium cansed progressive severe depletion of the thym of aice: definite depletion resulted in the thyrus of rats from doses as low as 0.125 uci/g. Riutonium vas deposited irregularly in the thyms of rats. the autoradiograph of aice vere entirely The autoradiogapu of ace vere entifely at any dose. Whether injected intravenously 
BTOZOGTCAT ASRECTS antrats

$\langle 159\rangle \mathrm{CONT}$

or intratascularly. The rats, on the other hand, showed consiaerable depletion of 1ymphocytes in sone specimens; in others the thyous was unaf fected. Areas containing plutchus vere depleted, and a diacent uncontaninated areas were relatively normal. Damage vas observed in one rat intravenously injected with only 0.008 uci/g of plutonium. (Auth) (F留m)

Several histological sections are shown.

<160

Murray, R.'., wot given. 1948

The spleen, part of $3100 \mathrm{~m}$, W. (BA.).

Hi stopathology of Irradiation from External and Internal Sources, chapter 7. McGraw Hil 1 Book
Company, Tne., Wew York. Wew york, (F. 243-347) $908 \mathrm{p}$.

Tne spleens of large mubers of rats mice. Guise pigs, and chickens yere histologically exarined after exposure to radiations from plutoníu, rabium, phosphorus 32, sodin 24, or mixed uranium fission products, or to externelly acplied fast neutrons, slow nevtror. 3 beta rays, gama rays, or $x$-rays. Single ang repeatei doses were given. Daily treatrents or 60 F of total-body $x$-rays severely depleted the white pulp of the mouse spleen ty 20 treatments, but erythropoieses spleen sy 20 treathentso but erythropoieses greater depletion occurred after 350 m given Greater depleticn cocurred aster 350 s given in a sing lo dose. Theragerit meal in jection mice cansed rapid moderate depletion of the splenic white pulp with complete recovery at 20 ays and corconitant hyperplasia of ectopic pyelopoiesis in the red pulo. Intracartial injection of 3.0 uCi $/ g$ of

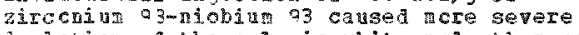
depleticn of the splenic white pulp than even 14.0 urifg of hariun 140-1anthantal 140 . In Eurther contrast to the ether beta anters studied, erythrophacytosis in the red pulp was very siking, and extopic welopolesis

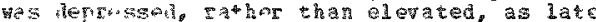
as six beks atter treatant. Intravenously injected plutomint $(0.08$ ucj/g) caused only
wid depletion of tho whte pulp of ace and

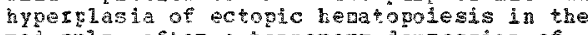
red culpo after a terporary depression $c s$ this funtion. Jamege to white pulp was nore severo in Iats, boing significa at at doses as or 0.3 ur $i / g$ calsed only slight byperplasia or 0.3 u $i / g$ calased only slight byperplasich spleer wa scolnat less with radum injected intraseritorealiv than with olutoni injected intzaverousiy. Although $1.0 \mathrm{uCi} / 9$ of radium ind consilarably more damage in nouse 50 teen than $9.08 \mathrm{nci} / \mathrm{g}$ of plutoning these are roujhly equilvalont microgean

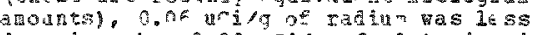
daraging then 0.03 uci/g of nlutoning it rats. Jutoraliograghs showed all matrials more chnoortraten in red pul? that in the white puif; the aeposition frequently vas

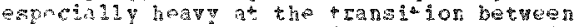

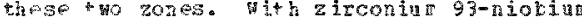

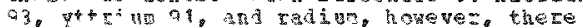
yas come heposts on in the white pulp, rost?y around the artariole. (Buth (ow

Wheroug histological sections are shorr.

《18 13

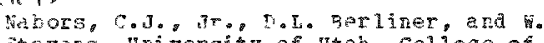

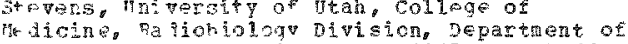

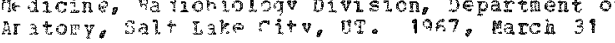

Preliminary Comparison of the ffects of spericiula 241 and plutoniul 239 on serum Enzymes. Coo-119-236; Part of Dougherty, T.F. Pesparch in Radiobiology, Anmul leport of vork in Progress in the Internal Irradiation Program. (p. $207-217), 268 \mathrm{p}$.

Previous reporta have described the effects of Pu 239 on seru enzymes in dogs. Elevated values for serua glutala-gyrnvic transaisase (SGET) vere found in $0.1,1.0$. 1. and 2.0, dose levels. The percen increasing dose. Also, pu 239 produced

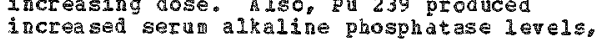
with an increase in these levels iron the 1.o with an increase in these levels 1 correlation betreen sera al kaline chospatase and incidence of ostecgenio Fhosphat ase and incidence of ostecgenic
sacona was seen at all but the 5.0 dose level. Increases in $3 \mathrm{gPT}$ and a 1 ka 1 ine fhosphatase measurements correlate with the acunt of jadioniclide-induced heptcoceliulat necrosis. A smat1 groug of test dogs has been injected with $\mathrm{Pa} 239$ at the 5.0 dose ievel and $A$ m 241 at the $1.0,2.0,3.0,4.0$ a na 5.0 aose levels. These animals were closeig studied in the initial post-infection perion. Eoth plutona and anericiur wero iver seeking nuclides. Increased SGT a m alkaline phosphatase levels have teen otserved in an 241 bearing dogs as early as feur months post-injection. Sixty percent more A 241 than Pu 239 depositid in the liver, and the changes in serum enzyes liver, and the changes in seram enzyes ccrresponced to the increase in radiation
dose to this organ. pu 239 in ${ }^{2}$ inced changes dose to this organ. Pu 239 inauced change changes in serum enzyme ievels in $\mathrm{Aa} 241$ dogs changes in serum enzye ievels in A 241 ag ith orevious findings for Pr 239 induced iver dapage. (Inth)

$\langle 152\rangle$

Nabors, C.J., Jr.. H. Stevens, and E. $_{\text {. }}$. Maxwell, University of utan, college ot medicine. Fadicholory Jivisior Departaent of anatony,

Comparative Eftects of Plutonia 239 and Americin 241 on Biocherical Parateters: Iftect of jese and gadionulide Burden Tide. Part or palichiology of plutorhat. J.h. Press. Salt Jake city, fotah, (p. 87-104), $552 \mathrm{~g}$.

comparison of the effects of $p u 239$ and 241 on serul biechenicel paraneters has been

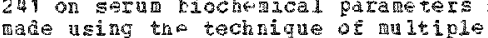

megression andysas. a separato andysis was made of ata irom

yoth plutoniul anials also bsiag seprated into turor and non-tunor groups. Two rajor differencos ere ovident A 241 appers to

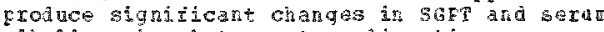

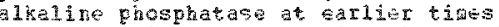
pest-injection that Pu 23\%; male reagle dogs apear to be more suscetinge to radiation-1naced changes in SGPT, $360 \mathrm{~T}$ and serug alkaline phosplidast than females. The significance of these finaings and their pcssitio relationsh to carcitogenesis ard

tormonal atrects is alscussed. (antent

Tale 3 gives a tablation of clinically diagncsed osteosarcons in pu 23 in-injucter homgles.

$\langle 163\rangle$

Menot, J.C. F, Mase, and J. Lacua, Centro d. protection sabutaie. Fonteray-aux-foses. 
Qasa are reported from a study on in minologic reactors including nonspecific and specif reactivity following a single and chrovic adtinistratior of radioisotopes (St 90 , I 131. Co $137, c 0144$. Fa 226, pu 239 to rats and rabits. The direrences os sule

Flutcrîu does not exist in an ionic form at physiological ph. It oves its chentcal indivianaty to the eact of the possible coexisterce of several valencies. The study of the general wetabolise of pa is based on the componats because they $a 210$ the isotope -o be ot ained in a monispere form. Linination is then a finction of the stabilify ir vito of the compound Tyo
phenoment, cellular uotake and hydrolymis. intervene in the liperation of $\mathrm{Pu}$ in the organist. The stury of the insoluble forms is more complax: a small percentago of local degradati cn tolloys the transporte with stoppage at the 2 evel of the gangitors and the reticuloendothelial Eyster. The dissociated salts of pu hydrolize on the spot; a seal? Exacton perhaps is taken up by the clasma protejns. The histological sway shor that for the idver there is uptake by the kupfer cells and hepatic cells for the the kuptez cells and hepatic cells for

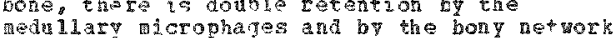

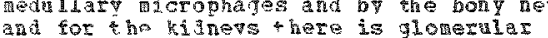
and for the kinnevs hare is glowerular precipitation. The metabolis of $P$ is is thas precipitation. The netabolis or Pas secondary deqradation and celinlar eransport. (tr-Fing

Table 2 shom distribution of insoluble Pu salts and reeal after local infection. Table 1 gives the percentage of niaration of 5 in 239 injected

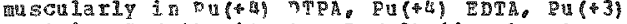
proteiu, pu(+4) citrato, Pu (-3) hicarbonate and Eu (4) carbonate.

<6 4 (1)

gunot, J.C.. N. moring P. wassey and J. Lafua,

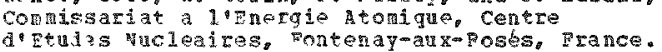
gต 7 , gecenber

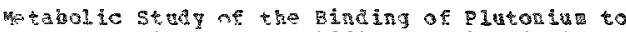
SE IU2a Poteins. p. (Frerch)

The aetabalish of plutondu-transferrin conplexes was studied is rats. Doubie labeling of fransfertin by Fo 50 and Pu 239 demonstrated fast igration from the site of transwarcular adnisistration, sinilar distribution patterns intravenous injections, the uninding of the transerrin-plutonin complex anie above all significant deposits of Elutoniu in bone. Jging $2 u 238$, nore accuracy stil1 was anieved in the kronledge of the element diseribution after intra ruscular or intravenous injections of the transterrin-plitonin complex; vithin one vees, $93 \%$ digrated Fon the site of intransculaz inqections and $70 \%$ of the migrating fraction vas aeposited in bone. (A)

〈165〉

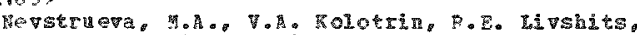

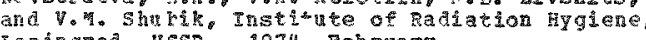
Geningrad. ISSR, TOT, February

Eriect of Tncorporated Paliondides on Tanarity. Cowp-730907<EART ill Part of styder.

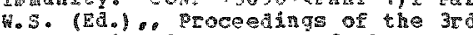
Irternational congress of the IRPA held in $(41-146), 1475$ p.(2ussian, English sugary) radioi sotopes aa total irradiation efrect on inamological action upon biophysical

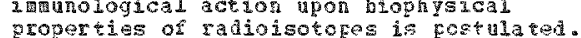
(Auth)

$\langle 166\rangle$

Nolibe, D., Centre a Brugeres-1e-Chatel, Montrouge, France. 1973. Janeary 22

FI Faticles by in Vivo Lang washout. Comptes Re nus lebdomadres des seances de 1 thadeaje

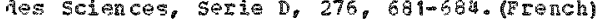

As lung washout frocessas ate ondy about 10 \% entcient. it is necessary to repeat the process several times. It was observed that process several times. it vas observed constart between the $10 \mathrm{th}$ and $40 \mathrm{th}$ day after constant between the loth and both day after Bapol vith a 70 to 200 uci per gra guoz.

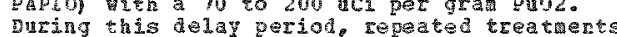

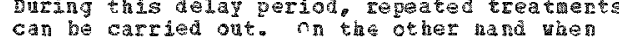
Can be carried out. nn the other nad when
higher doses are considered it in cound that higher doses are considered it is cound rapialy. It is thus necessary to intervene withi a shcrter delay periol. This last okservation inplies that the rate of 1 un washout treatmenta nust be adapted to the dose inhaled. The results obtained in rats. by lung lavage post worten also show that the afficiency of lavage as a function of time varies according to the lung alose.

(France) ( $\mathrm{F}$ 阳)

$\langle 167\rangle$

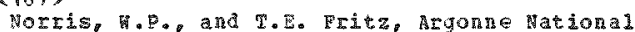
Laborator pivision of Biclegical and hedical pescarch. Ârgonne. II. 1972

Interactions of Total Dose and Dose Rate in Deternining Tissue Responses to Tonizing Radiations. Bart of Stover, B.J. and Jee, ค. S.S. (EAs.). Radiohiology of Plutoniun. J. p.

Young adult beagle dogs of bath sezes were exposed continlonsi to co 60 gan exposure rates rang ing from 5 to 300 E/22 hour exposure day. The study has frogressed to 1020 days of exgosinge. Three prinaty carses of death-septicenia, anemia, or meloproliterative disease (hPD)--irave been identified and related to exposure sate. $A$ 3 is day and above, all dogs died ith septicomias associated Septcinias associated the causes of death cocurred among

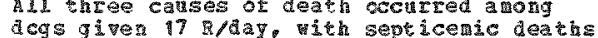
preceding death trom anemia and a deth from preceding deaths tron anetia and death ron R/day there were no deaths due to septicenia R/day there we no deaths rue to sept

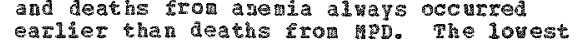
exrier tha death from in the beagle is about 19 Bay rhile the theshold exposure tate for aneme death is

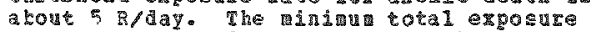
necessary to produce any of the three types of death seers to be bous 2000 h. The athors attenpted to demonstrate the relevance of these findings to the interpretation of radiation-induced effects 
GIC IOGICAL ASPRCFS

4 IIA 1 Ho

〈IE 7$\rangle \mathrm{CC}$.

from rain crucisdec denosited with the gammalian body. (a $u+h)$

$\langle 168\rangle$

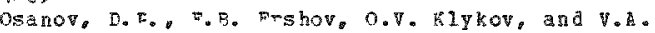
Fakova, Hot given. pa?l. Mav

The Rireticg of Dose nistribution 15 the Skin in Its contam 25 atron 1 ith Radioactive Substances.

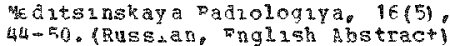

The paper deals with the results of experimental investugation of the knetics of ticrodustrabuton in the skin of tritiun oxyde, Ce 137 and ritrates of Sr 89, Pu 239 and 24 ?. The aluthors also oresent the obtaned acse distrubaticns in structural layers of the skin from these isotopes and dracuss the correlation of doses, surface contamination and beretration into the skin of the activity. Ight weeks old swine at arorcximately twonty and is per zsotope were stud ied. (auth)

$\langle 169\rangle$

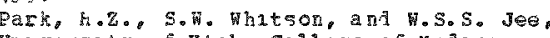

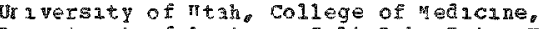
De partment of Anatomy, salt Iaxe caty, UT. 1972

Vasculat pecry of Radqation Intury to Bone. Fart of stcver, J. and Jee, R.S.S. (Tid.) kadioblology of Plutonian. J.⿲丿丨. Press, Salt lake catv, utah, p. $705-322, \quad 5=2$ p.

Mhe por pholody of the contents of the haversian canals of cortical bone of old controls ard irradiation-1ntured dogs was ezamined ry electron mercscopt. Tight unctuons were fom d petween a senchinal cel1s.preosteoblasts and osteoblasts la

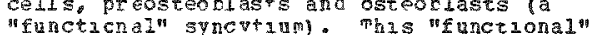
sycytan was powtulated to he involved vith coortinating the activities of cells. coordinating the actitities of cells,

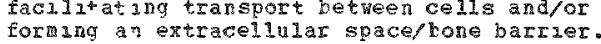
formang a extracellular space/cone pericytes fuxtaposed to processes of perivascular colls and osteoblasts an osteocytes containing centroles and marotubules. The order of decteasirg radiosensity 1 ty for cells in the haversian canal was endothellal cells, taesenchyal cells an osteoblasts. Trradiation-induced changes 1 n endothel la 1 cells nnciuder decreased numbers of procytotic vesicles. vacuclization, thichened and ragged basenent membrane, increasea numbers of 1 nelusion particles ard "blistering". Changes in pertivascular celis included dimuton $2 n$ numbers of cells and increased iysoromal-12ke numbers of cells and lacreased lysoro observed ir the pergyasular space. These observed ir the berdvascular space. changes ver I lated to our workag hypothesis of radiation-induced alterat 3h the transort of lons and nol
between blood and hone. (hath)

$<170>$

Park, J.F. HoJ. EasI, and W.J. Clarke, General Electrzc Compary, Hanford I acoratories, B10logy Iaboratory, Rechland, 1964

Chronic Texici*y of Inhaled lut on un in Dogs. Conf-556; Part of Proceedings of the lath Annual Sy

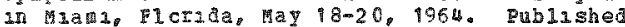
in Radiation Research, $22(1), 222$.

To study the longuter translocton and blological efrects of $1 \pi$ haled plutonum 40 beagle dogs tere given single 10-30 aldite cerpocures to Pu 239 puo2 aerosols. Seven degs died $28+48$ months after depositzon of ac in the langs. The boly burden at deat $n$ ins $1.5-3$ nct wath about 50 \% of the body burden in the lung and $a s$ ruch as $50 \%$ In the bronch $3 \mathrm{al}$ ard medsastinal lyoph nodes of sole dogs. The luver ccntained 2-lor an the skeleton, $1-4 \%$. The average radiaton dase to the lungs yas $9,000-23,000$ rads. The clinical signs priox to a wath were cardiogulmonary insufficiency and lymphorena. In adation to severe fabrotac and retaglastic changes, four aogs survivirq 36 montns after exposure evadenced bronchiolo-alveolar tumors. Most of these necplastas were locally hivasive and of wultzcentric ordgin, and nc evidence of regional or alstart netastasis was seen. The flutonum astrabution in the lung correlated wh fubrotic. metaflastic and neoplastic iesions. ana clinical cardiopulmonary symptoms indzcated the lug was the critlcal organ causing death. (Autn) (Complete Article)

$<171$

Park, J.F., D.I. Catt, D.K. Crazg, R.J. 01son, and $v_{0}$. Smath, Battelle memoral Institute Pacific Northest Lacoratorles. B 10lcgy Departaent, Rachland, WA. 1974, February

Solukility Changes of olutonal 233 oxide in Hater Susqension and effect on Brological Bohavior After Inhalat 1 on cy Beagle Dogs. Covf -730907 (Part l): Fart of Snyder, (ca.). Proceedugs of the 3ra Interational Congress of tare IFP held an dasnangton. D.C.

Beagles were exposed to aerosols of pu 239 Fuo2 or Pu 238 puoz prefared by 1 dentzcad nethod of calcining the oxalate at 750 degreas c sor 2 hours. The puoz 2 as stored

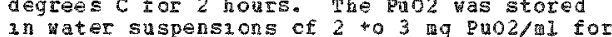
various perzods until required for exposure vario periods untal required for concentrations vere prerased by distacr cf concentrat lons were prepased by diuticn ct the stcck. kerosols were generated by nebulazing these suswascono.

vitrafilterability of the pu $239 \mathrm{FuO2}$ Suscension remaned stable rangang fron 0.1 tc 0.2 over a 16 month period. Dogs exposed tc Pu 239 PuO2 aurag thas twe and sacriflced 30 to 140 days posrexposure had wcre than $98 \%$ of the body burden at death in the lungs and thoracic lymph nodes. Dogs exposed to Pu $238 \quad \mathrm{Pu} 026$ gonths a tret

preparation of the steck suspensicn had 64 it and $50 \%$ ir the Iungs and thoracuc ly nodes, 3 th 23 and $34 \%$ in the skeleton and $8 \%$ and $19 \%$ in the Iner at 30 and 90 days postexposure, respectzely.

postexposure, respectipely. suspension was $25 \%$. andyses of the pu 239 puor and of fresnly prepared Pu 238 puoz yselded the expected geaks, bat the Pu 238 pub2 that had been $1 \mathrm{n}$ vater suspension for 9 months shoved nc $\mathrm{X}-\mathrm{ta}$ ceaks. Dogs exposed to freshly preparad pu 238 Fuo2 with $0.2 \%$ ultrafilterability showed mere than 98 of the $\mathrm{Pal}$ in the lungs and thoracic Iyph nodes 30 and 60 days posterposure, while the ultratilteraniley of the vateI suspension changed from $0.2 \%$ to $16 \%$ auring the $60 \rightarrow$ day post-expcsure period. Radlation damage to pu 23 puoz may be responsible for the duferences in the behavior of $\mathrm{Pu} 238 \mathrm{PuO2}$ and $\mathrm{Pu} 239 \mathrm{PuO2}$ in

vatex suspension and in 170 . (Aut:)

Table 2 shows tissues astrantion of 1 isaled a beagles, comparing aged and fresh $\mathrm{Pu}$ szons. Table excretion of inhaled $\mathrm{Pu}$ in beaqles cowparint 
$\langle 17$ 1

BTOLOGICAL ASEECTS

AMIMAS

$\langle 17 \uparrow\rangle$ contr.

aged vs. Erosh pu suspension. Table 5 shows tacsue dustrubution of pu $1 \mathrm{n}$ beagles after inhalution of $p_{1} 238 \quad 02$ and pi 23902.

$\langle 172\rangle$

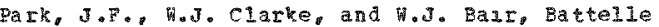

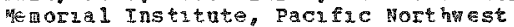

Laboratories, Bnolegy De partment, Pichland, wa. 1965

Plutonum Fartacle-Induced Heoplas a of the Carine Lung. 1. Climeal ane pross pathology.

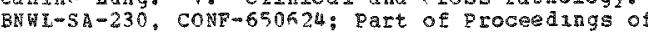
the 2 nd International symposium on lung yumors in animals held at penigia. Ftalyo June $24-29$, 1065, (20 $\mathrm{p}$.$) .$

Female reagle dogs 12 to 43 months ol were quer a single irhalation of plutomun oxide aerosol. They dsed or vere sacrufuced when death was and nert tiurang the 3 to 5 yr vost-1nhalation period. The body burdens at de and bronchial and mediastinal ly aph nodes cont annol 76 to 95, of of the bod contalned 6 to gro of the body burden.

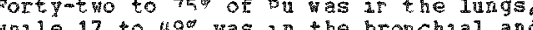

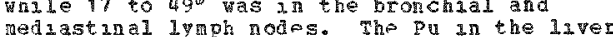
anged trom 2-15\%, and $1-c$ or of the body nurder wa 2 in the bone. The average total burden 2 an the bone. The average total ve $9,000-23,000$ rads. Cardaopin monary

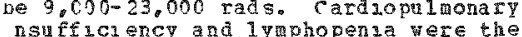

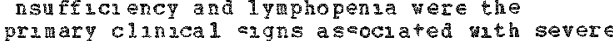
fibrosis of the lung and bronclial lyaph nodos. These organs contanned 76 to 95 percent of the terminal bod burden. Five of these an mals shoved primary vuluonary turors. "wree of the animis showed rajlograohic legucns suggestive of bulmonary neoplasia 4 to 9 months kefore death. The

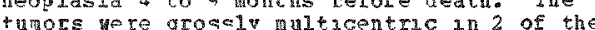
4 anils ar a listases vere rot evident. anlals ard netastases were rot evident. nuticentric origin in 5 animals and aulteentric or lgin an anjials and netastases to the hronchial lymph nodes in dog. $53 x$ of the 42 cgs exposed to pu 239 Hoved bronchiolo-alveolat carcinomes. an 1uglence cf it percent compared to a priary for canine necropsy raterial. (RAF)

$\langle 173\rangle$

Parkinson, J., Inzwersity of ttah, college of Medacine, Radioh $10109 \mathrm{~V}$ DIVIsion, Salt Lake City.

laspa fo study. AFCl-3109, Dart of senanneal Proyress Fepcrt, (p.71-73).

4 -tudy of rlasha fo values in normal beagle dogs was carried out followed hy a toxicaty seudy of dogs inrected with ar ious dosages of $\mathrm{pu}, \mathrm{pa}, \mathrm{s}^{\mathrm{m}} \mathrm{h}$ and $\mathrm{path}$. barge varuations

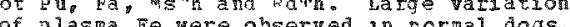
of 3 lasca me were obaerved in rormal dogs. in the animels admintered $\mathrm{Ra}$, disthe and vere noted in the early reeks a ter were noted th the errly weeks atter supornorial value were cherved. These changes $d \cdot d$ rot correlate on hematologic changes during thrs perzed. Fre pugroup dad not show heso drangoso p prela ninary report is avin on a studv dealing wh hotentyal

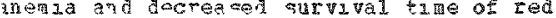
olood cel Is nroducen by $D_{u}$. a. psTh and

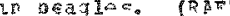

$\langle 794\rangle$

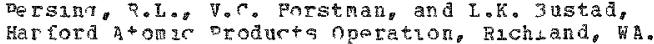

1960. Janausy 15

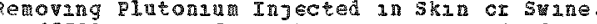

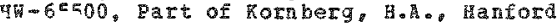
3 Hology Research antual Report for 1959 (p. $72-73) .208$ p.

Following intraderal adanistration of varyang doses of $P_{03}(44)$ nituate in sidne a lower retention (probably aue to goughng) va observed wath high levels than whth 10 w levels. Suction curs arplied to pevels. Stction curs actized to inefiective in rewoval of the contamaracn. metective in Ieloval of tie contamatacn. Prelininary observatons lnacate that tourniquets may ald in testructing translocation of Fu fron contaninated sites. (t)

$\langle 175\rangle$

Desterndkov, V.M., 1972

Deternation of maxamua Peraissible plutoman 239 Level A cordang to the osteosarccrogenac -ffect. aEC-tr-7457, Part of Mosidey Yu.T. and Kalistratova. V.S. (Ës.), Biological Effects of Fadiation from Externa 1 and Internal scurces. padiation fort $391-397), 5150$

A mathematzcal expression was obtaned fer $r e$ vear life expectancy of animals yin csteosarcona as a function of nean asorbed dose rate in the skeletal systen, Ior different anmal species (mouse, rat. og). The slope of the curve (gama) of the dose-effect Eunctior 35 b 3 versely proportional to the mean survival of a given andal species. Estrated maxima 1 peffective absorbed bose rates in the skelotal system constitute 0.05 for mine, 0.012 for rats, and 0.002 rad/day fer aogs. The estrated maxzma ineffectuve plutona levol in the haman crganism constututes

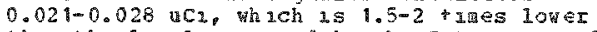
than the level approsed by the International

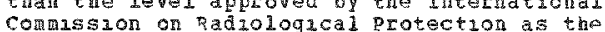
comission on adiologicas protect

$<176>$

Qesternikov, V.M.. and $\mathrm{Z}$. H. Bukhtoyarova, mo gaveฌ. 1972

Dvanacs of the Plutcming 239 -Induced osteosarconas groweh Rate. Med 2 sinskaya sadzclogy ya, 17(3), 19-24. (Buss 2 an, English Sum ary!

Roentgenologacal findings here the Dasis fer a guarititatue assesseent of osteosarcona growt rate in rats folloging intraperatoneal adimistration of $2.5 \mathrm{mcl} / \mathrm{kg}$ of plutonum catrate. Most osteosarcomas do not or 197 nate at the sutes of the highest l sotope concentratior. Sone tuors shoned a characteristic of prinary wultiple growth. characteristic ct prinary multiple growt osteosarcoma developent time as dicoussed. (Auth) (RAp)

$<177>$

Pifrce, o vot given. 1948

ne Gastrolntestinal Tract. part of B100m, (-). Hustopatholojy of Irradiat an from mternal and Internal Sources, crapter 10.

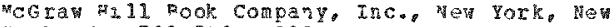
York, (p. 502-543), 808 po

The gastrontestnal tracts of a large number of tace rabbits, rats, guinea pugs, and collowang treatient uth externaly a plued 
$\langle 177\rangle \operatorname{cov} \%$

x-rays, fast neutrons, slow neutrons, beta and ganma rays and internally admintered plutcmun, Iadad, sodum 24, phosphorus 32 , uranau fission. After externaly apoized single treatments of about the in $50 / 30$ dag single treatnents of about the in s0/30 da 1500 to $800 \mathrm{n}$ the changes re s1mula in mace, rabbrs, rats, and chackens. Huclear swellings pyknosis, and fragmentation vere puts add intestinal crypts. Iarge doses 123 puts and intestinal crypts. Large doses 123

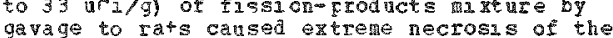
gavage to rats cansed extreme necross of the

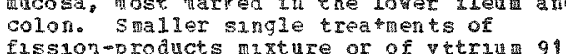

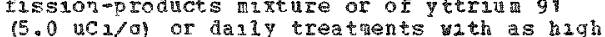

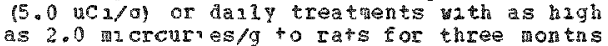
caused andmal changes. Among parenteraliy dan istered beta omiters. phosphorus 32 $(2.5 \mathrm{mc} / \mathrm{g})$, yttrut $91(2.0 \mathrm{uC} / \mathrm{g})$ and strontum 89 ( 3.6 ucl/g) produced moderate to mila datage, of decreasung severity in the order nadea. Parenteraly aamnsstered

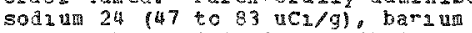

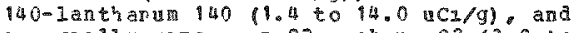

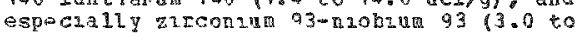
$7.0 \mathrm{Br} 2 / \mathrm{a})$ caused severe damage to the gastron estual nucosa. These changes vere

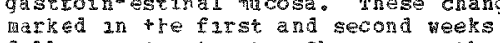
tarked an tre first ard second weeks
iollowng treatrent. changes in the

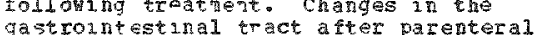

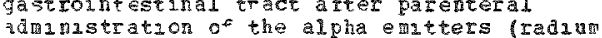
adminstration of the alpha emiters (radu and Flutonum occirred at later lntervals barage was roted after 0.125 ucs/g of radula in rats, and $0.06 \mathrm{ucl} / \mathrm{g}$ of plutongan in rats It as concluded that gu vas as toxnc as fa vere cempared on a nerocurie/g basis. $(\mathrm{huth})$ (FM阿)

\section{$\langle 17 \%$}

pohlit. H. E. and . Sehafer, cesedischat fuer

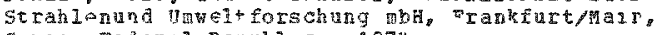

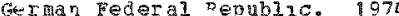

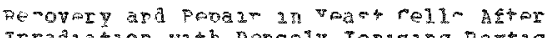

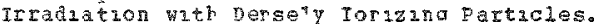
Con $O_{2}$ a 3 yoos nu or the fifects of reutron Irradiaticr Jpon rell punctach held in muremerg, Germany, nctober $22,9073,(p$. $177-1841$.

A cybernetac moded has ber devedoped for radiat_cr efererin in livang cells. This model includes quartitative charges in radiation sensitivity th absorbed dose. zecovery (splut mose reactivatica) and Iepar I (11qua-nclarg reactivation). The model has been $t \in s^{t} \varepsilon d$ axtensivelv with sparsely

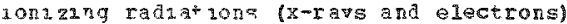
using aplose and haploud yea st celis. xperinents ars described 37 wheh ne model is ise for fralvoirg irradation 1 th alpha particleo from an americiun sonrce. These particleo are cepresentative for dersely

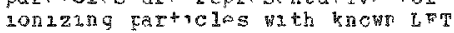

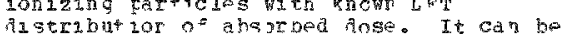

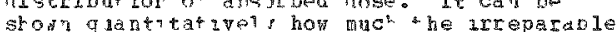

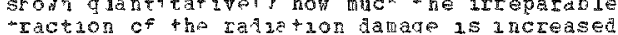

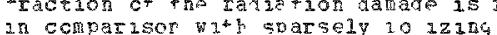

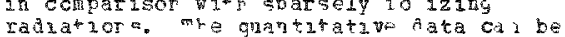

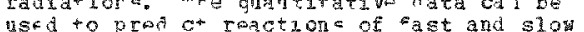
ustato pron ch ronction of a vat and sion nutrons of varing omergy astrabut

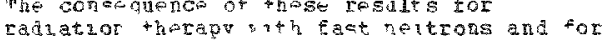
radiaticr pretoction are diaused. (Auth)

$\langle 174\rangle$

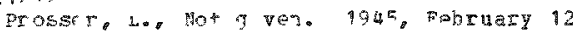

Project Council meeting. Balogy section,

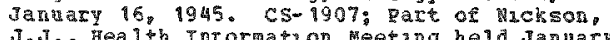
$16.9045,\left(p_{0}, 3-6\right), 6$.

The distruburion of lytravenously ningected Pu(t5) nitrate in the blood Dlasma of a dog was anestigated by aeans of the Tselins
ecchngue. The pu was attached to the al pha glchuin fraction. The tixst sign of clinical acnormality was a arop in whate count. on the 16 th day the count was 200. An elevation in temperature, and heart rate, and a fall an blood pressure are evadent on the 13 th day. The albumin and gama globulin fractions reganed unchanged in total guantaty. The
alpha and beta globulins alterea markediy. There was also an afcarent ncrease $n \pi$ fibrinogen. An essentially norma 11 ver function vas suggested. a mecnamiso sinalar to death caused by rays was suggested. In nice the 30 day $100 \%$ lethal dose with intravenous ingection of the chloride was 1 ug, 0.5 ag produced only $10 \%$ death in 50 days ndaer the same conditions. Radiln in mace had escentially the same tousc levels as dces Fu. In Iats, pu mingcted at the level of 2 ag produced $100 \%$ mortality u 30 days, $1.0 \mathrm{ug}$ produced death in $25 \%$ under toe same conditions. In markd afference 17 dastrabution of radiua and $\mathrm{Pu}$ in bono was seen by studying the radioautografis. (1tP)

$<180\rangle$

Puzprev, A.A. and A.P. Nefatev, 1972

Mcrodstrabution of ameraciua 241 in some pat organs Follow 1 id Intraceritoneal and Intratracheal Adinistration of this rsotope. AFC-tI-7457, Dart of oskalev, Yu. I. and Kalustratcva. V.S. (Eds.), Blological Effects of Fadiatzon fron Fxterral and Internal scurces, (p. $435-440), 51 \pi$ f.

Investigations were conducted on 92 hatar rats solition of adminstered intraberitonediy and

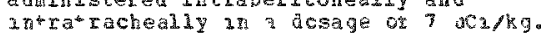

Three or four anzals vere sacr-ficed at each

of the following antervals atter

adruistration. $1,3,6,24$ honis, and 3,7 .

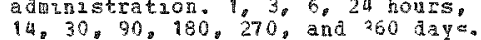
14, 30,90 , 180,270 , and 260 ays. is 15 toan oradiograis cf scft tissues were
crepared. Distribution of tho 3 sotope in prepared. Distribution of the ssotope in cone tissue tas studied on ashed and sections of femur, tib, and verterra. istoateradiograsas of the liver cacrat 2ced 1 hr to 90 ays arter revealad essent2ally uniferm astribution. after 6-12 months, nost of the isotope was an the retaculoendothelial cells. The histodutoradographic data pertaining to unashed bone showed that for IIst 7 ays
afer admuntration, a 24 doncentrates chiefiy or the active surzaces of bone at the site of formation or the csseous matrix. The netare of microdistr bation of a d 41 a arsequent stages is related to plocesses of growh and reoryanzaticn of bome. In comarifg ene data wh the literature, it is seen that at the early stages post of the Am seen that at the eary stages

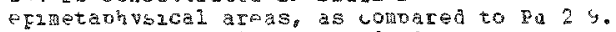
at later stages there is a jecinge in seotopo cortent il the er lost un and accumatation an the periosteun. mat acrodzatrabutzon of $A$ s 241 on the $11 v \in \mathrm{r}$ 。 katregs, splew and bore tisbue is sinlar for both intratractw and $2 n^{+}$racertionea

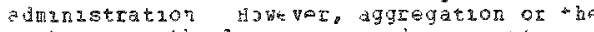
a.sotopes $2 n$ the lungs ocurcej scrn aIter 
<180〉

<180> conT.

intratracheal adnistration. Worphological changes deweloped a sites of accumulation characterized by in 1 and ation and resulting in peumosclerosis. The distribution of a ia piyn phatic tossue is predominanty fifferent. (Fum)

<ध 1)

Rehfeld, C.F. J.A. Elonguist, and G.N. Taylor argone vational loboratory, Division of bi ological and valical pasearch Argonine. II: Whiversity of luah college of mericine. De partment of Anatony, 3alt lake city, up. 1972

The Beagles. Part of Stover. B. B. and Jee.

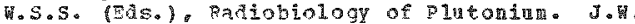
2ross, Salt take Gity, Jtak, (p. 47-58), 552 p.

The bistory of beagles as a research animal exterias back only to the comaratively recent yeat of 1950 . Starting at that time. the Fadioriciady Division a the university of titah has had a a for role $1 \mathrm{n}$ picneering the in-laboratory broenting and care or beagles Eor reseatch. This laboratory has produced 1427 beagles since
animals a cquired for hrepino purposes: each of 103 of the laboratory-bred beagles croduced cre or vose young to contribute to this total. The descenderts of 10 acquired and 21 laboratory-bred a nimals vere favored in selection of successive generations of breeding stock. AII of the 21 dogs vere related to the original 18, so a large proportion of the colong dogs were directly related tc ther. Blthough a large number of the labor atory-bred beagles were inbred, in a maforite $(80.70$ of these. the inbreating is less than that which would result from one sibling ating. Fis colon of beagles was sibling a ating. This colony or beagles vas research dog colonies in existerce and soon becat rodel colony thin arototype becat to rodel colony outh
shysical facility. (Auth)

$\langle 182\rangle$

Retherfora, A.C., A.I. Brooks, and R.o. FClellan, Lovel ace Foundation for Meaical zacaticn and Pesearch, Inhaleti on Texicology Research Institute, AIbuguerate, $\mathrm{H}$. 1973

Eary Distribution. Batention and cytogenetic Ef fects of 0.3 un monotisperse Plutoniu 239 Dioxide Particles in the chinese Haster. ConF-730431: Part of procedings of the 21 st Anrua Syacosing of the Radiation Research $29-1$ la 3 , 1973 . Published in padation Research. $55(3), 512$.

chinese hatgters were intravenousy injected

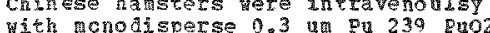

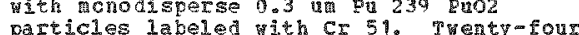
particles labeled ith Cr 51. Trenty-four of $2 \mathrm{~K} F(10-3)$ and $\mathrm{K} 10(\mathrm{E}-5)$ oci $\mathrm{Ru} 239 / \mathrm{c}$ bouy wejght. Four animels theach activity boly wejght. Four animels at each activity
level vere sacrificed at $0,2,4,816$ and 32 level vere sacrificed at $0{ }^{2}, 4,816$ and

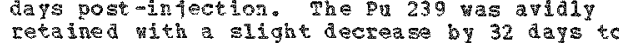
retaine with a silght decrease by 32 a 4 of the initial activity at all sacrifice times, the liver, spleen an remaining carcass contained about $90 \%$ o $20 \%$ and 8.0 \% respectivell, of the sacrisice bod butden. The activity per gra of tis indicating equal conpetence of the Feticulcendothe lital syster in these tro organs anc an equal ase comitrent. To determine the a aunt and astribution of the cytogenetic aamage to the liver cells.

additional hasters were injected yith six graded activity levels from $5 \mathrm{x} 10(\mathbb{E}-5)$ to 6
$810(\mathrm{E}-3)$ UCi pu 239 puoz/a bod weight

These activity level were calculated, on the basis of the nurber of particles present, tc irradiate 3 to $100 \%$ of the 1 iver. Agalysis at 6,15 and 42 days has show an increase in chromosome aberraticn frequency with time and with activity. (Aven)

\section{$\langle 183\rangle$}

Thoades, R. P. tot given. 1948

The Vascular system. Fart of Bloom m. IFd. Histopathology of Irradiaticn from Exterral a ra

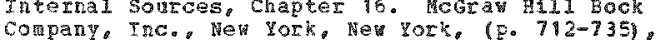
$808 \mathrm{p}$.

The early changes in blood vessels here all gantitatively alike in aninals treated with any one of the following agents: internaliy adrinistered pul citrate or nitrate, SI 39.4

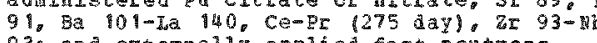
3, and excernaliy applied last nemtrons, clow neutrons and gama rays from a The a utoradographs showed that pa was deposited chierly in the small vessels and apparent caused dange in then. It vas thought that alterations in the blood vessels ce

irradited anials vas probably seconary to the course of inflateaticn of the surrcunding connective tissue. The lareart was found to be rssistat to all the types of radiations considered. Hovever, the hearts of radiuinjected rats showed deposits of radioactive anterial which damaged the a yocardi un itsele remained unaltered. (F

《184>

Phoades, R.P.e Not giver. 1948

The Lang. Past of Bloom, 此. (Ea.) Histcrathology of Irradiation from External and

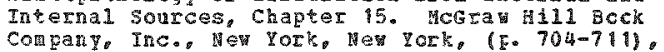
808 F.

Rats, mice and raboits were in jected with $\mathrm{sr}$ 89 in asounts varying frov 0.28 te 14.5 aci/g. Other seties of anirals $v e r e$

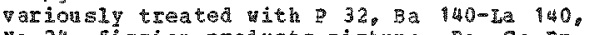
ta 24 , Rsion products nirture, Ra, Ce-pr $(275$ day)。 $91, \mathrm{Zx} 93-\mathrm{Nb} 93$ and $\mathrm{Pu}$. Mustard gas vas injected intravenougly into a small series of rabbits. The lung tissue of a fev rats was studied following inhalation of $Y$ 91. Ce-Pr (275 day) and Eu. These rats received 28 or 220 aicrocuries/rat of $\& 1$. 50 uci/rat of Ce-Pr, or 1.5 to 31.5 uCi/zat cf Pu. In a specimen fron a $\mathrm{cat}$ sacilficed one month atter dnhalatica of $\mathrm{Du}_{0}$ the groy or epithelial cells apeared suggestively meoplastic. one of the three Iats killed six wonths after inhation of ce-pr appeared epitheisal cell proliferation. The extects opithelial cell proliceration. The ef of irradiation of rat lungs by internal scurces was accurrence or abscesses in both the control and treated rats. Abscesses in the lungs rats that inhaled radicacive substances by a proliferation of epithelium that was possibly neoplastio. rice injected parenteraliy with radionctive isotopes shoved no changes in the lungs which could be attributed to irradiation. The eftects of $x$ radiation, neutrons, and beta rays fxom 132 were also reported. (FR)

¿185>

Rhoades, R.P., Hot given. 1948 
3IOLOGICAL ASE-CTS

AIIMAL,

〈185> CE

Strugtires cotaser to the castrontestinal

Tract. par of Eloon, w. (ri.). Tlatopathology

os Irradzat-cra from Fxternal and Pnternal

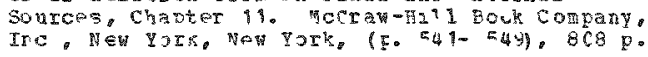

The livers of rahs ts, rats, mice, gun

pags, a chacks were cranned aster

total-boly y rradiation in doses rangung

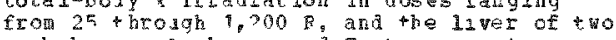

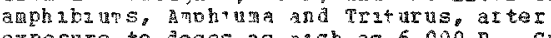

exposure to doses as nagh as 6,0005 . Gunea

plgs were exposed to gabma irradiation from

an exterr al rañum source, and

exposentc slow and fast neutrons axcept an

alterations consustent wth treatient were

sean in the liver. The effects on the spocies given parious radiations from

internal cources wox the same as in those

treated externallv, excent in he chick.

roturus and Ampuna. Tn a instion,

autoradodraws were made from several

autoradiodrath were made from severa

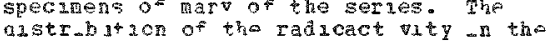

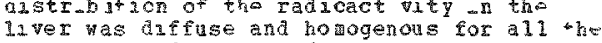

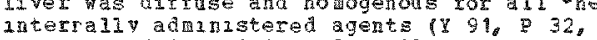

Ce-pI, Ba 140-Ia 14r, and $S r$ a) except

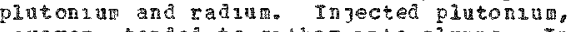
rowever, terded to ga ther into clups. In the autoradiographs of mase livers at hours throuah 42 davs after intravenous ingection of plutonum, the shadows changed

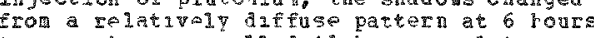
to one sroving suali dotlike accumulations. these 1 gereased $n$ size until at 42 days the agent vas aqulomerated in massos. In tre livers of anjals quven radiun, whoch enits alpha bota, ard ganma partseles, or fission-product: minture, the nistribution

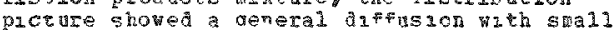
round concentrations scattered throughout the organ. Despots the deposition of raj $30 a c t i v e$ organ. desplth the depostton of morphobogea altera iona were siage an all speciners axcept in the rats injectod fith plutcrum. protoplas. an enornous ancrease 19 cellular nuclear material, and aboral 1 toses were

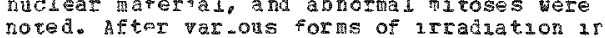
noted. After par cons forms of Mrraclation $2 \mathrm{r}$ anounts raging fron 10 to 1,10 or or Erom both 1 nternal and oternal sources, no
cnanges cells of the pancreas. Flutonum adminstered intranuscularis was not lasd down an the pascreas, but ant ratesous in

injected epecinens were cositive. (F)

$<186>$

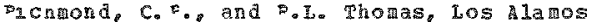
Scientyfic L aboratory, Ios A2anos, Ha 1974

Plutonum an other pctinde Dleante in Gonadal

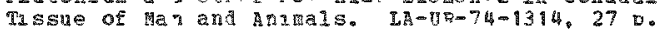

Thus Ieport sumarzzes avalable untormation on the gonadal content of mamalian species

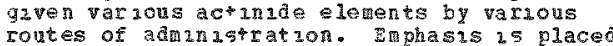
routes of administration. Enphasis 2
on plutonum. AIso discussed is the

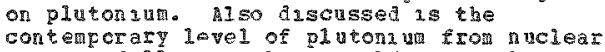
weapors faliout an huda subjerts. The fracticn of the admingtered burden of plutonum found 39 the gonads (FAsG) of fuve manmalian species following antravenous injection was about 3 \& $10(\mathrm{C}-4)$ weth only about a ractor of 10 berveen the highest and lowest values to allow for differences betmeen sexes, among species or as a fumetion of tine tolloning infection. PABG values rend to be smaler $3 \pi$ the fenale, as conpared wh the mle, and follow 3 ang andation of

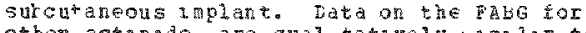

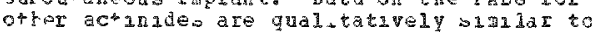
that for plutoniug. The gorada- plutonum that for plutoniug. The gorada-plutenum

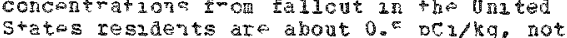
anlue that reforted ror other goft timsuts

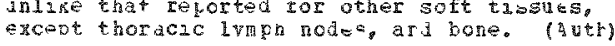

Thas report wall also bo publashed in fiealth physucs, 1975 .

(187)

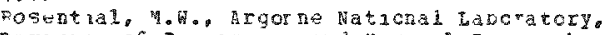

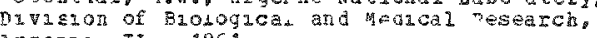
Argonin. IL. 1969

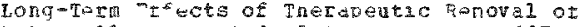
Interna1\% Deposzted Plutoniut. Avido637. Bat of Proceedings of the 7 th annual symeosiug on pioassay and andituca i Chearstry held a Argone, Il11no1s, ocober 12-13, 196\%, (F. Q $=11,100$ i. ince were trested orce a dav with an
interperitoned lijection or ced DTPA foo

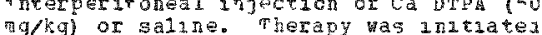
three ays after admiristration of $2.6 \mathrm{aci} / \mathrm{kg}$

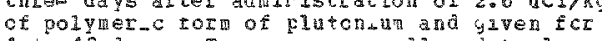
unt 1 worldund, when they vere sacrifucea and a utopsied, and roentgencorams were tacen of the I skeletors. otrer ace, used for aralysis of plutonia content a autoradiograss, were sacritaced seralay. The anour of plutonian in the bone vas reduced by about ore-hals and that ar the Iner by about one-thira it ace recenving ogtrial DPQA theragy (for 12 lays).

cormelated wh this renovi of plutoram from the skeleton, bone-tagor ancudence was also reanced oy one-haif, ising as ar undex the proportion of ance in each group to develop bone tumors. In adaltan, the surviva of the plutoma pousoned race as sagniticantiy incroasea by DTPA therapy for

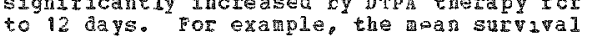

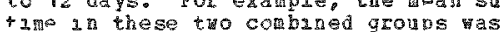
increased by 54 ays to 450.2 plus or wane increased by 54 days to 450.2 glus or winge which sas 396.5 plis or alaus 8.5 ays.

<188>

Rosentha 1, M.W. Argonre National Laboratory. Argonne, IL. 1965, December

Ffects of Experimental ateratuof of Ragocytuc AC 2 PIt on Tissue optake and Retertion of

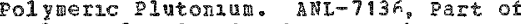
Bolcgical and hedical Researeh Division Angua Feport, 1955, (p. 194-196), $342 \mathrm{p}$.

A collordal fora ot Pu (30\% ultrafilter) 0.1 uci per mouse, was admistered meravenously tc 10 1/2-week-old mace at tade when the retzuloendothelial syster (R2S) was

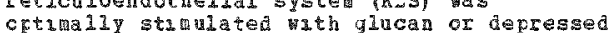
crtialiy stimuded wh glucan or depressed With carbon or methy palastate Fin after the injection of pa, the Inter contaned the sate anount of 20 in
Groups of PES-depressed mace. mace previously treated with pethy palmita $30^{\circ}$ more $\mathrm{Pu}$ in the bone and $15 \%$ less in the matrow thath 3 controls. hice pretreated wth collolal carbon showed no significant change an the agourt of Pu in the bone bit the spleen and bone narrow respectrvely.

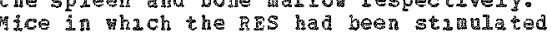
with glucan prior to pu admanatration showed no differences from controls in the $\mathrm{Pu}$ content of liver, spleen, bowe arson or bone at 5 days. Glucar treatment $121+12 t e d 5$ days after injection of polytar pu was rollcwed 
BTOLOGICAL ASPECTS AMTIMALS

$\langle 188\rangle$ CORT.

by a decrease in the pu content of the liver. This depletion of colloidal $P u$ in the liver i) giucan stimplation of the RES, if
confirmed, maq be usepl in combination with chelaticn therapy, which should prevent translocation to bone an a promote excretion. (FI?)

<189>

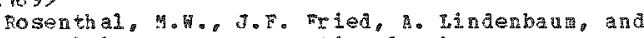
J. Schubert, Afgonne wational Laboratory.
argonine. II. 1961 , wovember

Progress Report: pqutonim Renoval, Tunor Incidence studies. AnL-6454; Part of Biological and hedical Research nivisicn Sentannual Report. January through June, 1961, (p. 82-8(4)。

Progress is reported on the experiment to correlating tamor incidence ont he degree and pattern of removal of Du from mice by delayed herany vith prpa. Daily intection of 500 makg Dops or of saline vere begun 3 of 500 tulkg $\mathrm{kmpa}$ or of saline vere begun 3 nicisg. and continued for eton 1 to 12 qays. Fach nonse was allowed to live until moribund, when it was sacrificed and autogsiod and a rontogenogram was taken of the skeleton. The tean death tite for the aice given Pu and saline (controls) vere 395.5 ays after injection, and all the aice pere dead by 515 days. DTpa therapy for either 8 or 12 days significant 1 increased the survival. Delayed DTPA therapy can increase the rean survival time by at least 50 days of hy 13 th of the control value. Survival of ince given DTPa for shorter periods vas wnchanged from that of the controls. In each group, the proportion of the rice in which at least one bone tumor appeared, has been tabulatea as a prelilunary inder of the efcectiveness of DTPA therapy. The incidence of hone turors are reduced by about one-tale by the 12-day course of DTPA about one-half by the idad covise or Dipa therapy. Shcrter pericds of DIPA theragy had, in general, less effect or the bone
turor incidence. Histological identification has increased the number of maligrancies aiscovered over that foud by $x$-ray alone. The ratio of thor incidence between control and treated mice, however remantned $2: 162 \%$ in costrol, 33\% in treatedy. The prelininaty results indicate that a siguificant reduction in bore +unors by DTPA therapy will be shom, and it is indicated that this reduction can be correlated with the degree of removal of the Ru frce the hone by Drpa. (TMm)

Table 27 shows octality of lutonlum-injected mice. Rigure 21 shows reaction of bone tumor incidence by STPA in pu-intected ice at 515 da $\mathrm{y}$.

$<100\rangle$

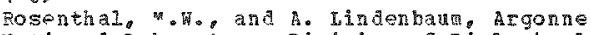
Netional Jabcratory, Nivisicn of piologicai and Hedical Eesearch, Argonne, TL. 1972

Fectivenss of Different Therapeutic Regimes of Gl ucan in peroval of bolpmeric D lutoniun from the gouse Livet. Radiztion Researei. 51, $54 \%$ He have proviously blow that he effects of of brgt are aditive in Eeroving polymeric vinterin from the mouse liver. Glucan appears to act upon intracellalar hepatic plutcning, unavalahle to DTra. To deteraine the optin titite, schedule, and dose for larger animals, pice injecter intraverousi

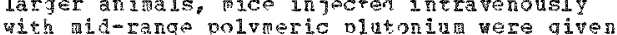

different regines of glucan in conjunction with continuing DTPA therap. An intravencus dase of $60 \mathrm{mg} / \mathrm{kg}$ of glucan removed the same fraction of injected plutonu $\mathbb{E r c m}$ the liver by 47 days $(8.0-9.5 \%)$ whether it was adrinistered in sincle injection 3 hours or 5 days before, or 5 days atter pluchius. or 5 days before or 5 days arter plucriv divided and given on 3 consecutive days gegining 5 ays arter plutonium. intracellular contact whether to reaches the iver cells before or several weeks ater the plutoniun. acse of $15 \mathrm{mg} k \mathrm{~kg}$ of glucan as almost as effective as 60 mg/kg. Since this $1 \mathrm{cw}$ dose does not induce a significant increase in liver or spleen veight. Ieticuloendothelial stimation may not be a prerequisite for glutoniur removal. Trjection of a second $60 \mathrm{mg} / \mathrm{kg}$ dose of glucan, 6 ineeks after the first, renoved a small adaitiond amcunt or hepatic glutonium by 90 days. This suggests that internittent administration of $1 \mathrm{ct}$ levels of glucan may be a useful theracutic procedure.

(Auti) (Complete aticle)

<191>

Posentha1. H. 筒, and A. Hindenbaut, Argonne National Laboratory, Arqonne. Tl. 1965, December

retabolic and Therapeutic studies of plutoniue. ANL-7136: Part of Biolcgical and Hedical Pesearch Dipizion Anmal Report, 1965. (P. $192=1931342 \mathrm{~F}$.

A prog ress report is presented for several experiments. Retertion data $t 90$ days are reported for nice adrinstered three different forms of $\mathrm{Pu}$ of increasing degreas of polymerization 190,30 , and $17.5 \%$ uitrafilterable). It is seen that the liyer content of $p$ uas refuced in all grougs, bot content of pu was reduced in 211 groups, respectively) decreased with increasing respectively) decreased with increasing Fclye rization of ado concentration of pu remained the same in arrow concentration of pu renained the sab in mice recelving the two wost polyteri

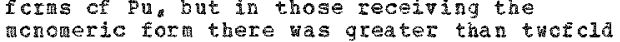
ancreric form there was greater than thetcid most polymerized forms alsc showed little or no loss of isotope from the ferur or tibial shaft. The reduction oflifetine incidence of bone tumars following reduction of the skeletal burden of $\mathrm{zu}$ by chelation therapy with DTPA has been regorted previously. This Feduction was proportional to the aonnt of skeletal $P u$ remoted in case of pu administered in the polyoeric form but not in the case of the mononerie form. It was suggested that the monomeric for was more carcingenic agent. Microscopic studes of standardized sheletal areas of ace receiving sither polymeric or monomeric pu, without erter polymeric or monomeric pu, without Drea therapy have oeel Erepared for the detailed studes or the carcinogenic proc

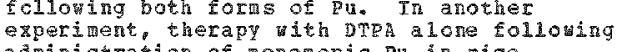
dainistration of monomeric Pu 3 mice
redrced the skeletal content by $65 \%$ whereas adainistration of both Vitamin and DTPA zeduced the skeleta 1 pa by 73 or a most tc $1 / 4$ of the control level. The practical seefulness of $v i t a$ in $A$ is however lind the severity of its physiological effects.

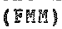

$\langle 192\rangle$

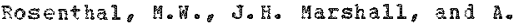

Lindenbala, Argonne vational deboratcry,

AEgCise. TL. 1968

Autoradiographic and Radiochericai stades of 
$21923 \mathrm{CO}$ พู⿱

the Irfect of collondal state of Tntravenously 15 gected P Iutomiun on Its Distrabutam in Bone

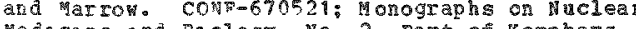

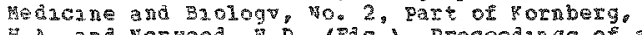

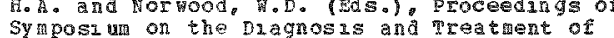
Sy posi um on the piagnos 15 and Treatrent wasugton. Hay $15-17,1967,(p, 73-80), 680 \mathrm{p}$.

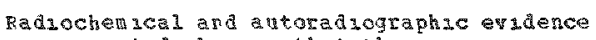
is presented shoing that there is apprecieble deposition of plutonium an bone Rarron $s 1 \mathrm{x}$ days afto ineravenous injection into 1 ce, whah remans for at least three Honths. The arount of platorin in the rascru, ard its degree of aggregation, are greater. and the amount of plutonam on bone suriaces is sqaller, after in jection of polymeric then monomerie plutonita. Blonough the anonis of plutonan in the marrow is deposited on the bone surfacese (Auth)

Tabe 1 show 5 the antrubutar of three forms of plutons an af ter antravenous njection of 0.1 uct in liver, spleen, feaurs a a tabial shaf of mee.

〈193>

Posentnal, M. W. and Y. Sandan, Argonne vatzonal Laboratory, Jivision of Malogical and Medical we search, argone. TL. 1973

Inproved Fenoval of Plutonz un from hace by Fi capsilaten of DTDA Heh in Inposones. Cof An rabl symposin of tho Radutuon esearch

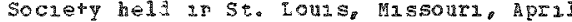
20-4av 3, 1973. Puhlished in sadiation Reswarch, 55 (3), 515-516.

The chelating agent

diet hy lerit $t$ aninepontaacetac acid (OIPA) wac

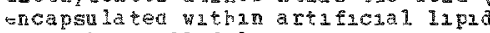
crcapsula ted hithin artific

sphezulea callod liposomes. LAposome-ncapsula og/kg) vare injectad into noce 3 days arter a mitonzan. If two experiaents.

ilposome-encapsilated DTp ropoved from 20 to $40 \%$ of te plutorizu $3 \mathrm{~g}$ the I lver not reqoved by nen-ercapsulatel (conventactal) Dipa therapy at to 10 days after olutomum administation. A second injecticn of booscual TIOA, givor 3 davg after tro fursto or adn-stration of both ancapsulated and

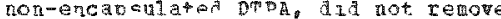
signaficantiv more plutonu frem the 1 tyer. The additional plutomin removed from the livor by litosone-oncapsulatea ThPA appears to be excreted in the urine. Both ligesones and colynerce plutona an rats are

associated with tho lysocomes in liver cells.

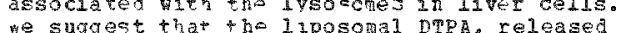
ny lysocomal enzynes, remaves from the liver ny lysocomal enzymes reares fro

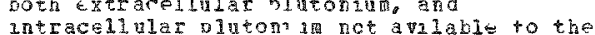
intracellular niluton 1 ing not

Liposome-encadilated Dipa was also more assective than monventional grog theraoy ur removing plutonug for the skeletor, at least a 1.5-tol greater removal fron the fenurs ar a p-old greater urinary excretion of plutcriug rere feund. The second ingection of liposoma DTPA romoved an addicical fractuon of pu from tre bone; this fraction was fond in the valno

(auth) (Comlete mext)

$\langle 1<$ as $\rangle$

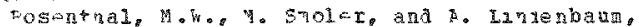

Argenne Mational Lberatory, Argonne, II. 1968

Conbaned zetzculoendoz he 12 a Strmbatron and

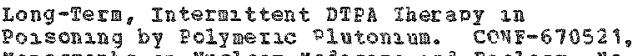

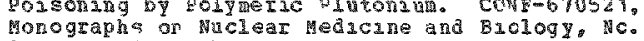
2. Eart of Rormberg. al. A. and vomood. 2. Eart of Rornberg, ki. A. and vormood, Buagosis and Treatment of Deposuted

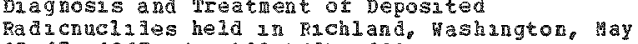
15-17, 1967, (F. 403-412).680 p.

lice were given a sugle atravencus

a jection of 0.1 or 0.2 ucl ot polymeric plutonan, about $30 \%$ nitrafalterarle, ano angraded as to particle size. Begintong 1 ve days later they were given 40 aglkg of the reticaloendotbelial system stiablat glucan once dadly for three days, or 500 m $96 \mathrm{~kg}$ of ITP once every three days for 28 injections or both treatments. In w ce given gincan alone there vas no effect on the plutongan content of any tissue at the henght of the reticuloendothelial stinulation.

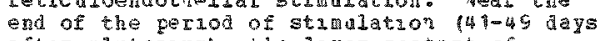
after plutonim. the liver content of plutonulu was lower (by about 10 of of be ingectod dosel than the level an controls. and the bore content was acreased by about and the bore content

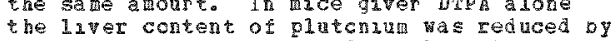
about the sane aount, and the bone burat about reduced to $30 \%$ or the control level by 89 days. Conbried, the tro treatnents hat a nearly adative efrect an reducing the $1 v e r$ burden and the same effect 3 n Dore as DTR alone. Butoradiograms of livers showed that toth oflucan and Drga reduces the

concertration of giltons a 1 in the aepatic parenchyna to a greater extent thar an tae sinusondal areas. corcentratrons of single alpha tracis and of stars, representing larger plutcruul decosits, vere reduced. In adition, in glacas -njuected ace elther wath or pithout DFR, the plutomum aggregates

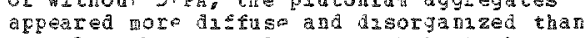
apperied wor dasus and dasotam zed the

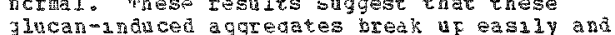
Incan-induced aggregates teak uf easily and
cerme are plutom to he removed by

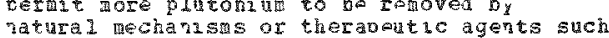

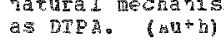

$4195\rangle$

Rouvroy. H. Lomisarat a L'Energie Aromigue, Centre ditudes, Bruyeres-je-chated. France. 1070

Study of possikite Charges Brought ahcur by

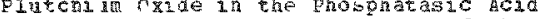
petuvity ci Alveolar vacropmages of the Tabut.

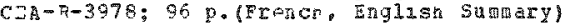

me report describes the various tecnnalues used for determining the ohosphatasic aciu acturty of alveolaI rambi t racrefrages after iphalatior of radioactive plitonilu oxide particles, exposine of the and lala, removal oarticles, exposide of the and male, remova techncal dosade. The resilts obtaned are

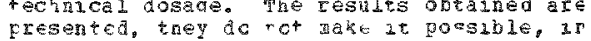
presented, trey dc ot mase it possible,

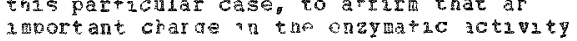
stuined occurs (autr)

$\langle 1963$

Fud natskaya, t.T., hot 31vนn, 1972

Sone sispects of Thyroud ard Parathyrca Jamad Due to Americh $44 ., \mathrm{C}-\mathrm{tr}-7457$, Eare or

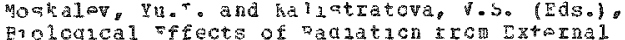
ar i Intorna 1 sourcesg $(0.486-490), 519$ p. 
Ater intravenous aninistration or A 241 chloride into abino rats, in the dose range of $0.2-0.002$ aci/aram an aggregation of 24 particles vas observed in the thytoid blood and lymph circulaticn and collota edema of the stroma uas poted. The radionelide vas peosere in the thyoid and parath proid in a tinedy dispersed for at all examintion times. An incicaso of clear cells tiratoliculart was noted. starting on the parafolicular was noted starting on pqunosis and enlargenent of sone cell nucles pqincsis and enlagenent of sone cell nucle looth ay indicat ions of hyperactivityere seen in the thyroid and cormation of pawilomatous processes peotriding into the lumen of scre EOlicles. (RAF)

\section{$\langle 197\rangle$}

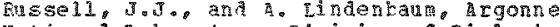
bational Lahoratory, Division of Blolouteal and Nedical pesearch Argona, Is。 1973

Autoradiographic focalization and quantitation of Articles Deposited in the Liver. Con $\vec{F}-730439$; Part of Proceedings of the 21 st Annul Sytosiut of the Radiaton te search society hela in 3 ? Lonis, Missouri, ApriI

29may 3, 1073. Published in Padjation Research. $25-19$ a 31.53

In cases of exposure to flutoniun or other hazardous actinides, bone $1 \mathrm{~s}$ considered to be the critical organ. There is mounting eviaence that accumlaticn of $\mathrm{Pu}$ in the liver may alsc be of concern for long-1ived species such as man. serious grobled wih internal anter-esgecially ith radionuclides that are easily hysrolyzed and aiscretely teposited in the tissues-is how to calculate the true dose received by the exact region of the tissue in which deleterious effects wil subsequenty apear. Qnantitative

autoradiography could provide one approach to this probler. Bo measuring the concerteration of alpha tracks formed in different regions of the liver, values can he obtaned for the anount of $\mathrm{Pu}$ associated with parenchy a sinisoida 1 cells, as vel 1 as the degree of variation in sin concentration in different vissue regions. In this paper ve recompute tissue regions, In this paper ve recon autoradiographic data from retabolic injected either with Bonometo on polymeric injected either vith Bonomerio or polymeric
Pu 239 or with polymeric Am $24 \%$. The nornalized data, expessed as tracks/dp days of autoradiographic exposure. deronstrate that track counts obtained atter พary ing exposure tios, and under a wde range of experinental conditions, are reasonaly yalid measure of the arount or deposited actinide in the entre liver. Ey extension, valid assays of $\mathrm{Pu}$ or $\mathrm{A}$ a deposted at specific hepatic micrologi are obtaisble. Data also are presented to demonstrate species differences in the zetention of both forms of $\mathrm{Pu}$ associated with parenchyal cells of the dog 1 iver, as compared to nouse liver. (Auth) (Complete Article)

<198>

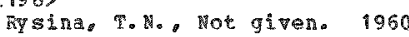

Pi atoni un Cistribution and Excretion in Dogs at Different Reriods of Time. Meditsinshaya Ra diologiya, $5(11), 9-53$. (Russian, Bnglish Sำ

4 study was done on putoniu aistributon and ezcretion in dogs following fourfold intravenous administration of Pu(nos) totailing 0.2 ucifkg. Three nonths after the 4th injection $73 \%$ of plutonim vas found in the organisa, of whel 40 \% vas in the skeleton and $30 \%$ in the liver. During the subseguent $1 / 2$ years the plutoniug level in the body renalied unchanged, except for its discharge frow the splean. By the end of the 3 rd year of observations the amout of the radiakcive elevent decreased in all tissus: including the skeleton and liver. The total dacrease thereof in the body comprased $17 \%$ of the dose introduced initilin. plutonin excretion vas studed within the space of one year and nine sonths. It reached its pea year and nine months it reached lts peak injection $(1.42-0.19 \%)$, then at the end of the 2 nd vear it graudily dina

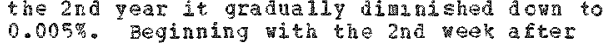
$0.005 \%$. Beginning with the 2 nd week a the introdection and throughout the fitst Froportions in urine and teces. But lacer on the amount of plutonian carried by feces พas $9.5-2$ times lower than that axcreted in urine. A possible rethod is shcwn wheh enables an approxinate estination of plutonim level in the organisn to be ade by taking account of iss activity in the egcreta. (Auth)

$\langle 199\rangle$

Sanders, c. I. Battelle vencrial Institute, Pacitic Northest Iaboratories, Fichland, 1968

Phagcoytosis and Trans location of Plutoni un 239 Puot Particles by Peri toneal Phaqocytes of the pat. CONF-670521; Monographs on a duelear tedicine and Biology, No. 2: Paxt of kornberg. G.R. and porwood, fi. (Eds.). Eroceedings of a syagcsilu on the Diagnesis and rreatment of Deposited Radionuclides hela in kichland. washington, Hay 15-17, 1967, (p. 81-90), 680 E.

Fenale. Sprague-Dagley rats $1275-390$ dody weight) gere given intraferitoneal injectiens of $1-2$ uCi Pu 239 Puo 2 vith $7-9$ x $10(246)$ Farticles anci count nean dianeter of abon $0.1-0.2$ il and range of 0.0207 .00 in diameter. Intraperitonaliy deposited $\mathrm{pu}$ carticles vere translocated andin into the iesentericonental region at five to aten mesertericomental region at five to hours after particle adinistration. Bhagoctosis of deposited farticles Grime ractor involvad in the rewowal of particles trom the peritoneal cavity. Significant direct penetration of the
peritonem by particles had probably also occurred during the first hour. phagocytic and translocative rates were related to particle size. (RRF)

Thotcricrographs (at $\times 560$ magnicication are given of perfeneal phagocytes after pu 239 puor administration.

$<200\rangle$

Sanders, C.I. and R.R. Alee, Bartelle menoral Institute, pacific Northest Laboratories. 9iology Departaent, Richlend, 1969, October

The vitrastructure of hononuclear phagocytes Folloning Intraperitoned Adain pitonin 239 guo2. Journal of the Reticuloendothalial society, $6,1-23$.

The udrestructural chages in rat peritoneal phagocytes during the first 7 day after inerapertoned adainistration of plutonid dopiae, uraniu aioxide, and latex garticles

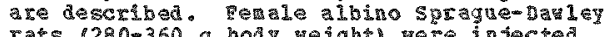
rats $(280-360 \mathrm{~g}$ body wejght) were injected vith i.4 uCi Eu 239 puo 2 parejcles feount 
(2⿺辶) CO RT.

rean dianeter, 9.92 a suspented in ainc

saline. other rats were ingected with

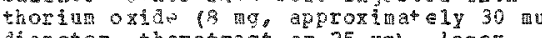

dareter, thorotrase ox $25 \mathrm{mg}$ ). Latex

particles (tom ainater 0.13 ul or saline.

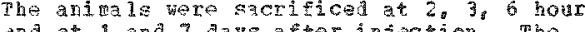

and at 1 and rays ateer injection. The

results show that numeros particles wer

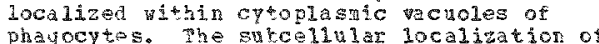

prayocytos. The sutcellular localization

electron aicroscopic autoradiography. Cnly

ainial alterations were found during the

b-hour ceriod aster plutenium. Significar:

alterations foum at 1 and 7 tays after

plutcrim included a mathed increase in phagocyte size. ant increased ruber of "pseudocosial propections, necrosis of pertonea? cells and their subsequent ergulfagnt by phagocpes. platonivo and interior surface ot insosomes at 7 days. Ho interior surface of lysosones at 7 day

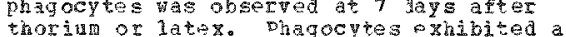
relitive radioresistace to apta irradicton relative radioresistace to apha irradich

$201\rangle$

Schuhert, J. Argonne varional Iaboratory.

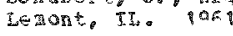

Fudiondeme: 2enoval by Chelating Agents: spolication dy Mass action lav and other Factors. Feaertion Proceedings, $20,219-220$.

The idea is expressed that chelating agents do net wort? as woll. as a substance that fixes the toxic netal at the site of its deposition. Fesults are cited of treatont of berpli ium poisoning ith wo identical chelating aquts, except that one has a sulfonic acia group. When these drum are given 4 hours after a ministration of Be. both comour ds cause the saje maked increase both comourds cause the sale marked increase does not. The a fiference lies in the ract does not. The aifferarce lies in the ract that the loss water solublo for inactivates a greater fraction of the torio metal

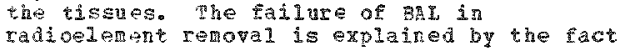
radionlement remotal is explained by the inportanc ac not react uith sulfur ligand atons, namely Pu, alkaline earths and rare earths. 0nder physiological conditions there is no sta sle complex formed and therefore. ezcept for Fo, $5 \mathrm{~A}$ i wil inefective. convenient way of testing the effect of chelating agents is nentioned, that is, to inject the radicelement inco the anigal then withara samples of blood containing the radioflentent. To the bioca one can then add the known amounts of chelating agents and measire the iltrafilterabilitt. It is pointed out that when eleants widely

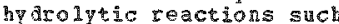
as $\mathrm{Hg}$, Ce and $\mathrm{Sr}$ are being compared, one has to insert adnitional terms, such as the hylroxylatin constants in order to have good correlatien. pron mass action considerations-onitting nonegu i lobran processes--it is possibie to estimate the fraction of radioelenent bound $\mathrm{ky}$ the legands involved. several equations are derived. The inportance of acertaining the degree of remotal of a rafioelement fron specific cell fracticns is mentioned. Thile it is possibl to renove nany radionlements from the body. it is also inportamt to deponstrate reavol also recuced the turor incidence which follows such later. In long tern experingrts, it was foun that removal of Eu infection ot qu caused a marked decrease in bcre tumor incidence. (rim)

$<0$

Schubert, Je, iniversity of $P$ ittsburgn

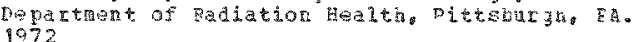

Fadioebent hetabolis and Decorporation as Trezenced oy chelation and complexes-Rapia sxperimental and calcularsive approaches to predict In Vive 9 ehavicr. Past of Stover, B.je and jee, H.S.S. (EAs.), Fadicblology of Rlutonar. J.仿. Press. Salt Iake city, 0tah, (p. 355-376), 552 D.

The solution chemistry and aetanolism of radive lenents (radicactive metal ions) are closely interralated. 2he relativ

efrectivanss of different chedating aguts fer the decorporation of radicelements deposited in malalian tissues can be sibely and rapidiy derermined by ultratilerability

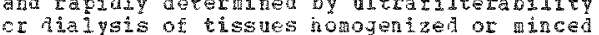
or tialysis of issues homojeri of $a$ gun chelating agent. It is pointed of a dus chelatirg agent It bo pointed ou that aptarent lack cf agrement betseen the in vitro and in vivo chervations are inerpretation e.g. the use of a single. interpretation e.g.p the us on a gingle. and neglect of the fact that a chelating agent with strongly hydrophisic groups sucin as sultonic acill is less able to ade

cortact in vito pith deposited padicelements. The role of al kel conplexes in aproved decorporation thera garticular, it is pointed out chat generally two gr pore complexing or clelating ageris vil bint a deta icn acre firmiy than a

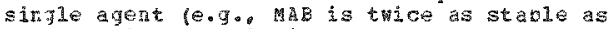
$M 2$ or $\mathrm{B} 2$ on statistical grounis a lonel. The response of monomeric and polyesic The response of monoweric and poly

decorporaticn theragy is show tc degend on decorgoraticn thera is show tc degend on the polyer by tie chelating a gent is mach slower then the rate of formation of the chelate frow the poncteric for. A siplified nethod For es idarirg the negrae to which a chelating agent binds radioelepent in vive is descirbed. Whe method enploys the so-called "conditional or erfective constant and side-reaction ceeficients. It is also pollded out that the slope of the ascending and bescending branches of the minary or tissue excretion curvess of a raidoelement folloving chelatica therapy can be utilized to deterine the thysico-chenical state of redoedenents deposited in the body $\left(i . e_{0}\right.$, the degree tc which she radioebenent is in a gonoreric or pclyberic statel. Such information can be Fclyeric state such information can useful for prcgoosis and for dete
schedules of treatent. (Auth)

$\langle 203\rangle$

Sch vartz, S., R. Zagaria, and C.J. hatson Chiversity of Chicago, Metaliurgical laboracory.

Studies of porphytin Metabolism. H. The Effect of Irradiation on coproporphyrin sycration. WDDC-1221: 18 p. Declassifiea August 8,1947$)$

The trfect of radiation exposure on coproporplyrin excretion has been studied in 38 dogs. Sore dogs vere exposed to single acses of 400 to $450 R_{0} 300$ to $350 \%$ and 100 I total body x Iadiaticn and some to 50,40, 25.12 .5 R dail g-ray exposure. Stronesum ugh and 2.87 ugho. Ieth d doses of Pu 
$\langle 203\rangle$

BIOLOGICAL ASEECTS

AHIDIAS

(203) COHT

10.48 ug and 0.766 ug is/kq body velght were injected antraverousl and 0.404 ug 2 urikg was unjected irtramsculariy. A duinshed

excretion cf coproporphyrin $q \eta$ uline and

fecos was found to follow the admantratzon

of lethal or nearly lethal doses of total

boay $x \mathrm{ray}, \mathrm{Sr} 89$, and $\mathrm{Pu}$. Th most

lastances, a sharp lnerease in porphy 15

axcreticn occurred aring the ternanal

perzod. Freluminary studes showed

signafacant change in the rat 20 of the 2

coproporohyran isoners $(1$ and 3 ) following

zEIdist on. (Auth) (RAF)

A11 data obtared are 111 ustrated in terms of the percent devintion of the per dien conrovorpnyr $-\pi$ excretion from the average control pallie for each dog.

$\langle 204\rangle$

scotes Ko z., D. Rxelrod, J. Crowley, and J,G falinton, tniversuty of Califorma, meducal School. Dispsions of Fadiology and pledine, San Francisco, chi linzorsaty of Californa crocker laboretory. Divielon of pedical ph serkeley, $\mathrm{CB} .1949$

$\checkmark$ position anf Fate of platcnum, vranizis ane the ar Fission producte Inhaled as aerosols by zats and yan. 3rohives of pathology, $48,31-54$

The purfoce of these experments was to acertar th posshle hazara resulting from rnalation of fissionabie reterials and fissicn oroducts. Aaroscls of oluton 1 ul (pu verates ard $D_{u}$ ox des) uran $1 u$ plus fissior

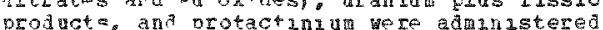
to rats." "Zr 89 aerosol was administered to human subrect ara to Iats. Berosols of the aforement ioned element w we almost totally retaried ry the had ard the langs 20aediatelv after exposure. After four days the lunge contaned the largest percentage of thise alomerts. The olenents deposited in the head and kronchal tree vere gulckly elaniated $v$ a the gastrontest a ral tract.

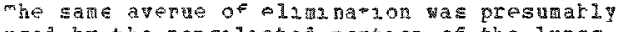
usen by the roncl 12ated portion of the lungs. but at a slower rate. rhe smal I percentage absrbed into the boiy wa prinarily absribed into the body va priarily depositer th the sboloton atter con

zadioatographe atudies indzcete that the

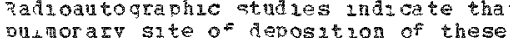
butorazy site oferosition of these Naterials is in the bronchial passages and the alveora structures. The naterials are

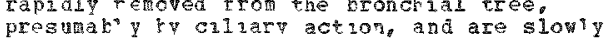
presurab" y by ciliry action, andare slow of any of the radioelements ras observed ir enther blood vassels or lyph nodes.

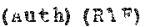

कadjoautographo ape given showng the prlnonary de position of $\mathrm{P}_{1}$ a erosols.

$205>$

Soaborg, G. ". Universit of caluferna,

Berkeley, $C A: 1972$

S utonu hevigutod. Dact of storer. Bos. and

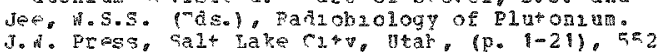
p。

The achioventents of the Fadzornology laboxatery of the inveresty or ltah wore revievel. The initial assagnent given the laboratory $\mathrm{was}$ to assess the role of plutcriut as an mduatzal bazard. The

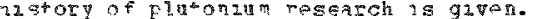

$\langle 206>$

Semenow, D.I. and I.P. mregabenk, Bcedery of sclences of the USSR, BHOphysics Laboratory. Sverdlovsk, USSR. 195e. January-Febrary

The Actron of Chelating compounds on Thsue Storage and Excretuen from the Livang organis

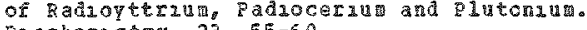
Biocheastry, 23, 55-60.

Crelating agents, bunding aetal catrons to fora soluble, stable chelates under the condrtions of the living oxganish, exert a fronounced erfect or tise radiolsotope of

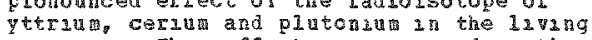

organs. Thas effect bs expessed lit the organisi. Fhis effect 45 expIessed lit the trasues and an the enhancement of the rate of excretion of the metal poicons inco the urine. Ezperiments were carried out or whate rats veighirg fe0-200 g. Yetran 91 and $c e$ 144 vere introduced in the for al of chlotides (FH 2) 2nito the caldal vein in proportions of 3 richat. Soina salts of the chelating compounds were anjected unto the ccntralateral cauda 1 velth in proportzons of 2 x $10(\mathrm{z}-5)$ mole $(\mathrm{pti} 7.3), 2 \mathrm{man}$. after infection of the radiossotope. Pluton 2 un 239 was introduced $1 n^{2}$ raperytonedily at a dose of $1 \mathrm{mc} / \mathrm{rat}$, an the form of the catroc ackd comples (pH 6). Sodzu salts of the chelate were anjected into the cauda wen 10 an.

fcllowng the injection of pu. A comparisca of the effectiveness of the varmous chelating ligands assignable to the grcue ef and nopolycarboxyl c acad compounds, and also those of the chosphate grcue, pontes out substantua difererces betweer the tho 9roups, ef both a cuantitatave and a gallitative nature. The ligaride most effectuve in promotipu the elimanation of vthium are uramldacetace and scdun othylenedzannetetracetate, while the wost vluton 2 m is heraretofhosthate. The qualicative 12stuctzons relate chiefly tc the fact that the phosphatea enhare storage of vetram and plutona in the tissues, although, 1is contrast to a ragovolycarboxylic acid chelatarg agents, they sisarply volvcarborylic acid chelating agents, they sharoly redace the accumulation of cerale in the skeleton. The data cbrasned attest to the fact that, aside from the stakility ct the fact that, aside from the stal sagnaficance $1 \mathrm{n}$ determañ $\mathrm{ng}$ the effect 2 veness sagnificance in determang tha exted

effectiveress of chelating agrats

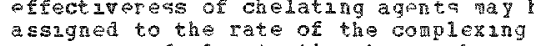
process, and alse to the fhysucceherical ccmplexing process, and also to the physicocnemacal state of the thetal an the blood strean and $2 r_{1}$ the state of tre netal as the blood strean and in the bodv slutas. The resules cuted and the conclusions aran frch then pont to a possible role of huologands occurrzig naturaldy in the laving orgamasn (anino acids, eatrac acid, phosphates, etc.) in maneral metabolisto. The agh level ct effectueness observad for hezametorhoswate with respect to cersum and pluconsum is not wiscepto sof the cover derable toracity of that of the cousiderable toxicity of that creparation. At the sanc time, the

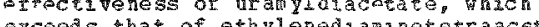
erceeds that of ethylenedianetetracetate. and which lencs ltself to uesizas $1 \mathrm{cn}$ ror the 4reatane of heavy-peter poisoning and radiolsorope bolsoning 1 a deserving of

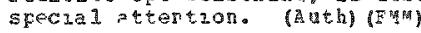

Tabie 3 shows gu contert in oradns and excreta of rets on fourth day or exberimart under action of variog ligands. 
BOLOGICAL ASPECTS

ANT MEZS

<207>

SIRov, H.R., and D.D. Hahbarn, Battenle hemorral

Institute. Pacific northest Laboratories. Biology Department, Richlane, mp. 1967, July

Trfect of Hge and Earicle Size on Eassage Tiae through the Gastrontestinal Tract of the Rat.

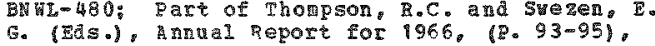
$207 \mathrm{p}$.

Q1utonum crade particies f chD $0.13 u, 0.15$

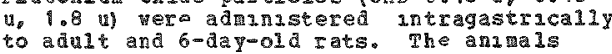
were sacrlitsed $a t, 3,7$ and 21 days after adinnstration and the ceention and astrabution in the gastrongtestral tract vas deter nned. A poorly arsorbed soluble

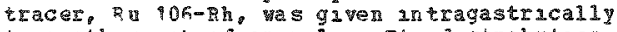
to anothe set of animajs. Its distribution in the ga strointestnal tract was deterinned from $1 / 2$ to 2 h hr atter adnistration. In from $1 / 2$ to 2 hi hid the siaglest particle size

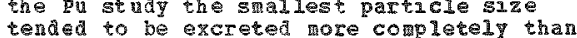
the other two, parthculariy in the newborn the other wo, barticularly an the pevborn
animals. A substantal fraction of all 3 animals. A sustantal fraction of all 3 particle suze distributans was still prost
at 1 to 3 days followng admanstation.

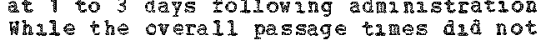
While the overall passage times dad not affer markediy for juvenzle and ault
anladis, the shorter tract length of the noonate resulted in a sabtantialiy reduced rate of passage and a concomitant increase in the avarage tite of contact wh any glven length of the tract. Fhere was clear avidence for a longor retenzan of materal in the stonach and in the lleum of the Infant rat as compared to the adult. (RAF)

$\langle 208>$

S1 Kov, H.R., ara D.D. Mahlum, Battelle Memorzal

Institlie. Pacific Hopthyest Iaboratories,

BIology Dopartment, Rlchland, WA. 1973

Influence of Age on the late Iffects of wonomerac Flutonum 239 in the $\mathrm{F}$ at. Corf 730431 . Part of Proceed 2795 of the 21 st annual Syposum of the Raduation Research bociety held in St. Louls, Missoury. April

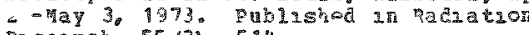
kesearch, a 5 (3), 594 .

It has been shown that the metabolisn as vell as the acute and subacute toracity of pu 239 varles wh age and phrsicochemical forro Th. late effects, including the eventual trmor resporses vere stadied following exposure of rats to 10 w levels of monomerac exposure or rats to low levels of bono
Pu 239 at several perpods aring life. Pu 239 at several periods aring life.
Adu-t. we aring. pewborn, and prenatal rats

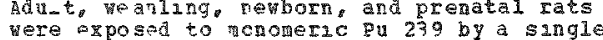

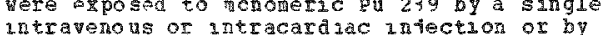
intravenous or intracardiac lniection or by intravenous injection of the dam. Three levels which would qive a verage radiation
doses of approxuately 723 or 70 rads to coses of approximately 7,23 or 70 I the ferur in the first ic ays after
exposire, were used. pats from each group wer sacrifuced at intervals for radroanalysis and autoradiography to establisn the ricrodosinetry. Fine remasring anzals and controls are being folloved until deatho At if norths postingectzon, the incidence of mortal ty and tumor developent is greator aborg nales than females. The hin thest incidence of esteosarconas and chloroleukemas, the predominent cunos types. has bern in the an 19 ls exposed as adults. Tumor 1 acidence $\mathrm{n}$ the earlier-exposed grouos is presently qnsuff 263 ent to indicate any

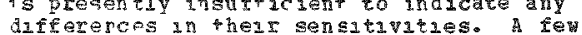
differercos in hear wensitivities. A few neonatally or prenatally but Bot in those -xposed as weanlungs or aduIs

(Auth) (Complesarticle)
<209>

Sikov, H.R., and D.D. Mahlug, Batrelle me vorlal Instatute. gacizic Morthest Laboratories. Depert, Rachland, 1972

Age- Lependence of Plutonum 239 metabolus a nd Fffect in the Rat. Bart of Stover, B.j. and 3e., $552 \%$.

A nuber of stadies vere performed to evaluate the retabolisi and effects of pu 239 relative to anial age at tame of

admanstration. Included iere experments Which have demonstrated differences in atsorstzon and dastrabution followng gavage t var lous ages. In other stadeso the partition and war to vary injecton. The resulting effects are clearly IIfluenced by metabolic a fiferences as weil as by the duferemces in age-related as by the differences in age-related rashon, cross-placental transfer, dashion cioss-placental transer, and biological effect changed throughout and biological effect changed throughout values obtanied in the adut for calculaticn values obtanis in the adit for radyorucludes way be inagropriate for imature malvidals. (Auth)

Teble 1 gaves the alstrabution of Ru 239 an rats 24 hr after injection cf ronoter and polytrer. rable 2 gives effect of age and physiochemical and fem ar and 7 days after injection.

<210>

Smith, D.D., yatzonal Eavifonmental Fesea Ich Center, Monitoring Systers Besearch and Development Davision, Las Vegas, MV. 1973, June

Status of the 0.S. Envaromental protection Aagncy"s Nevada mest Stce Exberamental Dary Herd, Jaruary 1, 1969-Decenber 31, 1970 जP $\mathrm{RC}-\mathrm{L} V-539-22,62 \mathrm{p}$.

The U.S. Tripron mental Protection Agency's National Environmental Research Center, Has Vegas, mantans an experimental dasry herd 18 Area 15 of the Mevada Test Site. The status of this herd, for the perzod January 1,1969 throagn December $31,1970,25$ described. The report lists changes and loprovenents ade on the faciluties, presents herd a ind wad foduction and reproduct 30 statist $16 s$.

detalls health problens and treatments, and sumarizes the metabolmsm, field and "ad hoc"

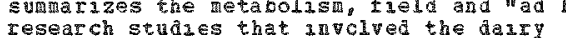
hera. The dazry hera yas utilized for herd. The daly herd as utilized for pathos of selected radionilides which pathing of selected radionuclides when lignt appeax in the enviroment followng a the basis of produrtion, stage of gestation. breed and neath. Specially designed metabolign stalls orere usea that grovied contanuous restrant but stall allowed sufficlemt movement for confort and easy access for likng ard saple collection. orally, via gelatin capsulaz. or Intraverously as an isotonic solution. Sampling of bloog, urane, feces and ialk tcok
place every sig hours until peak levels occurred. Metabolac studies iere undertaken wh the folloning radionuclides lodine 131 . wolf the following lead 203 thallan 202 ,olfram

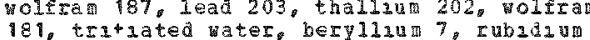
86 , mercury 203 and iron 9. (pas) 
BIOEOGICAI ASETCMS ANIMALS

<211>

Stath. H. and T.V. Chapman, Sunderland Polytechic, school of pharmacy, surderlama, wrhan. Fngl and; Iniversity of Dundee. Department of Redical Biophysics. Dudee. Departint of Medical Bioph
scotiand. 1969. August 9

use of citrate in lobilizing plutoniun in Rato peture, $223,542-543$.

The use wen citrate in the treatrent of acute $\mathrm{Pu}$ cisoning is investigated in rats whth a view of extrapolating the data to

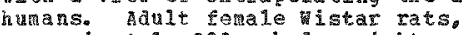

approximately $200 \mathrm{~g}$ bod welght were each given an injection of 0.2 al of a soluticn containing $1.7 \times 10(2-3)$ ag of $p 239$ isotepically lixed with $0.4 \times 10(2-5)$ ug of $\mathrm{Pu} 237$ in 0.1 oitrate at ph 7. The anials were divided into groups and given an IF infection of $730 \mathrm{~g}$ citrate/kg of body weight eather before, simulaneously vith or after
pu injection. The maximu effectiveness ras

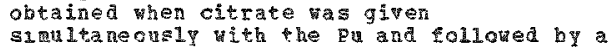
second injection after 90 in. Effectiveness fell of of citrate therapy was delayea but it was of some value up to 2 h $\mathrm{h}$ a citrate infected 30 min before $p$ was of no value. The excretion da ta of $\mathrm{QI} 237$ in urine and leces shored pererential excretion 1 arine in the citrate-treated group in the initial 2 day period follozing citrate and excretion in both urine and feces occurred
throvgher the 24 days of the experinent. I a study on the infuence of citrate (administered simultaneousiy with pu on the distribution of Pu 237 in the tissues, it was seen that in a $3 \mathrm{hr}$ period, there as more rapid transer of pu frol the peritoneal carzty, an enhanced urinary excretion and a marked retention in liver in the citrate-treated groug conpared with the controls. There vas, however, no difference in the areunt of pu transferred to bone. (F) (CTS)

Table 3 shous the influence of citrate on the distribation of Pu 237 in rat tissues.

$\langle 212\rangle$

Sm th, V.tingeneral Electric comany, Hanfora

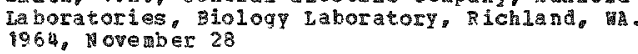

Prepention of plutoniam Deposition by Desfers ioxatine-B. Nature. 204, 899-900:
Ho $-5 \mathrm{~A}-3590 ; 2 \mathrm{p}$.

Eight-nouth-old female rats vere intravenoulsy injected ith 2 uci Pu $239(44)$. one, 5 , and 24 hr later they were with 0.5 mol $/ \mathrm{kg}$ of DTPA and DFA

(Desferxioxamine-B). Urine and fecal saples were taken. Five days later the animals were sacrificed. statistically sur arized results show that treatrent with DFR decreased bone deposition of to about one-half the value obtained by DTP and that the two agents given tegether prodrced a partilly aditive given egether prod rced a partially ad enhaced efrect of DFBS is probahiy due to its different in viro alstrobution and the its different in viro aistribution an the conseguent tapping of pu pools not avai.
to DTpA. This is also suggested by the to DTPA. This is a 150 suggested the consisterty lorer bore deposition and fecad ontgut of
andals. (RAs)

The effects of treatments on pu content of lizer, fidneys and fenur and ezcreta fitye days after adini terotion are given in tabular fora.
<213>

Stith. V. H. Batelle Menorial Institute.

Pacific lorthest Iaboratories, Biolcgy

De cartment, Richland, 再。. 1972

Comparison of Efficiency of gemoval of

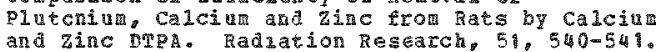

The relative radionucilde removal effucuby of calciul and zinc

aethylenetriainepertacetic acia (Ce DTEA) was estinated when single treatrents were given at one hour (prompt treatzent) or
lutiple treatments pere given starting at atiple reatuents were given sta intravenous administration of pu 238 , ce lut and $\mathrm{z} n 65$ citrate (qu 4.6 ) to rats. The DIPA was administered intraperitoneally to groups of 6 to 8 rats at each treatrent leved. In the prompt treatrent series the in DTP levels varied from 0.005 to 2 mol/kg ith the optimu dose for removal of $\mathrm{Pu}$ or ce from scft tissues and bone at about 1 to 1.5 riolog. which agrees with results of a similar uperiment with Ca DIEA. A greater fraction of the adinistered Pu thar ce and below 0.5 mol kg, Ca Drg than ce and below 0.5 mol/kg, Ca DTE otph. There as no optimu dose for tenovil of $z_{n} 65$ which was exchanged in direct proportion to the chelate dose. Tuelve Froportion to the chelate dose. Tuelve treatinents at DTp lepels cr 0.001 to

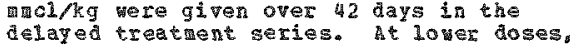
0.001 and 0.01 mol/kg, the Ca DTPR appeabed mcre efficient at removing pu and ce from sctt tissues wilo zh DTQA, caused gore renoval from bone, hovever, at abcut 0.1 molikg the aiferences disappeared. The effectiveness of both salts were essentially equivalent in cansing regoval of the 2 n 65. (Anth) (Complete article)

<2148

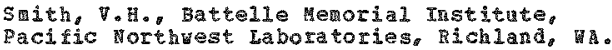
1974 , February

The giological Disposition of Einsteiniu Nitrate $\mathrm{ES}$ (MO3) 3 in Rats Mrter Intravenou. Ineramsucar 1 and Sabcutaneous Ad Coll-730907 (Part 1): Part of Snyder, (5d.). Proceedings of the 3ra Intertational

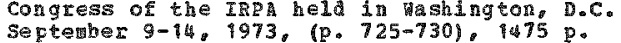

Adult, female, Wistar-strain rats were injected with 4.76 uCi $\mathrm{ES}$ as the nitrate $0.20 \mathrm{cc} \mathrm{ph} 2.0$ solution $90 \%$ ultrafilterable intravenous ly (IV), intramuscularly (Im) and subcutaneousiy (SC) R Regardiess of the infection route, 5 s (mo3) 3 was retainea creponderatiy in the skeleton up to 24 days fter adnistration. The liver burder decrea sed fron $26 \%$ of the inctal Bs adrinistered IV at hours to $14 \%$ at 1 day and less than $2 \%$ at 2 days. The skeletal. content increased to about $70 \%$ on der $y$ and decreased to about $56 \%$ by day 24 . The liter and sheletal cetention at 2 H das frol the sc and In injections vas sijght 17 less than fro and If injections vas sightig less than tro greater for the sc route, $16 \%$, than for the In ronte, $3 \%$. The popliteal iy In Toute, $3 \%$ The popliteal lym nodes adjacent to the In injection site retained to bout $0.7 \%$ of the injected dose/g compars

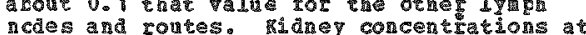
ncdes a routes. kidney concentrations

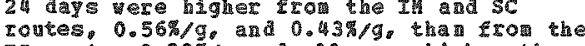
I rovte. $0.33 \% / g$ and all were higher tha the 1 iver concentrations of $0.11-0.16 \% / 9$ wet veight. In cowon with other "acthindes. Is 
(214) COHT.

Was concentrobed nore $2^{\pi_{3}}$ the vertebre and starnum tran in of hor boses. Freretion was n.gner artially in the urino, wut by the 5 th diy wore was being excreted i the feces. SkI absorption was very hagh, acold 4 of of

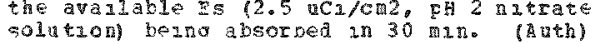

Fugure 2 shows Fs 253 anstrabut on an zats 24 davo tol3owng the ingection of Fs (NO3) 3 by various ratea. Table shows Es 253

corceptration 17 tissues after admingstration of 4.76 uca $\mathrm{Es}(\mathrm{ac})$ ) 3 to rats.

<215>

Sazth, V.F, J.L. Palotay, E.J. Mcclanahan, H. A. Ragan, and w.J. larko, Rattelle memorial Ir stutute. Pacifur Borthest In aboratories, Fichland, w. 1965, Jandary 3

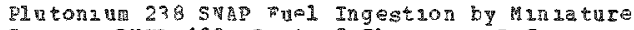

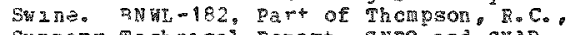
Surnary Tachneal Repnrt Simpor

3010gical Studzes, (p. 10- 14$), 16 p$

A $49.2 \mathrm{~kg}$ Hanford munature ply was fed a massive acse lapproksmately,$C_{-}$) of $\mathrm{P}_{\mathrm{B}} 238$ SWA fues baxticle. Total urane and teces collectzon and periodic blood sambles ver. optaned for 1 ta das folloning puoz feedno. The pu was then sacrifaced and tassus and yzed. mere was prolonged and extensive holndp of the partacles an the intestinal tract. slightiy less than half of the Irgested activity was excreted durung the trot 6 davs. whe romar 1 ing activity yas, however, almost tot ally excreted during the

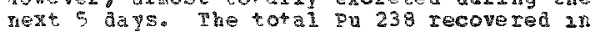

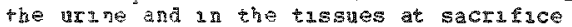
amolnted to $2 \times 10(\overline{7}-7)$ eines the amount fed. over 99 of this ahsorbed $P$ wi w recovered from 1 yph nodes. The relatively enormous cose of 9 a rosulted a

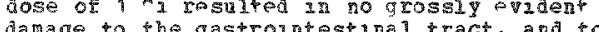
darage to the gastrolntestinal tract, and

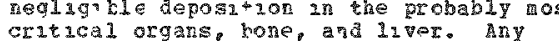
critlcal organs, hone, and liver. Any
concenvahie hazari from ingestion of this

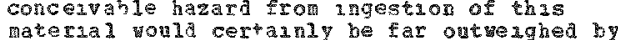
materlal wolld certalniy be far outwe ighed by

Tane 2 shows Fu 238 content of trssues of pag it days postangestion.

$\langle 216\rangle$

Sn1der, E. \$., Mot grven. 1988

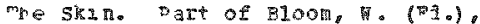
Histopathology of Irradiation from Frternal and Irternal Sources, Chater 4. hegrav Fill zook

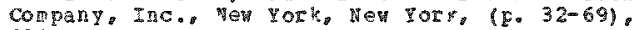
$808 \mathrm{~g}$.

Histopathological studies on the skin were made acter apolication of the followng made atter application of the folloning seta rays to mace $(2,500$ and 5.000 repl: zats Deca raps co mice 5.500 and 5,000 repl a rabbits $(2,500,0,000$, and 12,000 zep $100 \mathrm{an}$ apolued): (2) $x$ rays to rats $(600$ m), rabbats

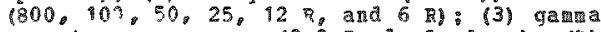

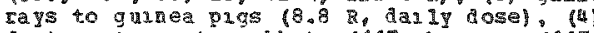
fast neutrons to rabist $1117 \mathrm{ni}$.

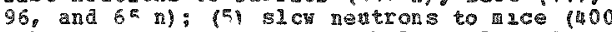
exbzexy units). Hastopatholog $2 \mathrm{cal}$ studas on the skin were wade after applicatmon of the following irradations from anteral sources: (9) alpha rays to rice fron antratuscular mjections of $0.1 \mathrm{uCm} / \mathrm{g}$ of plutong and to muce fron intraperatonea 1

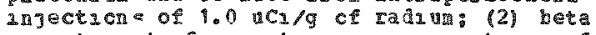
rays to rats frol Intravenous injection of 2.0 uci,g of yttrun 99 and to ratis frow
Intraperqtoneal injections of 0.6 and 0.25 uci/g of strontial 89 . Strukang changes not seen in any of the abcue preparaticns except in the ariagis treated wh extermal be a rays. Thas fact as aterpreted as beany due to the hagher dose used rather than to an action on the shin thich is specific axteral beta rays. 1 general, these $5 i x$

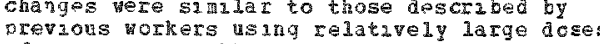

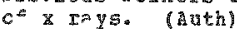

Several hastological sections are shewn.

\section{$\langle 217\rangle$}

Snzpes, H. F.o and H.L. Erooks, Lovelace Foundation for Medical Education and Research. In balation tox $20010 \mathrm{~g}$ Research instatute. Albucuerque, Nh. 1974, Decenber

Ap aralysis of Dosigetry and Cellular Rusk fer Flutomin Particles in the Iuig. LF-49. Part of Boecker, B.3. and Rupprecht, B.C. (BAs), Amual Repcrt of the Irhalation goxpology Research Repcrt of the Iralation axirology Reseatch Trsitute, october 1,1973
$1974,(\mathrm{P}, 29-36), 384 \mathrm{E}$

carrent standards ase absorbed radiaticn acse

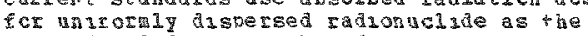

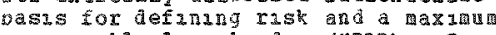
perassible lung burden (aPLB). Present atc are ansuffcaent to prove that a unform drspersion of plutomian in lung tissue is - cre or less hazardous thar a particulate form here discrete centers of alpa activity yaed higher radiat 10n doses to thes surroundings than would cccur for unztormily dispersed radionulides. Tussue adjacent to and urradzated by these partuches may Iepresent only a small fraction of the total lugg. The laplications of a higher dose and dcse sate to these small tassue robuth recessitates the deternation of the relative rass to lung tissue Ior this pattorn of radionuclice alstribution. The paper dascusses blologucal and chysuca factors dascusses blological and ghysucal factors tissue. Data are presented, along vith theoret cal exaples, whan suggest that

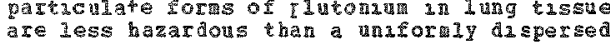
are less hazardous than anformiy d sparsed desinetry for particulate forms of plutonatur is cell tarnower tiae. Celis with short turonver tames are at greatest risk frol larger plutcila particles, whereas cells wth long tarnover times are t greatest risk fron snall plutoniu particies. Bnalys andicates that, asing 200 rads as a lethal dicse to inasidual cel1s, particles of $\mathrm{Pu} 238$ 2002 fow 0.1 un to 0.3 un represent the maximu size particles which deliver a sublethal dose to scoe prction of the dose
sphere around the particle during the tine sphere around the particle during the
geriod 10 to 36 days ater exposure. gerlod 10 to 36 days ater exposure.
cemparable numbers for Pu 239 Puor are 0.6 un ccmparable mubers for pu 239 pidor are to 2 una sespectively. gaxtzcles large enough to produce a raciation aose to surrounding cells greater than 200 rads durang the critscal time period yeld cell

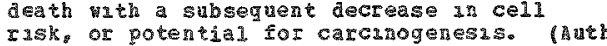

$\langle 218\rangle$

Spress, F。i. International Atome Energy hgency, qeña, Rustra. 1971

Brophyscal Basus for Raduation Hasatology.

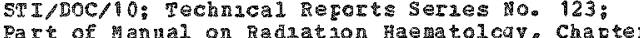
3. (F. $45-69$ ).

The siz parts of this techncel report Ieviev 
र218> COHT.

the following areas. physical characteristics of zonlzing radiations peharged partzeles. x-rays, g ama rays, neutrons, particle tracks): units of radzatzon dose (absorbed dose, radiatzon exposure, absorbed dose and LET. RBI) ; location of relevant helatological t1ssues: fhysical description of trabecular bove fistribution of active masrow, bone Bensuratron, a ney thod for specifying trabecular and garrow-cavity da gensions, path length distributions); determination of gea dose to active marror (sungle and altaple cavity calculations, experimental data of mean marrew dose and some results for 8-rays and teta partucles): al pha particle and meutron i rzadiation (volume and surface distrabuted 1sotopes, al gha particle dose from yolute and surface distribated asotopes, from yolume and surface distribated isotopes Pu 293 dosinatry in rabbit bone and bone

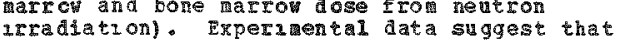
Pu 239 de cosits occur on all bone sur faces Pu 239 de posits occur on all bone surzaces w1th the greater concentration on endosteal
surfaces. plutonin was also found in the surfaces. Blutonium was also found in bone marrok itself a ppearang both as a dascrete small aggregates (stars). (RAF)

$\langle 219\rangle$

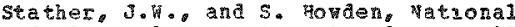
Rad 20 ogical protection Bcard, Harwell, England. 1975. January

The Iffect of Chemacal For on the clearance of Di 18 ton 1 an 239 from the pesorratory syste of the Rat. Fealth opysics, $28,29-39$.

This study has investigated the effect of chencal form on the tissue dustribution and excretion of plutoniun following 2 ts depostion in the respratory syster of the rat. Solutzons of various chamical forms of plutcrian (nitrate, citrate, oxalate loxide, CrPa complex) have been admistered to rats by intubation into the nasopharyngeal, tracheobronch 121 or puldonary reguons of the respuratory tract. The injection volure was less than 3 ul and the activity administered $(2-3$ nci/kg) was comparable to a fer maxima perassible body burdens of plutoniun in man. The absorptzon of both plutoniul nutrate and cutrate from the pulmonary region was appoximately four tures greater than the absoption from ezther thes greater than the asoprtion froa

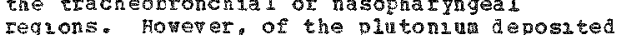
Iegions Howerer, of the plutonum deposite in any of the hree regions, the relative propcrtion that is tzanslocated to other as citrate than nitrate (approximately in the ratio of 1.6.11. The absorption of varzous chenscal forms of plutonum from the pulmenary region was in general areenent wh the conclisions of the ICPP Task Group on Iong Dynamies. shout $13 \%$ of activity entering the blood during the first peet arter a dinstration of pluton nim nitrate or cutrate $v a c$ retanted 28 the luver at 7 days lmplysig that plutonum was circulating in the blocd in a "monomerick form. The cumlatise excretion of plutonin in the uritue in the same period was equvalent to about $4 \%$ of the otal activity deposited in tissues fron the blood. whe experimental tissuls suggest that this value could be used cesults suggest that this val ne could be used urinary excretion mea sarements. (Auth)

$<220\rangle$

Stevens, W., D.R. Atherton, B.J. Stover, and

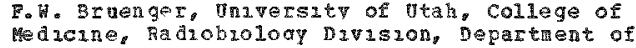

Bnatery. Salt Lake C2ty, 0x, 1973, July

Conparason of the Intraceliular Dustribution of Platcrum 239. Amerpciun 241 and califorain 249 in buyers After Intravenous Adinustration. Cont-730431; Part of Proceedings of the 21 ist Annua I Sypose un of the Radation Research

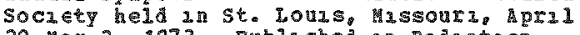
29-1ay 3, 9973. published di Radiation Research, $55(3), 513$.

The intracellular astribution in 11vers of beagies injected intravenously w th exther Pus+4) 239, An (+3) 241 or Cif(4) 249 in 0.08 if citrate, ph 3.5 as studied seraliy. I iver homogenates were fractionated by differentil centrifugaton. A ltochondral fraction vas obtained by centrifugation at Traction as obtalned by centrifugation a
$50,000 \mathrm{~g}$ an, a lysosola 1 fraction at $8 \mathrm{~g}$

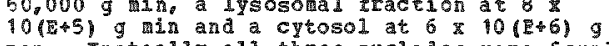

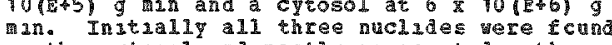
In the cytosol and mostly associated wth ferritin. Considerably higher concentraticns of arericaun asd calaforman chan platona remaned in the cytosol at progressively 1 cnger twes after adminstration. The ordes of the rate of removal of nuclide from the cytosol was Pu>CE $>$ An. as the nuclude was remoped from cytosol it becane associated 1th subcellulat organelles. No constant relatıonship was chserved between

cencentration of nuclude and mitochomaris or Iysosonal marker. The ratio of nuclide to lysosona marker was consastemely hager 2 a the mitochondrial fraction than in the Iysosotal fraction. However, signiflcant centamination of the mitochondrial fractios wth 1 ysosones has not been denonetrated uning electon wicroscopy. It is concluded using electron wicroscopy. It is conch from this study that astochondria and
iysosomes and possibly cther organelies are iysosives at pouclude banding in candue liver cells. (Awth) (complete article)

$\langle 221\rangle$

Stevens, W. añ D. I. Berliner, bnuerszty of Utah, College of Nedicine, Radiobiology Division, Department of Anatory, Salt Lake City, UT. 1964

Serut Transaminase Levels an Beagle Dogs Rurated with Platonqu 239. Radiation Pesearch, 23, 420-429.

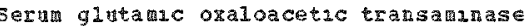
(sGoT) and serum glutame Fyruvic

transanase (SGPI) were casured $2 \mathrm{n}$ beagle transanase (SGPI) were gasured in beaglo

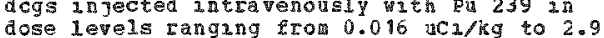
dose levels ranging fom between mes and females of the control between las and fendes of the control 9 rotp as detonstrated. There vas no
significant dufference between the sGoT Significant dufference betreen the SGOT
vilues of the rales and ferales. There 19 correlation between the injected dose of $\mathrm{kU}$ 239 and the per cent of SGCT and SGPT latancenents that are elevated. The dogs infected with the hignest doses of Pu 239 showed elevated transamase values over the perzod of the experiment. The increase in SGOT and SGPT 1. plutcna uburdened dogs is Eu 239 in the lavers of these anzals. (Auth)

<222>

Stevens, university of btah college of dedicine. Radiobiology Davision, Department of Anatcry. Salt take City, vit. 1967, March 3

In Vyo studies on the Interactrons of

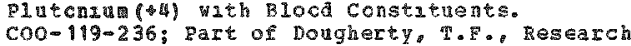


$\langle 222\rangle \operatorname{CONT}$.

In Racioblology, Annul Report of work $2 \pi$ PIOgress 15 the Internal Irradiation Prograa (p. $173-190)$. 268 po: Raduat lon Research. 33.

The distributzon of Pu(t4) in blood plasma of beagles ras determined as a function of time after Injection of $\mathrm{Pu}(+4)$. The animais were injected intravenously 2 th a mounts of pu ( 4 () ranging from 0.9 to 2.7 uCa of $\mathrm{Pu} 239 / \mathrm{kg}$ in 0.08 catrate, ph 3.5 . The plasma was subjected to gelfiltraticn on G-100, G-200 columins. Significant amcunts of pu(+4) yeI found in the region of 1 ow molecular weight protezns as well as in the rolecular we1ght range of srall molecules and lons. The amount of $p_{u}(44)$ bound to groteng ancreased during the first few hours after injection and reached a maxzmu at about 7 bours, From that time on 1 te decreased steadi1y. ConcomintantIv the Pu (\$4) fou ad in the region of low molecular weight conpounds decreased contunucusly from 5 minutes to 30 days. The decrease in the amount of pu $\{$ ( 4$\}$ in the reglen of Iow lolecular weight compounds occurred mere rapidly than did the decrease occurred more rabidy than ald the decte weight fretens. phe prctens that bound wo1ght Frcteins. phe prctezns that bound album. These proton- 1 - Fu( $(4)$ complexes were separated by ion-exchange chr cmatojraphy. Theis 1 dentity was contziriea by

electrophcresis as vell as Fe 1 abeling. The amount of $\mathrm{Pu}(+4)$ bound by transferrin greatiy exceded the a mount bound by al bumn. (Auth)

$\langle 223\rangle$

Stevens, W. C.J. Wabors, J5., a B D.L. medicane, Ratioblology Division, Department of Ana tomv. Salt Iake C2tv, UT. 1966, March 31

A Comparision of Serum Transamase levels and other Serin Constztuterts in Dogs Burdened with plutonam $23^{\circ}$, Troran 228 , Dadim 228 , and Radum 226. Con-110-234, Part of Dougherty

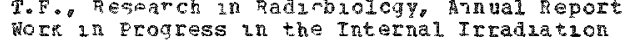
Wort in Erogress his the rnte

Eeagle dogs, 15-16 months old were irgected intravenouslv with different dose levels of the radionuclides ou 239, th 228, pa 228 and Ra 225, in a solution of cutric acid-sodium citrate buffer $D H 3.5$. The injection of these bcne seek ing radionuclides oroduced as the rajor hlologacal end pcint osteogenac
sarcomas. mhe incidence of hese turors increased as the injected dose of radionucl i les was ipcreased. Tn Th 2281.0 level doso, $100 \%$ of the dogs had osteogarcomas. In tall radionuc 11 de-1ngected grougs tho ncreased incidence of osteogenic sarcchas was accompaniea bo 1 ncreases in the nurber of serum alkaline whos ohotase

measurements thet wer elevated. Fu injected dogs had too greatest increase in elevated alkaline fhosphatase mea sureronts followed by alkaline phosphatase mea sureronts followed These data ndicate that in the case of the These dat ndicate that in the case
four radicnaclidee studied one of the four radicnuclide studied one ot the biood chenlstry values 1 s the distrubution of blood cheristry vallps 1 s the distribution the muclide in the andmal Th streletal
deposition fer Th 228 is about $80 \%$ of the retaned dose; and for $\mathrm{Pu} 239$ it is about $70 \%$ of the retarna dose. The remanng amount are depositod in the soft tascues. In soft tistues thoran 15 gore generally distributed than glutcring wh ich is manly in the liver. These two nucl-fes had the greatest effect on

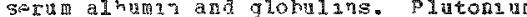

produced significant elevations in serum

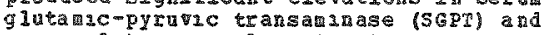

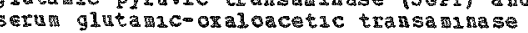

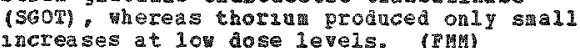

This article is ldentzcal to the journal article. Appearing an annals of the New York Acade⿴囗十 of Scuences, $145(1), 817-829,1967$, w 1 th the exception of Table 2 which duffers in 1 ts val ues.

\section{$\langle 224\rangle$}

Stevens, W.. C.J. Habors, and D.I. Berliner, university of jtan, college of meacune, Padioblology Division, Department of matcoly.

Relationsh F Between Seruin Alkaline Phosphatase and osteosarcoma in $\mathrm{P} 1$ uten 1 m 239 Burdened Dogs. CON $\$-660212$, Part of $P$ roceedings of the $14 \mathrm{th}$ annual Symposi un of the Radiation Research society held in corchado, Californa, February Society hela in Corchado, California, February $13-1 \varepsilon_{8}$
27.549.

The relationsnap between serum alkaline chosphatase ana tone dasease was farst descrabed in 1923. It was snown that serult alkaline phosphatase increases in bone diseases such as osteogenic sarccta. Serum akaline phosphatase vas geasured in a group of purebred beagle dogs 3 inected wth doses of plutonum 239 ranging from 0.016 uC 1 vu $239 / \mathrm{kg}$ to 3.0 uCl Pu $239 / \mathrm{kg}$. Alkalne g cosphatase was neasured ucing standard colortetric procedures and expressed in Bcdansky unats. The contrel groug consist of neninjected dogs raised and mantaned in eirr cclony under the sane ccridtions as the dcgs ingected with plutoring. The pear and standard deviation for the rormal female was 4.46 plus or mans $2 . E_{2}$ undts/100 ml and fer the norma males 4.56 plus or minus 2.52 units/100 ml. Values that exceeded the $90 \%$ confidence limis were considered levated. Definituve diagnasis of osteosacconas was Definitave daagucsis of osteosatccis was as wil as radiograpla diagrosis hi living as well as radiograpric diagrosis li l elevated pre-teranal alkaline phosphatase eletated pre-teranal alkaline phosphatase vas found anty-siz per cert of the dogs vas found. Elghty-\$1x pex cert of the dogs
originaliy injected with flutonia in this

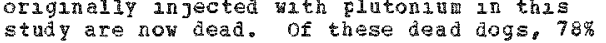
had osteosarcomas and 88 of these showea levated alkaline phosphatase levels. alkaline prosphatase levels uere also ineasured in control anzals boaring no raaloactivity. In this gromb, 19 of the anduls shomed elevated alkalne chosphatase $1 \in$ vels. These findings suggest that this measurement along unth other data can be used to ald in earil recogniticn of osteosa rccias before thay become clinicalit observable. (Auth)

$\langle 225\rangle$

Stevens, M. . C.J. Nabors, and D. I. Berluner

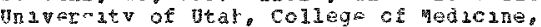
Radicbuologv Divisiong Department of hnatony, salt bake City. UT. 1967 , October 18

A Comparison of Serua Transamane Levels and Other Serun Constutuests in Dogs puraened wh Plutcring 239. Thoriun 228 , Badur 228 and Radur 226. Annals of the Neu York Acadery of sciences. $145(1), 817-829$.

Ycung beaqle dogs were given a single Intratenous $x$ joction of Iu 239 Tn $22 \%$, at dufferent dose levels. olood saples 
$\langle 225\rangle 60 \% \pi$

taken after 1,2 atr 6 months and at yearly untarvals follow nig in jection. The injection of these bone-seekrig radronuclides produced as the ma for bological end point osteogenze sarcomas. The incileace of the tumors increased as the dose of radionuclide increased. The ancreased incidence of osteogen'c sarcomas was accompanied by elevated serum al kaline phosphatage levels. plutcrum injectod dogs had the greatest increase in cerdin alkaling phosphatase measuremerts followed by $T h$ 229, Pa 228, and

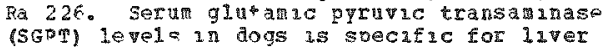
lanage and necrosis. Sagmefacant increases in $S G \mathrm{E}$ neasuremerts were noted in $\mathrm{Ru}$ anials. Flevation of $\$ G \mathrm{PT}^{\mathrm{s}}$ was also produced

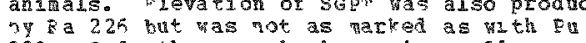

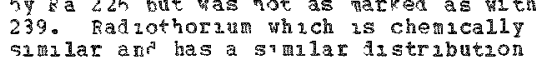
watterr did not prozuce the same effect on

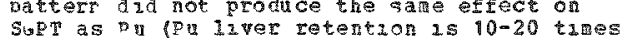
SuPT as bi (Fu 11 ver retention 1 s $10-20$ times
higner than the retention). Pa 228 had very higher than the retention). Pa 228 had very little fect on SGPT at ant dose level. The
effects of the 4 radionuclides on abbuan and globulin in serum rero thought to be related to theix diatrifution in the arimal. Radiug 226 and $\mathrm{P}$ a 228 why $2 \mathrm{C}^{4}$ deposit a 1 wost exclusively in the skeleton had little effect on serum rroteins. plutensun and Thich deposit r soft tissues, primarily liver. spleen, and kinov for Th, anl 12ver for $\mathrm{Ru}$. produced marked hyboalbu minernza and hyperglabulunema. Ho signufucant changes were observed in total prodens for any of the nuclide hurdened groups of anamals. Results ind cate that cne of the deterinning factors in changes of blood chen istry values factors an changes of biod chemistry values
as the dactrubution of nuclade in the anzal. (RAF)

Tabies are given of alkalune thophatase weasure ments elevated and ancr dence of osteosarcoma. The SGPT and Srop measurements elevated in Fis 239, Th 228, ia 226 and $\mathrm{R}$ a 228 burdened acge and changes in album 1 inglobulin
ratios are shown in graphic form. This article 19. Id ntical to the recort, coo-119-234, ip. at-119). 19R6. with the exception of rable? wh 2 ch differs 25 its values.

$\langle 226\rangle$

Stevers, 月.. F.J. Stover, F. H. Bruenger, and

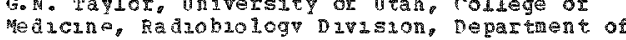
Anatomy, salt Lake Cxy, UT, 1969

Some observations of the Deposition of Marecing 241 in the Throra gland of the Boagle. Tadiation Resmech, 39, $201-205$

me astribution of $A$ a 24 in the thytond glards of three dogs after intravenous Injection was studied. Dog , weighng 10.7 sg. recerved 2.78 ucs of $\mathrm{Am} 241 / \mathrm{kg}$ and vas

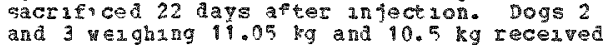
$4.45 \mathrm{uCl}$ of $\mathrm{Am} 24 \mathrm{Mkg}$ and were sacruficed at 7 and 8 ays after injection. respectively. The thyrodd glands vere zemoved, Erozen Ix medately in liquid 2 , and counted. Iater the thy rold thssue was homogem zed and separated uto fractions by arferential centrafugaticn. Eight-five to nimety per cent of the 241 was Fonnd 24 th the crude Fibrous residue. conbining this rubrous material yith cell mucles and membranes accounted for nore shan $90 \%$ of eabranes account an the total smal quantities were found 1 ith aicrosones. salid quantities were found with aic mitociondrate and in the $105,000 \mathrm{~s}$ g $241 \mathrm{~s}$ selectipely bound by the connectupe tissa elements of the thyroid. The concentratuon cf Al 24 ? 1 a thyroud connective tissue was tound to be 337 traes that of a sample of subcutaneoss loose connective tassue and tures that of connectiv
the inver. (Buth) (FMM)

Table 2 shows the average concentration of Al 241 in zelected organs (12yer, bone thyroid) ce 3 beagle dogs. Table 5 shows concentrations of Ar 249 In connective tissue resudues derived FEom organ homogentes (laver, splean, kldney, +hyrord and adrenat).

<227>

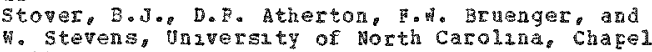

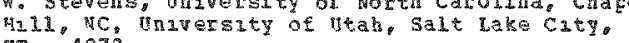
ก. 1972

Congarison of skeletal and hepatic Dose Rates Erom Plitonilu 239 in the Beagle is a Function of Dose level. Radiation Research, 51, 541.

The total skeletal retentucn was aeasured 1 g severa 1 dogs that were injected intravenous 1 y with 0.005 ues $239 \mathrm{pa}(44) / \mathrm{kg}$ in 0.08 N

citrate buffer, $p$ H 3.2 . The beagles vere yourg adults at the time of injection, and they were sacrificed suffuciently long after injection that the rate of renodelling of bone surfaces, a prceess yicn rewoves pu 239 devosited on bone surfaces, had decreased s gnificanty. The se results are conbraed vith previous data cn early deposition and zetertion in the skejetor, and oarly and long erin data on retention in the humerus and thard lumar vertobra. to obtan set of skeletal retentica equation applicabie to seven dose levels. Jsang these gutacis and sillar ones calculated previousiy for sinilar ones calculated previousiy for hepatic retention, the cululative rad doses furction of dose level. (ath)

$\langle 228\rangle$

Stover, B.J., D.F. Atherton, F.W. Bruenger, and C. I. Taylor, Dniversity of btah, college cr

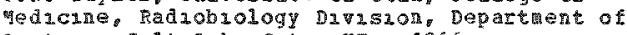
Aratong, Salt Lake CIty, 0T. 1966

Din chula 239 an fover, spleen, and Rudnegs ces

the Beagle. padzatzon Rescarch, $27,548-549$.

Followag a single intravenous anjection of 0.30 mCI Pil $239 / 9$ in beagle aogs both amount and concentration of pu 239 in liver stoes. and kndmeys vere found to decrease wht the tron 40 to 1950 davs. The rates of decreas elther descending expoaentals or stralght elther descending exporentals or stralgh Whes can be fit for thas tal interval, hen conpared rith the ftted Ines, Fesults

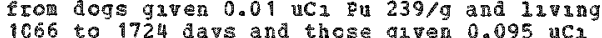

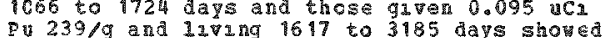
Pu $239 / 9$ and living 1617 to 3185 days sho a dose leval efect on retention an the 1.ver. There as no readily apparent dose kaneys. Possible relationsha cf gross ant macroscopic changes in the luver and the observed dose level effect w11 be discusged. (AvTh) (Conplete Text)

<229>

Stover, B.J., and D. E. Atherton, 1974

Kanetics of the Skeletal Retentron of Plutonian $239(44)$. Radation Research, $60,525-535$.

A knetrc analyss of the cbserved skeletal retention of $\mathrm{Pu} 239(+4)$ in the beagle is 
DOL GTCAL ASFRCTE ANIPAIS

$\langle 229\rangle \cos 2$

prasented. Since skeletal retontion 13 directiy $r \in$ lated to bone-renodeling processes, the ar a'ysis applies only to beagles that are injected in young ad ul thood at dose levels less than 0.095 uci Du $239(+4) / \mathrm{kg}$. At thase dose leve 1 the effect of irrad ation on bore remodelling and nence, sholetal retortion, is less than the variatzor between anzals. The innetzcs are derived rom these macro and mato shservaticns: (1) The initial deposition and the rate of decrease in retent 2 on are both higaer in bones that have a re? atuvely greater a mount of trabecular bone. One ulna. which has A relatively greater a meunt of cortical bore, was analyzea from each of 40 beagles at dose levels fron 0.00064 to 0.095 neyplog ar a at tuges from 35 to 4549 days after 1 is oction. Rotention of $\mathrm{Pu} 239(+4)$ in arter 1 injection. y5. "hich is in contrast with the retention in the humerus and in the thi re lumbar vertebra. In these bones retentzon decreased durlng the first several years and then approachea approximately constant values. A1so, comparison of the $2 n 1+3$ al concentratzons shews that that of the ulna was cnly about $25 \%$ hat of the other tro bones. (2) h.S.S. Jee has ghowr that 2 $239(+d)$ defosits initially on osseous surfaces. fren through ostooblastic actrvity surface deposits are buried and Ru 239 appears a ffusely in new bore. Through osteociastic $z c t-74$ surface deposits are resorbe and $F_{1}$ ? 30 apuears in osteoclasts. Later pu 239 appors in macrophages, whach in Later Pu 239 appors in macrophages, what macro and noroevents are consistent 10 time. macro and ncroevents are consistent in time. to the ldentifucat 1 or of a more meaningru to the ldentifucator of a more meaningal a cass for estater and also could provide oasis for estanating bors renod 11
in the poung adult beagle. (Auth)

Ti e retention of $>23917$ the ulra, humerus, and thla lubbar vertobre at 35 days-12.5 years after injection is given in tabular and graphic Eorm.

$\langle 230\rangle$

Stover, B.J., D.R. Atherton, F.W. Bruenger, and D.S. Bister, Unztersity of [tah, College of

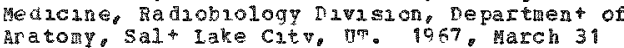

P2 utom2u 239 an ver, Splecr, and padneys of the Beagle. $\cos -119-236$ : Dart of Dougherty. T. F. Regearch in Rad ablozcgy, Annual Repote of

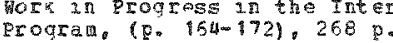

The ingtial deposztion of pu 229 in the liver cf dogs 12 independant of injected dose over the range 0.09 to 2.8 uci/kg. The long ter bepatic retertion depend $s$ on the unjected ose as well as +1 me. The rate of decrease of hepatic retention is proportional to the early radiation dose rate to tre jiver Sliliar pffect was not otserved 3 ñ renal and Eplonic Leterntor of Pu 239 . The radiation

less than that to the 12ver. (A uth) Table shows apdarent half-periods (1n days)
for pu 239 an beagle tissues 10.30 ucs pu $239 / \mathrm{kg}$ for Pu 239 an beagle tissues 10.30 ucs pu $239 / 1$ injected. Fquations vere calculated fiom the to since infection.

$\langle 23$ १ $>$

Stover, B.3., 萡. Bruenger, atherton, and $G$, Thylor, inatersity of utah.
College of medicine, Fadrobiology Davision Department of anatony. Salt Lake cuty, Or. 1974

The Ertect of the Plysical-chearcal state of Plutcnala on Its rarjy Retention in plasma and Selected soft missues of beagles. Padiatzon Research. 5 ?, 539 .

The early retention of $F$ u $239(+4)$ in plasia, $k$ idney spleen and other selected sot. +3 ssues was studad ar beagles after infection of the strictiy nonomeric Du-transferrus complex (Du-pe), nen polymeric pu(t) in eatrate buffer of $D y-5(E n-4)$, and largely polyaric $\mathrm{Pu}(+4)$ in citrate bufer of pr 6 (Pa-P). plasma concentraticns of clutonal were calculated as semi-log

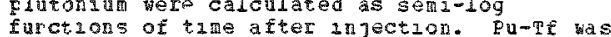
furctions of time after injection. Pu-Tf was
removed from the circulation at a rate slomer than Pu-f, whereas, pu-E lnitialiy lest the than pus whereas, very rapid rate. At je. after injection equivient to $87 \%$, $4 \%$ and $<2 \%$ of the three forms of wlutonian wer circulating, plasma, $100 \%$ of pu-Tf and a large fraction or Pu-M was procein cound. No protean binding of $\mathrm{Fu}-\mathrm{P}$ was seen. At two veeks after injection, concentrations of plutorian an mest soft tassues were quate sianlar for pu-Tf and pu-M. Fidne retention was decreased by a factor of 10 . whereas spieen retention was increased by a factor of $>20$ an the $E u-P$ lrjected andal. The concentration of $Q_{u}-P$ in the spleen was 1.0 times groater than the concentration ir the inver. Following afferental certrifugation of tissue homogenates from pu-p injected arimals the percentage of plutonum in the a rimals the percentage of plutonum in scluble fraction is greatiq reduced in cFleen, but not in similar fract 3 ons of kadney when compared to Pu-Tf and injocted dogs. lost of the ruclude in tho kaney as bound to the fraction pach lin
matochondra. In the case of pu-p. a large concentration of platomua also was rourd in the nuclear fraction of sfieen homogentes. The concentration of platonum in thyrold. abrena 1, pitutary, aura mater, loose cernectipe tissue and other soft tissues w11 be compared. Autoradiographs of selected sort issues will be shoun. (Auth) (Complete Atracle

$<232\rangle$ Stover, B.J., w. Stevens, and $F$. h. Bruenger,
unz versty of Worth Carolina, Department of pharmacology, Chapel HII, pic, oniversity of Bhardacology, Chapel HIII, hC, Unversity Divison, Departient of Anatory, Salt Lake city, DI 1 I 1972

Chemacal Associations of plutonatid 239 (4) and

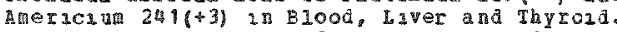
part of Stover. B.J. and Jee, W.S.S. (10as.) padrchology of plutchind. J.h. Press. Salt Lake catg, Utah, (p. 129-140).552 p.

Elutonum, as pu $239(4)$ in 0.08 citrate buffer of pH 3.5 , was gaven by 3 intravenous injection to young adult beagles. Fcllowa injection the concentration of plutona 1 rlood decreased slowly, since a large but variable fraction of the plutonila forma a complez with transferran, the $15 c h$ transport Frotedn. The ou(tu)-transterrin complez was suffucientiy stable to be separated from other serum constituents. The fermation of Fu(t) - transferrin was blocked by $\mathrm{I} \in(+3)$ ano Fu $(+4)$ vas dasplaced from the complez ty Te $(+3)$. The Pu $(+4)-t$ ransferrin assocsation was reversed by catrate at $\mathrm{pH} 7.5$. Sone plutonus deposits 1 n rost tissues, but the Frifcipal sates of depostizon are in the skeleton and the Iryet. Hepatic retention of Elutoni decreased siony lith tile at all 
BIOLOGICAL ASERCTS AMIMALS

<232> CONT.

dose levels, but the rate of dectease was greater at higher levels where there is marked asstruction of hepatic cells. At the subcellular level in the liver, significant

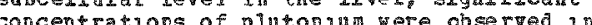
nuclear, atochondr al, and acrosomal fractions, in the cycosol, and also la
connective tisine. In the cytosol most of connective tissue. In the cytosol most of ferritin, the iroy storage protein. Jt was fertstin, the iron storage peotedne It was with an undentified waterial of molecular with an undentified waterial or wolecula plagh of about 1500 . The assoelation of The probable aechanvon by whach Pu $(\$ 4)$-ferritin 15 elininated from the luver is through death of the heptre cell followed oy ohagocytosis hy pe cells and subseguent localization in the portal regions. In

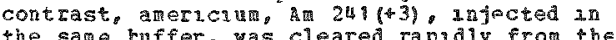
the sare vuffer, was cleared rapidy from th blood uth both transfercin and loum an ber they are less stabla under physiological conditicne than the complezes of plutonum. che skeleton and liver are also the principal deposition sites for ane ruciso the principa deposition sites for ane ricing and the rate w th ancreasing lose level beca use of Wh lncreasing lose level because
destruction of cells. Significant destruct on of cells. Significant concentrat ons of amerscuumere foum in th several 5 ubcellular frac ions of the laver. in camparisor with ol atoniu relatively mere anerlon un was found in the hepalic cytosol. in association wath ferr $3 t_{2} n_{p}$ in pofuscin, and a material of low molecular welght. The relative amount of americau found in the low rolecular weight fraction was greater than in the case of vilutonum. Sagnificant

concertratrors of anericiun were found in the connective tissup of the thyroid. (Auth)

Table 9 gues relative concentrations of 24 and $P_{4} 239$ liver frartions che week after 1. jection.

《233》

Stover, B.u.. apd C.N. Stover, Ir., Unuersity of North Carolina, Fepartment of pharmacology Chadel Hill, ve; ynuversaty of vtah, college of medicine, Radiohiologw Divis'on, pepartment of Anatomy. Salt lake $\mathrm{C}+\mathrm{y}, \mathrm{W}, 1972$

The isabratory for Padroblology at the ur aversaty of vth. part of stover. B.J. and

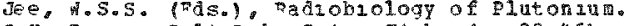
J. H. Press, Salt Iake cuty, gtah, $(0,29-46)$ 。 $552 \%$.

The toxicoloducal effects of Pu were investigated early in chicago and investigated early in chicago and osteosarcenas and group skeletal da informaticn on pu accurulated it becare informaticn on Pu accunulated, it becane raducnucl de was affected by chemcal form. danistration coute, ann and age at exposure. The developenent of Urah 29 described (HP)

\section{《2क्षे}

Stover, C. v., Jr., 19 verssty of Utah, College of mediclie Padiob ology 017zson, Salt Lake C.

Anual Frogress Deport, fareh $31,1959$. कo-218:22s

provress 15 renorta on the studies in dogs ri gected or Pu $23^{\circ}$. Cevre papers have been abstracted separatel罗 for anchusion in the data base. These include studzes on hastopathologic bcne changes in bones contanng pu, determanaton of $\mathrm{Pu} 239$ content of bone tissue, radution induced osteogense sarcola in dogs and the buchemistry report. (Fin

strelitsova, V.M. and Yu. I. Moskalev, Hot

given. 1957

Fanoactive Isotoges as Cancerogen 16 Agents. heditsinskaya Badiologiva, $2(5), 39-51$. [Russian

Tumors of various tissues appear in angals which are affected by radioactrve substances, such as osteosarcoma, adenora and cancer of the memary gland, leukenta, adenoma of hypophys 1 of suprarenal giands, of thyous and thyrond glands, sarcoma of lympn nodes. of subcutaneons tissue, of the ovaries. adenon and carcer of the liver, cancers of the lung, of the ovaries, the stcuach, the small and Iarge intestines or of the skan. Isotopes ming lntestint on skeleton wally case osteosarcomas, those in the skeleton and in the in the skeleton and an the iver--osteosarcomas, tumor of the liver or of the endocrine glanas. Isotopes hich are distributed eveniy all over the body cause various tumors of the sort tissises. The incidence of osteosarconas depents on the quantity of the radioactive substance whab was introduced and on the efrectuve period of the actual fisslon of the isotope. The nigher the actirity and the effective perica of the "actual" E2ss2on-othe more the percentage of development of the tumors. The oftinal osteosarcomagenic dose of absorbed energy for 1 rradiators equals to $10-20 \mathrm{kres}$ the Thumal dose being 2-3 krep. When dealing w 1 h isotopes which are racialy ara completely resorbed from a depot, the completely resorbed from depot, the nct depend on the method of thest ict depend on the lathod of the 1 in case of isotopes wach are coorly resorbed the tum reaction not only aepends but frequenty $1 \mathrm{~s}$ deterinind by the thethad of 1 troducticn cf actermined by the thethad of 1 troducticn of the isotope. Distribution of the lsotope has so gualitative effect on the aprearance the turors of the ranary glands and on leukemas. The lncidence of leukemas, from tc 10 percent. (Translator)

Tables are gaven of overall characterastac distribution of radionuclides $2 \mathrm{~B}$ skeleton 13ver, tuscle, k1dneys, spleen, 1y mh nodes ard bone marrow.

$<236$

Suliqvan, P.F.. and V,F. Smzth, Battelle Meporlal Institute pacific Morthest Laboratories, Fiofiand, WA. 1974, ugust

Renoval of Intramusculariv tagectas Dlutonat 238-liztrate from the pat by Cort-nuous InEusacn of Chelating agents. Pald-1850 (Part 1), $\vec{E}$ art of Thompson, R.C., et al, Arqual FegCEt for $1973,(\mathrm{P}, 112-114), 162 \mathrm{p}$

Chelating agents, Ca ELTA $\mathrm{Ca}$ DTDA and zn CTO were adminzstered by continnous anfuszon te rats injected intranusularly wath Pu 238 (mo3) 4. The approprate amount of chelatang agent $2 \pi 7.4$ mil of $\mathrm{FE} 7.2$ solutan was deluvered over every 24 hr. period by nifusion pups, via catheters inclanted in the peritoneal cavity or nder the sisin 2 nd the nuchal region of the rats. It was shown that continuous infusion of EDTA OF DTP thated lithous anfusion of EDT or DIPA 
ETOLOGICAL ASPECTS $\triangle$ AUT

<236〉co

rap1 dy a dmis 1 stered, single, dally

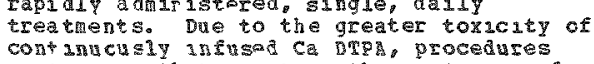
sustaning that agent in the systen overly long sheula be considered potentially nazardous. (Auth) (Fu)

$\langle 237\rangle$

SuI 3 va, H. F., and R.C. Thompson, General Electric conpang, hanford I azoratories, B10logy operaticn, 1 chland,

Absence of Lethal Radiation Effects Folloring Massive กral admingtration of Plutonul Nature, $180(4597), 541-652$.

Plutonu 239 yas administered to seventy-five rats, by stomach tube, as a hydrated polyner suspended ir a mitrate solution at $\mathrm{EH} 2$. Frow the results it was less than 88 mC1/lg, and that all mortalit2es resulting from plutonu ingesticn occurrea wh 2 in $24 \mathrm{hr}$. Rats surviving the plutonum weedings vere ooserved for at least sis feedings vere ooserved for at least sis
months. Elood counts and body weagt changes months. Elood counts and body weagt chang control andmals. The or al plutonam dose of

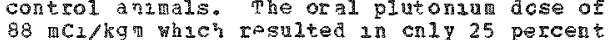

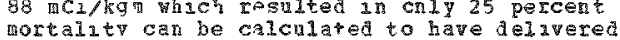
cortality can be calculatec to have del avered intestine a tadition dose of approxiately 550.000 rell. Since this very large dose resulted it nore of the sygtoms characteristic of the intestinal radiation byadrome, it may he conclujed that alpha-rad lation origlnating vithin the contents of the untestane is largely Ineffectrve 17 causing acute damage to the intestunal val1. Tt would appear that for all pract lcal purposes of haz ard evaluation. alpha-enutting rad 102 sotopes contamed mathin tni gastrontestini tract mav be ignored $1 \mathrm{n}$ calculati no rays an pernassible concentrations. In contrat to the results

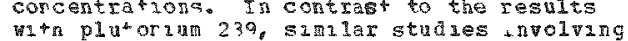
with plat or lun 239 , simlax stadies 1

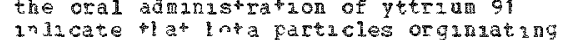

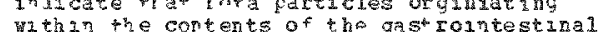
tract are approxs nateiv as ef fective as tract are approxinateiv as effective as

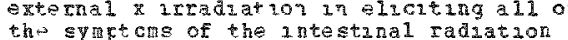
the eycting of
synd cone. (m)

$\langle 23.8\rangle$

Szot, Z.Z.. and D. M. Tavior, institute of Cancer Desearch Foyal Cancer Hospltal, Departinent of Physes, Londor, Fingland 1962

The wifect of reatrent wh

Diechylenetruannepentaacet $1 \mathrm{C}$ Best on the

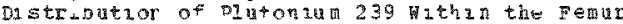
of the rat. Fadiatzon tesearch $10(4), 583$.

the anstrabution of intravenously

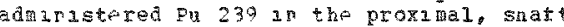
and distal reagons of the form ir has heer tadied in voung groming rats treatel yath

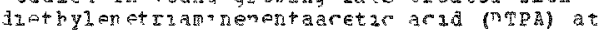
variois times aftor the administration of plutcrun. In untroated andnals the haghes concentrations of pu 239 are found 3.7 the distal (ofphropal) region of the bone. ana tre low regicr. Intraperatoneal injections of UTPA.

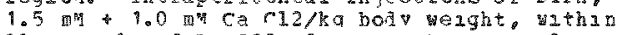

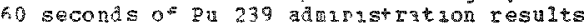
in a farly uniform reduction of the amount of Du 233 retaineo 18 the hree regions of the bone at 2 favs. When the treatment is

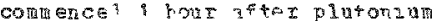

adanustratzon thoge as a greatex renoval of 2u 239 from the distal regan than from the other cro areas. I \$ \$lalar, but less pronounced, effect is seen when treatment is started 7 days after pu 239 anjectiong but 14 the start of treatrent is delayed until 17 days this effect $2 s$ not seen. The possible brologlcal \$ignd ficance of these cbservations
will be di scussed. (Auth) (Complete Article)

$\langle 239\rangle$

Takebe. H., ogaka unqversity, Osaka, Japan. 1972, February

Fffects of dow Dose of Radiation on the laving Body. Kagaku, 42(2), 79-8E. (Japanese)

A review is presented of the effects of 10 dcse arradiation. Topacs discussed are: the concent of pertassikle jose: effects of 5 te $2^{2}$ a doses on wutation 1 aluction 1 n Erosophla and other studies on hereditary effects: experiments on silkworns and buce to deternine releationships betueen ase rates and nutation: delayed effects of radiation on atomic bonb survivors in Hisoshia and

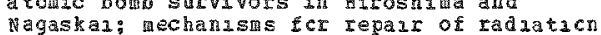
armage ip Lelation to genetics; and afplication of the target theory in studies Gr herealtary effects of environental cributants. (HI,
peilu)

$\langle 240\rangle$ Tarasenko, W.Hu., and H. A. Khodyreva, not given.
968

Fifects of Detargents on Skin and on the Absorption of Radicactive Substances. Hygene and Sanatat $30 \pi, 33,129-132$.

ohe regular daliy treatident of the skin of rabbits (wesghing $2.5-3 \mathrm{~kg}$ ) for 30 days 1 th the aost eiracient detergents pastes vos. 11 . 11 b solution op-7 with pC, soap no. 3 , freparation "2ashchita-7" and 72 nomseholo soapl did not produce any marked irritan or alergic effects. A solution of Pul $(+4)$ allergic efrects. A solution of Pu $(\phi 4)$ n1trate (0.4) was applied to a 25 cm 2 , ucs/ch 2 prot to the application of lsotope. ucich 2 pror to the applacation of 150 ofe. the skin area nad been processed for 30 days

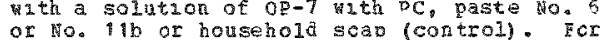
or Ho. 1 b or household scab (control) . Fcr plutoniug donia was abplued to a shor area of $5 k$ in in the forn of an aqueous suspensicn wh kaolin so as to provide a dose of $0.5 \mathrm{mg}$ of the fure elenent/anial. It was seen plutonau salt occurzed in all cases. vhereas the ancoluble olutoram comongat was at atsorbed. The percutaneous absorption of platonua nitrate was no higher after the use
cf specual deterger th than arter the use of household scap. The oxperimental results how

(ancluding pastes Nos. $11(\mathrm{v}) \mathrm{a}^{\mathrm{n}} \mathrm{f}$. Soluticn

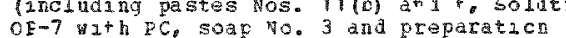
"Zashchita-7") for the regular cleansing os the skin from radioactive contanration.

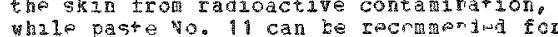
final (adaltonal) washrgs. (Auth) (r)y)

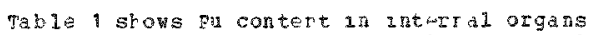
1 1 ver, spleen, kidney, heart, 1 angs, duscies bones) of rabbits. Table 2 shows affects of detergents or the aborption of pu by rabits.

$\langle 241\rangle$

Tayicr, G.W.H. H. Chr'stensen, L. Shabestari. an 1 .S.S. Jee, 0naversity ot ptah. College of

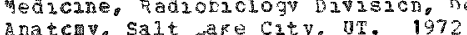


BTC TOGTCAR aserCTS AMINAIS

<24 cont.

The General synarome Induced hy olutonan 203 in the Beagle. part of stover. 3.J. ard jee.

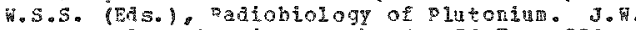
Press, salt lake city, vtah, (po $59-74), 552 \mathrm{p}$

The most cricical factors in the toxicity synarose induced in acos by a single Ir injection of tetratenter 239 vere the inducticn of bone cancer, hematocoiet ic changes, ard liver lemions. Some of the jess serion

serious act polits were pathologocial of

Enactures. dental changes, and atrophy of the carbinates. These later conditions produc
functional japaingent in only part of the dogs and principalig at the higher dose levels. In the sot tissues, poderat thyrcid atrophy and very focal kidney degeneration vero induced hy the 2.9 uci pu $239 / \mathrm{kg}$ dose but neither of the se changes vere detectable clinicaliv. Rin increased incidence of soft tistie neoplasia was also noted in the itradiated groups, but this was rot une givinocally established as a pu $239-i n d u c e d$ factor. (auth)

Table i gives incidence of pathological fractures following a single IV infection of 2 239. Table 2 gives average time (months) of tooth loss in Fu 230 treated dogs. Table 3 yives the average teight of thyroid tigsue control dogs and ags invectet with $\mathrm{Pu} 23{ }^{\circ}$.

\section{<द $2>$}

Teylor, G.M.. W.R. Christensen, 苚S.S. Jee, C.E. Fehfeld, and college os wedcine, adiobloleg yivision. Departan of Anatom, salt lake city, JT. 1962. $\operatorname{arch} 31$

Aratomical Distribution of Radation-Inducea Fractures in Beagles. coo-225: Part of nougherty. T.F. Research in Radiobiology. Annal Report of hork in Progress on the chronic Toricity prograt, (p. 31-42), $136 \mathrm{p}$.

The antomical distribution of bone fractures in beagles resultant to retained buraens of Ta 226. Pa 228, or Pu 239 indicated trabs that were unique for the respective

radionulides. Three different dose hevels uere considered for each of the

rationulides. The tracture tabulations were obtained ror radiograph taken at post morten of the defleshed skeleton. host of morten of the derleshed sicle con. wost of the animals died or vere sacrificed because
of bone tumors. plutonim 239 induced the

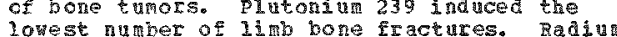
lavest nuber of inb bone riactures. Radiu the widest andomical aidribution. The Ra the videst anderical a i tributiono The Ra 226 cases more nearly resenbled those of Ra 228 , but the total wubor and distibution of
Eractures was lower. Involperents of the rib cage suggested patterns that vero specific for the given radiondides. (Auth) (Fin)

Figure 1 shows percentage sicilence of fractures in beagles receiving a single intravenous infection of par 225 , pa 228 or pu 239.

〈243>

Taylor, G. H. T. T. Dolghertyo and H.R. Cristensen, university of vtah, college of medicine, Heaical Center pepartment of Anaton. Sat lake city. 0\%. 1979

Some Toxiclty Aspects of Interral1y Daposited plutenin 239. part of Berd1is, C.C. (EA.). Fathology of Irrajiation. Chapher and $(10-119) .710 \mathrm{p}$.

Plutoniun 239 was andinstered in the tetravalent form at pl 3.5. via a single intravenous infection to beagle dogs aptroximately if to 17 months of age. The results showed that most of the retained radionuclide burden was ultimately localized in the skeleton (aptroximately $60 \%$ and the 1.ver (approximately $30 \%$ ). Wuch less significant deposition gitas thyroid, the kaney and the splen. The rest significant azrects of the toxicity synarone are sumarized. The earliest climically detectable radioinduced change was a drop in the leukocytes of the peripheral blood the loukocytes of the peripheral blood highest level died with primary pu-induced liver disease beginning at approximately 400 days post-injection. A poderate nateer of prinary liver tumors cccurred in the lcrg-tert low level andmals. At the three highest dose levels of $2.8,1$ and $0.3 \mathrm{uci} / \mathrm{kg}$ patbologic fractures cocurred. The eariest fracture vas observed approxirately 390 days pest-9njection, with an average sheletal dese of 3,180 rads. An abnormal rate of tooth lcss was first observed at the $0.094 \mathrm{aci} / \mathrm{kg}$ dose level and the rate increased with ach successively higher dose. Rnothex Pu-induced bore change vas turinate osteolysis. The leating cause of death following IV injection of tetravalent Pu 239 was the induction of osteosercomas. These tumers occurred as lou as the 0.0158 ucikg cose ievel ard at an average comulative skeletal dose as lov as 60 rads. Sone other conditions which devoloped and are considered as seccndary to the and are considered as seccnary to the

Iyphatic hyperplasia. increased incidence of lyaphatic hperplasia increased incidence o
soft tissue tumors and decreased longevity. (E)

(24)

Tay 1cr, G. college of Heaicine, Radobiclogy Division Department of anatony, salt iake city. UT. 1966. Septerber 30

Jiver Turors in Beagles Injected with plutonia 239. Coo-110-235: Past of Dougherty. $\mathrm{T}$. F . Research in Radioblolog\%. Semannal zeport of hork in Progress in the Internal Irradiation Prograt, $(p, 71-75), 144 p$.

The incidence of bile duct neoplasia in beagles injected with tetravalent pu 239 (highest dose level being appoxiatelg 2.8 ucifkgl very tentatively indicates that such turors mat be radiation-induced. these grouths were relatively $\$$ man bom findings at autopsy. Tho mlignancier were

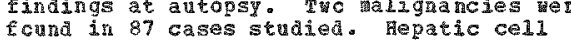
fcund in 87 cases stadied. Hepatic cell carcinowas and primary liver

hemangicendothelionas have not been observed. (Auth)

<245>

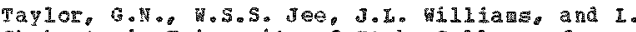
Shabescari, vaivergity of veah, college of Nealcine, Radiobiology Division, Salt Lake City.

Hepate changes Induced by Plutoniu 239. Bart of Stcwer. B.J. and Jee, Ko.S. (Tasol, Radiobiology of plutoning. J.h. press, salt Jake City. Utah (D. 105-127). $552 \mathrm{p}$.

For several handred deys following a single intratenous injecti on of tetravalent gu 239 in aog 3 (16-17 gonths of agel, most of the liver burden was retained in the hegat colls, but ultimately a high pereencage
shifted into the liver reticuloendothelial cells. The rate or translocation tas 
$\langle 245\rangle$ Crig $\mathrm{T}$.

gremest in the highest levels. The liver greatest in the highest levelso The liver hementic col nectosis followed hy hementic chl nectoris folloved ry

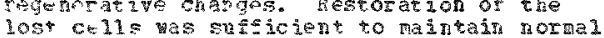

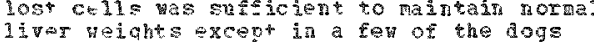
infoct at the hy hest level lapproximately 2.7 uci 5 ( $239 / \mathrm{k}$ ). Significant regenerative changes werp prohuced at in jected aoses extending down to 9.9158 uci Ea $239 / \mathrm{kg}$ and at average cam lative ilver doses of less than

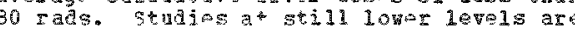
in progress, but the relatively short latent periods presently preclude evaluation. intrahe patic hile act turors were observed in 10 percent of the Pla $239-i$ miected dogs survivina reyond 130 al ps of age: however. most of these were sall teriga growth which were courd inciaentally at autopsy. only twenty parcent of the tubers were tatal mally pries. The ircidence of bile duce noon lasm in the pul $239-1$ injected dogs we 2

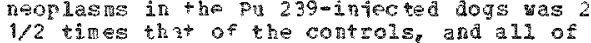
$1 / 2$ times that of the controls, and ali of the prinary liver waignancies cccurred in

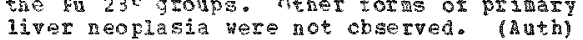

$\langle 24 b\rangle$

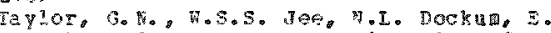

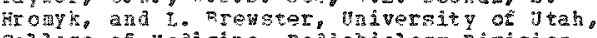
college of reatcine a dobzology Division. Department of natong salt iake city. Un.

Translocation of Plutonitu 239 in Reagl Livers. con-119-234; part of pougherty. T. F.. Peseareh in Radiowiclegy. Annul pepert of hork in proge ws in the internal Irrahiatior Prograd progrts in the inte.

The initial livex aeposition in the dog of totravalest an 230 given int

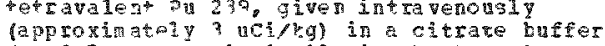

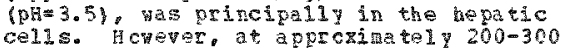

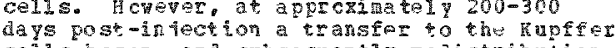
cells beqan, and subseguenely reaistribution

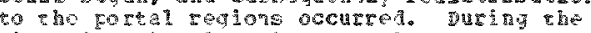

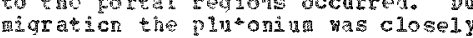
associaten with iron stasing oigment and the trat $10 \mathrm{ca}$ ticn appeared resultant to its attachent on this iron containing colloid. The princical vlutonin induces lesions in the liver consistel of tolitsed zegenerative changes zather then an imuediate primary ef ede at the initial degosition site and occurred arer long latent periods. (Auth)

Autoraliograms are present showing localizatio:

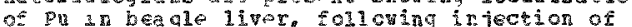
dproximte:

<247>

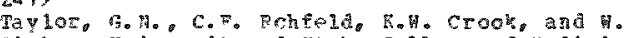
Fisher, Jiversisy of utab colipe of meatcine Radionjology tionson Departient of Anatory. selt Like city, UT. 1061 , Septembs: 30

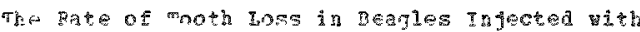

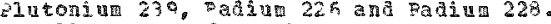

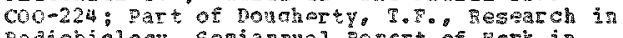

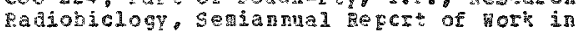
Progress on the chronic soricity progran. $1 P$. $32-37$. $104 \mathrm{p}$.

The rate of tonth loss in beales injected with givel coses of $R$ u 239 , R 226 and Re 220 tas compared as at the level at which a sion if cant asference occurres tas deturminea. The hate were compiled from 1227 semiannul dental exalinations aerived from 224 doqs. mbe rate of toch loss iniuced by
Ta $22 b$, De 228 a vith successively highet injected roses aftes the lintection leve? Has zaised ticove a

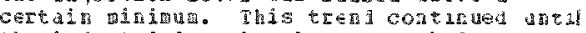
the ir teoted dose 10 vel was reached that

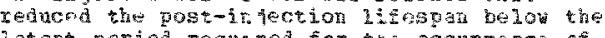
aten period regurea fex tha pcourrence cf significant tooth losses. (Auth) (FNM)

$\langle 248\rangle$

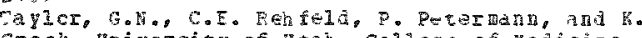
crock, Utipersity of utah, colled of pedicine, Fadiobiolgy Tivisicn pefartment of Anatong.

Electrocardiogran Evalution of Beanly with Fetained Padomuclide Burdens. coo-225: Dart or Fougherty, F. F., Besearch in Badobiology. Arinal Revort of Work in progress on the chrcuic Toxicity Prograg, (E. 43-47), 135 p.

Evaluation of the alectrocardichras of heagles rarsing in age from 480 to 3445 days. uith I Tetained burdens of Ra 220, Fa 22a, Eu

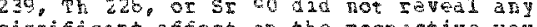
sighificant eftect of the respective wave patteris or the eine intervals of the $F$ wate

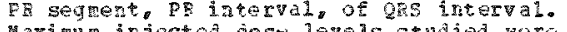

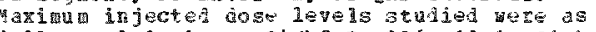
f Cliows: 3.0 aicror Ci/kE $1226,10.0$ uCi,kg

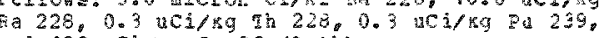
and $100 \mathrm{uCb} / \mathrm{kg} \mathrm{Sx} 90$ (Auth)

$\langle 249\rangle$

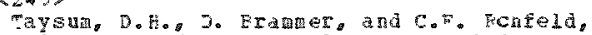
jniversity of utah, collese of luidine.

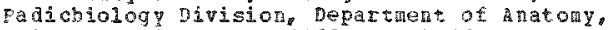

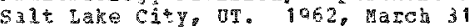

ateration of the metalis of the Eeagle by

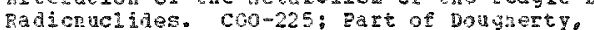

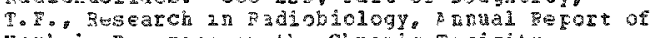
work in progress on the chronale Tosicity grogxa. (p. 109-121), $136 \mathrm{p}$.

Subjective changes in the appearance of

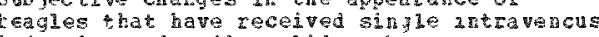
injectione of rationdelibes that ars principaliy bone seeking in character Foapted the exanination of their wetabolis sp neans or calorimery. Reanle dogs wetghing about $10 \mathrm{~kg}$ vere intocted with Bu 239 in doses varying from 0.049 uci/sg to 0.308 uci/kg, or Fa 226 , the 303 being 3.11 was observed that radiondelide burdened hogs was obse arout produce approxiataly lon nore calories of cGntrols. Respiratory guctient and body controls. Respiratory gacten and body tergerature are not significantly altered ky ther day mean skeletal dose, used in ene ger day pean skeletal dose, used in encen to
study. The change in wetabolist was seen to

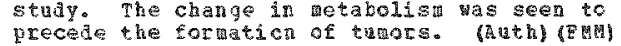

$\langle 350\rangle$

Temple, I.A.e S. marks, and i. G. Bair, General Electric Comany, hanforo Labratories, ächland, 1960

Tumors in ace after gulnorary pezasition ou Padicactive Particles. International joural of Fadiation Biology, $2(2) 143-185$.

Trelye-toek ola Bafl or CAP t female mice were useil in the experiment. The intratreheal a son in the experiatent. The intratrenea. adninstiation of plutonia and

irolyozyethyleme sorbitan morooleatel or (Folyozyethylene sorbitan porooleate) or pumonary denomas compared wh controls puinorary edenomas compared with cont 
$<250>$

BTOLOGTCAT ASPECTS

ANIMALS

<25, cont.

1068u02. Decrased incidence of adenomas vas obeained at 0.16 uCt239 Pug2 and 24.0 uci

1062u02. Entravenous administration of

sinilar particles cansea an increased

incidence at a level of 0.16 uci 239 puloul 4

incidence at a level of 0.16 arci 239 .

cera decreas a inconsigtercies in he incidence

certai inconsistencies in he incidence

and aethylcholunthrone were ised as cherical and aethy lcholinthrene experinent to a ford a conparison of the effects of cheaical careinogens with those of Eadioactive particles. Varions comblation of chenical carcinogens and $r$ adioactive particles vere also vsed. The dia of eu 239 Puo2 paridcles ranged Exom 0.06 to 0.6 in with a man of 0.5 ar. Wh mean particle dia. for

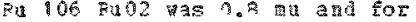
non-radiocot ive paricles 0.9 nu.

<25 1>

Terple, B.h., So mar's, and w.J. Bair, General Eilectic conpang, anford Laboratorias.

Tumors in pa ce bet Dulmonary neposition of Padioactive Farticles. International journal of

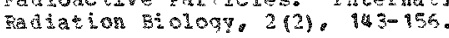

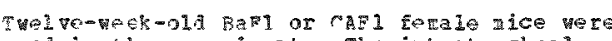
used in the experinert. The iatratracheal adrinistration of plutonum an ruthenium particles susponed in tween- $8^{n}$ or pluronics (polytcoviene glycolethyen aride polyner) calsed an increasea incidorce of puinorary aden Jmas contond

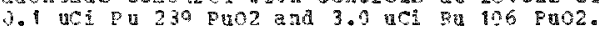
Intravenous zalinistration of similar particles causa an increased inciderce at

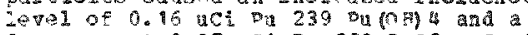

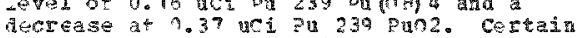
inconsistencies in the inciaence values oter inconsistonedes in the inciaence val mothylcholanthrege vere used as chemicaz carcinogens in aifferent phases of the carcinogr has in afferent phases of the tacts of chorical carciagons $n$ ith those of cacts of chomeal caratagens vith those of

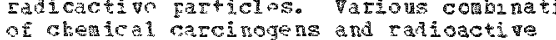
of cherical carcinogens and rantoactive

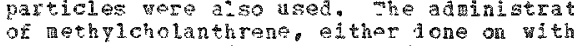
the agents caused the expected marked incerase in turor incidence. mistological Lesicns cesultina from aposition of plutorino particles inciured fibrosis with brenchiolar froliferaticn and squarous

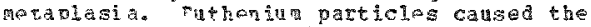
proserce of rumercus bizarre cells in inetic lestons. ol intonim particles were considered responeinhe $f \mathrm{cr}$ the developont of two equanous-cell carcinomas a a bronchiol ar carcinoma. Tro bronchiolat cronchiol ar cazcitopa. wo bronchiolar animals. (Auth) (Fong)

《252>

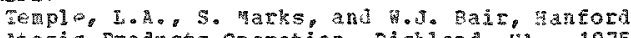
Beomic products operation, Plehiard, wa. 1975 Jenuary

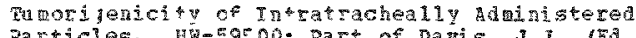
Particles bih-

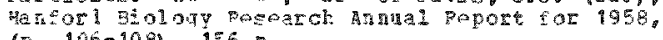
(P. $106-108), 1=a_{0}$.

Sugpensions of paricles, radioactive and non-rajioactive, in eithor 0.1 per cent Tyoen $h 0$ or $h .1$ per cent pluron 1 cs wese adninistered inteatrachalip ro two-month-ola

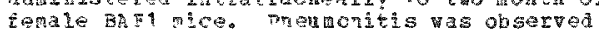
2n about fipi dor cort of aniala adninistered pasn 4 or pun 2 and 42 per cent

of the aniols administered Rin 106 Ruo2. In twc groups given su 239 Puoz wore that 70 gex cent shoved prenmontis. Several malignant

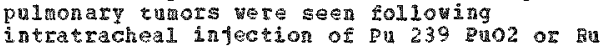
106 suo2. Total doses to lung tissue. Assuring 30 dar-blological half life and assuring 30 daY-biological half life and estinated. (Auth) (FMa)

$\langle 253\rangle$

Thowas, F.G. Lovelace Forndaricn Ecr Hedical Faluation ana Research, Inhalation Toxicology posearch Institate, Mivuguerqu, No. 1964

Int inence of derosol Froperties and the pespiratory Pattern Upen hazards Ealieticn Follcwing Inhalation Expostre. COMF-4k8; STI/EUB/84: Qare of Eroceedings of a SYmposiug on the Assessment of adioactive Body burdens in man held in Heidelberg, Germany, hay $11-16$. 1964, Vol. $(0,355-368), 10430$.

There are three impertant biologicsi carame ters thich are necessary in evaluating the hatas tron conounds antering the body by an route. These are (1) the anoun dy an rouce. These ace (1) the anoune and trangrocation $k$ inetics the and (3) the rate of excretion of the Material. Sufficient quantitative data on these points are gererally lacking in the case of an accidental exposure. Experinental arima 1 studies correlatisg different physical and cherical characteristics of inhaled particles with tac three biological valiables

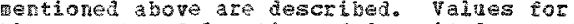
the amount and location of deposited material as a function of the particle size inhaled is presented for a tissue soluble compound (cesiur chloridel and for a tissue "insoluble conpound (treriula chloride). Evidence is also given to substartiate the veriations wial occar in tissue distribution vad excretion of an element, cepending urco its physical and chenical state when breathed. jat frow experivents with aeroscis

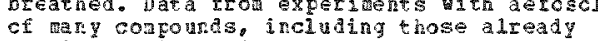
mentioned, is used to shou a a degu correlation between body burden an ceal - xcretion arigg the Eirst few post-exposure days. The advantages in percorning aralyses on both urine and feces for bioassay purposes are demonstrated. The fallacies in current mathods of practical hazard assessment frce air sameligg and bioassay techñques ara stressed throaghout, usblag the abcve data as exanples. (A) at?

akle 3 shows fecal to urinary ratios after inhalation of puoz in dogs and mobiug osadate in rats.

$254\rangle$

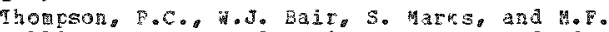
Sulliva, Ganeral Blectric Compay, Fanford

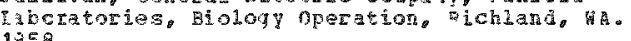
1258

Fualuation of Internal Exposure llazards $\mathrm{EOT}$ Several Radioi sotopes Enconntered in peactor

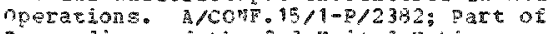

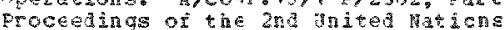

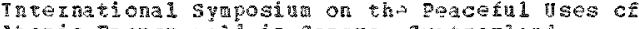
Atonic Energy neld ingevas switererand, Shlected aspecs of the hazads from
ranioisotopes enconterea in thi operation of a Pa production plant are eresented. Fhe experinerts described vere concerned chienty with 24239 , the princical product of tho vanford plant, and I 13 i, the nost 
$\langle 254\rangle$ CONT.

troublesore waste product of plant operation manot exposure ancalents wheh have occurred pornt to four jotental routes of plutonat entry to the body namely. puncture vounds

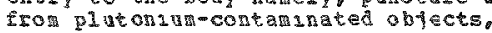
absorption through intact

plutonum-contaminated $s$ kn, ingestion and ahalation. Futensive axerzments wh ra*s. involving chronic intragastric administration of plutorn 1 over a vide range of concentrations, in solutions not more acid than pi 2 , have indicated a fraction absorbed than ph 2 , have indicated a fictaon confirmed in less extensive studies unth

coniraed in less extensive studies uh th plgs. ERporinents are teported hioh

ingestes, poorly absorbea alpha emitrers $P u$ 239) and keta omiters (1 91). Whth the effeces of $x$ undalation applied to the exteriorizel intestine and to the antestane In Siru. The ID 50 dose of $P$ ul 239 。 adwnusered untragastrically as the mutrate was about $90 \mathrm{mC} / \mathrm{kg}$. Survid tI we was less than $24 \mathrm{hr}$ ard deat $h$ was probably due to nitrate toxicity. As nuch as $200 \mathrm{MC}$ of $\mathrm{Pu}$ 239 puoz $/ \mathrm{kg}$ was adr-nastered intragastrically vithout synptoms of radiation effects. phis ase of $D$ u can bo calculated to have Aelivered at the surface of the contents of the arial antestine a radiation dose of approxitately $1.5 \times 10(28)$ ren. Experunents were performed wath ace to determine both the alstribution of the cartcles and tae long-term pathological effects. Both pu 239 puoz and pa 006 po2 were adminstered by

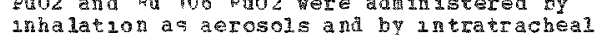
infection as ay arosols and the tissue injection as hyarosols and the tissil distrubut on followirg intratracheal admistration as shown. Malignant mors were seen after 4 ho days in tho of 17 andals 239 Euna. The romoval of unternally deposited Fu by zirconan citrate, EDTA. DTPR

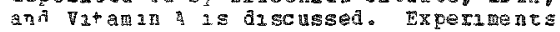
27 volving the feeding of I 131 to she parc the histopathologie and carcinogeme effects observed in the thysold glagd are reported. (

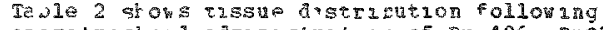

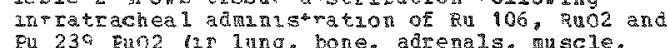
ovaries, sEleen, liper, lygh and kidney).

$\langle 255\rangle$

Tombropoulos. E.G., W.J. Banr, and J.F. Park。

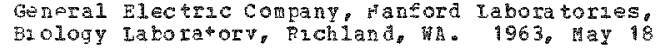

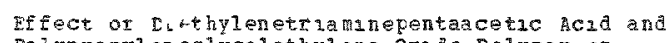
polypropyleroglycolet hylene nxide polymex on Excretzon of Thhaled Plutonza 239 PuO2 in Dogs. Nature, $198(4981), 703-704$.

Elgh 1-2 yr-old beade dogs were exposed to olutond um oxde aerosols. Following

txposure to $v_{11}$ each group of togs was exposed to an aexosol from an agueous solutson of one of the folloing., 5 th $3-\mathrm{Ca}$ salt of DTPA. 10" klurorics polveropy leneglycolethylene oxileh. of $8 \%$ olaronics plas 2 gum arabic. onemon treatients were glven dally for 15

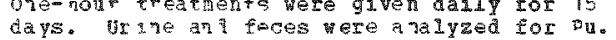

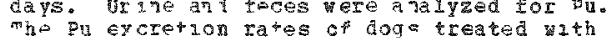
plurculcs ver consusteris areater thas those of untreated dogs. Dmp Has las utfective than pluronics in pronoting excretion of Pu. Alt nough plurond increased the rate of axcretion of $\mathrm{P}_{3}$, thers vas no large effoct on tetal. body burden. Pesults inscat than netcher Drin nor plurcrices 25 verv ofiective $i^{n}$ gemoving pluton un ox de from the lungs. (RAF)
The erfect of DIEA and plutonics on whole-body clearance of minlea $2 a$ dogs 13 gqven in graphe rorn. Tabular data are gaven or pu distrabution in dog tasues.

\section{<256>}

Totterp i.T.p Dos. Atoma Eneray Commsion, Division of Balogy and Medacine, hashngton,

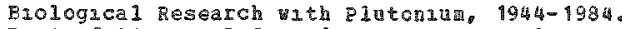
Fart of Stover, B.J. ara Jee, H.S.S. (ES.). Lake czty, ytah, (c. 23-27), 552 p.

Anmal experiments using CF-1 mace to deterine the toricity of uranian and plutonar were performed at the Metallurgacal taboratory at the university of chicago in 1544 by Brues. IIsco and Fankel. In 1947 these vorkers published a Faper 19 Cancer Research entitled "Carcunogema Action of Some substances Certaz Future Industrasi", and a paper $2 n$ Radrology entried, "Carcinoger $1 \mathrm{c}$ properties of Radoactzre Fissicn products and of Elatonum. Ir Decenber. 1952, the first dog vas injected at the onversity of $U$ tah for the purbose of comparing the long-ter b $3010 \mathrm{~g}$ acal effects of a sangle antravenous injectron of $\mathrm{Ra} 226$ and pu 239 an adult beagles. The utah project was established to verify the 0.04 uc "wole body tolerance level estabished for on 239 by the chal River. Carada, conference. Recentil. onohas has heer on whalation, non unz distribution of dose and bone cancer

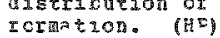

$\langle 257\rangle$

Tarapkin, S. F, and 2.6. Sych, tor given. 1959

The pction of puroniar 239 and strontun 89,00 on the gone warov or histe Rats. Meditsinstaya Padiology $4(6), 75-77$. (7ussian, Englush Suanaty

Exmarumens yere cerraed on rats to study the reacta on of bone marrow to nntroper.toneal adranstratzon of 1.5 med/9 of ST 99,90 and

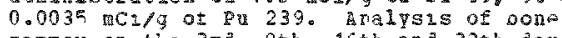
merrow on the 3rd, 8th, 16th and $32 t h$ day following the isotore adunistration showed a greater senstivity ot cells of the greter senstivit ot cells of the wh colls ci the granulopojectc ser aes the cells ci the granulopozetc serbes the

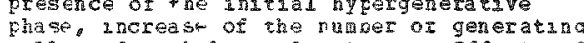
cejis and pathological miteses. Effects of Pu on bone marrow cowpared to those of $\mathrm{Sr}$ here characterized by inhibition of the hyperaenerative phase and lesaons of reteculoen lothelial an Issocytic cells, (AUt?) (BAF)

$\langle\geqslant 58\rangle$

Trevelevd, T.A., 1960, August-Septomber

The Elutonum content an the proten Fractacn of Rat Iubular Bones. Brockenlstry, $25(1)$. $497-489$. Baknamiar, $25(4), 636-639$.

Fyperaments (per o) ware carried out ox white

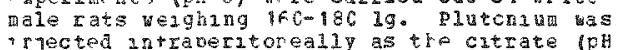
7. jected antrabertoreally as the catrata

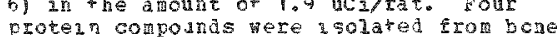
proten componds were a solated fron bone

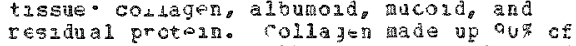
the bore protel. Mlbumolis, m3colds, and resiaual freteln maje up 2.9 .1 .6 and 6.97 
Influence of plutonum $239 \mathrm{cr}$ the free

Pabonucleot de grtabois in the rabbit Liver. AEC-tra6771; pate of Radiobiologye (p. 81-87.)

251 p.. Fadicbiologiva, 5(2) $218-223$.

Experzants vere conducted on gray rabbuts of both sexes, veighang $2.0-2.5 \mathrm{~kg}$. The arirals recevved a single intravenous ingection of a solubion of pul nitrate at ph of 2.01 a dose of 7 nci/kg. rie nueleotza content and listensity of ho incorporation or Iadioactive and 15 days one, two and siz months after and six anjala were used at each peraod. It as show that pu nut rate cased a sabseantial decrease in the nucleoside polychosphte content in the rabhit liver. After one content in the tabbit 1 iver. Atter one aption the and GT concentration vere appromately half the corresponding control values. whle afer three and siz month they A distinct ipcrease in the nucleoside

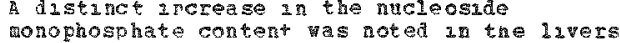
of the experimental andels. In all periods ot the intestigation, a distinct decrease In the arcorporatzon of radioact $2 v e$ phosphate into CDP-choline was detected, which pat be the cause of the agpearance of fatty dystrophy of the liper. A certain irerease In the rate of ancorporation of 132 into the carbohyarate derivatives of uridine dathosphate occurred one wonth after the adrinstration of plutonu while arter three mon ths this process was 1.6 to 6.0 tires as actire as normal. and was accompar ed by an intensification of the formation of connective plssue and the deviopant of curr losis of the inver. (A)

$<260\rangle$

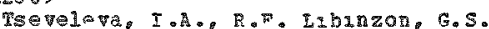

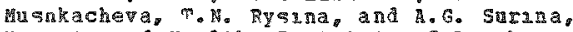
MInstry of nealth. Institute of Biophysics. Hoscor. USSE. 1968

Ba ocherical Changes in the Lungs of Rabutts After Inhalation of Plutonutu. ARC-tr-7015.

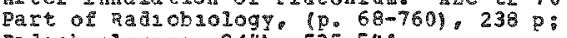
Rad lob 201092 ya, $8(4), 535-541$.

The results of a study of the wetabolist of the lung tissare after a single amalatzon of amona glutonum pentacarbonate by rabses ("we 2 ghing $2.2-3.0 \mathrm{~kg}$ ) in a dose producing sclerotic changes in the lung are presented. A single mhalation of a monitin plutonum

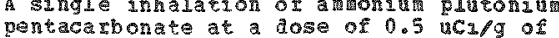
pentacarbonete at a ase of 0.5 uCa/g of

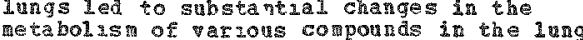
tetabolss of vas zous compounds it the lung tussue. The metabolic processes un the lungs

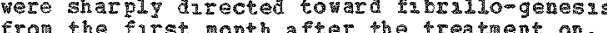
From the rurst month after the treatrent on

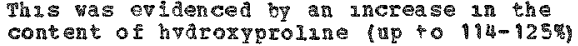

and rucopolisaccharides (up to $135-140 \%$ )

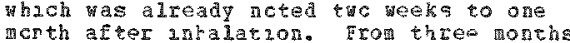
moth after inalation, from the nonchs $3{ }^{\circ}$ - nto the sulfated micopolysaccharldes vas observed. The most substatial changes duran the first pericds of anvestigaticn were noted If the 12piasg phosphol1pids, and sulic acads. Fhe content of these substarces tuc weeks after innalation vas 185,240 , and 164 . of the conerol, respectively. Aath

$\langle 25.9\rangle$

Thente, JoA., and W.S.S. Jee, unveraty of itah, College of Hedrcine, Fadrobsology Division, Department of andomi, salt Lake city.

The Determation of Localized Concentration ci Dilenan 239 in Bone. Health physics, 5 , $142-148$.

A macrodensitometric technigue of ansurang lccalized concentrations of alpha-enattang radronulides was used to determine the $P$ 239 an bone. The dats obtaned by microdensitometric scannag of quantitative

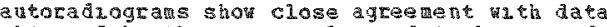
cbtaned by the previousiy used techngre of the 1sual courat ang of alpha-tracks. The accuracy of the rierodensitouetric technialu was verified by a ceparisch of the $p_{\text {in }} 239$ content of a thoracic vertahra centri determined microdensitonetricaliy with the Eu 239 content of an a jacent centrum nea surea Ead lockeracally. The wount of Pu 239 found w 1 crodensutopertical1y was 70 per cent of that deteraned raducherically. Tne average Pu 239 concentration associated with haversian systes, geriosteal surfaces, a d endosteal surtaces or trabecular bone in a lumbar vertebra firon a beagle hound a ajectea vith $2.85 \mathrm{uCl}$ of $\mathrm{Pu} 239 / \mathrm{kg} 92$ âns prict te

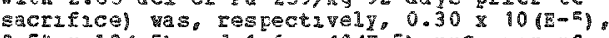
$0.54 \times 10(-5)$ and $1.6 \times 10(\mathrm{E}-5)$ en 02 per 2 of surface. The calculated average localized dese rate deliverea to bote tissue and warrow cells on the endosteal surface degosit is 40 and 60 rads per day. These rates are ten traes the previously caloulated average sikeletal dose rate. (Auth)

$<262\rangle$

Taughan, J. Churchin Hospatals Bone Researeh Iaboratory, oxford. Figland. 1972

Eone Surfaces: what Are Theq?. Part of Stover B.al. and Jee, Plutonsua 3. (0. $323-332), 552 \mathrm{p}$.

agone surfaces" bave complez character. They consist of osteogenuc cells ling on anera I/mater component which is ande up es calcur apatite impregnating collagen phers, and ground substance" composed of carbohyarate proter conpleres, lipuds and veptries. Platonia deposited on "bone sureaces" 15 bound by osteogentc cells and ther organelles, by specafre bore glycoprotenns and possibly by collagen. The presence of platons un 3 thin or on the aensitive osteogenic cells acconts for the Treat caresnogeniosty In dascussion of meta 1 binding by bone in the In dacussion oi wetal binding by bone in the

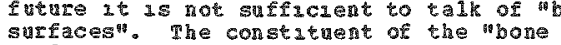

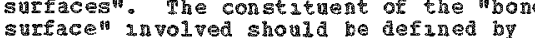
experswent. (Atth) 
BIOLOGICAL ASPECTS

AMTIALS

Churchil toepital, velical Research Concil, pone-seering Isntopes pezearch units oxrora. Fon 1 and 1967

mo vptake of Plutoning in Bone Marcon a Possible lavkmic pisk. British jeurral of Haenato $109 \%$ \% $19.42-502$

observaticns are reported on the pattern of distribution of pa 239 and of the radiation dose recelvel in the bone narron of the feaur cê "ung rabbits given a single intravenous

injection of $1.25 \mathrm{uci} / \mathrm{kg}$ of plutoniun

nitrate, and killed at subsequent time

intervals. The tcral ancunt of pu in the

mascon fej ry a tactor of ahout 30 between 1 day and 7 months after injection. mitially. there vere localized deposits of pr, largely in sacrophages containing an iron-containing pigent. There vas also a di feve

distribution. The diftuse distribution fell off $u$ ith the after injection, and at 7 month there vere predominanty 100alized deposits of pu. These containea abont one-fite of the ameunt of pu seen in deposits 2 hrs after injection. The possible Fhystological and dosidetric iateroretations of the patter of distribution and the ratiation hazar involved is discussed. It is suggested that martow totention shonia ho consugered in

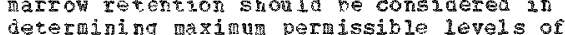
this radionuclide. (RAF)

62043

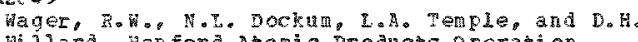

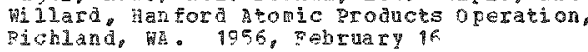

Tosicity of Eadioactive Particleso $1 \mathrm{~A}$ Intratracheal infection of RaAloactive

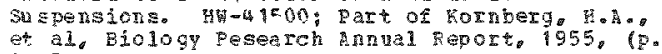
$61-72), 183 \mathrm{p}$

A suspension of plutoring or ratheriat particles vas infected ineratracheally into 12-week-01d 3A sub I ferale wice. The mean diameter of the Fu 10502 and Puon particies was 0.8 and 0.5 un, and the diageter of the Quo2 particles ranged frep 0.05 to 0.6 u.

Tueen -80 was enploved as protective

colloid. Fibrosis epithelial hyperplasia.

squaras prtaplasia, and squa mous cell

aice that vere injected with plutonam oxide.

reetrent vith $\mathrm{Bu} 106$ caused oni necrosis and eibrosis. (Anth) (Fis?

$\langle 265\rangle$

We ks, H. H. and W. Dakley, General piectric company, Hanford Atomic products operation. Fíchland, Wa. 1953, pril

Percataneous Absorption of Fadioelenents. Ho-27688; Tart of Pesearch and Developent Activities quarerly Progress peport tor Ja nuary-Rarch, 1953, p. 16).

The absorption of platoniun through the skin of $x$ ats was studied over tine-periods exteriaing to one veek. When abclied as a 10 MEtho 3 solution of Pu (No3) 4 , apcroximaty $10 \%$ of the olutoniun was absorbed by the aninals at the end of ore veek. about $4 \%$ of the clutoniu was absorbed during the first twerty-cour hours. sats sinilarly

containated vere subtected to

perranganate-sulfuric acid decontamination perranganatesulfuric acid decontamination procedure, which removed ap poximatel $90 \%$ rate of asorption of the remaining $10 \%$ was markedy accelerated by the decortagination procedure. This has long been Eecognized as grocedre the has long been cecoynias procedura moch nore data are needed in this

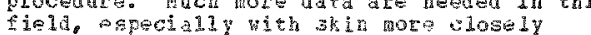

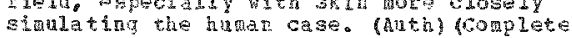
Text

$<266$

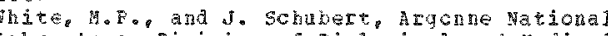
Labcratory, Division of Biological and Medica

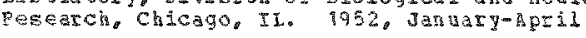

The Action of salts of airconiun and other Metals on Flutoniua and petrium bistribution and Excretion. Jourdal of pharaaco:ogy and
recerinental Therapentics, $104,317-324$.

And female rats vere injected either tetravalent pu 239 in a lo sodiam ditrate

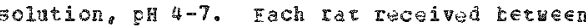
10 and 20 ug in afferent experifents.

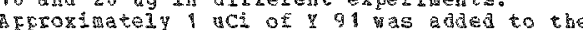
py solution in some experithents sciutions were injected intraperitoneaily or

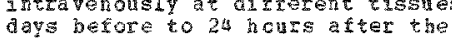

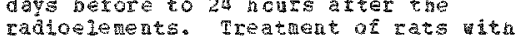
radoejements. Treataent at rats ato ytring loneren the apont of Pu and

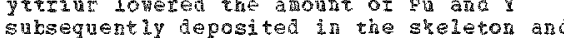
increased the anount of pu th the kidneys. increased the anom of pu in the kidneyso was correlated $z$ inth the length of tial between pretreatment and their injection. zr injected 24 hours after pu and $y$ Fitvented iurther depost tion of the radioelegent: ia bone but had no other coservable effect on their organ distribution. In addition to $z r$ other hyarolyzakle elements-anganeses iron, titanis, aluninu, and theriun-reduced bere deposition of Fu, but had various effects cr the amonts deposited in cther organs. Al ard Th increased the pu contert of the liver and other seft tissues. Non-hyarolyzable magnesium had ro signiricant effect on the distrihution of either Fu or $Y$. To mechanisms by which salt of $2 x$ and othes $h$ yarolyzable elements bay afrect metabolis is discussed. This incindes adsorption of the radicelement on collcidal aggregates in the circulation and the a gration betres particle size and the resulting discribation of the aggregate flus resulting distribation of the agregate flus

The efrects of pretreatment with $z r$ on the aistribution of $\mathrm{pu} 239$ and $\mathrm{y} 91$ are gaven in tebular foro.

$<267\rangle$

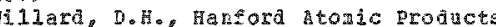
operation, Hichlan, A. 1960, January 15

Distribution and Toxiciey of inhaled Plutonia 239 Eioxide. How -65500 : part of Rornberg. HoA. (1. $122-128), 208 \mathrm{k}$

Adult beagle dogs were esgosed to Pu 2398002 atrosols of varying concentrations an particle size. Between 53 and 53 \% of the tctal pu 239 puo2 deposited nas present in the 1ung for two weeks after exposure. The extremely small quatities found in bore and other organs deronstrated the insolubility of Pu 239 Euo2. Other dogs depositing 25 to 150 uci Pu 239 puo2 died within 50 to 75 days. Death was preceded by decreasing total Death was preceded by decreasing total rate. (Auth) 
(26)

BTOZOGICAL ASEECTS

ANIMAIS

$\langle 268\rangle$

mi Ison, R. H., and J.L, Terry, UnIVersity of

B20logical studies associated with a Freld Release of Plutonum. Colp-670521; Honographs on puclear Medicine and Blology. Ho. 2, Rart of

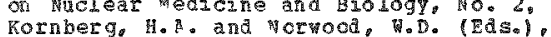

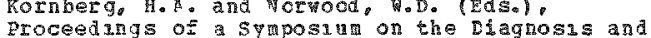
Treatint of Deposited radronucides held $1 \mathrm{~m}$

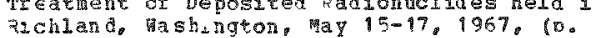
zalland,
$273-2901), 680 \mathrm{p}$.

Throe hurbed dogs, sheep and burcos were axposed to plutcnu a roeol generated ky hiqh-explcsse detonation. Imiailing burden for the taree species wete 22.6 .10 .6 and $17.9 \%$ of the respurable less than 10 u particles, Tespectipely, and of these burdens 67. 5. 1 a nd $22^{\circ}$ mas cleared 5 low $1 y^{\circ}$ Early days, but the data were nadequate to ostablish a slov clearance halr-tine diferent firor the usually accepted 365 days. Ten doos and ten sheep tere exposed to injar a erosol in concert 1 th a largo sandar a erosol an concert ath a largo anount of inert dust, and these andals
shoved it t thes greater clearance 2 the Shoved i tares greater clearance 2 the
firot 7 ays. vo dat are avalable for oxtrapolation heyon 7 days. (Auth)

$<269\rangle$

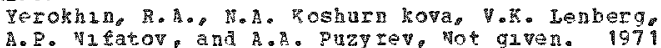

Some Pemote Afterefects of Irtratrachea 1 Ad malstration of Chem caliv Soluhie plutonam 239 Compounde Ac-tr-7387, Part of Rerote af tereffects of Radrat on Damage, (F. 344-363). 574 .

wistar rats weighino inatally $140-160 \mathrm{~g}$ were njected intrat-achea 11 v solutrons of pluton un trate (pH 2). sodula plut onyltriacetate $(\mathrm{pH} 6.5)$, and nutrac acad (pit 2). The pu comounds were gaven 2 in 7

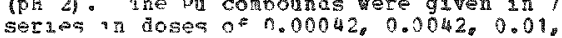

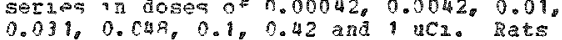

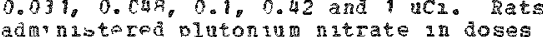

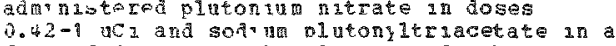
dose of 1 uc-/rat showed a conszderably reabed mean infetme in conparison 2 th the control anials and $u$ th rata admantered ritric acid. The m, crodistribution of Pu in the lungs and reajonal 1 ymph nodes at remote times $a f^{+}$er adinustration was characterized by a vell-expressed nonumaform ty. A reliticle ricrease in the frequency of pnoumosclerosis was observed in rats adin nustered Pu in hoses of $0.048-1$ a $\mathrm{Cl}$ in comparzeon with agmals given titzic acio. the opt 1 min hlastonegenc dose for nitrato sas 0.02 uca. An 2 acrease in the rrequency of occurrence of pulmonary cancer was seen in anals giten $\mathrm{pu}$ in doses $0.42-1$ ucl when compared o ana is a-ven m tric mote frequert occurrence of pulmonary cancer mote ireguert occurrence of pulwonaty cancer dose levela. in increase in extrapul monary dose levela. an increase an extrat

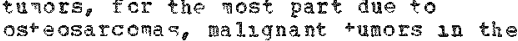
osteosarcomas, ra lignant tumors 1n the gastron endocrina glands vas seen in rats given

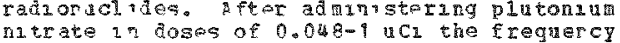
of accurrence of osteosarcomas vas cependent on the tu dose and the total ronzation dose an the sketon. Tn conparason vith plutordun natre (ur equal quantutes) sodau El utonyltriace ate had a more cleatly

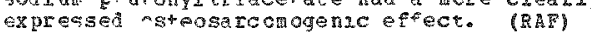

Ixtensive tarular data are grven of all experanental results.

$<270>$

Yukblov, A.K., and R.A. Knyazeva, Hot given.

9964

Changes 1 in the Absorption Characteristics of Corebra 1 and Fenal issue after the

Pincorporation of Radioactive fission products of Uranzun 235 in Loi Doses. AEC-tr-6405, part of Radicblology. (p. $50-57)$ : 211 p.. Padrobrologipas is (3), $370-374$.

when mice are given radioactive fission products of uranua 235 by gavage in acses of 0.01 and 1 acz per hiogran an merease is noted in the adsorptive activity of the carebral (25 percent) and renal 872 percent) tissues, whuch reaches a raximu on the first-thard day after the admnatration. The AYnamics of changes in the adsorptive characterastes of the renal and cerebral tissues at test to possiblintes of compensatory recovery of the proten substate of the renal and cerearal tassues substrate of the penal and cerearal tosises
tcwat the end of the farst weok after the

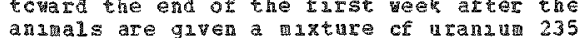
fission croducts. (Auth)

$\langle 271\rangle$

zalikin, G.A., Yu.I. Hoskalev, A.I. Semenov, Ye.S. Zhorova, V.N. Strel'tsova, I.R. Pertovich,

Materials on the Toxicology of Calufornum 252. CONF-730907 (Fart II. Eart of Snzder. Ea.). proceedings of the 3 Id International Congress of the IREA held st rashangton, D.C.. Septeaber 9-14, 1973, (p. 117-128), 1475

P. (Russan, Englash Suarary)

The report contans date on accumulatien distributzon a tia elimination of varzous compound of cf 252 frou the body of anzals and characterizes its buclegical action ator and characterizes Its blelcgical action ant cubacutely ard chronacaliy efect 2 pe doses.

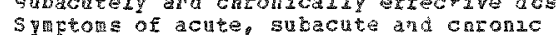

Sytrons of acute, subacute and car

chjury by cf 252 are abscrabed and efficiency as a fuction of dose a.g gaveno (Auth)

$<272\rangle$

Zalikin, C.A., and V.I. Frifonov, Not given。

Distrubution of Aneracuar 241 in the pat organism, Bs palded te tne properties of the Adanzstered salt. A"C-tr-7457, Part of Moskaiev, Yu.I. and Kalistratcva, V.S. (EdS.l. and Internal Sources, $(p, 427-434), 515$ p.

Inpestugat nons were conducted on female a buro rats welghing 200 phis or minus 10 abino rats welghing 200 plus or minus 10 dssolved in tirate, chlorade and catrato solutions, pH 3.0. The concentration of the cutrate sclution of asotope constututed 0.4 . the specific actitity of the solutions vas the specific active of $0.9-1$ acz/mi the solutiog in polyneric form of americu nat a specific

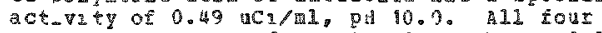

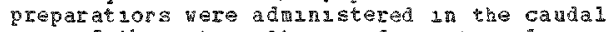
ven of the rats. at specienc interpals following admastration of the sctope, the rats were sacrificed and determatron wa made of acturiti level accorang to gama-emssun in samples cf dufferent organs ard trssues. The an 241 content in organs Was excressed as percentage of enjected 
EIOLOGICAL ASPEC API TILS

$\langle 272\rangle$ comp.

doses. The results show that the

distribution of 124 in 24 ine rat organism is of the be patic type since congiterably

grater (by $3-3$ times) accumalaton of the

isotcpe is observed in the liver as conpaco

to the sicletal system and it is little

related to he properties of the administered

salt. The americiun content of the skeletal

syster folloning intravenous anministration

oE scluble salts of this isotope does mot

exceed $21 \%$ of the aninistered ase. In the case of intravenous infection of the

polyeric form of a 240 (bydroxide), an aditional "reservoir of the isotope is

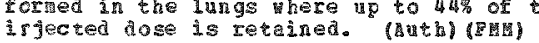

Table 90 shows an 241 content in lower skeleral syster, lungs, spleen and $\mathrm{kinheys}$ of rats after IV adoinistration of different sit soluticns of the isotope (th of injected dose.) 
<27 3>

BICICGICAL ASEECTS

PLANTS

$\langle 273\rangle$

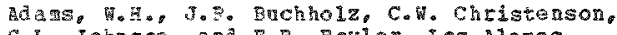
Gol. Johnson, an F. Fevier, sos Mlawos

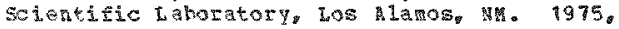
Janazy

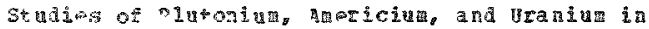

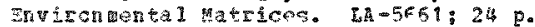

A nitric acia-hyrafluoric acia treatment for disselution of plutogiug oxides in soils has bor degriopedi its adaption to other biological matrices is ajscussed. Pintoniu recoveries of 94 to agr fron $1-9$ saples of spiked and heated soils are reported.

Alaptation of the acid scluticn to subsequent anion exchange separation of plutoning

followed by coupling te known electroplating

technigus, is aescriber. The uptake of

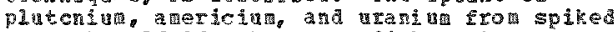

$3013 \mathrm{~b}$ alfalfa, beas, radishes, lettuce.

todatoes, and harloy is reported. The

"apparent" solubility of pu 238 puoz in tap

water was measured, and the ceposition ce

plitering in fish, algae, and srails in

aquaria containing De 238 PU2 2 werospheres

is reported, (ath)

$<274>$

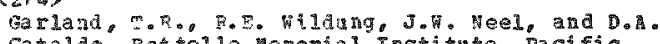
Cataldo, Batelle meroral Institute, Pacific Worthwest Iakorztorios, Bichland, recenber

Factors Affecting uptake and Distribution of Plutoriun in Bariey and soybean Plants.

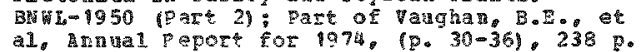

Earley ard soyben plants were grown on soils amended with Pin (NO3) is using the stit-root technigus. parametars investigated included the effects of il soil volume and soil colum height, 21 starch and a wendwents to optidize ojerohial activity, 3) soil type. ad a) increased levels of pu adition 1100 Ma $(i / g)$, on the uptate and istribution in barley. The distribution of Eu was

barley. The distribution of Eu was

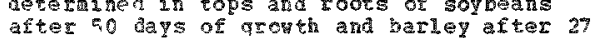

dater of growh. Troth and in the cotal

days of growe. Threases in the tota volure of soil resulted in ondv sight increases of total plant uptake. The height of the soil colun appeared to be the rost iaportant variable. Increased uprake in

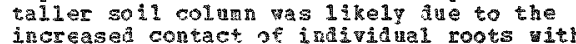

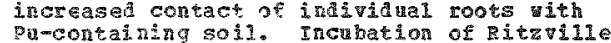
soll yith $v$ and $r$ marcedy increased Pe uptake by the roots. Elevation of the sojl pu levels to 100 "a on ly alightly increased Pu uptare compared to the 10 aci/g level. measureants or distribution of $\mathrm{Pu}$ in the shoots and roots of barley indicated that $B$. once in the plant, was rather noble. clae: leares shored accutulation near the base of the blade. with the rialie of the olant deficient and increased levels near the tip. Tn yosinger iriades the gradient continuons with the base of he blade exhibiting the lowest concentration of $\mathrm{Pu}$ an the tip the highest levels. In the root the gradient was reversed. The distribution of pa in soy bean tissus as, in general.

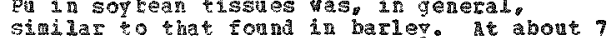
sian tar to that fou no barley. At about 7 days or growth the soybean plants developed disomer that linted the production ar seads. garley seeds, harvested after 100 days of grouth, did not contern pu in detectabie quatities. (RAF)

A1 the invertgated parameters are given in tabalar form. $\langle 275\rangle$

Hisieh, J.J.C., F. D. Fungate, and H.C. Bossch,

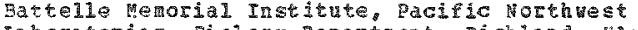
Labcratories, Biology Departant, Bichind, his: Rattille Herorial Institute. Pacific Northest Laboratories, Envizonantal and Radiclogacal

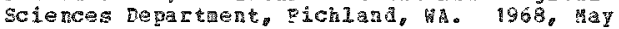

Teqgerature of suraces in contact vith pluterius 238 puoz hicrospheres

In the course of observing eftects of pu 238 puo2 a icrospheres on leaf surcaces the question arose as to the celative iaportance of iondzation versus sinple heat effects. Results of experidents showed thet the tenperature of a wel1-ventilated surface in contact ith a 200 u dieneter Eu 238 Pug2 particle may rise to $350-400$ a as measured by heat-sensing wheratab strips. The possibiliti hat leat datage frow 2 a 238 microspheres could be we to thermal effects was heightened by obserying that tcuching the tif of a hot glass rod to leaf surraces produced arage visiziy cengarate to that From the Pu 236. On the other 3 and it is nct certain that the melting and lackening of meratab a not be a consequence of icnization-induced breakdon of lattice icniation-ind

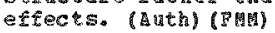

$\langle 276\rangle$

Rornberg, H. (Ed.), and E.G. Suezea (EA.), kanferd tonic Prodicts operation, Biology
Laboratory, Richland, 1962 , Jandery 15

Manford Bjology Research annal Report for 1961. Hiि-72500: 180 F。

The traditional emphasis in the scientific Erogra of the biolcg section has been on internal enitters. The toricity in sulne of intravenous ad alistered SI 90 , Ea 226 , and pu 239 vere compared. In a broad inha lation studies progran, toricity and related

coperies of several radionuciliez were

strdiad. The results of several diversified

studiad. The results of several diversified studies in anital and cellular physiol
included. The uptake of arsenic from

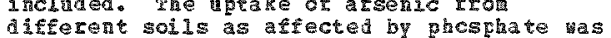
diferent solis as affected by phcsphate has ceasued. The uptake of calcin and rutidiua by poung plants seemed to cccur via an

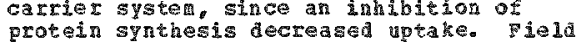
and daboratory studies indicate that columaris disease increases wh crowaing a mong tish and thet z-intadating the organis does not produce a more virulent strain than the parent stock. six papers from the anmal report were abstracted sera ra tely for the date base. (rit?)

<2775

Miller, c.E. Not given. 1968

The lature and Behavior of Local Fallout. Com-b80507: Eart of proceedings of a Sytosid on Radiological pretecton of the pilc il a Huclear Mass Disaster held in Interlaben. Switzeriand. May 26-Jun $1,1968,(0.49-64)$. 588 .

The general nature of fallout particles is discussed brieny in terns of the procosse Ieacing to thest formation in the sucleax fireball and tising cloud. Inhorgeneities in the clouds are given as a reason for the dispersion and rrag mentation in the observed fallow patterns. most attention has beer given to detalis of the deposition grocesses and the behavior of the fallout carticles 
BTULOGTCBL ASPRCTS F

〈277> rome.

during and after their contact with exposed surfacos with emphasis on the interception and setertion of articles by olantso The petarion of fallout parteles ip plane foliage iegerds rathy on the size and shape sf the flants. plant sparing and density. vind sper particle fall anglo fino

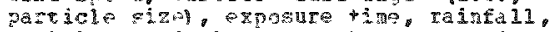
sutidity, as l plant grouth rates. axcoptions, the sumace characteristics of the foliage is a second crder variable. The dependency of the setont these var trese varinbles is ilus rated by data barley, of costa pica or the cereal os

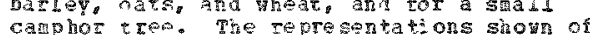
calphor exen. The representations shover of

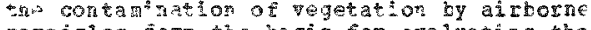
par icles rorm the hasis for evaluatiog tho beta and ganna dosages hat nants may

recaive fron faldont and, to wome degrec, the input infermation for the entry of

radioraclides it several food chains. Data an perscrnel wontalnation are rather scarce but the for data avid lable indicate thet hait retains partioles with a fairly high aegree

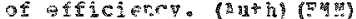

7)

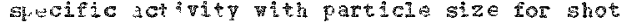

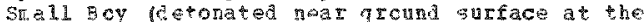

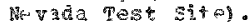

\section{$<278$}

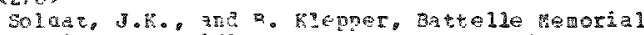
institute. Facific nozhwest Laboratories. Ervironentel and Ise sciences 3ivisiono
JdY Uary

TaAiation Doses Exom Iodine 129. BHL-1850

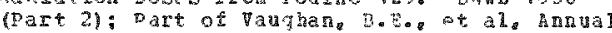
Ferert for $1973,(p, 42-44), 200 \mathrm{p}$.

A sunnary of a report dealing with I 129 levels fourd is. soils and vegatation ald the resulting radiaticn acses ro man and biota $i \mathrm{~s}$ resented. It is assuted that because of 1 th lenghalf-1ite I 129 will ceowa part of tre total iodine pool of any ecosystem The ratio of I 129 to I 127 available to living orgarisms will deterpine radition doses

received by the Fr. Fternal dosms wil bu insignificant conpared to internal doses bocase of the low hera and game radiation ozergy. The nator factor in part

crergy The pajos factor in pant

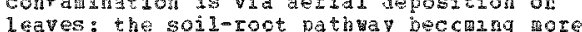

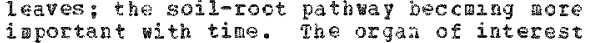
in any orjanisos is the thyroit wath a dcso pathwa of ingestion rather than irhalation. primcipal foods of concern are gilk.

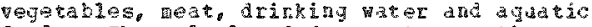
goods. The calculated aose rates to the

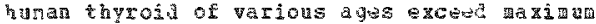
veraissible dose rates ander the assuptions that al1 jodine in the thy rold were 129. The adut dose rates are 34 times kigigr thar the MPDF. the one-year-old child wcula received 9 tires the dose in tha present उuide. (EAE)

Thas 2.12 shows human dose rates to the thyrcid

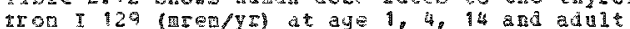
assuring all iodso to be 129. 
$\langle 279>$

Akatsi. 2. Japan Atonic snergy Mesearch

rastitite. "ckai, Japan. 1979

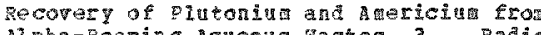

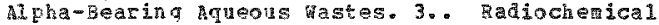

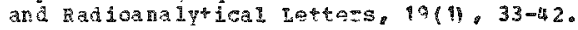

When Pu and an were fixed as theis hydroxides fror al tha-beating aqueous wases, trace anouts of then remained in the solutions. it was found in alkaline solueion that gu(t) it as found in alkaline solution that and Pu (t5) are instather converted into

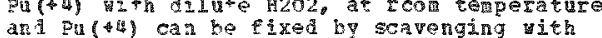
and Pu $(+4)$ can be fixed by scavenging uith

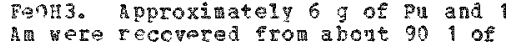
ascelianeous aqueous astes approximately acill. 1 th a recovery efficiency of $>90 \%$. The alpha activities of supernatant solutions were artroximately aci/1. (Auth)

$<280>$

Akatsu, 3., Japan A4cric Fnergy Research

Institute. "okat. Jaman. T97u

Recovery of plutoning and haericin from Al pha-Bearing aquous at a Rad ioamalytical Letters, 19 (1), 25-32.

From alpha-beariry zquous astes, pu and

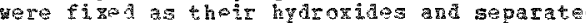
by decantation. The supernatant solutions vero decontanirated with Fent 3 , the slurry W Ma-nitrate solution, from which pu and an were recovered by 59 or $3 B$ e golvent extraction. Approxinately $g$ of pu and 130 aq of $\mathrm{Am}$, vith about $85 \%$ Yiel Eron 1301 of agenons tastes cotedning appreximately 2 mci, altha/l. The 3 ross aph-activity in the aecontaminated solution was approximately 19 uC

$\langle 281\rangle$

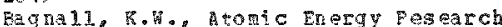

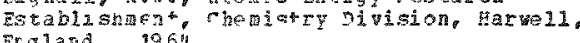

The Transuranizi " loments. Soience progress, $52,65-33$.

The discovery of the tranguraniu elements has resulted in the develogment of nem techniabes in the ohysical sciences ard has played a fart in the renaissance of nnorganic chemstry meit olace in the periodic classification is described as aze tneix Tarious valoncy states. crides and other compunds aro isted. Palloactive hazards in

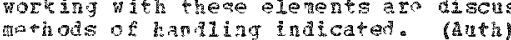

$\langle 2 \% 2\rangle$

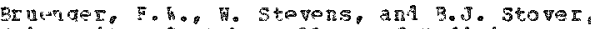

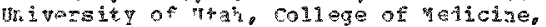
Radiobiology 3ivis sone Degartment of Anatong. 1057, 31

hin the Binding of plutoniu (ta) to rransterin and conalbuin. con-119-236: Part of Dongrerty.

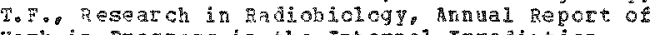
work in proarsss of the Intornal Tradiation program, (F. 191-195), $268 \mathrm{E}$.

The binding of pu 239 (\$4) by transferrin and conalbuin requites tho presence of kco3. Terminal sindic acis groups of transtertin

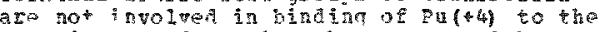
protein. coneotmation changes caused by remoyal of sialis acid resianes do not exfect the hinding ability for the nuclide.
Structural changes inducea by an enzyatic attach on the glycopeptide groups lead to tre loss of binding ability for glutoniua but not fer íron. (Auth)

<283>

Exuenger, $F$. university of itah college of vedicine salt lake city, 1T. 1962 , September 30

Solvent Extraction of Dlutonitu wh pristary aines. Coo-226: 2art of Dougherty. T. pesearch in Radioblology. Sealamual ieport of hork in progress on the chromic Toxicity Progra, $(\mathrm{E} \cdot 58-65), 135 \mathrm{p}$.

An accurate and giagle procedure for the determination of plutonin in biologica materials has teen develoged. conerutrated urine, or a solution of bone ash, was ade at 18ast in in eytracted with a bere of c 19 to c 23

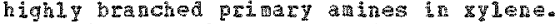
Plutoniun then extracted exos the crgand phase with 8 roch and neasured by alpha counetng. (Auth)

$\langle 285\rangle$

Delle site, A. G. Santori, and C. Testa, comitato Vazlionale per 1 ignergia nucleare. Rone. Italy. 1974, Eebruary

The rapia Deterination of the Transuranum rlements by Etraction chromatography in Urises containing DTPA. Conf-780907 (RaEt 1): PaEt CE snyder, H.s. (Bd.). Proceediags of the 3rd International congress of the Ing hald in wasington, D.C.. Septerier $9-14,1973$, (c. $=32-537$. 1 4 75 p.

Microporous pol yethylene prerotheng-710 sipgorting tri-m-octyl ghosphine oxide (TOEC) and di (2-ethylhexyl) phosghoric acld (HDEt has been used successfuily to extract respectively $\mathrm{Th}, \mathrm{Pa}, \mathrm{U}, \mathrm{NP}, \mathrm{Pu}, \mathrm{Am}$ and $\mathrm{Cm}$ from the urine. As the extraction takes place in an Hou mealum. DTPA ug to $2 \mathrm{~g} / \mathrm{l}$

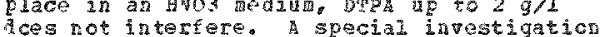
aces rot interfere. 5 secial iavestigatica Was carried ont for an in order to thd out deronstrated that great losses of actingtes deanstrated that great losses of actinidas occur when a cogrecipitaticn with a a a d g Ehosphates ar
LTPR. (Auth)

6235)

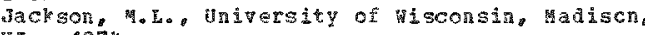
ง. 1974

Frchange of Lyotropic Series cations ot micacous Veriniculte and 7 th veathering Products netermined by Electron nicroscopy and Rad iochomical snalyi coo-1515-56: potort for the Eeriod Fnding august i, 1971-July $31.974: 30$.

The work is sumarized under three topics

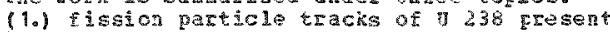
(1.) ission particl tratks of J 238 veroiculite, after ar decctation. chotog raphed by scasting electron aicroscong. wefore FE treatrent, diffusion of $K(+1), F e$. and 5j. (0 H) 4 was Enhanced by the fresence of the tracks, ard selective adsorption of firing cations such as ca $137(6)$ ) was

increased. Eligh resclution electror. alcroscogy (is atged-layer stacking sequence of most clays centain sone micaceous vernicalite. Lateral variation along the 10011 crystal planes was shown by blister morphology and also by fats thus demonstrating conclusirely the existence 
〈285> $\mathrm{CON}$.

of interlayer vedges active fin selectivity of such cations as Cs $(+1)$, (2.) Divalent cations of the $\mathrm{Sr} 90(+2)$ type and transition and heav setal type are specifically sorbed by gel forms of hydrous oxides of $F e(+3)$ and Al (+3) which are al nost universally present as coatings on soil particles. (3.) Tropospheric dusts, shown to circulate worla-wiac and accrete in soils, deep-sea sediments, and island mountain tors rom rainfall, sher significant reactions with fission products such as $\mathrm{Cs} 137(+1)$ and $\$$ I 90 They infinence the fate of radioisotopic They influence the Eate of radioisotopic of the findings is aiven, with teferences to the specific publications in which they are reported. (Auth) (crs)

$\langle 286\rangle$

kay, A. Rigadom Atonic Energy Authority, Harveli.

Q1utonitu 1965. CONF-651192; Proceedings of the Royal Comon mealth society 3ra International Sy noveroer $22-26,196^{\circ}$. chapman ana tall. London, Erglard, $1114 \mathrm{p}$.

At the confererce studies on $P u$ in netaliic fort was described as vell as the current now ledge of $\mathrm{pr}$ ceramics. The paperg were grouped into zechrical sessions ith the following headings: transformation studies. 110\% systers, mochanical propertas corrosion stuajos on ceranic fals ceramio phase studies andirradiation behavior. (FM)

$\langle 287\rangle$

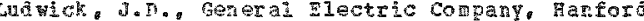
Laboratcries operation, Richlant, 角. 196

The Analysis of plutoniug 241 in urine. Health Physies, $6,63-t^{\mathrm{r}}$.

A tothod has been develored far the

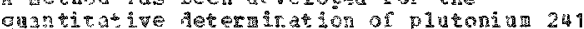
in exposed porsoniel through urine analysis, and was designed for use. when necessary. in

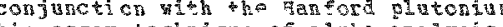
bio-assay technigu of alpha dalysis. This wethod is based or the recoverg of pintonin frovelectro-deposited disks and subsequent extzaction of the plutonda fro $1 \mathrm{k}$ nyarochloric acia juto a liquid scintillator contalnirg Aibutyl phosphate. Plutoniug 241 beta en $1 \mathrm{~s} s i o n$ is letected in a standara liquid ecintiliation spectrometer. and the yoeld for pluton at recovery asing spiked

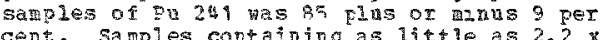
cent. Samples containing as little as $2.2 \mathrm{x}$ $10(\mathrm{E}-6)$ uc of $\mathrm{Pu} 24 \mathrm{a}$ may bo reliably detecte $\partial_{2}$ which represents 3.5 per cent of the maxinu formisstble dose 90 deys arter persennel oxprsure. (Auth)

$<268>$

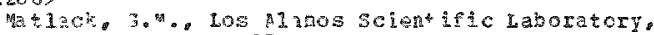

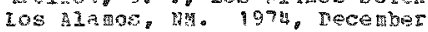

Thu chomistry of lutandu in Rolation to Its Exavior in Bologicat and Enyironmental systems. cons-740115; part of proceedings of the plutonia Informa ion Syrposiun bela in Los Aaros, Hew mexico, January $4-5,1974,(\mathrm{p} .2-7)$. Sh p.

Elutonim metal is ailvary-thite room tenperature and in the ansence of any surface oxidatin. Tt is har and brit de with a density close to 20 and melting point of 640 degrees C. The solid aetal exists in siy allotropic modifications, each of thich has different achanical properties, wuch as aifferent oensities and hatuesses. Du dissolves slowly in water; the comson dissolution agents in the laboratcry are acd and HBr. The alfha activity of gu rages from about 3 billion dis/sec/g to over 10 billion. This range comes from the fact thet Pu produced at high burnups and then recycled show an increasing fraction of the $\mathrm{P}$ 23 230 and Pu 240 isotopes which have shorter

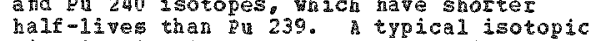
distribution in reactcrograde puligh be distribution in reactcrograde Pu right be 242 and orly $0.02 \%$ Pu 238 . There are g rays 242, and only $0.02 \%$ Pu 238 . There are ray decay of pu, although they are not neariy as acunant as the alpha particles. Ihe solid compound of pu display a vide range of clors. for exanple the fluoride is

blue-green, the sulfide golden $b r$ cnze and the chloriae is green. Pu in solution shous five oxidation or valence states raning frcm the trivalent to the heptavalent. All for $x$ of the comon $\mathrm{Pu}$ oxidation states $(3,4,5$ and 6) show a tendency to hydralyze; Pu(t) is the osidation state most subject to hyarolysis and $q u(V)$ is the least subject. A vnigue reaction of the least sub ject.

reaction of $\mathrm{P}$ a in solution is disproportionation: that is, starting vita any one oxidation state of Pu, ycu could yind ur with all four. In vater solution, pu bas the tendency to rolyarize. The pulons fcriage formation tenus to continue until large collodial aggregates, or polyoess tists. whose tolecular weights exceéa 200,000 . The polyuer is bright green and is inert to nearly all the ordinary reactione cf Pu. Some of the amions that rora conpleses

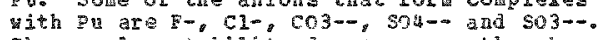
The coplex staility decranses as the charge on the cu ion aecreases and the divalent Inegative lons axe usuliz stronger corpled formers than the monovadent ilegative ions. Arion-exchange processes are inpertant for the purification or par several elements

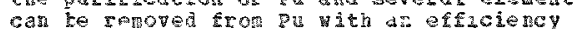
greater than $99.9 \%$. (Fra

$<289$

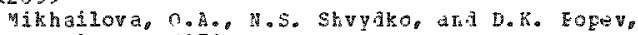
Not given. 1973 , Aagugt

Methed of peternining Flutonium 239 in urine. Gigiena i Sanitariqa, $B, 69-71$. (3ussian)

since purlatsed methods for pa 230 determination generally recomanded reagents ata resins not avajiable comerciallig in the ussR, locally available materíls ye irvestigated. I method was deviloped in which Fu(4) as the caprestonate is separated fron macro impurities by chloreferm utraction trom a sitric acid najum usint airconiar carriex or no carrier. Aa $24 \% y_{0}$

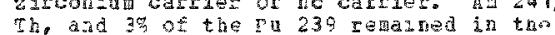
a dueous phase. The po 210 vas removed fror the plutonum vo procipitation on aichel the platonium procipitation on nickel chlorofor from the organic o chloroform from the organic asase the lanthan carrier ard was cointod after lanthan carrier, and vas conted arter further frocessing. The Pa
electroprecipitated. (TTT)

<290>

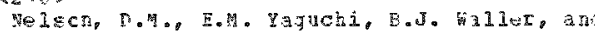
A. A higren, Argonn National Laboratory.
Argonno, IL. 1973 
$<290>$ comp.

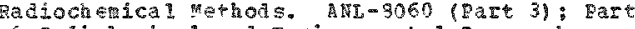
of Radiological and Frviron mental Besearch Division Annul Report, January through

jecember, 1973, (0. (-17). 897 .

3echriques to reasure Pu 239 , Pu $238_{0}$ sr 90. C5 137 and 日 samples of fresh vator, organisms, and sedidents are described. The procedure for initial separation fon vater saples.

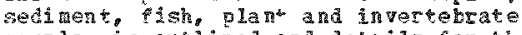
samples i outined and detis for the raciocherical andysis of Pa $\mathrm{Cs}$ and $\mathrm{SL}$ are

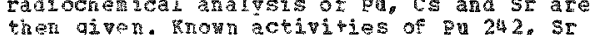
gh, and a knoun velght of stable cesiu are ac, and a knou velgh of stable cesing a ce acded to each saple initially a do then used to determine radicche mical racoveries. proparation of Pu 2 is of extreaty hish

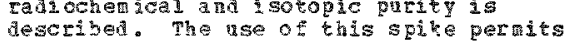
accurate peasurement of ralowherical yiela, whic maintaining a pery 10 backgrouna in the regions of interest. host ot the deterninations of gana-ray ait tita radinucl ides employ a $16-\times 10-\mathrm{cr}$ NaI $(\mathrm{T} T)$ crystal coupled to a $400-c h a r n a l$ pulse height analyzer. output frol this andyzer is ditrected sirutaneosily to a typerriter for pernanent cocy and to a keypunch to vermit

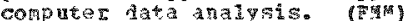

$\langle 291\rangle$

Sandals, F.J., and R. Morgan, Atonic Ener,y Pesearch Establisinent, Health ohysics an

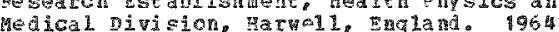

Procedure for the Deterantiotion of

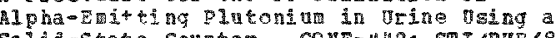
Solid-State Counter. CONF-448; STI/PUB/84; Sart of proceedings of Sy posin an the Assessment of padioective Body Burens in lan held in

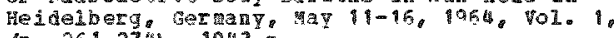
(p. $261-274,1043$ t.

A wethod for the routine teterandion of alpha-eritejing plutonin in urine is described. In evolvin this procedure various techilates for concentrating. purifying and electrotepositing Flutoniug weze compred, ard these investications are wuarized. in the procedure finelly sularized. In the proced ure inally aboted, urine is ret-ashed and the residue disscived in hydrochoric acid. Dlutonino Ithis this solution and extractod into rrom this solution and extractod into chloroform. Arter evaporation of the discrofor the residue is oxidiacd disscived in hydrochloric acia and the icor extracted into di-isoprogy ether. The aqueous phase containg the plutonim is evaporated and assolved in an mod anonim lectrodegosited onto stainless steel. 2untitative recoveries are obmained in the electrodeposition stage and on overall

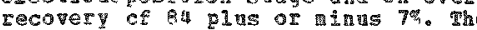
electrodeposited platonis is conted itb a solid-3tate (silicon faration atode) aetector in counter developea for this curgose. The low inherent back ground of this type of counter is effectively reduced stil further by counting only those alpha particles with energy in the 4. $2-5.4$ mev range. The good resolation which can be cbtaine ust thin electrode fosited sources of plutomin enables this nartow channel to be a sall 1 osses in conting efriciency. sand Loses in conting ecriciency. the biak actitity arising iron Joggents and the blak achivity arising from Jagen contaminats in urine is also zeduced by method is a pout $0.025 \mathrm{pCi}$ of Pu 239. (Antis)

$\langle 292\rangle$

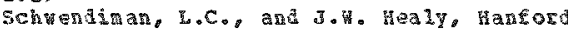

atomic products operation, Riehiand, Ma . 1958

A Senstive snalytical vethed for the

Derination of very lonevel Plutonin in

Naticns Ineernational syonsin on the peaces

ises of Atomic Erergy held in Geneta.

suitzerland, September $1-13$, 1958, Vol. 23 , (F.

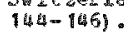

In the net method described, ancleat track orulsions replace the electronic counters used in the previous method as the in pha Farticle detector. The aralysis separated the plutoniu frca the urine sample and adeposated it unitorily on to a small disk. This disk vas hela againat the nuclear track ewilion efficiency, area exanned, area of eposit and expowure time. An

electrodeposition coll vas aeveletea ana muliposition equiprent designed to perait sinutaneous aralysis of as many as tyenty samples. The nallear track exision chosen to record the dpha particles antted was Kcear VTA emulsion 25 a thick on 1 by 3 in

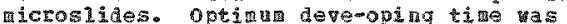
deterained to be 6 min in $1-19$ developer at 68 degrees $\bar{f}$ plus or ainus 2 degrees. radioa utographic "camera was constructed。 permiting the simlataneous a pirks. A scaning syster or counting as

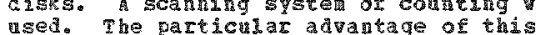
methou is shat there is vartually ne lint to wts ul tis te sensitivity since by its ultim te sensitivity since by increasing the exposure tive luost any destred sensitivity should be obtained. In a rcutine bioass progran designed to discover incipient platoning expcsures and identit such individuls who dey require vork ith
lest chronc exposure liability. this pethed has proved reliable, sensitive, and

adequately precise. (Pn)

ser also mucleonics. $16(6), 78-31$

《293>

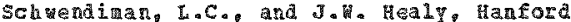

Atomic products operation, Fichian, 19. गทีย

Ruclear-Track Technigue fer Low-tevel Rlutonin in 7 rine, Pugleotics, $15(6), 78-81$.

A nuclear-track-ea lsion techrigue has been developed that is adequeely semsitive and reproducibie. The plutoniur, arter sepraton from the urine samle, is electrodeposited on a metal aisk. The disk is held against a nuclear-track endsicn for $168 \mathrm{hr}$. The nucleas track am $1 \mathrm{sion}$ chosen

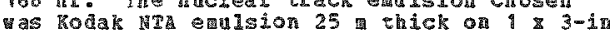
microsides. After enulsion develogment. tracks are counted uner a meroscope.

optina dereloging tive, whout agtation is 6 min in $D-19$ developer at 63 degrees $p$ lus or minus 2 degrees. Dxying reguireg 45 m in vith agitation and ashing, int. The aicroscovic connt of tracks is ade it

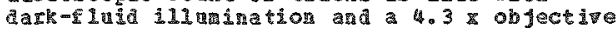
and $10 \mathrm{x}$ erepiece to gite total and lox eyepiece to give a total combing is employed. phe atection limit of less than 0.05 apm evrentig achieved on a routia basis is 20 enough co parit early rcutin basis is lovenough co par decosition. The orticulat advantage of the dethod is that there is virtualig ne 1 int to

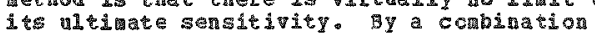


$\langle 293\rangle \mathrm{CONT}$.

of reduch ny source size and zacreasing the exposure timo, almost any desired sensitivity should be ohtained. Experiants have shown should be ohtaned. Experiants have shown feasible. Another advantage is the complete free don fron the nopredictable behavior of

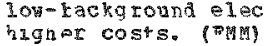

See also Proceeding of the $2 \mathrm{na}$ innted Nations Intermational swoposing on the peacerul Uses of

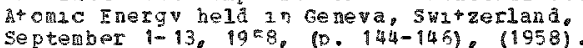

<as

Stower, B.3., F. F. Fruerger, and $W_{0}$ Stevens,

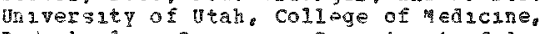
Radiobiclogv Buysion, Departaent of Anatory. salt Lake caty, jm. lank, septerber 30

The Peaction of Plutons $(44)$ wh the tror

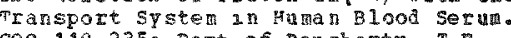
coo-119-235: Part of nongherty. T.F. Research in Falloblology. Senzannual Feport of Hork in progress $2 \pi$ the Internal Irradiation progran, (F

When human blood serum that has been taggea 2n. vitro wth mononer ac Plutonu un $(44)$ as subjected to gel filtraticn most of the Du (4 4) as found ir wo molecular verght rarges, that of the 1 or molecular velght seralaroteans and that of small molecules and 1cns. The dastribution of $D_{u}(+4)$ between the tho peaks was varable. In addition a snall amownt yas eluted in the highest wolecular vengt fraction. B a combation of gel filtratzon, ion exchange, and
elcctrophoresis the protean 1 the low molecular weight group that binds gu(s) has been ssolated and show to be transferran, been swolated and shown to be tra

plutcrum (t) a preared to be bound at the iton binding stos, and the reaction betwee

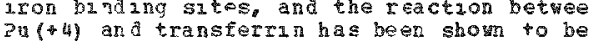
reversille. the stabliny constant of the coaplex was hrgh but less than that of the very stable aron-transfertan conder. The variation in alstrubution of Pu $(+4)$ between transferran and the 10 w. Th. Tegan thus 25 iron bour a by the transferran. (auth

$\langle 205\rangle$

Testa, C., ind 3 . Santor , Comato Nazanale pripnergia uciearf. Fad lotoxicology Laboratory ccupational Medicine Servace, Roge.

Sensative wethod for the Determation of Low urinary plutchill Levels in occupationaliy Exposed Work ers. Glornale di Fisica Sanitaria protezicne contro le Rafiaziong. $16(1), 1-6$.

The perfection of a sensitive and selective wethod for the periodic control of occupationally exposon personne 1 is presented. A IItre of urane was used. Batch extraction of pu(ta) is carried out in a nate 16 at nosphere wath 1 icrotene-710 (a azcroporous polyethylone) supporting tri-n-octylehosphane oxd de (TOPO) Pe-elution is oht an rea by refuction to pu(t) wh a wathe of hvdrochiorzo atd hydrozodic acid. After arying and rocovery with sulphuric acid plutonju is electrodeposited

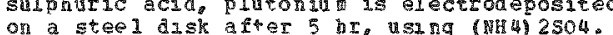
The als is then courted with a solud state detector mt a background of about 0.001

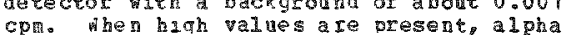
cpil. When wah values are present, algha spectrometry can also be carrued out. The
nethod gives a vield of $72.5 \%$. polonitu. thorlum, neptunium, uraniua, orotactinsum

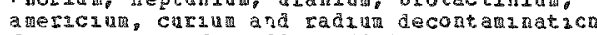
factors range from 30 to 13,000 . Blanks activity $(0.07 \mathrm{pcz} / 2 \mathrm{~h}$ hI $)$ was in line

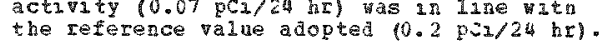
Ey conarison y 1 h andonacexchange resin Ey concarison ulh andonac exchange Iesin

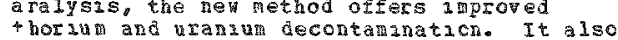

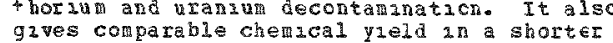
execution tial (Auth)

$\langle 296\rangle$

paghiri, Fo, Ohlo Agricultural pesearch an Development Center, Department of Agronony, mooster, OH. 1972

Decontamination of Solis containing Fissicn products. Coo-414-18, Part of Haghiri. F., AFC Final Techtscal seport for tarch 1971 to hugust 1972 . (0. $58-66), 67 \mathrm{p}$.

The method for physical removal of surface contanination after the applicatica of asphalt enulsion on case scil is dascussed. priants were condacted to exama effectureness of serera 1 compoumds

(urea-formaldehyde resin, pres rol-40 resin, Dresin-205 Iesin ard Vansayn-100 equision) as agents for erbedang soli surface

particles and to determan the avalability
of a given fissicn product to plants enbedded in these compounds. It vas stown thet Cresincl-40. Dresinel-205 and onsalyn-100 Etrisison spray forthed a satisfactory scil cryst wh fine sandy loang silt loar and sulty clay loan solis. The staolisty of the fila q ncreased with Increasing concent rat $1 \mathrm{~cm}$ of the coapounds. The experiment ath sold spaked wath 0.075 ucl ST 90 treated Dresincl 40 . Dresinol -205 and Vusabyn-100 Eulsion; frozen and thased, an then planted to oats showed that the actarty of $\mathrm{SL} 90$ ll to oats showed that the activity of $5 \mathrm{r} 901$ ancreasing concentration of both Dresirci-40 Increasing concentration ci both Dresinci-

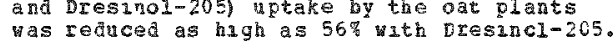
Although the actsvity of 5590 (Y 90$)$ an cat clants due to vinsalyn-100 was depressec. differer concentrations of thas ccopound had nc apparent efiect. It appeared that the compound ald not enbed the sutece soll partucles completely, or if the garticles were embedded the embeding fila eventuldy becane unstable under freezing and tha wing conditions resulting an separation of contamated sol 1 particles from the

eqbedang falat. (FM)

$<297>$

Langan, W. H. Los Alamos Scjentufic Laboratory

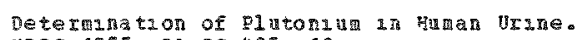
MDDC-1555; IA-DC-435; $10 \mathrm{~g}$.

A detalled account is given of the ccliection, ashing and analysis of a 24 -hcur urane sample for plutcnuma This is an account of the method currently in use at the Ics Alamos Laboratories for the blaginosis cr exposure of personat to flutonidu. The statstical method for evaluating cesults 25 a lso gavela (Auth)

<298>

Reller, C. Unaversity of Karlsruhe, karlsrube German Federal Repubilc. 1973, May

Chemical, uclear, and Blological properties of the Transmranum Elements.

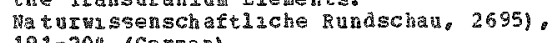
$191-204$. (German) 
CHE ICAL ASEETS

$\langle 298\rangle$ COHrs.

A detailed review is given of the chemical

and nuclear properties the biology and the

handing ef transuranics with comparisons to

other elements of the geriodic table. The

beha orior of the transuranics is largely

deterined by external, non-element specific intluences such as radioactive decay, release of hear and radiation. Pecularities such as microscale avilability and short hall-1ife have led to mew experimental techniques in the separation of the transuranics. (RAF) 
$<2993$

Eaturin, Gof, wot given. 1972 , Noveraber 1

Fatios of the Average concentrations of urandu and organic hatrex in wecent sea a wa ocean Sedinerts. Deklady hrademi Hakk SSSR, $207(1)$. 186-189. (Bussian)

Values of the ratio u/c organtc ware obtained on recent sediments of the nator seas and oceans of the earth. Tro classes vere Fecognized: mack ground on content $<5 \mathrm{x}$ $10(\mathrm{E}-4) \%$ ) and highes $(>5 \mathrm{~s} 10(\mathrm{z}-4)$ \%) relative unifornity of $0 / C$ (organic) among the wanles tested inajcated that on the whole the possibilstes of accululation of farinogenic o in the organic components of the hydrogenic o in the organic con
sedinents were litulted. (Rsw)

$<300\rangle$

Carnahan, C.1.. and P.R. Fenske, Teledyne

Isotopes, Las Vegas, 1 P. 1971, August

Digital computer Simulation of water masie.

ฟVO- $1229-173$; 41 p.

Initial stages of aevelopgent of a

digital-copputex nethod for sirilation of veter tabies have been ccmplet. The tethod way be wsea in Ieqions where hyarogeric data is sparse. A topographic surface. is parse. was smoothed. raised or lowered in ltitude. was woothed, raised or lowered in alditude provide a first apporitation to rine provice a first apprositation to tive toter takle. The Isse approzivation was the fitted to olserved pater elevticas at
preselected control poines. phis adjustaent produced exact fitting at control points nodes which do not correspont to conero? points were ajustea by arounts dependent or distance Erot all control points. The wethe was agpliel to the pat creek paley and Pahat hasa amas in pevara. possible deficiencies of the nethch requiring further develcrment inelufad lack of adeguate mean tor verifying or correcting a coupatea water

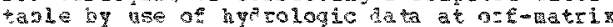
points, and lask of nears for datching

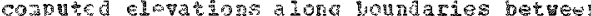
adicent matrices. conputer progran

functions are described and code list ing are जiven.

$\langle 3 C 1\rangle$

Cherảnesas $v_{g} V_{0} V_{0}$ and J. Schnorak (Translator), heological Institute of the Acadery of science of the 055 . Dating Lahoratory. Moscow. USSR.

Jy aram 234 in the croan. Part of cherlyntsev,

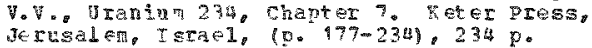

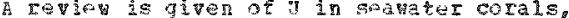
vollusk shw11s, ard dee sea deposits.

Stididas vere tade on the isntore compositios cf J In 2 in sperigens of water from the

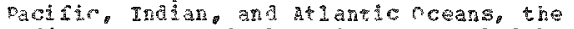
mediterranean ant the fea sea, sampin bots

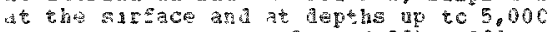

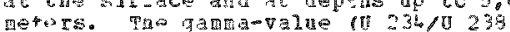

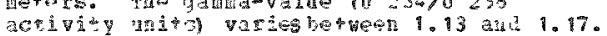

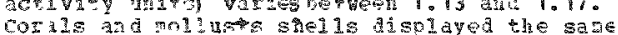

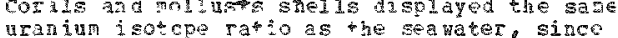
Mrani in isotcpe rat:o as bhe sea water thry as sal water to bwild un their

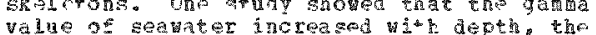
value 2 seavatar increased with depth the win which correspons to the whis oxp oxyen coneent. The avrsage content of tu in

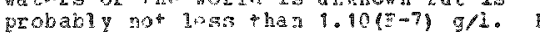

astimating the tine taken for river yater to Eill the bcean basth, it 15 anggested that $1.500,000$ years is the mana tis for the existence of 0 in searater. The ocean contain about 5 bildion fons of 8 of aczens of thousatis of tons escape evert year. The content of Th and also of Ionju and protactinu in ocean water have alse been determined. The dating of corals and wclinsts shelis is aiscussed vith menton mace of the use in level of the seas a a rece of the la in level or tie seas as a cesic of aeglaciation which eollored the ain quaternary giaciation. Studies on contain excess a douts of 023 and in rost crita cases are even dericient ulth respect to the equilibrin value. The gand values vasied the ayerage value. The sea cozes hovever as reraskable for their very high $\mathrm{Th} / \mathrm{U}$ ratio; these may be as high as 10 in isolated cases while the average value is 5.1 . The average content of 11 in oozes is quite high- $2 \mathrm{~g}$ $10(E-6)$ to $3 \mathrm{z} 10(\mathrm{E}-5) \mathrm{g} / \mathrm{g}$ and the urandu Leacied out of the cone ray act as an inportant source of $z$ upply of $y$ to the sea water. The u cycle in the sea ray be roginly represented as follch: elenents enter the sea with river waters, both as true solution iti collodial patticles cr as nater aksorbed on these particles. They then Ecro deep vater deposits. The is a ch is then leached out of these particle again becones only dissolved in water in the form of orange salts. (twh

Tale 72 shows 1 sotopie retio of 10 Tha and in certhic deposits of the world ocera. This is a rranslation of Report, URAN-234.

$<302>$

Coman, y... J2. Saraia corporation, Albuguerque No. 1960, Movereber

Plutonium contanation from one-point Detonation of an 8 or-25 (0). WT-1510; $113 \mathrm{p}$. (Secret)

<303》

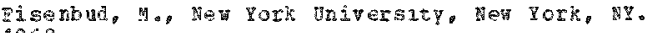
1968

Fadicrucidas in the Frvibondent. corp-670521 prosraphs on Haclear wedicine an piology.

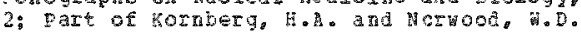
(rasol. proceding of $a$ symposian on the Tiannosis and Treetaent of Denoston padondelises held is Fichian. Washingtod, ay $15-17,1967,(5.3-19), 690 \mathrm{~F}$.

Trenty-five yedrs of exprience in the atcanc crergy industry hes shown that tadroactive substances can be anded wation. Traces of tission and activiation products can bo detecter in the envisondert and in some cares in human sock agd pisgues, bat the dose froe

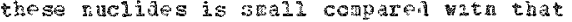
received forr the saturaly occurrigg radion uclides. Moreover, ossentidil ali fe the environmental contasination to date io ine to the testing of Iuclatr vapors: cortaninaton ford 1Tringtrial sources is

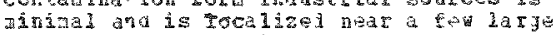
atenic anery tacilitios. A sonce of agposing in the future gay be tron tha use of Tationvelides like 55 a0, po 210 and adion uclas

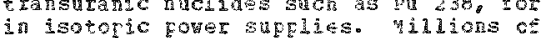
in sotopdc porer sugedes. Widions os

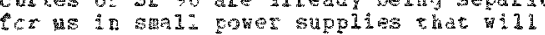
operate reather stariegs in ruate areas, in

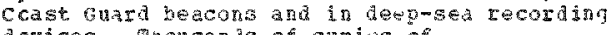
hevices. mousanis of curies of 
<30 3$\rangle \mathrm{CO}$ 期。

radionicities are also heing ueed in SNaP Tevices aboard satellites ig outer stace. Ore such unit containing 17,000 curies Eu 238 has re-er tred th at osphere prevaturely ard has presurablv barned up and become dispersed in the upper atrosphete from which if is in the apor atrosthere Irot which it is potentiat use of thermonuclear explosions for poreneful purposes is concidered. There is oescerul purposes is concidered hhere is a great deal ot prenusian about he Plogshar Proy tam as evidencod by the consideration

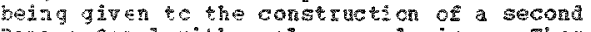

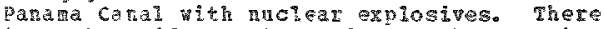

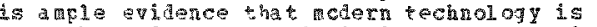
more than adequate to deal with the potential Iisk of radiogctive materials, and that the

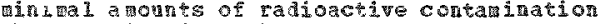
that resilits eron the ese of nuclear reactors and ather civilain aptications of atomic energy involve negligible risks tor which in return, there are tangible benefits. Perhags the greatest banefit from the use of the nucleas power is that as a substitute for cossil the is: it holps to redue ais polintion. (Buth)

$\langle 30$ is

ERery, R. R., and T. Garland, Sattelle merorial Institufo, Pacific vorthert Laboratores Richland 1974 , Decerher

The Ecological Behavior of pluton ur and Anericiua in a resh wer Ecosystem: Thase 2 , Tolications of oiferences in thansuran ic Isotopic ?atios. Bust-1950 (Part 2): Part of vaughas, 3. . . ot al, anual Report for 1974 (p. $99-19 \%), 238$.

The ecological benavior of Pu and an in a treshuter arocessing asterater pon has been sfutied to characterize the pond" iinclagy and aefine the isot apte istributions in the ecosyster. Results fron cistribat ions in the tcosyster. the study shor that the history of cransuratics discharged to the pond has and isotopic ratios. Vary large guartities and isotopic ratios. Vozy large garaticies

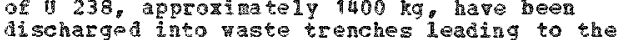
discharged into waste trenches leading to the 5ond. With regard to transurande isotopes. Fon unusulit high ratics cccur in the pon
The ratios of pu 238 to pu 239 , pu 2 in and A 241 to Pu 239, 240 occurting in the pond biota. are sign ificantly hidger tha those in enedirents. A common source "availate $e^{\text {pu }}$ and Al for pond biota is suggested by the rapid estabish tert of $\mathrm{Pu}$

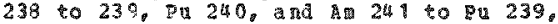
240. Iatios in goldfish (CRABSTUS) which yere experinentally introauced into the pond. 角thin 2 weks after the fish had been introduced into the posd they had accumatad transuranic ratios which were similar to those of othex pond blota and dissididax to those of the pond sediment. considering the rapid exchange rate f ater in the pond and rapid ezchange rate 1 inater ill the pon occurring pocurring in the pond is ecosyster it is is $n$ aval ablew to the bot is not the pone

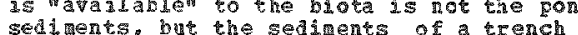

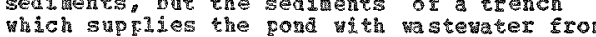
Which suplides the rond with

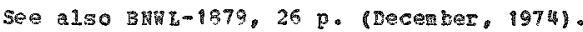

$<305\rangle$

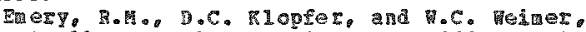
Batelle hemorial Institute, Pacific lorthest Laboratcries, Bleinand,

Fine Ecological Behatior of Plutonin and

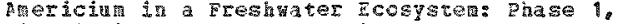
Litnological characterization and tsotoplc Vaughang. T. Bt al, Annual Report for 1974 aughang.

A stud concerned with the ecological behavior of $\mathrm{Pu}$ and $\mathrm{ar}$ is being carried cut in a shillow aste pond (14 acres) which has existed and recosed pu prcossing wasta for existed and recerved pu frccessir about 30 years. The syster is ultra-evtrophic and the ajor organdsas are

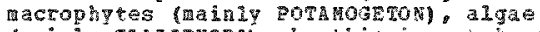

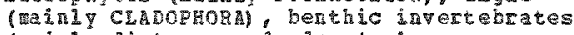
(mainly dipteran and odenate larvar. hemipterans, anphipods, an gastrcpods) and geldsish. Sedignt are the principal repository of Pu and sa centaining about 390 pci of Pu 238, 239, 240 (signa Puil/g (dry) and about $83 \mathrm{pci}$ of $\mathrm{Aa} 24 \mathrm{Mg}$. Pond yater hat wuch low concentrations of signa Eu 10.01 $\mathrm{pCi} / 1)$ and $\mathrm{A}$ (4) $(1.1 \mathrm{pCi} / 1)$. In the biata the principal concartrator of $2 \mathrm{u}$ and $\mathrm{n}$ a is decomposing algal aterial, the pajor feeding substate for the systed, containing atont?

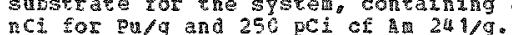
Hatercress (BORTPEA has calatively high watercess (RORTPEA) was calatioly high concentrations or slgaz pu and an 24 (532 and 125 pCi/g respectivelyl patios or gegerally higher than thcse of the sedinents (0.9). It appears that vast of the pond

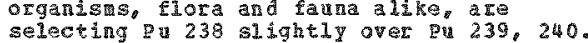
Plant materail having the highest accum 1 ation of $\mathrm{pu}$ hat ratios ranging from 1.3 to 1.6. OnIg goldedsh ascle tissue hat a ratio favoring 239.240 Pu. The ratio ci Pu 230 to 239,256 qu in the pond water is 3.5 which ma be reflected in the relatively high ratios of biota. Algal floc and exerging chironoaids were the only biological ccaporents with gatsos of 324

lcapor than that of the sedinents $10.13: 11$.

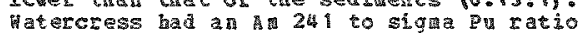
egual to that of the sediments $(0.23)$. while the remaning biota sampled had 3 at 2 to the remaining bita samples ranging from 0.4 to 2.0 . sigma ratios

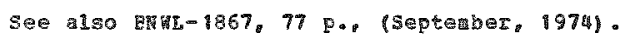

$<306\rangle$

Hardy, E. D., J5. Health and Safetr Zaboratory. Environgental studies Division, Ner Tork, Ut. 1974, October

Depth Distribution of Global Fallout Strontiu 90. Cesium 137, and platoniua 239, 240 i, 3 Sandy Loa Soil, HASL-286: Dart of Hardy, E.E.o Jr.. Fallcut Progra guarterly sumary peport, June 1. 1974 through septerber 1,1974 , (f. I-2 $I-10 \%, 169$.

The objective of this study was to neagrac the depth distributions of $\mathrm{St} 90, \mathrm{Cs} 137$, and Pn 239.250 on bjandual asis to estiva te the rate of arement. The first of seris of deper profile sampes taken at an und it andyzed for these isotopis. cesiug is7 shoved the least tencency to migrate downaro Eollowed by $\mathrm{Bu} 239,240$ and $\mathrm{Sr} 90$. (Auth)

《307>

Jordan, C.F., HoL, Stevert, and Jore kithe, argonne lasional Laboratory. Radiological and En

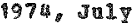

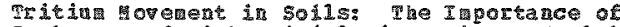
Exchange and high Intial Dispersion. Heast Physics, $27,37-43$. 
$\langle 307\rangle$ CONT.

Results of a fiela experitent to determine tritium measurement through sol 1 vere conpared yith several predictions made by a aatremat cat model. he inpa parameters of the wodel nere evaprtranspration, soll water

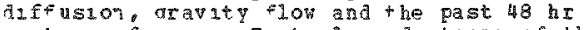

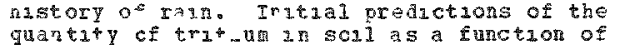
time werp about an order of inagnatade too 10\%. The t2t was greatly aproveô when * rutlus exchange with hydrogen on soll particles and a blgh $3 n+121$ dispersion throngh large soll pores were incorvorated unto tne noded. (anth)

$\langle 308\rangle$

3oryersen, C.D. Brighat Young bnzersitye

arovo, ittab. 1970

Free tiving patos of the vevada mest Site, Final Report. $\operatorname{con}-1739-4,47 \mathrm{p}$.

The 2 mfrctance of Aetermanang the effects of nuclear veanons testing on phytophagous at asstrbution and compositzon and to exame what free invira thites arf present at the pevada pect Site is apparent if nuclear energy is considered a tactical weapon. objectivas of the study were to axamine tro population rosponses (species a yersi 4 an trophic organazation) of desert mates, under field conditions te zonzing raduation and particalarly beta radiation. Five saplang sites Forthest and northoast of project car alolet fround zero pere designated. and the sonrce of radiation was he fallout clou fror cabriolet. Severteen pherotypicaliy fror cabrolet. severteen pherotypically distuct grous of ates vere laentit

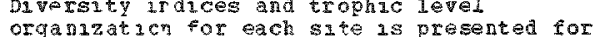
organizat 1 ch for each ste 15 presented for
Jife 1968 through septerker 1969 . The na jor forn of radzation was beta. but no atteapt was made to partition the effects of ganme and beta. pesults suggest that species diversity tended to inerease or reun stable when subjected to radution stress. analys 3 of trophic lavel organization agreed gerezaly with other findung that the predacor-rev ras 10 decreased with stress and that a m te predator was wore sersith ve to radiatzen stress than the wat prey.
moverer, two of the sites ald not conforin to predicted results. hore study mat be made pred lcted results hore stady wist be rad of the apparentiy unpredrctable and often oxtrene ardations $\mathrm{n}$ astrabution patter
of groups and the bology of the group. raxoncracal lists of olant species and faunal Taxomenacal lists of plant 5
sampling are includea. (BRi)

<309>

Koranda, J.J., and J.R. Martin, La wrence Livermore Ia boratory. Blomedical DIVision, I1vertore, $\mathrm{c}$. 1971: 1972, Ju1 3

The movement of Treterin a cons-710809 UCRI-73178 (Rev. Il: Part of Mghiss., A. A. ard Carter, M. W. (Fds.)

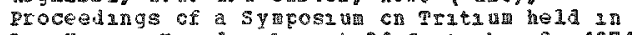
Las Vegas, Nevala, August 30 -September $2,1971$. he ssenger craplics, Puhl 1shers, bas Yegas. he ssenger graptics, Puh isher.

Tratiun mevent in ecological sysems is complex a na inyolves lany combartments, both cosplex and involves lany condartments,
physucal and byological. The uptake of

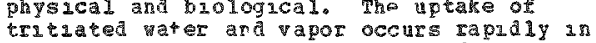
planes and annals, but becalus or the rapia turncver of boly or tissue-tater in living organds, the half-tames are generally short. Plathalf-tines may be measured an mates or hours, whale anzal body-vater half-tines are one to to days to 15 days.
In plants, organze fixatior of tratung occurs even 3 exposures of short duraticis and the half-time of tissue-bouna tratzum is corsaderably longer than that in

tssie-vater. Tritum movener to in sois 39 affected by sol 1 characteristies such as bul density and the distacentst of tho tritiul Folse whin the soid system by subsequen increments of rain or urrigational water. intermediate to long half-times are observed in sol 1 systems wh the major factors a fectung loss rates being porosity and raunfall rate. In well-araned, porcus ccils, vapor losses a a be effect ive in dssipating trical pulses vhile 1 n denser solls whth gher ranfall rates, leaching of scil water is the domant factor. The half-tuse of tratiug an giants grouan on tritum-contamared sori is extended ly the longer half-tine in the soll. whe root ache of the plant wil contall tritaug for varyan of the plant w1l contan trithum for paryang and soll characteristacs. The tollowing sumary statement concering the movenent of sumary staterent concering the worencht The behavior of tritzula 12 son sisters exhibits rapad ind ial loss with the ramaning activity decaying wh intermedate to long half-times, the half-tide or tratzum in the sholl syster wall determne the effect of the exposure on the rest of the ecological syster. the behavicr of tritau an plants is sumlar for vapor of $11 \mathrm{gu}$ a exposures wath a large fraction of the deposited activity beang lost in a short-13ved coaponent of tho half-life decay. Tre benavior or tritiul $3 \pi$ ecological wystems wil vary vith the flux os vater through the system and the rate of byosyrthesis. Haif-times in agricultural brosyrthesis. Half-times in agricultural ircorporation 11 occur. (Aat

$<310\rangle$

Mi.yake, Y., Y. Suginurd, and E. patsumoto, Hetecrological Reseatch Instatute. Koenjz-kata,

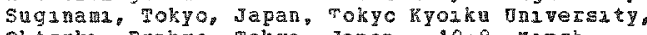
Ohtsuka. Bunkyo, Tokyo, Javañ. 1908, Masch

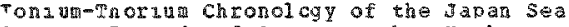
cores. Recerds of beeanograchie morki in Japaln. 9(2), 189-19\%.

The rate of detosation of tho cores collected at the aepth of about 3.000 in the central arat of the Japan sea basin was studzed by gart of the Japan sea basin was studied by showed tha rate of deposition of

Showed 5 ha rate of 14.5 $10(\mathrm{E}+3)$ y for the core $364-21$.

an/ $10(E+3)$ y for the core $154-21$, the surface repsect vely. Uraniug content in tac surfece layer was about $3 \mathrm{pgra}$. In abrapt zncrease in
uranam content was foum below $15 \mathrm{~cm}-20 \mathrm{~cm}$ uranam content was foum below 15 ch-20
crom the surface which contunes to the betron of the core of 1 long. This may ke related to the great sea level change durang the last glacial perzod. (auth)

Table 1 shoms act 1 vity ratios of $T h 230 / T h 232$ and $228 /$ Th 232 and total arounes of th and 3n Selfu core $364-19$ in the Japar Sea. Table 3
shovs total anounts of 0 and activity ratics cf v $234 / 0238$ and ofh $230 / 0234$ in Sencu core क्ष $64-21$.

<311>

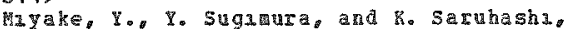
Meteorological Research Institute, Koanjalkta suginal, Tokyo. Japan. 19\%3, larech

content of Diutonum an hiver water 1 Japan. Papers 1 M Heteorology and Geophysics, 24 (1). $75-78$. 
$\langle 311\rangle$ CONT.

The content of plutonim in the vater of elgnt ain rivers in Japan was deteraned. The average value of the total content of plutonium is $1.4 \% 10(\mathrm{E}-3) \mathrm{pCi} / 1$ in which $0 . \mathrm{B}$ $\mathrm{x} 10(\mathrm{E}-3)$ pCi/ 1 is contained in the suspended

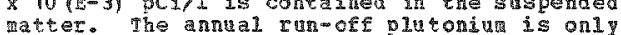
$0.12 \%$ of the accumiated plutoniu on land. Q. $12 \%$ of the accumulated plutoniu on land. adsorbed cn soil surface firnity and it is difficult to be leached out. (Auth)

Table 1 show the pesults of analyses of Pu 239 . 240 in Jacanese rivers.

\section{$\langle 312\rangle$}

Panderscn, $D_{0}$, and $J_{0} S_{0}$ Cornett, Rationa 1 Fe sources La horatories. Ias Veqas, 1 . 1973, hay

Wumerical Frediction of the Mesoscale Transport of tuospere EEluents: Philosophy and Horphology of Fxerimental hcdels for predicting the rind and potential Radiological Fields over the Nevada Test site. WOBA-TM-FRI-ARL-37: $M P L V-35 i-28 ; 56 \mathrm{p}$.

Tho experimenta 1 numerical models are described and entatively yerified. one adel predicts the mesoscale wind field over nountainous terrain and the other wodel forecasts the temporal and spatial changes in the airforme radfoactivity fiela that might be associated with an accidental release of debris during nuclear testing on the Nevada Test site. A a esoscale wind-prediction rodel is derived from the a ssumpion of the conservation of vertical wind shear for 2 tiac period of at least 6 hro oper an area $160 \mathrm{z} 160 \mathrm{n}$ m. This assuption is closely analogous to the conservation of horizontal vorticity. verification of the

wind-prediction wode? is accomplished through two different mores. First, 10 independent cases of different rind reques are used to werify the wind predictions for three aif ferent ations. The average

root-rear-souare error in sved for these

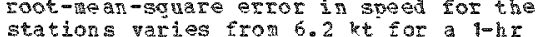
stations varies ion for hor a l-hr prediction $409.8 k$ for a hoh prediction. Second, Eor 20 different independent cases,
comparisons against persistence forecasts and conparisons against persigtence forecasts an forecaster for Yucca Flat, showed that the aodel did as pell as hoth for a 2 -hr prediction and wetter than both for a $5-h x$ prediction. The radiological-orediction model is difficalt to verify, but preliginar results 100 k relistic. In the single case used to verify the radiological forecasts. the model predicts the path of the debris cloud tc be too far east by about $13 n$ ris. 2 hr after detonation, and by about $20 \mathrm{n}$ mi. 3 hr after detonation. Ahove the 7000 -ft level, the speed of roverent of the cloud center is too fast by about 10 to 15 kt for a 3.5 hr. fcrecast. mhe $7000-5$ t trajectory compares reasonably well with the estimated clowd cositions reported by pilots, the cloud positions reported by plots, the predicted cloud center trajectory heing vithin about 8 n
centrot of the estingted cloud foracast. Predicted eloud-center $187-2 c t i v i t y$ palues are about an order of nagnitude too large: hovever, it is not know if the aerial-sampling ata used in this verificabion were taken in or near the region of naximu activity beyond $n$, 5 he after datonation. (Anth)

$\langle 313\rangle$

Robertson, D.C., Battelle Memorial Institnte Daciejo Northest Iaboratories, Edological
Sciences Department, Rchland, Septeaber 8: 1972

Influence of the Ehysico-chemical Forms of Radicunclides and stable Trace Elemente in Seawater in Re lation to optake by the pante 3iosphere. Buth-SA-4048: COHE-710988: Part of proceedings of a $\$$ yaposiun on parine Rad cecology held in Hamburg. Ger any, Seprenter $20-24,1978,($ p. $21-93), 214 \mathrm{p}$.

In laboratory egperimenta ama in actual field studies gross differences in the biological utake between radicnuclides and their stable isotopes fron seawater have been observed and atcributed to differences in physico-chenical form. These toras are usually classified into three categories, narely, species in tithe solution, collodial soices and particulate fors. The most important Fadionuclides entering the arine envisongm are those with relatively long hall lives and the ability to be sapidiy and efficiently taken up and retained by the marine

biosphere. peutron activation ptoducts of biologicaliy essential transition alements are freguentiy accumlated to a very high are Eregienty accumilated to a ver oredoninant activation products which have been observed in fallout and efluents from nucleas power reactors inciude $5055,2 n 65$ nuclear power reactors inciude 55 ,
co 60 and hn 54 . These elements are

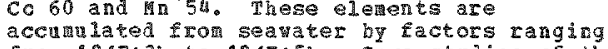
from $10(\mathrm{~B}+3)$ to $10(\mathrm{E}+5)$. Case studies of the influence of physico-cheacel forms of radion acides in relation to biolcgical urtake are presented for Fe 55, zr 65 , Ru 106 and $\mathrm{Qu} 239$. Pu 239 concentrations in ocern surface aters range from $0.11-3.0 \mathrm{~m} 10(\mathrm{~T}-\mathrm{m})$ cifing $(1.8-48 \times 10(E-15) \quad g / k g)$. The concentrations of 2 u 239 in marine organis

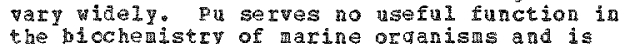
co-accumiated ing ingesticn of focd, water or sedinents or is adsorbed on the outer surfaces of organisus. It appears that the surfaces of ogganis acjority of the plutonila present assiniation ainly in a particulate form. assinistion and in a Eariculate form Fer seaveds and certain crustaceans the
relatively high accumiation of plutonima appears to be a surface adsorption process. This celatively bigh accumiaticn of platoniun by seaweeds suggests that the critical pathwa for pu 239 from the ocean to mali might be by consuring edible seavead roduts. Areas os reeden research on the distribution and behavior of vasicus forms of oceanic constituents are discussed. (F)

Table 15 shous $D$ u 239 concentration in varine organisas including fish, plankton, clars and starfigh.

〈314

Silker, pacific rorthrest Jaboratories, Richland, HA.

Plutoniu Concentrations in the Pacific ocean.

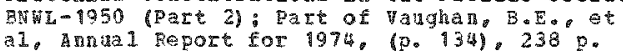

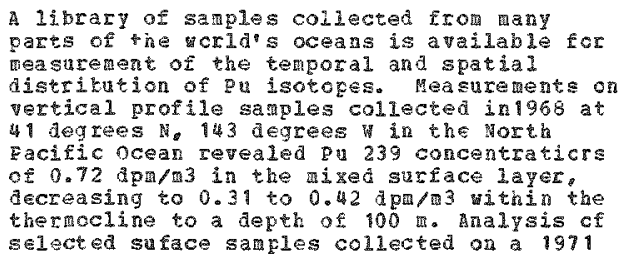


$\langle 39\rangle$ CONT.

crul se from Saattle to Smoa showed $p$ u 239 concentratons which averagea 0.30 apm/n(3) in the 30 degrees to un degreas lat litue cand 1 ncreased to $1.0 \mathrm{dra} / \mathrm{m}(3)$ a 20 degres

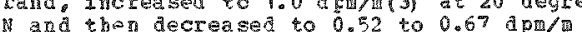
(3) at tne equator. the $239,240 / 238 \mathrm{zu}$ (3) at the equator. the $239,260 / 238$ Ru 11

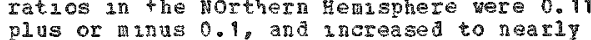
.3 south of the equator, reflectang the 17 troduction of Du 238 tc the southern Hens phere by fasiure of $5 \mathrm{Am}-9 \mathrm{~A}$. In the same year, samples were collected along the eastern boundary of the zacisic ocean. Fron the equator to 10 degrees $S_{p}$ the $239 \mathrm{Pu}$ concentrations averaged 0.18 apof north of the equator the concentration was gulte constant, averagng 0.31 dpa/n(3). Thas is interesting from tho sandponts. Fusst, ro concentration vaxinum in the $p$ in degrees $v$ latitude rezion. where arastically uncreasea concutraticns of Be(7) and shorter lived fission croducts were Be (7) and shorter lived rissi or seen. Secondy there vas no
concertrationgradient $1+h$ lyereasung concertrationgradient ith increasing latztude. Both of these condations ind what the water mass in this reglon was well-howogenized as a result of years of

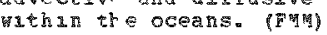

〈315>

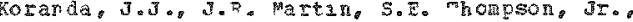

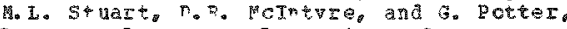
Lavence L I verwore Laboratory, Livermore $\mathrm{CA}$ : W. S. Fvironmertal Protectior Agrey, Las Vegas, 14. 1973, octoner

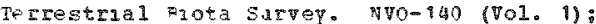
Fart of nneretak Banlolonical survey. $225-3481.736$.

The dustrinut son of radionuclutes ar the terreste al bata throughout ta 1 stands of werepas atol generally conforms to th resuits of the onvironertal radzation survey. on istands with olevated levels or raduatror, the brota contaned elevated concentration of radiontuldes. The nost proninent radionucindes are cs $137.5 \mathrm{r} 90$. Fe prominent radionuclides are Cs

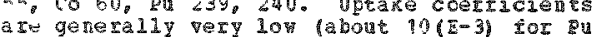
$299^{2} 240$ is plants. and only occassona comcentration effects are seen for co 60 cypacally in the livers of and mis. effectively transerrea radonaclide unth the terrestrial ecosystens or Fnewetak stold apears to be cs 137 . Fadionuclides such as ce 60 and Fe 5 a enter the elenental pools for those elements and are ryolcally found Wherever nose elenents accundate or seguester $2 n$ and nal tissues. L2vers, kidneys, and hepatocancreases are such suth in matsals, bords, and crustacea. Most radionuclide a atributions in elements of the terrestrial biora sabied in the surve ccrrora to the classical patrerns that hat evolved in the degelopment of radioblological

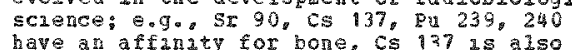
foun $1 \pi$ piysologicelly active tissues sucn toma in piysuologicelly active tissues sucn retaned in tho diver and haney. one retaned 2 th the divet and kidney. One date

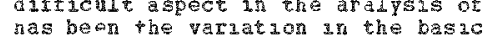

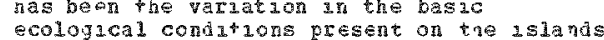
ecological conditions present on the 1 surveyed throughout the Atoll. Thas, a
concentration tactor deteraned fer a species when as colonzzing a catastrovhically A 1 grurbel habitat ay be ate disterent for the salie species grcurg in a stable ervirorment in clinatic ana edaph sc

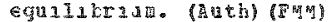

Tabie 59 givas ralioruclide corcentratzod leved

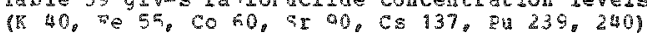
for terrestral bata samples collectad at Enewetar Aeoll, October 1972-Jaklary 1973. able 76 Jives the distr butzon of radionclides in terzestrial biota and $\$ 0113$ or dice,

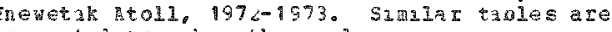
resented ror the other 2 slands. 
4316>

Carrard, co, and $c$. pilet, comissariat a 1. Energie Aconicue Division de metallargie et at Fude des Conbustibles Nucleaires. Fonteray-aur-roses. France. 1073 , october

Isotopic Cardje pacenaker safety Tests at 1300 Degrees centigrafe and 300 Degrees Centigrade (Source with Internal pressure and a Simalated Fuel). CER-P-44R; 23 p. (Fench, Fnglish Sumaty

In accordarce with the sarety guidelines which are specified by the wal ear Energy gency of the $n$. E.C.D. corganization Eot Foncric cooperation ant ceveloptent the test prchrat on the entire darens alcatel reatroni ty o ooos cardiac pacemarer has been continged vith fire testing $(300 \mathrm{C}(1472) \mathrm{F}$ ) for 30 mintes for 30 minutes and cremation testing $(1300$ o (2372) E for 30 minutes. In difiton to the previon tests, a simuted fuel was used in tho source, and the testing was conducted ander a pressure inside the inner tantalun capsule, corresponding to the presgure lualtup after at least ten years of operation. The fisst part of the report rresent the reasons of the choice of natural araning for the simuted fuel: in the second aran thita and this parts respetion the results of the testing at 800 degrees $C$ and 1300 degrees c are described. In all cases, the tantalua capsules remined fuld tight and no boserved. (a uth)

(E) Stianateur Cardiague Radioisotopigas Essais de Securite a $1300 \mathrm{C}$ et a $800 \mathrm{C}$ source avec pression I the errect colbustible actice

\section{$\langle 31\rangle\rangle$}

Doran, H. T. H. S. Atomic Energy Condission,

Nagnitude of neposited Radiondide proble Ba sed on Fut ure bage-citilian As pects. comp-67052\%: Monograph on wuelear medicine and

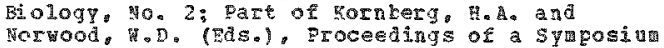
on the Diagncsis and rreathent of Deposited Radionuclides held in ichand, washington, hay $15-17,1967,(\mathrm{p} .471-481) .680 \mathrm{y}$.

The future uses of the increased production of radicnuclides can be categorized as follow: il source of heat and power, 2) medical alagnostic and therapentic applications, 3) improvements in general bechology including industral and agricultural, and 4) new epplications in scientific research. The grow of reactors in size and nuber is revieved, also the anoures and usage of radioisotopes produced by the reactors. Fhe use of radioisotoces as
a source of her and electricity is discussed in relation to space vehicles, veather predistion, navigation and commulcations satellites. The Eroperties of isotopes i portant for power sources are presented. bont 30 iscotopes are romisjing for porer sources a re resented. Alout 30 isotopes are pronising as fuel. physical nroperties and cotental costs which malse the attractive. of the nine practical make ther attractive, of the nine practi radicisorope fuels, the four beta-gana erdters (SI $90, \mathrm{Cs} 137, \mathrm{Ce} 144$ and $\mathrm{P}$ 1 147 ) nucher fuel reprocessing plants. H firth nucler fuel reprocessing plants o trith beta-gana enter. irfadiation or a stable isotopic target in nuclear reactor. The other fon are all alpha exters: PO 210 , 233, ct 242 and ca

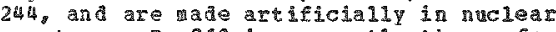
reactors. Po 210 is currenty the prefersed
Suel for short-1ived space poner systens. For long-lived space systers, pu 238 is the Freferred fiel. For long-ijved terestrial rissions, sr 90 and co 60 apgear to be best. wherein the higher cost of pu 238 must be afforded. The alagncstic applications of cadionucidaes are presented in tabuar form also the thisty-two yama or

positron-emitting and seven heta-enutring radionuclides in wedical use ate ij sted. The halth and safety problem was also discussed.

$\langle 318\rangle$

Mulins, I.J., G.M. Matlock, J. Bubernak, and J.A. Reary. Los Alamos Scientific Laboratory.

Characterization and Exoperties of heaical-Grad

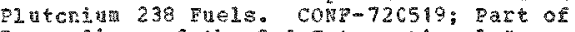
Proceedings of the 2nd Internationat syaposiu on Porrer from Radioisoccpes held in maxide

The Pu 238 requirements, $55-90 \mathrm{~g}$ for a a artifical heart or circulatory assist device demand a fuel having minimal radation properties. mhe preparation and evalation of potential pa 238 fuel ferws at the LOS lawos scientific laboratory has led to the development of four vuel compositions. electrorerined atal, Pu $238-3 a t, 7 G a$, Pu 230 $*$ and 23 Eub2. The dater 3 ruels are ade rom electrorefined Eetal. Theoretical and experimental studis ot these tuels led to the conclusion that pu 238 Puoz is the preferred composticn for high te a Elicition in the artificial heart progra whis fuel is prepared as a pressed a d sirtered oxide. Procedures have been developed for preparing and chatracerizing clindrial oxiae sources varying in size frog
one to yifty wats. (Auth)

<319>

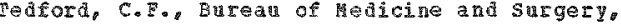
*ashington, DC. 1968

Magnitude of peposited radionulide probien Based on Future Usage-Defense dspects.

contr-670521: Monographs on muclear medicine and Biology, 2: 2: Rart of Rornbergs H. A. and

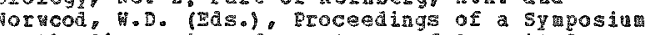
on the Diagnosis and Treatrent of Decosifed Radicruclides heid in Richland, majngtor, May $15-17,1967,(\mathrm{p}, 482-686), 680^{\circ} \mathrm{p}$.

The vân's interest and use or nuclear energ dates back tany years to 1939 when it was the Eirst governatertal agency to erpend woney on nuclear fission. During the 23 ensuing years the mavy has become one of the largest nsers or nuclear energy uithin the united states. * clear energi is videly used whin the rav fcr nuclear propulsion, medical diagnostic and therapentic purposes, research

application and in auclear weapons. velear warheats have posed problems oith respect to $r$ adiation safety $2 \pi$ the gast. However, it should be eqphasized that the wowever: serious accidents that have occurred are very

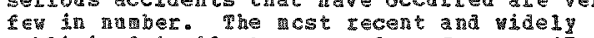
revin indiner. The cost recent and videly

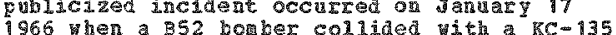
Tanke ircraft doring refaeling operaticn Tanker arcrart doring rekeling operatscas

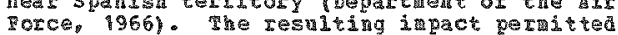
rotce 1966 ) the weontroliea dispersion of folr nuclear vapons throe of which foll on 3 panish
and one in the mediterranean sea. The and one in the redterranean Sea. The location of the fourth veapond remained a
speculative atter for a bout three month. large-scale operation continued on land and 
PETE

$\langle 319\rangle \mathrm{BN}$

sed whil march $2 \%, 1$ ginf when id thas renoved

fron the sna. Pecautions vere taken to

prevent gross oxposuros to plutonim. The

prevent gross hrosurs to plutonilu

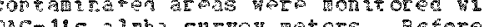

completion or the task, ceveral ton os

topsoil vere collected, sealed in barels an removed to a surial ground in the ongted Stares. Accidents of this nature are the

e zcaption rather than the rule. To majntain

a proper aesense posture, eertain calcolated

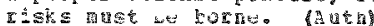




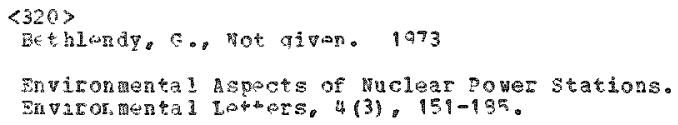

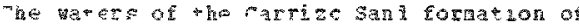

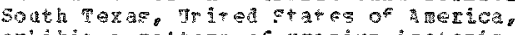

$<3223$

Fu 11. B.9. Brookhaver National Baboratory. IIptom, Eong Island, HY。 S7a

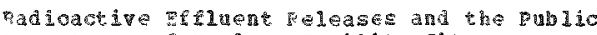
Acceferee of huclear Facility siten.

BNA-19492: ConE-741210; IAEA-3h-118/45: Pare of

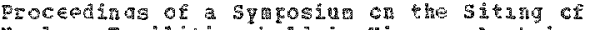
puciear Factlieles held in vienna, Anstria. Decenber $0-13,1974,(19 \mathrm{po})$.

A palic controversy arcut the tisks $\mathrm{trch}$

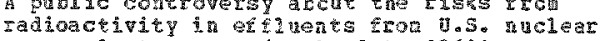
power nlants arose in tho late $960^{\circ}$ as power plant arose in tho late iged their whilation as growing torard scientific critics alleged rariourly that the existing piants hat occasioned excess inrat mortality in the it vicinisies, and that sne growth of ynclear power woul produce lazge increases in the carcer death rate in the general popalation. The controversy occasioned by thase aliegation 1 ed to the

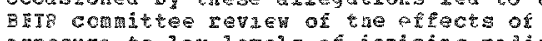

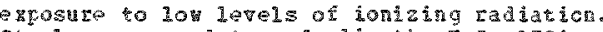
te also appeared to underlie the U.S. Aacis

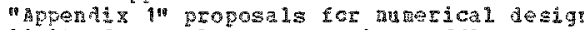
lints for nuclear pover plane eflatents. These provosals are intended to lint the dose of any nearby arividal to empro This critical revao ind inces that the criticis allegaticas gere oither whtout sobsance or irfaevat. jsing effluent

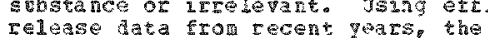
pepulation health rish tron pover teactor

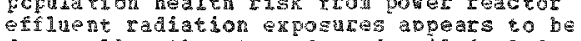
far salder thas

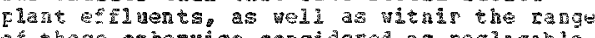
of those ot hervise corsidared as megligible. such conperisons are suggissed as more

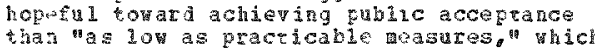
servo to pragerase the risks of radiatict. (A)

<23:

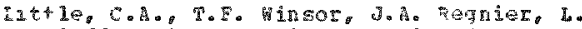
Harblore, and $\bar{r}$.

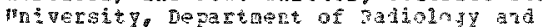

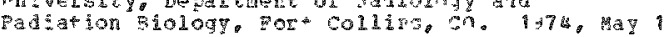

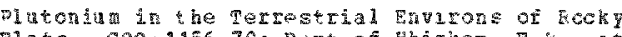
lats. con-1136-70: part of whekes, Fow.. et A. 12th Techrical Eroaress Beport on

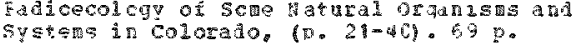

The Fort sumarizes experinces during the periol hay 1, 1373-Aorii 30, 1974 at poeky Flats with Iegara to field sangling, saplo rocessing, analpiteal procedures, bot 10

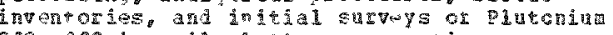

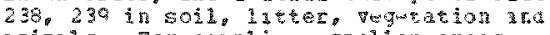

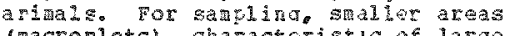
(racroplots) characterist of large pcrtions of the site were chustio Four genera and secies. representative or the

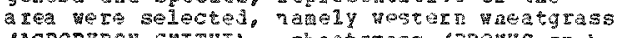

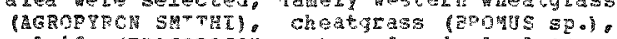

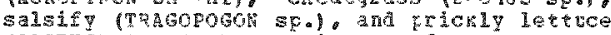

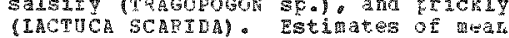
concentrations of gu in various cosysten

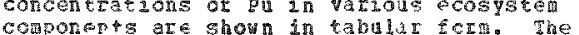
ate indicate that soil is by 2 te tne largest

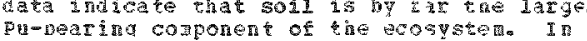

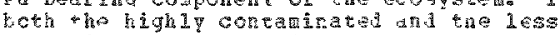
contan inated area scil a coars to have areater than 98 of the total Pu for a jivea square weter. Fot he less contanat a - tudy area, the constainatich afeears to be

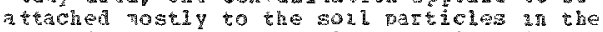
apper 3 en, for the bignig contaliated otudy area, ovar one-half of the cotal seses to fe 
$\langle 323\rangle \mathrm{COHT}$.

about $40^{\circ}$ appeass in the top 3 cra The ratio of 2 u 239 to pu 239 in soil as mell as in vegetation and small aamals are given. In the highly contatinated macropiot the ratio at the surface is anout 61 and decreases to about 39 rear $20 \mathrm{cr}$ aepth. In the less contaninated macroplot, the ratio is mear $4 \mathrm{c}$ at the surface and decreases to less than 10. The folidge group has a mean of 21.54 vilie the root group has a man of $5 \% .00$. It appears that vegetative structires closest to the scil have the pu isotopic ratio approaching that of soll. The mean ratio values for manais range from 11.04 for interna 1 issues of pocke gophers to 41.85 for etternal tissues of deer aice. Studies ror entenal tissues of deer mice. studies are undervay concernang soll woverent and the tanster of
vedetation. (E)

Tabie 2.1 shons the vertebrares observen at Booky sats faving class, weientific cassification an comon namel. Table 2.6 shous 2 u concentration for various terrestrial ecosyseer components (soil, sumface litter and detritus) coots, standing vegetation.

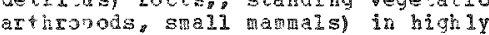
Cor a d nated and less contaninated study areas at rocky Flats. Pable 1.10 shows gu 239 don/g/Da 238 dpm/g in vegetation from the highy coneamnated study aroa at pocky Flats. Table 2. 9 Shons Eu $239 / 9$ a 238 in soils from Rocky Iats.

$\langle 32$ aी $\rangle$

Lungarong I. A. vingersity of hinnesota, Nas Distribution of Iarge atrosheric Particies. Fh. D. Thesis. university of Minfiesota; thi D. Tissertation Afstracts, vol. 34. 5005-8, cader

The paper describes the Iesults of a study to deturmine the to al pass and the mass distribution of latge atmospheric aerosols, especiall v tha mass associated with garticles greater than in un dianeter. Ihis

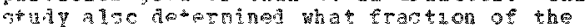
total acroso' nass a standard highovolue air sampler collects and wha traction and size interval setries out on a dustrall plate. A special aerogol sampline syster destgned ara buit for this study, was used to obtair built for this study, was used to obtain particles. A sururba samping site. Free of

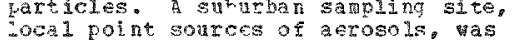

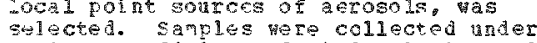
various centitions of vit velocity ant direction to obtain measurements on different types of aerosols. Stud nea suredents show thet atmospheric particulate natter has a biadal nass aistrintion. The large parricle mass aofe vas associated wh particles which rarged from an estimeto 0.02 to 5 un in size. Combineds these two distributions produced a himodal mass aberibution with a ririnum a round 5 ubarer. The high-volute air sapler was
found to collect host of the total aerosol mass, pot just that fraction not rally
considered associated with suspended particulater. one day dustfall measurepents particulater me day dustall measurebents or very useful mis ant of the arsosol mass

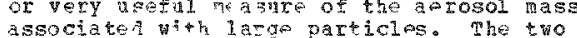
assactaten processes of aetosol formation turadment prockssos of aetosol forka condensatha aq dispersion a dor to account for the forration of a
distrinuton in heth natural and

anthroporenic awoscls. Darticle gize distribution masurements epenuenty are in + airborne particles are not obtaitro.

considering this discrepancy, aix gollution Iegulations should specisy or be based upon an oper particle size linito (3ath)

$\langle 325\rangle$

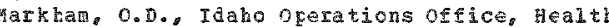
Services laboratory, Idabo Falls, ID. 1973. Nove $n$ be $\mathrm{x}$

National Feactor Testing Station Environertaly Felated publications. IDO-12078; $11 \mathrm{p}$.

The biklography was coapiled wile revieung the literature on environmental studies at the vational feactor resting station. The list has been restricted to publications list has been restricted to publications estasishment of the site. progress reports,

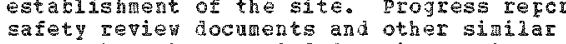
papers beve been excluded. Minety-six references are given. (Auth) (RAP)

$<326>$

"a yer, $\mathbb{R}_{0}, J_{0}$ Jesteris, S. Major, ana Davideon. Battelle columbus Laboratoriss, Colutisus, OH. 1974, June 30

Pioenvirongental iffects assciated with Holear Pover Plant: a selected Bibliography, First Addendum. BMI-X-654; 399 p.

The first addendu biblicgraph contains selected references collected to assiat the O.S. A tomic Enegy contssion in acquiring and organizing informatici to provide bases Eor goneral environmental siting guides tor nucledr pover plants. The inder was frepared cn Battelie's CDo 6400 computar utilizing a moditied Key-word-out-of-context (Koc) progran. Among the topics ccrered are therma gollution theral efrluents vaste asposal, eftuents, chloriztion, safety. environmental aspects of pluconian toxicity cf power glant chenicals tc aquatic life. (F)

$\langle 327\rangle$

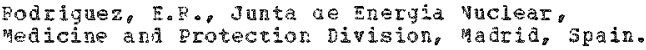
1968

Palonares Two Years After. COHF-6805u7; Part of Froceedings of a symposium on Fad lolegical protection of the Fublic in a tuclezs Mass Disaster bela min Interlaken, Suitzerland, May 26-Juse $1,(968,(0,36-38), 689 \mathrm{p}$.

A continution of the fork carried on at Palomares since the accident is described. on of the efforts is the search for fragments cf contaninated material with rearar to work on soils. Deeg-furrow flowing is recomended in order to produce sufficient reneval in the layers of acil to dillte the radioactive elenent. Dispersion of the radioactive eienents was a 150 achieved by eqveral passes yith rotavitors under if tive

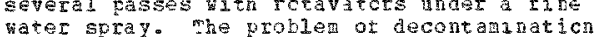
vater spray. Whe problem ot decontam inat

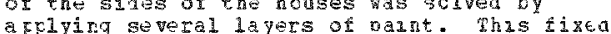
a priping several layers of bant. the contamination sc as to prevent resuspension in alr, and also absorbed the Weakly peretrating alpha radiatior The ast

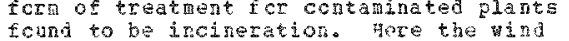
drecton and velocity vere inportant so that

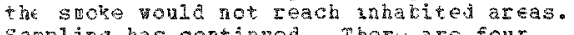
sampling has continued. The a a four 
$\langle 327\rangle \mathrm{CO}^{\circ} \mathrm{NT}$.

sateles are also taken of soll, vater crop, Hild plant life and non-domestic anials. The presence of pu $a$ the lungs of a group of The Ftesence of Pn in the lungs of a group people scin of yhon were exposed at the beginding, asd others ho were chosen
controls was tester with a whole body

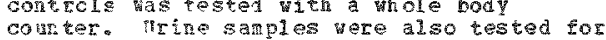
cowrer. The results zore negative for both the Pis The results re regetive for both the urine andyses and whole body counting. The several lccetiong should be invaluale in facilitating action in the case of a similar accidere (Pमn)

$\langle 38\rangle$

Se monin, E.G., and D. . Gatz, University of

Ilinoss, Jrtana IL. 1974, April

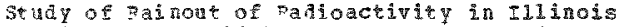
coo-1199-38; Twelth progress peport: $21 \mathrm{p}$.

The fiold expariments have been continued to

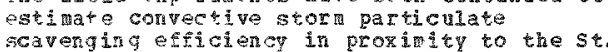
ncaverging efficicn in proxind to the comis, 1ssouriturban-industra complex. complint taty studies of the urban aero character ization, source strengtho and removal processes vere also stadied. The types of camples for amalysis and interpretation: 1) 1513 total rain sampes srom 59 sites: 29 450 sequential raillater samples from 3 locktons; 31 2f vetary samples from s sitog; 49270 air filter sameles rom 7 locations; 51 il Andersen iapactor samplos from 3 sites; 6114 water samples tron aizeraft in-eloud and prectpitation at cloud base: and 75 air finter saples fron aircraft. The nalysis procedures require that all rater saples andergo filtering for separate alyses of soluble and insoluble fractions of the chentural concentrations. This data colental concentrations. This data

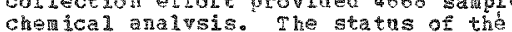
chalysis of ali types of data is described. analysis or all types or data is described. estimate urban aerosol source coefticients estiate urbar aerosol source coeficient prosented. (Auth)

<329;

Soldat, J.R., Battelle Menorial Tnstitute, Pacific Northest Iabora tories, Richland, wh. 1974 , June

Erviconentel Behavior and Radiation from Iodine

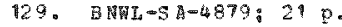

Pecently, atention has been drann to I 129. a radonuclide which, because of its long

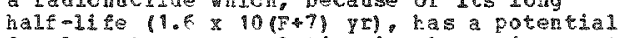
for long-term accunation in the environent from low-level chronic Ieleases at nuchear from low- level chronic Ieleases at nucheas the biosyhe and the resultant radition doses to nar are discussed. Hetabolic paraneter are tabulated for for ages 1.4 parameter ate tabulated for four ages

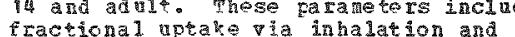

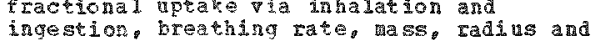
ingestion breathing rate, ass, Fadis and dre presented for calculation of doses from intake or concentsation of I 129 in the thyrcid. Factors are also derivea for esting ing thyroid doses from I 129 a i concentration via the inhalation leafy vegetable, milk os meat pathuas. Mnalysis of the aton ratios of I $129 / 1$ 127 in the thyrcia reguired to yield a dose rate of 1500 reafyr reveals that an this basis the adult thyreid reaches the liniting dose rete at a ratio of $1: 48$ (3.6 uCd I $129 / 9$ iodine). However, a higher atic of $1: 11$ (15 aci/g I) is required for the infant thyoid to receive the same bose rate. The reason tor this difference is the higher stable $I$ difference is the higher stahle 1 in 1350 ppm concentration in the adui thyrold 350 ppm than in the intant thycoid 190 pcal Ia a instances, hovevers dose rate or 1500 area/yr voula result fron a concentration ch $1.3 \times 10(2-3)$ nci I 129 Eer a grati of thyroid. (auth)

This report is based on work reported in ER⿴囗十 1783 (1973).

\section{$<330\rangle$}

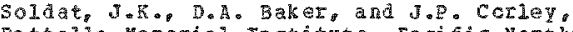
Batelie Memorial Institute, Facidic Morthest Iaboratories, Richland, wh. 1973

Applications of a General Conputacional Model por composite invircmental RaAiation poses. TAEA/SH-172/82; STI/EVS/345; CoRE-730503; Part of Froceedings of a symposin on the

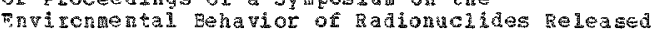
in the whelear Industry held in Ais-en-provence. Fince, 政 $14-18,1973,(19 \mathrm{co})$.

A mathenatical wodel for calculation on a large general-purpose aigltal conputer of regional radiation doses resulting from large-scale use of nuclear energy was previously developed and reported. This generai model has now been sub-divided to cermit rapid calcuitions for the several exposure pathw groupings in an interactive node using the BASTC compater lasarage. The sub-pregras ate completely jexibie as to the guclides, body crgans, and pathwas fer which radiation doses are to be calcuiced. hut include at the present tire: I ageroximately 150 radionaclides, incluaing

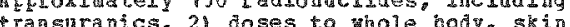
transuranics 2 doses to mole bady skin. bere, lungs, thysoid, and gastroincestind tract 3) suboprograss for cloud

inhadion of nuclides other than radioidines (resuspensicn of defosited nuclides is not included, angeston of dose from water and sedidents, and ingestion of irrigated crops. Thyreta dose from inhelation and ingestion and dose to aguatic biota can also be calculated. Dose factors in the programs for the varions

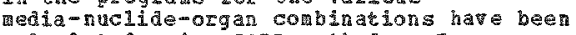
calculated using ICRP wethods. por racionuclides with long eftective hatr-lives. the sub-prograss calculate ither total dese cormitrent for a single year"s intate or the dcse-rate at the end of a specified period of years at constant annul 1 intake. Transfer factors between trophic levels have beeri taken in most part from siamaries pablished by others. and are updated as never data becomes a vailable. The major application to date of the compartwented wodel has been the calculation for the U.S. Atonic Energy statenents. 0Ise is 2180 being lade of the same podel for equation of potental radiological ingets associated with the

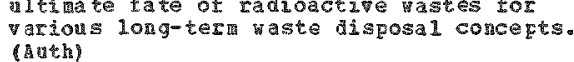

$\langle 331\rangle$

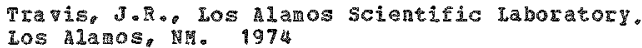

A Model for Predicting the Rediseribution of Particulate Cantrintints IA -0 F $-7401340:$ Cost $5-740929$ : Part of Proceding of the Atospheric-surface Exchange of 
$3,31>60 \%$

Pafticulate añ Gasecus pollutants sympoi un

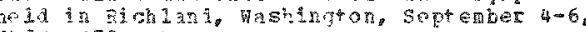
is $74,(a 8 \mathrm{go})$.

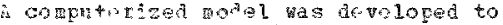
utsurise fhe restatibution of wind exoding

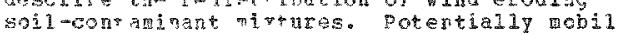
particulats contamingts cang in the fingt approxidastion, ho assumed to the

andistind a in which thy are Aistrihuted. A grid ratucre characterired important soll and contrel volums are corstructed on each cell. Contrel volums aro ccrstructed on each cell
Material is transported through the vertical nn top suraces of a control volume of a ch top sursaces of a control volute of formulation an molisipe gillette vertical

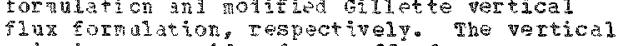
wissionce consilored as puffs frol area

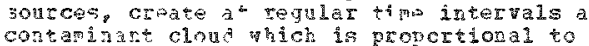
thi saspodable around concentration. prose

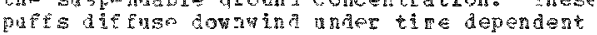

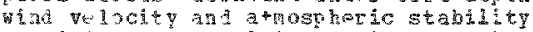
contiticns, haintaining turing the tive

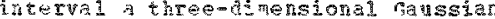
13 string ion of concentration volume. Anterial Eron each pufs is defosited in tew or tary different flights fron toese ne

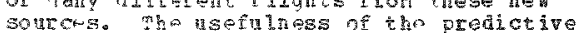

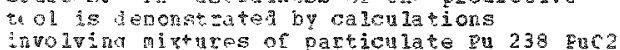

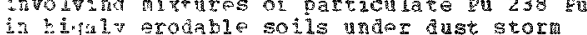
conditions. pine dependent surface comctition and breating zone exposure Cocurtration and breating zone exposure Isopleths, evolving rea a mall contaminat ar

$3 \div 3$

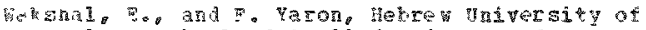
arusalew " chool of Applied seience an

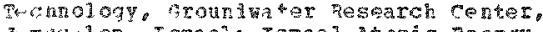

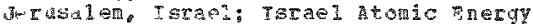
comassion, moleat sesearch center, weger. Israel. 1904

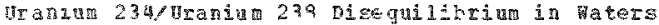
or tae Judea froup (Cenomanianorycoman) aquifer

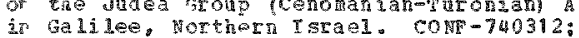

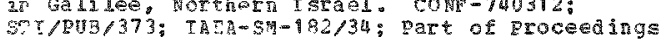

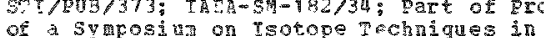
of 5 y

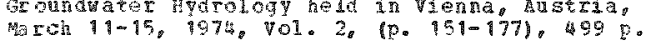

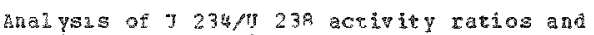
uranin concentrations vere carried out on sarples rom 50 water sources of the 3 udea froup cenomaninamuronian carbonate aguifer ô 3 alilee, northern Israel. The $0234 / 0238$ activity ratios mero found to vary from from 1.04 to 2.81, and successive anelyses of selected water sources show that values from the same sampling sites remained coasistent over a three-year periad $(1970-73)$. The recondad alues of the $274 / 0238$ activity rat 30 ay be grompen into three main clusters cleary related to the paleohyalogical crolution the area under considextion: (a) low $234 / 0238$ activity ratios ranging

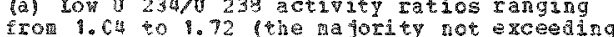

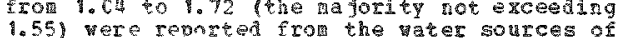
western " pert Galileg. This area is drained western "Ffer Galilee. This area is arai

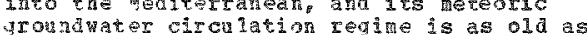
Jroundwater wirculatin regine is as old as

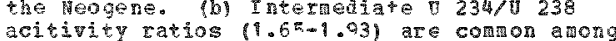

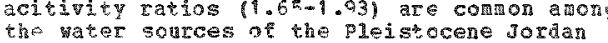

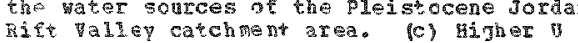

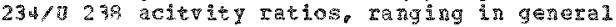

from 9.9 to 2.5 , weze foud I $_{1}$ the water sources of the lower Galilee, where there bas been resened active groudrater circulation hoth eastward ard westrarl called by the latest wbsidence of the Jordat pift Valley and the mediterratean Young plaistocene Sea Fogression. These results point to the Fossihility trat the mecuanisn of uraniun isotope fractionation Hitnia this type of aguifer is basically governed by the solia rock-fresheder flow contact histcry.

Futher information gafned by such stades night he ustal in developing a berter hyorogeological hod el for the grouduater

flow reaing ithin carbchate aqufers. (Auth)

<33

Rornderg, H. A. Hanford Atomic Prolucts operation, zichana, Wh. 1958, Janaury 10

graford Biology Fesearch Annul Feport for 1357. सด

Thes anvial sumary of the research ativities of the manford Biology operatior contains stulies er the pake, distributicy and turnover or radioelenents in plans.

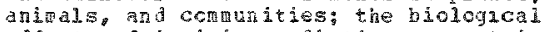
wfects of jonizing radiation on certisn organs ana organisns: and the effects of orerations at Hanford on its plant and andal 11fe. Individal reports deal vith factors that affect ralicstrontiug uptaise and assessment of fallout hazards of $\mathrm{Cs} 137$, and assessigent of fallout hazard of Cs 137 , and biological offects of I i3g in latje andmas. biological offects of I i 13 in latje Flutoning stalies reported range from

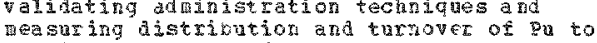
testing agents for its Iencral from the animal body. Small and large anicals a d scluble and insolubie forns of $P_{u}$ were used. papers dealing with radiation hazars inclute a discussion of the tirnover and regoval of radioactive patticles and pulmorary alignancies caused by the . Aso given are scme aspects of the fundawent mechatsis by which ionizing radiations a ams biological

effects. The last section deals with measuring concentrations of ceactor efrluent acasiring concentrations ar ceactcr ext aksorption and taricter of 2 n 05 , the effects atsorption and turacver of an os, the of chroniug on heat on ish and the crula tion density of fish in the vicinity of separately for the daca base. (RA)

$\langle 334\rangle$

porch, h. Lavrence Iivermore Laboratory. Livermore. CA. 1974

Fat-Response Iight scattering Measurenents of Aerosol suspension in a Desert Area.

observations wth a specially developed fast-response instrument for 11 ght scattering tasurewents show that aerosol suspensicn and resuspengion by diurnal winds in desert areas resuspenion by durnal winds in desert ar dusur in relatively concentrated gufrs of dust of short auration less than or about 2 Ain.). The freguency or these purfis aprears of the area. On chance occasions ast devis were observed by the instrumertation. eshibiting aerosol chacteristics appeciably aifferent frcm those of diurtal wind-susended particulates. (Buth) 
《335,

Mratrong, $F, E$, Bartlespil1e Energy Research

center. Bartiesville, OK. 1974

coal hine Dust Tmeombustbles content analyzer

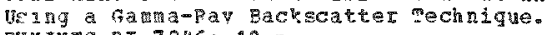

3U INES $-R T=794 \% ; 10 p$

dn Lnstrument using a gama-ray backscater rechiqu for determing the weight percegt incombus ibles content of coal dust and rock dust mixtures in coal mines has been built and tested. The ulit gives a drect remout in percent incombustibles for coal aine dust Riztures containing between 50 and 100 percent incomustibles; calibration of the device reguires using a saple of the rock anst enployed; this is usually litaestone but occisionally dolonite or gypsum. A small occasionally dolonite or gypsum A

arericiun 24 sonrco is used wh th Scintiliation detector hese output reeds rate beter. The sonrce-detector gernetry used was chosen to reduce the effects of variaticr in bul density Acenracy of the staten is within plus or minus 3 percent for
wost mixtures. phe instrument is portable most wixtures: phe instrunent is por rechargealle bateries suply poner for 300 to 400 deterpinations. (Auth)

$\langle 335\rangle$

Kotrapod E. Do. Bhantig S.K. Tua, and P.P. Physics Division, Fomay, India. 1974, JuIy

a Sirgle centripeter for papid Anasis of

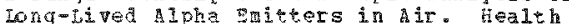
Physics, 27, 903-109.

Pa d detection of long-lived alpha emitters such as $p u$, ij, Th in ais is zendered diffigul because of the interference of ranon and thoron daugher products alvays ptesent in air. It is known that radon and thoron dagh*er produces are usually

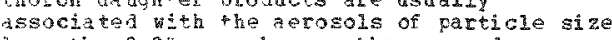
less the $0.04 u n$, whereas the nan-made aerosols are nsua ily larger. This property is riage 150 of in a specially designed single stage cortripeter sampling at $10001 /$ min. This is cund to ha collection efficiency for lorg-lived isofopes around $65 \%$ and for shotr-liven isotoper around 3. As the possit 16 to obtain an aperoxi matestimate of possible to obtain an aperoxi nate estimate of contributan ffom sadon/thoron daughter proincts to counting the sanplo reversed

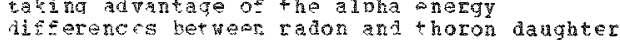
prowuts and $\mathrm{t}$, or pl. The refore, everi products and th or pu. The refore, evert this in car hor hotomined and iscounted comparisor is mase between the present instrunert and the anrular impactor an
instrumer also rases on the principle of instrumer also bases on the vinciple of
size sacaration. It is concluted thet this irst tument has goveral desirable features comparod to the antular inpactor and is netter siditol for fiela use. (Auth)

$\langle 337\rangle$

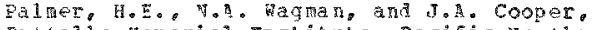
Battelie vemortil Institute pacific northtest

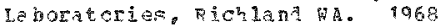

The Doternination of the nepth and hount of Plutonum 230 in CONF-670521; RWW-SA-12Fi; ponogragh on Nuclear melicine and Biolog\%, Ho. 2; Part ot kornbera.

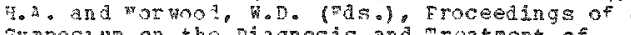
Sy noosi um on the biagnosis and reatment of Deposited Radionuclides held in Richland,

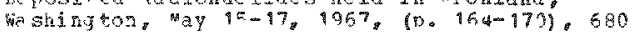
p.
The paper describes the use of a lithin drifted silicon detector for neasuring $P$ in wcunds. The derector is 3 mothin tha bas surface area or 3 con $(2+2)$. It is nonsed in an evacuted chaber about one-fourth inch benind a .25 ma ce window and aintained at 13quid nitrcgen tergerature. The resoluticn
of the detector is 0.95 keV for Eul width at half taximut for a $13.6 \mathrm{kaV} z$ - ray. The superior resolution allows the 3 low energy uranian gan $x$-rays of $13.5,17.2$ and 20.2 to be completely resolved. The use of the Si(Li) atector vill not increase the sensitivity for the measurerent of $P$ a in hounds even though it has a lower background. The real userulness of the counter wil be in the pore accurate reasurements of the tctal actipity and an indicator of the depth of the Pu in the wound. (RAS)

〈338>

Carver, R.D., and F.J. Dupzyk, Lavrence tivermore Iaboratory. Liverace, CA. 1973, June 26

Measurement of the lass Spectrometer Efficiency in the Isotopic Analysis of Very Small plutonium Saples. UCRL -74430 ; COME-730547; Part of proceedings of the 21 st A sycacsium on wass spectrometry and Alided popics held in san rrancisco, Califorma. May $20-25$. $1973,(2.351-353)$.

A method was developed to measure guantitaively and sotopically very saml

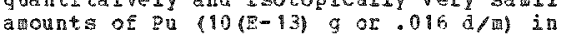
envizonarial sampes (soil. plant and andal

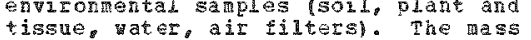
tissue, water, a ir biltersh The mass

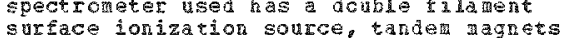

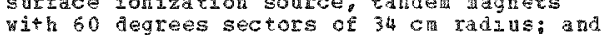
chputer controlled data acquisition, fast conputer controlled data aequisition sast The source is valve isclated fom tre a nalyzer portion and vith fast pumpiag. vorking pressures of $10(\mathrm{E}-7)$ torr can be achieved ir 15 mirutes. B1i pu samples vere traced with 350 pg of Pu 242 for isotope dilution normalization; total pa content a ra Pu 240/239 isotope ratios vere measured. Extensive chencal curifications were fourd tc a fect efficiency measirements me dia not cause large losses. (RAF)

〈339>

Iatrer, G.P., and $M$. Eisenbud, wot given. 1968

In vivo Hezurements of duclides Enitting sott Penetrating padiation. Con -670521 ; Monografhs on uclear wedicine and Biology, so. 2: part of Kornberg, H. A. and worwood. W. (3.s.) proceedings of a Symosint on the Diagnosis ard preatment of Deposited Badionuclides hela in Pichland, Washington, way $15-17,1967$ s (P. $199-20 \%, 680 \mathrm{p}$.

This study was performed because ct a need fcr a rapid, convenient nethod of deteraining whether exposed personnel have accuralated iung burders of tadionuclides sich as Eu 239. sr 90, Pb 210 and uranium. Measurenents of these ruclides are handicapped by the fact - hat they enit only soft radiations which are difficult to gantitate using conventional technigues. The primary objective is the reauction of backoround in the low energy reduct ion of backgtound in the low energ:

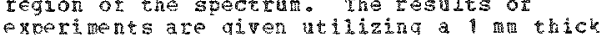

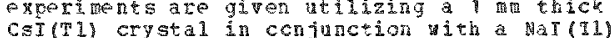
CsI(T) crystal in conjunction ith a tar guantitative in yiro assessient of body

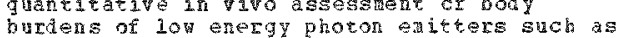


<339> CONT.

Pa $239.5 \mathrm{r} 90^{\circ}$ Pb 210 and natural and entiched uranium. Heasurements done to obtain optimuin crystal thickness, lasisis $\$ 2 / \mathrm{E}$ as a figure of werit. have shown thichiss as a ian to be a pactical compromise for all three nueliaes. phe use of this thin crystal three nuclides. whe use of this thin in conjuction with a NaT(II) crystal anci-coincidence gyster using isetine background in the low energy region $y$ background in the lov energy segion by approxinatel 70\%, and the Compton continuld of cs 137 by as moh as $70 \%$. The use prototype, portable in vivo counter with an

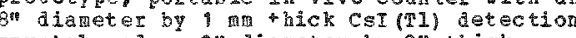
crystal are an on ataneter by $2^{\text {n thick }}$ NaI(T) anti-coinciaence crystal. The crystals are nounted in a moveable rig which allows noverent in the $X, Y$ and $z$ planes. The entise rig, including electronic apparatus vithout a multichannel analyzer. weighs cn the order of $2001 \mathrm{~b}$. Calibration measurements porforned yth the large crystal have shown migi ran significant measurable levels of activity (MSA's) which indicate levels of activity (us s) which indicate
that body burdens, mote particularly lung
buriens, may he neasured at a fraction of the burdens, may he measured at a fraction of the
MPEB without the use of a steel roon. (RAF)

$<340\rangle$

Not given, Anerican conference of Governmental Ir âdretai Hyolenises, Air Sampling Instruments conittee, cincinneti. oH. 1972

Air Sagling Instruments for Evaluation of At ospheric contaninants. Fourth Fation; 558

This fourth odition of Air Sampling Instrumerts is a revision and extension of the first three editions published in 1960. 1962, an 1966. The text is organized into ine najor parts. The first gert consists of seven introductory papers vhich discuss basic considerations in sampling air for specific purposes such as sampling acr contaninants purposes such as anding for containant work places for a drborne microorganisas

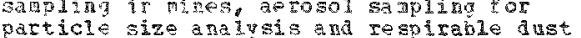
particle size analysis and re spirable sampling. The second pact contains discusions of sampler calibration, and instrantal factors. The thir part is ievoted to syoter componeng the fow to sample collectors incluing ra electrost atic ant thermal precipitators, and the fifth part to direct reading instrumests. Cach section in the third, fourth and fitth parts corsists of ar introductory paper and a serides of descripticns of dir sapling instrun to or syctem components in standari forato of the twenty-one technical dissussions, eleven are neviy prepared for this edition, and the other ten have had thajor tovighons. Two pavers have been

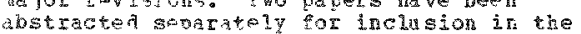
abstracted storistal

《34 १>

Not given, Intozrational atcuic Fnergy Agency. Visma, Antria. 1071
Advances in Physicai and Siological Radiation Detectors. conf-701112: STI/PUB/269: proceedings of a Syprosiun on Nen Developments in Physical and fological Radiation Detectors hela in vienna. ustrias Novenber $23-27$, 1970, 742 .

This sylogsiun sponsored the the thas one of continuing geries of geetings to further the exchange of inforation on all aspects personinel and area dosimery particular emphasis wa given to a stady of dose elements (both physical and biological) their ingtrumentation, calibration and standardization. International intercomparison studies on stanardization and calibration of leasuring equigrent and scurces here recomanded. Growing intersis in the develogment of biological dosineters was noted. The symposiun was attended by 170 participants fron 29 member states and 5 international organizations; 2 papers are given in full with aiscussions. (RAF)

$\langle 342\rangle$

Arnold, J.S., and C.T. iei, Hines yeterans Adninistration Hospital, Defartment of nuclear vedicine, ines, Il Fansas city General Hospital and Medical center. jepartment of pathclogy, kansas city, MI, 1972

Quantitative uorpholoy of vertebrab Trabeculat Eone. Part of Stover. B.J. and Jeeg i..S. (Das.) Radiobiology of Plutening. J.h. Eress. salt lake city, otahs $(p, 333-354), 552 \mathrm{~g}$.

The surface area of trabecular bone, the peat thickness of trabeculae. the marron space between trakeculas fand mean patis a a a bere were weasured in yertekral trabecular bone in 35 mormal" humans. The data serves as both a 3 dinensional quantitarive unigue exaple of guantitative morphologic study in aging, as veli as a data base for dosage aging, as veli as a dat base for dosage calcilations in alpha plus beta boue
raioisotopes. The hum vertebral

radioisotopes. The hum vertebral
trabecular boine is composes of three cypes of trabecular bone is conposel a diree types structure: Lorgitudital an transverse trabeculae, and longitudina plates. The vumbers of each of the structures per ce os thedullary tissue were abasured in weil as each decane of adult ilfe, using a thick bleck microradiographic techrique. The surface area per cc of aedullary rissue and per gn of ash were calculated froe tho measurea dimensional values. Comparison of the vinlus for of bone colculated from aimensiond 1 measurements and those neasured by water displacement gave a correlaticn cceficient of 0.65 . Calcilated and Measurea, trabecular spacang qave correlation of 0.73 to 0.90 . The results validate the gecmetric model and the accuracy of measurenonts. Fu1tho out 2 cases with rocal traumatic change rosuits in $a$ corralation coeseiciont 
$\langle 343\rangle$

Adans. W., aro v.t. Sroot, Natzonal Radiological motecton poard, prapli, Figland 1974

ka drey and pone peterton Functons in the Puar

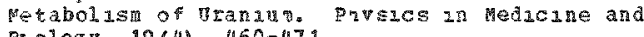
Biology, 19(4), 460-471.

The retem mon of uraniua by bose and kidney has been re-cta' uated thing accout of recontly Fublished data for a nan tho had bep occupationallv exposed to natural uzaniar a rosols and for adults who have angosted uranum at the normal detary letris. For 11 fetune occupat lonal exposure to uranu aerosols the rew retentur functions yield a greater retention in bone and a sallor retention $2 \pi \mathrm{klane}$ than the earlier ones, which were kased on acute intakes of uranim by terinal patsents. fence bon reblaces kidney as the critucal orqan. The occupational axasa pertussuble concentration in ir for 0238 and for natural based on radiological

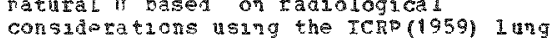
consalerations usigg the ICRo (1959) lung slaght ly lower than for the earliex ores.

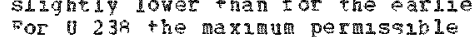
concentratior deternined by chended toricht condus the nore rostructiva. (A ats)

(3) \&)

Andersen, E. V.o P.F. Bratason, and H. W. Larson, Batelle wemerial Institute, pacific not thuest laboratories, chiang,

Dosimetry of Alph smiters in the lung. COnF-681013; BNHL-SA-1765; part of Eroceedungs of a Symgasun on the Dosimetry of Low Energy or St ort Range Irraulat rons hela in enton, France. octoner $9-11,1029,(0,28-68)$.

The lung and Iyphond tzscue ay well be the ctutical. orqans for many andustrial exposures to the ingolubie actinude radioacrosols. "In vipl lung measure +5 rrovade the oriary

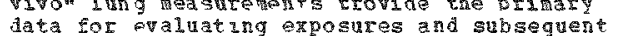
lata for evaluating exposires and subseguent interna rose. A use ful secondary nethod Involves fecal semilng and extrapolation by lug modoling and particle sizo irformation
to otrain a measure of the ling content. review is bri arly presented of experience wh "hn 1 wo" Inng pasurements, fecal excretion, pasticle size analysis and isotcpic colposation in their relation to the best dosmetr currentil cossuble for plutomu alpha equtters in the lung. Fxperience in the operation of several prototype svsters for the desection of

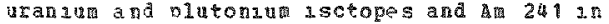
the lung is discussed. For idatural and

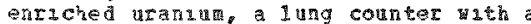

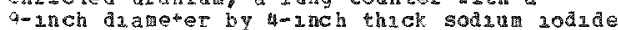
crystal provias atection level equivalen to about 20 percent of a ling burden. several lung counting systems are avalable for meanuring the $\mathrm{k}$ a nd gand ray from for measuring the and gand rays from

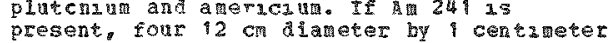
present four 92 cr diameter hy centrot low-rolse photomitipliers and located on both the front and he back of the chest are btilized. Guch a syster ril detect about

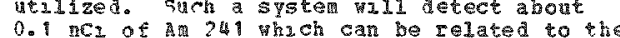

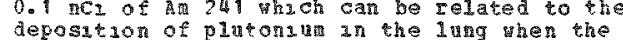

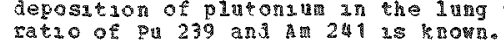

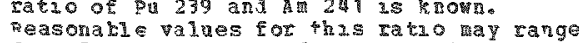

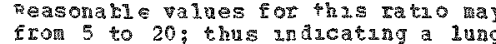
depositzon of Erom 0.5 to 2 z 3 C of $\mathrm{Du}_{\mathrm{u}} 239$ Thin sodru podide crystal (1 7 mich) arrays and proportional counters are also aval lable for detecting the 17 ker $x$ rays

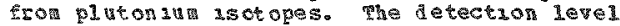
of these counters is abone 10 nCl. A progectson chest phator was designed and censtructed that is especiall isegul for calibration of "In vivo iang courtors when ncasurang low energy z- Iay and gama rays provides conplete variablisty of chest

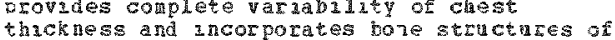
bone oquajent materal. (Autr)

(345)

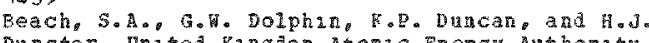

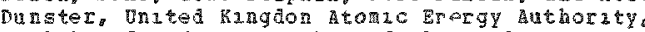
pealth and safet: Branch. Fadiologlcal protectior Division. Farkeli, England. 1906

Dasis for pontine vrore Sampling of workers

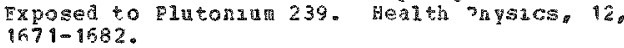

2 routzo prograb for the measurement of olutonzu 1 in urane is discussed an relation to the other rethods of controling the aternal raduation dose of those workang yth plutonal a The uranary excretion patteriu fcllowang atakes of pitonim compound consdered and $a$ value for o the maxian cody content apglicable to ali ccingunds, if body content apglicable to all ccingounds if Eroposed. A reforerce level and an act leve for urinary excretich ratas ate
suggesed. Factors influench the chesen of sabing procedure and trequenct ase

ascussed. An example is given shoming how

the reference level and action level are ured in a typucal sapring program. Special mention 25 wade of the arager al actions What are taken when a rorker's urinary excretion exceeds the reference level and the action ievol. (futh)

〈446〉

Bevan, J.S., and A.K. m.M. 留aque, Borough Polytechnac, Departient of physcs, London, England. 1968

Sone Speculations on the carcinogenac effect of Tahaled Alpha-Actave aterial. Physics an

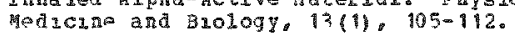

Calculations are repotted on tho possble size of malignant foc. in cases of 1 ang cancer atrubutable to the tahalation of alpha-active aterial. The calculations aze bssed on the probable dose-inciance fot cancers, the raduation sensitavity of lung Cells and the actual ase to the lung cells. foci probably lies betuen 15 and 20 , and that the proportion of cells in the bronch damaged by low doses of radiat ion ray be as hagh as $20 \%$ to $25 \%$ of the cell pepulatica at IISK. (FAP)

$\langle 347\rangle$

Bruever, F., and B. Righi, Colate to hazionale per lo Energia Nucleare, Division of mealth a controls, Rore, Italy, contato maziale get I Energa Hucleare, Natronal gaboratoraes.

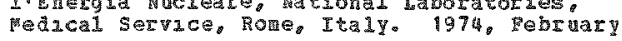

Torleologi of Transportable Uranum: critheal Contribution to lealh grotection of Horkers. Conf-730907 (part ll. Eart of Sigder. W.S.

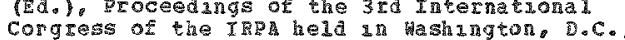

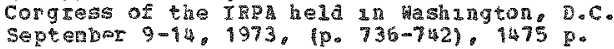

The cherical tosacaty of uranul is of importance in the evaluation of the rish of isternal contanation because of the transportable connoun of the leate. The risk becomgs most Iolevat when one has to Aea 1 ith natrial urangur or long-117ed 
$\langle 347\rangle \mathrm{CCN}$.

drandur 2 cotopes The nat concertrabions recomendes bv TCRP and the cther inat values nronosed are based on the and valu an the gr gereral outines are affectod hv the linvted technical

possiralitaes ava albe when afected. Sarce non the bosaluld tos or detecting ganal lesions are remarkably lmproved, it could bs

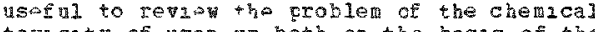
toxicity of urar the both or the casis of th advanced technique avidible and on the

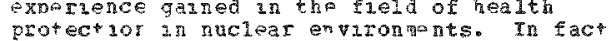

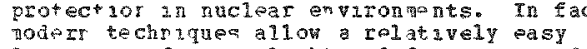
detect on of ever -light rodifications and of their characoristics, at the same time the analys on pery small prological saples 35 pocsible. Tt is mentioned that studies carried out on other Ienal toxic substances. like cadmium, are giving very +nteresting Iesu 1tg. (anth)

《3.3〉

Casarott, I J., Unzyersity of Rochester, Scrood or Medicane and nertistory. Department of Radzatzer ology, Docnestar, "1\%. 1960

Soma physacal and Dysiologrcal zactors Controlling the Fate of Inhalea substances. 2. Health Phy ca, 2, 370-386.

some of the mechangho ov whych partucles are -loarel fom the inngs aze d'scussea such as clizary activity of the opitheliu. pnagocytosis, 1 ymohat ic a bsorpt hon and solutilization. mprasis has been placed on relatzvel ansoluble rartacles degosztea in alveoli. Mentioned are he high

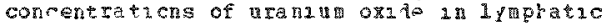
ordars. pork on plutoran orjae inducates

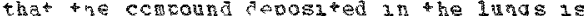

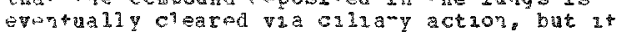
also appears that I wish node arcuaulation of plutch ur ordo a coneldorablo. Those

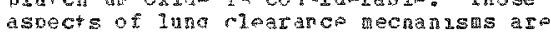

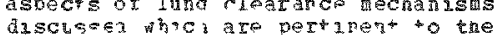
ascusen whe are pertinent to the

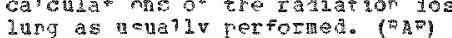

$\langle 349\rangle$

Taburon, $M$.L.. and I. Jeangarze, rommssarłat a 1. -nergie atomique centre a'Etudes Huclearies. Fonteriay-aus-Roses, France. 1974 , JuI

Calibration of a Iargo Area Proport 10 a tor Platon 1 a $239 \mathrm{x}$-rav Detection in bangs. $C R_{2}-R=4580,27 \mathrm{~m}$

A gethod of calzbration of a proportaonal counter for fintong measuremont in the lur has been devaloped an the basio of the afference of absorpions of the $60 \mathrm{keV}$ rat

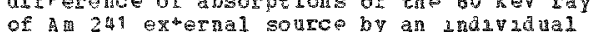
and a phentom. phe difference us converted

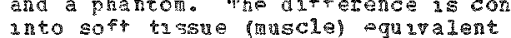

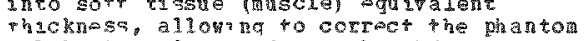
chlibneso, allow na to corract the phaton calibration factor for each subject.

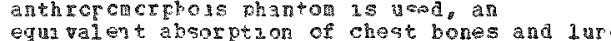
equal valent absorption ce cheat bones and lur

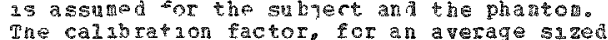
ndividual 255 couts per runte for 1 uc

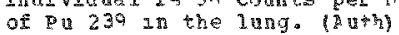

$\langle 350\rangle$

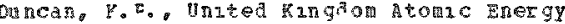
Authority, Health a ra safety pranch.

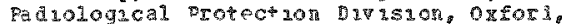

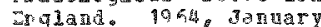

Come hspects of the prevtation ard "Ifathent of xcessive Internal Rad loakt 1 ve Cortandition. Brit3sh Journel of Radiolog廿, $37(4) 4\}, 120-123$.

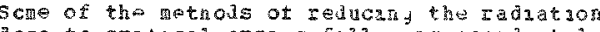
dese to critzcal organs following accidental

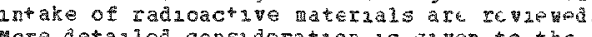
mere detalled consideration is given to the place of lsotope dilution petrols ysth syecial retererce to zisakes of radiolodire and to the redurt 10 of Cf $^{2}$ ternal

contamination by the adanistration of chelating agents with special reference to Irtake of platonaly. When the use ot chelatang agents 35 consadered there arc ta underiyina problems. One is the need lor the ascessment ir real terns of the hazard of certan guantelies of raducactive maprals in vartacular orgars of the pody abd the second is the lack cf cafacaty to estzeat oarly and accurately the actial anounts or some radioactive surstances an patzents. (EAF)

$\langle 251\rangle$

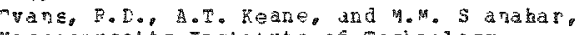
Massacussetts Institute of mechologye repartnent of Physics, Cambriggm. Ma. 1972

Padrogenac Ffects in man of Long-Term Skeletal 91 Fha- Irradzatzon. Part of Stoverp B.3. and Je. Wress, Salt Lake City, utah, (g. $31-469)$. $552 \mathrm{~F}$

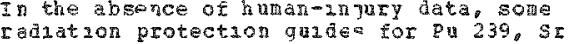
90 , and other kone-seekng Iadomelades are f cugded on the hunar radin base-1me or reference standara of $0.1 \mathrm{HCl}$ Fa residua burder, colbared wh th adiondaclide toxiclty ratios determaned from observaticns on long-1 yea experinental anmals. In the 4.T.T. serzes of hum leng-term radiug cases, =rom a vresertiy dentifled popalation

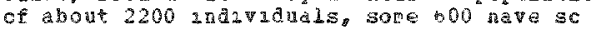
far been atudied (1970) while 12 ing pins acout 60 acter death throdn antogsy specimans, exhmations, or wilegbodics, $2 \mathrm{n}$ scecrmans, exhumations, or milea bodies, 15 At average skeleral culatative asages above A average skeletal cululative dosages a rout 1000 was marsed rad hob

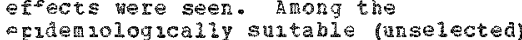

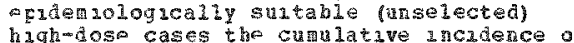
hagh-dose cases the cumatave lncidemce of bcne sarcomas plas read carcinomas is about
0.28 . The tum appearance trme in huans

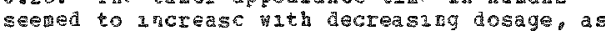

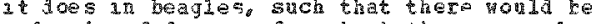
a dorain of dosages for which the regared truor apperrance tale exceads the 1 re spar. trus defuning a practical threshcld dosage.

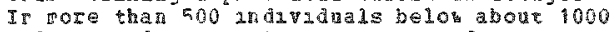
rads no radiogenc turors or significant skeletal effects wet seen and there wa ascernible life-soar shortonlat. Ho smoth

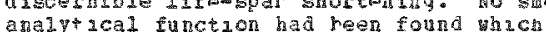

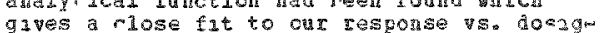
9ues a rose fit to cur Eesponse vs. dos

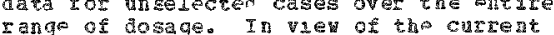
range of dosage. In viev of the curtent haspread pablicity alven to oxtravag death-predaction from low woses or DMSCEA-ICRE LI Tear nonthresold Dodels a formulating raxiaum-risk estrates for

large- copulation exposures vas revi aved. $I n$ the dosage doman below acout 1000 rads, the rrobabality that the observation of zero

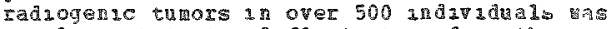

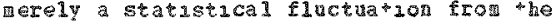
W

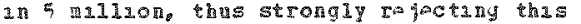
Bcdel. The rejection hecare even greatre

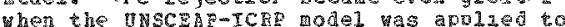
the Ma - Re 


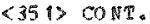

cases. In humans andergoing longoterm tkeletal $x-i$ radiation there vas evidence for recovery processes and dose-rate dependence. Iife-lcnq orservations vere required before the resconse-vs.-dosage relationships vere certainly the final values. For a significant fraction of the radiun and nesothorium subjects the life span will excend beyond the year 2000. Vigorous and long-term efforts ill be exerted by the AEC's Center for gunan Raloblology to obrain the maxinu informa tion from this unigue. husan copulation. (A uth)

<3라 23

Frost, H. H. Henry For Hospltal, Departient of orthopedic Surgerv, Detroit, MI. 1972

Ar. Efficient way to Mnalyze sone affections

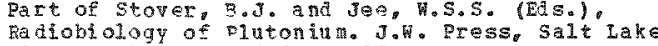
cleve vtah, (p. 293-304), 592 \%。

Using established organizational and statistical properties of biological systems. one can devise a strategy of sheletal reseatch which Iespectably minicizes the probahility that one will choose an inapropriate or irrelevant subject to study, the subject of enhances the probability that *ill prove relevant to physiological and pataclogical prohlens related to haman aisease. This article sketches in very brief fashicn sore of the reascring underiying such fash ich sone of the leasching underlying such strategy and one direction which one might

〈3.53>

Guskova, A. F., and G.D. Paysogolov, Mot given.

Bathogenetic Classification and Basic Ftolooical Factors of Radiation sickness 14a $\mathrm{R}$. AEC-tr-7401; Dart of Gusekova, $K$. and Baysogolov, $6.5 .$. adiztion sicknessin wan, $(0$.

a classitication of radiation sickness in man is provosed based vrimarily on the relationstif of biological effects to the dose of irrasiation as systeratized by $B_{2}$ of radiation siokross are due to either total comparatively unform irtadiation or to

comparativiv uniforn irtadiation or to

localited irradation in a decinite segment of the body cr organ. The entire ovolution of the response of the organisms and its outcen is aivided into acute (subacute) and chronte torms of raliation sichness. The several forme of acute radiation sickness with resoect to the leading pathogenesis are distinguished as acree radiation sickness with a) primary lesion of the nervous systen (cerebral form), b) with secondary lesion of the nervous syston (toxeric form), d with predcinant lesion of the gastrointestinal tract (intestinal fork), and d) with predcrinart lesion of the heratogenic organs (typical form). Acute radiation sickness due to thele rody irradiation is subivided into approxtrata dose ranges of 110-250, 250-400 and $400-1000 \%$. mho outcomes and conseguences may he outcones and consesuenc cos preexisting chandes an doterioration o preexisting chandes and doterioration o progressive clinlcal spraptons: In the develognent chrontc radet ion sickness itrad a to to itradition, 3 poriods are scheratically distinguished: the peris of formation of

\begin{abstract}
the disease, the recovery feriod and the
ceriod of atcomes and results of radiation sickness. The degree of axressicn of clinical lanifestations nay reach light moderate. severe and extrerely severe degrees. The aisease, just as in acute cadiation sickness, may end in complete recovery, recovery with aefects。

stabilization or deterioration of heals with a number of synaromes of polyethiological origin. The criteria of the degree of severity of chronic radation sickness aue to uniform whole body irradiaticn include the extent of the pathological process ( the involvenent of organs and systers uith different degrees of radiosensivity in the response to irradiation), the fature ata

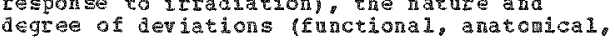
or structural changes) the degree of or structural changes) the degree of reversibility of pathological phenothen, the ccripteness of recowery after the cessat of irradiation and the imple
therapeutic measures. (RAP)
\end{abstract}

$\langle 354\rangle$

Igitman, A.I., R. Manoli, G.H. Sch molt, and B. A. Holnes, Medical Coliege of

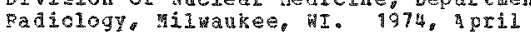

in assessment of Alveolar Degosition and Pulacnary clearance of Padiopharacenticais After lebulization. American Jcurnal of Foentgenologi: Radim Therapy and wuclear vedicine, 120 (4), 776-78\%.

A group of clear, nonviscia ratiophariaceuticals TC $99 \mathrm{mot}$, TC

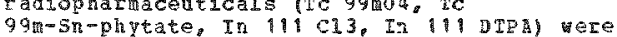
evaluated ising an ultrasonic nebuizer and scintillation canera to deterine the scintillation canera to determine the consistency of deposition in the alveoli at noral tidal freathing systeric absortion ultras onic nebulizer used produced particles of 1.0 u or silier. Twelve healthy volunteers ithout evidence of lumg disease inhaled $10-20$ mCi of the IC $99 \mathrm{~m}$ compounds or 2 to 5 mci of the In 119 compounds. of the four agents nebulized, the Tc $99 n-5 n-p h y t a t e$ demorstrated the best alveolar leposition and the slorest pulwonary clearance. only a vinimal anount of the radiophataceutical was deposited in the tracheobronchal tree and negligible systemic absorption occarred. The slow clearance allows inaging frow views rcutinely with excellent resolution anda relatively low radiation dose to the lung. (FAE)

$\langle 355\rangle$

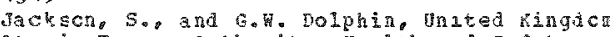
At onic Energy athority, geal th and Safety Eranch, Radiological protection jivieion. Ha rwel1, England. 1966

The sotimation of Internal Raidatich pose som Petabolic and Urinary Exaretion Data for a

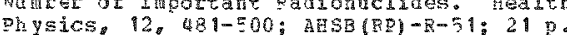

Investigation of an individual case of accidental intake of a radionucitas by deterination of the arount of radionucine in urine has as its opfect the best practicable estinate of the radiation ase practicable estimate of tae radiation ase purpose, it is desirable te analyze a purpose it is desirable to analyze a order to dimnish the uncertaint attacing te single, isolated results and to frovia data for a searching comparison with the best documenter cases of defined intake, which 
$\langle 355\rangle$ ConT.

provide the basis for interpretation. The primary purpcse of routine urine anaiysis of samples fros a group of radiation workers is to detect any significant intake which has otherwi mescaper attention. It is convenient to deruce from the avaibable netabolic data an investigation level of urinary exeretion rate below which no action is judged to be necessary, but above which investigation of the cause of intake and consideration of furthe action is required. Tevis is presented of the human data available on the netabolism and excretion of cesium, phosphorus, pelonium, piutonium, radium, Strontium, tritiua and uranium, and for these radionuclides. (ath)

Figure 3 shows urinary excretion of pu after an intake of 0.04 Fuci

\section{$\langle 356\rangle$}

Layerquist, C.R., S.F. Mammera, D. L. Boronski, ard D. B. .

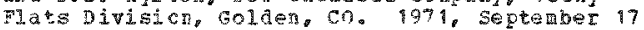

Suarary of the 0istributan of putonisu in the Tissues of ncenpat joral 1 y ixposed horkers.

PF $p-1783 ; 13 \mathrm{p}$.

This progress report deals vith an ongoing tissue sampling progran to check on methods of estigating systomic hurdens of Pu fror urine andysis. of the 12 cases of tissue donation, 2 had less than detectabie arounts in their tissues. Fotal anounts of $\mathrm{F}$ u in the body extrapolated frob tissue analysis yere comparod to the anounts estimated to be present from previons urine samplings. calculaten systemic burdens from urine andysis were consistent ly on the high side. Resulta sech to indicate that Pu

concentrations pere highestin the lungs and

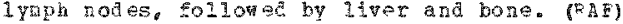

$\langle 357\rangle$

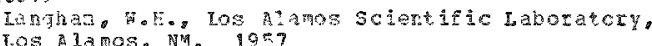

Excretion pothods. The Application of txeretion malyses to the Detarmination of gody Burden of padioactive Isotoves. British Jonrnal of Radiology, applenentio. $7,05-113$.

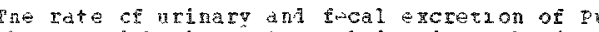
changes vith tham. A graph is given showing the percentade of the oriqinal dose of $\mathrm{Pu}$ axcreted por day by hum subjects as a fanction of davs aftor exposure cver a period of tive vears. mhe fat show that about $0.8 \%$ of the intravenously injected cose was excreted on the first day, and that only

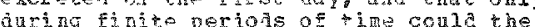
axcreticn curves bo reprosented by siple oxponestials. Than afte five vears the rate of elimination of D Eron tho hody still of elinination of D trob the body still

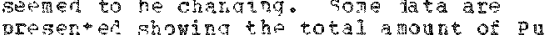
fresenter showing the total a

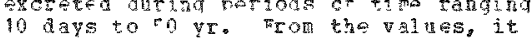
10 ays to yr. pron the values, it appars that he concent of a hioloacal nalt tine catnot be 3 plien in the case of Qu and sclution ce the integratad expressior. tor the 50 excretion tin suggest that about

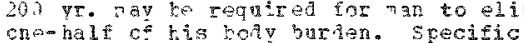
Triessions for the coefriciants ot elianaticn of pu, based on axcretion data 50r the exrasions soyeloper are us t to derongtrate general metols for the detormination of bod

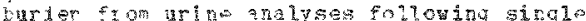

acute, variakle chronic and chronic invariant exposare, when the urinary excretion fals to follow a simole exponential patern. The problens of applying urinary to secal ratios as a recsure of iung buraten are di ecusaed ana certain generalatations are suggested. cre suggestion is that insoluble particles puot are regovea ith halfotioes of a few weeks and about sis month s presumably by tuo aifferent aechanisas. Ecth thethansws apparenty involve transport through the $\mathrm{G}$ tract. About 5 to $10 \%$ of the inhaled dose tract. About 5 to $10 \%$ of the inhaded dose may enterte the systemic burden. hile ccostitute the systemic burden ahile systenic burden. fecal excretion na be systemic burden fecal excretion laty
guntitatively zelated to pulanary eliniation of relatively jnsolublt raterials elinination of relatively insolublt materials and to the butden of such paterials a estimating systeric and lung burdens from the assay of urine and fecal salples. General ncdel for the retention, distribution and excretion of inhaled radioactive aerosols is pIesented. The application of vicle body ccunting for determining internal body buriens of radionuclides, and the biditatict of the method are discussew. (Fip)

Table 1 hows integrated valuts for

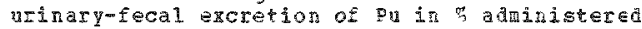
dose at varions times. Table 3 shons fecal to urinary excretion of $\mathrm{p}_{\mathrm{u}} \mathrm{y}$ Los Alaros waters in relation to notel of exposure.

$\langle 358\rangle$

Iushbaugh, C.C., g.J. Cloutier, a. Hulason, J. Langhat and 3. Guzak, Cak Figge Institute of Wuclear studies, Medical Divirion, bak kidge. W: Los Alamos Scientific Laboratory, Health

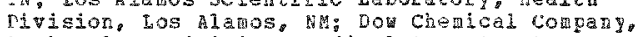
Rocky Flats Division, hedical gepartaent. Golder, CCo. 1967, Cotoher is

annads of the Now Work Acalemy of Sciences. 145. $791-797$.

Autoradiographic and histologic etudy of

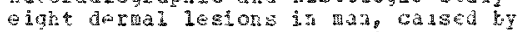
accidentally implanted tarticles or merillio Flutorian revealed that a minute jramiona Flatorian revealed that a mialue Jrandona cellagenous deceneration and linueraction collagenous degeneration and lizuesacton
occurred. A comparison or the lesions with occurted. A conparibon or the lesions with thorotrast suggested that softening of the

granulowa in the horiud cases as aore inkely a to to the chronic effect of the radiation exposure of the blood vesels than ugor the coldagen fibers theaselves. In breakiow of collagen fibers aroug plutonian deposits, however, sems to be reluted to the relatively enormous dose rate to which these fibers zere exposed. (anta)

$<359.3$

Magi, A. and hosta, Etaters

Stralskydasistitut iepartment or Radiation Phyics, soderstukhuset, Stockhola, sueder: Institute of Filiaticn phyics stooknoly. eqear. 9873, Juse

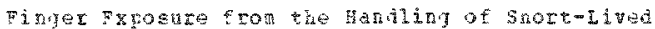
Padionclides. S5T-7973-14; 11 ip.

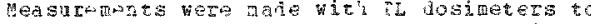
tear the a aurt of finger a posan receivad

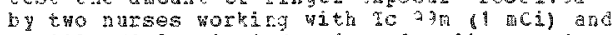
In $113 \pi$ (1.5 mCi) ingecticre for liver ath lung scintigrans tegpectivily. a cetailed description of infection hadliag techaldues je given, poses roceived bq ecu turse yen

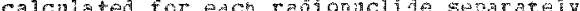


<35 sक cons.

because of atferent energies, halt-lives and because of dising tochiques. Fnr TC aqm the doge to

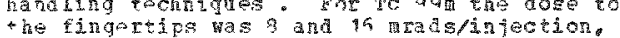

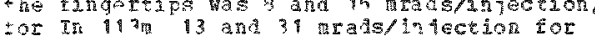
tor In 11 m 13 and 3 arads/in iection for che right afd left hand respect ively. The

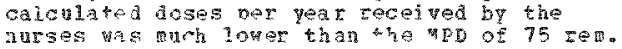
anrses

$<360\rangle$

Marks, E.R. S. Bacher, and L.9. Jacobsong Jn iversity se chicaco, Metalluraical taroratory. chicargo. II. \$ogr, Fohruary

tremateolooical studies of Elutoriug Prolect

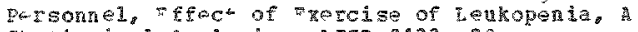
Statistical Analusis. Bap-2133; 20 p.

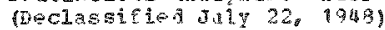

Eeukocyto and alferentel lenkocyte counts Were nado on 35 suhjots inmoditeby before, smadiately arter, and is exarcise. Fhese inividuals we re dale and ferale envloyees of the motallurgical Labotatory. one grou selectod potentialiy erposed to icnzing radiatione the other groun bas no know exposnce to significant anours of such radiations. certain adividuals in the potentialiy exposea croup had Ieukopenias: radiation expostre stastated in the etiolog: of these leutopenias. mpon analysis no differance in tesponse to exeIcise of these 2 groups was roted; all responted with an increase in levpocyte values inaediat ly after conpletion of the arerese. No change in the stace of waturatic of the colyor phoruclear nemerovitis or corvholchical change in the 1 vithocytes was roet in ofthar group. (Auth) (BAF)

$\langle 36$ is

qatsuoka, co, K. Toshikawa, and To Tukutoto. Mational Institute of adiological sciences,
Chiba. Japan. loks. Septenber: pof september

Ar Appicaticn of U1tra tich speec Alpha Autoradiography in tha petoction of piutonius 239 Stin Surface contamation. NSJ-tr-136:

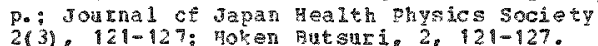

a high speed alpharadoatographe technigue was applied for the detection of Pu 239 shin surface contan ination to chein aceurate information on the contaningted area aronal the wourd. Silver activated ginc smidide was used as an intensitier in conthition with high speed polaroid sin. The intensieser filin nour ted on the double aluni oun coeted

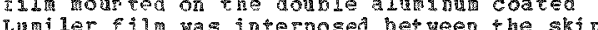
I and the photographic fll 111 of the above aucoradiographic procedare vas applicable Withear ark roon use by erploying a special i.ght-ight at ackane. The shape of the

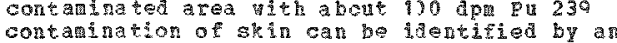
contanination of skin can be ldentipied by a
exposure of several aimutas by his mothod. (anth

$\langle 362\rangle$

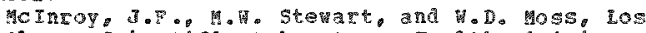
Alanos scientific daboratory. Healeh Division,

Studies of ofutondu in Fum Tracheobronchal

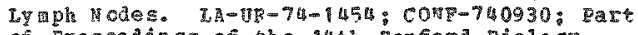
of Erocedings of the ith Hanford Biology

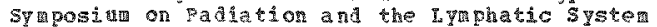
hela in Richland washingen september

\begin{abstract}
3h-0ctoher 2, 1074, (18 p.).
Since 1959 tissues from 79 former employees of the bos Alanos Scientieic laboratory with occupational exposures to plutomiun have been

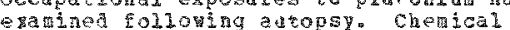
atritsps of selected sisues to determine the amount of platoridm in the body at the tial of ceath. Based uron the weasured tissue concentrations of pluteniut, extrapolations of tctal bojy burdens wete rage. Foposure in mest cases was to inhaled clutonium exide aerosols. Thirty-three of the reasured cases had fitoni ua degsicicos

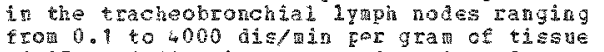
$(0.05$ to $1800 \mathrm{pCi} / \mathrm{g})$. The duration of ezposures ranged from \& to 30 years. microscopic extrination of reptesentative sections of these 1 yoph nodes reten led no sections or these 1 ah ares revealed no alnotalities other thas those which hirecty attibutable to the basic alse

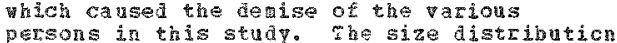
persons in this stuap. ine size distributicn or plutonu particles in nodes exom one case vas detarmited by exposure or tissae secticne to nuclear erack till The estioted ass

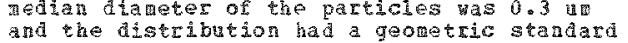
and the distribution had a georetric standar beviation of 1.6 . It is estitated
os the individul particles un had correspording plutoniun concentrations bethen 0.001 and $3.22 \mathrm{pci}$ (Aith)
\end{abstract}

Table I shows concentration of Pu and an in the -rackeobrorchial 1yaph hodes of a purber.

〈363)

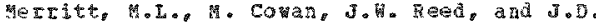
shrope, sandia corporation, abuquerque, 10

Rinorne Plutoniu from weapens Accidents. 3C-4 $326(\mathrm{~T} R$ ): $33 \mathrm{p}$. (Secrets)

\section{《364)}

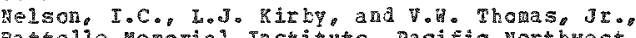

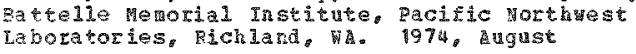

Pral ration of Postartem Tissue samples.

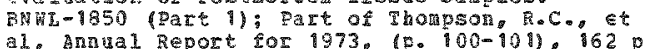

A collection of postrorten tissue saples 1ung. liver, bone end tracheobzonchill lyph (scdes) frow individuls resiang cr formerly restaing in the vicinity of the rancord complex is made in crder to establish baseline quatities of significant radionuclides as distributed within the body and as colated to age, occupation and as related to age, occupation conjunction vith Gabising the exvironmental iapact of muclear cacilities.

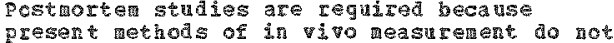
give acgute data on such important give adgute date on such inportant postmorten tissue sampis and blood sagdes

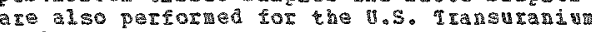
Registri. I four- detector alpha-spectronter systen vas ingtalled. which vìl Fertit sotopic amalysis of alph-eriteing potonin lisotopes in tisue sapies. In adition. this apparatus lov use of plutenin tracers such as pu 236 and Eu 242 yith hich cherical pield of the processing of each sample. (Frint) 
《305>

worwood, w. Hastorl pton ic peoducts Joratior, Health Cporations, Richlade, Wa. 1050, January

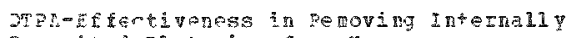
Jo posited DIutosing from Humans

D'sh has heen show to be about as eftactive in treating a shall series of hamans as previous work by others has shoun it to be in

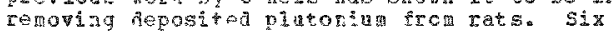

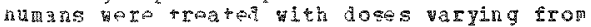
0.1 to 2.0 ar ne trea daliy. Rate of

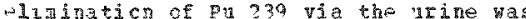
increased by focter ranging fect as to $12 n$,

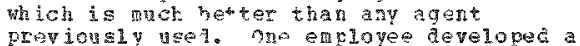
mild kidney rritation, possily as a Iesult

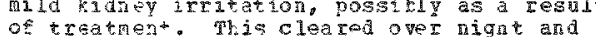
dis not recut moon zesuation of treatento dir not recut mon tosumtion of treatwent possibie following ar accident in which it is possibie following an accident in which

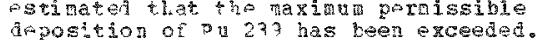
deposition of 3 u 23 has been exceeded. Wher the ienosithor excends the raximu dosage my zom donklea or tripled injtiliv. watis use? for more than a few hays, a dose of 1.0 gh twe or three times per reek for three wer $s$ is recomentel to be alternated ith periods of three neeks of no treatmert. This drag should ot pe used in the presence of sephritis or other bidney pathology and
shonld be used criv vith proper evaluarion of the patients renal status hoforeg diringo the patiegtis renal stat

Table 1 shous efrect of joph on urinary excretion of pa in mas.

$\langle 365\rangle$

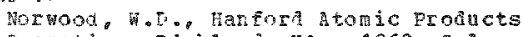

retertien, ichlana,

Eerly Jimuosis ard Treatert of Tndividuals who Have Excessive nepositions of Radiolsotopes. tournal of compational ved bine, 4 $17,373-382$.

Padionoteres maq aner the boly by ingestion. inhalation or absorption through the irtact or injured body surtace.

Inhalation is the rost usial method of entry in occupational contan ination. pany factors influence the deosition clearance. influence the deposition clearance. transincation, and excretion of inhaled particle cize aro of special importance. A lung podel mag be holptul in makng an educate 1 quess to deternine necessity for treatant when specific data are not dvailable. Neasurenents of radiation manating from the body and of the zadicactive wateria in urise feces, blood exhaled air, and hiopsy meterial may be of Great heip ir pstinating the anount and identity of depositer radiolsotopes. Tables of maxin permissible tody bardens of the most dangerous radioisonopes are availabie. as veli as other thies giving physal properties an grouging radionuclides

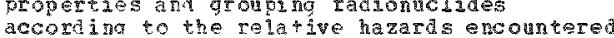
according the relative hagards encount in hataling the waterials feneral and ind: viduals who hava deposits of radioactive material on skin, in wcuns, in the lumgs, and fatre rndy. jop is the most valuable agent presertiv a wijable for increasing the rate of the uritary elicination of plutonim and some of the other transuranic eiements as we11 as uraniun and many of the fission prod zets. $_{\text {. }}$ (Aut

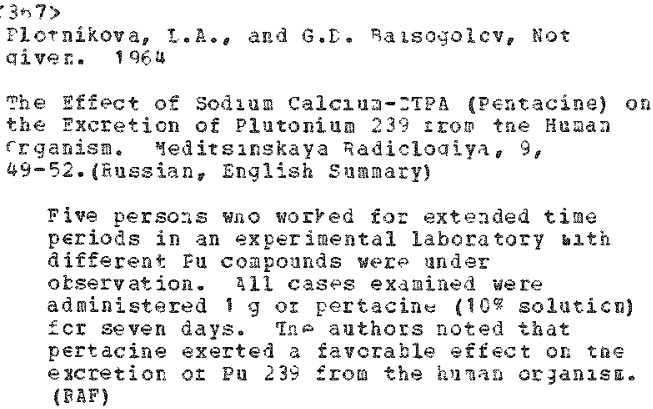

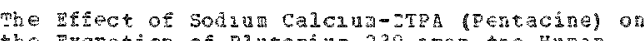

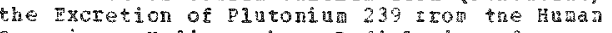

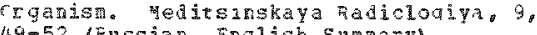
49-52. (Fussian. English sumary)

Five persons wo worled for exterded time periods in an experinestal laboratory bath afferent Fu componas were under otservation. $\$ 11$ cases exanined were adninistered 19 or pertacia (10\% soluticn) fer seven days. Tre authors noted that pertacine exerted a favorable effect on the excretion of $\mathrm{Pu} 239$ from the hana organas. (Ba?)

This article is ransiated as report, jpes-23500.

$\langle 358>$

Pocguet, G. \%. Guentrice and J.P. Gungalen, Centre de Recrerches du Survice de sante des Amees, Clamast, France. 1972

Escretion of Cesiun 137, cocal 60, Cerand 144 , Strontiun 9 and Plutorian 239 by CDSS-1972: Dart of Antual Pregress parert: Seiectific morks, $1972,(0.79-80), 260$ $P \cdot($ r rench)

Deterninations were ade of Cs 137, Co60, s 90 and $\mathrm{P}$ (口 239 in the urine and stcols of irdividuals voluntarily contaribeted by

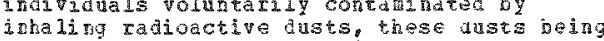
Inalis radioactive dusts these wust escretion is established for each of the radioisotopes concerred. (FR)

(369)

Eoe. D.A. o Cormeal universatys venter fos Fnvi ronental cality managene, Energy

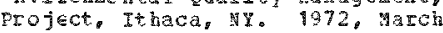

Health Mazards of the Coal and Uranim Maner. Eafer Ho. 72-7: Corneli trerg project on aticnal

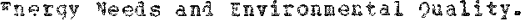

Her encloyed in coa 1 minity overations are exposea to the hazaras of lon 7 -tern coal a a infalation, which has been positively corredated with a high ancidence of corredated whoconjosts and its sequelie.

preutaconiosts and the sequelie. haditonaly, they are exposed to the ris naning accidents. current aorbidit a the Gcrtaing figures reflect past iseglect ot
dust control and safery precations in the dust control and sarety precal ion escalating health costs for medical care,

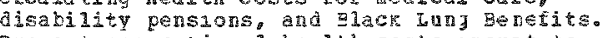
ipesent occupational hea ith costs anount to 5 oblion lollars per year. Projection o future heath costs as aficicit and degend on the eficiency of preventive measures ajmed at initing exposure of wcrkers to coal dust and nine safet yraniug workers also have a serious radionuclides which act as carcinogens in the development of lung cances. a statisticaliy developrent of lung cancer.

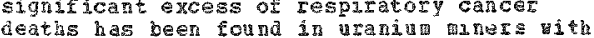
deng intervals between tise of initial leng intervals between tise of initial exposure and development of malignat disease. Minets aro also anposed to diesed of explosives, and dusts composed of silice and various metal ores. Dermatitis from akrasive hand cleansers, cils, and other pranary irritants are comon in urana

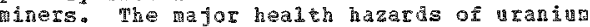
aners are comparable to those of nen 
<3F 9 > ConT. isvolved in fossil fuel tining and
processirgo viz. prenochiosis lung cancer, and accidents. Hoverer on a dol 2 ar cost and acciaentr. proverter on a dolia cost production is currently a health problen of production is currently a hea lth problem of greater agnitude becanse of the then larger naber of tacrets in these indaetries versu (a) hi)

$<370\rangle$

noss, D. H., pot given. 1968

A statistical sumary of 1.5 . At ond ic Energy Coll missicn contractors internal 5 yoosure Epperience. Covf-h70221; nonographs on nuclear

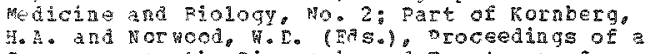
Symosim or the piancas and reatrent of

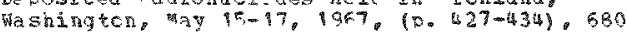

In response to an înternal eqposure information roquest hy AEC, fifty contractors to al1ea 32 cases. The foll ow 19 incormation was sought: 1) rad Ionuclide involved, 2) physical and chemical characteristics of radionuclide. 3) soute of antry. 4 ? late of exposure, 5) methos of Tedstiement ant calculation, fo kind of operatior, 7) extent of aeposition in terps

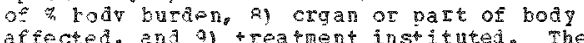
affected, and a) treatment inst ituted. tith $2^{5}$ m boly bueden selected as lowest estimated exposure. Entichea $0, \mathrm{Pu}_{0}$ eritum, o 210 I and $8 \mathrm{r} 90$ were the racionuclides involved in incerna 1 erpcesure cases. mbe inversty of radonuclides, poles of exposure and methols of estintion bere so great that few meani notul conclusions coud be drawn. rew meant netul conclusions could be drath. giveringiviually. Five contractors given injiviually Five comactor wepositions thet exceeded 2 cm of a body burdel. Bafority of these cases--1n 5-occurzed in two facilities. There ter $2^{\circ}$ cases durina the ro-yr period that exceered one body burder. The most srequent ronte of ontry was 1 . inhalation--87 cases. Fhere nere 33 cases which involved wondis. most pull astimations were done by uriralysiso me detals of nethods varied

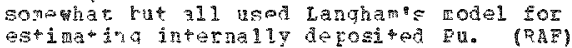

Table 1 ligt contractors ogerating major AF-OWgen faclilitias.

\section{$\langle 37\rangle$}

Fardo, J. ard J. Sediet Arconne vationa?

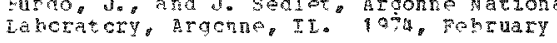

Eetention ar r riminatior of perkeling 249 , Califurnan 240 tol owing Acute Accitental Ir halaticn. Cogta-730957 (Part 1): DaEt of Snvder.

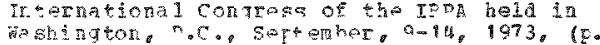
$72+7 ; 5$, , $147 \vec{r}, \dot{p}$

A case of accinenta? inhalation of a sali quntity ef an ianires minture of Bh 249 and its decay Frniuct of $24 \%$, was studied by hody radionctiph mensurements and excresing and iyse duning the first year after intake. Thw initial chese content of about 3 nci of "r 249 fecligel accordigg to a 2 -component exponorial functinn of tine fhalf-1:ves of

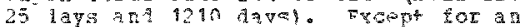

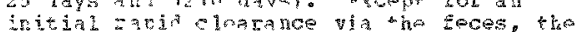

urinary and fecal excretich rates of both nucliaes increased with time until $60-70$ days ater intake, and then decined. If the early fecal excretion as meglected the eary fecal excretion as meglected the
resulp could be described as the diferences between tho expostuetial cononents hith

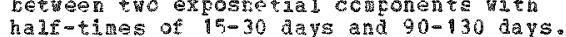
half - th
(Aut in)

see a1so peport, An -8060 (Eart 2), (p. 206-217).

$\langle 372\rangle$

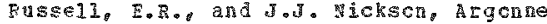

Naticral Iaboratory, Argonne, ILa 1946, octeter 2

The cistribution and Excretion of Plueons in Tho Huma subjects. CH-3607; $19 \mathrm{p}$.

(Declassifíd December 31,1946 )

Distribution and excretion studies vere pade of Pu $239(46)$ citrate in tho hula suleject given total intravenous doses of 5 and 94.91 given total intravenous doses of 5 and 9. aicrogtans of plutoniu respectively do
ciinical effect as noted wich ceula be attibuted to the biological action of the attributed to the biological action of the elementin 155 and 6 dags of observation
cespectively. Such changes as occurred in reapectively. Such changes as occurred
the hematolonical picture and in liter the betological picture and in 1 iner
functions can le ateributed to the terainal state of the subject, to the underiying disease, or both. The following tentative cenclusions were drawr. The urirary rate of excretion of plutonian in humas is exceedingly low. The evidence would indicate that the "chronic" (100 th day) excretion rate does not exceed 0.01 percert par day of of excretion of putonin Eitzed in the rooy is lower than the urinary tate of a factor affroxinateiy three. The evidance indicates afroxinateiy thiee. The evidance indicat exceed 0.00 percent per day of the amount in exced 0.00 percent per day of the amoun in
the bod\%. The highese concentration of the plutonium fired in the body is found in the plutoniun fixed in the body is found in th bone marrow. The liver concentration has varied 50 vacly in the tuc cases nere
reported that it is inposshle to preduct cr reported that it is inposenie to predict wighe be. The concentration of flutonan in the neoplastic tissue of these cases yas nct high. (auth)

<373>

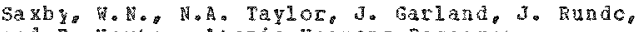
and $E$, Neton, Atonic Heapons Researeh retablishmert, tealth physics sranch. aldezmaston, Serkshite Fngland $190 \mathrm{~g}$

A Case of Znhalation of Entiched Uranian Dust.

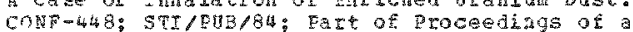
syocsiun on the assessment of Radidactive sody

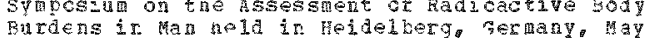

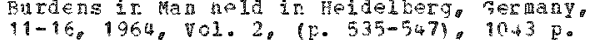

This papar presents the zesults chtained an the study of a case of inhalarion ot insolurle entiched uraniu bust. Tho prolined. The results of irine and fecal saming. agd ce boty radicactivizy

meastenents are presented and discussed. The authors" tertetige conclisions 1 neidue an assessment that the abpasent half-inte or insoluhio urania dust is the ciser bas arot 1 tr and a note on the fact that the

escrotion deta do not abparanty accoun fCr all the material leaving the shest the fact that the fecal excretion tate was higher than

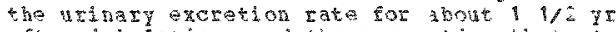
after inhalation, and the saguetion that at may be nsa to convert hally uriary unanto 


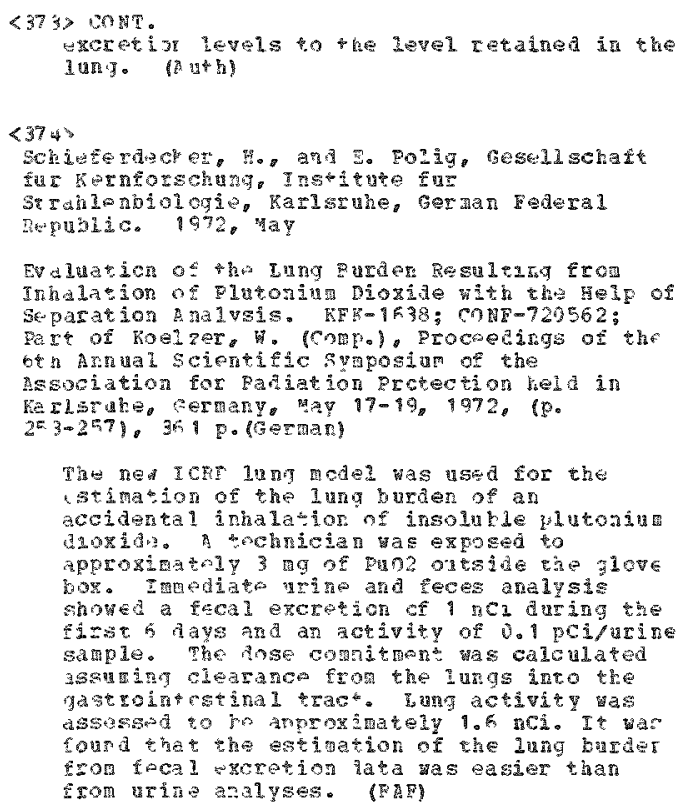

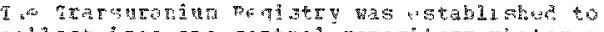

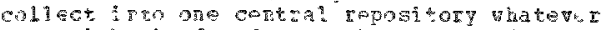

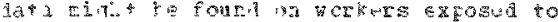

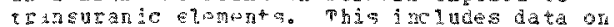

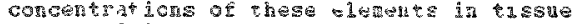

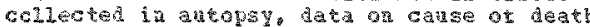

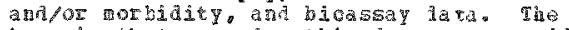

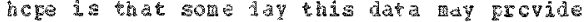
va these elamen a d on the haza Is encountw

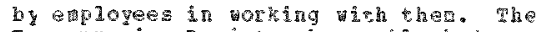

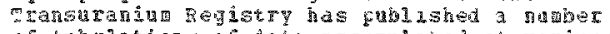
of tabulator of dara accuralated at vardous

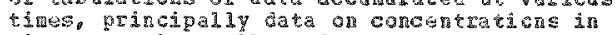
tasile 3anplez colleoted at autopsy. The study also coldectio dat of tho

study also collects dati ct those Feripheraliq exposed rhrongh oceupaton on on

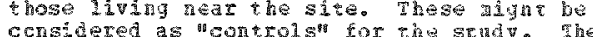
censedered as "controls" for the serdy. Wh data published as of september, 1971 , have

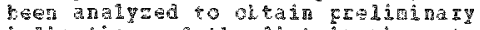

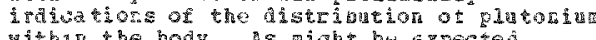
sthin the body. As right be exgecte

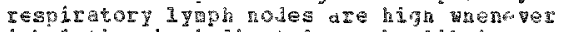
ishalation is inticated as the inkely route of exposure. The distribation of plutcris between liver ard hone is etratice the iner

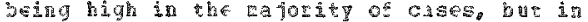

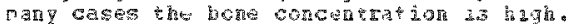

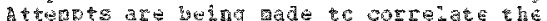
bonelitier ratio with the of arecom a lehough it is rocoun ized the other factors

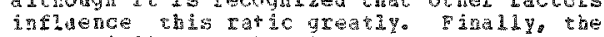

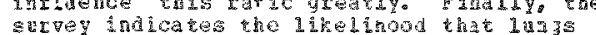

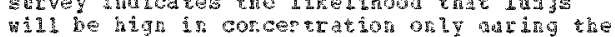

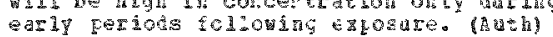

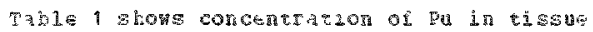
a日

$\langle 37\rangle$

37ge

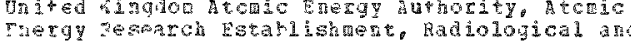

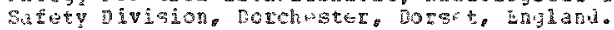
1006

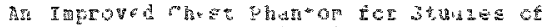

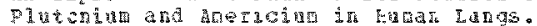

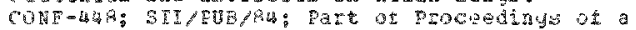

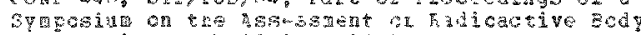

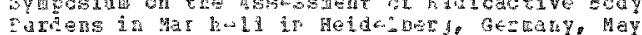

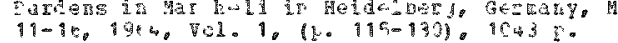

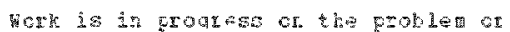

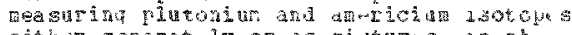

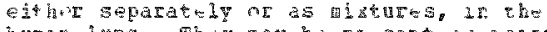

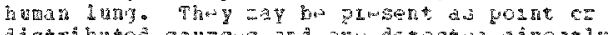

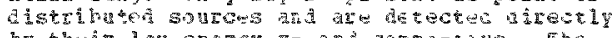

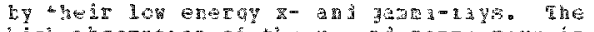

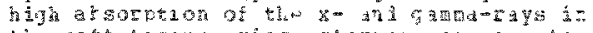

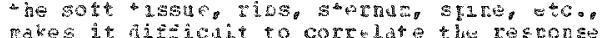

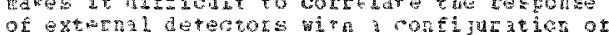
internal sodrcos.

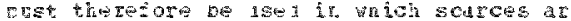

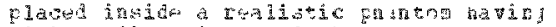

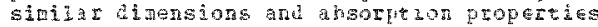
to the buma chest. obt desity ary

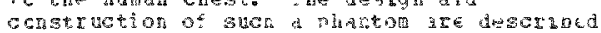
a

a

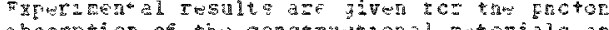

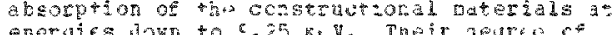

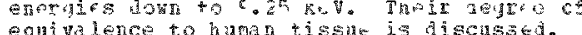

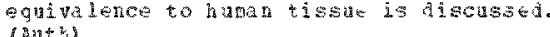
(n)

$\left.\left\langle 33^{3}\right\rangle\right\rangle$

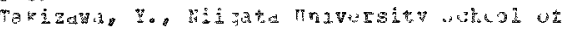

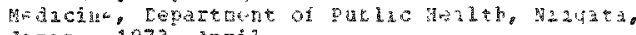
ง

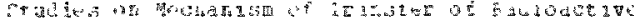

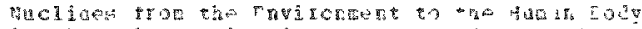

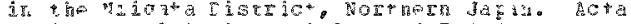

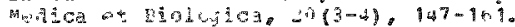


<379s tougr.

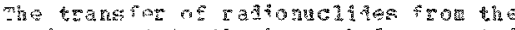
unviver mert to the huan boly has studied for

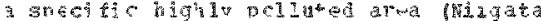

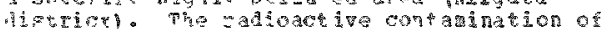
E130

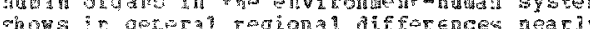
the neari

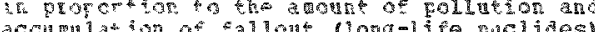
acer

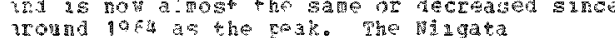
a)

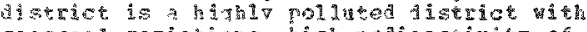

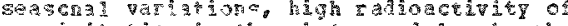

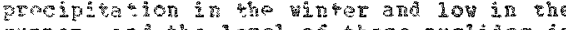
sumar. and he lover or these nuchides in the soil, food and huan organs is eviderty

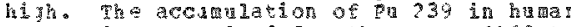
orgas is semaris for the years 1963 to 1970. Ihe loval of Eu $23 \%$ j.s highese in the

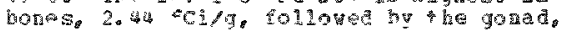

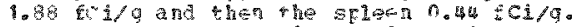

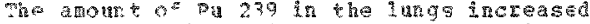

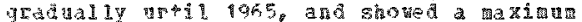

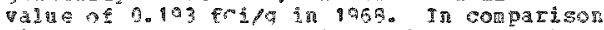
vith the rearatener values of the rst the

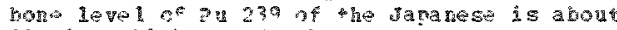

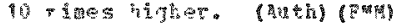

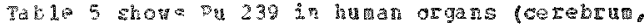

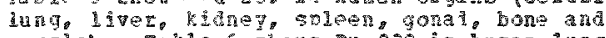

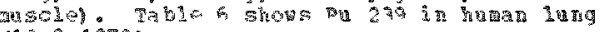

<379>

Taylor, D.h.. Inst itute of Cacer Pasearch,

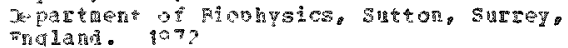

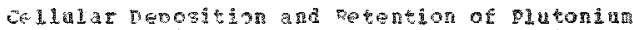

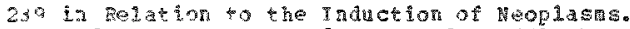

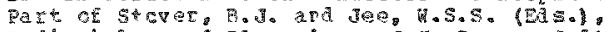

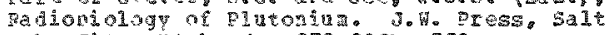
la

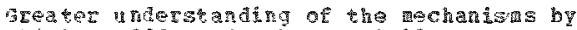
which 2 u 239, and orher actinides, are trancporter round the boty and deposited in colls and tisers is daportent in order to

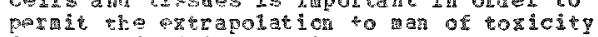
data obtined in experinental anjals.

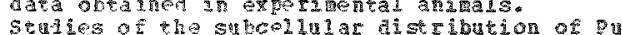

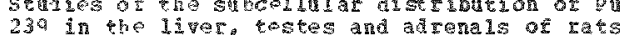
hate shoun that issomes are a jor sites of hute 230 localization. The aresible pu 239 locklization. Whe gossible 239 and $\mathrm{A}$ 241 is a scussea in relation to turor

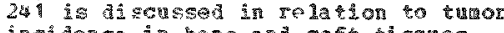
inchence in who and sort tissues. The need for further comparative studies of the sabe ellular Aistributon of 239 pu in huan and andal colis is eaphasized. (Avth)

$4380 \$$

Thomas, R. G. Lovelace soundation for medeal Bducation and Research, Fiss ion product Inhalation laboratory, Abrguerque, H. 1972

Tracheokronchlal Iq⿴囗十⺝ Hede Involvenent

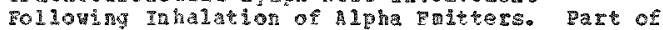
Stower,

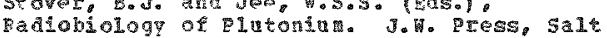
Lake city, itah, (0.23)-242). $552 \mathrm{p}$.

It is estiated that 50 years of chromic inhalation of a celat ive iv insoluble aterias vill result in a concentration in the tracheolenchial Iy⿴囗十 apprexinately 300 tides grea ter than tha the pallorar regton of the respiratory

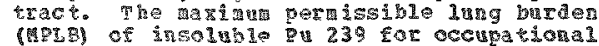
axposire basea apon tich an erposire schedile s: 16 nCi. vaing a 1000 gram lang the correspon

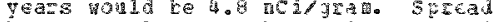

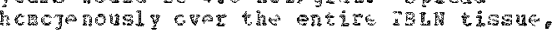

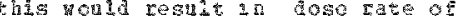

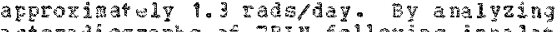

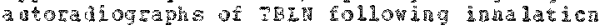

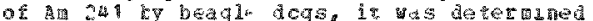
that on thae only abon por

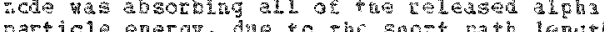
particle energip, due eo tir snowt path lence

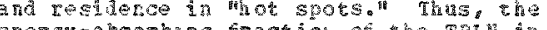
heray

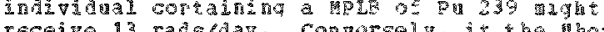
recelve 13 casasay conversely 1 is the wo

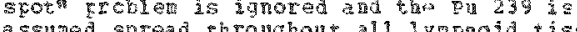

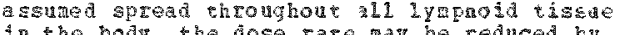
in the boly the wose race tay be reduced hy a tactor of 50 te 0.026 rads/ay. This is still fo thes the recognaed peraseible occibational dose rate te rote tissues a a could be interpretad co silyse a loweria of the mpte to about 3 nei. Die to the rany ancertainties involvaci in such a decisior at this tine, such as the lack of 3 atoration on the relative strisitivity of wodal tissug it

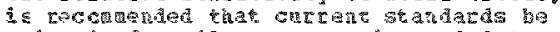

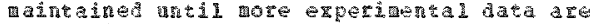
avilable tor evaluation. (Aute

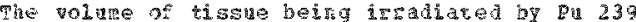
particles in the tracheorronial lyagn modes

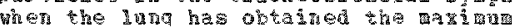
veris issiplo bureg is giver.

$381\rangle$

Thonsor, E.C.. J.Z. Eark, and

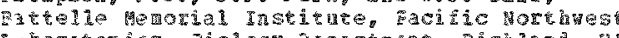

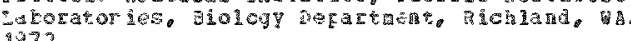
1972

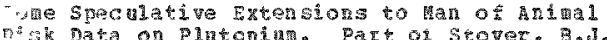

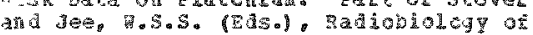

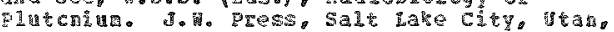
(0. $221-2308 \cdot 552$.

Speculative extensicn at the avaluble a ndal risk data to the problet of plutoni

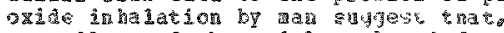
regardiess of the aotel eralogel for prealetion the risk or 3 mag tutes is not

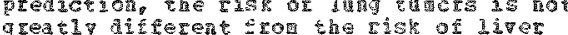

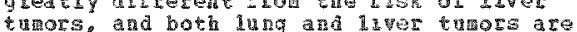

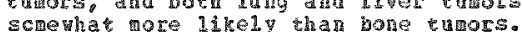
screvhat more likely than bone trars. Atsolute rumetical predictions of he tomor inositicn of plutoni depositich of plutoni and itthe reliance can be pleced on these nubers. The more conservative aproaches. horever. Lead to predictions of toral tumos incidence of a fer percent fron an initial bura deposit of 0.0 s wo which is a higher

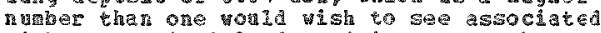
with a "poraissible deposition。 (nethy

<3:23

Volf. V., Kernforshugsentr karlsruhe, Gergan Eederal Republic. 1973

rreatrent after Incorporation of Fabjonchides. COHE-73034E (Part 2): PaEt of Feige. Y. (Bd.). roceedings of the Regional $\$$ prosiu on

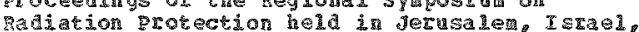
harch 5-8, $1973,(5,743-7601$.

In viev of the potentially hacand efracts of even small amours of certaln de cosited radionuclides, the Erocedures for reroving the from the bodr are or ureac inportance. sowe of twe decrepration wethols would be useful also in the removal of non-radisactive

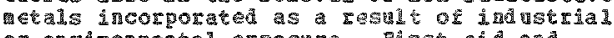
or environgental exposure. Fist aid ano 


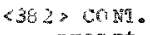

prompt treatan measuses afto incernal

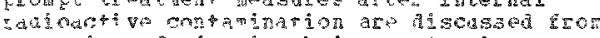

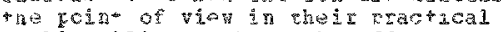

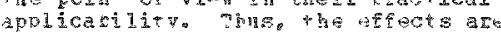

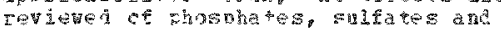

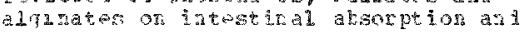

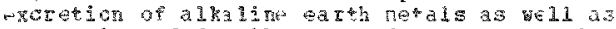

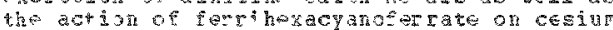
and thelisan. Furtherare, the nigh artecivents of nholation axents shoraly after incorporation or certan radion acdides

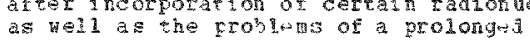
as wel a the probstos or a prolongt

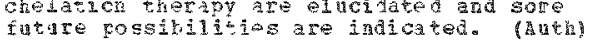

63. $3>$

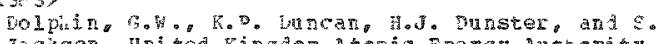

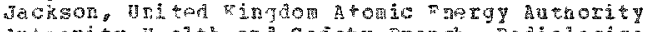
fat Protection Aivision, yarweli, Berishire,

Maxima 2 armissible Coneentration an Air for

The derivation of the values for maxinut pernissing concentration in air (kPc) es

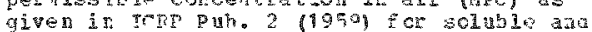

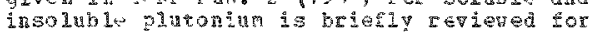
the cases of bone, 1 iver ard lurgs 25 organ the eases of hone, liver ara lungs 2 organs

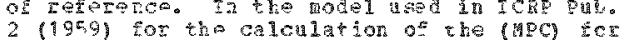
2 I1959) cor the calculation of the (HPC) ton

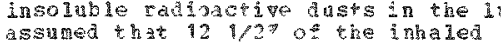
assumed that 12 1/27 of the inhaled
radionction

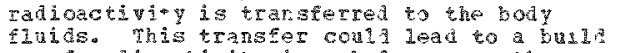
BE of radipactivity in a bodv organ ober than the 1und. Echever recent ata both rron dog experinerts and from huan antops ies shom that ehis is rot the case and the lar 7 is the crirical crgan following inhataon of

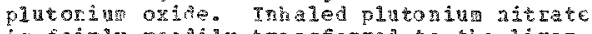
is fairly readily tranzerred to the liver ard hose ard conseguent ly the more

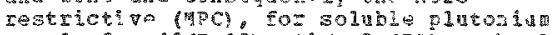

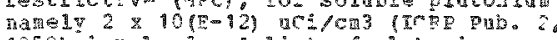
$1959)$ a a clver. A list of plat oniu conponds is oiven and aivide into those compontas is given and ajude into those

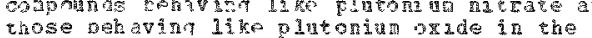
chose bahaving like platoriun oxade is the - (hesh)

Table 1 shows the dictribution of $\mathrm{P}$ il in body or qans (ling, iymbis nodes, liver and boñe) follow 190 intalation or pu oxide and Pa nitrate by dogs.

<3843

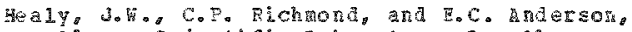

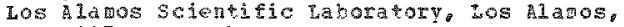
M. 1974, soverber

Theriar of the ratural pesources refense Council petition concetaing Ijitits for Tnsoluble

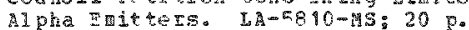

The inter pretations of the potential effects of insoluble alpha-pitting varticles in the lung as described in the document supporting the Natur al Pesources Deforso Council (ngDC petiticn of February 14, 197\%, are revieved in 1 ignt of present evidence. The origin of the vioc nroposal iles in the verg nor-uniform radiation dose to the tiosue surrount na a radionctive varticle. Sone description of the vature of the non-aniformity and the application of the concept of radiation dose to kiological problems is given. The Geeseman studies of folicular cancer produced is rat shi aro descrite and the afficulties of apulying whe resil of of one organ to another and the

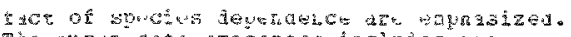

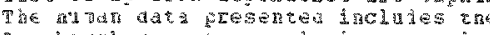

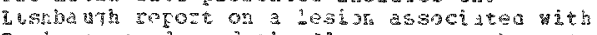

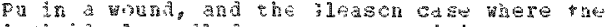

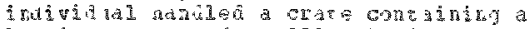

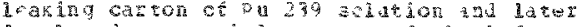

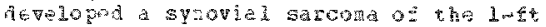

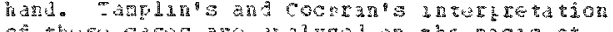

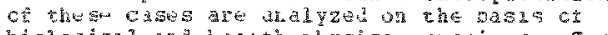

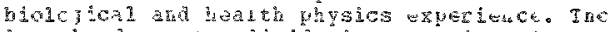

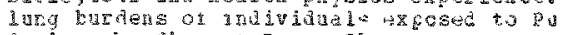

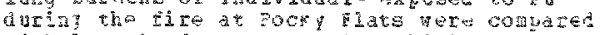

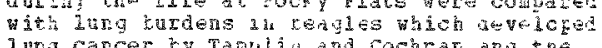

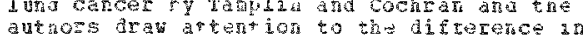
size betwer hupa and beage lungs a dab hero size betwer huth and beare luing a concluded cha the theories apon vhics tat preposal is based are not if aceord with the evijerce and that the tacorieg 10 not corretily prealct the outesat of experionts

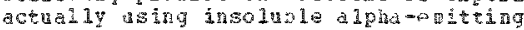
Farticles. The authors aso naintald thet

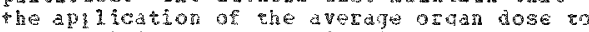

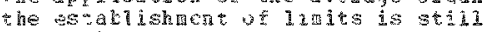

azproprate, althogh experiaentation to Tarror aristing whortanties on the efrocts

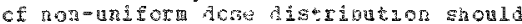

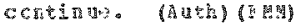

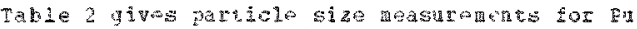

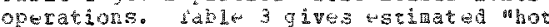

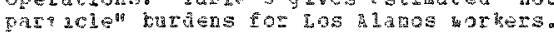

$\angle 39=3$

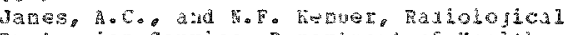
protection seryice. Ieparthent of health and

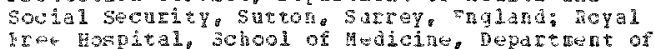
Helical Inysics, dordor, Engand. 1972

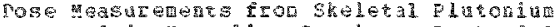
Compare 1 in vamalian species. Past of scover,

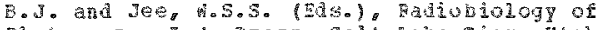

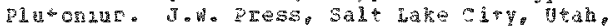
(p. $299-292), 592$ p.

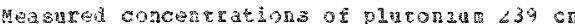

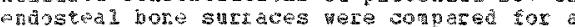

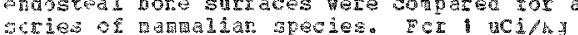

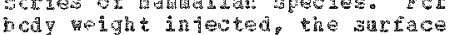

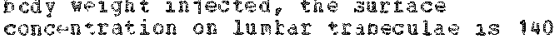

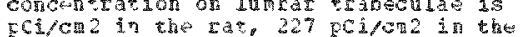

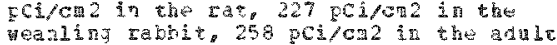

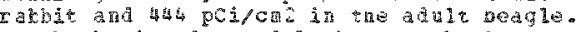
on the basis of a model whereny the buzes are simply alterel in scale frca species to species, the corcertration extrapolated to

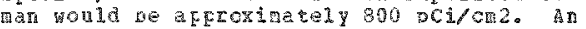
exprical model alving a betest tit to tae cherved concentrarjons in the smaler mansel gave an extracolated ty

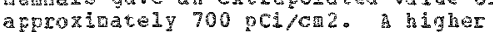
concentoation is predicsed when asasua

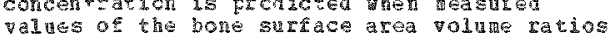
values of the bone surace area volume ratios

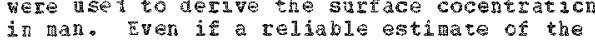
in nan. sarface concentrations for ocne sarface concentrations for avalable, leading to an accurate estimato of a vilable, leading to an accurate estiate of the variation between spectes of the kinetics of noma 1 and alignant cell populations voula stjl give an uncertain estivate of isk. \&uth

Table 1 gives Fr 239 concentrations on endogteal bone surfaces, A29, 5abbit, and rato Table compares total sheletal uptake betues apecies.

$\langle 366\rangle$

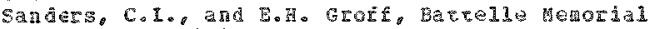

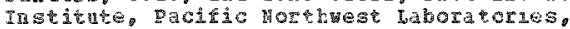


$\langle 385\rangle$ Cn

Fichland, wa. 1974, woverber

ablotography: Ifferts of Radiation on the Lung with Eecerences throuth 1972. Fith - 1970 ; 53 p.

Fhis bibl agraph is intorded te provide rapid access to the literature on the hiological eftects of variols radations delivered to the inng of man and experimentas aningls. A Inited number of the zore relevare papers published up to 1947 are included along $r i t h$ a comprehensive survey of the liter ature fron 1947-1972. Papers that describe the biolcoical effects of raditions tron occupational exposure, cinnical diagnostic or ratiotherapy exposure and dzathostio or ratiotherapy exposure and an als are ingluded in the strvey. Intividul omplasio mat be on the nolecular

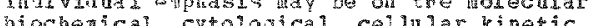
biochedica cytologica cellular tinetice raliation 9 al thouh the latter emphasis is the sartic ct of the na jerity of papers. The most-oter descritroi radat lons include freternal zerays anma rays, or meutrons ara 3ulaorary heposited bota or aloha eniteing radionucises. papers cercernea only ith dosinetry, wetabolism of radionuclides. radiographic diagmsis of pul monary disease.

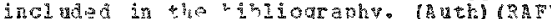

$\langle 387\rangle$

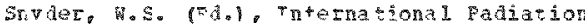
procectior ssociation. 107 is pencuary

Third Internatonal compress of the internationel Radiation Protection association.

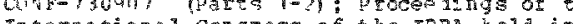

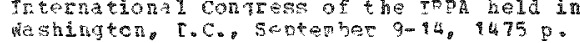

The conferonce tojetret consting of 237 papers, of which $?$ were abseracter sovarately in the lata base. In part one the man topics were. ratiatior netroctive in the usa. rajiaton And beri nos ionizing rediation: radiation

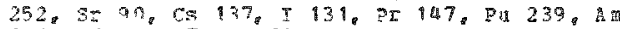
2ul and wp 237); ratoocoloty, such as the Histribut ior of environental pu in the Ir.nity ite omotsteg afeer 17 years; reactor uperioger. waste ma newent and

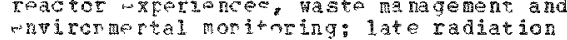

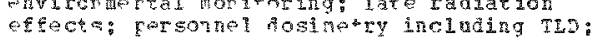

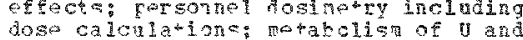
creastrar ind olonents; and radietion

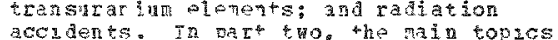
accidents. In ber tho, the main topics

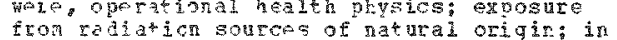
vivo masurenent; ox cosure frou nuclear pover: nedical exposure: aerosols and lung nodu Is; oublic information, legal aspects. sacution ar training: and netabolism of radiancliaes. In adition the 1973 sievert lecture entioled madjatior and wan" yas rroserted, (घ)

$\langle 368\rangle$

Suzakj, M., national Institate of Radiological seinces. Catra. Japan. 19?? ay

graniue. Shin tiagota, 19(5).

$118-123 .(3 a p a r e s e)$

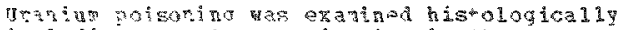
incliding revorts on poisching in the Mathat ar ropect in the snited states. In "urda and arima ow

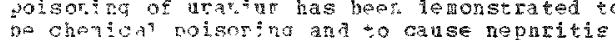

Wh uraning and other diseases related tc it. If enels containing thor 1 ind series aro used in the futre, radiation infury wil appear in the following riccasions: 1) when urasiun is accumblated in the organs of hutans especially in the lungs and 2) when the buan body gets near the place where a great ancun of urating yith daughet Ialdonuclides in a great quanticy is present. There are differences in the level of poisoning betreen uraniam $y$ ith valences of 4 and 6; abore all, urantu vith valence of 5 in aqueous soluticns has the ablity tc promere anionic complexes. The amount of uraniun aouse tissue was examaned in order to etwiy the knatics of uraniat correunds in the hody. The effect of urania poisoniag on nephrons of the kidney during its getabolism nephrons of the kidney during its getabolisw carbon monozide anon of moroxide croteins in carbon monozide hon of mororige croteing the cells, with denatures the proteins and (JA)

(389)

Vaghan, 3og Churchild Hospital, Frford, Figland. 1971 , Aptil

Henatological Consequences ot Fadisisotope Incorporation ilth particular lefererce to

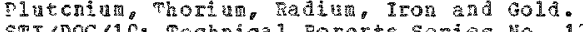
STI/DOC/10: Techical Fegorts Series lo. 123:

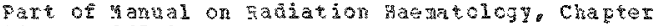

21, (T. $215-2+2$ ).

Tho technical report reviews the tissire Aistration and chenasty. dosiatery and

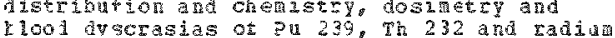
isotopes in hurans and aripala Also discissed are the absorptoh, utilization reasurements of blocd loss plasma turncyer and thermal rasge of $T$ / 2 plasa diearance and sarface courting of 59 . Hewatolosi inadedute, however, in vien of the astribution th arrou, severe blood dycrasias are to bo expecta. intornation is available on the grich is widely used as a contrasto ot its oxide. cases of lerkenda a rat ncr-levkenic blood ayscrasias are th Mockmenter in the it terature. Wuns and aniads exposed ro radulu 2sotopes ray develof leurenia severe anemis and osteosarcomas. Collodial jold ased for bore

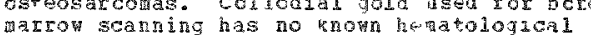
erfectso (nat)

$\langle 399\rangle$

Vatghan, J. 月, Churchi12, Hospital, Medical Fosearch condinci. oxford. Ingland. 1956

The Efrects of Radition on Bone. Part of Bourne, G.H. (ta.). The Hiccheristry and Ehystology of Bone, Chapter 23 . Acadello press,

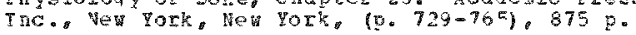

The three man sections of this revev deal whth the general aspects of radiaton dosinetry ith special relation to bone, the relatonships of anacony and phpiology of hone radiation to pathology ana dosmetry. and pethologacal changes irarced in bone by irradiotion. Aratomic and physiologac

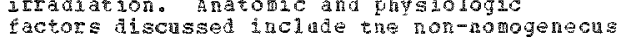
chactors discissed include tre non-romogened

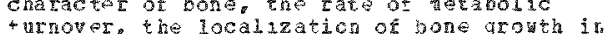

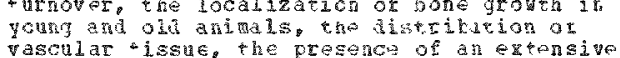
vascular + hssue, the presence of an extensive

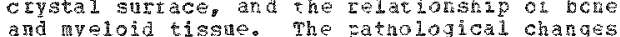

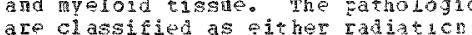

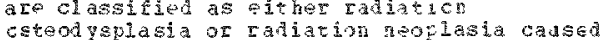


$<390>$ COHT.

by 1 nternal or external radiation. Both clinical and experineatal data are supported by an extensave bibliography. The data presented shon that sarcona nay develop in presented shou that sarcona maq develop in bone folloning both external and inte
irradation. In the case of erternal irradation. In the case of external
radiation, the latent period so far recorded had ation, the batent period so far recor latent per1od recorded as developing after internal raduation. Tum crs follown extermal Iadiation have developed an the gajority cf cases after a dose greater than 3,000 roentgens. The dose of internal radzation nocessary for tumor developient appears to be varable. the lover limit bung extrenely small. Po explanation 25 avalable at present for the delaged latent period in tas development both of radiation oztecdusplasia and of malignancy follow 2 ing the retention of minvte axounts of radioactive elements. In assessing risks of of suscertiklito of $19 \mathrm{~d}$ ividula should be

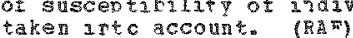

$\langle 399\rangle$

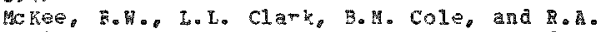

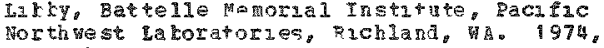
september

Dose-to-the-fopulat or Estanates for 0se of Radionsctope poveren cardiac pacenakers.

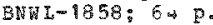

Istumates or tre population lose vere developer $1 \mathrm{n}$ terms of an ogul 1 iring first-1mplant rate of $10,000 \quad 1093-e g u x$ valent radussotope potored carilac pacemaker (PBCP) ind lants rer year a ajuste for poculation ancreases $1 \mathrm{n}$ future years. It was calculated that trere would be from 130,000 to 208,000

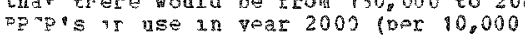

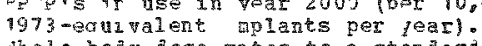
whole kchv des rates to stardard an pharton fon tro different 1nslanted PECP sources pere calculated using the $2 A D$ p $5 \mathrm{~A}$ conputer grograt. The two sources were the

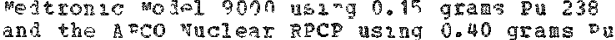
and the ADCo videlear RPCE using 0.40 23a. Dose rates from the scurce were
calcuated in four anrections and averaged to represent a single average dose rate to a person in the $\nabla$ icanty of a pacemakel user. In terras of rontal aose only dose rates would be 90 to $100^{\circ}$ haher than the average itom directions. The RPCP use projectuchs an 1 dosimetrv calculations provided inpat for

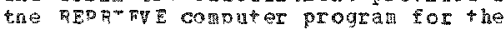
lose-to-the-vonulation caleugat 10 ss. The computer progran output provides a breakdow of the dose by age and sez for signiflcant atasifucations of Dersons who recelve the dose such as sponses, nembirs of the hose such as sponses, ne ribus of the results ho Isetria and work associates. The results of the calculat, wh of the calculations shom that the total population dose ranges from 1460 Iam/year to $6,000 \mathrm{rew} / \mathrm{year}$. Because of the larger source 3120 in the Anco tuclear EPCP. the population doses calculated vere appeckamately tware as great as those

calculated wath + ne MedtIor $2 \mathrm{c}$ odel 9000. Sponses recelyat the greatest nditudul doses but these range on 19 up to 15 or 16 mren per yoar, whle the other housenol members recenved on the order of 1 to 3 mren per vwr. Dcses to both nonwork associates and work associates are in the range of a ten tenths of rtrom por year. The alose to the general popu? are. vhach accounts for 33 to $43^{2}$ of the total pooulation ase, averages only two to seven micto regs tes porson per year. None of the exposures to ary grou appears to be excessue and it was concluded that the population ase rror BPCP's does not represent a sagnificant risk. (Iath) (roh)

Table shows year 2000 populatron acse estrites per 10,000 1973--equsvalent first zolats per year. Table 7 shows externa 1 a ose ta tes to a standara man phanto Iaglanted A heo Recp (areb/hr).

<392>

Rajewsky. B.. A. Raul, anô J. Heyder, Francurt/Man, German Federal Republic. 1964

on the Developtent of Devices for the Detergination of Total-Body gadioactivity $2 \pi$ Ma 1 : A listorical and crutcal Feviev COHF-448: $5 T$ TIFUB/84: part of Eroceedings of a Symcsin on the Assesement of Radioactuve Bcdy

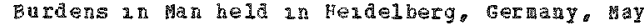
$1:-16,1964, \mathrm{Vol}, 1,(0,15-52), 1043 \mathrm{k}$.

The in vivo deterwaticn of the total-body ccitert of ancorporated radjoactive substances is 1 mportart mot only to deternare the natural content cf Iadionuclides whin the human body to obtann fundamental values for the Elxation of "maxal 1 body burden
also ror radiation protection to survey also ror radiation protection to survey

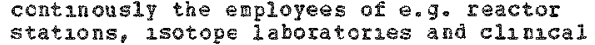
hcsprals, so that even the lovest incorporations can te detected as early as pcssible. The determation of the amount of incorporared radionuclides by external darect measurements of the radicactivity goes ack te the berly $1930^{\circ} \mathrm{s}$, when the furst cases ct radu possoning vere exanned ny means of zcrization chabers. on 1 a few years later a first "Institution for the Physical cuagnosis of Radau Rolsoning vas

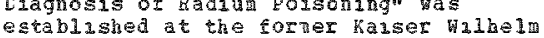
Institute for Blophys-cs an Frankfurt (Malm). in vero and post norten dagroses. In 170 diagnosis consisted rainiy of deterination of the feces urine ard the breath. In adation, feces, urine and the breath. In dadion

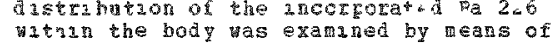

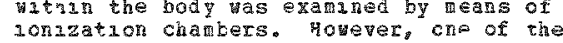
problems of radiation protection, nameiy $r \in c o g n 1 t i o n$ of even low Iadzoactive incorporations as early as possible, could nct be taken anto account at that tines sarce the instrumental 12 mt of detection wa the sane order of nagnutude as the naxnm perassible lody buraen for Ra $226(0.1$ ug/total body). Hovever, it became possuble a rout 15 uns ac to deternine adooct ncorporations of a cout che crder of ragnowa only below the nornal Ra 226 boay content ty means of high-fressure $10 n+2 a t i c n$ chabers ard. later ong by scirtiliation counters. Furtuercote, manly during recert years, the applacation of aethods ror the tears, the applacation of athols ror the radionuclides was extondea to clirical and radzonuclides was extended to clirlcal radiologicad problems concerning the The metabolsst of different Iadzonuclides. The exprermental possablates of the dar

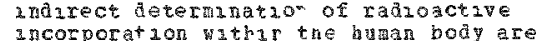
ancorporation with the balan body are discussed in this rustorucal and critical 1) restugtions and those of othars. (Autn)

Table 9 shows detectror 13 mats of shole-body

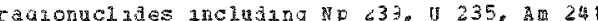
and cf 249 . 
$\langle 393\rangle$

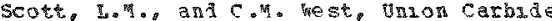

Corporation, $\$-12$ PIant, Oak Ridge. TN. 1964

Detection and Fvaluation of vraniug Exgosures. CONE-46; ST I/ping/84; Part ef Proceedings of Svarost un on the Assessuent of Racioactive Bod $11-16,1054$, Vol. 2, (0. $923-533)$, $1043 \mathrm{p}$.

Approszatelv 1800 personnel of the union Carolde corporation-operated united states Atomic Energy Compassion 1 - 12 Plant invoived in the routine industral-scale proc
uraniug Dersonel monztoring is

uranith bersonel andering is vivo gama-spectrun a nalysis programs. The interpretztion of dat a from the two prograns and the relationship the rec are presented. Personnel-mon toring results from the tvo progran are di ied nto four classes namely low urinalysis and low in vivo tesults: hugl urinalysis and low $\mathrm{xh}$ yvo results: $10 \%$

uri.ralysice and high in vivo reaults; and high urinalysis and nigh in $\checkmark 1$ vo results. The ad jomty of the persons montored fall into the ficst elass: however, frout the exposure standpoint the last three classes are of prime intesost. "rameles of cases faling prime interost. xamples of cases faling tnto these classes are presented. cases ranging from less than 100 d to approm 1 ately ranging from less than cases 111 istrate that the elimination of cases 1 linstrate that the ellanation of and uran wu from the lung varies both in wode the exposire material. Insoluble urania is excreted by both arine and feces. Urinalyses are asually adeguate o haghlight potertal erposure cases. powever, when dose

evaluations are to be made. conszderatzons should be given to the possubilities of fecal excretion and noderate rtensions of a blological half-life bey ond $120 \mathrm{~d}$. To evaluate a uranum exposure thoroughly. urlolvas, fecal andyes, and in viso spectru andyses aro desurahle. Correlatron coefficients for results of the topo programs groupling data by type mork, are also

presented. cormolian ranqed from o to

presented. ro
+0.32 . (nuth)

$\langle 344\rangle$

HeIa, K.R., R.C. Hente, and J. H. Selby. Battelle Nenorial Institute, pacific worthwest

Laboratories. Hichiand, Wh. 1965; 1968

Frompt Mt2qatory Action Ater Accidental

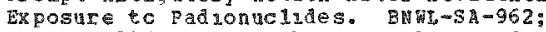
Conto -670921 ; prographs on welear Hedicine and Buologe NC. 2; Part of Rornberg. H.A. and Horvood, W.D. (EAs.). Proceedng of a Symposium on the Dagnosis and preatrent of Leposited

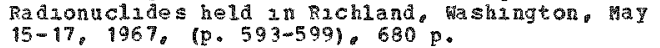

Through 1956 there have been 201 unfuries at Hanford that were potentally contamatec weh plutcnum. feasureable guantities of plutong un have ben detected in $123(62 \%)$ of these cases. Surgacal ezcsion was performed these cases. Surgacal excision was performed for 78 (39\% of he cases and 12 16\% vere adnuntered a chelating agent. Eleven case resulted in deposition evalua tea at greater than or equal to of the hPBB, four of whych $50 \%$. Some 1,000 cases or accidental exposure 50\%. Some ,000 cases of accidental exposh to arborne platonquis have been recorded
throvgh 1056 . of the se cnly 93 (9\% of the cases resulted in depositzon evaluated as greater than or egal to 0 \%. Ma inhalation cases have been adm nistered a

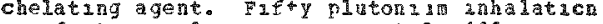
incidents iavolving appoximately 100 fersens cccurrang at hanford over a two-year perzod were examned in aetall. The ratio of the $n$ umber of persons exposed to oluton 2 as in an cride form to the nuber of parsons exposed to plutonum an a nitrate form was 10 to 1 . seperal types of data are bearg collected to assist un evaluatig inhalation cases in assist in evaluatig inhaling cases in wholuble form. Particle sige studies are insoluble corn. partucle gize studes are made of plutoniut collected on arr saples filers anc on nasal stearso also tecal saples are obtanned. otalizang the ICR Lurg Model and these data it is cften Fcssible to obtaln a preliminary estrmate cf the lung burden and the ultimate body burden whin a week or two. If avaliable data suggests that the deposition of pu via break an the skin tay exceed 0.01 uCl pa 239, a temporary work restraction precluding further verk wh plutonim of other biolcgicalit Simla r radionuclides 11 be $15 s$ ad util a formal evaluatzon can be completed. It the deposition is evaluated as exceeding $0.02 \mathrm{uCa}$ Pu 239. a perwanent work rastriction is recomended. This wcri restrictica vould a 1 so peciude further exposare to plutonia or bjologically sinjlar material and preclude or biologically similar naterial and radiation as tell. close liason between radiat ion as well. close lialson between radiation grotection and aedical bersoni even years $2 n$ the extreme cases. (Auth)

\section{〈395>}

Lloyd, E., and J.H. Marshall, Argonne Rational Laboratory. Radzologieal ghysacs DIvision, Argonne, It. 1972

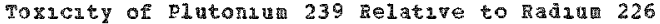
In ll an and Dog. Dart of Stover. B.J. and Jee, W.S.S. (Eds.) Radxobrology of Plutonala J. p.

The relative b1010qual effectu veness of Pu 239 compared to ra 226 in man cannot be regarded as being equal to that which has reen found experinentily 3 in dog hecanse of the diffecent as the as iserent aistributan patterns

differences an the very a dertant and dog. Som of the factors afecting the and dog. sone of the ractors a relative toxacities are bone ineral in trabecular bone of the dog was found to be higher than the corresponatno palues in ma yy about a Eactor of two. (2) The bustal rate of surface aeposits of Pu 239 la 21.5 year-old dog $2 s$ at least an order of gagnitude greater than $2 n$ an adult wan. This burcal rate in dogs appears to be criticaliy dependert on age and decreases rapid after the age of 1.5 years, the age at whach wost of the toxicity studies have been performed. (3) The percentage of the rarrou volude irradiated by alpha -eartting bone surface seekers as haghes in the dog-about $25 \%$ ccapared th about $10 \%$ an an. in the hugher proportion of bone volute ger unt hagher proportion of bone volue per unt

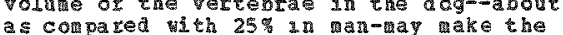
as coll pared with $25 \%$ an an-may rase the bore damage. 11 of these factors houla $16 a$ bone damag. 11 of these factors nou 1 l 1 ad Pu 239 and a 226 in man and dog. The Erst two factors would sugaest that the relative two ractors Hould suggest that the celative man tha in 1.5 year-01d dog. (Auth) 
$<3953$

Wharal Enz rornental Fesearch conter, bas

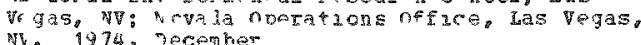

it site surveallancw a rond the Novade Test a 107\%. Padarion Data and (15, 112$), 202-817$.

Tratulu released hy the Julg through Decenter 1970 tlaring operatzons at project Pailson vas detected in ali trpes of eviromental saples ccllectod on tro ground an offsite azea oxcept for $191 k$. crops, confeed, urne, and andal issue. Tho hagrest concontration of $k x v p t o n-85$ in air was less thar 9.05 precent of the $\mathrm{BCC}$ standerd. and the highest trite um concentration in ar sabrles vas less than 0.5 pescert of the ACC stardard. The only

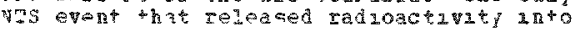
the offsate environnem during thas regortang perzod vas Baneherry, or Decenber 18,1970 .

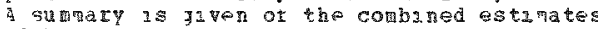
of hypothetical. on ant thyrond doses which were calculated from geasured concentrations of arsorno rajosodne, concentrations of ratiolodne in milk, and external ganm

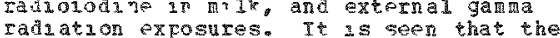

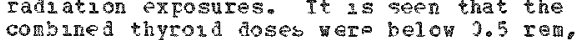
the radation protect $10 n$ stardar for thyroza

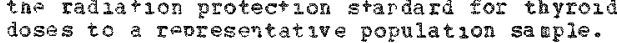

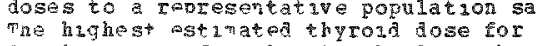
Aanetery was for the sheepherdars who vere working between Turpa and Dack water, Nevala, and using srou for cooking and dranking. although no snov heing used by the heraers was collected, inference from samoles collected around the area supports a thyroud lose estanate of 0.5 fer flus or manus a ractor of ${ }^{2}$, which 9 within the radiation of an andvidual wing the general popa latzon. (a atn)

$\langle 3 \mathrm{a} 7\rangle$

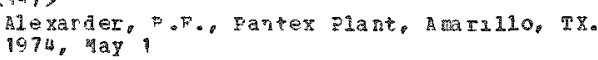

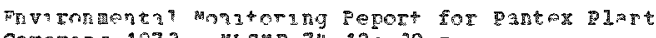

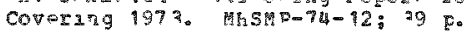

an envromental nonatoring Dzogram has row ostabil shed for the Panter plant wheh 3nvolves anr, water, soll and vegetat ar samplings and analys. lthough partes Plant operations anvolve the hading of significant guantities of uranang plutonate. trituid and toxic naterials. safeguards have preciuded potertial Iy hazardous releases of thase naterals. Release of materials has been restricted to stall amounts of tatural uranum depleted an the asotope $y 235$ durand

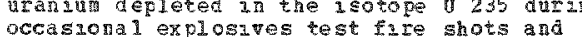
occasional explosives test fre shot and tritum wheh wigh be found in the entron 1 at at slighel higher than
background levels. Concentrations of these backgrond levels. Concentrations of thes AES criteria. (Auth) (RAF)

《98》

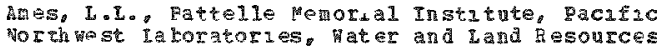
bepartment, Pichland, "po 1974, Febrary

Characteruzatuon of pctunde Rearing Sorls: Top S2xty centatineters of 216-2-9 snclosed Prench.

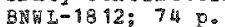

under pre-1965 waste ansposal pratrcies at sanford certain achndembering solution

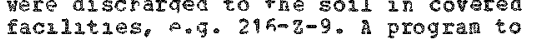

- xaine the soll-actinde telationsmig an 1natated. Soll mounts weze nale of scil recovered from a core or an wincontaninated yel1 arilied alongside the $z-9$ trerch The uncontam ated mounts shougd that the less than 30 mesh soul was conoosed of

than 3o mesh doal was conoosech of predolinately wetancrohic rock erayments c

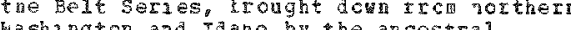

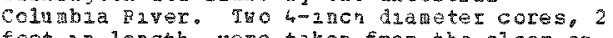
feet in length, were taker from the rloor $z-9$ trench. overying one of hese cores $(4-11)$, was a sludge layer of s112ca, aluma and water. The core $(4-5)$ had no sludge layer. at least two types of plutonum yore foun 1 in cores $5-11$ and $4-=$ by

a atora jograpric ara microprobe exalnation. The plutonzun fartzcles fuE to 10 ua 20 d lameter and 50 wto Puc2) were the wost conspicuous form. Theste ccurred noa tre tof of the core 4-11, but extendea jown nearly to the bottch of core $4-5$. The second forn oI viutongan occurred in lesser concentration $(<0.4$ wty $\mathrm{PuO} 2)$ bat was fourd througrout the length of both cores asscolated whth siliceto bydrolysis. Ioss of alkalies ard alkaline earths along with the absence of several metamorphac nuerals found in the several netamorphac matran found in the chemlcal attack of scil tock fragments

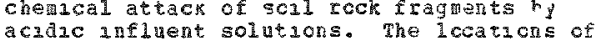
aciar influent solutions, The lccaticns of assoczated plutoning deçosztzon, are presertiy unknown. (Auth) (PMy)

Takles 12 and 18 show analyses of $P$ and assoczated dements.

(399)

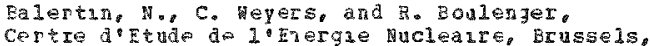
Belgzam. 1965, Ju1y

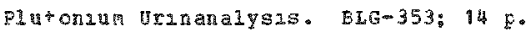

A saple method of urananalysis. sonsatye

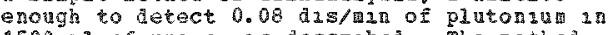
1500 of urae. 15 descrabed. The methca consusta of a phosphate preciphtatior folloved by the destruction of orgaric matters $\mathrm{kp}$ ashing. An anion exchange is usea tc separate platorium from other renanjig inorgaric $10 n$ s and the final purified plutonau is degosited or electrovlated on stalnless steel discs and counted in a $\mathrm{zh}$ scintrlator. Ter to twenty saples can be treated per day by tro persons, the result beng obtaned three days after the beganing or the andysis. The recovery of about 3 di./min of plutonum frcia litre of urame is 78 plus or minus percent vith $95 \%$ confudonce. (Auth)

$<400\rangle$

Phat. I.S. Tarapur stomic Power Statici Cclong. Fry ronental Surpey Laboratory. Bozsar. Maharashera. Inda. 1972, Novegber

veed for Environental Honitaring for Nuclear Is stallations. Indian Journal of occupatzonal Health, 15 औh, 8-14.

Increased use of rationsctopes for medicine. agriculture and 1 nejusty, fast growth of nuclear power production and assconated muclear fuel productacm and reprocessing. produce large amounts of radoactive wastes. The radioactive gascous an ligua wastes The radioactive gascous and liquad have to be disper sed sarely an the environdent: In the envircatant there are many pathays through whin the discharged 
<400> Colts.

The Health Fhyscs Division (HPD) of Bhabhe

The Health Phisics Division (HPD)

constituent unit of the cepartient of atomic inergy, conducts safety montoring of envion ntal rajuactive contan anation from nuclear Installations in the country. The envizonmental paranoters of 1 nterest to nuclear intallations include seasonal varlation of wind, water movent, ecological factors and denography. HPD organred and set up the Furrongental survey daboratory (ESI) on tehalf of the Tarapur Atonic power A thor ty when constraction of the powes reactors kegan. The laboratory and field research carrued out by the FI to obtan the basic factors regumed t $c$ control envi ron mental raduation exposare is described. Included are studies of soli-flant relation for fallout nuclides, diet-irin relation for fallout ruelides for the local. population, and stadies of the local. population and studies of enva iormental dispersion and reconcentrat beaches. (F)

$\langle 401\rangle$

Bogen, D.C., C.A. Henkel, C.G.C. whste, and G.A. velcord, Health and safety haboratory ves rork,

Thatum Thtake in New York C3t\%. CONF-710809; Part of poghiss?. A. A. and Carter, M. H. (Edso)。

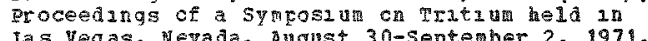
Las Vegas, Nevada, dugust 30-Septerber 2, 1971. Mesenger Grapt $10 s$, Publushers, Las Vegas. Nevada: $(p .(39-646), 907 p$.

In an attempt to establish base 11ne amounts allowale for exposure $+c$ tritiun by the general population three intake categories. diet, ar and Eludas wer analyzed for their tritiun concentration. The food $2 n$ the diet study vas purchased durıng wanter and spring 1970-1979. Samples were freeze-drued to

remove and collect loose wateI from the bulk saple an ashed. Fap ater vas dustiled tc renove 2 purities and electroly+1cally enrached pror to counting. Water in the amblent axr was condensed in a digy besacetone bath. The condersed water vas also distilled and electrolytically enriched Drzor tc liquad seantillataon countzng. nuetary trutium intake values were deteraned In 19 food ca-egorzes fer both loose water

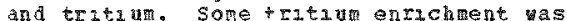
observed in the organic fract 10 of certast food categcrias. Calculated val mes for the total te th intato in

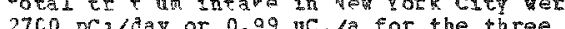
nodes of intake miet 0.62 vC1/a a 0.037

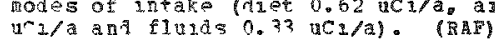

Diptary trutzum intake by food categorses are lssted in Tables 1-4. Trutum concentrations in

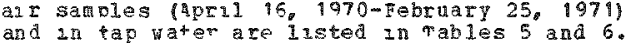

〈4⿻ 2)

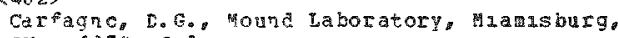
OH. $1 \rightarrow 74, \mathrm{JuIV}$

Mound Laboratcry's ar survelilance systen. WASH-132 Crif-740406, Dart of Proceedings of

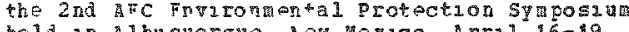
held in alinonergue, hew wexico, April 16-19, $1974, v 01,2,(0,560-576), 1151$ to.

\$ comphencrpe ar anvel11ance system was developed at mourd Iaboratory. The syster provides for survelliance of the source by provides for survellance of the soutce by enissions. The trasport conditans ate continuousiy monstored at an on site veteorological station. Hand speed and direction ace measured 160 ft above ground level by tomer-mounted 185 truments. level by tower-aunted 1 struments. elevations to ald in determing atmospherze elevations to ald in determing atrospher

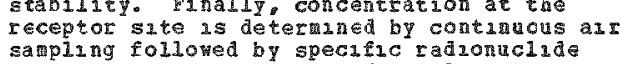
analysis. Several types of sagles are cllected at the continuous aur sapling locations. of particular interest is the continuous bigh volume particulate samie whose monthly composite 15 andiged specifical1y for $\mathrm{Pu} 238$. The annul averages obtaned for 1973 range from 1.9 to 57 ac1/a3. mother component of the ars survellance system is a salil computer whoh v11 collect data reduce it, nodify the atwospheric diffusion eguations, and atrive at an atrospherde diffusion model for mound Laboratory. An unusual aspect or the $\$ y s t \in m$ 1. the 1mpiementation of offite samplin

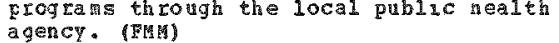

(403)

Cheever, C.In, C.H. Younquast, R.R. Hirsch,

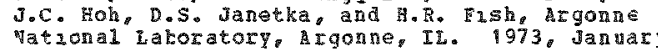

Effects of inghevel Garna Radation Exposure

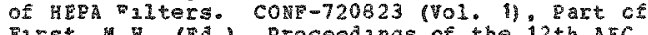
Fisst. H. (Ed.). Proceedings of the 12th AEC An Cleaning Symosim held in oak Ridge. Tennessee, sugust $28-31,1972,(0,638-645)$. 899 D.

Evalua 1 on of the effects of stepwise exposure of tuve $12 \times 12 \times 6$ inch $\mathrm{HIPB}$ exposure of 1 va $12 \times 12$ \& 6 inch HeP Ieported. To of the fliters had glass-pack recorted ar of the fliters had glass pack seals and cadisu plated steel frames, two had 91 ass-pack seals and chrom 1 zed steel
frames, and one had a pressed wood frame. In frames, and one had a pressed pood frame.
additional gressed wocd frame filter was
tested as mor-Imadated control. The tested as a mor-imadiated control. The ct $10(E+7) .10(E+8), 5 \times 10(E+8), 10(E+9)$. and $1.5 \times(10(5+9) \mathrm{D}$. At the staxt and aftex each perzod of drIadzatzon the fllters were tested at rated clow to detering the percent peretration of compressed alr geverated Dor aerosol. The filters were then stressed at 2 to 3 tites rated flow and the penetration tests were repeated at rated flow. Tuc of the steel frame filters were irradited in arrads ated in an argon atrosphere and the achar at ther vere irradiated in air til cther 1 ters vere lcradiated in a1s. All pertration results. There was no

panetration results on pere was no signizicant change in penetration except as in casured an the last step bor ilter nuber four. rlat sponge reoprene and PVC gaskets bere also 1 rradiated in both argon and

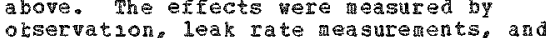

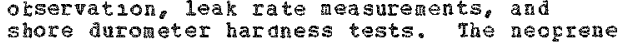
shore dutometer hardmess tests, The aeocren
gaskets vere prefered, although they becane nard. The pVC gaskets kecame tacky and we unaccertanle. The figp filters continued to perform acceptably after siradiation to than 10 (E) $\mathrm{R}$ of $\mathrm{Co} 60$ ganda radiation. (Auth)

《4043

Clemente, GoF., Compato Nazionale per i"Enegga fucleare, Environmental Radroactivity

Laboratory, pome, Itely. 1973

A Comparison of Calibration Techngues for the Assessment of P1 utonian 239 Lung Burdens. COHE-730345 (Part 2): Eart of Peige, $Y_{\text {. }}$ (Ed.). 


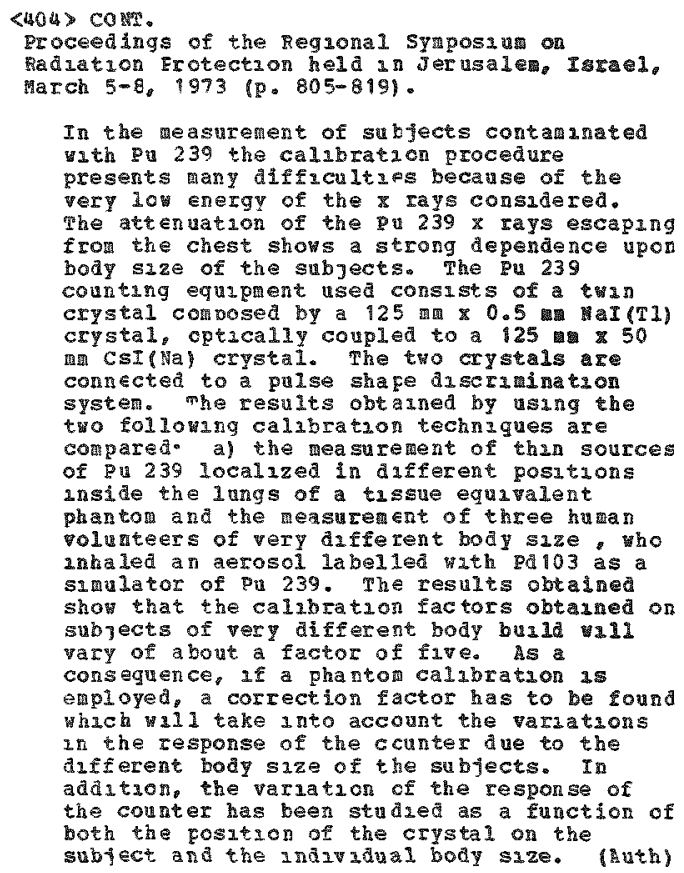

Nuclear Accident Dos3utry. Part 2. Dose Assessuen Procedure. AERE- $-7485: 29 \mathrm{p}$.

Thas report 's ore of three associated reports dealing with nuclear accident doszmetry. Detaliod operational anstructions on metheds of dose assessment for the united Kangdon Atchic Erergy Agency personnel critzcality dosineter and the installed vo 237 dosineter are providar. The reas inciuded in this report are general procedures for rakng a dose assessinent. personnel montoring. dosmeter measurements. body neasureneyts, deravation of doses from dosineter measurements and estimation of doses from blood, hair and clothing veasureants. Dose estinates arrived at by different wethods roquire anterpretation and corrections for particular acerdent circumstances. (RA)

The appendax gives measuring equipent and calibration procedures, and radiochemal ar alysis orocedures.

\section{<406>}

Dolgusrev, F.I., G.H. KaJdanovsky, H.V. Porozov, and $y$. Shatov, Instatute of Radation Hygene, Lensingrad, USSR. 1974, February

Monzeoring of Low-Energy $\mathrm{x}$ - Ray Radion ucinde Content in Hutar Body. Cong-730907 (PaIt 2): Part of siyder, H.S. (PA.). Proceedungs of the 3rd International congress of the IfPs held 3 n Washington, D.C.. Senterber 9-14, 1973, (P. $957-962)$, 1475 .

A 15 cr-a 0.1 ct thuck val detector and an
Ar-ch4 proportional combter w2th $300 \mathrm{~cm} 2$ wandoy vere used for fin vivo geasurenents ce Pb 210, Pu 239 and 241 content 2 di hata body. The subject's background tas deterimend from the correlation of the counting rates $3 \mathrm{n}$ to channels, e.g. for $\mathrm{PL}$ 210: $30-55$ and $100-150 \mathrm{kev}$, respectively. The detectors were calibrated on an anthroponorphous phantom with the thackess a nthroponorphous phanton with the thackness of the tissues absorption layer yaryng fres zero to $4 \mathrm{cti}$ calculation lethods for nuclide content in cratcal organs and cass 2liustrating different types of radounclide
distrubution in hum body are given. (Auth)

$\langle 407\rangle$

Daba, A.p A. A. Abey, and H.C. Heard, Lawrence L1 verizore Laboratory, IIVermore, CA. 1973. Noveruber

High Pressure Mechanical properties of an Area 12. Hevala rest Site Tuff. UCID-16377; $20 \mathrm{p}$.

The mecham 1 cal Eropertzes of tuff from instrument hole ve3, tunnel vi2e.06 at the vevada test site have been investigated to $1400 \mathrm{MPa}$. The shear strength increases frch about 5 ha unconrined to 12 Mpa at 300 MBa atout 5 ha unconrined to 12 pa at 300 MBa mas pricated at about 280 HPa. In was indica ted at about 280 MPa. In to the unlateral strain, the sapple loads to the vicintey of the fallure enveloge and then 2 pallel to that envelope up to the highest
stresses, $420 \mathrm{kPa}$. Hydrostatic pressure of 1400 wpa produces about 9 volume compression and $1.3 \%$ verranent compaction 1 a this apparertig saturated tuff. (A $u$ th)

<408>

Eakis, J.D.e and A.E. La1ly, united kingdol A tor 10 Energy Authority, Atom 1 Energy Research Estatishtent, Harwell, England. 1972

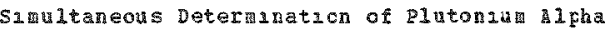
ACtivity and Plutonium 24 in Biological "aterais by bel Scantallation countag. CONF-71099 (Part 2): AERE-R-5640; Part of

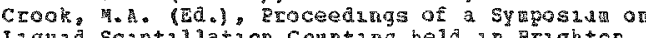
IIquid Scintillation counting held in Erighton. Unzted $\mathrm{K}$ ngdon, Septem ker $13-16,1971$ Heydens
and Son, Itd., London. England, (2. 155-165).

The method described utilizes a saple gel scantillation counting technague

sinultancously to determene both pu alpha activity and Eu 241 in a two-channel packard Tricarb hodel 3214 liqua scintillation scectrometer. By using the procedure given. 249 at the $10 \mathrm{oc}_{3}$ level of act adeguatelv detected. (IK)

$<409\rangle$

Fovler, E.B., R.0. G11bert, anō E.4. Essingtone los alamos Scientific Iaboratory Health

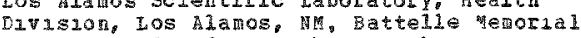
Institute, Pacufic Northwest Laboratories Systems Department, R2chland, WA. 1974

Samplang of solls for fadioactrvity: Phllesofiy,

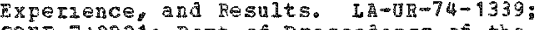
Cons-7\$0921: part of proceedangs of the atucspheric-Suxface Exchange of Particalate ard Gasecus Pollutants Symposiun held in Richland. washngton, sectenber 4-6, 1974 , (15 p.)

In many cases, the methods of samplug a scrl ratrig bave not recenved the attentaon regured when data derıved therefrom are tc le applied to froblems associated wh a malyses for radonucludes. The import or the soll surface as one ulta to receptor. 
(409) rons.

and hence source, of particulat 6 debras In the atmosphere-surface exchange syster is dzocussed. A rerzet as given or aspects of one approach to sampling of soils why has proved successful in a study of extensave

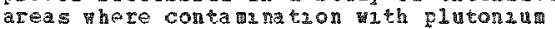
exists at $a$ wiv range of levels. The oractical apolacation of the work is reported as well as lata adentafyag one source tera. The aevelopment and field application of sanplang techniques based on a designea rand on sanping schere and on nowledge of

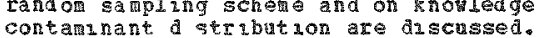
contaminant d stration ate ascusse

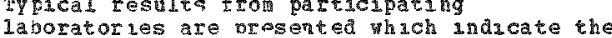
laborator les are oragented hach andicate aegree of success experienced when the approach described is used to ohtain
relative to inventory, horizont al and vertical distribution, and species of radionulide. Problems associated with the requarevent to obtan a most probably representative sample as well as the need for a com mon expession of extent of contanunt, are emphasien. the particle problen as its relates to sampling, a nayses. and znterpretetion of data is a iscussed. (Auth)

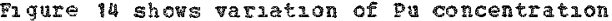

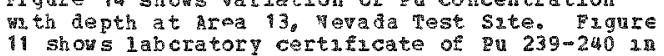
lishous labcratory certifucate of eu large meat saples. Figure 8 show an particle sizes (palomes soll).

$\langle 410\rangle$

Fre 2 berg, K.J., and C.G. Eaynes, Dow Chemeal compang, Rcoky Flats Divisicn, Golden, Co. 1974

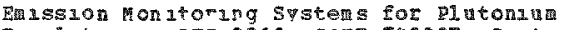
Fac1l1e1es. FFP-2218; CONF-740807: Paxt of Proceedings of the 13 th AEC 25 Cleaning symposiu he id in san trancisco, californa, August 12-15, $9974,(10 \mathrm{po})$.

Tre pruary parposes of monztorzng gaseous effluents are to insure that environisental discharges confor to specified guidelines and to evaluate the performence of the al cleanng syste. The paper descrubes a

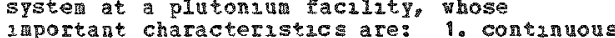

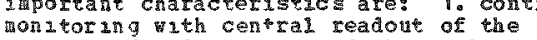
wonltorang wh central Iedout of th arounts of radioactrve and chem cal Follutans, 2o extensive fixed sample
collection, and 3 . Measurement of the total collection, and 3 . Measurement of the
effluent volume. Aso described is a effluent volume. Also described is a technique for 1 n-service contamination
surveys of filter plenums. The syster mets the reguz rements get forth in the wh num Design Re gra rements for Nev Plutomin Facilities。 (anth)

\section{〈Q 11}

glakins, D.E., LOS Ala mos Sczentzife Laboratory. Los Alamos, NH. 1974, February

Progress in Persongel ueutron Dosmetr. CONF-73C907 (Part i): Part of snyder, H. (Fd.). Froce edangs of the 3 rd Internetronal Congress of the IRPR held In washingtong D.C. - $14,1973,(p, 515-527), 1475$ o.

The paper reviews recent progress in perscniel neutron dosimetry. A survey of the yarious aibedo-neutron dosiger have been develofed shows the advantages and dusadvantages of each of the systems. The energy dependence of the albedo-neatron dosneters $3 \mathrm{~s}$ rather poor, and the effect of this on then accuracy and userulness as discussed. Fission-fragnent darage to polycarbonates has keen studed extenswyely. wth most investigators using the spark-counter technigue fer evaluaton. A survey is arde of the systens currently an use, and the probleas associated wh their use are discussed, fachudag senstavity. evaluation tila, and exposure of the vearer to the fissionable aterial. At present. three v.S. laboratorieg are know to be routraely using fiss 20 -track dosmeters on personel. Argonne mational Ioboratory is using a fi 235 syster with aca foris. grook aven Natromal Iaboratory is using Fidge National Labortory 29 asing a finger risg of thorilis and polycarbonate foll w

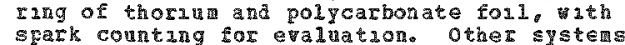
spark conting tor evaluation, othe

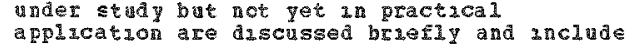
thermally stamiated exoelectron elissicn (TS:3). direct response of thermolumaescent-dosmeter (TLD) materials tc fase neutrons, and the response Tub paterials to cecoul protons. (Auth) (Fu)

$\langle 412\rangle$

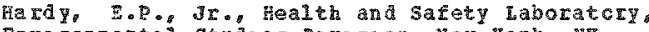
Envi conmental Stuares Divisiong Her Pork, NY. 1974, octoker

Fallout Progra Quareriy Sumary Regort, Jume Fallout Progra Quartery Sumary Regort, Jum 16967

The report presents current data from the iealth and Safery Laboratory (UASL) Progras. The Institute of Nuclear Science in Tatwan? and the Natzonal iadiation laboratory in we zealand. Three axticles have been selected fCr anclusion an the data bese. The injtal section consists of interpretive re ports and netes on depth astribution of artificial radionucludes (Sr 90, Cs 137 and gu 239,240 In s01. alpha contribaticn to be ta background, global deposition of $\mathrm{sr} 90$

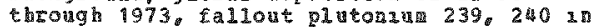

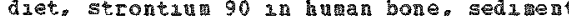
sampling near gund laboratory to obta information a hout the geocherical behavior of Pu in a freshwate \$yster and ocen strontua 90 fallout. 5 absegant secticns inclua tabulatons of radionulide levels in allua tabulations of radiondide levels Eallout, surface alr, allik, diet, and tap

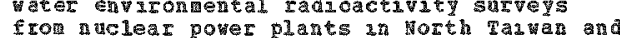
from aclear pover plants in worth Tayan and invironental rad loactivity surveys publacations related to radmonuclide studies is also gresented. (auth) (rum

Part is Table i. shows fallout Eu $239,240 \mathrm{dn}$ food in Mev York in 1972 . Dart 3. Table 8 shew the total beta actingty, and Sr 90 concentration in well vater at chienhua, Tayman.

$\langle 493\rangle$

Healy, J. Screntzic Laboratory, Los Alaros, septever

Contamntion Iq⿴囗十 for Real and Personal Property, Progress peport for the period of January-june, 1974 , L $-5726-E R: 5 \mathrm{p}$.

2 progress report sumary is given for work performed at Los Alabos Scuentific Laboratory to establish contamination lin its for real and personal property. Pranary trenton was devoted to che question of surtace

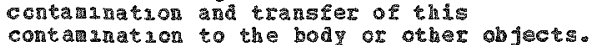
contarnation to the body or other objects. the ases of the various types of objects of 
(413) CกNT.

interest, and these anst te $x$ tlated to transfers of contarination ard resuleing

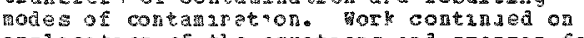
applicaticn $e^{f}$ the aquatrons and program for applicaticn che rovations and program tre wang 600 calculator 27 descr 1 corfaguratzons of glutonan and ancian in

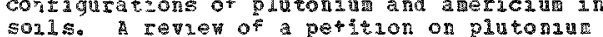
Sol1s. revien of peticion on plutonil 1 inits by the thatural ke sources Derense Couner and a sumary of connents on the proposed sol standard for plutonum are included. (BBm)

<414>

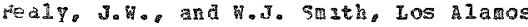

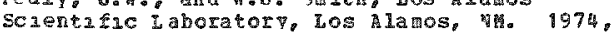
Ju 1 y

Contamnat 2 r Inzts for Real and Personal Property. WAsH-1332; Cov-740405: part of Proceedings ot the $2 \pi$ A $^{\text {"C }}$ Environmental

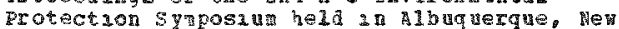

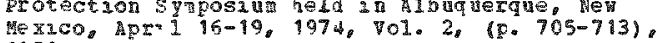

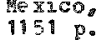

Tho profect on derivation of contamination Lan $t$ apflacable to real or persoral property was init3ated to propose and jugtify operaticn lams which afyly to the release or sale of property which has been used in work areas were radioactive materals are present. whe $3 \pi 2+21$ effert $2 n$ thrs study was a der 1 vat 10 of a oroposed standard for plutcmau 25 solis. In general the razian perrissibie hody hraen derzed at the chal piver conference and revised for non-oceupational exposire and the ICRP-nCBP Talue for dose to the ling of an ina value for dose to the lung of an individual was adopted. The ori nary mode 1ntale frcm solis is anhalation.

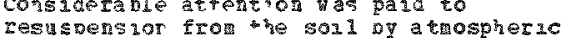

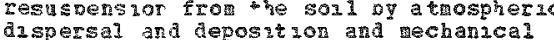
dasperal and aeposition and vechanceal disturlance a ver crua nodel was dervied to describe particie deposition as a of 1 ind speed, particle size surface roughness and athospher 16 stabl lity. the "re suspensicn factor" a lehough at is not complately satz sfactory. The recomended aterin standard for plutonin in the sol proposed is 500 apd peI gran in less than loc u particle sze. A Injtation of a cotal of

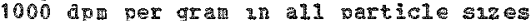

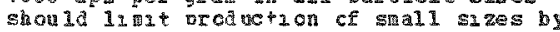
weathering. Thus gtandard is out for reviev

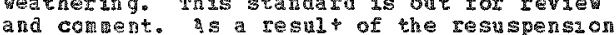

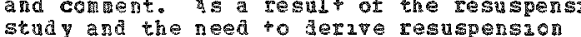
stady and the need to derive resuspens rates knestiation of response characteristucs of investigation of response chacactet the rDI 25 strument for pu and an stared. (25)

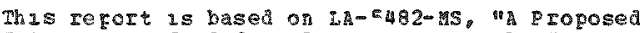

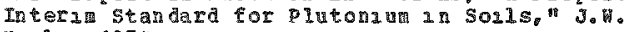
Fe $21 \%, 1974$.

〈415)

Herceg, 3. E., and \&.J. Johnson, Los Alaros

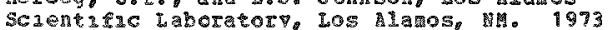

The Los Alanos serentific taboratory's Envuren mental penztoring progra

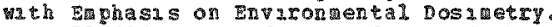
Conf-731101: part of Proceedung of the Jount Heeting of the anerican vuclear soclety and the Atomle Ind ustrial Forn aq Muciear Energy

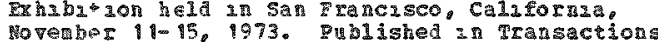
of the Rerncan fuclear Society, $97,541-542$.
The Los alaros scientzic Laboratory's environental womptoring progran consusts of several routane and special subprograms and at mea cursig both the concentrat jons of varmous constituents in air, vater. sediments, and sols and the levels of sediments and solis and the levels o environ. Atrospheric sables vere collected environe Atrospheric sangles vere collecto alpha, beta, and gara actrvitaes Iodine 13\%, total uranaug, plutonus 239, and a dericlug 241 were at rorial levels for werldy $2 d e$ fallout in the northern atmosphere.

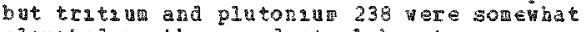
elevared in the imadiate laboratory envaross. Al caäoactive constutuents frck mater saples here attributed to ratural occurring species and worldwae fallout. (BE) (CTS)

Data ca amonnts of Pu vere not given put may be found in report, $\mathbb{L}-5184$.

$416\rangle$

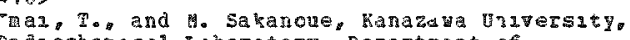
Radiochernacal Laboratory, Departaent of
Chemistry. Ranaza. Japan. 1973, April

content of Plutongu. Thorlua and protactmon in Seasater and Becent Coral in the lorth Dacific. Journa of the jeeanographical society of Japan, $29(2), 76-82$.

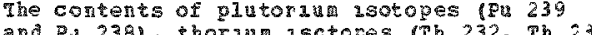
and $\mathrm{P} 4238$ ), thoram isctopes (Th 232 . Th 30 and Th 228 and frotactinzun 23 in seatater ccllected in the North Pecific (1970), the Tast chna sea (1969) and the Japan Sea $(1972)$ were determned. These nucludes vere

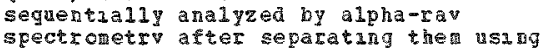
5pettometro after separating them usidg
solvent ertraction techingues. The contents

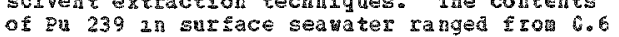

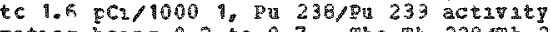
ratuos being 0.2 to 0.7 . The Th $228 / \mathrm{sh} 292$ activity ratios for the lorth pacific vaters waraed botwen 7.6 and 30 , wheras the sagl from the Fast china sea showed the very high value, 65. The comtents of Pa 231 were dess than 6 of that ir equalibral alth its parent if 235 . The analys of plutonul isotopes in recent cora 1 sron yoron Isiand vas carried out and it was confintued that recent coral wath the concentratson factor of atout 1 to $2 \times 10(\mathrm{E}+3)$. (Ateth)

<417>

KLezman, M.T., and H.L. Volerok, Health an

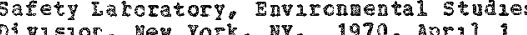

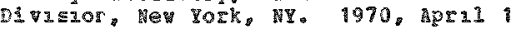

The culaty of Radiocherical analyses an ebe Health and Safety daboratory Surface a $2 x$ Saping Frogram During 1968. Hast-224; Fart of Hardy. F. P.. Jr. Fallout Brogra Q Q Sumary Report. December 1.1967 through Hach 1. $1970,10.1-9-I-13), 144 \mathrm{p}$.

Radiocheracal analyses for the sartice aIr sanplang program durng 1968 vere performan fer the riealth and Safery tavoratory thas by Tracerlat Inc. Three guality centrol samples are submited along 1 th each month samples are subnitted along vith each

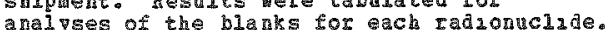
ara of contajnacon for nost radionuclides. of containarion for nost radipnclades

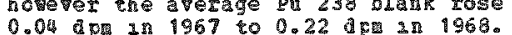

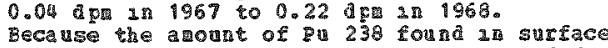
ans sapdes is frequenth bu the range of

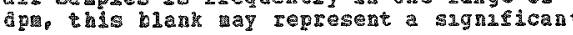


$\langle 417\rangle \cos T$.

fraction of the total activity and there appears to be a large positive bias in pu 238 values for 1963. Samples subitted to the contractor in 1960 yere prepared usth a ne contura standara solution a nd do not exhibit this reflect a degeneretion of the pu 238 standard reflect degeneration of the pal 238 standar quality control samples. (BBM)

$\langle 418\rangle$

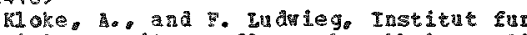
tichtparasiture pelanzentrankheite Blologische Bundesanstalt fur land und Forstuirtschat. Berlin, German Federal Repubic. 1962

Strontium 90. Cesium 137 , and Dlutoniu 239 in ha Salles frotio 1953 to 1951. Haturi ssemschaften, 49, 65-66. (German, English 5eต

Whe SI 90, C5 137 , and $\mathrm{P}$ u 239 content in hay samies as deterined frol 1953 to 1961 in somples as some sL 90 and $\mathrm{Cs} 137 \mathrm{Was}$ dotactable in 1953 , it increased greatly from detectable in 93. . It increased greati I fro

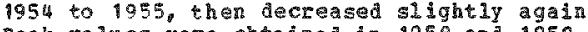
Feak values wero obtained in 1958 and 1959. Fuctuaticns in content corresponded to the fluctiati ons of the tro other radionu clides. Peans of Pu 239 rete reached in 1958 and 1959 wh 5 to 6 pci/100 9 hat The $\mathrm{Cs} 137 / \mathrm{St}$
ratio decreased considerabi from 1953 to 1961 due to preferpas root uptake of $\operatorname{sr} 90$. (RAE)

<499>

Knox, d.B., H. . Teves, T. T. Cravford, and T. Gison, JI. Lavrence Padiator Laboratorg. Li vermore, CA. 1970 , 整arch 2

Radioactivity Released from thergroun malear Detonations: Source, transoort, Diffusion, and

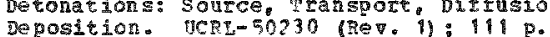

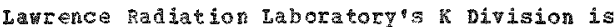
capable of predicting both the close-in exterral gema radiation field produced by a subsurface nucleat erglosion and the concentration of arrborne radionuclizes at lcng ranges, incluang changes in the difusion of the elowi. The regort presents the besis of and the rost recent results frcm the confutational physics notels of the zadionuclides produced the sourcel, the transport and sinultaneons lateral edy diffusion of the radionuclides injtiali in the statilized cloud the $\mathrm{FFC}$ edell. the developient of the man muclear cloud the GEM and THSOP models), and the

tor-dimegsonal atmospheric diffusion of the initial cloud throug a time and space dependent affusion environent (the 2 BPUEF dependent aifiusion enviconant (the 2 gR
model). The calculated resul ts have been compared to observed dat in order to devele compared to observed at in orcer inatication of ket areas that need further indication of vere selocted for inclusion in the data base. vere seloct
(Auth) (Crs)

$\langle 420\rangle$

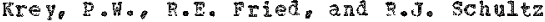

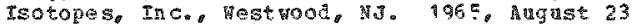

Operation Rollar coaster Praject of icers Fepore, pretect 2.3. Pallota Collection.

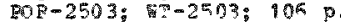

Intege 1 and tine afferentiated incremental tallout collectors vere exposed after each of the four Foller coster ponts. Each collector exposed stichy fild, tro vicroscope siddes, and a plathet The planchets vere alpha cadioassaged in the project 5. La fiela laboratory and served as an ing significant fallout. The sticky fil vicroscope slides selected for subseguent cadiochemical andyis and special particulate studies, respectively. mere chosen on the basis of the planchet radioassay. Deposition contours derived rrem Qlanchet activities are given. Soli cores were taken before and arter each evene to represent high, intertediate, and low-level depositer areas. only the 0- to $1 / 2-1 \mathrm{nch}$ riaction of the core was reserved for subsegnent analyses. (nit)

Per ission received June 20,1975 , via phene conversetion ith Project officer, P. H. Rrey, to enter as a declassified document rather than originialy classified as official one onl

429

Iippmann, M., Nev York unipersity, Institute ef Fnvíromental tedicine, New york, Hi. 1972

Tespirable Dust sampling. Part of Ait sapling Instruants for = Evaluation of Atrospherio Contanants. Fourth Edition, (3. G-1-G-16) 55850

Technigues of samiting for the evaluetion of the toxicological insult arising fron the inhalation of airborne particles are discussed. The hazard from alr borre particles varies vith their physicel chemical andfor biological properties. There are number of wajor subdivisions with the respiratory tract (rasal passages, pharyna laryng, tracheo-kronchial tree, alvelar regionj and the structure, size, function and different aechanism for particie alinination are discussed for these. Estimates of regional deposition based on living model regional deposition based on living inodel and definticns for respirable dust a and definticns for respirable dust to Eritish Hedical Research concil. u.S. Atomic Energy Comission, Aarican Conference of Governtental Industrial lygien ists and Eritish occupational Hygiene scoiety. A variety of acceptable instrumerts for sample collection has been proposed. with

alternatze specific indice of concentration fer each instrument. Basically there are two sapler acceptance curves described and they have similar but bot indentical

characteristics. Instrutents for size-selective satoling are described, such at two-stage and thiti-stage samplors. The later are designed to sidatate deposition ithin more restricted subdivisicns of the vithin ore zestricted subdivisicns of selective sampling and selective aanles are

instruments are described. (FMa)

$<422>$

sacta. Lo, and $R$, Felegadas, Environantal Science Services Aduingtration, Silver spring. HD. 1970

Fadioidine Leveis in the U.S. Bublic Heath Service Pastearized dis Netwerk from 1963-1968 and thed Rolationsip to Posidible Sources Health Physics, $19,669-485$.

lleteorolegical and ysis of the paths of

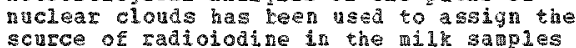
collecter in the li. S. Pulic Health servico 
(42) $\mathrm{CONT}$

Pasteurized Malk Metwork (PMM). Most of the instances of elevated values between Apri I 1963 and December 1968 are attrubuted to $\$ 1 x$ atmospheric nuclear explosions in western china. only one of five cratering events at the Hevada tese site (i.e. Palangun) caused

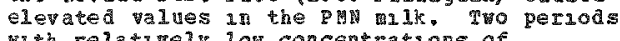
wh relative $2 y$ low concentrations of radzoldue $\mathrm{n}$ milk cossess no aparent explanation. By selecting periods with no atmospheric or cratering events, at \pm s argued that a cot the Dly can be atributed to accidental releases from underground inclear tests in the onated States auring the period of the onjted States auring the period os
analysis, Radioiodine from acelaental releases, reactor tests, and cratering events releases, teactor tests, and cratering events surrounding the nevada Test site. (Anth)

《423)

Ne1son, I.C., Battelle heral Instutute. Pacific Morthest Iaboratories. Richland, Wa. 1968: 1967, ray

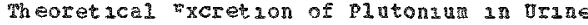
Based on the mew ICRP Inng Model. BHI-SA-1247; Conñ-670521, Monographs on puclear Medicine and ba ology. Ho. 2: Part of Rornberg, H. A. and Horvood, W.D. (Ide.), Proceedings of a Syra po un on the Diagnosis and reatment of Deposited padionuclides helf in Bchland, Mashington, May $15-17,1967,(0.256-278), 680^{\circ} \mathrm{p}$

The nex ICRP lung aodel as a sanficant advance in estabilshing a rational basis for internal depositions from anhalation of radioactive aerosols. In the case of platcraum mirate and flutonu ozzde. estrmates of Iung and syeteratic burdens can be ade from urane or fecal analysis for plutengum it the particle size astribution + known. I,ess sat usractorg, but an some instances adequate, estl nates of lung and systenac turdens can be made at long trues after Intake whout particle size data. Deta from urang atcretion of plutory are adeguate to estinate systenzc burden

regardiess of parracle suze at about one morth arter intake for plutonum nitrate and at about cre vear for plutona oxide. carefully performed a nalysis of feces for cluton un offers considerable ncrease pluton un of cers consuderable zncrease in the estanation of lung burans. The the estanation of lug bardens. The astinat 10 of boay burdens by analyso body excreticn or plat theoretical and assumes the new 145 molel tc te accurate in all respocts. In the absence of experimental evidence to the contrary it $s$ recomende $i_{\text {, however, that }}$ thase excretzon results be used $2 \pi$ the assessmert of internal depositions. Because of the largo depondency on particle sizes. cstu nates of lung ard systeatic kuran reguire better characterization of the alr Inhaled by the worker. (Auth)

$\langle 424\rangle$

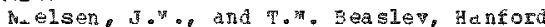
Laboratorias, Chenscal Kaboratory, Elchland, ha.

Fdd lochengcal Determiation of Plutoniun for Radiological Durposes. ConF-448: STI/PUB/84, part of proceedings ef a Svaposim on the assessment of Ratuoctive Body Burdens in $r$ an be $1 d$-n Heidelberg, Germany, 时 $11-16,1964$ vol. 1, (p. 245-250), $1043 \mathrm{~g}$.

Th thas paper the orocedures that have beer and are currant ly beng used for the determation of pacro-nacrogran guantaties of plutonza an biological and environgental samples are revieved. Spec1al amasis is placed on excretion analysis. urmary excretion rates have beer calculated using assumed levels of glutonu deposition. sc that the analytical sengturaties of * arjons procedures can be compared. complete dissolution of excreta. sol bone, tiste and vegetation are described with emphass on avoling the formation of refractory ccripound of plutoriug which are soulable

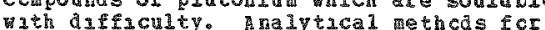
plutonu analysus of these aternals are revieved and lnclude co-precipltations 12gald-12guad extraction, ion exchage csotopes for y 1 la deterination by

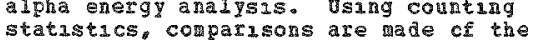
statistics, conparisons are rade ef the

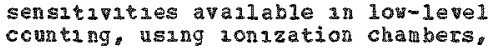
proportional counters. diode counters, and nuclear track exussors. Isotopic andysis of platoniu by alpha spectrometry, nuclear a mision technaques, and lagua scintillation ccunting are inciuded. The use of non-1sotoplc carriers as a source of extraneous actulty and the envirormental levels of plutonulu recently enccuntered a round the vorld are discussed $3 \mathrm{n}$ connection wth "Dlank" samples. Two possublities axe considered for future methods of flutom analysis where increased sensitivity is andysis where increased sensitivity is Iequired ahese are activation ana
fission fragnent counting. (Anth)

《425》

Not given. International Atomic Energy Agency. Venna, dustra. 1974 Environdertal survellance sround vuclear
Installations. Cons-731117: $\mathrm{STI} / \mathrm{pUB} / 353$, Proceedings of a Symposiun on the Environgental Survenlance Around uclear Installations helo -In Varsaw, Poland, November 5-9, 1973, Vols. $1-2,470 \mathrm{p}$.

Tho-nundred participants from 26 nember states and 8 representatives of 3 ternational organz zations paztzeqpaced in a symposium in harsay sponsored by the IAFA and the

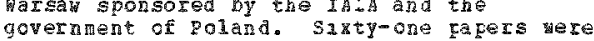
government of poland. Suxt-one paper

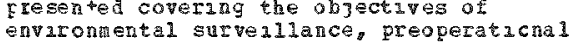
anvironental suvellances preoperaticnal

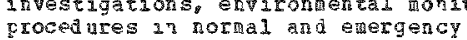
groced ures in normal and energency research and supportive studies. and examies of the environatal survelilance froyrans conducted at specific anstallations. A 5 all nubes of papers deait with non-radioactive contaninants. Thtoe papers dealt ritn the problems arzang in the establishment of standards and dersved scrking indts and the prera*ion of adeguate enviromental survezilance systens for both radioactive and ren-radloactive contaninants that wight oe released to the ervironaent $2 \mathrm{n}$ the nuclear released to the ervirongent his the nucle

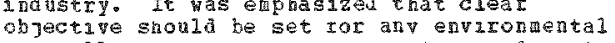

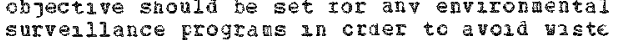

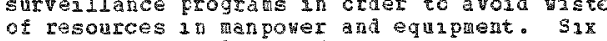
of resources 1 manporer and equ pinent Data Base. (RAF)

$\langle 426\rangle$

Hot guven, Dow chemucal Compay, Rocky Flats D2yiszon, Golden, co. 1973, April il

Errata: Annual peport Enviromental Safeguard, 1971. 25E- ZNy-718 (Errata): $17 \mathrm{~F}$. 
〈426〉 $\mathrm{CNT}$.

The Rockv Flats Division annul environgental report (REP-ENy-71B) Annal peport: Envirormental safeguads 197 , harch 10.1972 comtained several tabular and typographical srors. These errors. although insignificant in teras of conpliance with existing orvi rormental guldelines are inconsistant with the high degres of accuracy in seporting environatal survellance activities. The report represents pages 15 though 31 of TPP-ENV-7 iB as corrected. The entre tabular sumation ce that report is herein reprouncer, including data correct as stated and corrections where necessary. The noted corrections are the resul of a complete recomputation of totals, averages, percent of standards and sumations. The accompanying changes in text are also included. The changes in tert are also included The tabular data represeats saming at various
locaticns on and off ste for radiontive and locatichs on and off site for radiacti

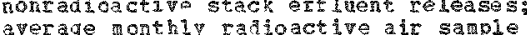

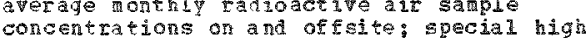

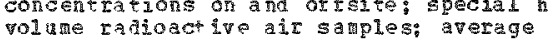
wonthly berylliun concentrations in air sapples on and offite: dustfall sample suna sedinert samples: surface sol I andyses. offsite contours and vegetation samples. surveys were conducted for plutand uraniut, and other long-lived particle releases. (BSH)

Corrections to the text and tabular data are given for RFP-Evy-71B, Annual Report: Ervirchental safeguart. 1971, tarch $10,1972$.

\section{<427>}

Not given, Healeh and satety Laboratory, Ne Pork, HY. 1073, 12 \%

Surface Air Sapling program, 80th Meriaian hetork, Jaruary throagh Deceaber, 1970.
Badiation Data and Reports, 14(5), 307-312.

The Health and Safety Laboratory Surrace air Sanjing progra studied spatial and temporal distribution of nuclear wearons debis and lead in surface air. Samples were taken at 21 Locations in the western hem isphere fror January te Decenber 1970 and sent to Trapalo Division, Eichond, Califoraia, ERphasis vas given tc determination of manganese 54 , iron 55, strontiu 90 , cad lina 109, cesium 137 .

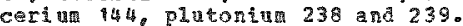

Concentrations for these radionclides were tabalated for each month of the year and each reporting station. The lenger lived fission products and plutoniu 239 concentrations shom $2 \mathrm{~d}$ describe the general aistribution in shoride a if in all previcus naciear veapons debris transered from the lower seratospher to the trecosphere during this colloction to the tregosphere during this collection disserinated to the stratosphere during the reentry burnin of a sMa-9h poner som see in

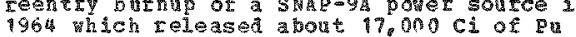
238. (BB)

\section{<4283}

petersone C. 降, fniversity of Minnesota, school of Public Health, Hinnea polis, MNo 1972

Aerosol Sapling for particle size Analysis.

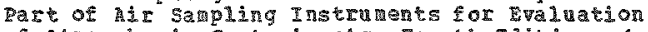
of Atrospireric Contarinants, Fourth Edition, fP.

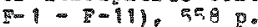

The reaning of the teras particle and particle size is discussed and the theory and solnces of error in sampling as well as the basics of presenting and interpreting particle size data are described. The ter "yarticle" is defined as a sabil discrete mas of solid or liquid mater. particles are jenerally defined according to shape as to one of the fellowing categories: spherical. Arrequar-cubical, flakes, fibcons ot condensation flocs laggregatesl. Depenting on the specitic sampling objectives and the nature of the aesosol the saple may be aram from a dynan ale strean or from near static cloua. In this regard, the state of the aerosol mast be considered yith respect to the ait strean velocity, relative concentration of particulates, chemical and Fhysical mature of the gascons system, and the possibility of tine dependent variations. The physical frocesses of sampling and transporting aerosols are complicated by several factors. many of wich tend to bias severa factors, many of wibis tend to bias sizing errors of this type are lateled

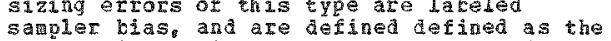
sampler tas, and are defined defined as the

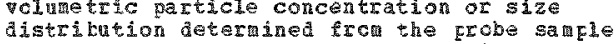
divided by the actula array of particles divided by the actular array of particles which existed in the aerosol cloud. The average primary factors affecting sample oi several dimensiondess groufs to predict sapiling errors. The most important of these various groups of parameters are the inertial inaction parameter and the velocity ratio.

Particles of an arosol 211 be heterogenecus in size and hence wen which particles are weasured the results are Eest presented and stadied by statistical methods. To sucy the difference between presenting and interpreting numer-size data bo the two ccomon means of classification ( 1 inear versus logarithic), a hypothetical sample of particle numer-size data is presented. It isticle numer-size data is presented. It is of paramour inpcrance that all data
reviewed for a specific purpose be analyod reviewed car a specific purpose be andized designated as to whot the method is.

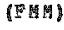

Q429>

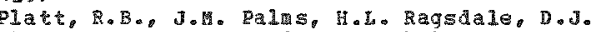
Shure, F.G. Mayer, and J.A. Hohrbacher, Eosy University Departaent of Biology. Atelata, GA Geofgia Institute of Technologys atlanta, GA. 1973

5rapled Benefits Derived from an Ecosysten Approach to Envircnental montoring of a Wuclear Fuel cycle reprocessing Plant.

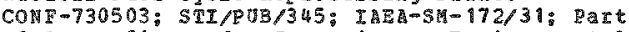
of proceedings of a Sy gosin on Envirchental Behavior of Radionuclides Released in the Wuclear Industry held in A ix-en-Provence, France. May $14-18,1973,(\mathrm{p} \cdot 673-700)$.

The envitonment noutoring program for Tuclear fuel reprocessing plast (aliedoculf muclear fuel reprocessing plast (Allie caclear servicesl located in the solth Carolina coastal plain, is based on a
man-enviroment ecosyster concept. In ract man-enviroment ecosyster concept. In fact

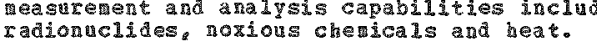
radion The principal pathwys to man, otospheric, terrestrial and agnatic, are each subitic ccaponents. Basic iaputs include meteorology, geology, surface drainage airection a pelocity of groundwater flow. interaction of waderlying aguifers and ecological descriptions of the various interbelated ecosystems of the site and region. Process water is aischarged through an ecological monitoring, conditioning and ccoling pond. Sampling erom a 100 sgiare mile gria is based on signicent link in the parions ecological pathways. Standerdized procedures for samp 
$<42930 \mathrm{con}$.

collectron, processing and analysas nave veer developed. All data hav be stored, retrieved and and 7 zed through an oven computer 12 ed progran, derigned $\$ 0$ that additons can be mad and data verified and retrieved under any crderea schene for enther pranted of any chic display. Fipirical benefits include a means of

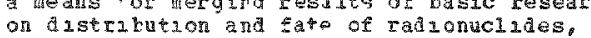
on 1 gtrqution and fate of radionaclides.

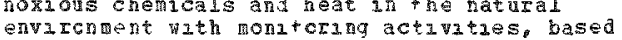

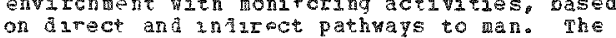
on drect and infiroct pathways to man. The use of ecclogically defined amples provides rates of dovement and biomaccumulation adequacy of source control with respect to enva rongenta cuality, (b) indicate magnitudes and trends of ecological 1apacts and therefore serve as an ariy warnas systen of potentral a dverse pfects to the

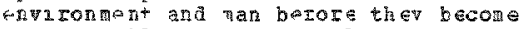
irsoversible or expensively reversuble, and (c) provido a base for comparason wh measurenents and analvses of effinents from other scurces on a regional and zoternational sther scurces on reganal and ater gale. The program can accomodate adiztonal gaestions from other source program can accomolate alditional questrons program can accomolate add tonal questuos ecological models are tranterable to other nuclear industry. $\mathrm{Th}$ as, through the character ist $\mathrm{cs}$ of comparability。 accoracalicn。 prea ctablinto and transference, the progra ea whasizes those basic factors and procedures that are necossary for deternang the capacity of the entaror a to receive ralionulides, vith - mohasis cr both natural and human radiatior exposures. (Anth)

$<303$

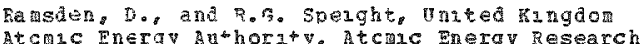

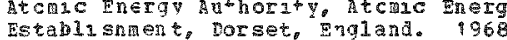

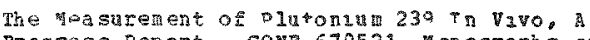
progress Revort. Conv-670221, Moncqraphs on Huclear vedicine and $30109 \mathrm{~g}$, Mo. 2 , Part of horrberg. H. and vorwood. Prockedings of a Symposiun on the Dagnosis and Treatupte of Doposited Faduonuclaes hela in Bicnland, Hashington, day $15-17,1967$, ip. $171-188), 68 \mathrm{C}$.

A prototype anstoring egupment, consisting of a 10 w background xenon-filed walta 1 ire propertional courter, usea in conjunction wh th a large area thy-windoned sodum lodide crystal, bas beer aevelopod for the

neasurement in vivo of the lung content of neasurement in yo vo of the lung content fasoluble pu 230 at the atoric Energy been useato pa measurements on sali neen used to make measurements on sali number of sublects wh ling buens of 239 around or 3 n excess cf the present callectan 1" mit of about fors for the detectors ander different gecnetric conditions have been btanea by using a realistic chest phanton. ohe equioment and techngue are detected and the nang sources of error drherent in such neasuredents are discussed. A number of refinements are suggested. It is proposed to modefy the dosign of counters and to nake sowe alterations in technuge. The resultang systern 11 be sutable for routine use and 1t 111 enable the detection mo soluble pu 239 lung budens down to a level of about 0.008 uca. Molifications to the phancor will pritarily consist of inccrporating the

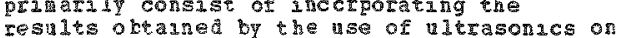
results ontained by the ase of ultraso
norat 1 abjects. The botroduction of howogenous zapregrated ingo anl a liver section is intended. a systen $\rightarrow$ described

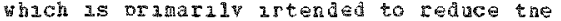
counting time fer complete examnation of a subject at 40 wan. and enable a routzin examition procedure for peoble gat risk" to be established. (Fin)

Figure ga shows a schomatdc plan or new equapent-whole hody montor. Figure 4 shcus the callaration chest phanton assembly.

$\langle 431\rangle$

Soldat, J.K. (Ed.), ara T. H. Essig (Edo), Battelle morial Institite, Eacific rorthest Laboratories. Inuzronental Health and Engineering hepertuent, Fichland, w. 1966. septenber

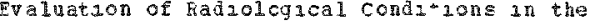
Vacandy of Hanford for 196\%, Bar program of the danford environs showed tat the anounts of radicactive naterials fresent

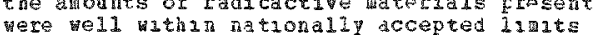
at all +3 mes and that releases of radicactive vastes vere vell controlled. pnosphorus 32 astes were well controlled. Enosphor as released to the columba hiver in reactor effluent contarued to be the most signaracant scurce of radiation from the fanford
Thus 32 is concentrated by fish that inhab the ruver dowrstrean from the reactors. Induvduals who rejulariy eat sucr

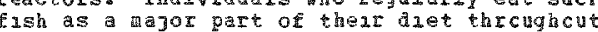
the year cond concenvaby have taken in as much as 19 of the annul gersisedole ascurt of this bone seeker. Iodne 131 in tre 4aniford ervicons reganed at very lom concentrations in 1965. The chinese nucleat test or hay $1+$ calsed a brief norease 3 in $I$ 131. but concentrations scen returned to the icw levels experienced during most of 1965 . The postulated "maximun "aniual dose from I tc only about un of he aliation protection Gude recomended for individia by the Guderal radiation council. Tne estamed whole body dose of the aperage ricniand resadent from nuclides of manrord oraga was resident from nuclides of manrord orag
mren. Whole body doses from natural background ard Fallout scurces th this reglon are estrmated at abcu 110 mrem/gr and 2 in rem/yt, respectively. ("rim)

Table 2 shovs andal average concentration of several radionuclides an Columa Baver vater an 196\%, (nncludzing ap 239 ).

$<432\rangle$

Sulnth, R.I. Battelle Memorial - nstutute, Pacifuc Morthyest Laboratories. achland wa. $1967, A$ ATI1 14, 1968

Interpreturg countina lata for Internaly

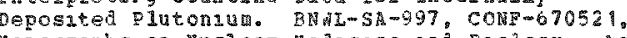
ponographs on Huclear fodzczne and Blology. No. 2; Part of Rornberg. H.A. and hornood, (Eds.). Proceedangs of a Symosina on the Diagnosis and Treatrest of Deposzted sadionuclides held in Rehiand, Washingtong hay $15-17,1967,(\mathrm{Bo} 209-221), 630 \mathrm{p}$.

Rapla mindations of inhaled aounts of Ejutonium at levels near the arima Permissible Body burden ( 40 ncu) are gossikle wath the equapent descrabea. Thas egulpment, coupled with the enancenent of sensitzity by raditions from the replady sensitivity by radations rrom the raplady

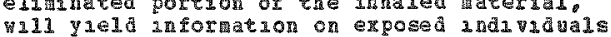
Who may have a retasmed cody burden constituting a fraction of an PEBS. The 
<432〉 COWP.

sensitivity can be enhanced by a factor of five but this enhencement is variable to a degree depending on exposuse conditions. The accuracy with bich a body burden estidation can be ade by in vivo z-ray counting is Aiscussed. As the data and calculations have indicated, the use of 241 as a tracer is less affected by the many variables present ard should yield greater sensitivity for wany isotopic compositions. The use of a 241 as a tracer cequires one to assume that the translocation taces of $A$ m 24 and plutonilu are the sane for connting to be perforned are the sane for connting to be performed an exposure. Recause of the great sensitivity of the scintillation counter and the ability to efficienty count both the x-rays and 241 gan ma rays, the use of these counters appears more promising the other methods. Proportional counters and, in the future, solid state detectcrs are

excellent for high-resolution x-ray detection and low background rates but the problews in and low background rates, but the proble bed cout data compases favorably vitb data
ottained from bioassay methods. (Fim) 
$\langle 433\rangle$

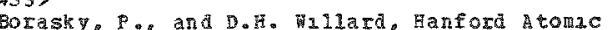
Eroducts operation, Richland, wh. 1958, Jana

Electron Macroscopy of Aerosolis Contaning

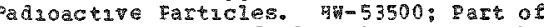
Kornberg. H. A. Hantora Blology Research Annual Report for $1957,(0.157-171), 226 \mathrm{p}$.

This report presents the electron 30 scopac appearanee of pareleles from three aerosols contanng ST 90, Sc4, Ru $106 \mathrm{RuO2}$, or Pu 239 Puo2. zhree types of $5 r$ farticles vere observed, needles, needle clusters and sphe rold particles. practicallv all of the Ru particles were three dithensional chan agregates of nutrate spherola tarticles. plutoni un particles were predominatiy lndividua ung of dense crore particles andividual uni s of dense eubre particles; and

Protograchic enlargenerts of electron

macrographs of $S r_{,}, \mathrm{U}$ and $\mathrm{Pu}$ aerosols are giver.

$\langle 434\rangle$

Glasstone, S. Los Mamos Seqentifie laboratort.

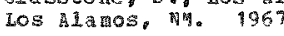

Sourcebcck on Atolle 5 nergv. D. Wan lostrand Company, Inc.. Princeton, Nev Jersey. $3 x$ d Eat a ton: 883 p.

The reference book describes ir sapple language, with a ning or mathematics, the most 3 mportant deve 20 ments 1 th those areas of science covered by the general term "atom energy". The hatorical approach has been energy" or he hiscorical approach has been usec wher eever possible. The chapters anclude sche of the rolloning tcelcs: Eoundations of the atonse theory, the
structire of the atom, natural radioactuvity structure of the aton, fatural radion detection and mea surenert of nuclear radiations, niclear fission, the ut 11 izat of nucleat energ\%, nuclear reactors the syinthet ac elenents fosmibing the alscovery

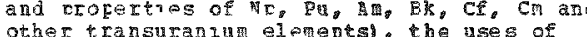
other transuraning elements) the nses of

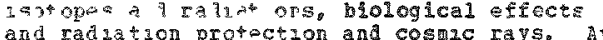
and radiation protection and cosmue rays. At the end of each rhater a list 25 gaven

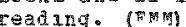

$\langle 435\rangle$

HorSt, T.H.. J.G. Dropoo, and C.G. Elderkin, Batelle temorial Institute gaciric Laboratories, Rlehiand,

Rin Assesstent of the Long-Tern Exposure Due tc Resucpension. Bsw S1apson, C.I.o et al (Eas.). Anmul Report for 1973 , (p. $223-227) \cdot 284$ p.

A siogle aodel of the anteraction between an a irborthe pollutant and the underlying surface is postulated which includes the crocesses of deposition, fixation by the sorl. resuspension and Iedeposition. Thy model is used to calculate the rat 10 betreen the eyposure to the resuspended materal and the

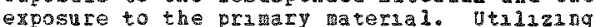
curcent estagates of 00 iel parameters current estiates of todel parareters, this rat10 could range frot 5 to $10(E-4)$. In the case hhere resuspension is locally balanced by redeposition, however, this range 25 hoxned to 0.5 - 0.05 . Horizontal homogenesty is a sufticient condition for
this balance to bold true. (Auth)

$\langle 436\rangle$

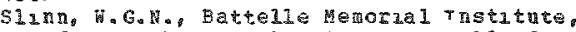
Pacific Morth test Laboratoras, Richland, HA. 1973, Apr 33

Inqtial Resuspension hodels. Buti-1751 Part

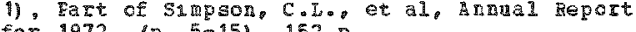
for $1972,(0.5-15), 1=2$ p.

1 Frogress report - $\$$ presented of effort a ade to understand the resuspersion of aerosol vat ticles from the earth's surface. It 35 seen that for u sub $*=20 \mathrm{ct}$ sec (E-1). (where is the kinematic viscosity of

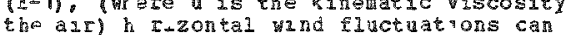
aslodge most sub-a 11 inetor particles rrom

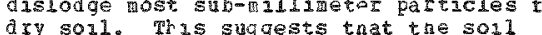

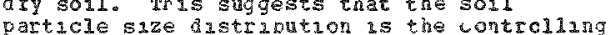
particle size distrabution is the conta factor of the alrborne particle size

distritution in the near-surface layer. Above the surface layer, It 15 is 5 an that the convective diffusiog equation is incapate of explairing experimental data atcroch hased on the probabilty explored and it 15 shown that onserved wind speed a ata dose correctly descrube the size astribution of larde, resusponded partacles. Directions are 3 nd cated for future

theoretzcal ard experimental stades. (Auth) 
$4477>$

《437

Christ, R., and B. Schuz-Ferherg, J.S. Atolic Energe Comission, washington, DC. 1974

Developmezt and pestind of

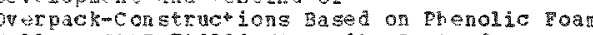
Weils. Cops-740091 (Pare 1): Part of Froceedings of the ith Interiational Syaposiun or packaqu and ranscortation of ratioactive Wateridals heldis Mini Beach, Florida Septerber $22-27,1974,(10.207-296), 9195$ p.

An overpack systen vas develoged for the shipment of liguid and solid

plutcriun-containing wastes. A phenolic foat

vas selected for its sheck-absobing and

insulating gualit jes, its ease of handing

and sconory. In the design of the overpack

and iccrory. In the design of the ove

boiling of liquids under fire conditions.

boiling of liqulis under fire conditions. basis. To prevent ierornation, the ianer container in the dounead area mas specially constructed. ip to date no problems were encountered aurina loading. tansport and unloatsing. (PAF)

$\langle 438\rangle$

Moulthrop, H.A., and J.L. Perp, Athanezo

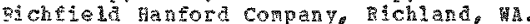

Deseription of delantio icheield reasond Company's ver compact platonin serage Faciliey. Conf-710u01: part of proceedings of the Rocky 1 ats symposin on safety in elutonlu Handing pailitios bela in colden " colorado. Handing zciliti, beld in colden, Co

A new plutoniua storage facility has been construct ed at pichland which uses a shielded culcle arrangenent for reducing radiation dose rates. Reduction in radiation exposure ny a fact of cen is expected in the vaults from that experienced in plutonium storage valuts previously used.

products-or-combustion fire aetection systen througholt the facility and a strinkler system in the scrap storage area provides continuore fire protectich. A prelininary erphasis is placed or fuel reduction concrete construction. Conpartientation within cuticles reduces the amount of plutoni un exposed to combustion if a fire should cocur. A storage density of 2.1 spots per square foot is pealized for the overail facility. The engineered const action of interconnecting precast concrete panels to finterconnecting precast concrete panels to storage cubicles provides increased safety at decreased unit cost. (Anth)

<द39?

Not giveng if.s. Atonic Eergy Comassion. Division of pechnical Information txtension, oak Fidge, TH. 1968, February

Transplutoni ut Elenents: Bibliography. TID-337?: $53 \mathrm{p}$.

part l of this bibliograghy conprises 332 pulbications aealing wh the production of and the phrsical and nuclear propertes of transplutoniun lements in the tromic-numer range 95 less than or equal to $z$ less than or qual to $10 \%$. Hucloar Science abstracts. chenical hbseracts, and physics Abstracts and other published sources for 1955 . 1966. and othex published sources for 1955 .
1967 gere scanned in preparing this bibljograchy. The references in this part bibljograghy. The references in this part

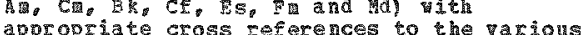
entries. Within each group. the Ieferences are arrange chronologically, except for cases in which dates are not kncur. References covering chenlatry priarily were not included for the elevents in Pat Part 2 covers al1 references available on the trangmaleviun elements eron 1957. Jourals used there the same as for part 1. Thas part ccvers chemistry as vel1 as production and physical ard nuclear properties. Rererences a te erranged chronologically. (Auth)

$<440>$

not given, U.S. Atonic Energy Comission, Ha shington, DC. 1974

Fourth procedings of the Internatioral Symposiua on Paciaging and Transportation of

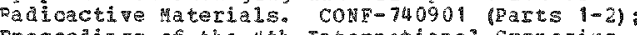
Froceedings of the the International Symesiug Materias held in

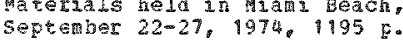

Dne hundred and one patar were presented at the conference, and twenty-three of then have been atstracted separately for the Data sase. A mong the topics covered vere regulaticns internationa, federal and statel and safeguards; new package design, contained tostiag including tistar and impact tests. and quality assurance for the packaging: transport studies, shipments, and the experience incountered such as contamination of Venicles and accidents; nucleat criticaity satect rish assessent, where the danger to the environdent was discussed;

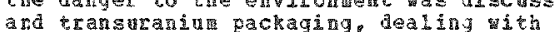
desing shelding requiremerts, cadiation design, shelding requiremerts, radiation
levels and transort of packages of ct 252, nepturiuanitrate. Fu atrate. Pu 239 and neptuniag

〈4थ 1)

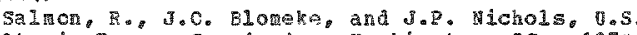
htomic Energy Comassion, Hasidaton, DC. 1974

prends and Projected shipments in the Nuclear Fiel crele Industry to the rear 2000.

Conf-740901 (Part if : Part of Procesdings of the 4th International Symosium os Packaging and Transportation of Radioactive faterials held in Mia i Beach, Florida, Septeaber 22-27, 1974, 10. $349-3649,1995 \%$

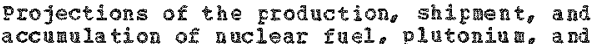
accumation on aclear fue plutonin

presented. The nuclear tover reacter compley presented. The mulear tower reactcr comple

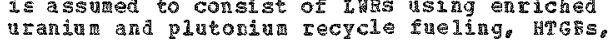
uranian and pirtoniur recycle pueling,

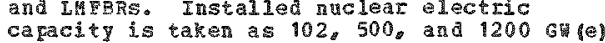
caracty is taken as 102,500, and 1200 , the

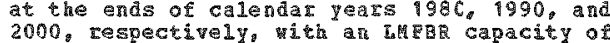
200 Gry $(e)$ at the end of year 2000. Frends seen in fuel and waste shifping are core stringent recovery of radiodsotopes from the effluents of all types of nuclear installations: more eaphasis ot shipping varions types of tase to federal repostrories, rather than to burial grouda; coneinued develonment of inproved sining ccncepts: shipment of greater proportion of spent fuel by rail wather hat oy tracks shipent of 8 in than as the nitrate solution. (A

$\langle 482$

MCSweeney, T.I., C.I. Brown, S. H. Heaberine, I

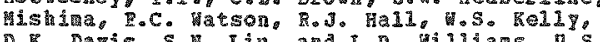
atomic Eargy Congission, Washington, DC, 1974 


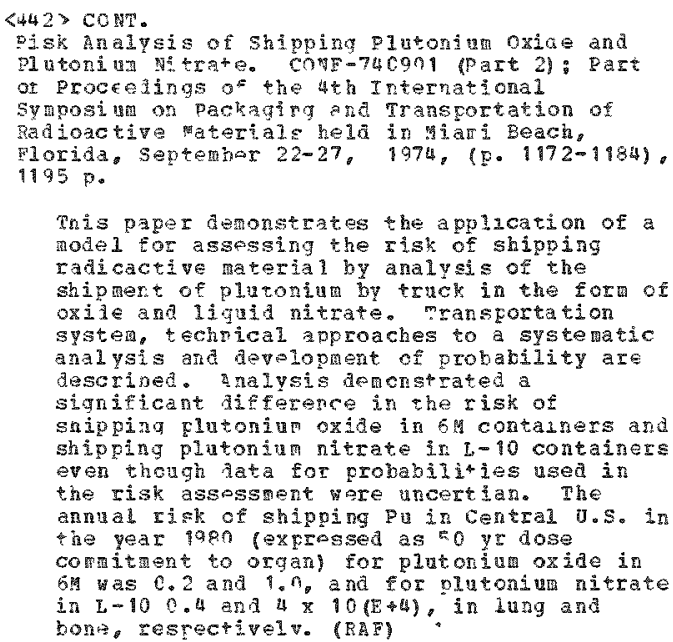

Mcsweeney, T.T., I.D. Williams, E.C. vatson, J.6. yropoo, Io. Rottuitz, an R.J. Hall, U.S Atcic Tnergy comission, Washintor, DCo 1974

A pisk Assessment Model for Padioactive material Shipants. CONF-740901 (Part 2): Fart of proceedings of the uth Trternathal Symposind on packaging and pranstortation of Radioactive Materials hela in in a september $22-27,1974,(p, 1100-1117), 1195 p$.

This paper presents a method for assessing the risk of zalioactive material shipments. At overyiew of a risk andyis nobel is jiven. The type of information to perform the assessmet is described Fhe syster

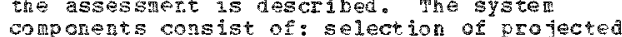
nacleat inlusty chatacterstics: naterial nucleas industy chatacteristics:
speciflation, amonnt, origin, and specifcaton amonit origing and

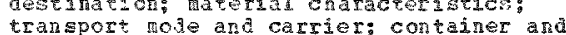
transport wole and carrier: contair
amount of atorial per contanex anount of atoral per container
specifications numer of shipments required and route, restrictions, population, and weather zones. (RAB)

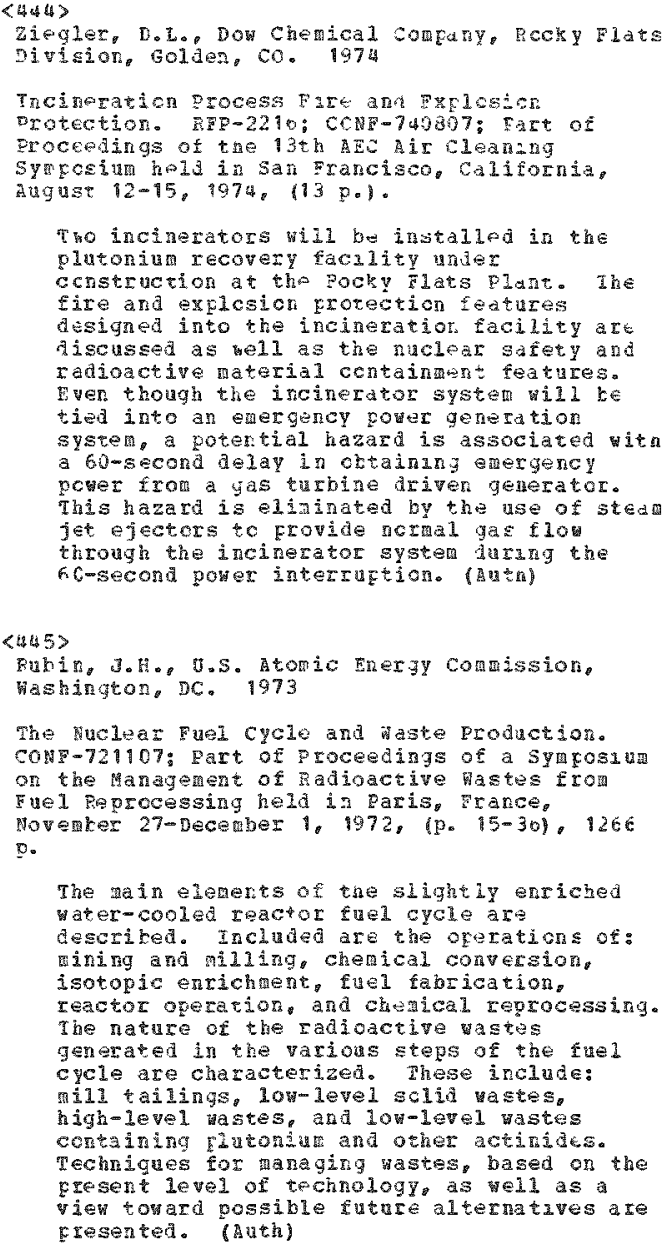


$\langle 446\rangle$

Arderson. R.D. and F. F. Olson, Atlantic

Richtield gantord Compan, Richand, Whe 197

Huan Blenent Design Considerations vith Glowe Boxes at the ditantic tianford Company.

CONF-710401: Part of proceedings of the Rocky Flats syafcsiut on safety in elutonium handing Facilities held in Golden, colorato, April

$13-16,197 \eta_{0}$ (P. $\left.4-15\right), 457$ o.

Inpottant factors which are necessary for the Inportant factors which are necessary for the
safety, cchert and etficiency involved in safety, ccntort and efriciency involved in glowe bot nork vere investigated. Particula
effort was expended to tefine the maxilut effort was expended to define the maxinut accessible areas of the himan hands when
working in qlove boxes. 1 list of basic criteria was established: 1) the maximu accessible area is to be provided for an operatot in a standing position, asing both hards concurrent? an a "cluteh-grip fashion, 2) as near as practical, there is to be 100 percent access to the hood when using one hand at a tine, 3) the hoods are to be accessitle from the sides with a desirable maximum of two tiers of glove ports, and a eqe rorts should he provided rather than eve ports should perovided tather than mounted $v i+h i r$ the hoods must be accessible mounted ithis the hoods must be acce wainterance. replacement and decontanination. proper location of vieng ro wows requires froper location or viens consideration of work location, reach phencmenon and shielding window depth. (RAF)

Figures $1-3$ show diagrans of reach patterns in glove Deres.

\section{(4) 7)}

Boncher, F., 2. Bartheleny, and C. Milet, Centre detades vicheaires. Fontenay-anz-poses, France. 1972

Sa fety Studies on Sealed Plutonin 238 Sources for Cardiac acerakers CoNF-720519: part of Proceedings of the 2 n. International Syaposium on power from padoj sotopes held in madrid. spain. May $24-J u n e 1,1972,(0,827-848), 986$ p.

In the design in this type of source the wain efforts order to chtain optimu containment of the radioisotobe. Safoty tests performed during these studies are based on: 1)

specifications concerning "radioactive materials in special. Corm" 2 , recomendations made by the study group on Isotopic Eatteries of the orcD fuclear Energy
Agency, and 3 additional studies considered necessaty for estimating the resistance linits of the sources. The resules shoved that the sealed capsules developed in these sevdies aresment a hich degree of safety. (Auth) (RAF)

$\langle 448\rangle$

Carpenter. G.D. Batto pemorial Institute. Pacific Northest Lahoratories. Fichland A 1969. Jaruary; 1972

Piltonium: Fersornel Exposure Control with

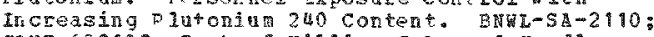
Conf-690103; part of illis, C.A. and gandloser; J. S. ( $\mathrm{E} d \mathrm{~s}_{\circ}$ ), Health physics operational Wonitoring, oroceedings of the 3 rd Health physies societ ofidyear povical symposina held in Los Angeles. California, Januty 29-31. 1969, Vol. 2. Gorton and Breach, science pablishers, Inc. New Work, NeV York, (F. $1223-1233$ ) 1848 p.

In recent years there has been a narked increase in the use of comerically recycled
Fu in fuel element fairication Frograme. ccraercilly recyched Ru has a higher qu 240 content than does the Pu wich inas been avaluble in the past. This higher pu 240 centent results in increased photon and neutron dose rates thich are sufficient to require modification of exposure conerol practices and procedures. Thas gacer piscusses some of the noditied procedures which have been put to use at the gacific worthest iaboratory to efrectively maintain Fersonnel dose with in the regulatory linits. Eersonnel dose win the regulatory linit exposure ace as follovs: is ainjuization of exposure ace as follows:
fuel quantities and of the total inventory. 2) atilization of photon shialda on glowe bores and hoods. 3 constant reexamination of the program and 4) evaluation of neutron acaiterer calibration. (Auth) (RAE)

<449>

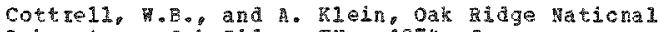
Laboratory, Gak Ridge. Tr. I974, Jane

Inde to Nuclear Satery, a Technical Progress Review by chromolegr, Ferauted Title, and Author Vol. 11, No. 1 hrough Vol. 14, No. 6 .

ORUL-USIC $-115 ; 52 \mathrm{p}$.

Abstracts are included for all articies in this section of the wherear safety Indey. seme of the areas covered are siting of nuclear Pacilities, transportation and handing of radioactive maride reactor
kinetics and sources of energy reiease nnder kinetics and sources of energy reiease nnder radion ulide release and wovenent in the enviconent, envirodated surveys, radiation dese to aan from racioactivity release to the environment, effects of therma modifucaticn on ecological systens. and effects of

radionuclides and icnizing radiation on ecological systers (RAE)

$\langle 450\rangle$

Doming, 特, Dow Chencai Conpan, Rocky wats Division, Golden, co. 1971

nesign of Filter Plenu Heat whahages. CONF-710401: Part of proceedings of the Rocky Flate symposiun on Safety in plutonia Hading Facilites heid in Golden, colorado, April $13-16,1971,(\mathrm{p}, 162-180), 457 \mathrm{p}$.

A fire test facility was constructed at ehe Rocky Flats Division of the Don Chemical conpany and consisted of a glove box. protective eqilding and titer plentu. Tests Ferforged within the filter plentra are sumatized. Heated air generated by a fire within a radioactive processing buildirg is likely to danage the exhaust fibers. The application of water strays to the face of the area filter tanks is likely te result in the aEpa filter banks is likely te result in is reakthrough of contamination Therefore. it is preferable to cocl the heated air with
hest exchange prior to filtration. The hest exchange prior to filtration. The

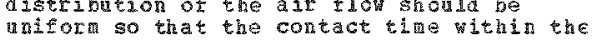
unifora so that the contect tial within the

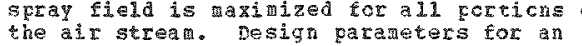
exchange are subject to uncertainties, and the greatest is the tenperature of the indet air expected from a fire. It appears that the value for the rheoretical heat transfer urit is inderendent of the disengagez used. and because of the relatively high inlet temperatures expected, has lithe effece on the exchanger length required In order to optimge the heat exchanger design for each filter plenul, it is necessary to deteraine the exchange inlet terceratures. This can be done by a survey of the combustible raterial 
$4450 \mathrm{COMT}$.

in the area served by the filter plentm, and knowleage of the relative heats of combstion and buraing rates. The design can be further optinized for the specific case $\$$ considering the fect of ailution aj and thowing mere accurate Iy the heat loss through the dacting. Based on the assumptions used for the exanple. which aptroxirates a general case, a hoat exchanger length of 5 to 6 feet appeare necessart for protection of the filters for a 1 hour fire. (3E)

$<451>$

Douglas. F.I.. Southesterr Radiological Health Laboratory, Las veqas, Nv. 1972

Health Fhpics rogran at the Nevada Test site Experimental Farm. Cont-690103; Part of $1111 \mathrm{~s}$. C.A. ard llas doser, J.5. (Eds.), Health Physics operational Mcnitoring. Proceedings of the $3 \mathrm{rd}$ Heaith Physics Socipty idyear copical Syaposium held in Ios Angeles, Callfornia, January 29-31, 1969. Vel. 1. Gorion and Breach, seience Fablishers, Inc., Hew York, New Pork, (P. $339-3601,1849$.

The Fublic Health service's Southuestern Radiological the Ith Laboratory has conducted a reserch program on the Nevada Test Site to study the passage of radiolodine through the corage-cow-mik-food chain. Tho types of corage-cow-min-food chajn. row the of artifical ly generated radioactive aerosol or artifical ly generated radioactive aerosol o presentation aescribes scme operational presentation describes scme operat

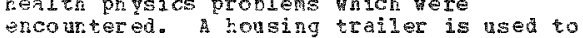
trcoutered. A housing trailer is used to Equi fuent is stored in plastic bags or cecontaminated. Preparation of the contaninated hy and care os pens and anirals are explained. It has been poseible to conduct these experinents in which, of normal standaris, the radiactivity is relatively uncontrol led. Jnder the provailang Eield conditions, the spread of contamination can be minitizad, and judgenent is reguired to aeteraine the degree of contanination control which is feronble and practical. wo date. no sinnif icant personnel exposures, interna or externa. have resulted from the tests. (BBi)

$\langle 452\rangle$

Duning, 6. M. J.5. Atomic Energy comission. 能 shington, DC. 9968

onserved $F$ al lou patterms and counterneasures raben. Conf-680507; Fart of Proceedings of a svmposium on the paliological protection of the public in a Nuclear Mass bisaster hela in Interlaken, Switzerland, May 26-June 1, 1968 , 10. $29-511,688$.

Several incidents rasulting in fallout material creating a hatar to the public are cited. The basis for decisions made the inplenent $\mathrm{a}^{+1}$ on, and results of protective acticn are recountod. Heavy fallout on the varshal Is 1 ands in igh required evacuation

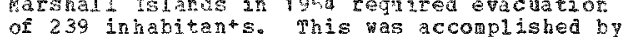
of 239 inhabitants. This was accorp

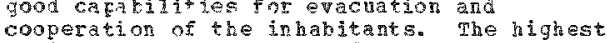
cooperation of the inhabitants. The highes radiaticn exposure vas second incident at $5^{+}$. Georges, Utah in 1053 resulted in a decision to send 4500 persons indoors for a perion of 2 hours. The total doses estinated aftorwards vere not large, yet the circunstancos under which the Eallou bccurred led to the decision. vearly all without panic or infuries because of ptior education programs conducted with local officials and the general cubic. A thisd incident at salt lake city, btah it 1962 required counter reasures by $106 \mathrm{l}$ and state health arthorities to redace loaine 131 ccntent in mik. cons vere placed on dry
ceed or milk was diverted into rilis products. citizens vere alarmed to the point where they switchea to axy milk er elintrated wilk from the diet. one huared eighty thousand Deonle vere affected, and a lack of understanding of Jadiaticn ptotection guides and the ambigut of gulaes resulted in the and the ambiguity or gudaes resulted in the fear that arose. The incident a t alowares, span resulted in platonin being released from two nuclear bonbs and contaminating the inediate area. Tests indicated the total exposure fron resuscension after initial deposition to be 5 to 10 tem but it as feasible to scrape of soil for $2-3$ inches and deep pow the area. Two hadred ejght-three ns 3 were stored at the A IC Savanah River plant. (RBis)

<453>

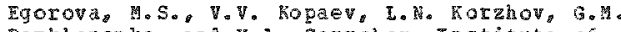
parkhorenko, and V.A. Sarycher. Institate ci

Eiothysics, hoscon, iss?. 1974, Februaty

Special Problems in Radiation Safety and Sanitary Dosinetric Monitcring when working with Transplutonieg Elenents. Cons-730907 (Dart 2): part of snyer, 3rd Inter ational congress of the IBga held it

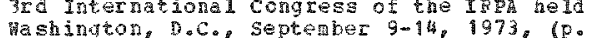
1ashington
$810-8(3), 1475$ p. (Russian)

The factors of Iadiction exposure at operationg with transpluto in gua ritative dependence or the physicomerical properties, the time of target irradiaticn ir the rexctors and the degree of their purification $\mathrm{xrow}$ the fragnent fissicn Excducts. The doses of external and internal irrabiation mere estistaterath

$\langle 454\rangle$

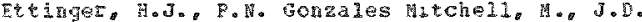
Depield, and J.C. Fider, LCS hanos soientific Laboratory. Heath Division. Los Adamos. $197 \%$ July

Test hethods ard Efficiency studies on Multi-Besh HEPA Filter systers. WASH-1332, Conf-740u of: part of Proceedings or the 2 gd ARC Envi rormental protection Sygposing held in

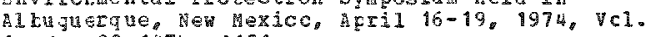
1. $(6.80-147), 1151 \mathrm{~g}$.

Mulrigle stages of high efficiency particulate ais (HEPA) filter banks to attain decontaniation factors of $10(\mathrm{E}+9)$ to $10(E+12)$ are proposed for the LASL ne plutonium facility. The a de design criteria for new plutomin facilitios regaires that the filtration syster shall be dessgned to allow reliable in-place testing and ease of replacenent. The design for a glove box replacerent. The and a fon stage process exnust filter instailation are shevg and metncas ci filter ingtallation are show and metncas cí
in-place testing and filter replacemert ane in-place testing and filter replacerent a
discusse. Whilg omtensine test data are discusse. While extersive test data are a vailable to substantiate decontam fictors of at least $2 x$ ariand individual HEP filters aganst sub-mic
lahoratory cest aerosols, such as Dop, guantitative 3 ata for the sctul al tork situation involving plutcniug aercsols mere act avalable. A tield sapling progra provided general crteria defining pluroniun aerosol size characteristicis ar a activity concentrations frop typical plutcrian 
《UE 4$\rangle \mathrm{CONT}$

operatiors. Ising laboratory produced

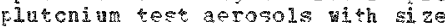

characteristics sinizat to those defined by

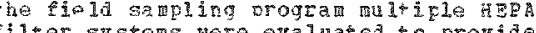

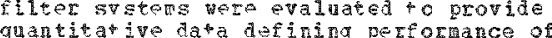

successive stajes of liph filters, and filter

performance as a function of particle size.

Test Jate shon that the first and secord HEF

filter each provia overall eftciencies in

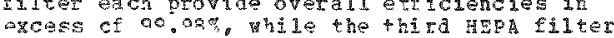

provides an average efeiciency in excess of

$9.0 \%$ These performance jevels exced a

requireme sata defing pertorance of

the first and second HeP filters as a

functicn of platoniun aerosol size show that

EEP Eilter eficiancies are in excess of

99.985 for sub-micron pluteni un aerosols. (Auth)

《6, 5,

Fisher, F.D. Fuclear paterials and Fquipent

Corporation, apoilo, EA. 1971

Giove $30 x$ Fire-pesistant paterials and Fire Suppression Tests. Contr-710401; Past of Procesding of the pock plats swinosin on Procedings of the pock lats Syposin on colden. colorado ipeil 13-16, 197, (p. 17-25) $457 \mathrm{p}$

An industry funded, Are sonsored Aa noc comatitee has been formed to fost and report on quve hor uindow materials and fire suppression system. The glove box Eire reststant materia is porticn of this study is inited to studies of relative percorances of different glazing materiais. whese are an Argonne "ational Laboratory type, HAPO type, Hapo $z$ frame trige, and Los Alamos scientific iaboratery type. sire suppession sy teas $1301-b a s e d$ systens and wil be manually activated. sirgle report is planed that wi1 serve as a hanhook for the industry. (B)

〈456〉

Foster, C.B., and m.o. Szulingki, Atantic pichrield Haford combang. Pichland, wa. 1974,

vecontamination of obsolete processing Facilitios at Hanford. ARH-SH-183; $31 \mathrm{p}$.

An overviev is presented of the decontarination zork asscciated with the remodeling of a latge fuels processing plant. preparatica of a reprocessing plant for stas-by and the aismanting of a $\mathrm{D}$ acrap processing facility (Recinclex). The best start on decontan in tor is contamination prevent design and operation 1 planing. planing is design and operationd planning planding fer decontanation priv to retodeling or deactiveing faciley and inolwes factor of design, operations, and personnel and compuning relations. At the Recuplen acility the glove botes vere contarinated internaly with gross acunes of pu. These glove bores and the equiplent vere cut with poner handsaw to a size which conld be loaded into star age boxes and the boxes vere seal and stored by burial in controlled zone. The surfaces of the room vere decont decergent until residual pu vas less than 1,000 disintegration/minute per $100 \mathrm{cr} 2$ The task was completed by repainting three or four coats of a mercoat. Deactivation of the Recupler facility denonstrated the feasibulity of aisuarting ma jor Pu processing facilities in afe maner with excellent containation control. (5)

$\langle 4.57\rangle$

Fu2sey. A. General Blectric Company, Sar jose.

Shielding Requirements for llepturaba hitrate shipping Packages. Conp-7409h! (Eart 2): Pare Shipping Packages. conp-7409h (Eart 2 ) symecium on Packaging and Transortation of eadioactive materials held in ala Beaca. Florida, september 22-27, 1974, (13 po), 1195 p.

As the market for neptunin develops, the iikelihood of separting and shippin neptunin increases. To aid the design of a shipping package, a stady of the radiation characteristios was gertoraed. Althongh the radiation frot $\mathrm{Np} 237$ is primarily alpa

gawa-rays from daugher froducts and ivfurities are significant. As Ra 233 grons in, the gand intensity increases. The dcse rate on the surface of stainless steel sterage bottle increases from about $1.8 \mathrm{R} / \mathrm{hr}$ to a maxima of about 3.7 Rh days after the neptunim is separated. This dGse rate levels off to abut 3.5 N/h5 after leo dag as a result of pa 233 reaching equilibriug with 237 . Shielding studices indicated that sone heavy actal was required whin tho shigping packege to atenute the
radiation to accegtable level.s. (Anth)

<458>

dantet, Ho D. Hechali, and G. Lacourly. Conissariat a 1" Energie Atoriatue Centre atudes Nucleaires, Fontenay-aux-Roses, france. 1973

Health Physics aspects of whied Pover Production. CEA-CONF-2513; COAT-730983: Eart of Proceedings of the congress of the society of Freceric Flectronic and Radic Enginesis syectic, Electronic and Radic engineers

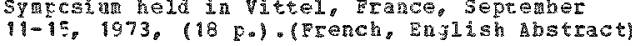

Radioactive pollaticn fron vastes norrally or accidentaliy produced by nuclear

installations gay result in exposure of certain groups of the population to

radioactivity. In normal operaticn.

radiological protection is secred by

establishing aosage limits and setting up a

acritoring systed to ensure their respect.

protection against accident risks is carried out by laysig down in tervertion litults and

preparation of emergency flans for limiting

the possible darage that aight result. (Auth)

$\langle 459\rangle$

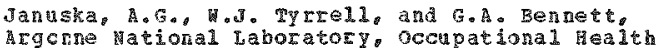
argorne tatonal Jaboratory, occupational yarional Iakoratory. plant operations Divisicn. ingrional Iatoratorye plant or

Decontamation of Riutonian-Contaminated Gove Bores

In connection we the Agrage vational L aboratory efforts to zeduce potential hazards fir the event a gutonian use facility as hit by a tornade. a decontariation experinent was carried out to estabish the 1 crest practicable liaits of loose contanination in an operatsing glovebos, and to atceraine the relative rerits of solvent wiging and vacur cleaning as methods of decontaninaton. The resules shoved that a 


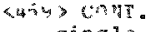

single wifirg of the heavily contaninated test glove hox ralign Hel-cat, yco Tiara, or Sonnglt 2197 solvent for a short period or

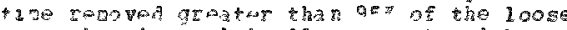

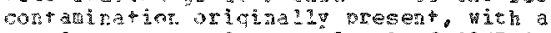

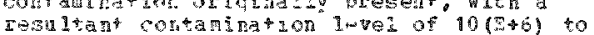

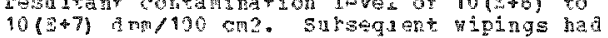
little efect on removing the renaing little ecect on removing the remanning loss

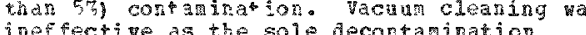
inestective as the sole aecontanination

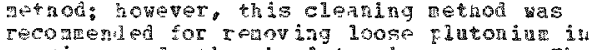
crevices and other hath-te-vipe areas. Thes results althourh limitel py the narrob scope of the experiment, offered tho possibility of decreaser aecontatination costs for glopeboxes compares to the stardarl

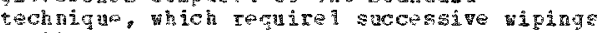
until the spers wore essentialiy clearo

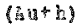

<4c 0)

Walpone B., Goolvat Aronic Corporation,

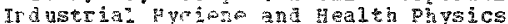

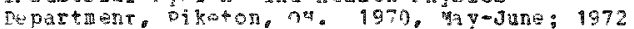

Aaninatraticn of ar Th vive Counting Program. American Ind ustrial tyiene Association Journal,

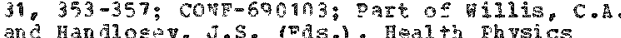

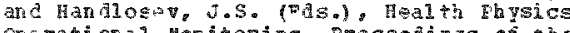
opo zational moritorirg. procedings of the 3 I Health Fhysice Socioty Midyear Topical Sy posiu held in Ios Bngeles, Califorria, Janvary 29-31,

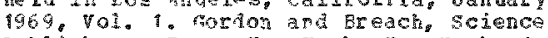

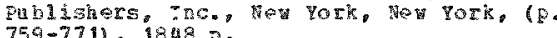

Bdninistrative centrols of an in vivo counting progran as applied to insoluble uraning conpounds wh the Iuno as the critical mrgan are foscribed. criteria for cestrictira work activities, and for removal Erom vor restrietions aeterkine the class of restriction. mhe assumption is wade that the restriction he assumption is ade that th the 1 ngs is one jeas until subscanert in the lings is ore zeas until subscquent in basis of a single in vipc count the 12 month basis of a single in visc count, the 12 mon

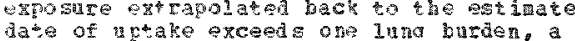
date of unake orceds one land burden, involves a vok assignaent in thich the individual $a$ not kovingly exposed to any for of uranim. If the exposore is between 70 , and $10 n$ of one lung burden, a class 2 restriction linits the individual to work areas vhere the average airborne alpha activity is not expracted to exceed $15 \%$ or less of the plant itgit depending on the

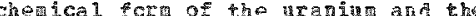
chen until suberuen valia in vivo ata inalcate

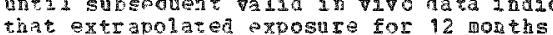
that extrapolated axposure for 12 months
prior to the ata of the nost recent count prior to the ato of the rost recent count is

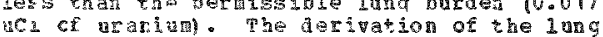

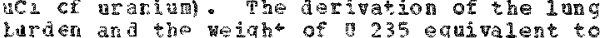

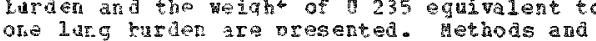
samp latg calculations of in vivo computation for a specific case are included. (BBA)

〈46 1)

Mainw, E.J., Mound laboratcry, mianisburg, OH. 1971

Veptilation Systors at Mound laboratory "ppu Buliding. cogt-710401: Fart of proceedings of

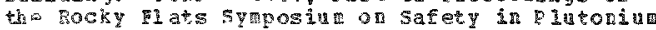
handing Facilities held in 3olden, colorado.

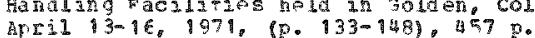

The purpose of this paper is to supply informatina on the Tutonin process 35.9

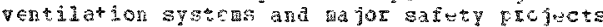
watartater at mound Laboratory in tho plutoniua procesing operation. Shoula an

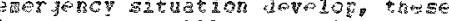
i

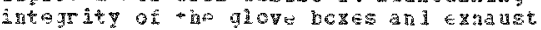
vertidation systera, a d thereby pievent relrase or radiotive acerias. Differontid prescules betreen the vertilation aystas are used to restracs the contanation from spreadan througnout the

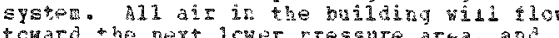

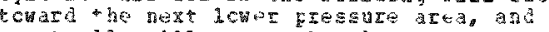
eventally vill jo to the glove boxes what have a -.65 negative pressure. All arr is

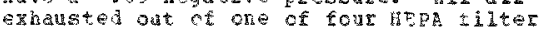
glerues. whe nigh fficiency air filtration systed cotpiles with lategt satoty requiremeres roccmentei far nucied $r$ th 1301 autonatic flle detection and protecticn system vas designea and iastalled for tho love bosks. (EEM)

$<62\rangle$ a theson, I.A. T.C. Jchnson, an A.J. OLver. Dow Chemded Compay. Focky Plats Division.
rolden, Co. 1974

Air Leakage Trto plupomita fleve Bores and Its Effect on Inert operations. cove-7164t: fart of rocedning of the Fochy Dlats symposing on

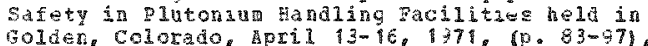
457 . 401 .

The pocky Fiats Plant plans to sukstute nitrogen for the dried air used in any of the present pa glow boxes to sappress ignition ard burning of $\mathrm{Eu}$ metal. Aif leakage into glove hoses will increase tre oxyger concentration and water vapor, both of wich mat be controlied. To nuelop quatitative information on air leakage, an developen to relate air leakage into glove developer to relabe air leakag into glove bcses to resultant increases in ates or orvgen concentrition. This a lious estiration of the leakage inth gleve boses and also the probable nitrogen reguirements. this materzal balance method ha ben acplied tc a large glovelor syster. The andyst ef the ritrogen reguirgants asing the vater vapor material balance methol is described. and other consiandions that arise during conversion of a glovebor syster th an inert atrosphere. optinun econolic operation will te a balance betuee extra maintenanee and operating labor and the cast of the nitrogen surclied to the syster. (RAB)

$\langle 4 \circ 3\rangle$

Hichels. [.E. DOW Chenical Company. Pocky Elats Eivision, Goluen, co. 1972, Jaly 21

Plutcrian Flant safety. Science, 177(4045), $200-290$.

Criticism and coments are made about a report by Dorothy shapley pubishea in Science or the Dow Chenical Company Eock Ilacs tivision. There was no inceneistancy an zaying the population is safe, ad wore Shapley inplied such an inconsistaricy. Shapley os principal source ch pecky Fits ccmato princion much of his coments bave been useful in that

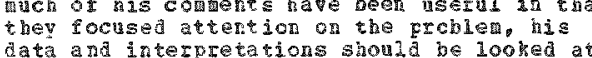
more closely. Duplicate saples at siggle 
《He 3> CONT.

sites disfrezed by a factor of $a$ and 9. Feal th and sarety Lahoratory porsonnel. clained a method used by fartell abused their data on lutorint contamination offsice. The praguapticn that equa 1 anounts of plutorium ife in guadranes borh southest and oest of the flant was disputer because of uind
dizecticns. nessite contaminat ion and directicns. nefsite contamination and exposure to workers inside the plant are trans-scientific problens, bu shapley seened to ingly row is neqligent in examining former terposed werkers only on a voluntary basiss

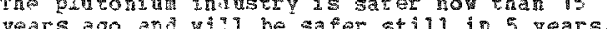
years ago and wi.t he safer still in public juagenent. (BB) (CTS)

<द⿱

Morse, JoL。 A.L. Marshalt, and A. Celons。 lawrence Padiaton taboratory. Liverare. CÁ.

In-Desidence nealth and Safery 5 uport in

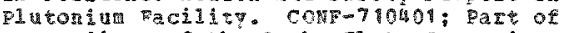
proceedings of the pockt Flats syaposina on safet in Plutoniu Handing Facilities held in Golden, Colorado, April 13-1F, 197 (p. $267-279), 457 \mathrm{~F}$.

\section{rieal th and gafory techricians (monitors)} metalinolica? resee safety sor of the plutonium facility at the lawrence padi at:on laboratory lavermore. The papt
describes the qualificatichs of these

tocnnicians and +ypical services rendered by then to he iacilito sointicic personel. such as contanintion control, waste such as, contanintion control, waste
recovery, moritoring of air sanpling equifment, frequent stear and swipe saples, out-processing of liquia an solic wastes to contral fire and cticility harard, ete. (a) $u+k)$

Tha apperdix gives an outline of safety indoctination for intoniur of facility.

〈4०5>

odland, I.S., P.G. Thonas, J.C. Zashner, H.Z. Kơ unang and . E. Eensor, U. 3. A ir Force

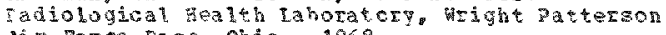
Air Fore base. 2hio. 1968

ER passay Experionces in 3aprot of Fiela nperation associate of Plutcrium. Covp-5-0521; morographs on Wuclear dicine and biology. wo. 2: part of Nuclear dicine and Biology, No. 2: Part Fornberge t. R. at? Proceediras a symposin on the Diagnosis and

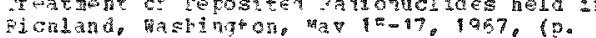

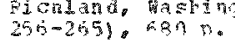

Bioascay exporpres associated with the palonares ruclear aceidest indicate that, in spite at the many hadicaps of sield operations, parsonel protection and drontanigation procerusez were effective.

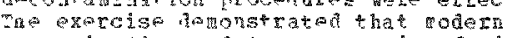
Gotruicatiot and transportation fecilities

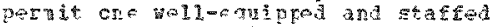
laboratory to provide alegrate suppore for ar

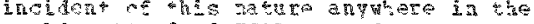
yor'd. stardazd mets orocedures were colloged to bespott or miniaize contamination of perscn rel be rafiad ive material.

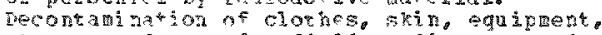

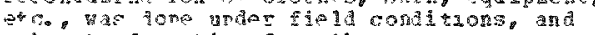
priot to anat ing from the area eaca

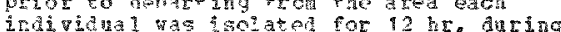
whoh the all utine out cut wa coldected for bioassay. of nearly 1.600 participants less than 20 h have s systemic tody burden of plutoniu detectakle by urinary bioassay, ana of this nuter, only 25 showe 2 value $i$ in the range of $7-67 \%$ of one peraissible body

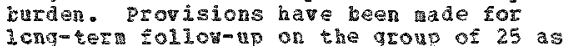
leng-ter tollow-up on the group of 25 as aterial as it becones availabie. Based cn a vailable aethods for estimation of systeric booy buraen of Pu 239 collowing an inhalation exposure, wot one individul who pareicipated in the Palonates operation has de systemic retention exceeding the rand Fermisabie anount. (Auth) (EAT)

$\langle 468\rangle$

Parker. H.

Plutcriun, Industrial Hygiene, Health Dhyics and Felated Asects. Fart of bodge, H.C.. et al (Eds.). Urania, Plutoniug, Transplutonic Flerents, Chapter li. Springer-Verlag, Ne York, New York, (p.613-667), 995 p.

The broad principles of protection from the predominanty alpha-particle emitting Pu ccnsists in isolating the aterial from contact wh the huar body by performing all orerations in closed glove boxes wh th secordary deferse of protective clothing. The enviconent is protected $b y$ filtration of exhaust aif from the glove boxes. These protective measures axe intended to eliminate irhalatjon. ingestien, ccntanination of contasination of wonds. other challenges to health physicists are discisgen ach as eriticality control. envirangantal releases, an waste storaye. The medical managent of contaminated person is revieved and specitic wethods of treatuent of contanination cases. such as by chelaticn therapy and lavage are discussed. The origin are purfose of the pransuranial Beqistry in anticald protection ageinst
criticality and protection from external ratiations are next dealt with. A sumary of Pu internal deposition experience is given. for exaple, the stanford experience for 1946-1967 \$novs 136 cases containing weacurable Pu with 15 cases showigg defosition about 5\% MPBB. Environtental protection for $\mathbb{B}$ is reviened wth wention wate of the samoling and ecological promer at the Vevada Test site, the atomic boub incidents at Falcon tire at Rocky slati. A scunis aste wamenent progran is meconended. In the appenir autopsy data are presented as well appendir atopsy datare presented a well as specific cases
demosition. (Fum)

《4,

Paleighe H. D. (Comp.). U.5. Atonqe Fergy comission, TGehnical Inforation Genter, oar Eidae, Th. 1973, Decerber

Fractor satety. A Literature seagch.

(2I $0-3535-75-58 ; 22 \%$.

rycludes are 267 chtaticns to references iscued during the retiod Janary 8972 through June 1973 on safery aspects or nucher reactor design. sirting acerials, ergineered

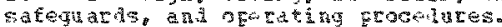
pepore died concern hazaris analyses of ertite facilities to satisty congtruction ad operation pernt requirenents, evalueicn $c$ f the reliablity of bector systers and

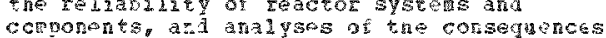
of poten ial accidat conitions. Subjot. of poten ial accide coniltions. Sub iumer-avalabilite indeseste inclued. 
FADIATYN SAFF"

$\{467\rangle \mathrm{COH}$

(Auth)

《468>

Foeder, 3. 5., Not given. 1968

Statistical sumary of United states Atomic Energy Cont Experierce, 1927-1965. conp-670521:

Monographs on Nuclear medicine and BIology, no.

2: Part of Rcrnberg, H.A. and Morwood, W.D.

(Dds.l Proceedings of a sypoosium on the

Di zanosis and Treatment of Deposited

RAdionuclides hera in pichland, washington, May

$15-17,1967,(0.35-450), 680$ p.

As part of the AEC Degulatory progran the bitision of compliance inspects materials and facility icenses to ensure that thei activity icenses to ensure that their activities are conducted in anger which heal he health and safetp. It is a 1 so responsible for the investigation of radiation accidents or incialatso the data pzesented in this paper are sor the period $1957-1966$ inclu

These dati, with a sev exceptions, are internal denosition of radionuclides which hate resulted in a dose to the critical orgar equal 1 to cr greater than $25 \%$ of the recommena andul dose limit for that organ. Chronic exposures are not included. Five cases involving misadrindstratior of radiopharmacenticals to patients are given. Tn the cases involving triting 5 rens used as the recompred annul aose 1 init. A total of 34 cases a re given invelving total of 3u cases are given invelving 535 po 210 , fission gasas/corrosion products ico Po 210 fission gasas/corrosion products

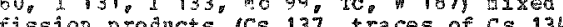
tission products iCs 13. traces or CS 134 and 1311, oxides (Ev 155, su 194, su 152$)$.

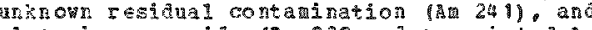
plutonin perorife (Tu 230 ard associated 24 in ar 3ptrosinato 9:9 ratio). (RA)

A sumaty cf the cases is gaven in tabular for listing physical-chemical characteristics. route of entry and date, lind of operation, Bethod of medurement-dose, and organ or part of body and trestment its situted.

<469)

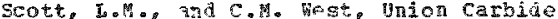
corporatior, t-12 plant, ok idge, TN. 1968

Health Physics Application of in Vivo Gama Spectromotry in a raniun processing plant. Spectronesy in a rantun processing plant. Biology, Mo. 2; Part of Rornier, $4 . \mathrm{A}$. And

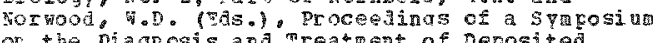

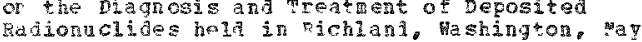

15-17, 1967, (0, 543-552), 680 .

In pivo gara spectronetry has been used rcutinely for the past six and a half years in the ineaith ohysics onitoring of uraniu processing workers. The major problems associated with the technigue aje: (1) effects of surface contamination, (2) relative insensitiveness of the methods, and (3) the difficulty of predicting the base srectrub in the uranium region. The sclutions to the problens at $Y-12$ have been to: (a) use the back detector data when contanination is indicated, (b) increase the number of detectors, and (c) derive

prediction equation and count a control popiation to assure continued reliability of the equation. Experience has show that urinalysis will not point out all exposur cases and that generaily once a person bas been renoved fror uranium oxposure, the urine been removed from taniu oxposure, the utine before in íno measurements do.

before in vivo measurements do.
conseguentiy, it has been conciuded that in conseguentiy, it has been concluded that as a montor for inscluble uranina However, fer soluble mranjum and areas of low exposure potential, urinalysis is of real value. (puth)

《a70

Valentine, A., E. Pitzgibbon, and I. Hartinez, Ios Alanos Scientific Iaboratory, Ios mamos, v․․ 1959, January $24: 1972$

Fea 1 th Physics at the Ios Alawos "hing 9 " Hot-Ce11 Facility. IA-4074; CoNF-690103: Part of of hilis, 6.A. and tand loser, J.S o proceedings of the 3rd Health Bhysics society Midyear Topical Syposiul hela in Los ngeles. california, Janary $29-34,1969$, vol. 1. Gordon California, Janary $29-31,1969$, vol. W. Gordon and Ereach, science publishers,
Hew tcrks (F. $141-164), 1848$.

Health Physics prograns at the Los Alamos " The 16-cell facility is used primarily fex testing and oxasnation of irradiated reactor fuel, hut it is also the main $\mathrm{L} A \mathrm{SL}$ facility fcr materis irIadiaticn, large source handing and other aiscellaneans hot-cell work. Eight cells are equipord with sealed alpa contaiment boxes for cafe handling ci plutoniun enriched fuels. control systeas and operatinc practices that affect health physics at the facility are aiscussed as well physics at the racility are discussed as well monitoring. perscinel dosimetry, ais acnitoring instruertation. (Auth) 
$\langle 479>$

GAST2 DISPOSA A

<479

Albensius, F.I., ard H.C. Feinig, Savanah Rives

zaboratery, Aiken, Sc. 197

Lorg Fange pargoment of

Transuranin-contamintea solid wastes at

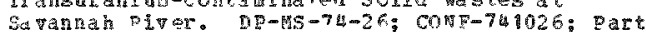

of proceedirgs of a symposium on the raragement

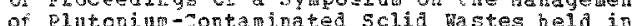

mecoule, Fince, gctober $14-16,1974,(9 \mathrm{p}$.$) .$

The Savarnak piver PIant, an 80,000 hectare isAEC production site in the southeastera

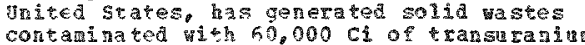

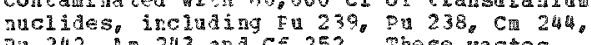
Pa 242 , A 243 and $C=252$. These vastes. abong vith 300,000 Cí of trarsureniug tastes fron cher ac gites, are stored in an 80 hectere aroz on the plantsite. The report îscusses a comprehensive planing program to retrieve and convert tine lastes to

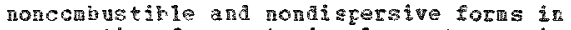

pregaticn for winturies-long storage in as

engineered repository. (Auth)

84728

Anderson, R.J. Attantic Richifeld Hanfors

Copang, pichind, wa. 1973, February

At lantic Ficheida Hanfora company.

CONF-721030: Part of Proceedings of the ABC

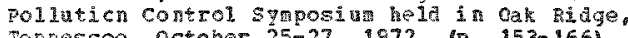
Tentessee, nctober $25-27$, 1972 , (p. 153-166). 549.

The Atlantic pich Eleld Hanford Company (ARHC) is currentiy instaling factilties for the compaction of both contariated and noncentaninated combustine wastes. The facilitios for roncotaninated conbutible wastes comorise collection contairers, two Exont-10ang compactor tricks, and a centrally-located continuous landfill.

Facilities are provided for the entire

Hanford $s$ ite th AFCH as responsible operator. For compliance 1 ith Excutive thos, open-pit buringing as current practicen till bo discontinter when the compacton tacilities are aqa llable in early calendar yeer 1973. The Eaciats tor contamated service on transuranic wastes comprises a lo-ton hy araulic press for compaction directli into 55-galion drums for 20-year retrievah le burial in cerpliance with Iamedite Action Birective $0511-21$. Fise
comactcr incorporates any features for personel safes and contaninaton control.

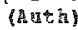

(4) 35

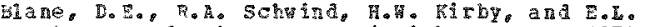

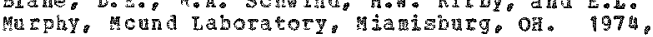
July

Me Process for peroving Plutoni un Exon Weter-A S Bogress Peport. MAsh-1?32:

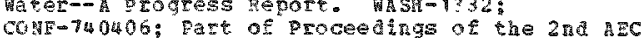

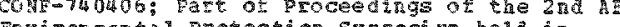

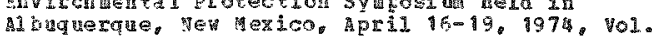

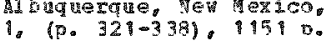

A process is under development at hound Iaboratcry to remove radionuclides

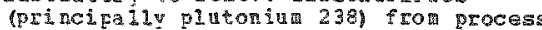
water pricr to atschargo of the vater to the Miagi piver. The containated vater normally is in the pli range from 6 to 9. Under these conditons, plutonim in all of its oxidation states is hydrolyzed and exists mostiy it a collcial cr polyneric state. The level of radioactivity in the lignid strean entering the waste treatment facility averages about
$25,000 \mathrm{dis} / \mathrm{an} / \mathrm{B}$ ( $(11.3 \mathrm{nC} / 1)$. The waste treatrent process curreaty used has consisherity reducel the radioactivity belcw the taldactive concentration gudeline (FCG)

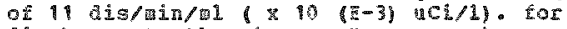
discharge to the river. Hovever. the frocess under developaent has the added advantaye of substantail reducing the rolu of solid waste generated. Pilot glant tests sbor that a contrinous ised hed phosphate trestane or ungrocessed inflent

hyroxide and polyelectrolytas is necesar hy remove colloidal or polyeric plitonia te remove collojal of polyeric platonia Fans in incluat the folloming $(1)$ continued pilot studies with $3-7$ tant we ard polyelectrolytes, (2) elividation of ccaphased putond umecies, (3) deternination of bone char capacity in clant effluent vater. (4) increaser sizes of bost char beds, and (5) regeneration cf bone char. (A) Alu

$\langle 474\rangle$

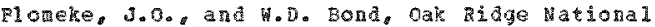
Lakoratry oak Ridge, no. 1974

High-level iaste danagerent Research and

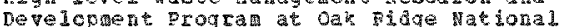

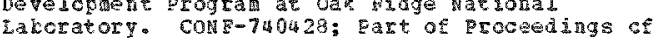
the $167 \mathrm{th}$ Hational $\$$ ywposium of the Berican

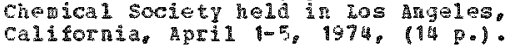

Three areas of major interest are being enphasized: projections of tuture radioactive waster from the nuclear fuel cycle for use in planning. design, and environatrial assessuents: investigations cf the techrical feasibility of regoving actinide elemert 50 wastes to render the resildvis aore manageabe in ter of hazards and storage reguirenerts; and ovaldaticns of geological cormatoms in adation co bedal

salt Eor use is tho disposal of various $k$ iads of radioactive wastes. projections of wastes io ke generated through the year 2000 fortend a fature managenent problen of ingresive

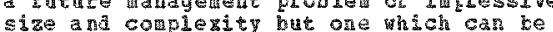
size and coplezity but one Which can te planded investigative progras. Early planed investigative programo EArly removed from waster by the minialig desined factors of $10(\mathrm{E}+2)$ to 10 (I+4); however. detonstrations and engineering agessents of the rost promising cherical flowsheets have yet to be made. Natural salt for believed to offer be best prospect icr dispol of high-level wastes, and he current program is direced towat obtainigs confirtation of this as well as evaluating other promising geological formations for their suitability for ese in the disposal of yastes. (Auth)

〈475>

Davis, T.F. (Coppo). T.S. Beciatc Energy

Comission, Division of Technical Information, oak Hage, Th. 1966. July 15

Radicactive Haste Processing and Dizposal an Annotated Biblography of selected diterature. TID-3311 (Suppi. 2): $180 \mathrm{p}$.

hethods for processing and disposing radioactive vastes have been a ccutinuia concern or the nuclear ind

vnclassified report and jonral hteracure ol this subject from February 1955 through Ju1 15, 1966 is covered is the bibliographo These selected, anotated references

supplement TID 3311, TID-3311 (SUEDL. H.

TID-3555, and TID-3555 (Supplo) The 
$4473\rangle \mathrm{CCHT}$.

references are arranged ty sub ject and cross refererced. allhor, corrorate author and teport tumporavajlability ingezes ats included (n ni2 peferenceso) (omu)

<470:

Hicknang Fe11s, ID. 9074,519

Elan for Retrieval of solid Low-tevel Radosctiv plutonium wate at the National tactor tostina Station (NRS). WSH-1332. con-740406: part of proceedings of the $2 \mathrm{n}$ Frvirongertal protection Symposium hela in Albugerque, ver pexico, Aprit $16-19,1974$, Vol. 2. 60. 1607-10391, 1959 p.
a plan for rotrieval of solia low-level rationetive plutonin (alpha) waste at the Maticnal peactor Tosting station (NRTS) is discusser. erhe Aiscusston asals with the desoriptions, atearitos ant volune of al wha wastos, wrorionce gainea in past alpha vaste retrieval activiries, the operations to be retrieval act in the thet osanple containent of aste for cranple cortalrent of aste fo

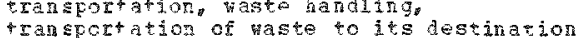 4ramsportation of waste to 4 castinat

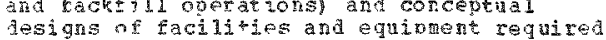 Aesigns of facilities and equintent requized dectector eruspment, ans general alpha contaninaticri protection clothing and k'quartant for tho norking personfell to retrieve alpha waste from the Nats Burial szound. (An+h) (PMa)

\section{$\langle 477\rangle$}

gacbeth, o... an H. H. Hichan, Berojet welear Conbary, Iftho Falis, TD. 9974, Decerber

TTSA: Above-Grond Fotrievable storage pethod

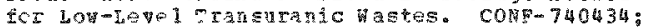

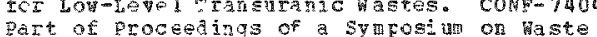

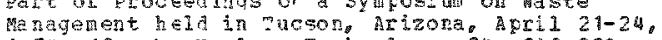
th $74,(9 \mathrm{p})$; Futear Technclogv, $24,393-390$.

The I laho Transurang stcrage Area (ITSA) consist of rastes packaged in

fiberglass-coated wooden toxes or steel drurs desicrea to retain their intogrity for 20 years. Containers aze stached on sloped asphalt paas. Tho array is covered vith

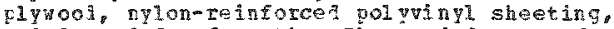
and 2 to fth of orth. The ned for safed and efficien methot for storage of low-level transuran ic vastes pronpted the development of ITSA. Storage costs in 1973 roz $208_{0} 000$ cubic feet of waste containing 24,500 ci of transuratic activity average $\$ 1.04 / \mathrm{cubic}$ feet. (A $a t h)$

《ू? 83

Not quven, oak Bidge pational kaboratory Che mical sechnologY Division, gak Ridge, Th. 1075 , danuary

Prouran for throver haste Management in conmerciai uclear Fuel Reprecessing Facilitios. OB $\mathrm{NL}-\mathrm{T} n=4783 ; 24 \mathrm{p}$

The principal obtective of the prograr propose in the report is to decrease the long-term (note than 1000 years) hazards of radicactive wastes from comereial nuclear tuel reprocessing tacilities. ond is to be accomplished by modicying reprocessing

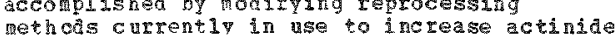
Wechos current 1 in use to 1 ncease actinide recoverifs ath to produce haste streas that ail vastos shold he treated so as to achieve scparaton into a solid.

ission-product-contairing fracticr wath lc concentrations of long-1iped actinides and a semipure concentrated rraction containang the actinides. After sufficiont information has been accumulated from labratory-scale studies to allco freparation of overail. detailed flowsheets and to perist making a technical evaluation, a detalled review yili continued through construction and operaticn
of a large-scale demonstration plant that 111 satisfactorily treat al daste streans from a modified nuclear fuel ieorocessing Exoma modified nuclear fuel reprocessing facility of There is a listing and brief sumary of the tasks required to carry cut the anponer, costs, and time required to complete the progratian. (Ath)

$\langle 479\rangle$

Eobinson, P.R., Not 9ivan, 1974, July-August

The Leak of Tank 106- $\mathrm{T}$ at Hanford. Nuclear safety, $1=(4), 460-46 n$

rhis article reviews an incident in wich a gorosimatedy 15,000 gal of ratioactive

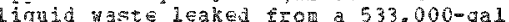
urdergrourd storage tank at the fiamera Dant at the v.5. Atonic snergy comission in 1973 . The onsuing investigation andicated that the leaked material was retained in the soil in the vicinity of the waste tanks and posed ro threas to the workess and the nearby Columkia River. Mowever, the investigation did gout cut the need ior incroved ronteritig rocedures, which ate presently keir. iplemented. In 1071 a nev type of tank cane into nse at Hancose for high-level liguid wases that are te le stcrea for long rerscis ct time. This design consusts essentialiy of a tank within a tank. The inner steel wall crovides the primary contand iquid. In the event or a leak, the liguio bill simply flow into the andar lar space betwen the inner and outur taris. The whele tamk asseroly is further conrained inside a corciote valt. (PAS)

<480

Fon, F. D. Lewis Hesearch Center, cleveland, ch.

Sumaty of the Study of Disposai of Muclear

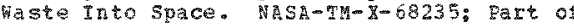
proceeangs of the loth space congress on Fechnology Today and Tcrorrow. held in cocoa Geach, Florta, Apeil 11-13, 1973, ip. $7.19-7.269$.

The Hational Aeronatic and $3 p a c e$ Adinistration (NASA), at the request of the ACC is conducting a preliginary study to aetermine the foasibility of disposing of nuclear waste material inte space. The study has indicated that the space shythle togethe wh expendakie and non-excendable orbital stages such as the Space Tug or centar cal
safely dispose of waste material by efecting it from the solar syster. (Mo launching system that is under development or planded can deposit waste material arectly into the sun). The safety problems associated with a 11 phases of laurching and operation (norma erergency and accident) of such syster are being examed. From the preliminary study it appears that solutions cas be found that shoula wake the risks acceptable when conpared to the benefits tc be obtained frou the disposal of the nuclear be obtained frou the disposal of the nucle a system acceptable read to be carefully 
〈480〉 CORT.

verified by further study and experinent.

Evan though wore than one hundred shuttle

lanches wevid be required per year by the

yent 2000 . the cost to the consuner would be

less than five percent of his electric bill.

mests of rodels of waste packages impacted on renforced concrete and soll have

demonstrated the feasiblitty of safely

contaning waste material at inpact speeds up

to $\$ 050$ feet per second. (Auth)

\section{$\langle 481\rangle$}

Stendier, .J., ข. Y. Levitz, L.E. Trevorrow. I.J. Gerding, a.J. Kullen, D.S, webstex, and I. Burris, Argorne vational Laboratory. Argonne, II. 1974, February

chemical Englueerang Division, waste Managenert Programs Quarterly Report, October-Decenber 1973. ANL $-8097: 41 \mathrm{D}$.

hatetal-con baction nethods have been reviewed and information on the irradiat 10 m-induced property changes of zircaloy surveyed as part of a study on the handing of vel calang huils. Inforwation organatang from AEC-sate visits and from a review of the cren iterature concerning decontanisation of plutondur contamated materlals is presented. The technal and economa feasibility of adapting zeverse csmosis to the concentratzon of tatulia from tratzaten fuel reprocessing wastes was briefly evaluated. Techncal feasulity as assued fron literature reports of a diffecence ci aboat $3 \%$ in the selifadiffusion coefficients of Th and 120 , and possibly greater differences in transport rates in solution-diffugion mempanes. The costs of such a process tere calculated from 1

esch process the calculated rron 1 estimates for the single-stage segaration
factor, 2 the heads fion rate for assuned concentrations and volumes of feed, product. and wate 1 an 1 deal cascade of renoranes and 3 published costs for reverse osmosis eguipment. The result ranged frod $10(\mathrm{E}-4)$ to 1 mil1/kh of nucleas power, depending on the assumed single-stage separatron factor and uhether tratım-depleted water yas recycled to the reprocessing plant. (Auth) 
AUT HOR INDEX

Abey, A.B. 407

abrams, R. 1

Adams, $\mathrm{B} . \quad 343$

Adams, Н.н. 273

Adee, R.R. 200

Akatsu, J. 279,280

Albensius, B. L. 471

Alexander, R.E, 397

Ames, L.L. 398

Andersen, B.V. 344

Anderson, E.C. 2,384

Anderson, K.J. 472

Anderson, R.D. 446

Arkhangelskaya, G.V. 127

Arinstrong, P.B. 335

Arnold, J.S. 3, 4, 342

A therton, D.R. $5,6,32,33,35$, $106,136,144,220,227,228$,

$229,230,231 ; 283$

A ue rbach, H. $37,38,39$

Axelrod, D. 204

Bagnal1, K. .. 281

Bair, W. G. 250 Bair, W.J. $7,8,9,10,11,12$,
$52,54,55,170,172,251,252$,
$254,255,381$

Baisogolov, G.D. 367

Baker, D.A. 330

Balentin, N. 399

Ballou, J.E. 13, 14, 15

Barron, E.S.G. 16

Bartheleary, P. 447

Bartley, M. H. 105

Baturin, G.N. 299

Baxter, D.w. 17, 128, 130, 131

Bay, R.C. 69

Baysogolov, G.D. 353

Beach, S.A. 345

Beasley, T. M. 424

Belyaev, Yu.A. 18, 19, 20

Bennett, G.A. 459

Bennett, S. 86

Benson, R. E. 465

Berdjis, C.C. 21 Berliner, D.I, $34,76,77,161$,
$221,223,224,225$

Bernard, S.R. 22
125

Bethlendy, G. 320

Bevan, J.S. 346

Bhanti, D.P. 336

Bhat, I.S. 400

Bland, M. R. 23

Blane, D.E. 473

Bleaney. B. 24,263

Blomeke, J.O. 441,474

Blomquist, J.A. 181

Bloom, M. 158

Boecker, B.B. 25, 145

Bogatov, L.V. 26

Bogen, D.C. 401

Bokouski, D.L. 356

Bond, W.D. 474

Borasky, R. 433

Borisov, V.P. 27,28

Boucher, R. 447

Boulenger, R. 399

Bowers, J.z. 69

Boy d, в. . . 29

Bradley, J.E.S. 150

Brammer, D, 249

Branson, P.E. 344

Brewster, I. 246

Brooks, A.L. 30, 31, 126, 182, 217

Brown, C.I. 442

Bruenger, F. . $5,6,32,33,34$, $35,36,220,222,226,227,228$,
$230,231,232,282,283,294$

Brues, A. 1. $37,38,39$

Brueuer, F. 347

Bubernak, J. 318

Buchholz, J.R. 273

Bukhtoyarova, Z.14. 40, 176

Buldakov, L.A. 41, 42, 43, 44, 151,152

Burris, I. 481

Buschbom, B.I. 60

Bustad, L.K. 45, 46, 53, 146, 147 174

Buster, D.S. 230

Cable, J.W. 46,146

Carfagno, D.G. 402

Carnahan, C.L. 300

Carpenter, G.D. 448

Carrard, C. 316
Carver, R.D. 338

Casarett, A.P. 109

Casarett, I.J. 348

Casey, H. H. 146

Cataldo, D.A. 274

Catsch, A. $47,48,49$

Catt, D.L. 171

Celoni, A.A. 464

Chapman, I.V. 211

Cheever, C.L. 403

Cherdyntsev, v.v. 301

Chipperfield, A.R. 50

Christ, R. 437

Christensen, W.R. 51, 241,242 , 243

Christenson, C.H. 273

Clark, L.L. 391

Clarke, R.J. 52, 53, 54, 55, 141 , $170,172,215$

Clemente, G.P. $\quad 404$

Cloutier, R.J. 358

cole, B. M. 391

cole, K.S. $56,57,58,59$

comar, C.L. 109

Cooper, J.A. 337

COPP, D.H. 114

Corley, J.P. 330

Cornett, J.S. 312

Cottrel1, พ.B. 449

Cowan, M. 363

Cowan, 1., Jr, 302

Cowart, J.B. 321

Craig, D.K. 60,171

Craig, P.H. 109

Cravford, T.V. 419

Crook, K. 248

Crook, K. W. 247

Crowley, J. 61, 204

Cuddihy, R.G. 25

Daburon, M.L. 349

Dagle, G.B. 62

Davidson, R.S. 326

Davis, D.K. 442

Davis, J.J. 120

Davis, T.P. 475

Debois, J.M. 63 


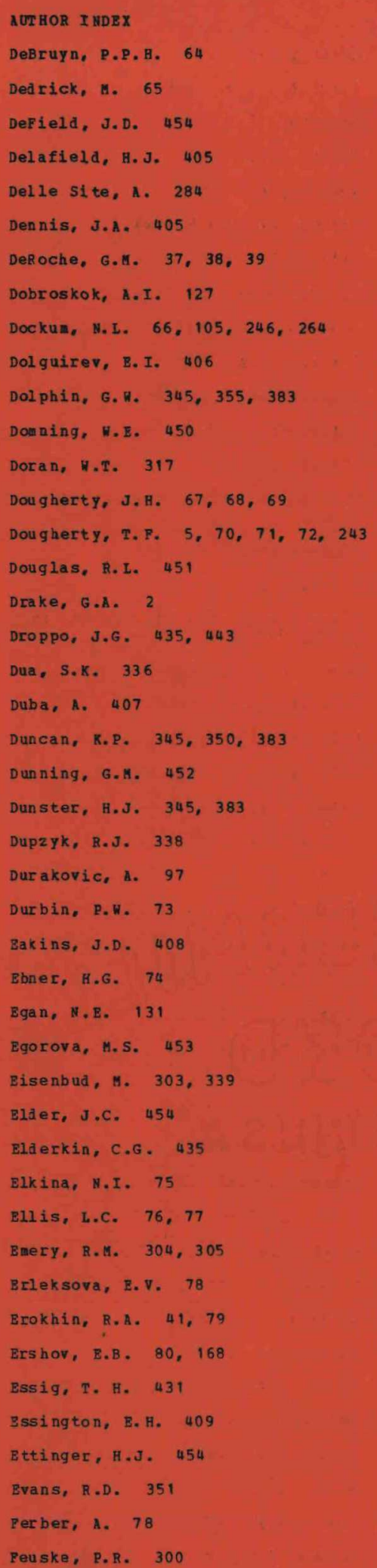

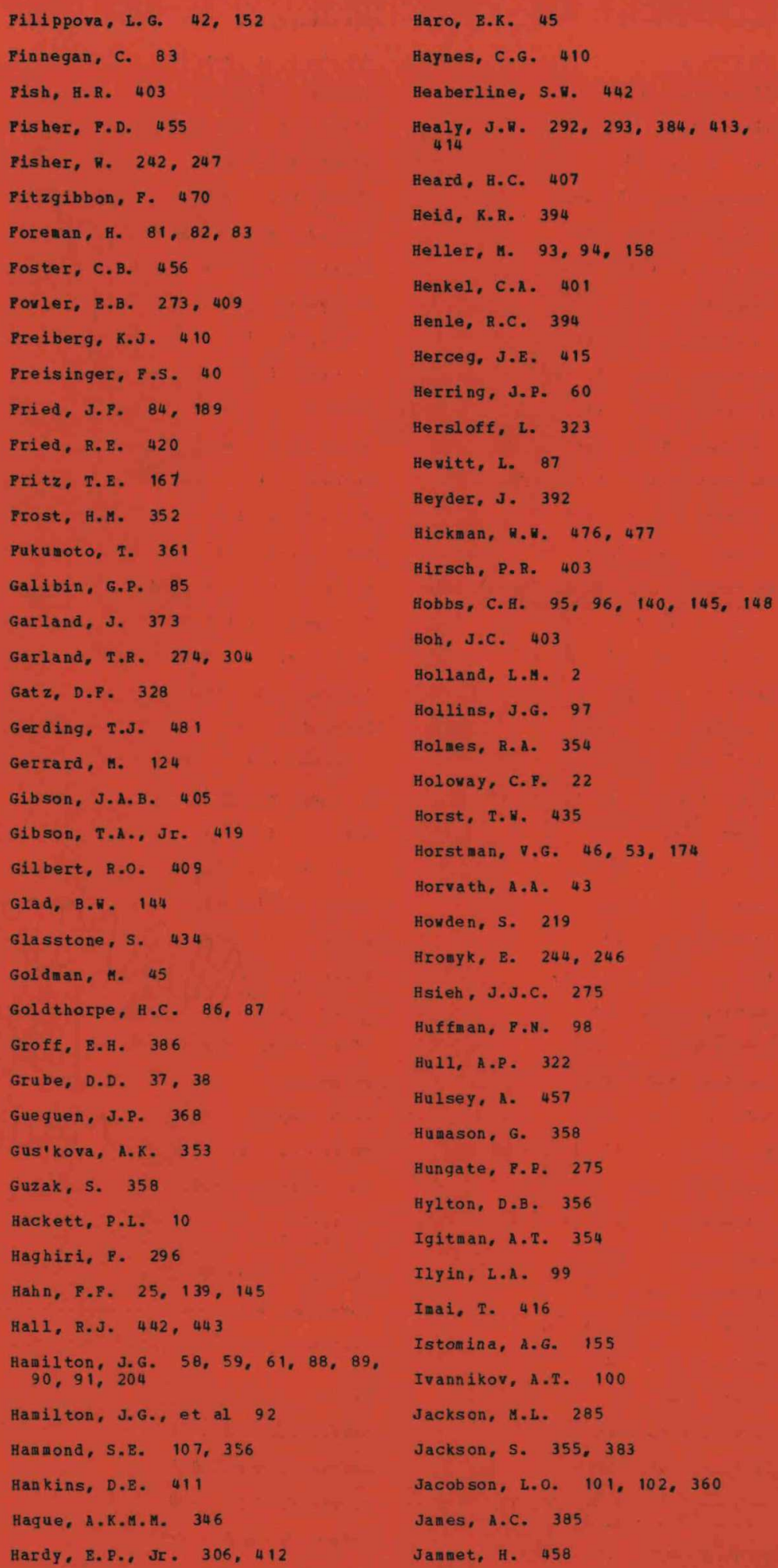


AUTHOR INDEX

Janetka, D.S. 403

Januska, A.G. 459

Jeanmarie, L. 349

Jee, w.S.S. 3, 4, 6, 51, 66, 103, $104,105,106,115,136,169$

$241,242,245,246,261$

Jefferis, J. 326

Jensen, D.A. 30

Johnson, G.L. 273

Johnson, L.J. 107, 415

Johnson, T.C. 462

Jones, R.K. 145

Jordan, C.P. 307

Jorgensen, C.D. 308

Joshi, P.P. $\quad 336$

Kajdanovsky, G.N. 406

Kalesperis, G.S. 131

Kalistratova, V.S. 108

Kallfelz, F.A. 109

$\mathrm{Kalmon}$, B. 460

Kalmykova, Z.I. 26, 110

Kat sapov, I.S. 108

Katz, J. 111

Kaufman, H.R. 465

Kau1, A. 392

Kawin, B. 112, 113, 114

Kay, A. B. 286

Kazbekova, D.A. 155

Keane, A.T. 351

Keller, C. 298

Kelly, พ.S. 442

Kenber, N. F. 385

Kemp. J.L. 438

Kenner, G.A. 105

Kenner, G.H. 115

Kerr, M. B. 147

Keyanonda, P. 69

Khalturin, G. V. 42

Khod yreva, M.A. 116, 240

King, s. 87

Kirby, н.И. 473

Kirby, L.J. 364

Kisieleski, "月.E. 134

Klein, A. 449

Kleine, P.J. 461

Kleinman, M.T. 417

127

Klepper, B. 278

Kline, J.R. 307

Kloke, A. 418

Klopfer, D.C. 305

Klykov, 0.v. 168

Knox, J.B. 419

Knyazeva, B. A. 270

Kolotrin, V.A. 165

Konstantinova, V. V. 117, 118

Kopaev, v.v. 453

Koranda, J.J. 309,315

Korelina, N.F. 127

Kornberg, H.A. 119, 120, 121, 276, 333

Korzhov, L.N. 453

Koshurnikova, N.A. $79,122,125$, 269

Kotrappa, P. 336

Kottuitz, D.A. 443

Kraevsky, N.A. 123

Krasnoshyekova, G.P. 127

Krey, P.H. 420

Krivchenkova, R.S. 28

Krivolutskii, A.I. 124

Kudasheva, N.P. 125

Kullen, B.J. 481

LaBauvé, R.J. 30,126

Lacour1y, G. 458

Laf una, J. 163, 164

Lagerquist, C.R. 107, 356

Lally, A.B. 408

Lang, H. 61

Langham, J. 358

Langham, ผ.H, 297,357

Larson, H.V. 344

Laurer, G.R. 339

Leary, J.A. 318

Lebel, J.L. 107

Leinberg, V.K. 122

Lem berg, V.K. 20, 40, 153

Lenberg, $\nabla . K .269$

Levitz, N.M. 481

Libby, R. A. 391

Libinzon, B.E. $118,259,260$

Likhtarev, I. A. 127

Lindenbaum, A. 17, 128, 129, 130,
Lindenbaum, A. 131, 132, 133, 189, $190,191,192,194,197$

Lippmann, M. 421

Lisco, Н. 134,158

Little, C.A. 323

Litvinov, N. N. 135

Liu, S.N. 442

Livshits, R. E. 165

Lloyd, E. 395

Lloyd, R.D. 136, 137

Logan, R. 138

London, J.B. 2

Loutit, J.P. 23

Ludwick, J.D. 287

Ludvieg, F. 418

Lund, C. 129

Lundgren, D.A. 324

Lundgren, D.L. 139

Lushbaugh, C.C. 358

Lustgarten, C.S. 95, 140

Lyubchanskii, R.R. 43, 79

MacBeth, P.J. 477

Machta, I. 422

Magi, A. 359

Mahburn, D.D. 207

Mahlum, D.D. $65,141,208,209$

Major, S. 326

Manoli, R. 354

Markham, O.D. 325

Markley, J.P. 142

Marks, E.K. 360

Marks, S. 250, 251, 252, 254

Marlos, S. 10

Marshall, A.L. 464

Marsha11, J.H. 192, 395

Martin, J.R. 309, 315

Martinez, L. 470

Masse, R. 163

Massey, P. 164

Matheson, I.A. 462

Matlack, G.1. 288

Matlock, G.H. 318

Matsumoto, B. 310

Hatsuoka, 0.361

Gatreev, V.I. 143 
AUTHOR I NDEX

Mauder1Y, J.L. 140

Maxwe11, R.B. 162

Mayer, P.G. 429

Mayer, R. 326

Mays, C. พ. $136,144,137$

MeClanahan, B.J. 12, 215

Mcclellan, R.o. 25, 30, 95, 96, $126,139,140,145,146,147$,

$148,156,182$

McInroy, J.F. 362

McIntyre, D.R. 315

MCKee, R.W. 391

Mckenney, J.R. 53, 147

Mcsyeeney, T.I. 442,443

Mead, D.K. 126

Mechali, D. 458

Merritt, M. L. 363

Mewhinney, J.A. 95, 96, 140, 148 , 156. 157

Mical, R.S. 106

Michels, D. B. 463

Miglio, J.J. 95, 96, 140, 148,

Mikhailova, O.A. 289

Milet, C. 316, 447

Miller, C.P. 277

Mishima, J. 442

Mitche11, R.N. Gonzales, M. 454

Miyake, x. 310,311

Mot rbacher, J.A. 429

Moretti, E.S. 131, 132

Morgan, A. 291

Morin, M. 164

Morse, J.L. 464

Moskalev, Yu.I. 43, 44, 123, 149 , Ioskalev, Yu. I. $43,44,123,149,150,151,152,153,154,155$,
$150,15,171$

Moss, W.D. 362

Moulthrop, H. A. 438

Mueller, В. 105

Uuggen burg, B.A. 156, 157

Mullins, L.J. 318

Murphy, E. L. 473

Murray, R. 158

Murray, R.G. 159,160

Mushkacheva, G.S. 260

Nabors, C.J. 224,225
128

Nabors, C.J., Jr. 161, 162, 223 P1erce, M. 177

Nebeker, N. 51

Nee1, J.ห. 274

Nelson, D.M. 290

Nelson, I.C. 364,423

Nenot, J.C. 163,164

Nevstrueva, M.A. 165

Nevton, D. 373

Nichols, J.P. 441

Nickson, J.J. $58,59,372$

Nielsen, J.M. 424

Nifatov, A.8. 41, 43, 79, 152, 180,269

Nigrovic, v. 82

Nolibe, D. 166

Norman, J.C. 98

Norris, W. F. 167

Norwood, W.D. 365,366

Not given $340,341,425,426,427$,

Dakley, W. D, 111, 265

odland, L.T. 465

oliver, A.J. 462

Olson, R.E. 446

Olson, R.J. 171

osanov, D.P. 80,168

osmond, J.K. 321

Palmer, H.E. 337

Palms, J. H. 429

Palotay, J.L. 15, 54, 55, 141, 215

Park, в.z. 169

Park, J.F, 8, 54, 55, 17C, 171, $172,255,381$

Parker, Н. М. 466

Parkhomenko, G. H. 453

Parkinson, J. 173

Peabody, C. $0 . \quad 377$

Perrings, J.D. 2

Persing, R.L. 174

Pesternikov, v. A. 175, 176

petermann, P. 248

peters, R.P. 31

peterson, C.H. 428

peterson, P.K. 29

Petrovich, I.K. 155, 271

pickre11, J.A. 140

Rom, P.E. 480
Pilarski, L.M. 39

Platt, R.B. 429

Plotnikova, L.A. 367

Pohlit, W. B. 178

Polig, B. 374

Popev, D.K. 289

Porch, W. \&. 334

Porozov, N.v. 406

Post, J. 83

Potter, G. 315

Prosser, I. 179

Puzyrev, A.A. 180, 269

Quentric, Y. 368

Raabe, O.G. 29, 95, 140

Ragan, Н.А. 215

Ragsdale, Н. L. 429

Rahman, Y. 193

Rajewsky, B. 392

Rakova, V.A. 168

Raleigh, н.D. 467

Ransden, D. 377,430

Randerson, D. 312

Rarbitnaya, L. M. 100

Rchfeld, C.B. 247,249

Reed, J.H. 363

Regnier, J.A. 323

Rehfeld, C.E. 181, 242, 248

Reinig, H.C. 471

Repin, v.S. 127

Resetov, G. N. 79

Retherford, J.C. 31, 182

Rhoades, B. P. 183

Rhoades, R.P. 184, 185

Richmond, C.R. 186,384

Righi, E. 347

Robertson, D.C. 313

Robinson, R.A. 479

Rocquet, G. 368

Rodriguez, B.R. 327

Roe, D.A. 369

Roeder, J.R. 468

Roesch, W.C. 275

Rosentha1, К. T. 17, 128, 129, 130, 


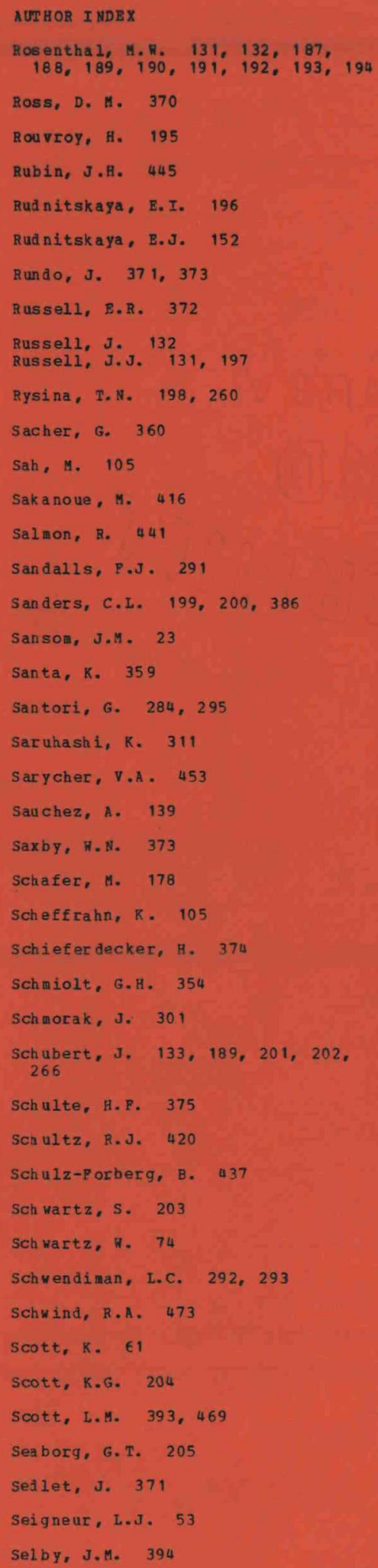

Semenov, A,I. 27 Serenov, D.I. 206 Semonin, R.G. 328
Suezea, E.G. 276

Sugimura, $\mathrm{Y} .310,311$

Sullivan, M.P. 236, 237, 254

Surina, A.G. 260

Suzuki, H. 388

Swinth, K.L. 432

Sych, Z.G. 257

Szot, z.z. 238

Szulinski, M.J. 456

Takebe, H. 239

Takizava, Y. 378

Tarasenko, N.YU. 240

Tashner, J.C. 465

Taylor, C.N. 228

Taylor, D. 18. 50, 238, 379

Taylor, G.N. 5, 33, 51, 136, 181 , $226,231,241,242,243,244$, $245,246,247,248$

Taylor, N.A. 373

Taysum, D.H. 249

Tedford, C.P. 319

Tegge, R. 106

Telegadas, K. 422

Temple, L.A. 250, 251, 252, 264

Terry, J.L. 53, 268

Testa, C. 284,295

Teves, H. A. 419

Thomas, B.G. 43, 253, 380, 465

Thomas, R.L. 186

Thomas, V.T., Jr. 364

Thompson, R.C. 237, 254, 381

Thompson, S.E., Jr. 315

Tikhomirova, A. L. 124

Todd, R. 138

Tombropoulos, B.G. 255

Totter, J.T. 256

Travis, J.B. 331

Tregubenko, I.P. 206

Trevorrow, L.E. 481

Trifonov, V.I. 108, 271, 272

Tsarapkin, S.R. 257

Tseveleva, I.A. 258, 259, 260

Turchamimooa, V.A. 124

Twente, J.A. 261

Tyrrell, W.J. 459

Ushakova, A. F. 127 


\section{AUTROR INDEX}

Valentine, A. 470

Vaughan, J. $262,263,389$

Vaughan, J. H. 390

Vog t, G.S. 147

vol chok, H. I. 417

Volf, V. 382

Hager, R.พ. 264

Magman, N.A. $\quad 337$

Wahlgren, M.A. 290

Wakshal, E. 332

Waldron, M. B. 286

Maller, B.J. 290

Warner, D.E. 121

Watson, C.J. 203

Wat son, E.C. 442,443

Watters, R. I. 107

Webster, D.S. 481

Weeks, М.н. 111, 265

Hei, C.T. 342

weimer, W.C. 305

Welford, G. A. 401

Welland, D. B. 9

West, C.M. 393, 469

Westfal1, म.M. 132

weyers, c. 399

Whicker, P.พ. 323

Whipple, н.C. 375

White, C.G.c. 401

White, M.R. 266

Whitson, S.W. 169

Willang, R.F. 274

Villard, D.A. 10

Willard, D. H. 11, 12, 264, 267 , 433

illiams, J.L. 245

Villiams, L.D. 442,443

Williaason, M. 263

Wilson, J.S. 2

Wilson, R. H. 268

Winsor, T.F. 323

Yaguchi, E.H. 290

Yaron, F. 332

Yerokhin, R.A. 269

Yoshikawa, K. 361

Youngguist, С.H. 403
Yukhlov, A.K. 270

Zagaria, R. 203

Zalikin, G.A. 271,272

zhorova, Ye.S. 271

Zhuravlev, V.P. $\quad 155$

ziegler, D.L. 444

Zvonova, I.A. 127 


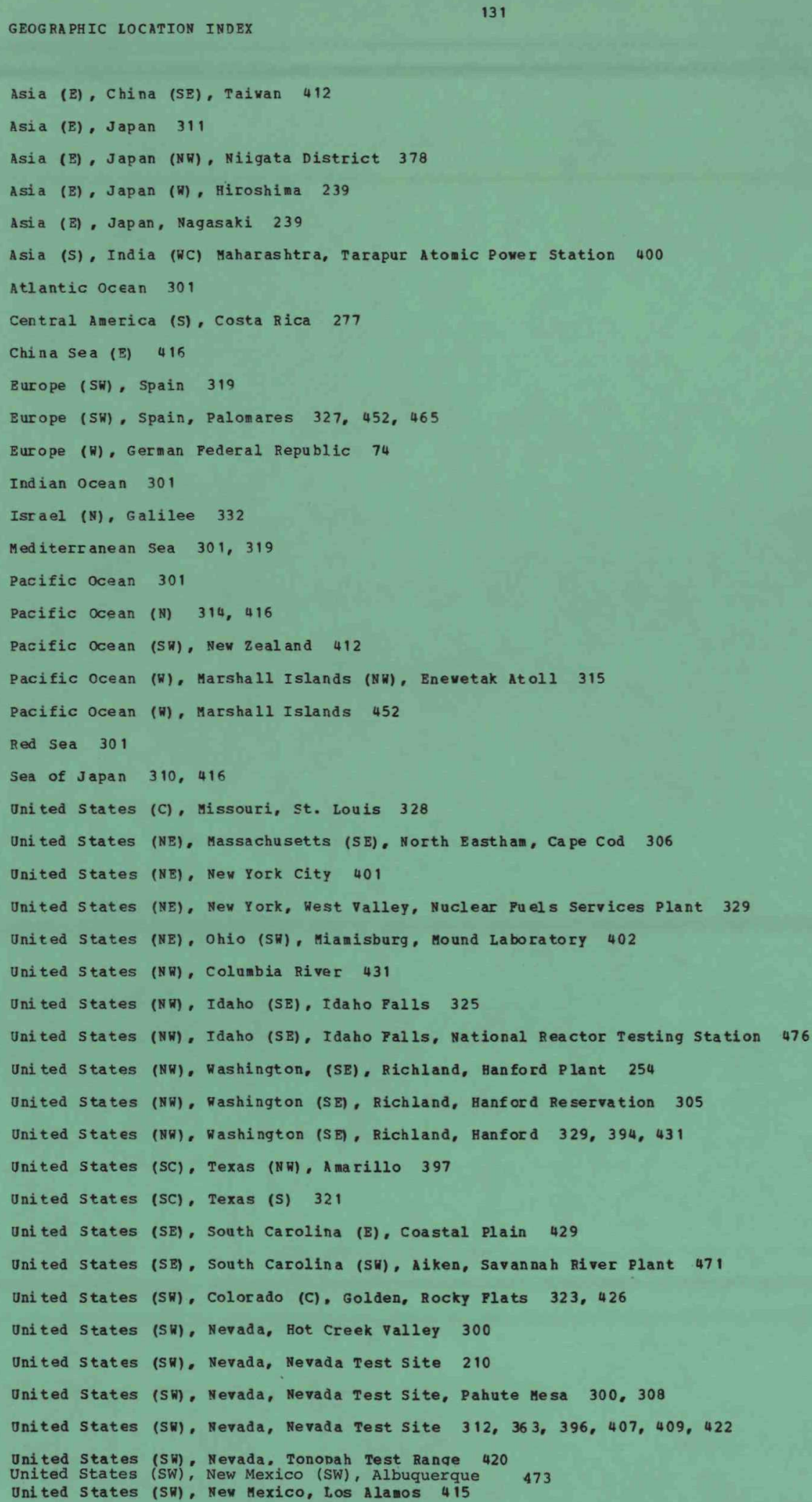




\section{GEOGRAPHIC LOCATION INDEX}

United States (SW), Utah (N), Salt Lake City 452

United States (SW), Utah (SW), St. George 452 
KEY HORD INDBX

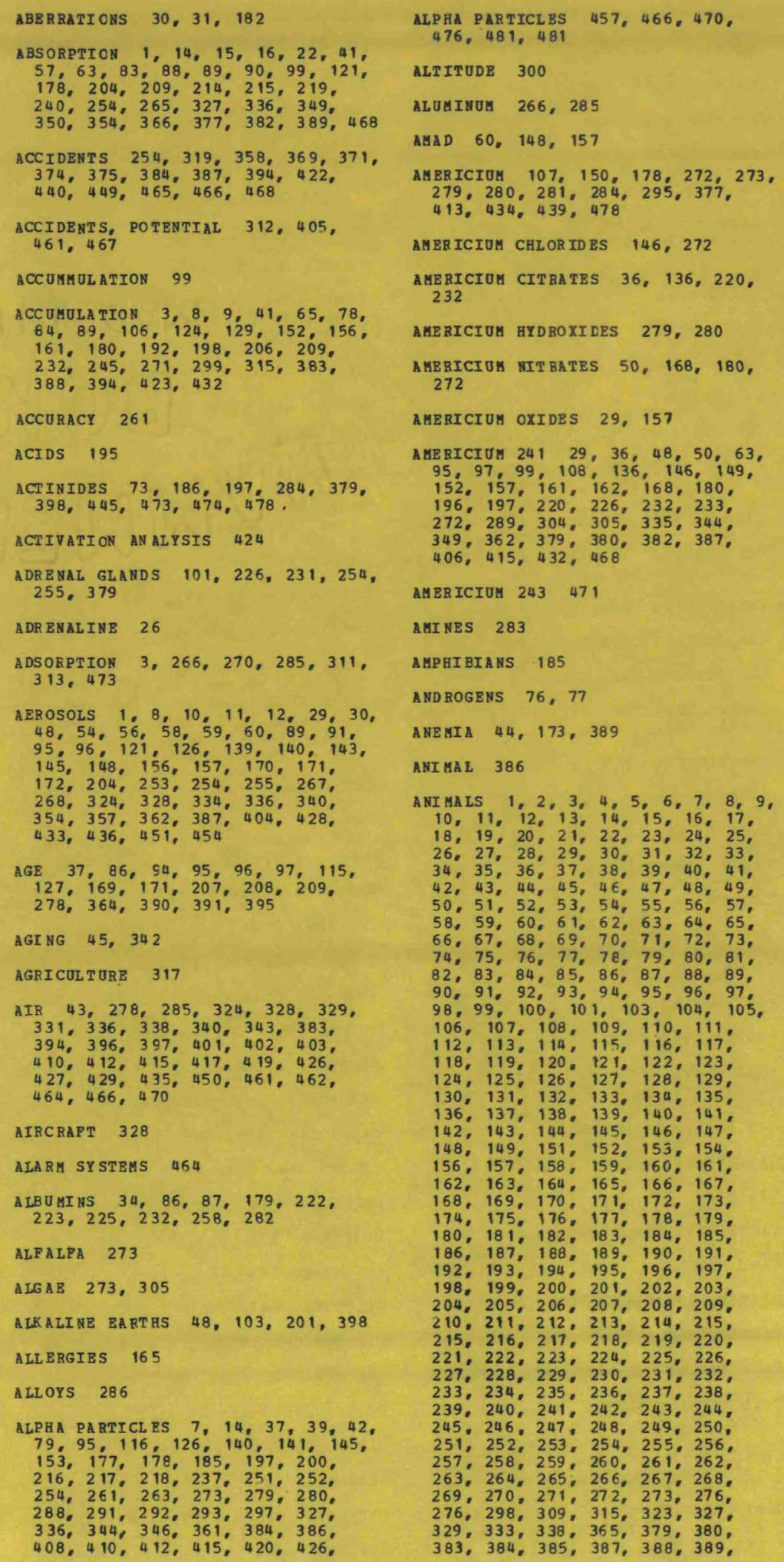

ANI MALS $390,395,451,155$

ANIMALS TISSUES 150

ANTIBODIBS 139

ANTIDOTES 382

APRTICLE SIZB 454

AQUATIC ORGANISMS $320,326,329$, 330

AQUATIC SYSTEAS 273, 429

ARGON 403

ARTHROPODS 323

ASHING 399,424

ASPHALT 296

ATOMS 149

ATROPHY 241 AUTOPSIES $55,138,362,364,376$,

BABOONS 166,186

BACKGROUND 291, 339, 359, 397, $412,424,431,469^{\circ}$

BACTERIA 17,74

BAI. $47,114,201$

BAN BB ERRY EVBNT 396

BARIUM SULFATES 28,252

BAR IUM $14093,94,99,159,160$ 177, 183, 184, 185

BARLEY 273, 274, 277

BEANS 273

BEETLES 124

BERKELIUM 281, 434, 439

BERKELIUM $249 \quad 37 T$

BERYLIIUH 201，210，426

BERYLLIU $7 \quad 314$

BETA PARTICLBS $37,141,149,153$. $155,159,160,177,184,185$. $216,218,237,254,278,287$, $308,386,412,415$

BIBLIOGRAPHY $325,326,386,412$ $439,449,467,475$

BILE 15,73

BIL B DUCT 244, 245

BINDING $33,34,36,49,50,73$, $149,164,220,222,231,282$,

BIOASSAY 465

BICCHEMISTRY 149,234

BIOLOGICAL HALP-LIPE 1, 10,25 , 145, 230, 252, 309, 357, 371. 373,393

BIOLOGICAL MATERIALS 283, 408

BIOLOGICAL STRESS 26

BIOSPHBRE $\quad 313$ 
KEY WORD INDEX

BIOSYNTHESIS 76, 77, 309

BIOTA $278,304,305,315,323,387$

BIRDS 315

BLOOD $10,26,37,53,67,68,69$,

$102,110,116,125,128,133$,

$146,151,153,155,201,210$,

389,405

BLJOD CELLS $37,67,69,151$

BLJOD CELLS, RED 26, 44, 57, 69,

BLJOD CELLS, WHITB $16,26,30,44$,

$57,68,69,102,125,147,1552$,
$155,160,179,195,243,360$

BLOOD PLASA A 34, $110,112,113$, $133,146,163,173,179,222$,

231,389

BLOOD PLATBLETS 69

BLOOD SERUM $35,70,86,87,161$,

BLJOd VeSSELS $3,71,105,160$, 183,358

BODY $43,198,357,362,364,371$, $376,378,383,391,392,406,431$

BODY BUR DEN $4,14,25,52,53,55$,

$60,63,72,84,131,145,170$

$171,172,182,186,243,248$,
$249,253,339,357,362,370$,

$249,253,339,357,362$,
$384,394,423,432,465$

BODY COUNTING 138

BONE PRACTURES $70,103,241,242$, 243

BONE $\triangle A R$ ROH $4,21,23,24,89$,

$109,118,128,129,132,150$,

$188,191,192,218,257,261$,

$263 ; 372$

BONE REMODELLING $4,70,115,229$

BONES $1,3,4,6,13,17,18,19$,

$20,21,23,24,27,28,37,38$,

$41,42,44,47,48,49,50,51$,

$53,55,57,61,63,66,67,68$,

$85,88,89,90,91,94,93,84$,

103, 104, 105, 106, 107, ii1.

$112,113,114,115,116$; 126 ,

$128,129,130 ; 131,132$; 133;,

134 ; 135, 136, 138, 142, 144,

145,$149 ; 150,151,152$; 1 153,

154; 156; 157, 163, 164, 169,

170; 171; 175; 179; 180, 187;,

188 , 189, 191, 192, 193;, 194;,

198, 201, 204, 200, 208, 211 ,

$212,213,214,215,208,211$,

$212,213,214,215,218,223$,

$224,226,227,229,232,234$,

$235,238,241,242,243,249$,

$269,272,283,315,330,342$,

$343,344,349,351,352,356$,

$364,376,378,379,381,383$,

$385,390,412,424$

BRAIN 270,378

BRE MSSTRAHLUNG 109,339

BRONCHI $54,79,170,172,204$, 346,354

BUILDINGS $438,464,476$

BURDEN $2,30,54,95,96,139$,

$140,156,157,268,374,394,430$

134

BURIAL 456, 472, 476, 477

BURNING 444,462

CADIIUI 347

CADMIUM $109 \quad 427$

CALBIRATION 405

CALCIPICATION 8\%, 134

CALCIUM 75, 81, 82, 86, 97, 119, $120,121,127$

CALCIUU DTPA $20,84,142,187$, 213,236

CALCIUM EDTA 236

Calcualtions 345,346

CALCULATION 387

CaLCULATIONS 22, 143, 162, 218, $278,312,321,329,330,331$, $348 ; 359 ; 383 ; 391,397,401$. $405,406,421$

CALGON 1

CAL IBRATION $335,339,340,341$. $349,359,404,448,464$

CAL IFORNIUH 281, 434, 439

CAL IFORNIUM CITRA TES 220

CAL IFORNIUK $249 \quad 220,371$

CALIFORNIUI $25263,109,271,387$, 440,471

CALORIMETRY 249

CAR BOHY DRATES $17,259,260$

CARBON $28,188,299,473$

CARBON DIOXIDE 86

CARBON $14 \quad 77,94$

CARCI NOGENESIS $7,37,39,106$,

$162,191,217,235,254,256$, 346,369

CARCINOGENS $141,250,251,262$

CARCINOGENSIS 21,152

CARCINOMAS $103,153,172,244$. $251,264,269 ; 351$

CARCI NOMAS ADENO 251

CARCI NOMAS, ADENO 235,250

CARRIERS 289

CARTILAGE 131，196

CASE HISTORIES $372,375,393,466$

CATtLE $50,119,451$

CATTLE, DAIRY 210

CELL NUCLEI $33,185,196,226,231$

CELI ULTRASTRUCTURE 33, 200, 201 , 220,226

CELLS, ALVEOLAR 54, 79, 88, 170 , $172,195,204,348,354$

CELLS, BIOLOGIC AL 3, 4, 21, 23, $24,31,33,55,62,64,66,77$,
$79,93,103,106,115,135,163$,
CELLS, BIOLOGICAL 178, 184, 185 ,

$190,196,199,200,217,220$,

$229,244,245,246,250,251$,

CBRAMICS 286

CBRIUA $89,94,154,183,184,185$, 201

CBR IUM CHLORIDES 146

CERIUH CITEATES 213

CERIUH OXIDES 139

CERIU I $144 \quad 27,28,47,49,139$, $141,145,149,165,213,317$, 368,427

CBSIU 382,468

CESIUM CHLORIDES 253

CESIU $135 \quad 478$

CesTum $13725,48,99,121,150$,

$155,165,168,276,285,290$,

$306,315,317,333,355,368$,

$387,412,418,427$

CESIUM 14199

CBSIUM $14499,112,113,146,206$

CHARACTERIZATION 328

CHELATBS $1,5,15,17,18,19,20$, $28,47,48,49,82,84,100,107$, $131,132,133,142,150,187$, $188,189,191,201,202,206$ $212,213,236,238,254,350$

$365,375,394,466$

CHELATION $62,130,156,157,193$. $255,367,382$

CHEMICAL ANALYSIS 134, 192, 290 , $291,295,297,328,362,398,424$

CHEMICAL CaLCIUM 131

CHEIICAL FORM $6,33,34,63,95$, $128,130,182,190,197,201$, $206,208,219,231,253,313,468$

CHEMICAL PROPERTIES $22,32,43$, $201,281,282,286,288,298$, $370,434,439,453,47 \mathrm{~b}$

CHEMICAL TOXICITY 388

CHEMICALS $265,326,429$

CHEMISTRY $338,389,445$

CHEST $344,371,373,377,404,469$

CHICK ENS $159,160,177,185$

CHILDREN $278,329,431$

CHLORIDES 86

CHLOR IN B 287,326

CHROM A TOGRAPHY 77, 222, 284, 424

CHROMIUY 47, 333

Chromosomes $30,31,182$

CIRCULATORY SYSTEM 21, 98

CIRRHOSIS 259

CITRATES 1, 69, 225, 266, 272

CLADDING 447 
KEY HORD INDEX

CLASSI PICATION 353

CLAYS $90,145,285$

CLEAN SLATE 1420

CLEAN SLATE $2 \quad 420$

268

$\begin{array}{ll}\text { CLEAN SLATE } & 2 \\ \text { CLEAN SLATE } & 3 \quad 420\end{array}$ CLEARANCE $8,12,25,30,62,79$,
$126,128,148,194,219,268$,
$348,354,374$

CLIMATE 321

CLINICAL STUDIES 354,373

CLJUDS $312,328,331$

CLOUDS, RADIOACTIVE $277,419,422$

COAGULATION 26

$\mathrm{COAL} 335,369$

СОВ АLT 47

COBALT $57 \quad 2$ $\underset{468}{\operatorname{COBALT}} 60167,315,317,368,403$,

COENZYMES $\quad 77$

COLLAGEN $258,262,358$

COLLOIDS $3,22,84,132,188,266$, $301,313,473$

COMPACTION 472,481

COMPLEXES 33

COMPUTER PROGRAMS $127,300,330$, $331,391,402,429$

CONCENTRATION 60

CONCENTRATION FACTOR $313,315,416$

CONCRETES 438,480

CONDENSATION 324

CONNECTIVE TISSUE 183, 226, 231, 259

CONTAINERS $437,442,457,472$, CONTAINERS 437,
$476,477,479^{\circ}$

CONTAINMENT 320,437, 444, 447, $449,470,479$

CONT AMIN ATION $58,59,63,80,124$, $166,168,239,240,277,278$, 303,$319 ; 320,326,327,331$ $340,361,378,409,413 ; 425$, 438,$440 ; 450,451,452,456$; $458,461,463,464,466,469,472$

CONTENT $9,11,13,19,20,27,36$, $38,47,53,56,61,65,75,79$, $90,91,97,100,113,116,118$ $137,138,142,146,186,187$ $188,191,194,197,204,214$, $220,221,224,228,229,230$, $231,234,238,258,259,261$, $274,278,283,291,296,299$, $304,305,306,310,311,313$, $314,315,321,323,329,332$, $333,337,338,339,344,345$. $356,362,370,371,372,376$ $392,396,399,401,406,408$, $409,416,418,427,431,435$, 448,473
CON TRAST MEDIA 389

CONTROL $448,460,464,470,472$

CORALS 301,416

CORROSION 286,479

CORTISOL 5

CRATERING 422

CRITICAL ORGA NS $170,343,468,469$

CRITICAL PATHAAY 313

CRITICALITY 405, 438, 440, 464, 466

CRITICISM 322, 463

CROPS 327

CRUSTACEANS 313,315 CURIUM $63,281,284,295,434$,
439,478

CURIUM $24295,233,317$

CUR IUH 24495,317

CrTOSOL 220

DATING 301

DCTA 19

DDSTA 100

DEBRIS 312,369

DECAY 321

DECAY PRODUCTS 392

DBCONTAKINATION $15,18,19,20$, $28,49,58,63,85,100,107$ $121,130,157,174,190,193$ $202,212,255,265,295,296$ $327,328,333,350,367,370$ $382,410,451,452,454,456$. $459,465,473 ; 481$

DENSITY $33,288,335$

DEPOSITION $1,3,7,9,10,11,12$, $13,24,28,33,36,37,42,47$, $77,88,94,100,103,110,111$, $112,132,133,134,140,142$, $148,152,160 ; 164,183,187$, 197, 201, 204, 212, 215, 219, $221 ; 226,227,229,230 ; 243$; $246 ; 250,251,263,266,267$, $277,278,301 ; 310,348,354$; $358 ; 362,365 ; 366,370 ; 414$, $419,420,420,421,435,466^{\circ}$

DEPTH 310

DESBRTS 334

DES IGN $2,335,377,437,438,440$, $446,447,454,456,457,474$, 476,479

DETRCTION 461

DETBRGBNTS 240,456

DIAGNOSIS 366

DIBT $97,141,400,431$

DIPPUSION 263, 307, 402,419,481

DISEASES $37,44,54,79,96,100$,
DISEASBS $158,167,170,172,173$, $210,224,243,259,269,276,390$
$352,353,365,369,388,389,390$ 352, 353, 365, 369, 308, 389 DISPERSIOH

DISTRIBUTION $1,4,6,31,33,34$, $41,42,43,48,55,60,63,65$, $67,70,71,73,79,83,85,88$ $89,91,92,94,99,106,111$, $114,123,126,128,129,131$ $132,134,142,149,150,161$, $164,168,170,171,179,180$, 182,$185 ; 198,207,211,214$, $217,218,219 ; 220,222,223$ 226 ; 229 ; $235,238,242,252$. $253,254,254,255,258,263$. $266,267,269,271,272,274$, $302,306,314,315,324,333$, $353,356,357,362,364,372$ $376,383,387,389,406,409$. $412,413,436$

DIVERSITY 308

DNA 37,118

DNAase $\quad 117$

DOGS $5,7,10,12,26,29,32,33$, $51,56,86,87,98,109,143$, $152,169,175,197,198,203$,
$234,253,256,268,383,395$

DOGS, BEAGLE $4,6,8,9,11,25$, $34,35,36,45,52,54,55,60$. $77,95,103,104,105,106,107$, $115,128,130,131,136,137$, $140,144,145,148,156,157$, $161,162,167,170,171,172$, $173,181,186,217,220,221$, $222,223,224,225,226,227$, $228,229,230,231,232,233$, $241,242,243,244,245,246$ 。 $247,248,255,261,267,380$ $384,385,249$

DONKEYS 268

DOSB RATE $4,24,41,48,98,109$, $123,175,239,261,278,329$,

DOSE RATES 67

DOSIM BTERS $341,359,405,415,448$

DOSIMETERS, BIOLOGICAL 341

DOUBLE TRACK 420,268

DRAINAGE 429

DRUGS 28,201

DTPA $5,13,15,17,19,28,47$, $48,49,62,82,107,127,130$, $131,132,133,142,156,157$, $189,191,193,194,201,212$, 238 ; $254,255,284,350,365$ 。 $366,367,382$

DUST $14,268,285,327,334,335$, $340,368,369,373,383,421,426$

DYBS 94

EARS 21 BCONOMICS $369,437,462,477,478$,
480,481

BCOSYSTEA ANALYSIS $329,429,449$

BDTA $19,47,48,49,81,82,133$, 
KEY WORD INDBX

BEDTA 19

BPF ICIENCY $15,18,336,338,410$,

BPF LUENTS $313,322,326,333,429$, 431

BIN STEIN IUM 281, 439

BINSTEINIUM NITRATES 214

EIN STBINIUM $253 \quad 214$

BJECTA 480

BLECTR $O C$ ARDIOGRAPHY 248

BLECTRODEPOSI TION 273, 287, 291, $292,293,295,399,424$

ELECTRON MICR OSCOPY $62,169,200$, 285,433

ELECTROPHORESIS $35,50,70,87$, 222,294

BLIM INAT ION 1,120

BMBEDDING 296

EMBRYOS 65

EMERGENCIES 28,464

BMULSIONS 292, 293

ENDOCR INE GLA NDS $21,77,122,153$, 235

ENG INBER ING $464,467,474$

ENR ICHMBNT 401,445

ENV IRON A ENT $121,239,273,303$, $320,325,326,329,330,333$, $338,341,364,378,387,397$. $400,410,412,424,425,426$. $429,431,440,449,466,474$

ENZ YMES $23,75,82,117,118,161$, 193, 195, 224, 225

BQUATIONS $22,24,41,127,144$, $175,201,227,229,230,263$, $277,300,312,329,355,357$ $371,373,402,436,443,462$,
469,481

BQUATIONS, DERIVED 104

EQUIPMENT 476

EROSION 331

BRRORS 253, 312, 359, 428

EUROPIUM 459

EVALUATION $28,61,69,133,138$, $166,206,213,261,291,292$, $293,298,318,322,336,341$ $365,375,392,403,409,411$, $429,448,455,467,469,469$ $474,478,480$

BVA PORATION 307

BXC RETION $5,8,12,13,15,20$, $25,28,47,48,53,56,61,73$ $84,89,90,100,112,113,114$ $121,126,128,132,133,134$, $150,156,157,171,188,193$. $198,201,203,204,206,210$, $211,212,214,215,219,253$ 。 $255,266,267,271,283,344$, $345,350,355,356,357,365$

$366,367,368,370,371,372$,

$373 ; 374,382,392,393 ; 399$.

136

BXCRETION $423,424,465,466,469$ EXPERIMENTAL ST UDIES $318,377,440$ EXPLOSIONS, MON-NUCLEAR 335, 369, 444

EXPLOSIONS, NUCLEAR $239,303,308$, 312

EXPLOSIONS, NUCLEAR, ATMOSPHERIC 268,422

EXPLOSIONS, NUCLBAR, CHINESB 422 , 431

EXPLOSIONS, NUCLEAR, UNDERGROUND $268,419,422$

EXPOSURE, ACUTE $54,68,100,135$, 357 EXPOSURE, CHRONIC $45,85,98,302$,
343,357

EXPOSURE， EXTERNAL 353

EXPOSURE, INTERNAL 370,468

BXPOSURE, OCCUPATIONAL 59, 287 , $395,344,345,347,355,356$, $376,380,393,438,448,451$, $453,460,463$

BXPOSURB, PER SONN EL 387

BXPOSURE, POPULATION $58,322,351$, $387,391,396,397,452,458,463$ EXPOSURE, SUBACUTE 135 EXPOSURE， EXTERNAL 390 EXPOSURE, INTERNA L 390

EXTRACTION METHODS $279,280,283$, $284,289,291,295,424$

EXES 21,446

FABRICATION, FUEL RLEMENT 445

FRLLOUT $186,277,303,306,311$ $313,378,400,412,418,420$, $431,451,452$

PASTING 83

PATTY ACIDS 188

FEC ES $5,10,12,13,16,20,25$ $47,61,73,90,91,100,114$. $126,134,198,203,210,211$, $212,214,215,253,255,266$,

$267,344,357,368,371,372$,

$373 ; 374 ; 392 ; 393 ; 394 ; 423$

PEDERAL LEVEL 454

PERIIUM 281, 439

PERRITIN 33, 35, 36, 220, 232

PETUSES 45,81

PIDLER 413

PIBLD STUDIES 210, 306, 307, 308, $328,416,418$

FILIS 361

FIL TERS 29, 328, 336, 340, 394, 450,466

PILTBRS, BEPA $403,410,454,46$

PINGERS 359
FIRE 327

PIRES $384,437,438,444,450$, 455,464

FISH $119,121,273,276,290,313$ $326,333,431$

FISSION PRODUCTS $27,64,88,89$, $91,94,99,123,159,160,177$ $184,185,204,270,285,296$, $314 ; 366,449,453,478$

FISSION TRACK ANALYSIS 285, 411 POOD $278,303,313,329,330,378$, FOOD CHAINS 326,451

FORESTS 124

PRACTIONATION 151, 154, 258, 332 PRESHWATER SYSTEMS 304, 305, 329 FRUIT PLIES 239

PUEL CYCLE $441,445,474$

FUEL ELEMENTS $215,286,316,448$

FUBLS, FOSSIL 322, 369

PUNGI 17

GASES $441,462,481$

GASTROINTESTINAL TRACT $1,10,14$, $16,21,27,28,41,57,83,89$ 。 $121,126,153,177,204,207$, $215 ; 235,237,330,366$

GAVAGE $14,15,64,83,177,237$, GENBTICS 21,239

GBOCHEMISTRY $\quad 321$

GEOLOGIC STRUCTURBS 474

GEOLOGY 332, 429

GILS 121

GLOBULINS $34,86,87,179,223$, 225

GLOVE BOXES $446,450,455,456$, $459,461,462,466$

GLUCAN $17,130,131,188,190,194$

GLUCOSB 121

GOATS 121

GOLD 389

GOLDFISH 304,305

GONADS 186,378

GOPHERS 323

GRASSES $\quad 418$

GRAVITY 307

GROUN DWATER $300 ， 321,332 ， 429$, 479

GROWTH $94,176,390$

GUINEA PIGS $42,56,64,93,159$, $160,177,185,216$

HA IR 277,405 
KEY HORD INDEX

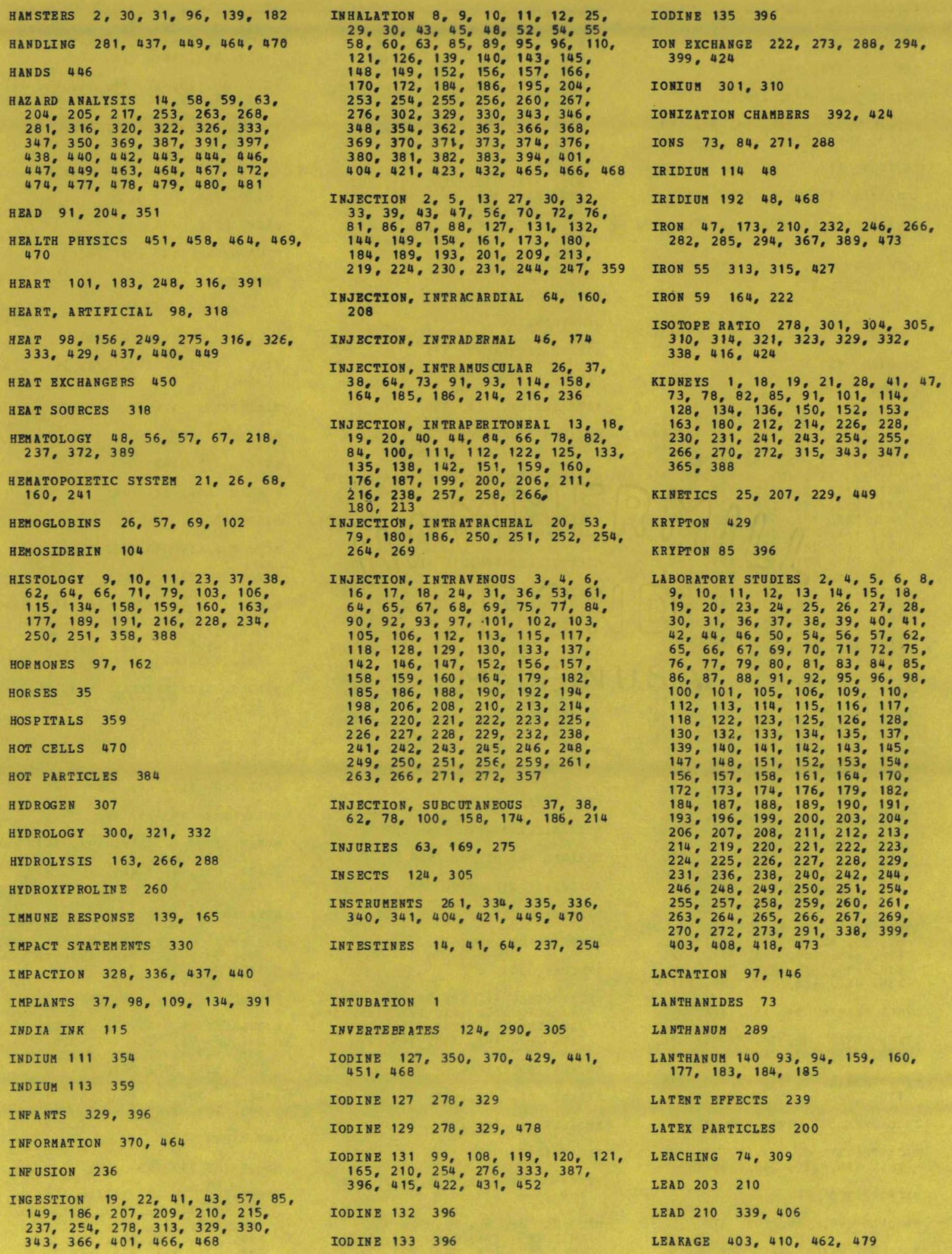


KEY WORD INDEX

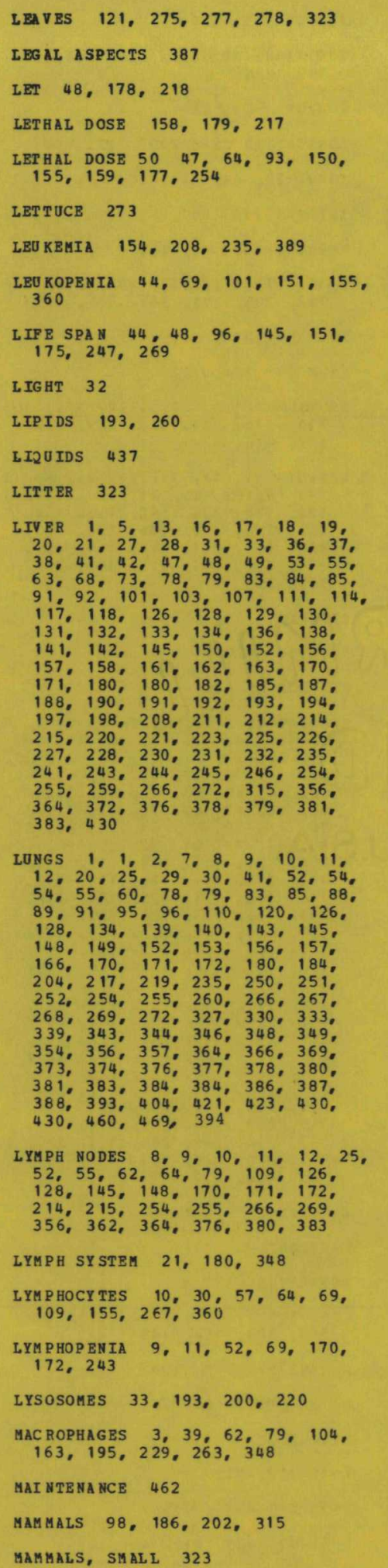

MAMHARY GLANDS 37,235 $\operatorname{MAN} 21,43,45,48,51,56,61,6$ $205,239,277,278,287,292$. $293,294,295,297,327,329$, $393,294,295,297,327,329$, $333,337,339,341,342,343$, $345,346,347,348,349,350$, $351,352,353,355,355,356$ $357,358,359,359,360,361$, $362,364,365,366,368,369$, $370,371,372,373,374,375$. $376,377,378,379,381,382$, $383,384,385,386,387,388$, $389,390,391,392,393,394$ $395,399,404,405,406,411$, $412,423,429,430,431,442$. $446,448,449,451,460,464$, $464 ; 465,466 ; 468,469 ; 470 ; 472$

MANGANESE $47,82,266$

MANGANESE $54 \quad 427$

MARINE ORGANISHS 313

MAR INE SYSTEMS 329,416

МатнвHATICS 175,355

MAX IMUM PERMISS IB LE BODY BURDEN

MAX IMUM PERHISSIBLE CONCENTRATION $43,48,343,347,383,400$

MAXI MUM PEEMISSIBIE DOSE 239, 278, $287,355,365,394,460$

MAXIMUM PERMISSIBLE VALUE 175

MEA SUREMENT $15,19,20,24,27$, $36,56,75,79,90,100,116$, $118,137,138,186,197,198$, $204,221,224,229,234,258$, $261,274,283,287,291,292$. $293,297,306,311,314,321$, $327,329,332,333,334,335$, $337,338,339 ; 345,349 ; 356$; $357,359,368,37 \mathrm{c}, 373,374$. 377,$399 ; 401 ; 404,405 ; 406$, $407,408,410,416,418,424$. $429,434,462,468,469 ; 387$

MEAT 329,409

MECHANICAL PROP ERTIES 407

MEDICAL MANAGBMENT 466

MEDICINE $317,319,387$

MEMBRANES $33,65,226,231,481$

MENDELEVIUM 439

MERCURY 201, 210

HET ABOLISM $16,53,59,63,88,92$, $99,101,120,121,127,163,164$ $202,209,210,249,258,259$,

METALLURGY 464

METALS $65,382,481$

MET APLASIA 54,170

METASTABLES 359

MET BOROLOGY 312, 334, 422, 429, 449

METHODS 29, $56,74,90,132,138$, $143,195,198,234,261,283$,
$284,287,289,290,291,292$,
MBTHODS $293,295,297,310,335$. $337,338,341,350,361,370$, $404 ; 405,408,409 ; 417,429$ $459,462,468,469,476$

IICE $17,23,37,38,39,48,49$, $51,56,57,58,64,78,84,93$ $103,121,128,129,131,132$, $139,142,158,159,160,175$. $177,179,184,185,186,187$, $188,189,190,191,192,193$. 194, 197, 202, 216, 233, 239, $250,251,252,254,256,264$, 270,388

MICR, DEER 323

UICROORGANISMS 119,340

MICRO SOMES 226

MICROSPHERES 275

MIL ITARY OPERATIONS 319

MILK $26,146,210,276,278,329$, $396,412,422,452$

MILII PEDES 124

MINBRALS 285

MINES 335,340

M IN IN G 369, 387, 445

MITES 308

MITOC HONDRIA 33, 220,226, 231

MITOSIS 185,257

MODELS $7,25,127,178,219,229$. $300,312,331,343,344,357$, $366,370,374,381,385,402$, $413,419,421,423,435,436$, $442,443,480,394,387$

MODELS, MATHEMATICAI. 104, 302 , 307,330

MOLLUSKS $121,124,301,305$

MOLYBDENUM 9999,468

MONITORING $46,387,393,397,400$, $402,405,410,415,422,425$, $429,430,431,449,458,464$, $469,470,479$

MONKEYS 30,126

MONOK ERS $6,22,33,42,128,129$, $130,131,132,182,191,192$.

MORPHOLOGY 79, 135, 285

MORTALITY 9, 11, 13, 37, 52, 54, $65,82,96,100,122,125,151$, $155,167,170,189,203,208$. 217 , 237, 243, 267, 369

MUSCLES 27, 38, 150, 254, 305. MUTATIONS 239 NEODYMIUM $147 \quad 99$

NEOPL ASMS $7,10,38,39,52,54$, $55,67,71,72,123,131,145$, $149,162,170,184,187,189$, $191,201,208,242,243,249$, 
KEYWORD INDBX

\section{NEOPLASMS 384,390}

NEOPLASMS, BENIGN 153, 241，244, 245,269

NEOPLASMS, MALIGNANT 37, 51,68 , $94,103,122,132,141,152,153$ $154,172,175,188,223,235$,

$241,244,245,250$,
$269,333,346,389$

NEPTUNIUM $89,281,284,295,434$, 478

NEPTUNIUH CIT RATES 14

NEPTUNIUM NITRATES $146,152,440$, 457

N EP T UN IU M $237 \quad 14,63,146,149$ 152, 276, 387, 405, 457

NEPTUNIUM $239 \quad 233$

NER VOUS SYSTEM $21,149,231$

NEUTRON ACTIVATION 313

NEUTRONS $64,149,159,160,177$,

$183,184,185,216,411,93$

NIOBIUM 89

NIOBIUM OXALATES 253

NIOBIUM $9364,93,94,159,160$, $77,183,184$

NIT RATBS

NITRIC ACID 269

NITROGEN $75,86,462$

NON PROTEIN NITROGEN 16

NOSE 21,394

NUCLEAR FACILITIES 322, 364, 370 ,

$400,410,425,449,453,456$.
464,467

NUCLEAR POWER $317,320,400,434$

NUCL EIC ACIDS 118

NUCL EOSIDES 259

NUCL EOTIDES 259

NUT R IT ION 308

OATS 277,296

OCE ANS $285,301,314,416$

OPERATION PLUMBBOB 302,363

OPERATION ROLLER COASTER 268,420

ORES 74

ORG ANIC COMFOUNDS $17,111,255$ 284,296

ORG ANS $19,27,41,49,78,89$,

$116,118,129,134,143,152$;

$156,182,197,226,266,267$,

$272 ; 330 ; 333 ; 355,370,378$;

$383,388,406,442$

OVARIES $39,235 ， 254$

OXIDATION 32,321

OXIDES 285

OXYGEN $101,110,249,301,462$
PAC EMI AK BR S $316,391,447$

PACKAGING 440

PAINTS 327,456

PAL BONTOLOGY 332

PALLADrUM $103 \quad 404$

PANCREAS $185,266,315$

PARATHYROIDS 97,196

PARTICLE SIZE $6,9,11,29,31$ $48,55,60,95,129,140,148$ $157,199,200,204,207,217$, $250,251,253,264,266,268$, $277,324,331,336,340,344$, $348,354,362,366,384,394$, $398,409,414,421,423,428$. 433,436

PARTICLES $29,39,52,55,62,95$, $145,182,195,200,217,250$, $252,277,285,296,30 \%, 307$, $313,328,331,334,340,348$, $384,421,428,436$

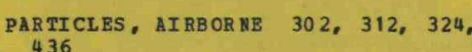

PATHOLOGY 9, $10,11,41,46,52$, $55,56,62,70 ; 71,79 ; 82,115$, $125,131,147,152,153,161$, $172,177,216,234,245,250$. 353,390

PER IODIC TABLE 73

PER ITON EAL CA VITY 211， 236

P ER ITON BUM $199 ， 200$

PERSONNEL $56,287,295,297,339$, $341,347,355,356,359,360$,

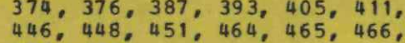
470,472

$\mathrm{pH} 22,50,73,473$

P HA GOCYTOSIS $31,160,188,199$, 200,348

PHANTOM, TISSUE 377

PHANTOMS $344,349,391,404,406$, 430

PHOPHORUS $32 \quad 121$

PHOSPHATASE 195

Pho SP hata SES $23,75,86,162,223$, 224,225

PHOSPHATES $28,29,161,206,399$, 473

PHOSPHOLIPIDS 16,260

PHOSPHORUS $56,75,86,118$

PHOSPHORUS $3216,93,94,159$, $160,177,184,185,259,355$, $405,431,468$

PHYSICAL FORH $6,33,84,128,131$, $206,208,231,253,313,46$

PHYSICAL PROPERTIES 22, 43, 49 , $65,132,150,165,281,286,288$,

PHYSIOLOGY 21, 150, 390

PIGEONS 94
PIGHBNTS 232,246

PITUITARY 153, 231

PLACENTAS 65,209

PLANKTON 313,326

PLANT-SOIL INTERACTION 400

PLANTS $90,119,120,121,273$, $274,276,277,278,290,296$, $305,308,309,315,323,327$,

329 ; 333 ; 338, 397, 424, 426

PLANTS, INDUSTRIAL 441

PLOWI NG 327

PLOWSHARE 303

PLUTONIUM $1,4,7,10,13,16,17$, $23,34,57,58,59,61,64,81$, $89,91,92,93,94,107,111$, $119,120,127,131,132,159$, 185, 183, 187, 173, 177, 184, 193. 194, 187, 180, 190, 191, 193, 194, 198, 201, 202, 203, $205,216,217,233,260,265$, $268,279,280,281,283,284$, $286,288,292,293,295,302$, $319,326,327,333,336,350$, $356,357,366,376,377,381$, $384,394,397,398,399,410$, $413,414,423,426,429,434$, $437,438,441,444,445,448$, $452,454,456,459,461,462$, $463,464,466,470,476,478,481$

PLUTONIUM ACBTATES 79

PLUTONIUM CARBONATES $7,20,110$, 260

PLUTONIUA CHLORIDES 114,156

FLUTONIUM CITRATES $3,4,6,7,15$ $18,22,30,31,33,41,44,53$, $66,83,102,106,115,128,131$ $136,143,151,176,179,183$, $186,189,213,219,220,222$, 229 ; 231; 232, 258; 372

PLUTONIUM FLUORIDES 288

PLUTONIUM HYDROXIDE 132

PLUTONIUM HYDROXIDES 251,264 , 279,280

Plutonidu nitbates $7,19,20,22$. $24,26,40,46,50,53,56,57$, $75,79,101,102,116,117,118$ $122,125,143,146,158,168$, $174,179,183,186,198,204$, $219,236,237,240,254,259$, $263,265,269,274,383,394$, $423,440,442,473$

PLUTONIOH OXALATES 219

PLOTONIOH OXIDES $2,7,8,9,10$, $11,12,30,31,48,52,54,55$. $60,62,73,89,90,91,95,96$, $148,166,170,171,172,182$, 195, 199, 200, 204, 207, 215。 $217,219,240,250,251,252$, $253,254,255,264,267,273$; $275,288,302,318,331,348$ $275,288,302,318,331,348$, $358,362,374,381,383,394$,

PLUTONIUH $236 \quad 364$

PLUTONIU⿴ 237138,211

PLUTONIUM $238 \quad 2,31,43,65,90$, $95,98,109,140,141,148,164$. 
KEX WORD INDEX

PLUTONIUM $238 \quad 171,213,215,217$. $236,273,275,288,290,303$ 。 $304,305,314,317,318,323$, $331 ; 370,391 ; 415,416,417$,
$427,447,471,473$

PLUTONIUM $2392,3,5,6,8,9$, $11,12,15,18,19,20,21,24$ $30,31,32,33,35,37,38,39$, $40,41,42,43,44,46,47,48$ $49,50,52,53,54,55,60,63$, $65,66,67,68,69,70,71,72$ $75,76,77,78,79,80,84,86$ $87,95,96 ; 97,99 ; 103,104$, $105,106,110,112,113,114$, $115,116,121,122,125,126$. $130,131,133,135,136,137$, $138,139,142,143,144,145$, $146,147,149,150,151,152$, $153,154,156,161,162,163$, $164,165,168,169,170,171$, 172, 175, 176, 180, 182, 189, $192,197,199,200,206,208$, $209,211,212,217,218,219$ 。 $220,221,222,223,225,227$, $228,229,230,231,232,233$, $234,237,238,241,242,243$ 。 $245,246,247,248,249,250$, $251,252,254,255,256,257$, $259,261,263,265,267,269$, $274 ;, 276 ;, 282 ; 286,267 ; 269$; $291,294,304,205,306,290$, $291,291,304,305,306,311$, 313,34, $355,342,344,345,349,351$, $355,361,362,364,365,367$, $368,370,372,375,378,379$, $380,382,383,384,385,387$, $389,394,395,402,404,406$ $409,412,415,416,418,424$, $427,430,432,433,440,465$, 468,471

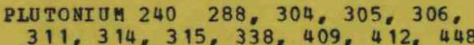
PLUTONIUM $241287,288,408$

PLUTONIUM $242288,290,338,364$, 471

PLUTONIUM, METALLIC 134, 286, 288 , 358

PLUTONYL ACETATES 269, 7

PLUTONYL NITRATES 89

PNEUMOSCL,EROS IS $152,153,180$, 252, 269

POLONIUM 48, 201, 295 POL ONIUM $21028,47,99,149,153$,
$287,303,317,348,355,370,468$

POLYMERS $6,17,22,33,38,42$,

$128,129,131,142,187,188$,

$190,191,192,197,231,255$,

272,288

POPULATICN 391,400

POPULATION DENSITY 124

PORHYRINS 203

POTASSIUM 121,285

POTASSIU⿴囗十 $40 \quad 315$

PON ER PLANTS, NOCLEAR 320, 325, $326,387,412,441,458$

POWER SOURCES $98,109,447$

PRASEODYMIUM $94,184,185$

140

PRASEODYMIUM CHLORIDES 146

PRASEODYHIUM $143 \quad 99$

PRASBODYYIUA 144 141, 146

PRECIPITATION 277, 285, 307, 309, $328,396,399$

PRECIPITATION, CHEMICAL 32, 289, $291,297,424,473$

PRECIPITATION, CHEHICALS 284

PREDICTIONS 178, 307, 312, 331, $419,429,441,465,474$

PREGNANCY 65,97

PREPARATION 29,318

PRESSURE 300,461

PRIMATES $30,98,126,166,186$

PROCESSING PLANTS 446

PRJCESSING PLANTS, NUCLEAR 444 , 456,469

PRODUCTIVITY 448

PROGENY 149,181

PROGESTERONE 77

PROJBCT RULISON 396

PROJECT 57302,363

PROMETHIUM $147150,317,387$

PROPORTIONAL COUNTERS 349,406 , 424,430

\section{PROSEODYNIUM 183}

PROTACTINIUA $204,284,295,301$,

PROTACTINIUM 231416

PROTACTINIUM $233 \quad 149,457$

PROTBCTIVE COVERING 405, 437, 466

PROTEINS $33,34,35,70,73,86$ $87,149,163,164,222,225,231$ $258,270,294,38 \varepsilon$

PROTEINS, GLYCO 50,262

PULSE HEIGHT ANALYZERS 290, 410, 424

RABBITS $24,56,58,64,75,93$ 116, 117, 118, 134, 153, 159. 165,$169 ; 177,184,185,186$; $195,216,218,240,259,260$, $262,263,385$

RADIAITON EPFECTS 247

RADIATION DETECTORS $137,290,291$, 292, $295,297,337,339,341$, $359,361,364,392,393,404,476$
$406,408,432,434,464,469,476$

RADIATION DOSE 2, 4, 7, 14, 30, $31,41,44,46,48,64,69,72,96$ $15,85,93,94,95,96,103,10$ $106,115,123,126,131,140$, $144,145,149,150,151,152$, $153,154,158,159,161,166$, $168,170,177,178,179,185$, $203,208,216,217,218,221$, $223,225,227,228,229,230$, 252 ; 254, 263; 269, 270; 278;
RADIATION DOSE 297, 329, 330, 344, $345,346,348,353,355,358$, $359,387,391,393,396,397,468$

RADIATION DOSIMETRY $217,218,341$, $344,387,390,391,405,411$

RADIATION EPEECTS $4,10,21,31$, $37,43,44,46,54,56,57,58$, $83,64,66,67,69,77,78,83,93,93,94,95,98,100,101$, $102,103,105,106,108,109$, $115,121,124,134,135,141$, $145,147,150,151,153,155$, $159,160,161,165,170,176$, 177, 178, 183, 184, 185, 196, $216,223,225,229,237,239$, $239,243,244,248,249,250$, $251,254,257,259,260,264$, $267,269,270,286,308,333$, $346,360,369,384,386,387$, $388,389,390,434$

RADIATION EFFECTS, ACUTE 151, 203 , 271,353

RADIATION EPRECTS, CHRONIC 26, $271,353,358$

RADIATION EFPBCTS, LATENT 70,110 $132,149,152,208,243,246,254$

RADIATION EFRECTS, SUBACUTE 151 , 271,353

RADIATION PROTECTION 341,347, $392,426,434,451,452,458$, $463,466,476$

RADIATION SICKNESS 151, 353

RADIATION, COSMIC 434

RADIATION, DOSIMETRY 470

RADIATION, GAMMA $26,56,93,108$, $137,149,155,159,160,167$, $177,183,216,218,278,288$, $290,308,335,339,344,377$, $386,393,396$,
$432,457,470$

RADIATION, GaMMa RADIUM 185

RADIATTON, LOW LEVEL 243, 322, 329 RADIATION, LOW-LEVEL 346

RADIATION, NEUTRON $153,178,218$, 386,448

RADIATION, NEUTRON, FAST 178

RADIATION, PHOTON 339, 377, 448

RADIATION, PROTON 153, 411

RADIATION, $x \quad 23,37,56,64,83$, $94,120,153,159,160,177,178$ $184,185,189,203,218,237$. $254,339,344,349,377,386$, $404,432,288,93$

RADIOACTIVITY $73,312,315,322$. $328,373,396,412,419,458$ RADIOACTIVITY, NATURAL 387,434

RADIOADTOGRAPHY $3,4,6,31,33$, $38,58,59,62,65,70,78,81$. $89,90,91,93,104,129,131$, $136,159,160,179,180,183$, 185, 187, 192, 194, 197, 200, 204,$208 ; 231,242$, 246, 261; 


\section{KEYWORD INDEX}

RADIOAUTOGRAP HY 262, 263, 292 , $293,358,361,362,380,398,409$

RADIOBIOLOGY 298

RADIOCHBMISTRY $62,261,285,290$,
$291,298,405,424$

RADIOECOLOGY 387

RAD IOGRAPHY 106, 342

RADIONOCLIDE RATIO $301,304,305$, 310,418

RADIONUCIIDES $21,23,48,49,71$. $73,76,99,99,103,127,127$, $132,133,150,165,210,235$, $249,290,303,313,315,317$,

$319,330,333,350,364,369$,

$378,382,387,389,392,400$.

$402,416,417,419,425,427,473$

RADIOPHA RMACE UTICALS 354, 468

RADIOSENSITIVITY $93,183,185$, $200,216,341$

RADIOTHERAPY 21

BADIOTHERAPY EXERCISE 360

RADISHES 273

RADIUM 4, 64, 89,93,94, 159 . $160,173,177,179,183,184$,

RADIUM CHLORIDES 4

RADIUM CITRATES 115

RADIUM $22621,23,51,67,69,70$, $71,72,76,77,86,87,103,105$, $115,121,147,165,223,225$, $233,234,242,247,248,249$, $256,276,355,392,395$

RADIUM $228 \quad 21,70,71,72,76,77$, $103,105,223,225,234,242$, 247,248

RADON DA UGHTERS 336

RARE EARTHS $48,149,201$

RaTS $1,2,3,13,14,15,16,18$, $19,20,22,27,28,37,38,39$, $40,41,44,47,49,56,57,58$, $59,61,64,65,66,73,78,79$, $81,82,83,85,88,89,90,91$, $93,94,97,100,101,102,108$ $110,111,112,113,114,119$ $121,122,123,125,127,133$, $134,135,138,141,150,151$ $152,153,154,159,160,163$, $164,165,166,175,176,177$ $179,180,183,184,185,186$ $196,199,200,202,204,206$ $207,208,209,211,212,213$, $214,216,219,236,237,238$, $253,254,257,258,265,266$, $269,272,365,379,384,385$, 155

REACTORS $303,313,317,320,400$,
$422,431,434,441,445,453,467$ ERCOMMENDATIONS 448

RECOVERY 57, 178，270，353

REDISTRIBUTION 106, 331, 435

RBGENERATION 246

REGULATIONS, PEDERAL LEVEL 440 ,

141

REG ULATIONS, PEDERAL LEVEL 468 REGULATIONS, IN TERNATIONAL LBVEL

REG ULATIONS, STATE IEVEL 440

REL ATIVE BIOLOGICAL EFPECTIVENESS $155,178,218$

REPROCESSING 445,481

REPROCESSING PLANTS, NUCLBAR 429 。 478

REPRODUCTION 124,210

REPRODUCTIVE SYSTEM 21

RESINS 222，255，296

RES OR PTION $3,4,27,227$

RESPIRATION 9, 101, 249, 267, 340, 392

RESPIRATORY SYSTE M $10,21,52$, $126,148,219,251,348,421$

RESUSPENSICN $334,426,435,436$ 414

RETENTION $1,5,6,8,12,13,17$, $25,30,37,41,47,48,49,53$, $55,61,69,78,79,85,88,89$, $96,97,104,121,126,130,132$ $134,141,142,143,144,145$,
$163,171,174,182,186,187$, $188,189,191,197,198,204$ $207,210,211,213,214,219$ $220,227,228,229,230,231$ $238,277,343,348,357,362$ $371,373,379,479$

RETICULODENDOTH EL IAI SYSTBM 150

RET ICULOENDOTHELI AL SYSTEM 3,33 , $163,180,182,188,190,194,245$

REVIEH $7,21,43,48,63,73,103$, $205,218,235,239,281,298$, $301,322,348,350,355,389$, $390,392,424,425,481$

RHODIUM 207

RICKETS 81

RIVERS 301, 311, 473

RNA 118

RNAase 118

ROCKS 335,398

RODENTS 29

RooTs $274,278,323,418$

RUBIDIOM 210

RUBIDIU: $86 \quad 121$ RUTHENIUM CXIDES $250,251,252$,
$254,264,433$

RUTHENIUM $10648,119,120,121$ $207,250,251,252,254,264$, $313 ; 433$

SAP BG UARDS $335,369,438,440$, $444,449,464,465,467$

SALIVARI GLANDS 21, 101

SALT REPOSITORTES 474

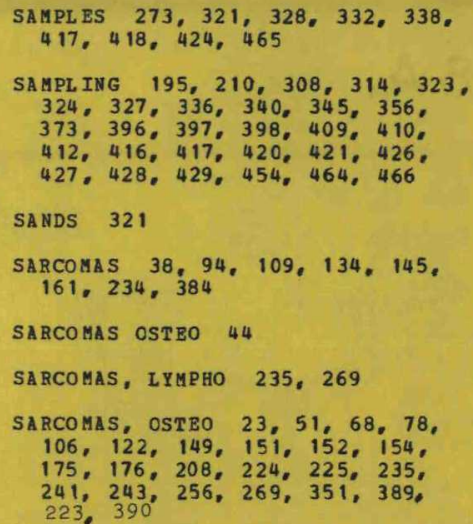

SATELLITES 317

SCANNING 389

SCINTILLATION $62,335,336,339$ $392,399,401,408,424,432$

SEAS 299,412

SEASONS 124,307

SEAWATER $301,313,400,416$

SEANEEDS 313

SEDIMENTS $285,290,299,301,304$ $305,310,313,330,398,412,426$

SEPARATION PROCESSES $29,34,35$, $36,77,222,258,273,279,280$, $289,290,291,294,295,336$ 。 $399,424,474,478,481$

SEX $97,162,186,208,221,391$

SHAPE $\quad 428$

SHEEP 119, 121, 146, 254, 268, 276

SHIELDING $98,438,440,446,448$,

SHоОтS 274

SIALIC ACIDS $25,50,260$

SILICA 369,398

SILICON 285

SILKWORMS 239

SIMULATION 109,300

SITE EVALUATION 326, 449, 467

SIZE 404,446

SKIN $1,21,27,37,46,80,83$, 99, $116,134,168,174,214,216$ $236,240,254,265,330,358$, $359,361,366,369,384,394,466$

SMALL BOY EVENT 277

SMOKE, DIESEL 369

SNAILS 124,273

SNAKES, CONGO 185

SNAP 215,303 
KEYWORD INDEX

SNAP-9A 314,427
SODIUM CARBCNATES 28
SODIUM CITRATES 211
$\begin{gathered}\text { SODIUM } 24 \quad 64,94,159,160,177, \\ 184\end{gathered}$
SOIL PROFILE 306
SOIL TRANSPORT 306

SOILS $90,119,121,124,273,274$.

$278,285,296,307,309,311$,

$323,327,329,331,338,378$,

$397,398,409,412,413,414$,

$415,420,424,426,435,436$,

$452,477,479,480$

SOILS, SANDY LOAM 306

SOL AR SY STEM 480

SOLUBILITY $25,29,73,156,163$,

$240,253,288,333,348,357$.

373,383

SOLUTIONS 313,354

SOLVENTS $280,283,459$

SOYBEANS 274

SPACE VEHICLES 317,480

SPECIFIC ACTIVITY 65

SPECTROSCOPY $32,287,338$

SPECTROSCOPY, ALPHA 295, 364, 424

SPECTROSCOPY, GAMMA 469

SPERMATOGENESIS 109

SPI.EEN 1, 18, $19,37,38,68,85$,

$91,101,109,118,128,129,134$

$142,150,155,158,160,180$,

$182,188,192,198,226,228$,

$230,231,243,254,255,266$,

STABILITY $18,35,36,73$

STACK BMISSIONS $322,402,410,426$

STANDARDS $384,396,421,454$

STANDARDS, FEDERAL LEVEL 397, 410 , $413,425,448,472,414$

STA NDARDS, INTERNATIONAL LEVBL $341,343,447$

STATISTICS $60,117,212,224,269$ 297, $300,360,370,393,397$, $428,436,468,469$

STEROIDS 76,77

STOMACH 53,254

STORAGE $363,438,471,474,477$, 481

STR A TOSP HERE - 427

STRESS $\quad 308$

STRONTIUM $47,89,120,127,154$, $201,257,333$

STR ONTIUM NITRATES 168

STRONTIUM SULPATES 433

STRONTIUM $85 \quad 290$

142

STR ONTIUH $8956,64,93,94,99$,
$168,177,183,184,203,216$
STR ON TIUM 89
STR ONTIUM $90,21,23,27,28,37$,
$70,71,72,77,103,105,109$,
$119,121,124,144,145,147 ;$
$149,150,165,234,248,249 ;$
$276,285,290 ; 296,303,306 ;$
$315,317,339 ; 351,355,368 ;$
$370 ; 387,412 ; 418,427,433,468$
SUL PUR 201

SUL FUR $35 \quad 260,355,468$

SUR GERY $38,39,47,97,107,394$

SURVEYS $410,425,426,464$

SURVIVAL TIME $2,7,9,10,11,30$,

$52,55,67,132,145,155,175$, $187,189,243,254$

SWINE $80,99,119,168,174,254$,

276

SWI NB, MINATURE 53 SWINE, MINIATURE $46,121,147$.
186,215 $\begin{gathered}\text { SYNERGISE } \\ 250,251\end{gathered} 17,108,120,142,194$,

TAILINGS 445

TANTALUM 316

TAXะ 308

TECHNETIUH 468

TECHNETIUM $99354,359,478$

TEETH $71,103,241,243,247$

TELLUTUM $132 \quad 99$

TEMPERATURE $86,98,249,275,316$,

TBRRESTRIAL SYSTEMS 315,429

TESTES $76,93,128,134,379$

THALLIUM 382

THA LIIU M $202 \quad 210$

THEORETICAL STUDIES 22, 127, 153 ,

THERAPY $5,13,15,17,18,21,48$, $49,63,84,107,111,114,131$. $132,142,156,166,187,188$, $189,190,191,193,201,202$, $206,211,213,236,238,254$, $317,319,350,365,366,382$, $394,466,468$

THERMOLUMINESCENT ANALYSIS 411 THERHOLUMINESCENT DCSIMETERS 387

THIOLS 382

THORAX 430

THORI UM $48,73,133,266,284$, $289,295,301 ; 310,388,389,478$ THORIUH CHLORIDBS 253

THORIUM OXIDES 200

THOR IUM $22821,70,71,72,76$,
$77,103,105,144,173,223,225$
THORI UM $228234,248,310,416$

THORIUL $230301,310,416$

THORIUM 232310,416

THORIUM $23447,49,84,133$

THORON 336

THORON DAUGHTERS 336

THOROTRAST 358

THROIUM 411

THUIIOM $170 \quad 317$

THYMIDINE 37,66

THYMUS $21,101,155,159,235$

THYRO ID 136, 196, 226, 231, 232 。 $235,241,243,254,278,329$, $330,350,396,431$

TIME FACTOR 13, 19, 44, 105, 154, 162, 171, 186, 190, 199, 211 , $229,238,307,321,330,332$; $334 ; 350 ; 369$, 478

TISSUES $1,4,10,21,27,55,59$ $64,72,73,78,91,96,111,123$, $130,131,132,133,134,138$, $148,149,156,180,198,206$, $211,213,214,215,217,218$, $223,230,231,243,254,266$, $338,349,355,362,364,372$, $376,379,384,389,406,424$

TITANIUM 266

TOLERANCE 98

TOMATOES 273

TOXICITY $13,14,21,43,45,47$. $48,63,65,70,71,72,82,89$ $121,131,132,147,150,158$,

$177,201,206,236,243,254$,

256 ; 267, 326; 347, 350; 375; 392

TOXICOLOGY 233

TRACE BLEGENTS 313

TRACER STUDIES $1,58,59,164,222$

TRACERS $338,364,389$

TRACHEA $1,79,354$

TRAINING 387,464

TRANSAMINASES $161,221,223,225$

TRANSFERRIN $6,33,35,36,149$ $164,222,23 i, 232,282,294$

TRANSLOCATION $8,10,12,17,25$, $38,52,107,120,121,142,145$ $148,157,170,188,199,219$,
$245,246,253,256,267,379$

TRANS MENDELBVIUA ELEMBNTS 439

TRANS FLANTS 21

TRANSPLUTONIUM ELEMENTS 99, 186 , 439,453

TRANSPORT $16,35,79,127,146$, 163, 164, 307, 309, 312, 378, $163,164,307,309,312$,
$419,429,435,437,481$

TRANSPORTATION $440,441,442,443$ $449,457,476$ 
KEY WORD INDEX

TRANSURANIU II ELEMENTS $63,95,99$, $149,152,281,284,298,304$ $330 ; 366,376,387,434,440$, $330,366,376,387$
$471,472,477,48$

TRA NSURANIOM REGISTRY, 0.S. 364 , 376,466

TRITIATED WATER 210,481

TRITIUM $66,77,155,168,307$ $309,355,370,396,397,401$,

$415,429,441,468,481$

TRITIUM OXIDE 168

TRITIUM OXIDES 108, 149, 155

TRO POS PHERE 285,427

TROUT 276

TTHA $13,47,49$

TUFF 407

TUMORIGENESIS $23,123,141,151$, 154

TUNGSTEN $181 \quad 210$

TUNGSTBN $187 \quad 210,468$

TUR NOVBR 217

TUR PENTINE 122,125

ULTRAFILTRATI ON $50,129,132,133$, 171,201

ULTRASONICS 354

UPTAKE $81,91,92,112,113,121$, $131,1 \equiv 2,163,188,210,263$ $273,274,296,309,313,315$, $323,329,333,350,418,431$

UPTAKE: TISSUES 53

URANIUM $14,27,47,74,99,123$, $149,160,204,273,281,284$, $289,295,299,301,302,310$, $336,344,347,355,366,369$, $370,373,387,388,393,397$,

URANIUM OXIDES $85,204,348$

URANIUM 233150,440

URA NIUI $234301,310,321,332$, 469

URA NIOM $235270,411,460,469$

URANIUM $23828,285,301,304$, $310,321,332,343$

URANIUM, NATURAL $316,339,343$ URA NYL NITRATES 47,100

URBAN AREAS 328

UREA 86

URINE $5,8,12,13,20,47,56$, $61,73,90,91,100,112,113$, $114,126,132,134,156,157$, 193, 198, 203, 206, 210, 211 , 193, 198, 203, 206, 210, 211, $214,215,219,253,255,266$, $267,283,284,289,291,292$, $293,295,297,327,345,355$, $356,357,365,368,370,371$. $372,373,374,392,393,399$,

$400,423,424,465,469$
143

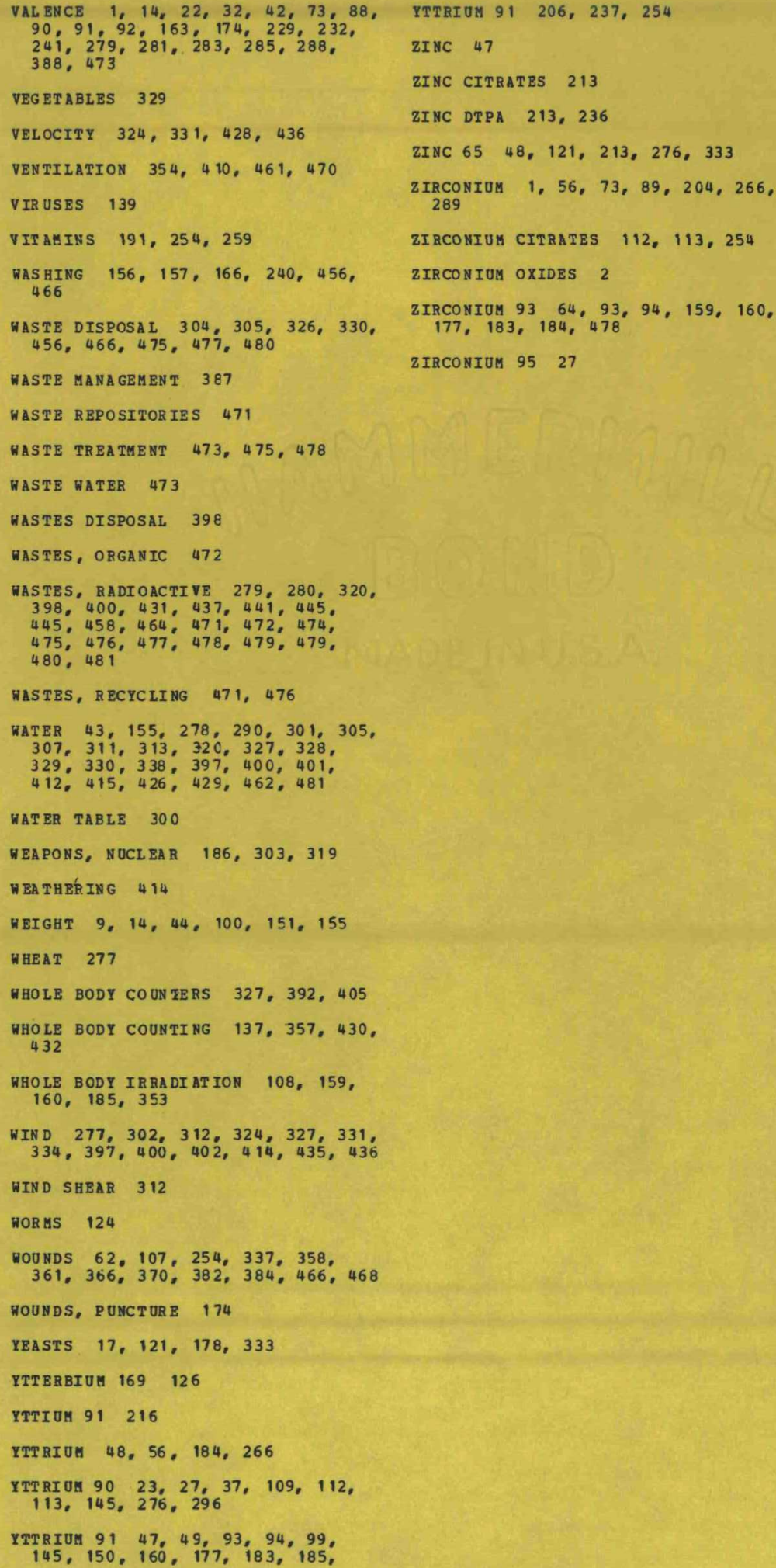

ZINC CITRATES 213

ZINC DTPA 213, 236

ZINC $6548,121,213,276,333$

ZIRCONIUM $1,56,73,89,204,266$, 289

ZIRCONIU CITRATES 112, 113, 254 ZIRCONIUM OXIDES 2

ZIRCONIUM $9364,93,94,159,160$, $177,183,184,478$

Z IRCONIUM $95 \quad 27$ 
•

• 
TAXON INDEX

AGROPYRON SMITHII 323

AMPHIUMA 185

ARANEA 124

BROMUS sp. 323

CARABIDAE 124

CARASSIUS sp. 304, 305

CLADOPHORA SP 305

CURCULIONIDAE 124

DIPLOPODA 124

DIPTERA 124

ELA T ER ID AE 124

GEOPHILICAB $\quad 124$

GLYCINE MAX 274

HORDEUM VOLGARE 274

LACTUCA SCARIDA 323

LIT НОВ IIDAE $\quad 124$

LUM BRICICAB 124

MER MITHIDAE 124

MOLLUSCA 124

PAPIO PAPIO 166

POT A MOGE TON sp. 305

RORIPPA sp. 305

STAPHYLINIDAE $\quad 124$

TRA GOPOGON sp. 323

TRITURUS 185

TROMBIDIIDAE $\quad 124$ 
•

• 
PERMOTED INDEX OF TITIB

with Plutoniun 239 Lung Burdens*

The Bffect of Microdose Distribution on Chromosome oral Administration of plutonium*

\# The Bffect of Irradiation in the \#ffects of Detergents on Skin and on the Percutaneous

after the Inccrforation of Radioactive *Changes in the Bvaluation of Some Immediate Measures Against Injury \#Fadicactive Effluent Releases and the Public \#Nuclear *Prompt Mitigatory Action After of Eerkelium 249, Californium 249 Following Acute \#Airbcrne Elutonium from Weapons Excretion of \#ffect of Diethylenetriaminepentaacetic Bffect of Treatment with Diethylenetriaminepentaacet ic Brought abcut by Plutoniun oxide in the Phosphatasic * \#Ef fectiveness of Diethy lenetriaminepentaacet ic posited Elutcnium by Triethylenetetranine Hexaacetic
of plutonium on the Content and Renewal of Nucleic

of plutonium on the Content and Renewal of Nucleic
\#peoxyribonuclease
"Characterization of

9 Enclosed Irench* on the Carcinogenic BPlutonium and other Nitrogen in Rabbit Bony Tissue after \#Phcschata se Gel \#Simultaneous Determination cf Plutonium Alpha \#imultaneous Determination cf Plutonium Alpha Abcut by Plutonium Oxide in the Phosphatasic Acid
\#Bffects of Experimental Alteration of Phagocytic of Experimental Alteration of Phagocytic
\#Morphological Changes of Bone Tissue in Elimination of Berkelinm 249. Califcrnium 249 Following Mammals*

with Ytterkium 169 in the Rhesus Monkey After a Single Nuclear Fower plants, a Selected Bibliography, First Decorpcration by Glucan and Related Compounds as the Rat organism, As Relat $\in d$ to the Properties of the

Changes in these organs Following Intratracheal Rat organs FCllcving Intraperitoneal and Intratracheal Compounds* \#Some Remote Aftereffects of Intratracheal Distribution of Plutonium and Americiua: Subcutaneous cf Mcncnuclear Phagocytes Following Intraperitoneal Acid Pollowing Intratracheal of Iethal Radiation Effects Pollcwing Massive oral A Technique for DCsed Effects of Froduct

239 Metabolism in the Case of Prolonged Feror al Rats After Intravenous. Intramsucular and Subcutaneous 241 and Californium 249 in Livers After Intravenous of Irhaled Plutonium 239 Dioxide in Immature, Young \#The Long-Term Effects of Plutcnium 239 in
Seeking Radionuclides on the Vascularity of Bones from

the Size Distribution of Plutonium 239 Puo2 Aerosols, Hazards Evaluaticn Pollowing Inhalation "Influence of

*Fast-Fesponse Iight Scattering Measurements of Uranium and their Fissicn Products Inhaled as of Three Sizes of Monodisperse Plutonium 238 Fu02 Vitro Disscluticn*Production of Monodisperse Respirable \# Aechnique for Losed Administration of Radicactive *lectron Microscopy of

Between the Size Distribution of Plutoniun 239 Fuo2 Changes of Bone Tissue in Acute and subacute Chemically Soluble plutonium 239 Compcunds*\#Some Remote Elements*

of Bones frcm Adult Beagles* $\begin{array}{rr}\text { Gastrointestinal Tract of the Rat* } & \text { \#ffect cf } \\ \text { the Bat* } & \text { \#Influence cf }\end{array}$ in the Rat*

Plutonium 239 Dioxide in Immature, Young Adult and January 1. IStatus of the U.S. Environmental Protection on Inert operations* Contaminant $s *$

Analyses in the Health and Safety laboratcry Surface through Lecemker, $1970^{*}$

Murface

for Fapid Analysis of Long-Lived Alpha Euitters in

\#Health Fhysics at the Lcs Program: An Overview with Emphasis on \#The Ics Burdened Dogs* \#Relationship Between Ser um
Materials by \#Simultaneous Determination of Plutoni um Materials by \#Simultaneous Determination of Plutonium
Skin Surface \#Dosimetry of
Aberration Prequency in Elood Iymphocytes of Animals Aberrations Frequency in Liver Cells of the Chinese

Absence of Iethal Radiation Rffects Pollowing Massive Absorption of Elutonium in the Gastrointestinal rract* bborftion of Radioactive substances*

absorftion of Radioelements*

Absorption Characteristics of Cerebral and Renal Tissue

Acceleration of Excretion of Radioactive Isotopes,

Acceleration of Excretion of Radioact

Acceptance of Nuclear Facility Sites*

Accident Dosimetry. Part 2. Cose Assessiment procedure* ccidental. Bxposure to Padionuclides*

Accidental Inhalation* \#Retention and Elimination

Acid and Folypropylenoglycolethylene oxide Polymer on acid on the Distribution of Plutonium 239 within the Acid Activity of Alveolar Macrophages of the Rabbit* Acid Fcllowing Intratracheal Administration of Flutoniun Acid*

Acids in Some Rabbit Tissues*

\# Removal of
$\#$ The Bffect

Acitivity in Rabbit iver affected by Plutonium

Actinide Bearing Soils: Top Sixty Centimeters of 216-2ctinide Elements in Gonadal Tissue of Man and Animals* Active Material*

Some and animals*

ctivity and Content of Calcium. Phosphorus and

Activity and Flutonium 241 in Eiological Materials by

Activity of Alveolar Macrophages of the Rabbit* Brought

Activity on Tissue Uptake and Retention of Folymeric

ccute and subacute Affection ith Plutonium*

cute and subacute affection

* Retention and

Acute Fffects of Plutonium on the Peripheral Blcod of

Acute Inhalation Exposure*239 Dioxide Particles Labeled Addendu* \#Bioenvironmental Bffects Asscciated with Adjuncts to DTEA Therapy*

inistered Particles*

dministered Salt* \#Distribution of Americium 241 in

Administration of an In Vivo ccunting Program*

Administration of the Isotopes*Liver, and Morphologica Administration of this Isotope*of Americium 241 in Scme Administration of Chemically Scluble Plutonium 239

Administration of Flutonium Dioxide and the Bffect of

Administration of Plutonium 239 Fuo2*The vitrastructure Adinistration of Plutonium*

Administration of Plutonium* \#Absence

daministration of Radioactive Aeroscls to Dogs*

a inistration Intramuscularly to Mice

aministration"

"zinetics of the Elutonin

of Einsteinium Nitrate ES (NO3) 3 in ministation Adnistration*Distribution of Flutonium 239, Arericium
Adult and Aged Syrian Hamsters. 2.* Adult Eeagles*

dult Eeagles*

$\#$ Bffects of Age and Bone-

vances

Aeroscl Concentration, and Nebulizer Suspension

Aeroscl Properties and the Resfiratory Pattern Upon

Aeroscl Sampling for Farticle Size Analysis*

Aerosol Suspensicn in a Lesert Area*

Aeroscls by Rats and Man* and Pate of Plutonium,

Meroscls in Beagle Dogs* \#Short-Term Metabolism

Aeroscls of Americium 241 Dioxide and Pvaluation of In

Neroscle to Dogs*

lerosols Containing Radioactive Particles*

Aeroscls, Aeroscl Concentration, and Nebulizer

ffection with Elutcnium

iffections*

Aftereffects of Intratracheal Administration of Aftereffects of Radiation Damage*

Aftereffects Associated with lamage by Transuraniun

ge and Bone-Seeking Radionuclides on the Vascularit

Age and Particle Size on Passage Time through the

Age on the Iate Effects of Moncmeric Plutonium 239 in

lge-Defendence of Plutonium 239 Metabclism and Effect

Aged Syrian Hamsters. 2.* \#Toxicity of In

Agency's Nevada Test Site Experimenta

Air Leakage Into P1 utoni un Glove Boxes and Its Effect

Air Sampling Instruments for Evaluation of Atmospheric

Air Saufling Program During 1968* of Radiochemica

Air Sarfling rrogram, 80th Meridian Network, January

Air Surveillance system*

Air*

* A single Centripeter

Mirborne Plutonium from Weapons Accidents*

Alamos "Hing 9" Hot-Cell Facility*

Alamos Scientific Laboratory's Environmental Monitorin

alkaline Phosphatase and Osteosarcoma in P1 utonium 239

Al pha Activity and plutonium 241 in Biological Alpha Autoradiography in the letection of Plutonium 239
$\mathrm{CCO} 30$

000031

000237

$\mathrm{C} 00083$

000240

000265

000270

000270

000028

$0 \mathrm{C} 0322$

000185

000405

000394

000371

000363

00255

000195

000020

000013

000118

00117

000186

CC0346

000075

00408

CC0195

00188

000135

000371

000102

00326

000017

000252

000272

$0 \mathrm{CO} 460$

000079

00269

CCO200

000020

C 0237

000143

000158

c0004

00214

0 C0220

000106

000115

0 COC6O

000253

000428

OC0334

000204

000748

$0<0029$

000143

000433

000060

C C 0135

000352

00269

cco149

000152

000115

000207

$\mathrm{CCO} 2 \mathrm{Cg}$

C 0270

000462

000340

000417

000427

$\mathrm{C} 00402$

000336

000363

000470

000415

000408

000361 
* Aingle Centripeter for Rapid Analysis of Iong-Lived Iymph Node Involvement Follcuing Inhalation of Ccuncil Petition Concerning Iimits for Insoluble Some speculaticns on the Carcinogenic Bffect of Inhaled \#Recovery of Plutonium and Americium frcm
"Recovery of plutonium and Americium from Counter* * A Procedure for the Determination of * Badiogenic Effects ir Man of Long-Tern Skeletal Radi onuclides*

\#nternally Deposited Radionuclides and the Subsequent Retention of Folymeric

* Bfects of Bxperimental

Effects of Icnizing Radiaticns Cn Endocrine Cells. 6 . Retention and clearance of Cesium 137 Inhaled in Fused Radicpharmaceuticals After \#An Assessment of by Plutonium cride in the Phosphatasic Acid Activity cf of Plutoniua Farticles* "Bronchioloand Artificial HCrmonal stresses on the Retention of \# The Binding of \#Recovery of Plutonium and \#Recorery of Plutonium and Limnclogical \#The Ecological Behavior of PIutonium and Implications \#The Ecological Behavior of Elutonium and \# An Inproved Chest Phantom for Studies of plutcnium and of tre Intracellular Distribution of plutonium 239 , Pilot Study* * Preliminary Compariscn of the Effects of Removal of Inhaled Properties of the Administered Salt* \#Distribution of "Some observations of the Deposition of Skeletal Distritution *

Int raperitoneal and Intratracheal *Microdistribution cf and \#Ccmparative Effects of Plutonium 239 and \#Production of Monodisperse Respirable Aeroscls of \#Chemical Associations of Plutoni um $239(+4)$ and Some Aspects of Thyroid and Parathyroid Damage Due to \#Studies of Plutonium, Dioxide and the \#The Distributicn of plutcriumand \# Solvent Extraction of Plutoniun with Frimary cells and Hemodynamics in the Case of Inhalation of Radionuclides* \#Dse of a Specialized Air Sampling Frogram \#The Quality of Radiochemical \#Excretion Methods. The Application of Excretion
Particles in the Lung* Particles in the Lung* \#A Single Centripeter for Rapid of Plutonium in Human Tissue: A Preliminary Nitrate*
\#Fisk \#Aerosol sampling for Particle size Fffect of Exercise of Leukopenia, A Statistical etermined by Blectron Microscopy and Radiochemical of Flutonium Dioxide with the Help of Separaticn Level plutonium in Bumans* \#An Bfficient Way to in Beagles* \#Coal Mine Dust Imcombustibles content

Radiaticns on Endocrine Cells. 6. Alterations in Radicnuclides and the Subseguent Alteration of \#Distribution of Flutonium 239 in the Due to soil contamination with \#Changes in Structure cf *Scme speculative Extensions to Man of Chrcmosome aberration prequency in Blccd Lymphocytes cf "Fhospholipid Turnover in Product Eciscned \# The Hct Particle Project. Bxposure of

Other Actinide Elements in Gonadal Tissue $\mathrm{cf}$ Man and
\#adioactive waste Frocessing and Disposal, An \#Radioactive Waste Frocessing and Disposal, An

\# Hanford Biolcgy Research "Hanford Biology Research \#Hanford Biology Research \#Hanford Biology Fesearch

Toxicity Erogram* \#Research on Radiobiolcgy, * Research in Radiobiolcgy. An \#iology Fesearch,

Inhalaticn of Cerium 144 Dioxide or Elutonium 239 and Hixed Comflexes--Rapid Experimental and Calculative \#Recovery of Elutonium and Americium from Al fha-Bearing * Recovery of Elutonium and Americium from Alpha-Eearing in waters of the Judea Group (Cenomanian-Turonian)

* Uranium 234 and Oranium 238 in the Carrizo Sandstone Detection in Iungs* \#Calibration of a large *High Pressure Mechanical properties cf an Measurements of Aercsol Suspension in a Desert lpha Imitters in

Al pha Boiters in

* Tracheokronchial

lipha Fmitters* Review of the Natural Resources Defens

1 pha-Active Material *

Alpha-Eearing Agueous Wastes. 3.*

Alpha-Eearing Aqueous Wastes, $2 . *$

Alpha- Imitting Plutonium in Orine Using a Solid-State
Mlpha-rmitting Radionuclides--An Bxperimental Afproach Alpha-Irradiation*

Alteration of the Metabolism of the Beagle ky

Alteration of Androgen Biosynthesis by Canine

Alteration of phagocytic Activity on Tissue uptake and

alterations in Androgen Biosynthesis by Canine

al umincsilicate Particles by the Beagle Dog* fulmonary

Alveolar Carcinomas of the Canine lung Pollowing

alveolar Deposition and Pulmonary Clearance of

Alveolar Macrophages of the Rabbit* Brought About

Alveolar Tumors of the Canine Iung Following Inhalaticn

Alveclar Tumors of the Canine Iung Following Inhalaticn
Americium and plutonium by Rat Bone*

americium and Flutonium to Eone Glycoproteins*

americiuil from Alpha-Bearing Agueous Wastes. 3."

americium from Alpha-Bearing Aqueous Wastes, 2 .

Mmericium in a Preshwater Bccsystem: Phase 2,

Americium in a Preshwater

Americium 241 and Californium 249 in Iivers after

Americium 241 and Plutonium 239 on Serum Enzymes*

Americium 249 from the Beagle Dog by Lung Lavage: A

americiuli 241 in the Canine Liver*

Americium 241 in the Rat Organism, As Related to the

Americium 241 in the Thyroid Gland of the Beagle*

Americium 241 in Beagles: Biolcgical Effects and

Americium 241 in Some Fat organs Following

Americium 249 on Biochemical Parameters: Bffect of Dose Americium 241 Dioxide and Bvaluation of In Vitrc Americium $241(+3)$ in Elood, Liver and Thyroid*

Americium 241 *

Americium*

Americium, and Uranium in Environmental Matrices*

Americium: Subcutaneous Administration of Plutoniun

Amines"

Amoniug Plutonium Pentacarbonate by Rats*the Fed Elood Analcg Computer for the Model of the Metabolis il of scm analyses in the Health and Safety Laboratory Surface andyses in the Health and Safety laboratory surfa

analysis of Dosimetry and Cellular Risk for plutoniu Analysis of Long-Lived Alpha Buitters in Air*

Analysis of Plutonium 241 in Orine*

nalysis of Reported Data*

\#The Distributio

Analysis*

Anal ysis*

Analysis*

Studies of Plutonium Project Personne 1 Vermiculite and Its Weathering Product Analysis* of the lung Burden Resulting from Inhalation Analytical Method for the Leterminaticn of very Low Analyze Bone Affections*

nalyzer Using a Gamma-Pay Backscatter Technigue*

Anatorical Distribution cf Radiation-Induced Practures

Anarogen Biosynthesis by Canine Testicular Tissue after

Anarogen Biosynthesis by Canine Testicular Tissue*

Animal organism*

Animal Fopulations (Terrestrial and Soil Invertefrates)

Animal nisk Data on Tlutonitu*

Animals vith Plutoniun 239 Lung Burdens*

enimal $\leq *$

inimals*

Animal ${ }^{*}$

Annotated Bibliography of Selected Iiterature*

Annual Erogress Report, March 31, 1959*

Annual Beport for 1957 .

Annual Report for $1958^{*}$

Annual Report for $1959 *$

Annual Report for 1961 *

Annual Feport of Work in Progress on the Chronic

Annual Report of Work in Progress on the Chronic

Annual Report, 1955*

Annual Report: Environmental Safeguard, 1971*

Antibody Responses and Pulmonary Lesions After

PEFroaches to Predict In Vivo Behavior* by Chelation

Aguecus Wastes. 3.*

Aquifer in Galilee, Northern Israel* 238 Disequilibrium

Aquifer of South Texas*

Area Eroportional Counter for platonium 239 x-ray

Area 12 , Nevada Test Site muff*

Area 12, Nevada Test Site Fuff*
Area*

Articles Defosited in the Liver*
000336

00038

000384

00034

$0 \mathrm{CO} 279$

00291

00009

00035

00024

00007

00018

000077

000025

000055

C0354

00195

000054

000097

0005

000279

00028

C CO305

000304

.

OC0220

00161

000157

CC0036

000272

00022

000136

000180

000162

C 0232

00019

000131

000273

000273

$0 \mathrm{CO} 283$

OCO110

000417

000417

000357

000336

0038

000376

000442

000338

$0 \mathrm{CO} 428$

000360

000285

000374

000292

000352

00335

CCO242

000076

$\mathrm{CCO} 78$

000124

CCO3\& 1

000030

000016

000002

000186

00434

000333

0 CO 120

000121

000276

000070

000071

000119

00426

000139

$\mathrm{COO} 202$

CO279

000332

000321

000349

000407

000197 


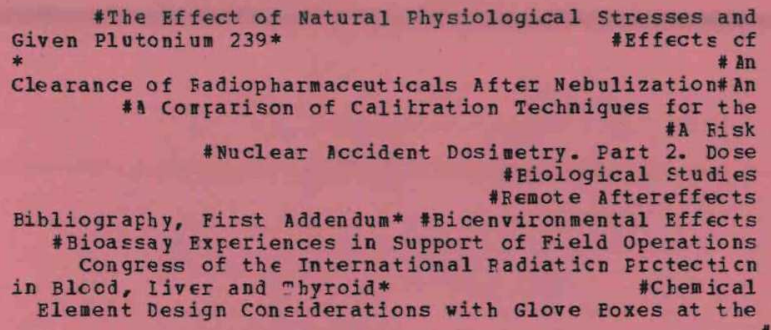

Plutonium Storage Pacility*

\# Numerical Prediction of the Mescscalescription of * Air Sampling Instruments for Bvaluation of \#Mass Distributicn of Large
\#A Statistical summary of V.S.

Bxperien ce*

Experience. \#A Statistical Sumary of United States

Progress Review by Chronology, Fermuted Title, and Effect of Colloidal State of Intravencusly Injected

Articles Defosited in the li ver*

Polymeric and Monomeric Plutonium. Radiochemical and Surface \#An Application of oltra High Sceed Alpha Dasage of Radium 226 and Plutonium 239 in the Bones of Bones as Visualized by Photographic and Neutrcn-Induced Recent $S \in a$ and ocean Sediments* \#Ratios of $t$ he A. Mcnodisperse 1.5 um plutonium 238 Dioxide Farticles. \#Preventicn of piutonium Defosition ly DesferricxamineDust Imcombustibles content anal yzer Using a Gama-Ray Investigations on the \#Effect of 2,3-Dimerca ftoprcpanol \# Test Methods and Bfficiency Studies on MultiAffecting Uptake and Distribution of Plutonium in
"Pathogenetic Classification and \#Alteration of the Metabclisil of the

and Hefatic Dose Rates from Plutonium 239 in the \# Removal of Inhaled Americium 241 from the Glucan on Decorporation of Monomeric PIutonium in the 137 Inhaled in Fused Aluminosilicate Particles by the \# Serum Transaminase Levels in Dioxide *Ioxicity of Inhaled pl utonium 238 Dioxide in * Ioxicity of Inhaled pl utonium 238 Dioxide in Toxicity of Inhaled Beta-Bmitting Radionucildes in Sizes of Mcnodisperse Plutonium 238 PuO2 Aerosols in and Effect on Biological Behavior After Inhalation by * The General syndrome Induced by plutonium 293 in the plutoniul 239 in \#Plutcnium 239 in Liver, Spleen, and Kidneys of the Node Clearance of plutonium from Subcutaneous Wcunds in Depositicn of Americium 241 in the Thyroid Gland of the Calcium ITP Enhanced Bxcretion of Plutonium 239 in the cf Moncmeric and Polymeric Plutonium 239 in the * Blectrocardiogram Evaluation of

Radiun 228* *iver Tumors in * The Rate of Tooth Ioss in

* Skeletal Dosimetry in Otah

* The Icng-Term Bffects of Plutonium 239 in Adult Hematclogic changes Induced by Plutoniun 239 in Distribution of Radiation-Induced Practures in uclides on the vascularity cf Bones frcm Adult of Polymeric and Monomeric Plutonium 239 in of Polymeric and Monomeric Plutonium 239 in Parly Retention in plasma and Selected Soft Tissues cf * Americium 241 in * Recovery of Plutonium and Americium frci Alpha Enclosed Irench* \#Characterization of Actinide \# Bnvircnmental

\#T he Chemistry of Plutoniua in Relation to Its * The Nature and Ecosystem: Fhase 2, Implications of \#he Ecological
Bcosystem: Fhase 1, Iimnological \#he Bcological Ecosystem: Fhase 2, Implications of \#he Ecological
Bcosystem: Fhase 1, Iimnological \#he Bcological 238 oxide in Hater suspensicn and $\mathrm{ffect}$ on Biological and Calculative Approaches to Predict In Vivo Environmental Monitoring of a Nuclear Puel \#Buricical \#Comparative Toxicity cf Inhaled Radioactive aste Processing and Disposal, An Annotated Associated with Nuclear Power Plants, a Selected References thrcugh $1972 *$
Artificial Hormonal Stresses on the Retention of Aseptic Inflamation on Long-Term Sequelae in Rats issessment of the Ion - Term 00122 assessnent of Assessment of Flutonium 239 Lung Burdens* $\quad$ C 0404

issessment Model for Radioactive Material Shipments* 000443 Assessment procedure*

Associated with a Field Felease of plutonium*

Associated with Damage by Transuranium Elements* Associated with Nuclear Fower Flants, a Selected Associated with Widespread Dispersion of Plutonium* Association* \#Third International Associations of Flutonium $239(+4)$ and Americium $241(+3)$
Btlantic Hanford Company*

Atlantic Richfield Hanford company

itlantic Richfield Hanford Company's New Compact Atrosphere Effluents: Philosophy and Morphology of Atmospheric Contaminants*

Atmospheric Particles*

Atcmic Energy Commission Contractors' Internal Exposure Atomic Energy Commission Licenses' Internal Expcsure Atomic Bnergy*

Author vol. 11, No. 1 through $\nabla c 1.14$, No. 6 * Technical Autoradiographic and Radiochemical studies of the

Autoradiographic Localization and Quantitation $c f$ Autoradiographic localization and Quantitation cf Autoradiography in the Detection of plutonium 239 Skin Antoradiography in the Localization and Radiation a toradiography* Average Concentrations of Oranium and Organic Matter in E. Moncdisperse 3.0 un Plutonium 238 Dioxide Farticles. Eackscatter Technique*

Eacterial Leaching of Uranium ores*

*coal aine

BAI) OFon Distribution and Excretion of Plutonium* Eank BIPA Pilter Systems*

Earley and Soybean Plants*

Factcrs
Easic Ftiological Factors of Radiation Sickness in Man* Eeagle by $\mathrm{R}$ adionuclides

Eeagle for Radiobiologic Studies*

Eeagle As a Function of Dose Ievel*

Reagle Dog by Lung Iavage: A Pilot study*

of skeletal

Eeagle Dog*

\#Bffect of ITPA and

Eeagle Dog* Pulmonary Retention and clea

Eeagle Dogs Burdened with Plutcnium 239*

Eeagle rogs. A. Monodisperse 1.5 um Plutoni um 238

Eeagle Dogs. 2.* and DIPA ireatment for the Bemoval

Eeagle Dogs*

Eeagle Dogs*

Beagle Livers*

Eeagle*

Beagle*

Eeagle*

Eeagle*

*Some observations of the
Beagle* Study of the Effect of Cortisol cn Irisodiut

. Blood Clearance and Sir cortisol cn Trisodium

Eeagles with Retained Radionuclide Burdens*

Beagles Injected with Elutoniun 239*

Eeagles Injected with Plutonium 239, Radium 226 and

Eeagles*

Eeagles*

Eeagles*

Eeagles

Feagles

Beagles* \#Skeletal Retention and Distributio Beagles*the Comparison of Bffects of Lethal Body Burdens Peagles: Biological Effects and Skeletal Distritution* Fearing Aqueous Wastes. 3.*

ing Agueous Nastes, 2 .

Eearing Soils: Top Sixty Centimeters of 216-2-9

Eehavicr and Radiation from Iodine 129*

Eehavicr in Biological and Bnvironmental systems* Behavicr of Local Fallout*

Eehavicr of plutonium and Americium in a preshwater

Behavior of Plutonium and Americium in a Preshwate

Behavicr After Inhalation ry Beagle Dogs* of Plutoniu Eehavicr* and Mixed Complexes--Rapid Experimental Eenefits Derived from an Bcosystem Approach to Eerkelium 249, Californium 249 pollowing Acute Reta-Buitting Radionucildes in Beagle Dogs* Ejbliography of Selected Literature*

Eibliography*

Eibliography* First adendum* tioenuirongental zffects

Bibliocraphy: Bffects of Radiation on the lung with
0 C0268

000152

000326

000465

000232

$0 \mathrm{CO} 446$

000472

000438

000312

C 0340

00324

000370

CCO468

000434

000192

000197

000129

CCO0004

000299

CO 140

000212

000074

CCO114

000454

000274

000353

00249

$0 \mathrm{CO227}$

000157

0 CO 130

000221

000140

000156

00145

00148

C 0246

000241

$0 \mathrm{C} 0228$

000230

000062

000226

000005

000128

000248

000244

000247

000181

000144

C00106

000068

000242

CCOOO6

000067

000231

000136

0 CO280

$0 \mathrm{C} 0398$

000329

000288

000277

000304

000305

000171

000202

000429

000371

000145

000439

000439
000326

CC0386 


\section{\#Plutoni um \\ th he \\ \# Metabolic study of the \\ $y$ of the}

Associated with Widespread Dispersicn of plutonium* Inhalaticn cf plutcnium*

Bffects of plutonium 239 and Anericium 241

Plants, a Selected Bibliography, Pirst Addendum*

Chemistry of Plutonium in Belation to Its Behavicr in Entry Into the organisn*

P1utcnium 238 oxide in Water Suspension and Bffect $\mathrm{cn}$ in Rats after Intravencus, Intramsucular and

\#Americium 241 \#Relative \#Preliuinary observations on the Pharmacodynamics and Plutonium 238 Fower Sources in Dogs*

of Elutcnium Alpha Activity and Plutonium 241 in \#Chemical. Nuclear, and \#Advances in Fhysicai and

* Eiological Effects observed with Combined Expos

Eiological Materials by Gel Scintillation Counting Eiological Froperties of the Transuranium Elements*

Eiological Radiaticn Detectors*

\# Piological Research with Plutcnium, 1944-1984*

* Eiological Research Section*

* Piclogical Pesearch Section*

Plutcnium*

Eiological studies associated with a Field Release of

Eanford Eiology Research Annual Report for 1957*

*Hanford Biology Research Annual keport for 1958*

*Hanfora Fiolog Rescer

\# Eiology Research, Annual Beport, 1955*

Eiology Research, Annual Report, 1955
Eiology Section, January 16, 1945*

\#Project Council Meeting.

in seawater in Relaticn to Optake by the Marine on Endocrine Cells. 6. Alterations in Andrcgen
Radionuclides and the Subseguent Alteration of Androgen Radionuclides and the Subsequent Alteration of Androgen
\#Some Results of Studying the \#Some Results of Studying the \#Acrte Effects of Flutonium on the Feripheral
of Aditional Pathological Factors on Peripheral
Adation of Ammonium Plutonium Pentacarbonate \#State of the Red Monomeric and Folymeric Plutcnium 239 in \#Ccmparison cf Vivo Studies $c n$ the Interactions of plut cnium $(+4)$ with Burdens* \#Chromoscme Aberration Frequency in Plutoniun $(+4)$ with the Iron Transfcrt system in Human of Flutonium $239(+4)$ and Anericium $241(+3)$ in Radioactive Nuclides from the Envircnment to the Human Pentoxide* \#Distribution of Oranium in the of Fxcretion Analyses to the Determination cf Hematopoiesis in acomparison of Effects of lethal \# Whole

Develogment cf Devices for the Determination of Total "iffects of Low Dose of Radiation on the Living of Low-Energy $X-R$ ay Radionuclide Content in Human Intravenously Injected Plutonium on Its Distribution in "The Binding of Americium and Flutonium to "The Binding of Americium and Flutonium to
The Action of Plutonium 239 and Strontium 89,90 on the Uranium* *The Optake of Fiutonium in

Changes in Vascularity of cortical Bones Induced by and Metachromasia in Murine Tumors Induced ty

Plutonium* *Radiaticn Dose-Rates Nea

\#) Horphological Changes cf

*Vascular Theory of Eadiation Injury to Ouantitative Morpholcy \#Plutoniull Binding by The of Vertebral Trakecula \#The Bffects of Radiation on
of Iccalized concentration of plutonium 239 in on the Petention of Americium and Plutcnium by Rat

from Adult Eeagles* Autoradiography*

\#Bffects of age and and "Plutcniun 239 in Radiation Dosage of Radium 226 and Flutoniul 239 in the \# Preliminary Feport: Changes in vascularity cf ccrtical

\#Bffect of Daily Injecticns of Plutonium 239 on Rat Ccntent in the protein Fraction of Rat Tubula Content of Calcium, Phosphorus and Nitrogen in Rabbit

\#Air Leakage Into Plutonium Glove \#Human Element Design Considerations with Glove
Eiophysical Basis for Fadiation Eaematology*

Eiosphere* of Radionuclides and Stable Trace Elements Biosynthesis by Canine Testicular Tissue after the Eiosynthesis by Canine Testicular Tissue* Deposited Eiota Survey*

Elastomogenic Effect of Eadioactive Isoropes*

Elood cf Mammals"

Elod lutoniun $239 *$

Elcod Clearance and

cod Constituents*

Flood Iymphocytes of Animals with Plutoniuil 239 Iung

Blcod Serum* in Roaction

Term Periods after

Elood, Liver and Thyroid* *Chemical Association

Body Ater Single and Chronic Bntry of uranium oxide-

Eody Burden of Radioactive Isotopes* The Application

Body Eurdens of Flutonium 239 and Sadium 226 on

Eody Ccunting of Plutonium in Rats*

Eody Gamma-Ray Counting of Plutonium 239*

Eody Gamma-Fay Counting of Plutonium $239 *$

Ecdy*

Eone and Marrov*

Eone Glycoproteins*

Eone Marrow of white Rats*

Eone Marrow: A Possible leukemic Risk*

$\begin{array}{ll}\text { Marrow: A Possible Ieukemic Risk* } & 000263 \\ \text { e Retention Punctions in the Human Metabolism of } & 000343\end{array}$

Eone Seeking Fadionuclides* \#Preliminary Report: CC0105

Eone Seeking Radionuclides* *Histochemical Fhosphatases 000023

Eone Surfaces: What are They?*

Eone

Eone*

Eone*

Eone*

Ecne*

Ecre*

Rone*

Stresses and Artificial

The Determination

Eones as Visualized by Photographic and Nevtron-Induced Eones from Adult Beagles* \#ffects of Age Ecnes cf Dogs* \#atoradicgraphy in the Iocalization and Fones Induced by Bone Seeking Radionuclides*

Eones*

Eones*

Eones"

Eony Tissue after Injury with Plutonium $239 *$ Plutoniu Eox Pire-Resistant Materials and Fire Suppressicn Tests* Eoxes and Its Effect on Inert operations* Boxes at the Atlantic Hanford Company*
Bone Affections* c coce 1

000050
000036

C C 0164

000282

000465

000162

C COCE6

000326

000288

000044

$0 \mathrm{CO171}$

$0 \mathrm{CO} 214$

000136

000010

C00109

000408

$0 \mathrm{CO} 298$

000341

000056

000057

000333

000120

CC0121

000119

000179

$0 \mathrm{CO} 218$

000077

000076

000123

C CO1C2

oC0110

000128

000030

000294

000232

000378

c coc85

000067

000138

000137

000239

$\mathrm{CCO} 406$

0C0192

000352

0005

000023

C CO262

000135

000094

000169

00008

00084

000390

000261

000097

CC0103

000115

000104

000115

000004
000105

CCO103

000066

C00258

000075

CCO455

000462
000446 
* Lecontamination of Plutonium-Contaminated Glove Following Plutcnium "Plutonium Inhalation Studies. 7. Inhalation of Flutonium Particles* *Ventilation Systems at Mcund Labcratcry "PF" \#entilation Systems at Mcund Labcratory "PF"
of Bxcretion Analyses to the Determination of Body with the Help of Separation Evaluation of the Iung Biochemical Parameters: Bffect of Dose and Radionuclide * Serum Transaminase Levels in Eeagle rogs Levels and other Serum Constituents in Dogs Ievels and other Serum Constitutents in cogs Alkaline Fhosphat ase and osteosarcoma in plutcnium 239 Hematopoiesis in \#Comparison of Effects of Lethal Body Bvaluation of Beagles with Retained Radionuclid rechilgues for the Assessment of plut onium 239 Iung \#Comparison of Bfficiency of Removal of Elutonium, \#Comparison of Bfficiency of Removal of Elutonium,
Removal of Flutonium, Calcium and zinc from Rats by plutcnium from Mice by Combined Therapy with the * pilot Study of the Bffect of Cortisol cn Trisodiun 239 from the Human organism* \#The Effect of Sodiu after Injury with $*$ phosphatase Activity and Content of Plutcnium $239 \mathrm{x}$-ray Detection in Lungs* 239 Lung Eurdens

* A C cmparison of Distribution of Plutonium 239, Americium 241 and Retention and Blimination of Berkelium 249 . * Materials CD the Texicclogy Radiation

\#On the Binding of adoactive Isctcpes a *Bronchiolo-Alveolar Tumors of the Studies. 7. Bronchiolo-alveolar Carcinomas of the *Plutcni um Particle-Induced Neoplasia of the

Cells. 6. Alterations in Andrcgen Biosynthesis by the Subsequent Alteration of Androgen Biosynthesis by Model for Eredicting the Redistribution of Farticulate * Mechanisms of \#Some speculaticns on the

* Mechanisms of

\#Plutcnium Inhalation Studies. 7. Bronchiclc-Alveclar *Safety Studies on Sealed Plutonium 238 scurces for Populaticn Fstimates for Dse of Radioisotope Fowered \#ranium 234 and Oranium 238 in the Products Letermined by \#Bxchange cf Iyotrcpic Series \# Health Physics at the LCS Alamos "Wing 9 " Hot Ammonium Plut onium \# State of the Red Blocd

cn Chromosome aberrations Prequency in Iiver \#Recovery and Repair in Yeast Canine *Tte Effects of Ionizing Radiations on Endocrine Relation to the Induction cf Neoplasms*

$$
\text { \#An analysis of Dcsimetry and }
$$

238 Diseguilibrium in Waters of the Judea Group Safety Tests at 1300 Legrees Centigrade and 800 Degrees Isotopic Cardiac Pacemaker Safety Tests at 1300 Degrees \#Characterization of Actinide Bearing Soils: Top sixty \#A single

\#Changes in the Absorption Characteristics of Responses and Pulmonary Iesicns After Inhalation cf Year study of the Pulmcnary Retention and clearance of to $1961^{*}$ Plutonium $2 \Xi 9$ ky Man*

Strontium 90 , Graded Polymeric and Monomeric Plutcnium. "Preparation, in a Freshwater Bcosystem: Phase 1, Limnological plutonium 238 Fuels*

Centimeters of 216-2-9 Enclosed Trench* View*

* Scstained Action of Injected Nephrotcxicity

238-Nitrate from the Rat by Continuous Infusion of Cther Factors"

from the Iiving organism of \# The Action of Metabclism and Deccrporation as Influenced $t$ State cn the Removal of Hydrolyzable Radioel
Americium $241(+3)$ in Elood, Iiver and Thyroid* Programs Quarterly Report, october-December 1973* \#Metabclic Characteristics Mithin \#Metabclic Characteristics Mithin
\#The Effect Elements in seawater in \#Influence of the Fhysico*The Bffect of the Fhysical plasma and selected soft
Removal cf In haled Plutonium 239 of Varied Solubility Chelation and Mixed Complexes--Rapid Experimental and \# Mechanisms c Centigrade and $8 \mathrm{co}$ Degrees Centigrade (So urce

"Depth Distribution of Global Pallout Strontium 90 Administration of Plutonium Dioxide and the Effect cf

Eoxes*

Eronchiolo-Alveolar Carcinomas of the Canine Iung Eronchiclo-alveolar Tumors of the Canine Lung Pcilowing Eronchcpulmonary Lavage and ITPa Treatment for the rought about by Plutoniuil oxide in the Phosphatasic Euilding*

Purden of Radioactive Isctopes*Methods. The Application Eurden Resulting from Inhalation of Plutonium Dioxide Burden Time* of Plutonium 239 and Americium 241 on Eurdened with Plutonium 239*

Eurdened with Flutonium 239, Thorium 228, Radium 228 Eurdened with Plutonium 239, Thorium 228, Radium 228 , Eurdened Dogs* * Relationship Retween Seru Burdens of Plutonium 239 and Radium 226 on * Electrocardiogran

Eurdens*

\# A Comparison of calibration Eurdens* \#Chromosome Aberration Frequency

Calciun and zinc from Rats by Calcium and Zinc ITPA*

Calciur and zinc DTPA* \#Comparison of Bfficiency Calcium Chelate and Penta-Bthyl Bster of DTEA*Pclymeric Calciun DTPA Enhanced Excretion of Plutonium 239 in the Calciun-DTPA (Pentacine) on the Excretion of Plutcnium Calcium, Phosphorus and Nitrogen in Rabbit Bony Tissue Calculative Approaches to Predict In Vivo Behavior* Calibration of a large Area Proportional counter for Californium 249 in Iivers After Intravenous Californium 249 Pollowing Acute Accidental Inhalation* Califcrnium 252*

Cancercgenesis and the Probleu of Restoraticn* Cancercgenic Agents*

Canine Iiver*

Canine lung Following Inhalation of Plutonium Farticles* 000054

Iung Pollowing Plutonium Particle Inhalation*

Canine Iung, 1, Clinical and Gross Pathology*

Cantaninante fron soil surfaces*

Carcincgenesis*

Carcincoenesis*

Carcincgenic Effect of Inhaled Alpha-Active Material*

Carcincgenicity of Inhaled Radicnuclides*

Carcincgenis*

Carcincmas of the Canine Lung Following Plutonium

Cardiac Pacemaker Safety Tests at 1300 Degrees

Cardiac Pacemakers*

Cardiac Pacemakers*

Carrizc Sandstone Aguifer of Scuth Texas*

Cells and Hemodynamics in the case of Inhalaticn of

cells cf the Chinese Hamster Pcllowing Excosure to

Cells After Irradiation with Densely Icnizing Ear

Cells. 6. Alterations in Androgen Biosynthesis $k y$

Cellular Deposition and Retenticn of Plutonium 239

Cellular Risk for Plutonium Farticles in the Iung*

Cenomanian-Turonian) Aquifer in Galilee, Northe

Centigrade and 800 Degrees Centigrade (Source with

Centimeters of 216-2-9 Bnclosed Trench*

Centrifeter for Bapid Analysis of Long-lived Alpha Cerebral and Renal Tissue after the Incorporation of Ceriun 144 Dioxide or Plutonium 239 Dioxide and Cerium 144, Strontium 90 and Plutonium 239 by Man* Cesiua $137^{\circ}$ Inhaled in Fused Aluainosilicate Particles Cesium 137, and Plutoniun 239 in Hay Samples frcm 1953 Cesium 137, and Elutonium 239, 240 in Sandy Loam Soil* Cesium 137, Cobalt 60, Cerium 144, Strentium 90 and Characterization and Distribution in Mouse Tissues cf Characterization and Isotopic Distribution* Americium

Characterization and Eroperties of Medical-Grad

* Characterization of Actinide Bearing Soils: Top Sixty Chelate and Penta-Ethyl Ester of DTPA* Flutoni

Chelating Agents in plutonium reposition--a Mincrity

Chelating Agents
Chelating A gents*
Chelating Agents*

Chelating Agents* of Intramuscularly Injected Plutoniu Chelating Agents: Application by Mass Action Iaws and Chelating Compounds on Tissue Storage and Excretion Chelation and Mixed Complexes--Rapid Experimental and Chelation Therapy*Flutonium and Americiun: Subcutanecus
Chelation*

* Chemical Associations of plutonium $239(+4)$ and

Chemical Engineering Division, Haste Management Chemical Family*

Chemical Form on the Clearance of Plutonium 239 from

Chemical Porms of Radionuclides and Stable Trace chemical state of plutonium on its Barly Retention in
000459 000055
000054 c 0156 000461 000374

0 0162

000225

CO223

CCOO67

000404

$0 \mathrm{CO030}$

000213

000142

000367

000202

000349

000404

00037

000271

000154

000076
000331 000039

000038

000346

000037

CCO055

000316

000391

000285

CCO470

000110

000031

000178

$0<0077$

000379

000217

000316

000316

000398

000336

000270

000139

$\mathrm{CCO} 368$

000025

000418

$0 \mathrm{C0306}$

000368

000129

C CO305

000398

000375

$0 \mathrm{C} 0133$

000082

$0 \mathrm{CO} 236$

000201

C00206

000202

000107
000084

000232

$\mathrm{CCO} 48$

000073

000219

$0 \mathrm{CO} 313$ 
Transuraniun Elements* Biolote iftereffects of Intratracheal Human Lungs*

\#An Improved

Chrcmosome Aterrations Frequency in Liver Cells of the un Monodisperse Plutcnium 239 Dioxide Particles in the of the Transuranuiun Animals with plutonium 239 lung Burdens* \#Distributicn cf Uraniul in the Body After Single and \#Distributicn Cf Uranium in the Body After Single and
the Blood System in Dogs in the Long-Term Feriods after

Radiobiclogy, Annual Report of Work in Progress on the An Annual Report of $W$ crk in Progress on the Seriannual Report cf $W c r k$ in progress on the \#Ioni um-Thori um Index to Nuclear Safety, a Technical progress Review by Radioișo topes* 4 Effects of Zirconiun Deposited Radionuclide Pritium Intake in New York Radiation Sickness in Man*

and Polymeric Plutoni um 239 in the \#Pathogen nd Polymeric Plutoni um 239 in the \#Comparison of Blood
\#A Seven-Year Study of the Pulmcnary Retention and Beagle* of the Rat* \#The Bffect of Chemical FIymph Node \#An Assessment of Alveolar Deposition and Pulmonary Particle-Induced Necplasia of the Canine Iung. 1. Gamma-Ray Eackscatter Technigue* of the Canine Iung. 1 . Collecticn* by Man*

\#Operation Roller Coaster, Froject officers Report, Project 2.3. Fallout and Radiochemical Studies of the Effect of \#Program for Infroved Waste Management in \#A Statistical Summary of 0.S. Atomic Bnergy - A Statistical Sumary of United States Atcnic Energy Descripticn of Atlantic Richfield Hanford Company's New Dioxides Inhaled by Dogs*

on Biochemical Parameters: Effect of Dose and Radionucildes in Beagle Dcgs*

plutonium 239*

Serum Constitctents in Dogs Burdened with Plutonium \#A the organisn*

and Decorfcration as \#Relative Efficiency cf Certain as Influenced by Chelaticn and Mixed

\#Applications of a General Computational Mcdel $\mathrm{fer}$ \#Flutonium Deccrporation by Glucan and Felated organism* \#Relative Bfficiency of Certain Complex \#Maximum Permissible concentrations in hir for Living Organism of *The Action of Chelating * Estimate fer pluorine 1 for Plutonium Administration of Chemically Soluble Plutonium 239 Radiation Doses \#pplications cf a General
Use of a Specialized Analcg Radionuclides* \#Use of a Specialized Analcg

\#On the Binding of Plutonium $(+4)$ to Transferrin and \#The Determination of Iocalized Aerosol Concentration, and Nebulizer suspensicn Distributicn of Plutoniua 239 PuO2 Aerosols, Aerosol * Flutoni um

Sea and ocean Sediments*

Association* \# Maximum Permissible * Ratios of the Average \# Third Internaticnal Compariscn of Serum Transaminase Levels and other Serum Studies $c n$ the Interactions of Flutcnium(+4) with Blood of Serum Transaminase Levels and other Serum \#Development and Testing of cverpack \#Air Sampling Instruments for Evaluation of Atmcspheric \#Long Range Management of Transuranium\#PJutonium

\#The Kinetics of Dose Distribution in the skin in Its (Terrestrial and Soil Invertebrates) Due tc Soil

Progress Refort for the Period of January-June, 1974* of Plutonium 239 in Intact Skin in Its surface and Treatment of Excessive Internal Radicactive in the Detection of Elutonium 239 skin Surface \#A Statistical Sumary of 0.S. Atomic Energy Commissicn \#Piutoni um: Personnel Exposure \# Some Physical and Physiolcgical Factors

Porphyrin Metabolism. 4. The Effect of Irradiation on Thorium and protactinium in seawater and Recent \#Icnium-Thorium Chrenclcgy of the Jacan Sea
Chemical, Nuclear, and Biological Properties of the Chemicaliy Soluble Plutonium 239 compounds* \#Som Chemistry of Plutonium in Relation to Its Behavicr in Chest Fhantom for Studies of Plutonium and Americium Chinese Hamster* and Cytogenetic Effects of Choice of the Beagle for Radiobiologic Studies*

Chromatcgraphy in Orines Containing DTPA* Determination Chromatcgraphy in Orines Containing DTPA* Determination Chromosome Aberration Frequency in Blocd Lymphocytes of Chrcmcscme Aberrations Prequency in Liver Chronic Entry of vranium Oxide-Pentoxide*

Chronic Influence of Ionizing Radiaticn* State of Chronic Toxicity of Inhal

Chronic Toxicity Program*

\#Fesearch on Chronic Toxicity Program* \#Rearch in Radiobiology, Chronolcgy of the Japan Sea ccres*

Chronology. Fermuted Title, and Author Vol. 11, No. 1 citrate in Motilizing Flutoniua in Rat*

Citrate on Early Pemur Uptake and Urinary Bxcretion of City*

Civilian Aspects*

\#Magnitude of

clearance and Six-day Tissue Distributio

clearance of Flutonium from Subcutaneous Hounds in

Clearance of Flutonium from Subcutaneous wounds in

Clearance of Plutonium 239 from the Respiratory Systen

Clearance of Radiopharmaceuticals After Nebulization*
Clinical and Gross Fat tology*

*Plutoniu

Coal Mine Dust Imcombustibles content Analyzer using a

coaster, Project officers Report, Project 2.3. Fallout

cobalt 60 . Cerium 144. Strontium 90 and plutonium 239

collection* Colloidal state of Intravenously Injected Plutonium ci Ccmmercial Nuclear Fuel Feprocessing Facilities*

Commission Contractors " Internal Exposure Experience*

Commission Iicenses' Internal Exposure Bxperience, 1957

Compact plutonium Storage Pacility*

* Comparative Disposition of Pour Types of Plutonium

- Comparative Effects of Plutonium 239 and Americium 241

Comparative Toxicity of Inhaled Beta-Bmitting

Comparative Toxicity of Strontium 90. Radium 226 , and

Comparision of Serum Transaminase Levels and otter

Complex Compounds in the Removal of Plutoni um 239 from

Complexes--Farid Experimental and Calculative

Complexons by Mouth*

Composite Environmental Badiation Doses*

Compounds as a jjuncts to DTPA Therapy*

Ccmpounds in the Pemoval of Plutonium 239 from the

compounds of thutonium $230^{*}$

Compounds on Tissue Storage and Excretion from the

Compcunds*

Compounds* \#Some Pemote Aftereffects of Intratracheal Computational Model for Composite Environmental

computer for the Model of the Metabolism of some

computer Simulation of Water Table*

conalkemin*

concentration of Plutonium 239 in Bone*

Concentration* of Plutonium 239 Puc2 Aerosols, Concentration, and Nebulizer Suspension Concentration* concentrations in the Facific ocean*

Concentraticns in Air for Compounds of plutoniun 239* Concentrations of oranium and organic Matter in Recent Congress of the International Badiation Protection Censtituents in Dogs Burdened with Plutonium 239 ,

Constituents*

Constitutents in Dogs Eurdened with Plutonium 239

constructions Based on Phenolic Foam Walls"

Contauinants*

Contaminants*

Contaminated Solid pastes at Savannah Biver*

contamination from Cne-point Detonation of an $x k-25$ (0)*

Contanination with Radioactive Substances*

Contamination with Strontium 90* of Animal populations

contamination Iimits for Peal and Personal Prcferty*

Contamination Limits for Real and Personal Frcperty,

Contamination*

\#Distribution

Contamination* \#Some Aspects of the Prevention Contamination*of U1tra High Speed Alpha Autoradiography Contractors" Internal Exposure Experience*

control with Increasing Plutcnium 240 Content*

contrclling the Fate of Inhaled Substances. 2.*

coproporphyrin Excretion*

Coral 1 *

Studies of
000033 000298 000269 000288 000377 000031 000182 000045 000284 000284 000030 ccoces 000170 000070 000071 000072 000310 000449 000211 000112 CCO401 000317 000353 000128 000025 000062 000354 000354 000172 000369 (0) $0 \mathrm{co420}$ 00368 000420 000192 000370 000468 0,0438 000008 $0 C 0162$ 000145 000147 $0 \mathrm{CO223}$ 000018 000202 CCOC19 000330 000017 000018 $\mathrm{CCO} 383$ 000206 000022 000269 000330 000127 . $0 \mathrm{CO282}$ 000261 000060 000314 000383 C CO299 000387 000225 $0 \mathrm{CO222}$ 000223 000437 000340 CCO459 cco 459 $0 \mathrm{CO} 471$ CCO 168 000124 000414 000413 000080 000350 0,0361
000370 0 C0448 000348 $\mathrm{CCO} 203$ 000416 000310 
PER MUTED INLEX OF TITIF

of Uranium Fissicn with Resorftion Thereof "Changes in \#reliminary Report: Changes in Vascularity of of Plutonium 239 in the \#Pilot Study of the Effect cf Bmitters* \# Eeview of the Natural Resources [efense *calibration of a Ire irea Prcrerticnal Alpha-Eaitting Plutcnium in Urine Using a Solid-State \#observed Fallout Patterns a n \#Whole Eody \# Total Body Garma-Pay

\#Administration of an In Vivo 241 in Piological Materials by Gel Scintillaticn \#Environmental Monitcring Report for Eantex plant \#The Metabolism of the Radioactive Element Moxicology cf Transfortable Uranium: of Total-Bcdy Radioactivity in Man: A Historical and 239 Dioxide \#Early Listribution, Retention and * Effect of

Protection Agency's Nevada Test Site Experimental \#Remcte Aftereffects Asscciated with \#Some Aspects of Thyroid and Parathyroid \#REmote Sequelae of Radiaticn \# Remote Aftereffects of Fadiation \# Remote Aftereffects of Fadiation
"Fossible Therapeutic Agents for Radiaticn plutonium 239 in \#Comparison of Blocd Clearance and SixWaste Management Programs Quarterly Repcrt, Octcher\# Offsite Surveillance Around the Nevada Test Site, JulyHan for d*

Frogram, 80th Meridian Network, January thrcugh

Complexes--Fapid

Adjuncts to DTPA Therapy*

\#Radioelement Metabolism an

Effect of DTPA and

Deposited Radicnuclide Prctlem Based on Future OsageInsoluble Alpta

\#A Review of the Natural Resources Safety Iests at 1300 Degrees Centigrade and 800 with \# Isoto fic Cardiac Pacemaker Safety Tests at 1300
and fefair in Yeast Cells After Irradiation with Localization and Quantitation cf Articles Acid* \# Removal of DTFA-Effectiveness in Removing Internaliy \# Some Toxicity Asfects \#Long-Term Effects of Therapeutic Removal of Internally \#Interpreting Ccunting Data for Internally Defense Aspects* \#Oral Therapy for \# Magnitude of *Internali of Androgen Biosynthesis by Canine and Trends in Therapeutic Removal of Internaliy * Ccmparison of Hematologic Effects of Internaliy Fission Froducts Inhaled as Aerosols ky Rats and Man* Radiopharmaceuticals After * Cellular to the Induction of Neoplasms* Plutonium Beagle* * Some Observations of the \#Tumors in vice After Pulmonary \# Tumors in \#) Cumcrs in Mice after Pulmonary Nuclear Detonations: Source, Transport, Diffusicn, and *Chelating art, Diffusicn, a nd and Treatment of Individuals Who Have Excessive Detectors*
Cesiume Determination of the
137 , and Plutonium 239, 240 in Sandy Ioam Soil* Cesium 137 , and Plutonium 239,240 in Sandy Ioam Soil*
Scattering Measurements of Aercscl Suspensicn in a Scattering Measurements of Aercscl susfensicn in a \#Prevention of Plutcnium Deposition ty

Han ford company*

\#Human Element

Large Area Eroportional Counter for Plutonium 239 x-ray of vltra High Speed Al pha Autoradiography in the \#Advances in Physical and Eiclogical Radiatic Depth and Amount of Plutonium 239 in Wounds with SI (II) Substances*

\#iffects of

by Micaceous Vermiculite and Its Weathering Products * Plutonium Ccntamination from Cne-Pcint

\#Radio activity Released frcm Underground Nuclear Plutcnium Nitrate (Plutonium 239) * \#Tumors

Tumors Radioactivity in uan: A $t$ the Bxcessive Depcsitions of Radioisotopes* \#Early
and Course cf \#Bffect of N, N, N, N, -Tetracetic 2, 2 ,
Poly Polypropylenoglycolethylene oxide Polymer cn \#Rffect cf of Plutonium 239 Nithin \#The Bffect of Treatment with
Intratracheal Adinistration of
Correlation Between Isotopes in a Mixture of Prcducts Cortical Bones Induced by Bone seeking Radicnuclides* Cortiscl on mrisodium Calcium CIPA Enhanced Excretion Council Meeting. Biology Secticn, January 16, 1945* Ccuncil petition Concerning Limits for Insoluble Alpha ccunter for Elutonium 239 x-ray Detection in Lungs* counter* \#A Procedure for the Determination of Countermeasures Iaken*

Counting of Flutcnium in Bats*

counting of plutenium $23 \mathrm{c}$

Counting Data for Internally Leposited Plutcniur*

Counting Program*

Counting* of Plutcnium Alpha Activity and Plutoniun Covering $1973^{*}$

Created by Nuclear Fission

Critical Contribution to Health Protection of Hcrkers* Critical Review* Cytogenetic Effects of 0.3 um Monodisperse Plutcnium raily Injections of Flutcnium 239 on Rat Bones* Lairy Ferd, January 1, 1969-December 31, 1970*

Damage by Transuraniun Elements*

Camage Due to Americium $241 *$

Lamage *

Lamage*

day Tissue Distribution cf Monomeric and Polymeric

ecember 1973* \#Chenical Engineering Divisicn, Lecember 31, 1970*

ecemt $\in \mathrm{r}, 1970^{\circ}$

Lecember, $1970^{*}$ \#Chemical Engineering Divisicn,
Frctection Agency's Nevada \#Surface Air Samplin

\# Cecontamination of obsolete Processing Pacilities at

* Lecontamination of Plutonium-Contaminated Glove Eoxes*

Lecontamination of Soils Containing Pission Products*

recorpcration as Influenced by Chelaticn and Mixed

Decorfcration by Glucan and felated compounds a

Decorpcration of Monomeric Plutonium in the Beagle Dog* Lefens $\epsilon$ Aspects*

Defense Council Fetition Concerning limits for

Iegrees Centigrade (Source uith Internal Pressure and a Degrees Centigrade and $8 C 0$ Degrees Centigrade ISource

Iensely Ionizing Particles* \#Recovery

Ceoxyritonuclease Acitivity in Rabbit liver Affected by Leoxyilonuclease Acitivity in Rabbit \#ver affected by Leposited Plutonium by ? riethylenetetranine Hexacetic Deposited plutonium from Humans*

ceposited Flutonium 239*

Ieposited Plutonium*

Deposited Plutonium*

Leposited Plutonium*

Leposited Radionuclide Problem Fased on Future Usage-reposited Radionuclide Problem Eased cn Future Osage-Deposited Radionuclides and the Subseguent Alteration reposited Radionuclides*

Leposited Radium and Plutonium in Dogs*

Deposition and Fate of Plutonium, Uraniua and their Deposition and Pulmonary Clearance of

Leposition and Retention of Plutonium 239 in Relation Deposition by Desferrioxamine-F*

Deposition of Americium 241 in the Thyroid Gland of the Deposition of Radioactive Particles*

Deposition of Radioactive Farticles* Leposition ef Some Radionuclides* Androgen Biosynthesis Deposition* \#Fadioactivit

Leposition--A Minority View*

Lefositions of Radioisotopes* \#Early Diagnosis Lepth and Amount of Plutonium 239 in Wounds with SI(II) repth ristribution of Global Fallout Strontium 90 Desert Area*

Lesferrioxamine-B*
lesign of Filter Plenum Heat Bxchangers*

Design Considerations with Glove Boxes at the Atlantic

retection and Bvaluation of Vranium Bxposures* Letection in Iungs*
Letection of plutonium 239 skin surface Contaminaticn*

Letectcrs*

\# The Determination of the Ietergents on Skin and on the Abscrfticn of Radioactive Determiation of plutonium for Radiological Furfeses* Letermined by Electron Microscopy and Radiochemical Letonation of an XW-25 (U) *

Detonations: Source, Transport, Diffusion, and

Detonations: Source, Transport, Diffusion, and Develofing in Rats after Intraperitoneal In Diagncsis and Treatment of Individuals who Have ciamincdiethylsulfide on Excretion of uranyl Nitrate Liethylenetriaminepentaacetic Acid and riethylenetriaminepentaacetic Acid on the Distribution riethylenetriaminepentaacetic Acid Following
CCO1C5

000005

000179

000384

000349

000291

000452

000432

CCO460

000408

000307

000089

000347

000182

000210

$0<0152$

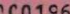

$0<0196$

00749

$0 \mathrm{CO} 128$

0481

$0 \mathrm{CO} 210$

000396

000427

000459

$0 \mathrm{CO} 296$

000017

000130

000319

000384

000316

000316

000178

000117

000013

c.0243

$0 \mathrm{C0015}$

000319

000317

000076

000049

000069

000204

000354

000379

000212

000226

000251

000250

000077

000419

000375

000366

000306

000334

000212

000450

000446

000393

000349

000361

000341

000240

000424

000285

000285

000302

000419

$0 \mathrm{CO040}$

000392

$0003 \in 6$

$0 C 0100$
000255

000255
000238

000020 
in a Preshwater Ecosysten: Phase 2, Implications of Undergrcunations: Source, Transpcrt,

Bxcretion of Flutonium*

\#Effect of Internal Bnitters on Iiver Tumor and Anericiun Subcutaneous hdainistration of luchedis : Sulcutancous adilinistration of Plutoniu After Inhalation of Cerium 144 Dioxide or Plutcnium 239 Plutonium 238 \#Toxicity of Inhaled Plutonium 238 Hain sters. $2 . *$ \#axicity of Inhaled Plutonium 23 and Pulmonary Lesions After Inhalation of Cerium 14 the Iung Burden Resulting from Inhalation of Elutoni \# Fxcretion and Translocaticn of plutonium 239 Fffects of 0.3 um Monodisperse Plutorium 239 *Retenticn, Distribution and Bxcretion of Plutonium 239 in Beagle Logs. A. Monodisperse 1.5 un Plutonium 238 Dioxide Farticles. B. Monodisperse 3.0 um Plutonium 238 \#Distrikuticn and Toxicity of Inhaled Elutonium 239 Turonian) Acuifer in Galilee, \#Dranium 234 /Uranium 238 Support of Field operations Associated with Hidesfread Support of Field operations Associated with in Soils: The Importance of Bxchange and High Initial
\#Summary of the Study of \#Summary of the Study of
Literature* \#Radioactive Waste Prccessing a n by Dogs* \#Ccm rarative cf in vitro Petoplacental Onit of the Rat* of mime*

Sub jects

\#Plutonium Farticles Labeled with Yttertium 169 in the \#Retention, "Bffect of 2, 3-cinercaptceropanol (BAI) CPCn of Zirccnium and other Metals on Plutonium and Yttrium Dioxide*

\# Regularities in $t$ he
utonium on Its Barly

the Physical-chemical Radioactive Substances*

\# The Kinetics of Dose State cf Intravenously Injected Plutonium on It Related to the Properties of the Administered Salt* Related to the Properties of the Administered Salt*
137 , and plutcnium 239, 240 in Sandy Ioam Soil* \#Dept Sarccma in Various species*

in \#Ccmparison of Blood clearance and six-day \#iss in \#Ccmparison of Blood clearance and Six-day Tissue Administration of Plutonium $[$ icxide and the Effect $\#$ The
occupaticnally Bxposed

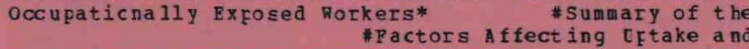
Preliminary Analysis of Reported Data* \#Th Surface contamination*

Concentraticn, and \#Relationships Between the Size with Diethylenetriaminepentacetic Acid on the in Beagles* \#Skeletal Retention an

Chrcnic Entry of oranium oxide-Pentoxide*

\#Anatom ical

Liver Cells of the Chinese \#he Effect cf Microdose 241 in Beagles: Biolegical rffects and Skeletal

phase 1. Iimnological Characterization and Isotopic um Monodisperse Plutonium 239 Dioxide Particles \#Earl from $t h \in$ Envircnment to the Human Body in the Niigata october-Lecem rer 1973* \#Chemical Bngineering

\#Removal of Inhaled Americium 241 from the Beagle on Decorporation of Monomeric Plutonium in the Beagle

in Fused Aluminosilicate particles by the Beagl \#Plutonium Inhalation Studies. 4. Mortality in "Plutonium Inhalation studies. 4. Mortality in of the Functional state of the Blocd syste in \#Serum Transaminase Levels in Beagle

rransaminase Levels and cther Serum Constituents in Transaminase Levels and other Serum Constitutents i \# Toxicity cf Inhaled Plutcnium 238 Dioxide in Beagle of Inhaled El utonium 239 of Varied Sclubility in Beagle *Chronic Toxicity of Inhaled Flutcriua in

for Dosed Administration of Radioactive Rerosols to Radiaticn from Simulated Flutonium 238 Pover sources in of Pcur types of Plutonium Dioxides Inhaled by Effects of Internaliy Deposited Radium and Plutcnium in Phosphatase and osteosarcoma in Plutonium 239 Burden ed Phosphatase and Osteosarcoma in Plutonium 239 Eurden
of Moncdisperse Plutonium 238 Puo 2 Aerosols in Beagle Fracticns in Radium 226 and Plutonium 239 Injected Polymer cn Fxcretion of Inhaled Plutoniun 239 Fuo2 in Dosage of Radium 226 and plutonium 239 in the Bones of Lifferences in Iransuranic Isctopic Ratios* Americium
Diffusicn, and Deposition* \#Radioactivity Released frct Iigestive Tract* Isotopes in a Mixture

Digital Computer Simulation of Water Table*
Cimercaptopropanol (BAI) Upon Listribution and [i methylaminoarcteur $\in$ nce*

Dioxide and the Effect of Chelation Therapy* Elutoniu cioxide and Fvaluation of In Vitro Dissolution" rioxide and Subsequent Influenza Virus Infection in cioxide in Eeagle Logs. A. Monodisperse 1.5 um Lioxide in Imature, Young Adult and Aged Syrian Dioxide or Elutonium 239 Dioxide and subsequent rioxide with the Help of Separation analysis* lioxide After Inhalaticn* rioxide Particles in the Chinese Hamster* Cytcgenet Dicxide Particles. B. Monodisperse $3.0 \mathrm{um}$ Plutcnium 238 Lioxide Particles. 1.*Monodisperse 1.5 um Plutcnium 238 rioxide*

Dioxides Inhaled by Dogs*

Disequilibrium in waters of the Judea Group (Cenomanianrispersion of plutoninm* \#Bioassay Experiences i

risposal of Nuclear Waste Intc Space*

Cisposal, An Annotated Bibliography of selected risposition of Einsteinium Nitrate Es(NO3) 3 in Rats Lisposition cf Four Iypes of Plutonium Dioxides Inhaled Iissolrtion* of Monodisferse Respiratle

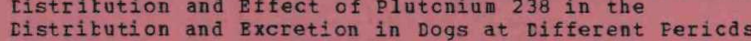
iistritution and Excreticn of Plutonium in Two Huma ristrifution and Excretion of Flutonium 239 Dioxide ristrikution and Excretion of Flutonium*

Listritution and Excreticn* \#?he Action cf Salt

ristribution and Toxicity of Inhaled Flutonium 239

Distribution and Toxicity of Badioelements*

istritution in the Liver* \#The Effect of cistribution in the skin in Its contamination with ristritution in Bone and Marrcw*the Bffect of Cclloidal ristrikution in Mouse Tissues of Graded Polymeric and

Cistritution of Americium 241 in the $P$ at organism, As

listrifution of Global Fallout Strontium 90. Cesium

Distribution of Interral Radiation-Induced Cstecgenic istritution of Iarge Atmospheric Particles*

ristritution of Monomeric and Pclymeric Plutonium 239 Distritution of Flutonium and Americium: Subcutaneou Distritution of plutonium in the missues of

istritution of plutonium in Barley and Soybean plants* Distribution of Flutonium in Human Tissue:

cistritution of Plutcnium 239 in the Animal organism

Iistribution of Flutonium 239 in Intact Skin in Its ristribution of Plutonium 239 Puo2 Aerosols, Aerosol Distribution of Flutonium 239 Nithin the Pemur c

ristritution of Polymeric and Mcncmeric plutoniun 239 Listritution of Fadiation-Induced Fractures in Eeagles*

Iistribution of oranium in the Body After Single and ristritution on Chromosome Aberrations Prequency in Distribution*

\#Americiu

ristribution* and Americium in a Freshwater Bccsystem

cistritution, Retention and Cytogenetic Effects of 0.3
ristrict, Northern Japan* of Radioactive Nuclides

Livisicn, Waste Management Programs Quarterly Eeport,

Log by Iung Iavage: A Filot Study*

$\log *$

Dog*

Toxicity

Dog* Retention and clearance of Cesium 137 Inhale logs after Inhalation of Plutcnium $239 \mathrm{PuO2}$ *

cogs after Inhalation of Elutonium 239 Puo2*

Logs at Different Pericds of Time*

Dogs in the Long-Term Periods after Chronic Influence

Dogs Eurdened with Flutonium 239*

Logs Eurdened with P1utonium 239, Thoriun 228, Eadiu

logs Brrdened with Flutonium 239, Thorium 228, Fadiu

Logs. A. Monodisperse 1.5 um Flutoni um 238 Lioxide

cogs. 2.* Lavage and DTPA Treatment for the Femoval rogs*

Logs*

Logs*

Dogs*

\# A Technique

* Comparative Toxicit

*Biological Effects of

* Comparative Disposition

Logs*

Dogs*

Logs*

Logs*

Dogs* \#Relationship Between Serum alkalin \#Short-Term Metabolism of Three Sizes In Electrophoretic Study of Serun protei acid and Polycropylenoglycolethylene oxide ogs* Ipreliminary Observations on the Pharmacodynamic rogs*\#Autoradiography in the Iccalization and Radiaticn
000304

000419

$000 C 27$

00030

$\mathrm{C} 0114$
$0 \mathrm{C} 0141$

000107

$\mathrm{CCO} 029$

000139

000140

000139

0 C0 374

000012

000182

$0 \mathrm{C} 0126$

000140

$0 \mathrm{CO} 140$

$0 \mathrm{C} 0267$
000008

000332

000465

$0 \mathrm{CO} 307$

$\mathrm{CC} 0480$

000475

000214

000008

000029

00006

000198

C 0372

00011

CCO26

000267

000150

000033

000168

000192

000129

COO 306

C00306

$\mathrm{C} \mathrm{C} 0324$

$0 C 0324$
000128

000107

$0 \mathrm{CO} 356$

000274

000376
000078

000080

0 00060

000238

000220

000242

000085

000039

000136

000305

000182

00037

000481

000157

000395

000025

000009

00011

0 0198

000026

000221

000225

00022

000140

000156
$0 C 0170$

000143

000145

cc0109

000008

00006

000148

000148

000255

0,0255
000010

C00004 
on Biclcgical Behavior After Inhalation by Beagle Dogs**Autcradicgraphy in the Iocalization and Radiation Ionizing Fadiations* "Interactions cf Tctal and Americium 241 on Biochemical Parameters: Bffect of Number of * The Estimation of Internal Radiation

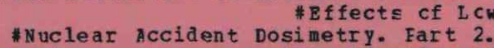
Radioactive Sulstances* \#The Kinetics Rates frcm Flutonium 239 in the Beagle As a Function of Mammalian Species*

\#adiations*
Puncticn of Dcse \#Comparison of Skeletal and Hepatic Radioisotope Fowered Cardiac Pacemakers*

Injection of Elutonium*

* Radiation \#A $T \in c h n i q u e ~ f C I$ * Radiaticn

Mcdel for Composite Environmental Radiation of Radioactive Pission Products of Uranium 235 in LCW \#Special Froblems in Radiation Safety and Sanitary the Iung*

* An analysis ce

is keletal

\#Nuclear Accident *Prcgress in Fersonnel Neutrc Program: an Overview with Bmphasis on Bnvironmental the Human Organism* \#The Effect of Sodium Calciumin the Beagle rog* Bffect cf

Study of the Effect of Cortiscl cn Trisodium Calciu Stimulation and Long-Term. Intermittent by Glucan and Related Compcunds as Adurcts to of Varied Sclubility in \#ronchopulmonary lavage and Removal of Plutonium frco Mice by Encapsulation of with the Calcium Chelate and Eenta-Ethyl Ester cf

by Extraction Chrcmatography in Urines Containing Plutcniu i frol 8 umans*

"Coal Mine Plutchian fro thans*

*A Case of Inhalaticn of Enriched Urani un Growth Bate* Excessive Depcsitions of Radicisotopes*

of the Physical-Chemical State of plutcnium on Its of 0.3 u m Mcncdisperse olutonium $23 \mathrm{~g}$ Dioxide Particles Radicisotopes*

inffects of zirconium on Radioiso topest

* Effects "Ef ects of Zirccilui cn of the Physical-Chemical State of plutonium on it Preshwater Fccsystem: Phase 1. Iimnolcgical of \#The Preshwater Ecosystem: Phase 2, Implications of ithe Nuclear Fuel Cycle \#Fmirical Benefits Derived from a

Behavior cf Flutonium and Americium in a Freshwate Behavior cf plutonium and Americium in a Preshwater Plutcnium from Humans*
Pollowing Intratracheal Administration of Flutonium* \# DTPA-

in Removal cf Polymeric plutonium frcm the Mouse Liver* Pacility Sites*

Mradicactive

Prediction of the Mesoscale Transport of Atmosphere Intramsucular and Radionuclide Eurdens*

Vermiculite and Its weathering prcducts Deterwined by Particles*

Radium $22 \epsilon$ and Plutcnium 239 Injected Dogs*

Acute Accidental Inhalation*

Vivo Lung Washeut*

Retention A A

\# An
a nd

Centriceter for Bapid Analysis \#Dosimetry of Alpha Dimethylaminoarobeurence*

of Long-Iived Alpha

Lymph Node Involvement Pollcuing Inhalation of Alpha Council Petition Ccncerning Iimits for Insoluble Alpha \# A Procedure for the Determination of Alpha\#Ccmparative Toxicity of Inhaled Feta\#Toxicity of Inhaled Alphas Envircnmental Monitoring Program: An Cverview with to Environmental Monitoring of a Nuclear Puel Cycle \# Improved Removal of flutonium from Mice ky Eearing Soils: Top Sixty Centimeters of $216-2-9$ of Internal pxposure Hazards for Several Biosynthesis ly \#The Effects of Ionizing Radiations on
\#Study of the Bffects of daditicnal Bxperience* \#A Statistical Summary of U.S. At cmic * A Statistical Sumary of Dnited States Atcmic \#onitoring of Low \#Uarterly Feport, October-December $1973^{*}$ \#cok on Atcmic
\#Chemical
Dogs*Flutonium 238 oxide in Water suspension and $E f f \in c t$ cosage of Radium 226 and Plutcnium 239 in the Ecnes of Dose and Dose Rate in Determining Tissue Responses tc rose and Radionuclide Burden Time* of Plutcnium 23 Dose from Metabolic and Urinary Excretion Data for a cose cf Radiation on the Living Body*

Lose Assessment Procedure*

Dose Distribution in the skin in Its Contanination wit rose $I \in v e 1 *$ \#Comparison of Skeletal and Hepatic DCs Lose Measurements from Skeletal plutonium Compared in Dose Fate in retermining Tissue Responses tc Icnizing Dose Rates from Plutonium 239 in the Beagle As a

Dose-tc-the-Fopulation Estimates for Use of

cose-Rates Near Bone Surfaces in Rabbits after an Ccsed Aministration of Radioactive Aerosols to Dogs* coses from Iodine 129 *

Coses* \#Applicaticns of a General computational Doses*Cerebral and Renal Tissue after the Incorforation Losimetric Monitoring when Working with Transplutonium cosimetry and Cellular Risk for plutonium Particles in cosimetry and Cellular Ris

Losimetry in Otah Beagles*

cosimetry. Eart 2. Dose Assessment Procedure* rosimetry*

Dcsimetry*

Iaboratory's Environmental Monitoring DTPA and Glucan on Decorporation of Monomeric Flutonium DEFA Enhanced Excretion of Flutonium 239 in the ITPA Therapy in Poisoning by Polymeric plutonium*
DTPA Therapy*
\#Plutonium Decorforation *Plutonium Decorforation IPA Treatment for the Remcral cf Inhaled Plutcnium 239 DTPA* Folym Liposomes* LTPA* Fapid Determination of the Transuranuium Elements DTFA*\#CCmparison of Pfficiency of Removal of Plutonium , DTPA-Effectiveness in Femoving Internally Deposited

Iust Imcombustibles content Analyzer Using a Gama-Ray Dust Sawpling*

cust*

Dynamics of the Flutonium 239-Induced Osteosarccmas

Farly riagnosis and Treatment of Individuals Who Have Early ristribution in the Liver* \#The Effect

Farly ristribution, Retention and Cytogenetic Effects Early Feaur optake and Urinary Excretion of

Early Fenur uptake and Urinary Excretion of

Farly Fetention in plasma and selected Soft Tissues cf Ecological Behavior of plutonium and Americium in a Fcological Eehavior of Plutonium and Americium in a Ecological systems*

Ecosystem Approach to Environmental Mcnitoring of a Eccsystem: Phase 1, Iimnological Characterizaticn anc Fcosystem: Phase 2, Implications of Differences in Fffectiveness in Femoving Internally Deposited Fffectiveness of Diethylenetriaminepentaacetic Acid Effectiveness of Tritium*

Fffectivenss of Different Therareutic Regimes of Glucan Ffficient Way to Analyze Bcne Affecticns*

Fficient Way to Analyze Bcne A fecticns* Effluents: Philosophy and Morphology of Experimental Effluents: Philosophy and Morphology of Experimental
Finsteinium Nitrate Es (NC3) 3 in Rats After Intravenous, * Flectrccardiogram Evaluation of Beagles with Retained Flectrccardiogram Evaluation of Beagles with Retaicroscopy and Padiochemical Analysis*

Flectrcn Micrcscopy and Padiochemical Analysis* Flectron Microscofy of Aerosols Containing Fadicacti

Elimination of Berkelium 249. Californium 249 Fcllowing Elimination of Inhaled Elutoniou oxide Particles by In Faissicn Monitoring Sy

Emitters in the Iung

Emitters on Liver Tumors Induced by Emitters*

\#A Single

\# Beview of the Natural \#racheotronchial Emitting plutonium in Drine Dsing a Solid-state Counter*

Fmitting Radionucildes in Beagle Dogs*

Emitting Radionuclides--An Bxperimental Approach*

Emitting Soft Eenetrating Radiation*

Emphasis on Environmental Dosimetry* Encapsulation of DiPa Within Ii

Enclosed \#Characteri

Iaborator Fncountered in peactor operations*

Fndocrine cells. 6. Alterations in Androge Endogenous Heat*

Fnergy Commission Contractors' Internal Exposure

Energy Commission Iicenses' Internal Exposure

Energy $x$-Ray Fadionuclide content in fuman Body*

Energy*

Engineering Division, Waste Management Programs
$0 \mathrm{C} 0171$

$\mathrm{CCOOOL}$

000167

$0 \mathrm{C} 0162$

000355
000239

$\mathrm{C} 00405$

000168

$\mathrm{CCO} 227$

000385

000167

OC0227

000391

000024

000143

$0 \mathrm{CO} 278$

000330
000270

$0 \mathrm{CO} 453$

000217

000144

000344

000405

$0 \mathrm{CO} 411$

000415

000367
000130

000005

0 C0194

000017

000156

000193

000142

$\mathrm{CCO} 284$

000213

$\mathrm{CC} 0365$

000427

000976

000366

000033

$\mathrm{C} C 0182$
$\mathrm{OC} 0113$

000112

000112
$0 \mathrm{C} 0231$

000305

000304

C $\mathrm{CO} 309$

000429

CCO 305

000365

000365

000155

0 0190

000352

000322

$0 \mathrm{CO} 312$

000214

$0 \mathrm{C0248}$

$\mathrm{CCO} 433$

000087

000371

000166

000410

000344

OCO336

00141
$C C 0380$

000384

000291

000145

000095

c 0339

000415

000429

OCO193

000398

000254
$C C 0077$

000098

000370

000468

C CO4C6

000434

000481 
PER IIOTED INDEX OP TITIE

of the Fffect of Cortisol on Trisodium Calcium DTF of oranium in the Body After sing Inhalation of Biological Action of Plutonium Upon the Rhyth of It Mechanism cf Iransfer of Radioactive Nuclides from the \# Badionvclides in the

Mcnitoring Program: An Overview with Emphasis on * Studies of Flutonium, Americium, and Uranium in

Benefits Derived frcm an Bcosystem Approach to Buph asis on

Experimental Lairy Herd, January 1, \#Status of the $0 . S$. of a General computational uodel for ccrposite * Brrata: Annual Feport:

Plutoniu in Relaticn to Its Behavior in Biological an Reactor Testing Station \#Plutonium in the Terrestria

the Bffects of Americium 241 and Elutonium 239 on Serum

\#The Biological Disposition of Einsteinium Nitrate

acemakers*

\#Dose-to-the-Fopulation

and Vrinary Excretion Data fcr a Number of

\#T he

by Ccmbined Therapy with the Calcium Chelate and Penta\#Pathogenetic Classification and Basic

\#Barly riagnosis and Treatment of Individuals who Have

\#Scme Aspects of the Frevention and Treatment of

After In halation*

The Action of Chelating Compcunds on Tissue Storage and Strontium $9 C$ and Plutonium 239 by Man*

Acid and Folypropylenoglycolethylene oxide Polymer cn

Lung Model* The Distribution and \#Thecretical

*The Effect of Sodium Calcium-DTPA (Pentacine) on the Bffect of Cortisol on Trisodium Calcium DTPA Enhance with Ytterbium 169 in the \#tetention, Distribution and of 2,3-Diuercaptopropanol (EAI) Upon Distribution an Immediate Measures Against Injury by \#Acceleration \#Bffects of Zirccnium on Farly Pemur Dptake and Erinary

of zirccniom Citrate on Early Femur Uptake and Urinary of N, N, N, N, - Tetracetic 2,2i-ciaminodiethylsulfide on of Radioactive \#Bxcretion Methods. The Application of of Internal Badiation Dose from Metabolic and Orinary analyses to the Letermination of Body Burden of

4. The Effect of Irradiation on Coproporphyrin other Metals on Plutonium and Yttriug Distribution and Studies of Plutcnium Preject Personnel. Bffect cf tomic Bnergy Commission Contractors' Internal Exposure \#Sampling of Soils for Radicactivity: Philcsothy.

Atcmic Bnergy Commission Iicenses. Internal Exposur With Widespread Dispersion of Plutonium* \#Bioassay \#Incineraticn Process Pire and

\#A Basis for Routine Orine Sampling of Workers

of Flutonium in the Tissues of occupationally

of $L C W$ Crinary Plutonium levels in occupationally

tThe Het Particle pringer

\#Effects of High-Ievel Gamma Project.

in Iiver Cells of the Chinese Hamster Fcllowing \#Biological Bffects observed with Combined * Frompt Mitigatcry Acticn After Accidental \#Plutoniur: Personnel *An Assessment of the Long-Tern of U.S. Atomic Energy Commission Ccntractors' Internal States Atcmic Energy Commission Iicenses' Internal

in Reactor cperations* \#Evaluation cf Internal

Pattern Upon Hazards Evaluat in the Rhesus Monkey After a Single Acute Inhalatic * Letection and Evaluation cf orani u solvent

Rapid Determination of the Transuranuium Elements by \#Decontamination of cbsolete Frocessing * Emission Monitoring systems for plutonium Managenent in Commercial Nuclear Fuel Feprocessing Effluent Beleases and the Purlic Acceptance cf Nuclea \#In-Residence Health and Safety Support in a plutoniu \# Health Physics at the Ics Alamos "Wing 9 " Hot-Cel Hanford Company's New Compact Plutcniuu Storage Filler Coaster, Project officers Beport. Froject 2. 3.
Enhanced Bxcretion of Flutonium 239 in the Eeagle*Study Enriched Uranium Dust*

Entry cf Uranium oxide-Pentoxide*

ntry Into the organism* * Dependence of the nvi rcnment*

Envircnmental Aspects of Nuclear Power Stations*

Envircnmental Behavior and Radiation from Iodine 129*

Environmental Dosimetry*

Laboratory"s Envircni29*

Environmental Matrices*

Envircnmental Monitoring for Nuclear Installaticns*

Environmental Monitoring of a Nuclear Fuel Cycle

Envircnmental Monitoring Program: An overview with

Environmental Monitoring Report for Pantex Plant

Envircnmental Protection Agency's Nevada Test Site

Envircnmental Fadiation Doses*

*Applicaticns

Envircnmental Surveillance Around Nuclear Installaticns* invircnmental Systems*

Environmentally Related
Envircns of Rocky Flats*

Enzymes*

\#T he Chemistry of

\#reliminary Comparison of

(NO3) 3 in Pats After Intravencus, Intramsuciar

ster ef DTPA*Polymeric Plutonium from Mice by Combined

Fstimate for Pluorine 1 for Plutonium Compounds*

Stimates for Use of Radioisctcpe Powered Cardiac

thyl Fster of DIFA* of Polymeric plutonium from Mic

Etiolcgical Pactors of Radiation Sickness in Man*

xcessive Depositions of Radioisotopes*

Excessive Internal Radioactive Contanination*

Exchangers*

Excretion and Translocation of Plutoniura 239 Dioxide Excreticn from the living organism of Radioyttrium.

Excretion in Dogs at Different Periods of Time*

Excretion of Cesium 137. Cabalt 60, Cerium 144,

Excreticn of Inhaled Flutonium 239 Fuo2 in Dogs*

Excretion of plutonium in Two Buman Subjects*

Excretion of plutonium in Urine Based cn the New ICBF

Excretion of plutonium 239 from the Human organism*

Excretion of plutoniul 239 in the Beagle* Study of the

Excretion of Elutonium 239 ricxide Particles Iakeled

Fxcreticn of plutonium*

Excreticn of Radioactive Isctopes, Evaluation of Some

Excretion of Fadioisotopes*

Excretion of Radioisotopes"

Excreticn of Uranyl Nitrate and Course of Uraniug

Excretion Analyses to the Determination of Body Burden

Fxcretion Data for a Number of Important Radionuclides

Excreticn Methods. The Application of Excretion

Excretion*

Application of Excretion

The Apolism. Excreticn* \#he Action cf Salts of Zirconium an
Exercise of Ieukopenia, A Statistical Analysis*

Ixercise of

xperience, and Eesults*

Experience, 1957 - 1966* Sumary of United State Experiences in Support of Field operations Associated

Explosicn Protection*

Exposed to Plutonium 239*

Exposed Workers*

\#Sumary of the Distrifution Exped Workers*\#Sensitive Method for the Determination Exposure from the Ha

Exposure of Animals*

Exposure to Flutonium 239 FuO2 or Plutonium 238 PuO2

Exposure to Radiations*

Exposure to Radionuclides*

Fxposure Control with Increasing Plutonium 240 content* Exposure Due to Resuspension*

Expcsure Experience*

\# Statistical summary

xposure Experience, 1957 - 1966* Sumary of United

Exposure Hazards for Several Radioisotcpes Encountered

Exposure* of Aerosol properties and the Resfiratcry Exposure* Dioxide Particles Labeled with Ytterbium 165 Exposures*

Extensicns to Man of Animal Risk Data on Plutenium* Extraction of Plutonium with Primary Amines*

Extraction Chromatography in vrines containing DMPA*Ihe Facilities at Hanford*

Facilities*

Facilities*

Facility Sit

\#Program for Improved Waste

Facility*

Facility*

$\begin{array}{lll}\text { Fallout Collection* } & \text { \#Operation cCO420 } \\ \text { Fallout Patterns and countermeasures Taken* } & 000452\end{array}$

\#Description of Atlantic Bichfield

$\begin{array}{lll}\text { Fallout Collection* } & \text { \#Operation cCO420 } \\ \text { Fallout Patterns and countermeasures Taken* } & 000452\end{array}$

000005

CC0373

000085

$0 \mathrm{CO} 378$

000303

000320

000329

000415

000273

000400

000429

000415

000210

000330

000426

000425

000288

000325

$0 \mathrm{C0323}$

000426

000214

000142

000022

000391

000355

000142

000353

000366

OCO350

000450

000012

00020

$0 \mathrm{C} 0198$

00036

000255

000372

000423

000367

000005

000126

CCO114

000028

OCO113

000112

000100

CC0 357

000357

000357

OCO203

000266
$0 C 0360$

o $037 \mathrm{C}$

000409

000468

000465
$0 \mathrm{CO} 444$

000345

000356

OCO295

000359

000002

c 0403

00039

$0 \mathrm{CO} 448$

$0 \mathrm{CO} 435$

000370

c 00468

000253

C $C 0126$

000393

C 038

000283

00028

000410

$0 \mathrm{CO} 478$

000322

000470

000438

000452 
through Septemter 1, 1974*

240 in Sandy loam Soil* \#Depth Distributicn cf Glcbal The Nature and Pehavior of Lccal \#Metarolic Characteristics Mithin a chemical Physics Frcgram at the Nevada Test Site Experimental Inplanted Into Rabbits and Rats*

some Physical and Physiclogical Factors controlling the Inhaled as Aerosols by pats and Man* \#Deposition and \#P1 asma

Acid on the Distribution of Plutonium 239 Within the \#Effects of Zirconium Citrate on Early Effects of Zirconium on Early on the Exchange of plutonium 4 istritution and Effect of Plutonium 238 in the of Plutcrium* \#Bioassay Bxperiences in Support of \#Eiological Studies Associated with a

for Fredicting the wind and Potential Radiological \#Test Methods and Bfficiency Studies on Multi-Bank HEPA \#Effects of High-level Gamma Radiation Exposure of BEFA \#Free Living Mites of the Nevada Test Site,
Radicnuclides* \#Glove Box Fire-pesineraticn Frocess \#Glove Box

Between Isotopes in a Mixture cf products cf [ranium and Renal Iissue after the Incorpcration of Radioactive \#Deposition and Pate of Plutonium, Uranium and their \#Decontamination of Solls ccntaining \#Technical Prcgress Report on the Metabolic Studies of of the Badioactive Flements Created by Nuclear "Plutcnium in the Terrestrial Bnvirons of Rccky * Fstimate f cr and Testing of Overpack-Constructions Based on Fhenclic Respiratory System of the Rat* \#The Rffect of Chemical Packaging and Transfortation of Radioactive Materials* * The plutonium content in the Frotein *an Electrophoretic Study of Serum frotein \# Inatomical pistritution cf Radiaticn-Induced Plutonium 239 Iung Burdens* \# ${ }^{*}$ Micrcacse Distribution on Chrcmosome Aberrations The Ecological Eehavior of Plutonium and Americium in a \#The suclear \#Trends and Projected Shipments in the Nuclear Approack to Envircnmental Monitoring of a Nuclear SNAP

for Improved Naste Management in Comercial Nuclear (Source with Internal Pressure and a Simulated and Froperties of Medical-Grad Plutonium 238 Dcse 8 ates from Plutonium 239 in the Beagle As a Long-Terill Fericds after Chronic \#Investigation of the * Kidney and Bone Retention Retention and clearance of Cesium 137 Inhaled in \# Magnitude cf Leposited Radionuclide Problei Based cn * Magnitude cf Deposited Radionuclide Problem Based on of the Judea Group (Cenomanian-Turonian) Aguifer in neffects of $H i g h-L \in V \in l$

* Health physics Application ef in $\nabla i$ vo *Coal Mine lust Imcombustibles Content Analyzer using a of Age and Particle size on Passage rime thrcugh the * Structures accessory to the

of Irradiation in the Abscrption of Plutonium in the Activity and Plutonium 241 in Biological Materials by 239, 240 in Sandy Loam Soil* *Depth Distribution cf Tests*

* Air Leakage Intc Plutonium * Human Element Design Considerations with \# Lecontamination of P1utonium-Ccntaninated *Plut oni um Decorporation by
Liver*\#Bffectivenss of Different Therapeutic Regimes cf Beagle DCg* \#Effect of DIPA a nd

The Einding of Americium and Plutonium to Fone \#Plutonium and cther Actinide Elements in \# Characterization and Properties cf MedicalCharacterization and Distribution in Mouse Tissues of Induced Neoflasia of the Canine Lung. 1. Clinical and

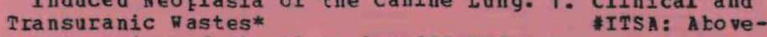

\#ynarics of the Plutoniur 239-Induced Osteosarcomas Incorporaticn with particular Reference to Flutonium, * Btophysical Basis fcr Radiaticn Aber rations Frequency in Liver Cells of the Chinese
Flutonium 239 Dioxide Particles in the Chinese
Fallout Program Quarterly Summary Peport, June 1, 1974 Fallout Strcntium 90, Cesium 137, and Flutoniua 239. Fallout*

Family

Fate and Pathologic Effects of Plutonium Metal

\#Health

Fate of Inhaled substances. 2.

Fate of Plutoniun, Orani um and their Fission Frcducts

Fe Study*

Femur of the Rat* With Diethylenetriaminepentaacetic Fenur OFtake and Drinary Excretion of Radioisotcfes*

Femur Uptake and Urinary Excretion of Radioisotcpes* Ferritin in Vitro*

Fetoflacental Jnit of the Bat*

Field Cperations Associated with widespread Dispersicn Field Belease of plutonium*

Fields cver the Nevada Test Site*of Bxperimental Models Filter Flenum Heat Exchangers*

Filter systems*

Filters*

Final Feport*

Finger Exposure from the Handling of Short-Iived Fire and

Fire Suppression Tests*

Fire-tesistant uaterials and pire suppression gests*

ission ith fest 000027 Fission products of 0raniun 235 in Low Doses* Cerebral 0C0270

Fission Products of 0raniun 235 in Low Doses* Cerebral oc0270 Fissicn Products Inhaled as Aerosols by Rats and Man*

Fissicn Products*

Fission Products*

Fissicn*

Flats*

*The tetabolis

Foorine 1

Elutonium Compounds*

\# Development

Form on the Clearance of plutcnium 239 from the

crms cf Radionuclides and Stable Trace Blements in

Fourth Froceedings of the International symposium on

Practicn of Bat Tubular Eones*

Fracticns in Badium 226 and Plutonium 239 Injected Degs*

Fractures in Beagles*

Frequency in Blood Iymphocytes of Animals with

Frequency in Liver Celis of the Chinese Hamster

Fresh water Ecosystem: Phase 1. Limnolcgical

Freshwater Fcosystem: Fhase 2; Implicaticns of

Fuel cycle and Waste production*

Fuel Cycle Industry to the Year 2000*

Fuel Cycle Reprocessing Plant*Derived from an Bcosyste Fuel Ingestion by Miniature Swine*

Fuel $8 \in$ processing Facilities*

Degrees Centigrade $\quad$ \#rogra

vels*

Dose Level*

dou Degrees Centigrade \#Characterizaticn

Functicnal State of the Elood system in Dogs in the

Functicns in the Human Metabolism of Uranium*

Fused Mluminosilicate Particles by the Beagle Dcg*

Future Usage--Civilian Aspects*

Future Usage--Defense As pects*

Galilee, Northern Israel* 238 riseguilibrium in Water Gamma Badiaticn Exposure of BFPA Filters*

Gamma spectrometry in a vranium Processing Flant*

Gamma- Fay Backscatter Technigue*

Gamma-Fay Counting of Plutonium 239*

Gama-Far counting of plutoniun 239

Gastrcintestinal Tract*

Gastrointestinal iract*

Gastrcintestinal Tract*

Gel Scintillation Counting*

Gland cf the Beagle*

* Some Cbservaticn
Som

Glove Eox Pire-Resistant Materials and Fire Supfression

Glove Ecres and Its Effect on Inert operations*

Glove Eoxes at the Atlantic Hanford Company*

Glove Ecxes

Glucan and Related Compounds as Adjuncts to DTPA Therapy Glucan in Removal of Polymeric Plutonium from the Mouse Glucan on Decorporation cf Monomeric Plutonium in $t b \epsilon$

Glycoproteins*

Gold* of Radioisotope Incorporation with Farticular Gonadal Tissue of Man and Animals*

Grad Plutonium 238 Fuels*

Graded Folymeric and Monomeric Flutoniun. Radicchemical

Gross Eathology*

Ground Retrievable Storage llethcd for Iov-Ievel

Eaematclogical consequences of Radioisotope

Baematclog $y^{*}$

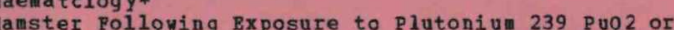

Hanster* and Cytogenetic Bffects of 0.3 un modisperse
000412

00030

00073

00134

00204

000173

000112

$0 \mathrm{CO} 113$

00465

000268

000312

00454

CO40

000308

0035

$0 \mathrm{CO} 296$

00089

$0 \mathrm{C} 0323$
000022

000437

000219

COO313

$0 \mathrm{CO} 44$

000258

000087

000242

00030

CCOO39

000305

C00304

000445

000441

000429

000215

$0 \mathrm{CO} 478$

$0 \mathrm{CO} 318$

OCO227

00002

000343

000025

000397

000319

000332

$\mathrm{C} \mathrm{CO} 403$

00469

000335

CC0137

000207

000185

000177

0008

000226

$\mathrm{CC} 0306$

000455

000452

C CO446

000459

000017

000190

c 0130

000050

000389

OC0186

000318

000129

000172
000477

000176

00038

000218 
PER MUTED INDEX OP TITIR

239 Dioxide in Immature, Ycung Adult and Aged Syrian Subsequent Influenza Virus Infection in Mice and Syrian
of Padiclogical conditions in the vicinity of

"Atlantic Bichfiela Design Considerations with Glove Boxes at the Atlantic *Description of Atlantic Bichfiel Frccessing Pacilities at \#Strontium 90, Cesium 137, and Plutonium 239 in Reactor Cperations* *Evaluation cf Internal Exposur of Aeroscl Properties and $t$ be Respiratory Eattern Upcn Program \#The Quality of Radiochemical Analyses in the In-Residence

Pacility*

\#Plutonium, Industrial Hygiene,

Spectrometry in a Uranium Prccessing Plant*

Experimental Farm*

of Transfortable 0ranium: A Critical contributicn to Period Ending June $30,1944 *$

and their \#Radioidine Levels in the 0.S. Putlic \#Design of Filter Plenun

\#Study of the Bffects of Adaitional Endogenous tTransfer cf

Resulting from Inhalation of plutonium Dioxide with the Effect of Exercise of Leukopenia, A Statistical

\#T he

Plutonium in logs*
\#Ccmparison of Lethal Eody Eurdens of Plutonium 239 and Radiun $226 \mathrm{cn}$ \#Test nethods and Ffficiency Studies $c n$ Multi-Bank \#Bffects cf High-Level Gama Radiation Expcsure cf

a Function of Lose Level* \#Ccmpariscn of Skeletal and Protecticn Agency's Nevada Test Site Experimental Dair \# Removal of Deposited Plutonium by Triethylenetetranine Iumors Induced by Bone Seeking padicnuclides*

the Determination of Total-Body Radioactivity in Man: Bffect of Natural Physiological Stresses and Artificial

Health Physics at the los Alamos "Fing

of Elutonium(+4) with the Iron Transport Syster in of Radioactive Nuclides from the Bnvironment to the \# Monitoring of Iow-Energy $X-F$ ay $R$ adicnuclide Ccntent in

the Atlantic Fanford Company*
Chest Phantcm for Studies of Flutonium and Americium in \#CI Studies of Flutonium and Americium in
\#Ridney and Bone Retenticn Punctions in the (Fentacine) cn the Excretion of Plutonium 239 from the

*The Distribution and Excretion of plutcniun in Tw \#The Distribution of plutoniug in * Studies of Plutonium in \#)termination of Plutcniu in in Reroving Internally Deposited plutonium fr on He Cetermination of Very Low Level Plutcnium in
\#Influence of Physical state on the Bemcral of

Excretion of plutonium in "Priutoniun, Industrial * Study of Bainout of Radioactivity in Backscatter Technique* *Coal Mine Dust \#Ioxicity of Inhaled plutonium 239 Dioxide in Excretion of Radioactive Isctopes, Evaluaticn ef Some \#iffect of Incorporated Radicnuclides cn

\#The Pate and Pathologic Rffects of Plutonium Metal

and Americium in a Freshwater Bcosystem: Phase 2, Regularities in Metabolism of Radioactive Isotopes opon in Metabolism of Radioactive Isotopes upo Chronology, Permuted Title, and Author Vol. 11, No. 1 Radioisotopes* \#Eariy riagnosis and Ireatuent c and Frojected Shipments in the Nuclear Puel Cycle leakaçe Intc Plutoni um Glcve Boxes and Its Effect ca or Plutonium 239 Dioxide and Subsequent Influenza Virus
Plutonium 239 \#

144 Dicxide cr Plutonium 239 Dioxide and subsequent Plutonium 238-Nitrate from the Rat by Continuous * Plutcnium 238 SNAP Fuel

Suspensicn and Effect on Biological Behavior Afte *Tracheo kronchial Iymph Node Involvement Pcllowing of the Red Blccd Cells and Hemod ynamics in the Case ce Dioxide Antiledy Responses and Pulmonary Lesions Afte
Pamsters. 2.* Hansters* 1965 Banford for $1965^{*}$

Banford Biology Research Annual Report for 1959*

Hanford Biology Research Annual Beport for 1961* Eanford Company*

Hanford Company*

Human Blement Hanford con

Banferd*

Hay Samples from 1953 to $1961 *$

Hazards for Several Radioisotopes Encountered in Hazards of the Ccal and Uranium Miner*

Hazards Evaluation Fcllowing Inhalation Exposure* Health and Safety Iaboratory Surface Air Sanpling Health and Safety Support in a Pluconium Facility.

Health Hazards of the Coal and Dranium Miner*

Bealth Fhysics and Belated Aspects*

Eealth Physics at the IOS Alamos "Wing 9" Hot-Cell

Health physics application of in vivo Gama

Health Fhysics Aspects of Nuclear Power Production*

Health Physics Program at the Nevada Test Site

Heal th Frotection of Horkers*

\#Toxicolcgy

ealth Report on Problems Relating to Froduct fcr Heat hervice Pas

Beat*

Beavy Fadionuclides to Milk*

Felp of Separation Analysis*

Analysis* of the Lung Eurden

Hemateclogical Studies of Plutcnium Prcject Personnel.

作 lematologic Effects of Internally Deposited Radium and Hemodynamics in the Case of Inhalation of Ammonium ABPA Filter systems*

HEPA Filters:

Hepatic Changes Induced by Plutcnium 239*

Bepatic Dose Rates from Fiutonium 239 in the Beagle As Herd, Canuary 1, 1969-December 31, 1970* Environmenta fexaacetic Acid

Histochemical Phosphatases ana Metachromasia in Murine Bistorical and Critical Review* of Devices for Hormonal Stresses on the Betention of Americium and Bot Farticle Froject. Exposure of Animals*

Hot-Cel1 Pacility*

uman Elood Serum* $\quad$ \#he Beacticn

Human Ecdy*

Human Ecdy

eman Element Design Considerations with Glove Boxes at uman I ungs*

Puman tetabclism of Vranium* uman Crganism*

Human Subjects*
Human Tissue: A Freliminary Analysis of Reported Data* buman Tracheobronchial Lymph Nodes*

uman Urine*

Bumans*

\#DTPA-Effectiveness
\#A Sensitive Analytical Method

Henans

Fadioelements by Chelation*

ICRP I Ung Mcdel*

Illinois*

Imcombustibles content Analyzer Dsing a Gamma-Ray
Immature, Young Adult and Aged Syrian Hamsters. 2.*

Immediate Measures Against Injury by Radioactive

Immunity*

Implanted Into Rabbits and Rats*

Implications of Lifferences in Transuranic Isotcpic

Incidence on the Skin*

Incidence on the 5

Incineration Frocess Fire and Explosion Protection*

Index to Nuclear Safety, a Technical Progress Beview by ndividuals who Have Excessive cepositions of

Industrial Bygien $\epsilon$, Health Fhysics and Related Aspects* Industry to the Year 2000 "

nert Cperations*

Infection in Mice and Syrian Hausters* 144 Dioxide Inflawmaticn on Iong-Term Sequelae in Rats Given

Influenza Virus Infection in Mice and Syrian Hamsters* Infusicn of Chelating Agents* Intramuscularly Injected Ingesticn by Miniature Swine*

Inhalation by Beagle Dogs* Plutonium 238 oxide in wate Inhalation of Alpha Bmitters*

Inhalation of Ammonium Plutonium Pentacarbonate by Rats*

Inhalation of Enriched vranium rust*
000096

000139

000431

000333

000120

$0 \mathrm{C} 0121$

0027

000472

000446

$0 \mathrm{CO} 438$

00456

$\mathrm{CCO} 479$

COU 18

000254

C00369

000253

000417

CCO464

000369

CC0466

$\mathrm{CCO} 470$

00469

000458

00045

$0 \mathrm{CO} 347$

000059

000422

000450

$0 \mathrm{co} 450$

00014

000146

000374

000360

00068

000069

000067

000110

000454

$\mathrm{CCO} 403$

000245

000227

CCO210

000013

Q00023

$0 \mathrm{CO} 39$

000097

$\mathrm{CCOOO2}$

000470

000294

$0<0378$

000406

000446

000377

000343

000367

000372

C00376

$0 \mathrm{CO} 362$

000297

000365

000292

C00084

000466

000423

000328

000335

$0 \mathrm{C0096}$

000028

000165

000134

000304

000189

000189

000444

000449

000366

000466
000441

C 0462

000139

000122

OCO139

000236

000215

000171

000380

OCO110

000139 
* Fvaluation of the Lung Burden Resulting frch Bronchiolo-nl veolar Tumcrs of the Canine Iung Following Inhalation Studies. 4. Mortality in Dogs afte Inhalation Studies. 4. Mortality in Logs after

* Biochemical Changes in the Lungs of Rabbits After Respiratory Pattern Upon Hazards Evaluation Pollowin Ytterbium 169 in the Rhesus Monkey After a Single Acut Inhalaticn of Flutonium 239 FvO2* "Plutoniu Inhalaticn of Plutonium 239 FuO2*

IPlutoni u of the Canine Lung Following Plutonium "Plutoniu and $T r$ anslocation of Flutoni un 239 Dioxide After 249, Californium 249 Fcllcwing Acute Accidertal cf the Canine Lung Pollowing Plutonium Farticle Fate of plutonium, Oranivm and their Pission Froducts risposition of Four Iypes of Plutonium Dioxides of the Fulmonary Retention and clearance of Cesium 137 * Some Speculations on the Carcinogenic Effect c Approach*

Lavage: A Pilct Study* Toxicity ce \#Comparative Icxicity * Chronic Toxicity of on the Pharmacodynamics and Biological Effects of Washout* \#Eliminaticn $c$ Monodisperse 1.5 um plutonium 238 Dicxide \#Toxicity Iavage and DTPA Treatment for the Rercval c and Aged Syriar Hamsters. 2. * "Toxicity cf \#istributicn and Ioxicity c
Oxide Polymer on Excretion *Carcincgenicity cf

and Fhysiological Factors contrclling the Fate of Movement in soils: The Importance of $\mathrm{Bxchange}$ and High

\#Removing Plutoniun \#Iiver Tumors in Feagles \#The Rate of Tooth Loss in Eeagles \# Sustained Action of Serum protein Fractions in Radium 226 and Plutonium 239 of the Effect of Colloidal state of Intravenously Continuous Infusion of atemoval of Intramuscularl

\# Iumcrs Develofing in Rats after Intraferitonea \#omcrs Develofing in Rats after Intraperitoneal Toxicity of Radioactive particles. 1A. Intratracteal * Studies of the oxidation States of plutonium $23 \mathrm{~s}$ in \#he Rate of Elutonium 239 in the Case of Subcutaneous \#Effect of Dail iffects of Intradermal Isotopes, Evaluation of Some Immediate Measures Against \# Vascular Theory of Radiatic

Ehosphorus and Nitrogen in Rabbit Bony Tissue afte Petiticn Ccncerning liwits for Annironmental surveillance Arcund Nuclear \# Need for Environmental Monitcring fcr Nuclear *Air samplin \#Distrifution of Plutcniuw 23 c i \#Tn Vivo Studie

Tissue Respcnses to Ionizing Radiaticns* Biosynthesis by Canine Testicular Tissue after the Dimethylarinoarcheurence*

after the

Sumary of c.S. Atomic Energy Commission contractors

of onited States Atomic Energy Comissicn Licenses Bncountered in Reactcr Operations* untered in Reactcr Operations* \#Evaluation of
Centigrade and 800 Degrees Centigrade (Source with Bxcretion Data for a Number of Varicus Species* \#Distribution CI nticn and Treatment cf Excessive *DTPA-Rffectiveness in Removing \#Lcng-Term Effects of Therapeutic Remcral c \#Interpreting counting rata for Alteration of Androgen Biosynthesis ky Canine

\#Frinciples and Irends in Therapeutic Removal of * Comparison of Hematologic Bffects cf

Protecticn Asscciation* "mhird International congress of the

\#Third of Radioact

\# Pourth Proceedings of the

\#Lyufh Ncde and

on Excreticn cf Uranyl Nitrate and Course of Uraniu 241 and Californium 249 in Livers \#Ccmparison of the Binsteinium Nitrate $B S(N 03) 3$ in Rats After Intravencus, Rat by Ccntinuous Infusion of Chelating \#Reval of of mericium 249 in some Bat organs Fcllowing
Inhalation of Plutonium lioxide with the Help of nhalation of Plutonium Particles* Inhalation of plutoninm 239 PuO2* Inhalation of Flutonium 239 Puo2* Inhalation of Plutonium* nhalation of Plutonium* Inhalation Exposure*
Inhalation Exposure* 239 Dioxide Particles Iakeled with Inhalation Studies. 4. Mortality in Dogs after Inhalation Studies. 7. Bronchiolo-Alveolar Carcinomas Inhalation* \#Fxcretion

Inhalation* \#Retention and Elimination of Berkelium Inhalation* Studies. 7. Eronchiolo-Alveolar Carcinomas Inhaled as Aerosols by Rats and Man* \#Defosition and Inhaled by Dogs* Inhaled in Fused Aluminosilicate Particles by the Inhaled Alpha-Active Material*

Inhaled Alpha-Fmitting Radionuclides--An Bxperimental

Inhaled Americium 241 from the Beagle Dog by Iung Inhaled Beta-Emitting Radionucildes in Beagle Dogs* Inhaled plutonium in Dog $s^{*}$

Inhaled Plutoniun oxide in Dogs*

Cbservaticas

Inhaled plutonium oxide Farticles by in vivo $I$ ung Inhaled plutonium Farticles*

Inhaled Plutonium 238 Dioxide in Beagle Dogs. A.

Inhaled plutonium 239 of Varied Solubility in Beagle

Inhaled plutonium 239 Dioxide in Immature, Young Adult

Inhaled plutonium 239 Dioxide*

Inhaled plutonium 239 FuO2 in logs*

Inhaled Radionuclides*

nhaled substances. 2 .

Initial Dispersicn*

\#Scme Fhysical

\#Tritium $\mathrm{CCO} 307$

Injected in Skin of Swine*

Injected with plutcnium $239 *$

Injected with Flutonium 239, Radium 226 and Radium 228*

Injected Chelating

Injected Dogs* \#An Electrophoretic study of

Inject $\epsilon d$ plutonium on It $s$ Distribution in Bone and

Injected Plutonium 238-Nitrate from the Pat by

(Plutonium 239)

injection of plutoniun

Injection of Radioactive Suspensions*

Injection solutions*

Injecticn*

Injecticns of Elutonium 239 on Rat Bones*

Injections of Plutonium*

Injury by Radioactive substances*

Injury to Bone

Injury with p1utonium 239*

Insolutle Alpha Emitters*

Installations*

Installations

Instruments for Bvaluaticn of Atmospheric Contaminants Intact Skin in Its Surface Contamination*

Intake in New York City*

Interactions of Plutonium( $(+4)$ with Blocd Constituents*

Interactions of Total Dose and Dose Rate in Determinin

Intermittent DTPA Therapy in Pcisoning by Polymeric

Internal Deposition of Some Radionuclides* in Androcen Internal Bnitters on Iiver Tucronuclides*

Internal

Internal Exposure Experience, 1957 - 1966* Statistical

Internal Exposure Hazards for Several Radioisotopes

Internal Pressure and a Simulated Fuel)*at 1300 Degrees

Internal Radiation Dose from Metabolic and orinary

Internal Radiation-Induced ostecgeni

Internally Deposited Flutoniull from Humans*

Internally Deposited PIutoniui 239*

Internally Leposited Flutonium*

Internally Eeposited Plutonium*

Internally Deposited Radionuclides

Internally Deposited Radionuclides

Internally Deposited Badium and Elutonium in Dcgs*

International Congress of the International sadiation

International Badiaticn Frotection Association"

International symposium on Fackaging and Transfcrtation

Interpreting counting Data for Internally Deposited

Intestinal Iymphatic

Intoxication in Rats* 2,20-Diaminodiethylsulfid Intracellular Distribution of Plutonium 239, Americium Intradermal infections of plutonium*

Intramsucular and subcutaneous administration*

Intram $x$ scular and subcuta Intraferitonear in fected Plutonium 238-Nitrate from the 000236
000007

000436

000174

000374 000009 000011 000260 $0 \mathrm{CO} 253$ 000009 000011

00055

00371 00204 0 C0025 000346

000095

000145

$0 C 0170$
000010

000166

000140

0015

00156
00056

267

000247

000133

00087

OC0192

000236

$0 \mathrm{COO} 40$

000264

000032

000042

CCO066

000046
000028

0 00169

000075

000384

CCO425

$0 \mathrm{CO} 340$

000080

CCO401

000167

OC0194

000077

000141

000370
000468

000254

000316
$\mathrm{C} C 0355$

000051

000350

000365

000243

c00187

000076

000049

000069

000387

$0 \mathrm{CO} 440$

000432

000064

CO0 100

000220

C 0046

158

000180 
\# The Ultrastructure of Mononuclear Fhagocytes Following Plutonium 239)* \#Tumors Develcfing in Rats a fte and Mcr fhclogical changes in these organs Following 241 in Scme Rat organs Following Intraperitcneal and Plutoniun $2 \equiv 9$ Compounds* \#Some Remote A ftereffects of of riethylenetriaminepentaacetic Acid Pollowing "Toxicity of Radicactive Particles. $1 \mathrm{~A}$. Tumorigenicity of

239. Americium 241 and Californium 249 in Iivers Afte of Finsteinium Nitrate Bs (NC3) 3 in Rats After Studies of the Bffect of Colloidal State of Structure of Animal populaticns (Terrestrial and Soil * Tracheobronchial Iymph Nod \#Environmental Eehavior and Radiaticn frcm \#Radiation Doses frcm

Repair in Yeast Cells After Irradiation with Densely in the Iorg-Term Periods after Chronic Influence of in Androgen Biosynthesis by Canine \#The Iffects of
Dose and Lose Rate in Determining Tissue Respcrses to

Dose and Lose Rate in Determining Tissue Respcrses to
Particular Reference to Elutoni um. Thorium, Fadium, \#The Reaction of Plutcnium $(+4)$ with the Gastrointestinal "Tract* \#The Effect of

\#Studies of Porphyrin Metabolism. 4. The Effect of * Recovery and Bepair in Yeast Cells A fter

\#Radiogenic Fffects in Man of Long-Term Skeletal Alphaand Intratracheal Administration of this "Radicactive

with Rescrpticn Thereof \#Changes in Correlation Retween "Fegularities in Metabolism of Eadicactive
of Studying the Blastomogenic Effect of Radicactive organs Pcllcwing Intratracheal Administration of the to the Determination of Body Burden of Badicactive Injury by \#Acceleration of Excretion of Radicactive \# Measurement cf the Mass Spectrometer gfficiency in the Centigrade and 800 Degrees Centigrade (Source with

cosystem: Fhase 1, Limnolcgical Characterization and
Phase 2, Implications of Differences in Transuranic (Cenomanian-Turonian) Aquifer in Galilee, Ncrther Level Transuranic Wastes*

Surface Air Sampling Program, 80 th Meridian Netwcrk, Agency's Nevada Test Site Experimental Dairy Herd, \#Froject Ccuncil Meeting, Biology Section,

Personal Property, Progress Report for the period of
\#Content of Tlutonium in Biver Water in

Personal Property, Progress Report for the period of
\#Content of Tlutonium in Biver Water in to the Fuman Body in the Nilgata District, Ncrthern Uranium 234/0ranium 238 Disequilibrium in Waters of the on Frcblems Relating tc Product for Pericd Bnding

* offsite Surveillance Around the Nevada Test Site. "Pallout Program Quarterly Summary Feport,

on Frcblems Relating tc Product for Pericd Ending

Property. Progress Report for the Period of January Metabolism of Oranium*

\#Plutonium 239 in Iiver, Spleen, an Prolonged Feroral administration*

Contamination with Radioactive Substances*

and Excretion of Plutcnium 239 Dioxide Particles \#Ventilation Systems at Mcun

of Radiochemical Analyses in the Health and Research and Develcpment Prcgram at Cak Ridge Natjcnal \#M cund

overview with Emphasis on \#The Los Alamos Scientific \#Influence of age on the Plutoniun 239 of Varied Solutility in \#Bronchopulmonary of Inhaled Americium 241 from the Beagle Dog by Iung Renoval by Chelating Agents: Application ky Mass Action \#Investigations on the Bacterial

\#A ir

Inert operaticns*

Plutonium 239 Dioxide \#Antibody Responses and Fulmonary Hematopoiesis in Eeagles*

Aministration of Plutcnium*

Comparison of Bffects $c$

\#The Uptake of Plutonium in Bcne Marrow: A Pcssible of Plutcnium Project Personnel, Effect of Bxercise of the Depth and Amcunt of Plutcnium 239 in wounds with SI Sumary of United States Atcmic Energy Comrissicn

\#Past-Fespon se
Natural Rescurces Defense Council Petiticn Ccrcerning
\#Contaminaticn \#Past-Eespon se for the Period of January-June, 1974* \#Contamination and Anericium in a Freshwater Bcosystem: Phase 1, of Plutcnium frcm Mice by Bncapsulation of DIP W Within
Intraperitoneal Administration of Plutonium 239 Fuo2* Intraperitoneal Injection of Flutonium Nitrate Intratracheal Adninistration of the Isotopes*and Liver, Intratracheal Administration of this Isotope* Americiu Intratracheal Administration of Chemically Solutle Intratracheal Aduinistration of Plutonium*Effectiveness Intratracheal Injection of Radioactive Suspensions* Intratracheally administered Farticles*

Intravenous Administration* Distribution of Flutonium Intravenous, Intramsucular and Subcutaneous

Intravenousiy Injected Plutoniu on Its Distribution in Invertebrates) Due to Soil Contamination with Strontiu Involvement Pollowing Inhalation of Alpha Bmitters* Iodine $129 *$

Ionium-Thorium Chronolcgy of the Japan Sea Cores*

\#RECovery and Ioniziag Radiation* State of the Blood Systen in ICg lonizing Radiations on Endocrine Cells. 6. Alterations lonizing Radiations*

Iron and Gold*

Ircn Transport system in Buman Elood Serum*

Irradiation in the Abscrption of Plutonium in the

Irradiation on Coproporphyrin Bxcretion*

Irradiation with Densely Ionizing Particles*

Irradiatcion*

Irradiation

in Some Rat organs Fcllowing Intraperitoneal Isotcpes as Cancerogenic Agents*

Isotopes in a Mixture of Products of Uranium Pission Isotopes opon Incidence on the skin*

sotoçes*

* Some Results

Isotopes* and liver, and Mcrphological Changes in these Isotopes*Methods. The Application of Bxcretion Analyses Isotofes, Bvaluation of Some Immediate Measures against Isotopic Analysis of Very Small plutonium Samples*

Isotopic Cardiac Pacenaker Safety Tests at 1300 Degrees Isotopic Distribution* and Americium in a Freshwater Isotopic Ratios* Americium in a Preshwater Eccsystem Israel* 238 Disequilibrium in Waters of the Judea Grcu IISÁ: above-Ground Retrievable Storage Method fCr LCvJanuary through December, 1970*

January 1, 1969-December 31, 1970*

Protection

January $16,1945 *$

January-June, 1974* \#Contamination Iimits for Feal an Japan Sea Cores*

Japan*

Japan*

of Radioactive Nuclides from the Environmen Judea Group (Cen

July 31, 1944* 1970 *

June 1,1974 through september $1,1974 *$

June $30,1944^{*}$, Monthly Health Repcrt June, 1974* \#Contamination limits for Feal and Ferscna kidney and Bone Retention Functions in the Human

Ridneys of the Beagle*

rianeys of the Beagle

Rinetics of the plutonium 239 Metabolism in the Case cf Rinetics of the skeletal Retention of Flutonium $239(+4)$ Rinetics of Dose Distribution in the skin in Its Iabeled with ytterbium 169 in the Rhesus Monkey after a Iaboratory "pp" Euilding*

laboratory for Fadiobiology at the University of Utab*

laboratory Surface Air Sampling Program During 1968*

Iaboratory*

*High-level Waste Managemen

Iaboratory's Air Surveillance System*

laboratory's Environmental Monitoring Program: An

late Bffects of Monomeric Plutonium 239 in the Fat*

lavage and DTFA Treatment

lavage: A Pilot Study*

laws and other Factors*

*Removal

leak cf Tank 106-T at Hanford*

leakage Intc Plutonium Glove Boxes and Its iffect on

Iesions After Inhalaticn of Cerium 144 Dioxide cr

Tethal Body Burdens of Plutonium 239 and Radium $226 \mathrm{cn}$ Iethal Radiation Effects Pollowing Massive Oral Ieukemic Risk*

leukofenia, A Statistical Analysis* Studies \#The Determination
Iicenses" Internal Exposure Experience, 1957-1966* Iicenses ' Internal Exposure Experience, $1957-1966^{*}$
Iight Scattering Measurements of Aerosol Suspension in Iight Scattering Measurements of Aerosol Suspension in Iimits for Insoluble Alpha Emitters*
Iimits for Feal and Fersonal Froperty*

Iimits for Feal and Perscnal Prcperty, Progress Feport

Iimnolcgical Characterization and Isotopic Distributicn* Ii posomes*

Iiterature Search*
000200

00004

000679

100180

000269

(1)

000252

(0) 22

OCO214

000192

$\mathrm{CCO} 380$

00329

0027

CO310

000178

000077

000167

$\mathrm{C} 038$

00029

$\mathrm{CCOO} 8$

000203

00178

$0 \mathrm{COO} 21$

000351

$0 \mathrm{C} 0180$

000235

$0 \mathrm{CO027}$

000099

00123

C COC79

00035

$0 \mathrm{C} 0338$

00316

000305

00304

00332

00047

$000-427$

OCO210

OCO179

000413

C0310

000311

000378

CC0332

00058

000396

0 C0412

00005

000413

0034

CCO228

CO23

CO229

000168

000126

00023

000417

00047

$\mathrm{COO} 402$

C00415

000208

OCO156

00020

000201

00047

$0 \mathrm{CO} 462$

C 0139

000067

$0 \mathrm{CO} 237$

$\mathrm{CC} 0360$

000337

(1)

$\mathrm{CC} 0334$
000384

00413

000305

0C0193

000467 
PRF MUTED INDEX OF TITIB

and Disposal, An Annotated Bibliography of Selected Iiterature*

\# A Single Centripeter for Rapid analysis cf Ion of Plutonium $239(+4)$ and Americium $241(+3)$ in Blcod, \#Deoxyribonuclease Acitivity in Rabbit

Distribution on Chromosome Aberrations Preguency in

\#Effect of Internal Bmitters on

\#On the Einding of Americium 241 in the Canine e Pree Pibcnucleotide Metabolism in the Rabbit and cuantitation of articles Deposited in the

State of flutonium on Its Barly Distribution in the Glucan in Remcral of polymeric Plutonium from the Mouse Microdistribution of plutonium 239 in the $R$ at Lung and Plutonium 239 in *Plutcriuar 239 in of Elutcnium 239, Americium 241 and Californium 249 in \#Translocation of Plutonium 239 in Beagle \#Fffects of ICw Dose of Radiaticn on the \#rree

Compounds on Tissue Storage and Excreticn from the 90, Cesium 137, and Flutonium 239,240 in Sandy

the Iiver* * The Nature and Eehavior c Plutoniue 239 in the Bones of \#Autoradiography in the \#The Determinaticn cf \#Health Physics at the Monitoring Frcgram: An Overview with Bmphasis on \#The and Fadium $228 *$ \#The Rate cf Tcoth \#ffects of

of Radicactive Fissicn Frcducts of Uranium 235 in Workers* \#Sensitive Methcd for the Determination of \#acnitcring c * Nuclear-Track Technique $f \mathrm{cr}$ Reactor Testing Station \& \#Flan for Retrieval of Soli \#ITSA : A hove-Ground Retrievable Storage Metrod fcr
\#Billiography: Fffects of Radiation on the Dioxide with the Help of Separation \#Bvaluation of the Techniques for the Assessment of plutonium 23

in Elocd Lymphocytes cf Animals with Plutonium 239 \# Eronchiolo-Alveolar I umors of the Canine Removal of Inhaled Americium 241 frcm the Beagle Doc Bxcreticn of Plutonium in Urine Based on the New IC cf In haled Plutonium oxide Earticles by In vi vo

\#Plutonium Particle-Induced Neoflasia of the Canine \#Dosimetry of Alpha Bmitters in the

and Cellular Risk for Flutonium Particles in the and Microdistribution cf Plutcnium 239 in the $R$ at cf Plutcnium 239 in the Rat Phantcm for Studies of plutonium and Americiug in Huma counter for Elutonium 239 x-ray Detection in

Wounds in Eeagle*

Bmitters*

\#Tracheobrenchial *Studies of Plutoniur in Human Tracheobrcnchial * Iym ph Node and Intest inal \#Chromosome Aberration Prequency in Bloc Its weathering Prcducts Determined by \#Exchange cf Cxide in the Phosphatasic Acid Activity of Alveclar Fut ure Usage--Civilian As pects*

Future Usaç--Defense Asrect $\leqslant *$

\#ose Measurements from Skeletal Plutoni um Ccmpared in *Acute Fffects cf plutonium on the Peripheral elood of of the Metabolism of Plutonium (Plutonium 238) in and cther actinide Elements in Gonadal Tissue cf

\#Toxicity cf Plutonium 239 Relative to Radium 226 in * Some Speculative Extensions to \#Padiogenic Effects in and Basic Btiological Factors of Radiation Sickness in 60, Cerium 144, Strontium 90 and Plutonium 239 by their Pission Products Inhaled as Aerosols by Fats an for the Letermination of Iotal-Bcdy Radioactivity in Facilities* Savannah River* \#Chemical \#ngang Range 1973*

Ridge Naticral Laboratory* *High-level Waste

Trace Elements in Seawater in Relation to Optake by the of Plutonium 239 and strontium 89,90 on the Fone Injected flutonium on Its Distribution in Bcne and * The Vptake of Plutonium in Fon Removal by Chelating Agents: Application ky

of Very Sma11 Flutoniun Samples* \#heasurement of the Iived Blpha Emitters in Air*

\#Radioactive waste Frccessing 000475

Iiver and Thyroid*

liver Affected by Plutcnium*

000359

$0 \mathrm{C} 0117$

Iiver Cells of the Chinese Hamster Follawing Exposure

Iiver Tumors in Peagles Injected with Flutonium 239*

iver Tumors Induced by Dimethylaminoarobeurence*

Ii ver*

iver*

\#Influence cf Plutonium 000259
Iiver* $\quad$ \#Autoradiographic Iocalization 000197

\#Influence of plutoniu

000031

000244

000036

Iiver, and

Iiver, Spleen, and Kidneys of the Beagle*

Iiver, spleen, and kidneys of the Beagle*

Iivers

Distribution 000220

Iiving Body"

Iiving Mites of the Nevada Test Site, Final Report*

Iiving organism of Radioyttrium, Radiocerium and

loam Scil* Distribution of Global Fallout Strontiur

Iocal Fallout*

Iocalization and Quantitation of Articles Deposited in Localization and Fadiation Dosage of Radium 226 and

Iocalized Concentration of Plutonium 239 in Bone*

Ios Alamos "Wing 9 " Hot-Cell Pacility*

Ios Alamos Scientific Laboratory's Bnvircnmental

Ioss in Beagles Injected with Elutonium 239. Radium 226

Iow Dose of Badiation on the Living Body*

Iow Doses*

Iow Level plutonium in Humans* \#A Sensitive

Iow Urinary Plutonium Levels in Occupationally Exposed

Iow-Energy $x-$ Ray Radionuclide content in Human Ecdy*

low-level plutonium in Vrine*

Iow-Ievel Radioactive plutoniu waste at the National

ICw-Level Iransuranic wastes*

Iung with References through 1972*

Iung Burden Resulting from Inhalation of Plutcnium

Iung Eurdens*

\# A Compariscn of Calibratio

\#Chromcsome Aberration Frequency

Iung Fcllowing Plutonium Particle Inhalation* Studies.

Iung lavage: A Pilot Study*

Iung ModeI*

Iung Washout*

Iung. 1. Clinical and Gross Fathology*

Iung*

Iung*

\#An analysis of Dcsimetr

Iungs and Iiver, and Morphological Changes in these

Iungs of Ratbits af horphological Changes in thes

Iungs* \#An Improved Cbest

Iungs* *Calibration of a Large Area Propcrticnal Iymph Node and Intestinal Iymchatic Tissue*

Iymph Node Clearance of Plutonium from Subcutaneous

Iymph Node Involvement Following Inhalation of Alpha

Iymph Ncdes*

Iymphatic Tissue*

Iymphocytes of Animals with Plutonium 239 Lung Eurdens* Iyotrofic Series Cations by Micaceous Vermiculite and

Macroplages of the Rabbit* Brought About by Elutoniu

Magnitude of Deposited Radionuclide Proklem Based on

Magnitude of Deposited Radionuclide Problem Based on

Mammalian Species*

IIamma1s*

Man and the Bat*

Man and Animals*

A Comparison

Man and Ani

Man of Animal Risk Data on Plutonium*

Han of Long-Term Skeletal Alpha-Irradiation*

Man*

Man

*Pathogenetic Classification

\#Deposition and Pate of Plutcni um, Orani um an

Wan: Historical and Critical Review* of Device

Management in Comercial Nuclear Puel Reprocessing

Management of Transuranium-Contaminated Solid Hastes a

Management Frograms Quarterly Report, October-DecembeI

management Research and Develcpment Program at oak

March $\$ 1,1959 *$

Marine Biosphere*

Marrow of white Rats*

Porms of Radionuclides and Stakl

Marrow the Effect of colloidal State of Intravenously Marrow: A Possible leukemic Risk*

Mass Action Laws and other Pactors* \#Radicelement

tass Srectrometer Efficiency in the Isotopic analysis

\#Arsence of Lethal Fadiation Bffects Following

000239

$\mathrm{CCO} 308$

000206

$\mathrm{C} \cos \mathrm{C} 6$

000277

000197

$\mathrm{CCOOC4}$

00026

$0 \mathrm{CO} 470$

00024

000239

000270

000292

000295

00040

000293

000476

000477
C 03386

000374

$\mathrm{CCO} 404$

000030

00005

000055
000157

000423

000166

000172

$\mathrm{CCO} 344$

000184

000217

00007

CCO260

000377

000064

$0 \mathrm{C} 0062$

000380

000362

000064

000030

$0 \mathrm{C} 0285$
000195

000317

000319

000385

CC0102

000061

0 0 0395

$0 \mathrm{C} 0395$

000381

00035

000353

000368

$\mathrm{COO} 204$

000392
$0 C 0478$

000471

000481

C C 0474

000234

000313

000257

000192

000263

000201

000324

000338

000237 
PER MUTED INDEX OF TTTIE

\#A Risk Assessment Mcdel for Radicactive on the Carcinogenic Effect of Inhaled Alpha-Active Alpha Activity and Plutonium 241 in Biclogical on Packaging and Transportation of Radicactive of Plutcniug, americium, and Uranium in Environmental of the Average Concentraticns of Uranium and Crganic of Plutonium $239 *$

the Osteosarccmcgenic Bffect * \# Determination of Isotopic Analysis of Very Small plutcnium Samples*

Mammalian Species*

Fast-Response Iight \# rose Radiation* *in Vívo of Radicactive Isctopes, Bvaluaticn of Some Immediate Tuf $f *$

\#High Eressure Enviranment tc the Human Body in the

* St ndies

\#Characterizaticn and Properties cf
\#Project Council
and Morpholcgy of \#Surface Air Sampling Frcgrall, 80 th
Americiug*
Americium*

Whe Bstimation of Internal Radiation Dose fro

\# Technical progress Repcrt on the \# Technical progress Report on the \#Technical Prcgress Repcrt on the

Proteins*

* Technical frcgress Report on the

pid Experimental \#Fadioelement IIRintics of of Plotonium 239 Administration* \#Rinetics of the Plutcnium 239 *Influence of Flutcnium 239 on the Pree Rilonucleotide of a Specialized Analog Computer for the yodel of the Nuclear Fissicn* *Alteraticn of the

$$
\text { tT he }
$$

Rat *

the Skin*

Fuo2 Aercscls in Eeagle Dogs* 6) Nitrate*

\#A Comparison of the

\#Regularities in

\#hcr

\#T he

\#Kidney and Bone Retention Functions in the Human Coproporphyrin Excretion*

Histcchemicadies of Porphyri Radionuclides* $\quad$ \#istcchemical Phcsphatases a n * Fadicactive

Excretion* \#The Acticn of Salts of zirconium and 0 ther Toxicology: Radicactive \#Therapy of Pcisoning by Badoactive and Nonradicactive Determined by \#Bxchange of Iyotropic Series Cations ty
\#Tuncrs in 239 Dioxide and Subseguent Influenza Virus Infection in Penta-Ethyl Ester * Removal cf polymeric plutonium frcm Penta-Et byl Ester *Removal cf Polymeric Plutonium frcm
\#Improved Remcval of Plutonium frcm \# Tnproved Remcral of Plutonium frcm * Effects of Froduct Administration Intramuscularly to Following Intraperitoneal and Intratracheal

Liver, and Morphelogical changes in these levels and Frequency in Iiver Cells of the Chinese \#The Effect cr and Its weathering Products Determined ky Electrc

\# Flectron

of surfaces in contact with plutonium 238 EuO2

Levels in the U.S. Public Health Service Fasteurized \#Transfer of Heavy Radionuclides to

Ray Eackscatter Technique* \#Coal * Health Hazards of the Coal and Uranium *Plutonium Metabolis in

\#Plutonium 238 SNAF Puel Ingestion ty

\#Chelating agents in Plutcnium Defcsiticr--l

Radion uclides*

* Free living IPr Cm Ft

and Leccrporation as Influenced by chelation and * Radioactive Metal * Radioactive Metal

\#Applications of a General Ccmputaticnal Cantaninants fron scil Surfaces*

A Risk Assessment

\#Use of a Specialized Analcg Computer for $t$ he of Plutcnium in Orine Based on the New ICFP Iung
Material Shipments*

Material*

Materials and Pire Suppression Tests* Materials by Gel Scintillation Counting* of Flutonium

Materials* Proceedings of the International symposiun

\#Studies Matter in Recent Sea and ocean Sediments* \#Ratios Maximur Permissible Concentrations in Air fcr Ccmpoun Maximum Permissible plutcnium 239 Level Acccrding to Measurement of the Mass Spectrcmeter Bfficiency in the Measur $\in$ ments from Skeletal plutonium ccmpared in Measurements of Aerosol Suspension in a Desert Area* reasurements of Nuclides Emitting Soft penetrating Measures Against Injury by Radioactive substances* Mechanical Froperties of an Area 12. Nevada Iest Site Mechanisin of Transfer of Radicactive Nuclides from the

Kechanisms of Carcinogenesis*

Mechanisas of Carcinogenesis*

Mechanisms of Carcinogenis*

Medical-Grad plutonium 238 Puels*

Meetinc, Biology Secticn, January 16, 1945*

Meridian Network. January thrcugh December, 1970*

Mesoscale Transport of Atmosphere Effluents: Philoscehy

Metatolic and mherapeutic Studies of Plutonium and

Metabolic and Therapeutic Studies of Plutonium*

Metabclic and Urinary Excreticn Data for a Number of

Metatolic Characteristics Within a Chemical Fanily*

Metabclic studies of Fissicn Products*

Metabolic Studies of Plutonium*

Metabclic Studies of Flutonium*

Metakolic studies cf product*

Metabolic study of the Binding of plutonium to Serum

Metabolism and Decorporation as Tnfluenced by Chelation

Metabclism and Effect in the Bat*

Metabclism in the Case of Prolonged peroral

Metabclism in the Rabbit Iiver*

Metabclism in Miniature Swine*

Metabolism of sone Badionuclides*

Metabolism of the Beagle by Radionuclides*

Metabclisu cf the Radioactive Elements Created ky

etabolism of Neftunium"

Metabolism of Flutonium (Plutonium 238) in Man and the

retabclism of plutoniun

Vetabolisir of Padioactive Isotopes Upon Incidence on

Metabclism of Three Sizes of Mcnodisperse Plutonium 23

Metabclism of missues of Rats Ireated with plutonium 1+

Metabclism of mransuranium Blements*

Metabolism of Uranium*

Metabolism. 4. The Effect of Irradiation on

Metachrcmasia in Murine Tumors Induced by Bone seeking

Metal Implanted Into Rabbits and Rats*

Metal Mcbilization*

Metals on Plutonium and Yttrium Distribution and

Metals*

Micacecus Vermiculite and Its Weathering Prcduct

after Fulmcnary Deposition of Radioactive Farticles 000250

Mice and Syrian Hamsters* 144 Dicxide or Plutoniur Coo139

Mice ty Combined Therapy with the Calcium chelate and 000142

Mice by Encapsulation of DrPA Fithin Iiposomes* 000193

Mice After Fulmcnary Deposition of Radioactive Earticles 00025

nice*

Microdistribution of Americium 241 in some Fat Organs

Hicrodistribution of Plutoniun 239 in the Rat lungs and

$\begin{array}{ll}\text { Micrcsccpy and Radiochemical Analysis* } & 000031 \\ \text { Merations } & \text { Verniculite } 000285\end{array}$

Hicroscoy and Radiochemical Analysis* Vermiculite 00028

Microsccpy of Aeroscls Ccntaining Radioactive Farticles* 0 0433
"Tencerature 000275

milk Network from 1963-1968 and their Belationship tc 000422

000146

vine Dust Imcombustibles Content Analyzer Using a Gama- OCO335

Miner*

Miniature Swine*

Miniature Swine*

Minority view"

Mites of the Nevada Test Site, Pinal Report*

Mitigatcry Action After Accidental Exposure to

mixed Complexes--Rapid Experimental and calculative

Mixture of Products of Uranium Fission with Rescrption Mcbilization*

Mobilizing Flutonium in Rat*

Model for Composite Environmental Radiation Doses*

Model for Predicting the Redistributicn of Particulate

Hodel for Radioactive Material Shipments*

Wel cf the Metabolisa of some Radionuclides*

Node1*

*Theoretical Bxcretion 
Effluents: Philosophy and Morphology of Experimenta *Initial Resusfensic Derived from an Ecosystem Approach to Envircnmental Human Body*

Problems in Badiation Safety and Sanitary Dosimetric \#The LCs llamos Scientific Laboratory's Envircnmental

Particles Iabeled with Ytterbium 169 in the Rhesu \# Short-Term Metabolis a Three Sizes of Petention and Cytogenetic Bffects of 0.3 un Dioxide and Evaluation of In Vitro * Production o

of Inhaled Plutonium 238 Dioxide in Beacle Dcgs. A. Monodisperse 1.5 um Plutoniui 238 Dioxide Particles. B. of Blocd Clearance and Six-day lissue Distribution of *Influence of age on the Late Bffects of

\#Skeletal Retention and Distribution of Polymeric a no Distribution in Mouse Tissues of Graded Polymeric and Administration of plutoniun 239 "The 01trastructure of for Period Ending June 30, 1944* for Period Ending June 30,

of Plutonium 239 in the Rat Iungs and Liver, an Subacute Affecticn with Plutcnium

Transfort of Atmosphere Effluents: Philosophy and * Quantitative \#Flutonium Inhalation Studies. 4. \#plutonium Inhalation Studies. 4. \#Ventilaticn systems at

of Glucan in Removal of Pclymeric Plutonium frcm the * Prefaration, Characterization and Distribution in \#Plutoniuln Removal in Rats Given Some Complexons yy Initial Lisfersion*

\#Iritiu

\# Test Methods and Efficiency Studies c

\#Histocherical Phosphatases and Metachromasia in of Uranyl Nitrate and Course of \#Effect of $N, N, N$, of Urany 1 Nitrate and Course of Uranium \#Rffect of $N, N$. Bxcretion cf Cranyl Nitrate and Course of $\#$ Effect of $N$, Bxcretion of Cranyl Nitrate and Ccurse of \#Bffect cf
Fesearch and Eevelopment Frcgram at Oak Pidge of Solid Iow-Ievel Radioactive Plutonium Waste at the Rel ated Futlications *

Stresses $c n$ the Retention of Americium \#The Effect of limits for Insoluble Alpha Emitters* \#A Review of the

and Pulwcnaly Clearance of Radiopharmaceuticals Afte plutoniun 239 Fuo2 Aerosols, Aerosol Concentraticn, a n Pat holog $y^{*}$

of Plutonium 239 in Relaticn to the Induction

Shielding Requirements for Metabclis I $c$

in the U.S. Public Health Service Pasteurized Milk "Surface Air Sampling Frcgram, 80th Meridian *Prcgress in Personne 239 in Bones as Visualized by Photographic an * Status of the 0.S. Environmental Protection agency' \# Health Physics Program at the \#High Pressure Mechanical Froperties of an Area 12, the Wind and Potential Radiological Fields cver the \# 0 ffite Surveillance Arcund the Nuclides from the Environment to the Human Bcay in the

n Rats after Intraperitoneal Injection of plutoni 2,2'-[i aminodiethylsulfide on Excreticn of Urany \# Remcval cf Intramuscularly Injected plutonium 238 "The Biological risposition of Einsteiniu *Shielding Fequirements for Nertunin

Risk Analysis of Shipfing Plutonium Cxide and Plutoni un of Tissues of Rats Treated with plutcnium $(+6)$ Activity and Content of Calcium, Phosphorus and

Title, and Author Vol. 11, No. 1 through Vol. 14, Beagle*

\#L ym ph and protactinium in of Poisoning by Radioactive a nd Judea Group (Cenomanian-Turcnian) Aguifer in Galilee, Envircnment to the Human Body in the Niigata District, * The Biological Disposition of Binsteinium Nitrate Es Procedur $\epsilon^{*}$ Waste at the National Reactor Testing Station Deposition* odels for Predicting the Wind and Potential rode 1 s

Nonitoring for Nuclear Installations*

Monitcring of a Nuclear Fuel Cycle Reprocessing Plant* sonitoring of Low-Energy $X-F a y$ Fadionuclide Content in Monitoring when Working with Transplutonium Blements* Monitoring frogram: an overview with Emphasis on Monitoring Peport for Pantex Plant Covering Monkey After a Single Acute Inhalation Bxposure*Dioxide Monodisperse Plutonium 238 PuO2 Aerosols in Beagle Dcgs* Mcnodisferse plutonium 239 Dioxide Particles in the Monodisperse Respirable Aeroscls of Americium 241 Monodisperse 3.0 um P1 utonium 238 Dioxide Particles. 1.* 000140 conomeric and Polymeric Plutcnium 239 in the Beagle* 000128 Monomeric Flutonium in the Beagle Dog* Monomeric Plutonium 239 in the pat* Monomeric Plutoniula 239 in Beagles*

monomeric plutonium. Badiochemical and Autoradicgrapric Mononuclear Phagocytes Pcllowing Intraperitoneal

conthly Health Report on Problems Relating tc Product

Monthly Repcrt on Problems Relating to Product for

Mcrphological changes in these organs pollowing

Mcrphological changes in these organs pollowing

Norphology of Experimental Models for Fredicting the Acrphcloy of Vertebral Trabecular Bone*

crphcloy of vertebral Trabecular Bone* 1000342 ortality in Dogs after Inhalation of Plutoniu 239 Fuo 000011 Mcund Iaboratory "EF" Euilding*

Mound Iaboratory's Air Surveillance system*

Mcuse Iiver* of Different Therapeutic Regimes Mouse Tissues of Graded Folymeric and Monomeric

Mouth*

Movement in Soils: The Importance of Exchange and Hich Movement of Tritium in Bcological Systems*

Multi-Eank HEPA Filter Systems*

urine Tumors Induced by Bone Seeking Fadionuclides*

-Tetracetic 2,2'-Dianinodiethylsulfide on Excretion ,N, - Tetracetic 2, ${ }^{\prime}$-Diaminodiethylsulfide on Bxcretion $N, N, N,-$ Tetracetic 2,2 '-Diaminodiethyl sulfide on

$N, N, N, N,-T e t r a c e t i c 2,2$ '-Diaminodiethylsulfide cn

vational laboratory* ${ }^{2}$ \#High-level Waste Management National Reactor Testing Staticn (NRTS) * for Retrieval National Beactor Testing Station, Bnvironmentally

Natural Physiological Stresses and Artificial Hcrmonal

Natural Resources Defense Council Petiticn Concerning

fature and Eehavior of Local Fallout*

Nebulization* \#An Assessment of Alveolar Defosition Nebulizer Suspension Concentration*Size Distrikution of Neoplasia of the Canine Iung. 1. Clinical and Gross Keoplasms*

\#Celluiar Deposition and Eetentio

Nephrotoxicity of Chelating Agents*

Neptunium*

Network from 1963-1968 and their Relationship to

Network, January throuch December, 1970*

Neutrcn Dosimetry*

Neutron-Induced Autoradicgraphy*

Nevada Test Site Experimental \#Pluton

Nevada Test Site Experimental Farm"

Nevada Test Site Experi
Nevada Test Site Tuff*

Nevada Test Site* of Bxperimental Models for Predicting Nevada Test Site, Final Feport*

Nevada Test Site, July-December, 1970*

Nilgata District, Northern Japan

Nitrate (P1utonium 239)*

of sadoactive

itrate and course of oranium Intoxication in Fats*

Nitrate from the Rat by Continuous Infusion of

Nitrate PS(NO3) 3 in Rats After Intravenous,

Nitrate Shipping Packages*

Nitrat $€ *$

itrogen in Rabbit Bony Tissue after Injury with

No. 1 through Vol. 14, No. 6* Technical Erogress Feview No. 6*Iechnical Erogress Review by $\mathrm{Chr}$

vcde and Intestinal Lymphatic Issue Node Involvement Nodes*

Nonradicactive Metals* lorthern Israel* 238 risequilibrium in Haters of the corthern Israel*

(N) 3) 3 in of Radioactive Nuclides fro NO3) 3 in Rats After Intravencus, Intramsucular and
NRTS) * of Solid low-Level Radioactive Fluto
Nuclear Accident Dosimetry. Part 2. Dose Assessment Nuclear Accident Dosimetry. Part 2, Dose Assessment
Nuclear Detcnations: Source. Transport. Diffusicn, and
000312

000436

$\mathrm{COO400}$

$0 \mathrm{CO} 406$

000453

000415

(0)

00148

182

00140

$\mathrm{C} 02 \mathrm{C8}$

000006

0 C0129

000200

.

.

000135

000011
000461

$0 \mathrm{CO4} 02$

000190

Co129

000307

$\mathrm{CCO} 309$

000454

CC 0100

OCO 100

C CO 100

000100

000474

000325

00097

000384

000277

000354
000060

000172

000379

000082
000457

000014

OCO422

000427

000411
$C 0104$

000210

C CO451

$\mathrm{COO} 407$

000312

ccosos

000378

0 C0040

000100

OC0236

000214

$0 \mathrm{CO} 442$

000101

000449

000449

OCOOE4

00062

000362

000132

$0 \mathrm{CO} 416$

000332

000214

000476

$\mathrm{C} 00405$ 
PER MUTBD INDEX OF TITLE

Bffluent Releases and the Public Acceptance of \#The Metabolisu of the Radioactive Elements Created ky

*Trends and Projected Shidents in the an Bcosystem Aprroach to Bnvironmental Monitoring of \#Progra If fcr Improved Haste Management in Commercial \#Bnvironmental Surveillance Arcund dadendum* *Need for Environmental Monitoring for

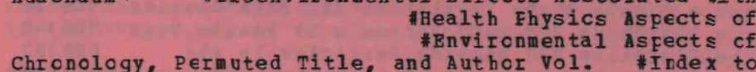
\#Sumary cf the Study of Dispesal of Sumary cf the Study of Dispcsal of
"Chemical. Blements* \# $f \in c t$ Cf Plutonium on the Content and Fenewal of
Studies on Mechanism cf Transfer of Radicactive
\#In Vivo Measurements of \#In vivo Measurements

Atmosphere fffluents: Philosophy and Morpholcgy cf
Waste Manacement Research and Levelopment Program \#Decontamination of of the Distribution of Plutonium in the Tissues cf the Determination of LCW Drinary Plutonium Levels in of Uranium and organic Matter in Recent sea an \#Plutonium Concentrations in the Facific Division, Waste Management Programs Quarterly Repcrt, December, $1 \subseteq 7 \mathrm{C*}$ operaticn Roller Coaster, Froject

\section{project 2.3. Fallout collection*}

Plutcnium* \#Bioassay Experiences in Support of Fielo" Into Plutonium Glove Boxes and Its Bffect on Inert for Several Radioisctcres Encountered in Reactor \#Absence of Iethal Radiation Bffects Pollowing kassive

\#Investigations on the Bacterial leaching of Dranium \#Ratios of the Average Concentraticns of oranium and n $T$ issue Storage and Bxcretion from the Livin Distribution of Flutonium 239 in the Animal

of Flutonium Upon the Rhythm of Its Entry Into the

Ccmfcunds in the Removal of Plutonium 239 from the

on the Excretion of Plutonium 239 frow the Huma Administered \#Distribution of Americium 241 in the $R$ at \#Micrcdistribution of Americium 241 in Scme Rat Rat Iungs and Liver, and Morphological Changes in the se

\#Relationship Between Serum Alkaline Phcsphatase an *Dynamics of the Plutoni um 239-Ind uced

Permissible Plutonium 239 Level According to the \#Develofment and Testing c

Laboratcry's Environmental Monitoring Program: An \#Risk Analysis of Shipping Plutoniu \#Study of Pcssible Changes Brought About by Plutonium * Study of Pcssible Changes Brought About by Plutoni um
and Eiological Bffects cf Inhaled Plutcriun Sclubility Changes of Elutonium 23 \#BIimination cf Inhaled Plutoni un
Acid and Fclyprofylenoglycclethylene

in the Body After Single and Chronic Entry of Oraniun 300 Degrees Centigrade (Source with \#Isotcfic Cardiac Studies on Sealed plutonium 238 sources for Cardiac Bstiuates for Use of Radioisotope Povered Cardiac \#Plutcnium Ccncentraticns in the Protactinium in Seawater and Recent Coral in the North \#Shielding Fequirements for Neptunium Nitrate Shiffing
\#pourth Proceedings of the International Symposium on

\#Environmental Mcnitoring Refcrt for

of Plutcnium 239 and Americium 241 on Biochemical

Carcinomas of the Canine Iung Following plutonin \#The Hot Gastrointestinal Tract of the Rat* \#Bffect of Age and Clinical and Gross Pathology* \#Flutonium of Cesium 137 Inhaled in Fused Aluminosilicate "Elimination of Inhaled Plutonium oxide \#Phagocytcsis and Translocation of Plut onium 239 Fu 02 analysis of Dosimetry and Cellular Risk for plutonium

Distributicn and Excreticn of Plutonium 239 Dioxide

Dogs. A. Mcnodisperse 1.5 um plutoniu 238 Lioxide particles. E. Monodisperse 3.0 um Plutonium 238 Dioxide Suspensicns* * Toxicity of Radicactive Tumorigenicity of Intratracheally Administ $\in \mathrm{re}$ \#Fathologic Bffects of Inhaled Plutoniu \#Electron Micrcscopy of Aerosols containing Radioactive
\#Mass Distritution of Large Atmcscheric
Nuclear Pacility Sites*

Radioactive

NucleaI Pission*

Nuclear Puel Cycle and Waste Production* vuclear Puel Cycle Industry to the Year 2000 Nuclear Puel Cycle Reprocessing Plant* Nuclear Fuel Reprocessing Facilities*

Nuclear Installations*

Nuclear Installations*

Nuclear Power Plants, a Selected Biblicgraphy, First

Nuclear Power Production*

wclear power Stations*

vuclear Safety, a Technical Progress Review by

ulear waste into Space*

Nuclear-Track Technique for Low-Ievel plutonium in Urin Nuclear, and Biological Properties of the Transuraniu ucleic Acids in Some Rabbit Iissues*

Nuclides from the Environment to the Buman Body in the Nuclides Bmitting Soft Penetrating Radiation*

Numerical Prediction of the Mescscale Transport of Cak Fidge National Iaboratory*

Cbsolete Processing Pacilities at Hanford* * High-level occupationally Bxposed Workers*

Cccupationally Exposed Workers* \#Sensitive Method for ccean sediments* \#Ratios of the Average Concentraticn ccean*

Cctober-December 1973*

Chemical Engineering

Cfficers Report, Project 2.3. Fallout Collection*

- Cffsite Surveiliance Around the Nevada lest Site, July-

Cperaticn Rcller Coaster, Project officers Refcrt,

perations Associated with widespread Dispersion of

operaticns* \#valuation of Inte

Cral Administration of Plutonium*

Cres*

CIganic Matter in Becent Sea and ocean Sediments* organism of Fadicyttrium, Radiocerium and Plutonium Crganism*

Crganism

Dependence of the Eiological Action Crganism* \#Relative Efficiency of Certain Complex organism*\#The Effect of Sodium Calcium-DTPA (Pen

CIganism, As Related to the Froperties of the

Crgans Following Intraperitoneal and Intratracheal

organs pollowing Intratracheal Administration of the

Csteogenic Sarcoma in Varicus Species*

Csteosarcoma in Plutonium 239 Burdened Dogs* Csteosarcomas Growth Fate*

Osteosarcomogenic Ef fect*

* Determination of Maximu over rack-Constructions Based on Phenolic Foam halls*

Cvervisw uith Emphasis on Environmental Dosimetry*

Cver with Emphasis on Environmental Dosimetry*

cxide and plutoniun yitrate*

Cxide in the Phosphatasic Acid Activity of Alveclar

cxide in Dogs* Observations on the Pharmacodynamics cxide in Water Suspension and Effect on Biological

Cxide Earticles by In Vive Lung Washout*

Cxide Fclymer on Excretion of Inhaled plutonium 239

oxide-Fentoxide* pacemaker Safety lests at 1300 Degrees Centigrade and Eacemakers*

Pacemakers*

Facific

\#Dose-to-the-Eopulation

Eacific*

Ealomares Two Years After*

Farameters: Bffect of Dose and Fadionuclide Eurden Time* Farathyroid Damage Due to Americium 241*

Farticle Inhalation* Studies. 7. Bronchiolo-Alveola Farticle Project. Exposure of Animals*

Farticle Size on Passage Time through the

Farticle Size Analysis*

Farticle-Induced Neoplasia of the Canine lung. 1.

Farticles by the Beagle Log* Retention and clearance Farticles by In vive Iung washout*

Farticles by Feritoneal phagocytes of the pat*

Farticles in the Chinese Hamster* and Cytcgenetic Farticles in the I ung*

Farticles Iabeled with ytterbium 169 in the Rhesus th

Farticles. B. Monodisperse 3.0 um Plutcnium 238 Dioxide Farticles. 1.*Monodisperse 1.5 um Plutonium 238 Dioxide Farticles. $1 \mathrm{~A}$. Intratracheal Injection of Radicactive Farticles*

Farticles*

Earticles*

Farticles*
000322

000089

000445

00044

$0 \mathrm{C} 0429$

000478

000425

$\mathrm{COO} 400$

000326

$0 \mathrm{CO} 458$

000320

000480

$0 \mathrm{CO} 480$

OCO298

000118

000378

000339

000312

000474

000456

000356

000295

000299

000301

000314

$\mathrm{CCO} 420$

000396

000420

CCO465

000462

000254

000015

000074

000299

$\mathrm{C} \mathrm{CO} 206$

000078

00015

CCOO18

000367

000272

0 C0180

000079

000051

000224

OCO176

000175

000415

000032

000442

OC0195

000010

000171
000166

000255

000085

000316

000447

000391
000314

000416

000457

0 CO440

000327

000397

0.

000196

C 00055

000207

CCO428

000172

000025

C 0166

000199

000182

OCO126

OCO 140

000140

OCO264

000252

$0 \mathrm{CO} 433$

000324 
in Mice After Pulmonary Deposition of Radicactive

in Mice after Pulmonary Deposition of Fadioactive in Yeast Cells After Irradiation with Densely Icnizing of the Canine Iung Pollowing Inhalation of Plutoni um Exposcre to P1utonium 239 FuO2 or Flutonium 238 Eu 02 Rat \#R Predicting the Redistribution cf

* Radicidine Levels in the D.S. Public Health Service Factcrs of Fadiation Sickness in Man*
Rabbits and Rats*
\# The Fate and \#Ef fects of Additional

Neoplasia of the Canine Iung. 1 Clinical and Gross

Influence of Aerosol proferties and the Respiratory tobserved pallout \#In Vivo Measurements of Nuclides Buitting Soft

Mice by Contined Therapy with the Calcium Chelate and in the Case of Inbalation of Ammonium Plutoni un Human organism* \#he Effect of Scdium Calcium-DTPA Body After Single and Chrenic Entry of Uranium oxide-

State of the Blood System in Dogs in the Icng-Term Distribution and Excretion in Dogs at Different \#Acute Effects of Plutonium on the \#Effects of Additional Pathological Factors on Plutcnium 239 *

osteosarcomogenic Bffect* \#determinaticn of Maximum Safety, a Technical progress Review by Chrcnclcgy,

the Plutcniul 239 Metabolism in the Case of Prolonged \#Contamination limits for Real and January-June, 1974* \#Contamination limits for Real and \#lutonium:
\#Progress in \# Hemateological Studies of Plutonium Froject

\#A Feview of the Natural Resources Defense Ccuncil of Elutcnium 239 P v02 Particles by Peritoneal $\begin{array}{rl}\text { Plutonium } 2 & 39 \text { Puo } * \text { \#The vitrastructure of Mononuclear } \\ \text { Polymeric } & \text { \#ffects of Pxperimental Alteraticn cf }\end{array}$ Polymeric \#ffects of Experimental Alte
Particles by Feritoneal Phagccytes of the Rat* *An Imfroved c best Plutcnium oxide in Logs\#Preliminary observaticns on the of Plutonium and Americium in a Preshwater Bcosystem of Plutonium and Americium in a Freshwater Eccsystem: and Jesting of overrack-Constructions Eased on

of $t k \in$ Mescscale Iransport of Atmosphere Bffluents: \# Sampling cf Soils for Radicactivity: Dogs* and Nitrogen in Rabbit Eony Iissue after Injury with by Bone Seeking Radionuclides*
Changes Brought About by Flutonium Cxide in the

Injury \#Fhcsphatase Activity and content of Calcium, Retenticn in plasma and Selected Retenticn in plasma and Selecte
Distribution in the Iiver* \#Influence \#The Bffect of the *Influence of the "Plutonium, Industrial Hygiene, Heal th

Vranium Processing Plant*

\#Heal th

\#Health

Health

Far $\mathbb{R}^{*}$

Substances. $2 . *$

\#heal th

on the Retention of Americium Calcium DTPA Fnhanced Bxcretion of Plutonium 239 in Americium 241 from the Beagle Dcg by Lung Iavage: $₫$ plutonium aste at the National Reactcr Testing

$$
\text { \#Environmental Mcnitoring Report for Pantex }
$$

* Plutoni un

of in Vive Gamma spectrometry in a vranium Processing Mcnitcring of a Nuclear Puel cycle Reprocessing

and Cistritution of plutonium in Barley and Scytean Bioenvironmental $\mathrm{B} f$ fects Associated uith Nuclear pouer Chemical state of Plutoniu on its Barly Retention in

Design of pilter * A Comparison of the Metabclis of \#Recover y of Mastes, 2.* Phase 1 , Iinnclogical \#The Ecolcgical Bebavior of Phase 2. Implications of \#The Bcological Behavior of * An Improved Chest Phantom for studies of and Translccation of Plutonium 239 Pu02 Farticles by * Plutonium 239 in Bones as Visualized by

\#Advances in
\#

of Inhaled Surstances. 2.* Trace Blements in Seawater in \#The Bffect of the * Reccuery cf
Farticles*

Farticles*

Farticles*

Farticles*

\#Eronchiolo-Alveolar Tumcrs

Iiver cells of the Chinese Hamster Followin

Eassage Time through the Gastrointestinal Tract of the Fastevized Milk Network from 1963-1968 and their

Eathologic Effects of Inhaled Plutonium Particles"

Eatholcgical Pactcrs on Feripheral Blcod of Rats Given

Fathclcgy

\#Plutonium Particle-Induce Eattern Opon Hazards Bvaluaticn Pollowing Inhalation Fatterns and Countermeasures Taken* Fenetrating Badiaticn*

Enetration of Plutoning 239 through the Skin*

Eenta-Fthyl Fster of DTPA* of Folymeric Plutcnium fIC Fentacarbonate by Rats*Red Blood Cells and Hemcdyna inic Fentacine) on the Excretion of plutonium $239 \mathrm{frcm}$ the Fentoxide* \# \#prcutaneous Absorption of Radioelements*

Feriods after Chronic Influence of Ionizing Radiation* Feriods of Time*

Feri fheral Blood of Mammals*

"Plutoniu

Eeripheral Blcod of Rats Given Plutoniun $239 *$

Eeritcneal Fhagocytes of the Rat* Eermissible concentrations in Air for compounds of Fermissible plutonin 239 Level According to the Fermuted Title, and athor Vol. 11, No. 1 throuch Vol. Feroral Administration*

Fersonal Property*

Peroral a duinistration*

Property, Frogress Report for the Bxposure Control yith Increasing Plutcnium Eeutron Dosimetry*

Eersonnel, Effect of Exercise of leukopenia,

Petiticn Concerning Limits for Insoluble Alpha Emitters* Ehagocytes of the Rat* \#Phagocytosis and Translocatio Fhagocjtic Activity on Tissue Optake and Retention c

Phagocytosis and Translocation of Plutcni um $239 \mathrm{Pu} 02$ Phase 1. Limnological Characterization and Isotopic Fhase 2; Implications of Differences in Transuranic henolic Foan Walls*

Fhiloscphy and Morphology of Experimental Models for Fhilcscphy, Experience, and Results*

Fhosphatase and osteosarcoma in Plutonium 239 Burdened Fhcsphatase Activity and Content of Calcium, Phcsphorvs Fhosphatases and Metachromasia in Mrine Tu Fhosphatasic Acid Activity of Alveolar Macrophages of

Fhosphclipid Turnover in Product Poisoned Animals*

Fhosphcrus and Nitrogen in Rabbit Bony Tissue after

Fhosphcrus and Nitrogen in Rabbit Bony Tissue afte
Ehctographic and Neutron-Induced Autoradiography*

Fhctographic and Neutron-Induced Autoradiogra

Fhysical and Biological Fadiation Detectors* Fhysical State on the Removal of Hydrolyzable

Fhysical-Chemical State of Plutonium on its Barly

Fhysical-Chemical state of Plutonium on Its Barly Fhysical-Chemical state of Plutonium on Its Barly Fhysicc-Chemical Forms of Ra

Fhysics and Related Asfects*

Physics at the Los Alamos "Wing 9" Hot-Cell Pacility*

Fhysics Application of in Vivc Gama Spectrometry in a

Fhysics Aspects of Nuclear Pover Production*

Fhysics Program at the Nevada Test Site Experimental

Physiclogical Pactors controlling the Fate of Inhaled

Fhysiological stresses and Artificial Hormonal stre

Filot Study of the Effect of Cortisol on Trisodiu
\#Removal of In

Flan fcr Retrieval of Solid Lov-Level fadioactive

E1ant Covering 1973*

Flant safety*

Elant* Elant* from an Bcosystem Approach to Envircnmental
Flants*

\#Health Physics Applicaticn Flants, a selected Bibliography. Pirst Affecting

Flasma and Selected Soft Tissues of Beagles* FhysicalFlasma Fe Study*

lenum Heat Bxichangers*

lutonium (Plutonium 238) in "ran and the Rat*

Flutonium and Americium from Alpha-Bearing Aquecus

Flutonium and Americium from Alpha-Bearing Aqueous

Elutonium and Americium in a Preshwater Bcosystem:

plutonium and Americium in a Preshwater Rcosystem:

Flutonium and Americium in Human Lungs*

Flutonium and Americium* articrlate Cantaminants from Soil Surfaces*

Fatholcgic effects of Plutonium Metal Implanted

Fathclcgy of Irradiation* Ehagocytes Following Intraperitoneal Administration cf

Fhantcm for Studies of Plutonium and Americium in Human Fharmacodynamics and Biological Effects of Inhaled
$\mathrm{CCO} 251$

$0<0250$

000178

000031

000331

$\mathrm{C} C 0207$

000422

000353

000134

000125

000021

000172

000172

000253

000452

00116

00142

00110

000367

000085

$0 \mathrm{CO} 026$

$0 C 0158$

000102

000125

000199

$0003 E 3$

000449

000041

000414

000413

000448

000411

OC0360

000384

0corgs

000200

000199

00377

C C0010

000305

000304

000437

000312

$0 \mathrm{CO224}$

000075

$0 \mathrm{CO} 023$

000195

000016

000075

000104

000341

000348

00084

OC0231

000033

000313

OC0466

000469

000458

000451

000348

000097

C COO05

000157

000476

0 0397

000463

000429

000274

000326

000173

$0 \mathrm{C0} 450$

000061

$\mathrm{CCO} 280$

000279

000305

OCO304

000377
000131 
Plutcniun Dioxide and the Bffect \#The Distribution of of Man and Animals*

\#The Acticn of Salts of Zirconium and other Metals c Hormcnal stresses on the Retention of Americium and \#Femoval of Deposited \#Radiochemical Determiation cf Therapeutic Regimes of Glucan in Removal of Folymeric \#DTPA-Effectiveness in Rencving Internally Defosited Calcium Chelate and Penta-Ethyl \#Removal of Polymeric \#New Frocess for Pemoving \#Airbcrne

Effect of DTPA and Glucan on Decorporation of Monomeric *The Effect of Irradiation in the atsorftion cf

Workers*

\#Summary of the Distribution cf \#Factors Affecting Uptake and Distribution cf \#Chronic Toxicity of Inhaled Hematclcgic Effects of Internally Deposited Badium and Reported rata* \#he Distribution cf \#Determination of Methed for the Determinaticn of Very Low Level * Use of Citrate in Mobilizing \#Whole Body Ccunting cf \#he Chemistry of
\#Content of

Envircnmental Systems* \#The Distribution and Excretion of \#mheoretical Excretion of

\#A Procedure for the Determinaticn of Alpha-Eritting \#Nuclear-Track Technique for Iow-Level
Soft $\quad$ The Effect of the Fhysical-Chemical State cf in Scme Rabrit Tissues* \#The Effect cf *Acute effects cf the Effect cf colloidal state of Intravenously Injected The Effect of the Fhysical-chemical State o \#The Binding of Americium and \# Metabolic Study of the Einding of Biolcgical taterials by \#Sirultaneous Determination for from skeletal

$\mathrm{XW}-25$ (0)*

Tubular Eones*

as Adjuncts tc DIPA Therapy*

plutonium and Americium: Subcutaneous Administration of Flutonium and Yttrium Distribution and Bxcretion*

Flutonium by Rat Eone* Stresses and Artific

Elutonium by Triethylenetetranine Hexacetic acid*

Flutonium for Padiological Purposes*

Elutonium from the Mouse Iiver*

Elutcnium from Humans*

of Different

Elutonium from Mice by Combined Therapy with the

Flutonium from Mice by Encapsulation of DTPA Within

Flutonium from Subcutaneous wounds in Eeagle*

Flutonium from Waste Water--A Progress Report*

Elutonium from Weapons Accidents*

Flutonium in the Beagle Dog*

Flutonium in the Gastrointestinal mract*

Flutonium in the Terrestrial Environs of Rocky Elats*

Flutonium in the Tissues of Occupationally Exposed

Flutcnium in Earley and Soybean Plants*

Elutonium in Bone Marrow: A Possible Leukemic Bisk*

Flutonium in Dogs*

Flutonium in Dogs*

Flutonium in Human Tissue: A Preliminary Analysison of

Flutonium in Human Tracheobronchial Iymph Analysis of

Flutonium in Human Urine*

Flutonium in Humans*

Elutonium in Bat*

Flutonium in Fats*

\# A Sensitive Analytical

Elutonium in Belation to Its Behavicr in Biological and

Elutonium in River Water in Japan*

Elutoniun in Two Human Subjects*

Flutonium in Drine Based on the Ney TCRP Inng Model*

Elutonium in Orine Using a solid-State counter*

Elutoniun in vrine*

Flutonium on its Early Retention in plasma and selected

Flutonium on the Content and Fenewal cf Nucleic Acids

Flutcnium on the Peripheral Blood of Mamals*

Flutonium on Its Distribution in Bone and Marrou*

Flutonium on Its Early Distribution in the Iiver*

Elutonium to Eone Glycoproteins*

Elutonium to Serum Proteins*

Flutonium with Frimary Amines*

Elutonium Alpha Activity an

Elutonium Compared in

\# Flutonium Concentrations in the Pacific ocean*

Flutonium Contaminaticn frcm One-Point Detonaticn of a

Plutonium Content in the Protein Praction of Rat

* Plutonium Decorporation by Glucan and Related Compounds

Flutcrium Defosition ky Desferrioxamine-B*

\#Prevention of * Chelating a gents in

Plutonium and Americium: Subcutaneovs Administration of of the Iung Burden Resulting frcm Inhalation cf \#Ccmparative Disposition of Four Types of Different Periods of mine*

\#Bmission Monitoring systems for \#In-Residence Health and Safety suppert in * after Inhalation of Plutonium 239 Puo2* after In balaticn of Plutoniun 239 PuO2* ir leakage into carcinomas of the Canine Iung Following plutoniu

\#Removi

"Sensitive Method for the Determination of Iow Urinary

\# The Fate and Pathologic Bffects cf Develofing in Rats after Intraperitoneal Injection of \#Risk Analysis of Shipping Plutonium oxide and *Risk analysis of shipping

Alveolar \#Study of Possible Changes Brcught ALout ky the Pharmacodynamics and Biclogical Bffects of Inhale \#Flimination of Inhaled

Alveclar Carcinomas of the Canine Lung Fcllowing Iung. 1. Clinical and Gross Fathology*

* An analysis of Dosinet * Pathologic Effects of Inhale

Tumors of the Canine Lung Following Inhalaticn cf and Hemodyra rics in the Case of Inhalation of mmoni um Leukopenia, A Statistical

\#Hemateclogica 1 studies cf \#Progress Report

Plutonium Depition--A Minority vien*

Flutonium Dioxide and the Effect of Chelation Therapy* Flutcnium Dioxide with the Help of Separaticn Analysis* Flutonium Dioxides Inhaled by Dogs*

Flutoniun Distribution and Excretion in Dogs at

Flutonium Facilities*

Elutonium Pacility*

Elutonium Glove Boxes and Its effect on Inert operation

\# Flutonium Inhalation Studies. 4. Mortality in Dogs

* Flutonium Inhalation Studies. 4. Mortality in regs

Flutonium Injected in skin of Swine*

Flutonium Levels in occupationally Exposed workers*

Elutonium Metabolism in Miniature Swine*

Elutonium Metal Implanted Into Rabbits and Fats*

Flutonium Nitrate (Plutonium 239)*

Elutonium Nitrate*

Flutonium Oxide and Plutcnium Nitrate*

Elutonium oxide in the Phosphatasic acid nctivity of

Flutonium oxide in the phosphatasic acid Activity of

Flutoniva oxide in Dogs*

Flutonium oxide Particles by In Vivo Iung Washout*

Elutcoiun Particle Inhalation * Studies. 7. BICDCh

Elutonium Particles in the Iung*

Elutonium Particles*

Flutonium Particles*

Elutonium Particles*

Flutoniua Pentacarbonate

Flutoniua Plant Safety*

ium Froject Fersonnel, Effect of Exercise of 000463

lutonium Froject Fersonnel, Effect of Exercise of 1000360

Flutonium Removal, Tumor Incidence Studies*

- Flutonium Revisited*

Elutonium Samples*\#Measurement cf the Mass Spectrometer
Flutonium Storage Pacility* Elutonium Storage Facility*

Elutonium Toxicology*

Bfficiency in the Isotopic Analysis of Very $S$ mal problems of \# Dependence of the Biological action cf

Flutonium Upon the Rhyth

Flutcoium orinanalysis*

Elutoniun Waste at the National Reactor Testing Station
C $\mathrm{CO} 107$ ос0186 $000 \mathrm{Cs} 7$

000013

000424

000365

OCO142

CO193

000473

000363

000130

000083

$0 \mathrm{CO} 323$

000274

$\mathrm{CCO} 263$

000170

000376

000362

000297

000211

000138

000288

000311

000423

000297

$0 \mathrm{CO293}$

000118

000102

000192

000050

000164

000283

000081

000385

000022

000314

000017

000212

$\mathrm{C} C 0375$
000107

000374

$\mathrm{CCOOOB}$

000198

000464

000462

000011
C 00009

000055

000174

$0 \mathrm{CO} 295$

000134

000040

000442

000195

OC0010

000166

000055

000172

C0110

CO0205

000338

000438

$0 \mathrm{COO} 43$

000151

000399

000476
( \#Plan for Retrieval of Solid Low-Level Radioactive 
un Plutcniun 238 Dicxide

Distrikution and Effect of

Elutonium 238 in the Petoplacental unit of the Fat*

000065

Plutcniun 238 Dicxide Hoxicity of Inhaled Plutcniun 238 rioxide Particles. E. Mcnodisferse 3.0 um \#Characterizatien and Eroperties of Medical-Grad
Biological Eehavior After \#olubility Changes of "Biclcgical Effects of Radiation from simulated \#Short-Term Metabolism of Three Sizes of Mcncdisperse

\#Temperature cf Surfaces in ccntact with
\#Safety Studies on Sealed \#A Comparison of the Metabolism of Plutonium
Infusion of Parameters: Bffect of Dose and * Comparative Bffects cf * \#Ccmfariscn of Bffects of lethal Body Burdens of
of White Eats* \#The Action cf
of Cesium 137, Cobalt 60, Cerium 144, Strontium 90 and of Sodium Calcium-DTPA (Pentacine) on the Bxcretion of of Certain Complex Compounds in the Remcva 1 of \#The Effect of Chemical Porm on the clearance of \#istribution of

\#Comparison of Skeletal and Hepatic Dose Rates frcm Six-day Tissue Distribution of Moncmeric and Polymeric cn Trisodium Calcium DTPA Enhanced Excretion of the Localization and Radiaticn Dosage of Radium 226 and Morphological Changes \#Levels and Microdistribution of \#Influence of Age $c n$ the late Effects of Monomeric \#Translccation of

* The Hematologic Changes Induced by

Retention and Distribution cf Polymeric and Monomeric \#The Determination of Iocalized Concentration of
The and Neutron-Induced Autcradicgraphy*

\#Strontium 90 , Cesium 137 , and

Cont amination* \#Studies of the oxidation States of Flutonium 238 Dioxide in Beagle Dogs. A. Monodisperse 1 . Elutonium 238 Dioxide Farticles. 1. Monodisferse 1.5 un Elutonium 238 Puels*

Flutonium 238 oxide in Water Suspension and effect on Elutonium 238 Fower Sources in rogs*

Elutonium 238 Puo2 Aerosols in Beagle Dogs*

Elutonium 238 PuO2 Aerosols in Beag

Flutonium 238 Fuc2 Microspheres*

Elutonium 238 SNAP Puel Ingestion by Miniature Swine* Elutonium 238) in Man and the Bat*

Elutonium 238-Nitrate from the Rat by continuous

Elutonium 239 and Americium 241 on Biochemical

$\begin{array}{ll}\text { Elutonium } 239 \text { and Americium } 241 \text { on Biochemical } & 000162 \\ \text { Flutonium } 239 \text { and Radium } 226 \mathrm{cn} \text { Hematoroiesis in Eeagles } 000067\end{array}$

Flutoniun 000257

\#Iutonium 239 by Man*
\#lutonium 239 from the Human Organism*

Elutonium 239 from the Organism* \#Relative Efficiency 000018

Flutonium 239 from the Respiratory system of the Rat* C00219

Elutonium 239 in the Animal organism*

Elutcnium 239 in the Beagle As a Punction of Dcse Ieve1* 000227

Flutonium 239 in the Beagle* of Blood Clearance and OCO128

Elutonium 239 in the Beagle* of the Bffect of Cortisol 000005

Flutonium 239 in the Bones of Dogs* \#Autoradicgraphy in 000004

Flutonium 239 in the case of subcutaneous Injection* 0 0042

plutonium 239 in the Rat Lungs and Liver, and 000079

Elutonium 239 in the Rat* $\quad$ C00208

Elutonium 239 in Adult Beagles* $\quad 000106$

Flutonium 239 in Beagle Livers* $\quad 000246$

Elutonium 239 in Beagles* 000068

Flutonium 239 in Beagles * \#keletal 000006

Flutonium 239 in Bone* $\quad 000261$

$\begin{array}{lll}\text { Elutonium } 239 \text { in Bones as Visualized by Photographic } & 000104 \\ \text { Flutonium } 239 \text { in Hay Samples from } 1953 \text { to } 1961 * & 000418 \\ \text { Flutonium } 239 \text { in Injecticn Solutions* } & 00032\end{array}$

$\begin{array}{ll}\text { Elutonium } 239 \text { in Injecticn Solutions* } & 000032\end{array}$

Flutonium 239 in Intact Skin, 000080

Beagle*

- Elutonium 239 in Liver, Spleen, and $K i d n \in y s$ of the

Flutonium 239 in Liver, Spleen, and Ridneys of the C C0230

Elutcnium 239 in Urine*

\#Cellular Deposition and Retention c Method of Determining

\#The Determination of the Depth and Amount of lavage and CTPA Treatment for the Removal cf Inhaled the Rabbit Iiver* \#Bffect of Daily Injections of Comparison of the Bffects of Americium 241 and \#The Penetration of *Nacte cn the Exchange of Between Seruil Alkaline Phosphatase and osteosarcoma in of Intratracheal Administration of Chemically Soluble Lesicns After Inhalaticn of Cerium 144 Dicxide Lesicns After Inhalaticn of Cerium 144 Dicxide $\mathrm{CI}$ Syrian Hamsters. 2.* \#Excretion and Translccation of and Cytogenetic Effects of 0.3 un Mcnodisperse 169 in the Fetention, Distribution and Excretion of \#Listribution and Tcxicity cf Inhaled

Study of Serum Protein Fraction \#The Measurement of Study cf Serum Protein Fractions in Radium 226 and of Calibration Technigues for the Assessment of Frequency in Blood Iymphocytes of Animals with

Peroral Aduinistration* \#Age-Defendence of \#inetics of $t$ he
Oxide

Cells of the Chinese Hamster FCllowing Exposure to \#Relationships Between the Size Distribution of

studies. 4. Mortality in Dogs after Inhalation of

Studies. 4. Mortality in Dogs after Inhalation of Fhagocytes Following Intraperitoneal Administration of of the Rat* \#phagocytosis and Translccation of \# the Rat* \#Pagocytosis and Translccation of

High Speed Al cha Autoradiography in the Detection cf \#Calibration of a large Area Propcrtional Counter for and Thyrcid* \#Chemical Asscciations cf \#inetics of the Skeletal Fetention of \# Hepatic Changes Induced ty fliver Tumors in Beagles Injected with \#scme Icxicity Aspects of Internally Deposited \#Serum Transaminase Ievels in Beagle Logs Burdened with \#Observations on the Biological Action of \#Comparative Toxicity of Stronti um 90, Radium 226, and
\# Total Eody Gamma-Ray Ccunting of Basis for Routine Orine Sampling of Workers Expcsed to

Perrissitle concentraticns in Air for $\mathrm{Ccm} F c u n d s$ of Pathclooical Factors on Peripheral Blood of Rats Given

ounds with $S I$ (LI) Detectors

lutonium 239 of Varied Solubility in Beagle Dogs. 2.* Flutonium 239 on the Free $\mathrm{Bi}$

Plutonium 239 on Serum Bnzymes*

lutcniun 239 Between Tranferrin ana Perritin in vitro* Elutonium 239 Burdened Dogs*

Flutonfum 239 Compounds* "Some Remote Aftereffect Flutorium 239 Compounds* Remote Aftereffect

Flutonium 239 Dioxide in Immature, Young Adult and aced Flutonium 239 Dioxide After Inhalation*

Elutonium 239 Dioxide Farticles in the Chinese Hamster* Flutonium 239 Dioxide Particles Labeled with Ytterbiu Elutonium 239 Dioxide*

Elutonium 239 In Vivo, A Frogress Report*

Elutonium 239 Injected Dogs* \#An Blectrcphoretic

Elutonium 239 Level According to the osteosarcomogenic

Elutonium 239 Iung Burdens

Elutonium 239 Lung Burdens

\#Chromosome Aber

Elut*

Elutonium 239 Puo2 in Dogs* Polypropylenoglycolethylene

Elutonium 239 Fuo2 or PI utonium 238 PuO2 Particles*

Elutonium 239 Puo2 A $\in$ rosols, Aerosol Ccncentration, and

Elutonium 239 Puo2* \#Plutonium Inhalaticn

$\begin{array}{ll}\text { Elutonium } 239 \text { Puo2* } & \text { \#Plutonium Inhalaticn } \\ \text { Elutonium } 239 \text { Fuc2* } & \text { \#Plutonium Intalaticn }\end{array}$

Elutonium 239 Puo2* \#The 01trastructure of Mononuclear

Elutcnium 239 pu02 particles ty Peritoneal phagccytes

Elutonjum 239 pelative cles

plutonium 239 Skin Surface Contamination* of of Ultra

Elutcnium 239 Fithin the Femur of the Bat*

Flutonium 239 x-ray Detection in Lungs*

Elutonium $239(+4)$ and Americium $241(+3)$ in Blood, Iiver

Flutonium $239(+4) *$

Elutonium 239*

Elutcnium 239*

Flutonium $239^{*}$

Flutonium $239 *$

Elutonium 239*

Elutonium 239*

E1utonium 239*

Flutonium 239*

Flutonium $239 *$

Elutcnium 239*
060289

000156

$0 \mathrm{C0259}$

000066

000161

000116

000035

000269

000139

00096

000012

000182

CCO126

000267

$0 \mathrm{CO} 430$

$0 \mathrm{C0087}$

000175

000030

000209

000041

000255

000031

000009

000009

000200

00199

$0 \mathrm{CO} 395$

000361
$0 C 0238$

$\mathrm{C} C 0349$

000232

000229

000245

000244

000243

000221

000044

000147

000137

\# A C CO345

"Maximum 000383

\#Effects of Aseptic 000122 
and Nitrcgen in Rabbit Bony Tissue after Injury with after Intraferitoneal Injection of Flutonium vitrate Dynamics of the

Livers \#Ccmparison of the Intracellular Distribution of The pate of Tooth Loss in Beagles Injected wi th and Cther Serum Constituents in Dogs Burdened with and other Serum Constitutents in Dogs Burdened with of Glcbal Fallout Strontium 90, Cesiua 137, a nd *Plutonium: Fersonnel Exposure Control with Increasing Determination of Plutonium Alpha Activity and \#The General syndrome Induced by

in Mouse Tissues of Graded Pclymeric and Monomeric Hon the Binding cf

Blood Serum* *T he Reaction of Chemical state of \#Metabclisi of Injections of \#Effects of Intradermal Injections of
\#Inhalation cf ncral Therapy for Deposited * Technical progress Report on the Metabolic Studies cf \# Technical Progress Report on the Metabolic Studies of Biological Studies Associated with a Pield Release cf
\#etabolic and Therapeutic Studies of \#Interpreting counting Data for Internaliy Defositea Deoxyribcnuclease Acitivity in Babbit Liver Affected by Speculative Extensions to Man of Animal Risk Data cn
Effects of Therapeutic Removal of Internally Deposited Changes in the Iungs of Rabbits After Inhalation of Near Eone Surfaces in Raklits a fter an Injecticn of cf BCne Tissue in Acute and subacute Affection with Intermittent DTPA Therapy in Poiscning ky Polymeric

Bffects Following Massive oral daninistration Acid Pollowing Intratracheal Aministration of (BAL) Opon Distributicn and Excretion of the Living organism of Radioyttrium, Radiocerium and Activity on Iissue Uptake and Retention cf Eclymeric operaticns Associated with Widespread Dispersion cf Matrices* Decontamination of Related Aspects* \#Comparison cf Bfficiency of Eemoval of Related Aspects* Badioisotope in the North pacific* Particular Feference to as Aerosols by Rats and Man* \#Depcsition and Fate of Plutonium 240 content*

Hamster Fcllowing Exposure to plutonium 239 Euo 2 or Phospholipid Turnover in Eroduct Stimulation and Long-Term, Intermittent D TPA Therapy in \#Therapy of

Acid and polyprepylenoglycolethylene oxide \#Skeletal Retenticn and Distribution cf

Different Therapeutic Regimes of Glucan in Remcral cf the Calciul Chelate and Penta-Ethyl Ester \#Removal of and Six-day Tissue Distribution of Moncueric and

Phagocytic Activity on Tissue optake and Retention cf

long-Term, Intermittent DIFA Therapy in Foisoning by of \#Bffect of Diethylenetriaminepentaacetic Acid and Cardiac Pacemakers* "Dose-to-there of Animal Copropor chyrin Fxcretion* \#Studies of

of Fxperimental Models fcr Predicting the Wind and * Bioenvironmental Bffects Asscciated with Nuclear \#Health Fhysics Aspects of Nuclea Bffects of Padiation from Simulated Plutonium 238 \#Envircniental Aspects of Nuclear

to-the-Fopulation Fstimates for use of Radicisotope Rapid Experimental and Calculative Approaches to Cantaminants from Soil Surfaces* \#A Mcdel fcr Philoscehy and Morphology of Experimental Mcdels fcr T te listribution of Plutoniu in Human Tissue: $A$ and Elutcnium 239 on Serum Bnzymes*

Biological fffects of Inhaled plutonium oxide in Dogs* Bones Induced by Bone Seeking Radionuclides*

and 800 Degrees Centigrade (Source with Internal $T$ of $f *$

\# Some Aspects of the

Radioactive Ccntamination*

* Solvent Extracticn of Plutcnium wit and Transportation of Radioactive Materials \# \#Pourth Changes in Correlation Eetween Isotcres in a Mixture

Tissue after the Incorporation of Radioactive Fission
P1 utonium 239*

and Content of Calcium, Fhcsphorus \#Tumors Develofing in Rats

Futonium 239)*

Flutcniui 239-Induced Osteosarcomas Growth Bate*

Flutonium 239, Americium 241 and Californ:

Elutcnium 239, Thorium 228, Badium 228 and Radium 226*

E1utonium 239, Thorium 228, Radium 228, and Radium 226*

Flutonium 239,240 in 5

Elutonium 249 in Biological Materials by Gel

Flutonium 241 in Urine*

Flutoniul 293 in the Beagle*

Flutonium. Radiochemical and Autoradiographic Studies*

Flutonium $(+4)$ to Transferrin and conal tumin*

Elutonium $(+4)$ with the Iron Transport system in Buman

Elutonium $(+4)$ with Blood Constituents*

Flutonium $(+4) *$

Elutonium $(+6)$ Nitrate*

Elutonium*

Elutonium*

Flutonium*

Flutonium*

Elutonium*

Elutonium*

Elutonium*

Plutonium*

Flutonium*

Flutonium*

Flutonium*

Elutonium*

Elutonium*

Flutoniun*

Plutonium*

F1utonium*

Elutonium*

Flutonium*

Elut onium*

Flutonium*

Elutonium*

Flutonium* \#Eioassay Experience

Flutonium, Americium, and 0ranium in Environmental

Flutonium, Calcium and zinc frca Rats by Calcium a

Flutonivi, Industrial Hygiene, Health Ehysics and

Flutonium, Thcrium and Protactinium in Seawater and
Elutonium, Thorium, Radium, Iron and Gold*

Elutonium, Dranium and their Pission Products Inhaled

Fut onium, 1944-1984*

Flutonium: Personnel Exposure Control with Increasing

FIutonium 238 PuC2 Farticles*Iiver Cells of the Chinese Eoisoned Animals*

Foisoning by Folymeric plutonium* Reticuloendothelial Foisoning by Radioactive and Ncnradicactive Metals*

Fclymer on Bxcretion of Inhaled Plutonium $239 \mathrm{FuO2}$

Folymeric and Monomeric Flutonium 239 in Beagles*

Folymeric Plutonium from the Mouse Liver*
Folymeric plutonium frcm Mice by Combined Therafy with Folymeric Plutonium 239 in the Beagle* Blood Clearance

of Experimental alteration cf

Folymeric Plutonium*Reticulcendothelial Stimulation an

Fclyfrcfylenoglycolethylene oxide Polymer on Excreticn

Fopulation Fstimates for Use cf Radioisotope Fonered

Fofulaticns (Terrestrial and Soil Invertebrates) Due tc

Forphyrin Metabolism. 4. The Fffect of Irradiation on Fostmcrtem Tissue Samples*

Fotential Radiological Fields over the Nevada Iest Sit $€$ * 00031 Eower Elants, a Selected Bibliography, Pirst Addendum* CCO326 Fower Froduction*

Fower scurces in Dogs*

Eower Stations*

\# Eiclcgical OCO458

\#DCse- CCO320

Predict In Vivo Eehavior* Chelaticn and Mixed Complexes- 000202

Fredicting the Redistribution of Particulate

Fredicting the wind and Fotential Radiological Fields OCO312

Frediction of the Mesoscale Transport cf Atmosphere

Freliminary Analysis of Reported Data*

Freliminary Comparison of the Effects cf Americium 241 OCC16

Freliminary orservaticns on the Pharmacodynamics and 000010

Freliminary Report: Changes in Vascularity of Ccrtical 000105

Fressure and a Simulated Fuel) * 1300 Degrees Centigrade 000316

Fressure Mechanical Properties of an Area 12, Nevada

Erevention and Treatment of Excessive Internal

Frevention of plutonium Defosition by Desferricyamine-

Erimar Anines*

000283

Froceedings of the Internaticnal Sympcsium on Packaging 000440

Froducts of tranium 235 in waw Loses*Ceretral and Renal oc0270
0040

0220
00276

00247

000306

0408
00287

00241

$\mathrm{CO} 282$

C0222

00101

00046

C0015

COO92

0
0 199

00117

C0187

00024

$C 0135$
00194

C0237

00114
0.0206

00188
00465

00273

000213
00466

000416
00389

00204
$C 0256$

.

0016
000194

C0132
00255

COOOO6
CO 129

00190
0142

. 0188

00194

000391

\section{.} .

9


PERMUTED INDEX CF TITIE

Caticns by Micaceous Vermiculite and Its Heathering and Fate of Plutenium, Orani $\mathrm{rm}$ and their Fissicn \#Decontamination of Soils Containing Fissicn

Progress. Report on the Metabolic Studies of Fission
\#Chemical Engineering Livision, Waste Managenent

\#Pesearch in Padiobiology. An Annual Report of Work in

\#Res earch on Radiobiology, Annual Report of Nork in Products*

\# Iechnical Technical "Iechn ical

The Measurement of Plutonium 239 In Vivc, \#New Process for Bemoving Plutonium from Waste water-Studies* Aut hor 1945*

Statistical

\#Index to Nuclear Safety, a Technical \#operation Boller Coaster, Project officers Repcrt,

to the $Y \in a r 2 \mathrm{COO*}$ \#The Hot Farticle Rinetics of the Plutonium 239 Metabclism in the Case cf Radicnuclides*

\# Contamination Limits for Real and Ferscna June, 1974* \#Contamination limits for Real and Ferscnal in Lungs* \#Calibration of a Iarge Area Pacific* * Content of plutonium, Thcrium and Uraniun: A Critical Contribution to Health Herd, January 1, 1969-\#Status of the U.S. Environmental Internaticnal congress of the International Radiaticn \# Incineration Process Fire and Explosion \# The Plutcnium Content in the Injected Dogs* \#An Electrophoretic Study of Serum \# Metabclic study of the Binding of Flutcoiul tc Serun $1963-1968$ and the *Radioactive Bffluent Releases and $t$ he Reactor Testing Staticn, Environmentaliy Felate Nebulization* \#An Assessment of Alveolar Deposition an * Tumors in vice after *Tumors in Mice Afte

Dioxide or Flutenium 239 \#Antibody Responses an in Fused 1 uninosilicate \# A Seven-year Study of the

oxide Fclymer on Excreticn of Inhaled plutonium 239 the Chinese Hamster Following Exposure to Flutonium 239 Metabolism of Three sizes of Monodisferse Plutonium 238 Between the Size Distribution of plutonium 239 *Temperature of Surfaces in Contact with Flutcrium 238 4. Mortality in Dogs after Inhalation of Plutonium 239 4. Mortality in Logs after Inhalation of Plutcnium 239 Intraferitoneal Administration of Plutonium 239 Determiation of Elutonium for Fadiological * Fhagocytosis and Translocation of plutcnium 239 Safety Latoratcry Surface Air Sampling Program \#Th *autoradiographic Localization an

Engineering Division, Waste Management Frograms September $1,1974 *$ \#allcut Frogra and Content of Calcium, Fhosphorus and Nitrcgen in

$23 \mathrm{c} \mathrm{cn}$ the Free Ribonucleotide Metabolis in in the on the content and Benewal cf Nucleic Acids in Some Acid Activity of Alveolar Macroptages of the * Fadiation Dose-Bates Near Bone Surfaces in

Pathologic Effects of Plutonium Metal Implanted Into \#Biochemical Changes in the Iungs of Dogs* Annvironmental Behavicr anc "Biological Bffects of \#Effects of Low rose of \#The Bffects of

\# Femote sequelae of * Remote ifter selae

\#Possible Therapeutic agents for

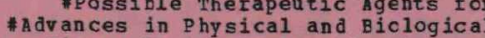
Bones of Dogs* \#Autoradiography in the Localization and Data for a Nunter of after an Injecticn of plutonium*

General Computational Model for Composite Bnvircnmental of Plutoniun* \#ffects of High-Ievel Gamma
\#iophysical Basis for
Froducts Determined by Electron Microscopy and Froducts Inhaled as Aeroscls by Rats and Man*Defosition Froducts* Froducts*

Erograils Quarterly Report, Octoter-December 1973*

Frogress in Personnel Neutron cosimetry*

Erogress on the Chronic Icxicity Program*

Frogress on the Chronic Toxicity Program*

Frogress on the Chronic poxicity program*

Frcgress Report for the Period of January-June, 1974*

Frogress Report on the Metabolic Studies of Fission

Frogress Report on the Metabolic studies of Plutonium*

Frogress Report on the Metakolic Studies of plutcnium* progress Report on the Metabolic Studies of Product* Frogress Report*

Ircaress Berort*

Frogress Report, March 31, 1959*

Frogress Report: Plutonium Removal, Iumor Incidence

Frogress Review by Chronology, Fermuted Title, and

Eroject Council Meeting. Biolcgy Secticn, January 16. Froject officers Report, Project 2.3. Fallout Collectic Froject Personnel, Bffect of Exercise of Leukopenia, A Froject 2.3. Fallout Collection*

Eroject. Exposure of animals*

Frojected Shipments in the Nuclear Fuel Cycle Industry Erclcnged Peroral Administration*

Erompt Mitigatory Action After Accidental Exposure tc Ercperty*

Froperty, Progress Report for the Period of JanuaryEroportional counter for Plutcnium 239 x-ray Detecticn Protactinium in Seavater and Recent Coral in the North Frotection of workers* \#Toxicology of Transfortarle Frotection Agency's Nevada Iest Site Bxperimental Dairy Frctection Association* protection*

Frctein Fraction of Fat Tubular Eones*

Frotein Faction of kat Tulular Eones* Froteins*

Eublic Accertance of Nuclear Facility Sites*

Fublic Health Service Pasteurized Milk Network fro Fublication $s^{*}$

Fulmonary clearance of Radiopharmaceuticals After

Eulmonary Deposition of Padioactive Particles

Fulmcnary Deposition of Badioactive Particles*

Fulmonary Lesions After Inhalation of Cerium 144

Fulmcnary Retention and Clearance of Cesium 137 Inhaled Fuo2 in Dogs* ACid and Polypropylenoglycolethylene Fuo2 or PIntonium 238 Puo2 particles* in Liver Celis of FuO2 Aerosols in Beagle Dogs*

Fuo2 A frosols, *ShcrtFuO2 Microspheres*

EuO2 Farticles* Cells of the Chinese Hamster Fcllowing

EuO2* 2 \#licles* Cells of the Chium Inhalation Studies.

FuO2* \#Plutenium In halation Studies. Fu02*01trastructure of Mononuclear Phagocytes Fcllowing

Furposes* \#Radiochemica.

Fu02 Particles by Feritoneal Phagocytes of the kat* Cuality of padiochemical Analyses in the Health and cuantitation cf Articles Deposited in the Liver*

Cuantitative Morphclcy of Vertebral Trabecular Eone*

Quarterly Report. October-December 1973* \#Chemical

Cuarterly Summary Report, June 1, 1974 through

Fabbit Bony Tissue after Injury with plutonium 239

Fabbit Iiver Affected by Plutoniun*

Babbit Liver*

Fabbit Tissues*

*Influence of Plutoniun

Fabbit* About by Flutcnium oxide in the Fhoschatasic

Fabbits after an Injection of Plutonium*

Fabbits and Rats"

Fabbits After Inhalation of Plutonium*

The Fate an

Radiaticn from Iodine 129*

Fadiaticn from Simulated Flutonium 238 power scurces in

Fadiation on the Iiving Body*

Badiation on the Lung with References through 1972*

Badiation on Bone*

Fadiaticn Cancerogenesis and the Problem of Restcraticn*

Fadiation Damage*

Radiation Bamage*

Fadiation Damag*

Fadiaticn Detectors*

Radiation Dosage of Radium 226 and Plutonium 239 in the Radiation Dose from Metabolic and Urinary Bxcretion

Radiaticn Dose-Rates Near Bone Surfaces in Rabrit

Fadiation Doses frcm Iodine 129*

Radiation Doses*

* Applications of a

Radation Effects Following Massive oral Administration

Fadiaticn Bxposure of BEPA Pilters*

Radiation Haenatology*
$0 \mathrm{CO} 285$

COO 204

000296

000088

CCO411

000072

000413

CCOO88

000092

000090

000091

.

00189

000449

000179

$0 C 0360$

000420

$\mathrm{C} 00002$

000441

000041

0ट0394

000414

000413

000416

000347

000210

000387

000444

000258

COOC87

(000

00322

000422

000325

000354

000250

$0 \mathrm{CO} 251$

000139

000025

00039

000148

$0 \mathrm{COC60}$

000275

0 C0031

0 c0011

000009

000200

00424

000417

00197

000342

000481

000412

000075

000117

000259

000118

OC0195

(c)

CCO109

OC0239

000386

000386

0 C0390

OC0153

000149

000111

000341

000004

000355

000024

000278

000237

000403

000218 
PER MUTED INDEX OF TTMIE

*Vascular Thecry c Third Internaticnal congress of the Internaticnal Clag with ransplatonium special Prcblems in Classification and Basic Btiological Factors of vivo Mea surements of Nuclides Fmitting Soft Fenetratin Long-Term Periods after Chronic Influence of Icnizin Anatomical Distribution of Distribution cf Internal Androgen Bicsynthesis by \#The Effects of Icnizing *Biological Effects observed with ccmbined Expcsure to \# A Technique fer Dosed Administration of of the Prevention and Treatment of Excessive Internal of Nuclear Facility Sites"

\# The Metabolisw of $t$ he of Cerebral and Renal Tissue after the Incorporation of

* Regularities in Metabolis n of

\#Some Fesults of Studying the Blastcmogenic Effect cf analyses to the Determination of pody Burden of Measures Against Injury \#Acceleration of Excretion cf * A pisk isoessment symposium on Packaging and Transportation of \#Toxicology: Body in the \#Studies \#Tansfer of Radicact ive \#Iumors in Mice after Pulmcnary Defcsition cf \#Tuacrs in Mice After pulmcnary Defosition cf \#Electron Microscopy of Berosols Containing Testing Station ("Ilan for Retrieval of Solid Lcw-Ievel \#Effects of Detergents on Skin and $C n$ the Absorption of Dose Distritution in the skin in It $s$ Contaminaticn with Evaluaticn cf Some Immediate Measures Against Injury by Bibliography of Selected literature*

\#Study of Bainout of of Devices for the Determination cf Total-Eody Detonations: Source, Transport, Diffusion, an Sawpling of Soils for \#The Dhoice of the

the Chronic Texicity Progran* \#The Lateratory for *Research in Research in Chronic Toxicity Program* the Chronic Tcxicity Prcgram* \#Research in and Excreticn from the Iiving organism of Radicyttrium, Laboratory Surface Air Sampling Program \#The cuality cf Radiclogical Furfoses*

of Intravenously Injected * Autora dicgraphic a nd by Chelaticn and Mixed Complexes--Rapid Experimental by Mass lction Iaws and other Pactors*

of Physical State on the Removal of Hydrolyzable

Regularities in the Distributicn absorption of Irradiation *

Pasteuri ded Milk Netuork from 1963-1968 and plutcnium, Ihcrium, \#Haematological Conseguences cf Dcse-to-the-Population Bstimates for Use of Dose-to-the-Population Bstimates for Use of * Evaluation of Internal Exposure Hazards for Several
cn Early Pemur Optake and Orinary Excretion of Citrate on Early Penur optake and Orinary Excreticn cf 1965* of Individuals who tave Bxcessive Depositions of Models for Predicting the Wind and Pctential \#Radicchemical Determiation of Flutonium for \#Comparative Toxicity of Inhaled Beta-Fuitting
$241 \mathrm{cD}$ Eiochemical Parameters: Effect Cf Dcse and
ctrccardiogram Evaluaticn of Beagles with Fetained \#Blectrccardiogram Evaluaticn of Beagles with Fetained \# Monitoring of Low-Energy $X-R$ ay \# Magnitude of Defosited Aspects*
Aspects* Biosynthesis by Canine Testicular \#Internally Deposited Belation to \#Influence of the Physico-Chemical Fcrms cf Beagles*

of Age and Bone-Seeking *Transfer of Heavy

\#Pinger Bxposure from the Handling of Short-Lived \#Carcincgenicity cf Inhaled *Prompt Mitigatcry Action After Accidental Exposure to \#ireatient After Incorfcration cf *Alteration of the letabolism of the Beagle by Trends in $\mathrm{T}$ herapeutic Removal of Internally Defosited
Eadiation Injury to Pone*

Fadiaticn Protection Associaticn*

adiation Safety and Sanitary Dosimetric Monitoring Fadiation Sickness in Man* \#atbogenetic Radiation* Radiation*
fadiation* State of the elood system in Logs in the
sadiation-Induced Fractures in Beagles*

Fadion-Induced osteogenic Sarcoma Fadiations on Endocrine Cells. 6. Alterations in

Fadiations*

Radiations*

Fadioactive and Nonradioactive Metals*

Eadicactive Aerosols to Dogs*

Fadioactive Contamination* Fadioactive Blements Created by Nuclear Fission*

Fadioactive pissicn Products of Draning 235 in Ion Dcses

Badioactive Isotopes as Cancerogentc Agents*

Fadioactive Isotopes Upon Incidence on the Skin*

Fadicactive Isotopes*

Eadioactive Isotopes* The Application cf Bxcretion

Badioactive Isotopes, Evaluation of Some Immediate

Fadioactive Material Shipments"

Fadioactive Materials* Proceedings of the Internationa Fadioactive Metal Mobilization

adioactive $M \in t a l s *$

Fadioactive Nuclides from the Environment to the Human

Fadioactive particles. 1A. Intratracheal Injection of

Fadioactive particles*

Fadioactive Farticles*

Fadioactive Particles*

Fadioactive Flutonium waste at the National Reactor

Fadioactive Substances*

Fadicactive Substances*

Eadioactive Substances*

Fadicactive suspensions*

\#The Kinetics of of Radioactive Isotopes.

Fadioactive waste Processin

Gadioactivity in Illincis*

Fadicactivity Peleased from Underground Nuclear

Radioactivity: Philoscphy. Experience, and Fesults*

Badioactivity: Philoscphy
Fadiobiologic studies*

Fadiobiologic studies*

Fadiobiology, An Annual Report cf Work in Progress on a diobiolo an and Fadiobiology, Semiannual Feport of work in Progress cn Fadiobiology, Semiannual keport of Work in Progress cn Fadiocerium and plutonium* Ccmpounds on Tissue Storage
Fadiochemical and Autoradiographic Studies* in Mouse Fadiochemical and Autoradiographic studies*

Radiochemical Analyses in the Health and Safety

Badiochemical Anal ysis* Vermiculite and Its peathering Fadiochemical Determiation of Plutonium for

Padiochemical Methods*

Fadiochemical Studies of the Effect of collcidal state

Fadioelement Metabolism and Decorporation as Influenced

Badioelement Eemcral by Chelating Agents: Applicatior

Fadicelements by Chelation*

Fadio $\in l \in$ ments*

Padiegenic fects in Man of Iong-Term Skeletal Alpha-

Fadioidine levels in the 0.S. Public Health Service

Fadioisotope Incorporation with Particular Reference $t$ Fadioisctope Powered Cardiac Pacemakers*

Fadicisctopes Rncountered in Reactor operations*

Fadioisotopes*

Radioisotopes*

\#Effects of zirconiu

Fajolcoical conaitions in the vicinity of Hanferd for

talcical

Badiolcgical Furfoses*

Fadionvildes in Beagle Dogs*

Fadiontclide Burden Time*of Plutonium 239 and Americiu Badionuclide Burdens*

Fadionuclide Content in Human Eody*

Fadionuclide Problem Based on Future Usage--Civilian

adioncclide problem Based on Puture Usage--Defense

Radionuclides and the Subseguent Alteration of androgen Eadionuclides and Bones*

Badionuclides and Stable rrace Flements in Seawater in

Radionuclides in the Environment*

Eadionuclides on the Vascularity of Eones from dult

Fadionuclides on Immunity*

Fadionvclides to Milk*

Fadionuclides*

Badionvclides*

Fadionvclides*

Radionuclides*

Badionuclides*

Eadionuclides*
\#Some Aspect

000169

000387

000453

000339

$\mathrm{COO} 2$

$\mathrm{CCO} 242$

00005

00007

000167

C0167

000143

$0 \mathrm{C} 035$

000322

ccoos

000235

00009

000123

C 035

00028

000443

000440

000047

00048

C CO264

000250

00025

$0 \mathrm{CO} 433$

000476

$0 \mathrm{CO} 240$

00168

C0028

000264

000475

$0 \mathrm{CO} 328$

0c0328

000419

CCO409

000045

$0 \mathrm{CO} 233$

COO7

00070

000072

000417

000285

00290

000192

$\mathrm{CCO} 202$

000201

00008

000265

000150

000351

000422

c coses

000254

c00113

C00113

000112

00031

00041

000312

000424

000145

000248

000406

000317

000319

000076

000103

000313

000303

000115

000165

000146

000359

000007

000007

000382

000249

*Princifles and 000049 
Analog CCmputer for the Model of the Metabolism of some Metachrcmasia in Murine Tumcrs Induced by Ecne seeking Vascularity of Cortical Bones Induced by Bone Seeking Testicular Tissue after the Internal Depositicn cf Some and Urinary Excretion Data for a Number of Imfortant "Toxicity of Inhaled Alpha-Emitting of Alveolar Deposition and pulmonary clearance cf Stcrage and Bxcretion from the Living organism of of Hematologic Effects of Internally Defosited in the Localization and Radiation Dcsage of *An Electrch cretic Study of Serum Frotein Fractions in of Tooth loss in Beagles Injected with Plutcnium 239 , "Toxicity of plutonium 239 Relative to of Bffects of Lethal Body Burdens of Plutonium 239 and with Flutonium 239, Thorium 228, Radium 228 and with plutonium 239. Therium 228, Radium 228, and \# Comparative Toxicity of Strcntium 90 , in Dogs Eurdened with Plutonium 239 , Thcrium 228 , in Beagles Injected with plutoni um 239, Radium 226 and in Dogs Burdened with Plutonium 239. Thorium 228, with Particular Reference to Plutonium, Thorium, *A Single Centripeter for Extracticn Chrcmatography in Orines Containing DIPA as Influenced by Chelation and Mixed ccmflexesIntramuscularly Injected plutcnium $238-N i t r a t e$ from the Stresses on the Retention of Americium and Flutonium \#Fffect of Caily Injections of Plutonium $239 \mathrm{cn}$ * Levels and Microdistribution of plutonium 239 in the Administered Salt*\#Distribution of Americium 241 in the \#icrodistributicn of Americium 241 in some Tre Flutonium Content in the Protein Fraction of \#Use of Citrate in Mobilizing Plutcniur in of plutonium 239 Metabolism and pffect in the on the Iate Effects of Moncmeric plutonium 239 in the Metabclism of Plutcnium (PI rtoni um 238) in Man and the of Plutonium 238 in the Petoplacental unit of the Fassage Time through the Gastrointestinal iract of the

239 PuC2 particles by Peritoneal Phagocytes of the of Plutonium 239 from the Respiratory System of the Distribution of Plutoniun 239 within the Femur of the Radiations* \#Interacticns of Total Dose and Dose Injection*

239. Radium $2 z 6$ and Radium $228 *$

iT be

of the Flutonium 239-Induced csteosarconas Grcwth Dose Level* \#Ccmparison of Skeletal and Hepatic Dose of Plutcriun* \#adiation LoseOrganic Eatter in Pecent Sea and ocean sedisents*

2. Implicaticns of Differences in Iransuranic Isotopic vitrate (P1utonium 239)* \# Iumors Developing in

and their Fission products Inhaled as Aercscls by of Removal of plutonium, Calcium and $\mathrm{zinc}$ from Dispcsition of Binsteinium Nitrate Es (BO3) 3 in Additional Pathologiamaticn on Long-Term Sequelae in \#plutonium Remcval in \#The Metabolism of Tissues of * Whole Body Counting of Flutcniul in

239 and Strontium 89,90 on the Eone Marrow cf White Effects of Flutonium Metal Implanted Into Babbits and of Inhalaticn of Ammonium Plutonium Pentacarbcnate by of Uranyl Nitrate and course cf vranium Intoxication in a Large Area Froportional Counter for plutoniun $239 \mathrm{X}$ Mine Dust Imcombustibles Content Analyzer Using a Gamma-

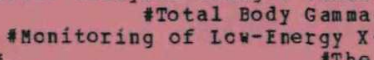

System in Hum an Elood Serum* Hazards for Several Radioisotopes Encountered in

Low-Level Radioactive Plutoniun waste at the National Publications* \# Naticnal Period of January-June, 1974* \#Contamination limits for Inhalaticn cf mmonium plutonium *state of the Surfaces* \# Model for Eredicting the \#Bibliography: Bffects of Radiaticn on the Iung with from the Mouse "Bffectivenss of Different Therapeutic Radioelements*

Incidence on the Skin*

Plutoniul 239 PuO2 Aerosols, Aerosol Concentration, * Eiological Studies Asscciated uith a fiel Transport, Diffusion, and Deposition* Radioactivity Sites* \#Radioactive Effluent Cheuically Soluble Flutonium 239 Compounds* \# zransuranium Flements*

\#

\#DTPA-Ef fectiveness in
Fadionuclides* Fadi onvclides* Badionvclides* * Prelidinary Report: Changes in a di adrogea Blosynthesis by Canine Eadionuclides--An Experimental Approach*

Fadior harmacenticals After Nebulization* * An Assessment Fadioyttrin Fadium and plutonium in Dogs* fiadiun 226 and Flutonium 239 in the Eones of Degs* Fadiun 226 and Plutonium 239 Injected Dogs* Radium 226 and Badium $228 *$ Fadiul 226 in Man and Dog*

Fadium 226 on Hematopoiesis in Beagles* "Ccmparison Fadium 226* Cther Serum Constituents in Dogs Eurdened Fadiun 226* other Serum Constitutents in Dogs Eurdened Eadiul 226, and Plutonium 239*

Padium 228 and Fadium $226 *$ and other Serum Constituents Fadium 228* \#The Rate of Tooth Icss Gadium, Iron and Gold* $226 *$ other Serum Constitutents Fainout of padioactivity in Illincis*

Fapid Analysis of Long-Lived Alpha Bmitters in Air*

Fapid Letermination of the Transuranuium Elements by Fapid Experimental and Calculative Approaches tc

Fat by Continuous Infusion of Chelating Agents* of Fat Bone*physiological stresses and Artificial Hormonal

Rat Iungs and Liver, and lorphological Changes in these Fat organism. As Related to the properties cf the Rat orcans Póliowing Intraperitoneal and Intratracheal Fat Iulular Bones*

Fat*

Fat*
Fat*

Fat*

Fat*

Fat*

Eat*

Fat*

Fate

Fat

Fate of Tooth Loss in Feagles Injected with Plutcnium
Fate*

Plotonium 239 in the Beagle As a Functicn of

Fatios of the Surfaces in Rabtits after an Injecticn

Fatios* and Americium in a Freshwater Bcosystem: Phase Fats after Intraperitoneal Injection of Plutonium

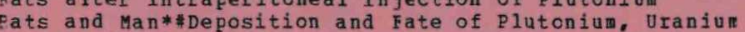
pats by Calcium and 7 inc DTEA**Comparison of Ffficiency Rats $y$ Calcium and Zinc DTEA**Comparison of Fficiency Fats After Intravencus, Intramsucular and Subcutaneous Fats Given Flutonium 239*

Rats Given Plutonium 239*

Fats Given Some Complexons by Mouth*

Bats Treated witb Plutcnium $(+6)$ Nitrate*

Rats*

Fats*

*The Action cf Plutcniun tThe Pate and Pathologic

Bats* the Ped Blood Cells and Hemodynamics in the Case Fats*Ietracetic 2,2'-Diaminodiethylsulfide on Excreticn ray Detection in lungs*

\section{Bay Backscatter Technique*}

*Calibration of Fay counting of Flutonium 239*

Fay Radionuclide Content in Buman Body*

Reacticn of Elutonium $(+4)$ with the Ircn Transport

Beactor operations* \#Evaluation of Internal Exposure Feactor Safety. A Iiterature Search*

Feactor Testing Staticn (NRTS) * for Retrieval of solid Feactor Testing Station, Bnvircnmentally Related Feal and Ferscnal Froperty*

Feal and Personal property, Progress Report for the Bed Blcod Cells and Hemodynamics in the Case of Fedistribution of particulate Cantaminants from soil Feferences through 1972 *

Fegimes of Glucan in Remcval of Polymeric Plutoniu

Pegularities in the Distributicn and Texicity of

Fegularities in Metabolism of Badioactive Isotcfes Dfon

Felaticnships Between the Size Distribution of

Release of Flutonium*

Feleased from Dnderground Nuclear Detcnations: Source, Feleases and the Fublic Acceptance of Nuclear Pacility

Remote Aftereffects of Intratracheal Administration cf

Remote Aftereffects of Intratracheal A dm

* Femote Aftereffects Associated with Damage by

Bemote Sequelae of Radiation Damage*

Femoving Internally Deposited Plutoniun from Humans*
000127 00023 000105 000355 000095 000354 cco206 000004 007 c 00087 000247 000395 000225 000223 000147 OCO225 000247 000223 000389 000328 000336 c 02284 000202 OC0236 000066 000079 000272 C0180 000258 000211
$\mathrm{C} C 0209$ 000209
000208 000208 O00061 000065 000207 000199 000219 $0 \mathrm{CO} 238$ 000167 000042 000247 00176 $\mathrm{CCOO} 24$ 000299 C0304 000040 000204 $0 \mathrm{CO} 213$ 000214 0 0122 000125 000019 C 0101 000138 000257 $\mathrm{CCO} 134$ 000110 C 0100 000349 000137 000406 000294 000254 00467 000476 000325 000414
$0 C 0413$

000110

000331

000386 0 09990 000099 0C0060 000268 000419 C00359 C00269 000149 000152 000365 
\#New Prccess $\mathrm{fcr}$

in the Assorption Characteristics of Cerebral and \# The Bffect of Plutoniul on the Content an Ionizing Particles* Ionizing Particles*
of plutonium in Human Tissue: A Preliminary Analysis cf Plutonium in Human Tissue: A Preliminary Analysis cf
Improved Waste lanagement in Ccm mercial Nuclear Fuel Improved Waste Management in c cmmercial wuclear Fuel
to Environmental Honitoring of a Nuclear puel cycle Laboratory* Progress cn the Chronic Toxicity Frcgram* Progress on the Chronic Toxicity Program* progress on the Chronic foxicity Erogram*

* Biological \#Hanfcrd Eiology * Hanford Eiology \# Hanford Eiology *Hanford Eiology

\#Biclogica

* Biological Eiology

Facility*

* Glove Eox Pire

in a Mixture of Products of oraniu Pissicn wit for Insoluble Alpha Bmitters* a Review of the Natural
Bvaluation of In Vitro "Froduction of Monodisperse Bvaluation of In Vitro froduction of Monodisperse

Inhalaticn \#Influence of Aerosol Properties and the Form cn the clearance of Plutonium $239 \mathrm{frcm}$ the Suspensicn in a Desert Area*

Cerium 144 ricxide or plutonium 239 Dioxide Antitod of Total cose and Dose Rate in Determining Tissue *Radiation Cancercgenesis and the Frctlew of

Initial

*An Assessment of the Iong-Term Bxposure Due to

\#Flectrocardiogram Evaluation of Beagles with Aluminosilicate \#A Seven-Year Study of the Fulmonary Monodisperse Flutonium 239 Dicxide Early Distritution, Plutoniua 239 in Beagles*

249 Poll cwing Acute Accidental In halation*

iskelet ai

the Physical-Chemical State of Plutonium on its Early Stresses and Artificial Hcrmonal Stresses on the of Neoplasms* \#Cellular Defcsiticn and Alteration of Phagocytic Activity cn Tissue Optake and \#kidney and Eone Dioxide Farticles Labeled with Ytterbium 169 in the Intermittent ITPA Therapy in Poiscning by \#Ccmbined Intermittent ITPA Therapy in Poiscning by. \#Ccmbined \#ITSA: Above-Ground
Waste at the National Reactor Testing Staticn \#Plan for Waste at the National Reactor Testing Staticn \#Plan for
11, No. \#Index to Nuclear Safety. a Technical Progress Petiticn Ccncerning imits for Insoluble Alpha Body Fadioactivity in Man: A Historical and Critical

239 Dioxide Particles Labeled with $\mathrm{Ytterbium} 169$ in of the Riological Action of Plutoniul ofen the *Influence of Plutonium 239 on the Free

Storage Facility* \#Description of Atlantic Managerent Research and Develocment Frogram at Oak Nitrate* *An analysis of Dosimetry and cellular

\#Sore Speculative Extensions to Man of Animal

\#Sore Speculative Extensions to Man of Animal
plutcnium in Bone Harrou: A Possible Ieukemic \#Content of Flutcniul in of Transuranium-Contaminated Solid Hastes at Savannah tFlutonium in the Terrestrial Bnvircns Fallout cellecticn*

\#operation

\#ound Iabcratory

Bmphasis on \#he Los Alamos Scientific Labcratory.

\#Status of the 0.S. Bnvircnmental Protection Agency " *Description of
Bxposure Bxferience*

Bxperimental rairy Herd, January 1, \#tatus of the U. $1963-1968$ and their

\#Brrata: \#Radicioine Levels ir the U. with Transplutonium \#Brata: Annual Report: Environmental The Cuality of Padiochemical Analyses in the Health and Cardiac Fac $\in$ makers*

Centigrade (Scurce with In-Residence Health and Permuted Title, and Author Vcl. 11, \#Index to Nuclear

As Related to the Properties of the Aduinistered Yttrium Distribution and Excretion* "The Action cf Bxperience, and Results*
Fenoving Plutonium from Waste Rater--A Progress Report* Removing Plutonium Injected in Skin of Swine*

Fenal rissue after the Incorporation of Radioactive Denewal of Nucleic Acids in Some Rabbit Tissues* Fepair in Yeast Cells After Irradiation with Densely eforted Data

Peprocessing Facilitties* The Distribution Program for Reprocessing Plant* Derived frcm an Bcosystem Approac Fesearch and Levelopment Frogram at Oak Ridge National

Fesearch in Radiobiclogy. An Annual Report of Work in

Sesearch in Radiobiology, Semiannual Report of Rork in

Fesearch on Radiobiology. Annual Report of Work in

Eesearch with Plutcnium, 1944-1984*

Research Annual Eeport for 1957*

Research Annual Beport for 1958*

Fesearch Annual Report for 1959*

Fesearch Annual Report for 1961*

Research Section*

Fesearch Section*

Fesidence Health and Safety Support in a Plutoniu

Fesistant Materials and Pire Suprressicn Tests*

Fesorftion Thereof from the Digestive Tract* Isotofes

Fesources Defense Council petition Concerning Iimits

Gespirable Aeroscls of Americium 241 Dioxide and

Eespirable Lust Sampling*

Fespiratory Pattern 0pon Hazards Evaluation Following

Respiratory System of the Rat* *The Effect of Chemical Fesponse Light Scattering Measurements of Aerosc1

Gesponses and Pulmonary lesicns After Inhalaticn of

esponses to Ionizing Badiations* \#Interacticns

Festoration*

Besusp̣nsion Models*

esuspension*

Eetained Radionuclide Eurdens* Retenticn and cytogenetic Effects of 0.3 um

Fetention and Distribution of Polymeric and Moncmeric

Fetenticn and Elimination of Berkelium 249. Californium

Fetenticn in Plasma and Selected Soft Tissues cf Beagles

Setention of Americium and Plutcnium by Rat Bone*

Retention of Flutonium 239 in Relation to the Induction

Eetention of Plutonium $239(+4) *$

Fetenticn of Polymeric Plutonium* of Experimental Cetention Punctions in the Buman Metarclism of Oranium

Eetention, Distribution and Excretion of Plutonium $2 \equiv 9$

Feticulcendothelial Stimulation and long-Term.

Eetrievable Storage Methcd for Low-Level Transuranic

Fetrieval of Solid Low-Level Radioactive Plutonium

Geview by Chronology, Fernuted Title, and Authcr vol.

Feview of the Naturai Resources Defense Council

Revien*

Eevisited*

Shesus Monkey After a Single Acute Inhalation Bxposure* khythn of Its Bntry Into the organism* \#Defendence Ribonucleotide Metabolism in the Rabbit Liver*

5 ichfield Hanford Compan $y^{*}$

Bichfield Hanford Company's New Compact plutonium

Fidge National Labcratory"

Fisk fcr Plutonium Farticles in the Lung*

High-level พast

Fisk Analysis of Shipping Plutonium oxide and Flutoniu

Fisk Assessment Model for Radicactive Material Shipments

Fisk Data on plutonium*

Fisk*

Fiver nater in Japan*

Fiver*

ocky Flats*

oller Coaster, Froject officers Report, project 2.3.

Air surveillance Systen*

Envircnmental sonitoring Program: An overview with

- Nevada Test Site Experimental Dairy Herd, January 1,

s New Compact Plutonium Storage Pacility*

s. Atcmic Energy Commission Ccntractors' Internal

S. Bnvironmental Prctecticn Agency's Nevada Test Site

Safeguard, $1971^{*}$

Safety and Sanitary Dosimetric Monitoring when Working

Safety Iaboratory Surface Air Sampling Prcgram curinc

Safety studies on Sealed plutcnium 238 sources for

safety suppcrt in a Flutonium Facility*

Safety lests at 1300 Degrees Centigrade and 800 Degrees safety*

cafety, a Technical Progress Heview by Chronolcgy,

Safety, A ilterature Search*

Salt*istribution of Americium 241 in the Rat organism, calts cf zirconium and other Metals on plutcnium and

Sampling for Particle Size Analysis*

" Sampling of Soils for Fadioactivity: Philosophy,
000473

000174

000270

$0 \mathrm{CO} 118$

00178

0376

$0 \mathrm{CO478}$

000429

00071

00072

000070

00075

000256

(1)

0012

000276

000464

000455

000027

CO384

00029

00253

.

CC0139

000167

000154

000436

$0 \mathrm{CO435}$

000248

000025

000182

ccooc6

000097

00379

000229

000188

CON34

000126

000477
00047

00476

000449

$\mathrm{CCO} 384$

000392

C CO20s

000126

00015

000259

00472

c0438

000217

CO442

00443

000263

00031

000471

000323

CCO420

CO4O2

00415

CO210

000438

000 $=70$

OCO270

000422

000426

000453

060497

000447

000464

CC0316

000463

000449

$\mathrm{CCO} 467$

000272

OCO2EE

0 CO428 
Contaminants* AA Basis for Routine Urine in the Health and Safety Laboratory Surface $\mathrm{A}$ ir through recemter, 1970* \#Respiratle Dust
\# Oranium 234 and oranium 238 in the Carrizo

Strontium 90 , Cesium 137, and Plutonium 239, $24 \mathrm{C}$ in \# special problems in Radiation Safety and \#Distrikution of Internal Radiation-Induced osteogenic Management of Transuranium-Contaminated Solid Wastes at Desert Area*
Program: An overview with Fmphasis cn \#The Ics Alamcs Program: An overview with Emphasis cn \#The ICs Alamcs
and Flutonium 241 in Biological materials by Gel concentrations of oranium and organic Matter in Recent \#Ionium-Therium Chrcnology of the Japan \#REactor Safety

\#Content of Plutonium, Thori um and Protactinium in Forms of Fadionuclides and Stable Trace Blements in of Uraniull and Organic Matter in Fecent sea and ocean

Adult Beagles* \#Effects of Age and Boneand Metachrcmasia in Murine Tumors Induced ty Bone In Vascularity of cortical Bones Induced ky Eon Processing and Disposal. An Annotated Bibliography of Processing and Disposal, An Annotated Bibliography of
State of Elutcniul on its Early Retention in plasma and State of Flutcnium on its Early Retention in plasma and
Toxicity Program* Toxicity Program*

Very Iow Ievel Flutonium in Bumans*
Plutoniun Levels in occupationally Exposed werkers*

Plutoniun levels in Occupationally pxposed Workers*
from In halation of Plutonium Dioxide with the belf of Program cuarterly Summary Refort, June 1, 1974 thrcugh \#Effects of Aseptic Inflammation on Iong- Term

Weathering Eroducts Determined \#Bxchange of Iyctrcpic Plutoniun 239 Burdened Dogs* *A Comparisen of Serum Transaminase Levels and other *A Ccmparisicn of Serum Transaminase levels and other of the Effects of Americiun 241 and Plutcnium 239 on Injected Dogs* \#An Blectrcphoretic study cf Hetarclic study of the Binding of Elutoniul to in Dogs Eurdened with plutonium 239 , \#A Ccmparison of in Dogs Eurdene
plutonium $239 *$

Plutonium $239 *$ witb the Ircn Transport System in Human Blood +4) With the Ircn Transport System in Human Blood
their Packages* *A Risk Assessment Model for Radioactive Material sk Assessment Model for Radioactive Material
* Shielding Reguirements for Neptunium Nitrate of the Depth and Amount of Plutonium 239 in Rcunds with Degrees Centigrade (Source with Internal Pressure and a \#Biological effects of Radiaticn frc * Digital Computer and Flutonium 241 in Biological Materials by Gel 241 in Biological Materials by Gel
Distribution of Oranium in the Body after Labeled with Ytterbium 169 in the Rhesus Monkey After a Alpha Buitters in Air*

the U.S. Bnvironmental Protection Agency's Nevada Test * Bealth Physics Pregram at the Nevada Test Mechanical properties of an Area 12, Nevada Test and Potential Radiological Fields cver the Nevada Test \#ree Living Mites of the Nevada Test toffsite Releases and the Public Acceptance cf Nuclear Facility \#Characterization of Actinide Bearing Soils: To Beagle Dogs*
the Beagle is a Function of Dose Level* \#Ccrfarison cf the Beagle is a Function of Dose Level* \#C "cmarison cf \#Americium 249 in Beagles: Biclcgical Bffects and

Monomeric Plutcniul 239 in Beagles* Finetics of the niffects of Detergents on *The Kinetics of Dose Distribution in the \#Distribution of plutcnium 239 in Intact \#Removing Plutonium Injected in

Alpha Autoradicgraphy in the Detection of plutonium 239 "The Penetration of Plutonium 239 through the of Fadioactive Isotopes ofon Incidence on the 239 from the Human organism* \#1utonium 238 Plutonium 239 from the Human organism* \#The Effect of
plutonium on "In vivo Measurements cf Nuclides Emitting
its Barly Retention in Plasma and Selected
Sampling of workers Bxposed to plutenium 239* sampling Instruments for Evaluation of Atmospheric Sampling Prcqram During $1968^{*}$ of Radiochemical Analyses Sampling Program, 80th Meriaian Network, January Sampling*

Sandstone Aquifer of South Texas*

Sandy Ioan Soil* \#Depth Distribution of Glokal Fallcut sanitary Dosimetric Monitoring when Working with Sarccma in various species

Savannah River*

\#Long Range

Scientific Iaboratory's Envircnmental Monitcring

Scintillation Counting* of Plutonium Alpha Activity

Sea and Ocean Sediments* \#Ratios of the Average

sea crres*

Sealed plutonium 238 sources for Cardiac Pacemakers* Search*

Seawater and Recent Coral in the North Pacific* Seawater in Relation to Optake ky the Marine Bicsphere* Sediments* Seeking Radionuclides and Bones*

seeking Radionuclides on the Vascularity of Bones frcm Seekinc Radionuclides*
Seeking Radionuclides* \#Histochemical Fhosphatases \#Preliminary keport: Changes
selected Bibliography, First Addendum*\#Bioenvircnmental selected Bibliography, First Adendum*\#Bioenvircnmental
select 6 diterature* Select $\epsilon$ diterature*
Selected Soft Tissues of Beagles* the "Radioactive Faste Selected Soft Tissues of Beagles* the Physical-Chemi
semiannual Report of work in Frogress on the Chronic Semiannual Report of Work in Frogress on the Chronic
Sensitive Analytical Method for the Determinaticn of

Sensitive Method for the Determination of LCw orinary Separation Analysis* of the Iung Burden Resulting September $1,1974^{*}$

Seguelae in Fats Given Plutonium 239*

Sequelae of Radiation Damage*

Series Cations by Micaceous Vermiculite and Its

Serull Alkaline phosphatase and osteosarcoma in

Serum constituents in Logs Eurdened with Plutonium 239 , Serum Constitutents in Dogs Eurdened with Plutcnium

Serum Fnzymes* \#reliminary ccmparison serum Frotein Fractions in Radium 226 and Plutcnium 239 Serum Eroteins*

serum Iransaminase Ievels and cther Serum constituents serum Transaminase levels and other Serum Constitutents serum Iransaminase Ievels in Beagle Dogs Burdened with serum Iransaminase levels in beagle Dogs Burdened with
serume Reaction of plutonium Service Pasteurized Milk Network from 1963-1968 and

shielding Requirements for Neptunium Nitrate Shipping

Shielding Requirements for Neptunium Nitrate Shippin
shipments in the Nuclear Fuel Cycle Industry tc the shipwents
shipments*

Shipments*
Shipping Eackages*

Shipping Plutonium oxide and Plutonium Nitrate*

SI (LI) Detectors*

sickness in Man"

Sickness in tan*
simulated Puel)* at 1300 Degrees Centigrade and 800
simulated Plutonium 238 Fower Sources in Dogs* Simulation of $\nabla$ ium 238 Fower Sources in Dogs*

Determination of plutonium Alpha activity ingle and Chronic Bntry of Uranium oxide-pentoxide*

Single Acute Inhalation Exposure* 239 Dioxide Farticle single Centripeter for Rapid Analysis of Iong-Iived

Site Experimental Dairy Herd, January 1, 1969-December Site Exferimental parm*

\#igh Eressure

Site* of Experimental Models for Predicting the wind

site, Final Report*

Site, July-December, 1970*

sites

\#Radioactive rffluent

sixty Centimeters of 216-2-9 Fnclosed Trench*

sizes cf Monodisperse P1utonium 238 PuC2 Aerosols in

Skeletal and Hepatic Dose Rates from plutonium 239 in Skeletal Alpha-Trradiation

skeletal Distribution"

Skeletal Dosimetry in "tah Beagles*

Skeletal plutonium compared in Mammalian Species*

skeletal Retention and Distribution of Polymeric and

Skeletal Retention of Plutoniun $239(+4)$ *

Skin and on the Absorption of Radioactive Sukstances* skin in Its contamination with Badioactive Substances* Skin in Its surface contamination*

Skin cf Swine*

skin surface contamination*

skin*

Skin*

SNAP PVel Ingestion by Miniagularit

Sodinm Calcining

scft Tenetrating nadiaticat

Soft Tissues of Beagles* the Physical-Chemical state of
000345

000340

$0 \mathrm{CO} 417$

000427

000421

000321

000453

000051

CC0471

000334

000408

000299

$0 \cos 10$

000467

000416

000313

000299

000103

c00715

c c0023

000326

$\mathrm{CCO} 475$

000231

.

000292

000295

000374

000412

OC0122

000153

000285

$\mathrm{CCO} 224$

000225

.00223

000087

CCO1E4

000225

000223

000221

000294

$\mathrm{CCO} 422$

000457

000441

000443

000457
000442

000337

$0 \mathrm{C} 0353$

000316

000109

$\mathrm{C} C 0300$
000408

000085

000126

OC0336

000210

000451

C 00407

$\mathrm{c} \mathrm{CO} 308$

000396

000322

000148

000148
000227

000227
000351

000136

000144

000385

000006

000229

000240

000168

000080

000174

000116

000116

000216

000099

000215

000367

000339 
Populaticns (Terrestrial and Soil Invertebrates) Due to in Structure of Animal Pcfulaticns (Terrestrial and the Bedistribution of Earticulate Cantaminants from 90 . Cesium 137, and Plutonium 239, 240 in Sandy Ioam Results* Dispersicn* \#Decontanination of \#econtamination of
\#ritium Mcvement in National Characterization of Actinide Bearing \#Long Fange Management of Transuranium-Contaninated of Alpha-Emitting Elutonium in Urine Using a for the Removal of Inhaled Plutcnium 239 of Varied Suspensicn and Effect on Biological Behavior After of Intratracheal Administration of Chemically of the cxidation States of plutonium 239 in Injecticn

at 1300 Degrees Centigrade and 800 Degrees Centigrade Feleased from Underground Nuclear Detonaticns:

\#Safety Studies on Sealed Plutcrium 238 Bfects of Radiation frcm Simulated Plutonium 238 Fower frcm $1963-1968$ and their Relaticnshif tc Fcssible 234 and Uranium 238 in the carrizo Sandstone Aquifer of Uptake and Distribution cf Plutonium in Barley and * Summary of the Study of Disfesal of Nuclear Waste Intc Metabolis

\# Use of from Skeletal plutcnium ccmpared in Mamalian Radiaticn-Induced Osteogenic Sarcoma in Various Very Small Flutonium Samples* \#Measurement of the Mass \#Health Physics Afplication of in Vivc Gamma Alpha-Active material*

Plutonium*

Plutonium 239 Skin \#An Application of oltra High \#Plutcnium 239 in $\mathrm{Liver}$,
\#Plutonium 239 in $\mathrm{Liver}$,

of the Physico-Chemical Forms of Radionuclides and plutonium Waste at the National Reactor Iesting * Naticnal Reactor Iesting

\#Environmental Aspects of Nuclear Pcuer Project Ferscnnel, Effect of Bxercise of Leukopenia, A
Contractors ' Internal Exposure Experience* Commissicn Iicenses' Internal Bxposure Experience, \#A Nevada Test Site Experimental Dairy Herd, January 1 , Poisoning by Folymeric \#Ccmbined Reticulcendcthelial The Action of Chelating Compounds on Tissue
Richfield Hanford Company's New Compact Flutoni um \#ITSA: Above-Ground Retrievable Retention of \#he Effect of Natural Physiological Natural Ehysiological Stresses and Artificial Hermenal \#The Action of Flutonium 239 and

*Excretion of Cesium 137, Cobalt 60 . Cerium 144 , and Soil Invertelrates) Due to Scil contaninaticn with Samples from 1953 tc 1961*

Sandy Loam So il* \#Depth Distributicn of Global Fallout *Cmparative Toxicity cf
Invertebrates) Due to Scil contamination \#Changes in

\# Morphclcgical Changes of Bone Iissue in Acute and the The ristribution of Plutcnium and Americium: ES (NO3) 3 in Rats After Intravenous, Intramsucular a nd The Rate of plutcnium 239 in the case of \#lymph Node Clearance of Plutonium frcm Distributicn and Bxcretion of Plutonium in Two Human Physiological Factors Contrciling the Fate cf Inhaled Detergents $c n$ Skin and on the Abscrption of Radicactive

in the Skin in Its Contamination with Fadioactive
Some Immediate veasures Against Injury ty Radicactive of Occupaticnally Exposed Workers*

Space*

Internal Bxposure Experience* \#A Statistical Licenses' Internal Exposure Experience, \# Statistical

\#In-Residence Health and Safety * Bioassay Experiences in Glove Box Pire-Resistant Materials and Fire inalyses in the Health and Safety labcratory anuary throuch December, 1970*

* Distribution of Plutonium 239 in Intact Skin in Its Autoradiography in the Detection of plutoniul 239 skin Badiation Dose-pates Near Eone Redistributicn of Particulate Cantaminants frcm soil December, $1970^{*}$ \# Eone

Bnvirongite Mound Iaboratory's Air \#Terrestrial Biota soil Contamination with Strontium $90 *$ of Animal Invertebrat Contamination with \$A Model for Predicting
Soil Surfaces* \#Depth Distribution of Global Fallout Strontium \#oil* Depth Distribution of Global Fallout Stront
scils fcr Radioactivity: Fhilosophy. Experience, and soils containing Pissicn Products*

soils: The Importance of Exchange and High Initial Sils: Top sixty Centimeters of 216-2-9 Enclosed Irench* 000398 Solid Iow-Ievel Radioactive Plutonium waste at the 0C0476 Solid Wastes at Savannah River*

solid-State Counter* \#A Erocedure for the Deterninaticn Solubility in Beagle DCgs. 2.*Lavage and DIFA Treatment Solubility Changes of Elutonium 238 oxide in water Soluble plutonium 239 Compounds* Remote Aftereffects Solvent Bxtraction of Elutonium with Primary Amines* Source with Internal pressure and a simulated Fuel)* scurce, Transport, Diffusion, and Deposition*

Sourcetook on Atomic Energy*

sources for Cardiac Facemakers*

Sources in Dogs* \#Biological Sources* public Health Service Pasteurized Hilk Netwcrk soybean Plants* \#Factors affecting pace* Nodel of the

speciali

species* (D) Spectrcmeter Efficiency in the Isotopic Analysis of spectrcretry in a Oranium Processing Flant*

speculations on the Carcinogenic Effect of Inhaled speculative Extensicns tc Man of Animal Risk Data on speed Alpha Autoradiography in the Detection of Spleen*

Spleen, and Kidneys of the Eeagle* spleen, and Kidneys of the Beagle*

Stable Trace Elements in Seawater in Belaticn tc Uptake staticn (NRTS)*Retrieval of Solid Iou-Tevel Badioactive Staticn, En

tatistical Analysis* Studies of Flutonium

Statistical Summary of United States Atomic Energy

status of the .S. Envircnmental Prctection Agency's

Stimulation and Iong-Term. Intermittent DTP $\mathrm{Ih} \in \mathrm{I}$ apy in Storage and Excretion frcm the Living Crganism of Storage Facility* \#d
storage Method for Iow-Ievel Transuranic Wastes* Storage Method for Iow-Ievel Transuranic Wastes* Stresses and Artificial Hcrmonal Stresses on the stresses on the Fetention of Americium and plutonium by Strontium 89,90 On the Eone Marrow of White Rats* Strontium 90 and Plutonium 239 ky Man*

Strontium $90^{*}$ of Animal populaticns (Terrestrial Strontium 90. Cesium 137, and Plutonium 239 in Hay Strontium 90, Cesium 137, and Plutonium 239, 240 in strontium 90 . Fadium 226 , and plutonium $239 *$

Structure of Animal populaticns (Terrestrial and Soil

structrres Accessory to the Gastrointestinal Iract*

Subacute affecticn with Plutcnium*

Subcutaneous Administration of Plutonium Dioxide and

subcutaneous Administration* of Finsteinium Nitrate subcutaneous Injecticn*

subcutaneous wounds in Beagle* subjects*

Substances. $2 . *$

Substances*

substances*

substances"

\#The

\#he Rinetics of Dose Distribution

Sumary of the Study of Iisposal of Nuclear Waste Intc

Sumary of V.S. Atomic Energy Commission Contractors

Sumary of United States Atomic Bnergy Commissicn

Sumary Report, June 1, 1974 through September 1, 1974* Supoort in a plutonium Pacility*

suppcrt of Field operations Associated with Widesfread Suppression Tests*

Surface Air Sampling Program During 1968* Radiochemical surface Air Sampling Frogram, 80th Meridian Netuork,

surface Contanination*

Surface Contaminaticn*

of 0ltra High speed Alrba

curfaces in Contact with plutcnium 238 EuO2 Microspheres Surfaces in Rabbits after an Injection of Plutonium*

Surfaces in

Injection of Plutonium*

Surfaces: What Are They?*

Surveillance Around the Nevada Test Site, July-

surveillance Around Nuclear Installations*

surveillance system*

Survey*
000124

000124

OCO331

00306

.

00471

000291

000156

000171

010269

000032

(c00283

.

C00434

000447

CCO109

000422

C 00321

000274

OC0127

000385

000051

000338

000346

000381

000361

CCO1EO

000228

OCO230

000313

$0 \mathrm{CO} 476$

000325

000320

000360

000370

CO468

0194
00194

CCO206

000438

000097

000097

00257

000368

000124

000418

000306

000147

000124

000185

000135
000107

000214

$\mathrm{CCOO42}$

000062

000372

000348

000168

000028

o 0356

000480

000370

000468

000412

000464

00465

000455

000427

C COOBO

000361

000275

000024

000331

000262

000396

$0 \mathrm{co} 425$

000402 
"Solubility Changes of Plutoniu 238 oxide in Water * Fast-Resccnse Light Scattering Measurements of Deroscl 239 FuO2 Aerosols, Aerosol Concentration, and Nebulizer Particles. 1A. Intratracheal Injection of Fadioactive

\#Removing Plutcnium Injected in skin cf 230 stip ruel Ingestion by Miniature *Plutonium Metabclism in Miniature Radioactive \#pourth Froceedings of the International \#The General Plutonium 239 Dicxide in Immature, Young Adult and Aged and Subsequent Influenza $\nabla$ irus Infection in Hice and \#Investigation of the Punctional state of the Blocd \#he Reaction of Plutonium $(+4)$ with the Ircn Transfort on the Clearance of Plutonium 239 from the Respiratory * The Vascular * Hound Lakcratory's Air Surveill ance * Emission Monitoring \#The Movement of mritium in Bcclcgical
iency Studies on Multi-Bank BBFA Pilter nd Efficiency Studies on Multi-Bank BRE Pilter t T be Leak of Tank 106

\#Digital Ccmputer Simulation of Water *okserved Pallout Patterns and Countermeasures

Plut onium*

Plutcnium*

Product*

Fission Froducts*

Title, and Autbor Vol. 11, Index to Nuclear Safety, Puo2 Microspheres,

Deposited Plutonium*

\#An As sessment

\# The Iong\#Iong-

Plutoniun 238 Puo2 Aerosols in Beagle Dogs* of the longState of the Blood System in Dogs in the long* Iffects of Aseptic Inflammation on long\#adiogenic Bffects in than cf long-

* Combined Reticuloendothelial Stimulaticn ard longichanges in Structure of Animal Fopulaticns

\#Plutcniur in the

\#T he

6. Alterations in Androgen Biosynthesis ty Canine Alteration of Andrcgen Biosynthesis by Canine Uranyl Nitrat $\epsilon$ and Course of

Uraniun 238 in the Carrizo Sandstone Aquifer cf $S$ cuth the Neu ICBE Iung Model*

Plutonium from the Mouse Padicnuclides* * Vascular \#Effectivenss of Different *Principles and Irends in *long-Ter II Effects of * Metarelic a nd * Metabolic and \#Oral

Metals* Stimulation and Long-Term. Intermittent ITFA

\# Removal cf polymeric Plutcnium frcm Mice by Combined by Glucan and Related Compounds as Adjuncts to ITEA of Plutonium Dioxide and the Effect of Chelaticn Mixture of Products of Uranium Pission with Rescrption the kat Lungs and Liver, and Morphological Changes in Radiation Protection Association* Bone Surfaces: What Are in the North Facific* \#Content of plutonium \#Ioni um -

Serum Constituents in Dogs Burdened with Plutcnium 239 , Constitutents in Dogs Burdened with Plutcnium 239 , Incorpcraticn with Particular Reference to Flutonium, * Some Aspects of Observaticns of the Deposition of Americiun 241 in the $239(+4)$ and Americiun $241(+3)$ in Blood, Liver and * Fffect of Age and Particle Size cn Fassage and Excretion in Dcos at Different Fericds cf Parameters: Bffect of Dcse and Radionuclide Burden in the Absorption Characteristics of Cerebral and $R \in$ enal in Androgen Biosynthesis by Canine Testicular of Calcium. Phosphorus and Nitrogen in Babbit Eony

\#Plutcnium and other Actinide Elements in Gonadal Plutonium \#Comparison of Blood Clearance and Six-day Interacticns cf Total DCse and Dose Rate in Determining "Evaluation cf Fostmortem of Radioyttrium, \#The Action of Chelating Compcunds cn of Exferimental Alteration of Phagocytic Activity on
Euspension and Effect on Biological Eehavior After suspension in a lesert Area*

Suspension concentration $\$$ Size ristribution of plutonium suspensions* \#Toxicity of Radioactiv Sustained Action of Injected Chelating Agents* swine*

Swine*

Evine*

symposium on Packaging and Transportation of

yndrcee Induced by plutonium 293 in the Beagle* \# Toxicity of Inhaled syrian Hamsters* 144 Dioxide or Plutonium 239 Dioxide system in Dogs in the Long-Tern Periods after Chronic system in Human Elood Serum*

System of the Rat*

*The Bffect of Chemical Pcrm system*

systems at Mound Laboratory "FF" Building*

systems for Plutcnium Facilities*

Systems*

Systems*

systems*

Tystem $\varepsilon^{*}$ Table*

Taken*

Tank $106-T$ at Hanford*

Technical Progress Report on the Metabolic Studies of

lechnical Progress Report on the Metabclic studies o

lechnical Progress Repcrt on the Metabolic studies of

Iechnical Progress Peport on the Metarolic Studies cf

lechnical Progress Peviex by Chronology, Permuted

Temperature of Surfaces in Contact with plutonium 238

Term Effects of Elutonium 239 in Adult Beagles*

- erm Effects of Therapeutic Rencval of Internally

- Term Bxfosure Due to Resuspension

Term Metabolism of Three Sizes of Monodisperse

Term Periods after Chronic Influence of Ionizing

Ter sequelae in Rats Given Flutonium 239*

Term Skeletal Alpha-Irradiation*

Term, Intermittent DIPA Therapy in Poisoning by

Terrestrial and Soil Inverterrates) Due to Scil

Terrestrial Biota Survey*

Ierrestrial Environs of Rocky Flats*

Testes*

"esticular Tissue after the Internal Depositicn of Scme Testicular Tissue* Radionuclides and the Subsequen Tetracetic 2, 2 '-Diaminodiethylsulfide on Bxcretion of

Texas*

Theoretical Excretion of Plutonium

Therapeutic Agents for Radiaticn Damage*

Therafeutic Regimes of Glucan in Removal of Eclymeric

Therapeutic Removal of Internally Deposited

Therapeutic Removal of Internally Deposited Plutonium*

Therafeutic Studies of Plutonium and Americium*

Therapeutic Studies of plutonium*

Therapeutic studies of Plutoniug*

Therapy in poisoning ty Polymeric Plutcnium*

Theracy of Poisoning by Badioactive and Nonradicactive

Therapy with the Calcium Chelate and Penta-Ethyl Ester

Therapy*

Therafy* and Americium: Subcutaneous Administraticn Thereof from the Digestive Tract* Between Isotofes in a these organs rollowing Intratracheal Administration of They?*

Third International congress of the International

Thorium and Frotactinium in Seavater and Recent cora

Thoriu I Chronology of the Japan Sea cores*

Thorium 228, Radium 228 and Radium 226*levels and other Thorium 228, Fadium 228, and Fadium 226*and other Serur Thorium, Radium, Iron and Gold*

of Radicisotcpe Thymus*

Thyroid and Farathyroid Damage Due to Americium 241* Thyrcid Gland of the Reagle*

\#Scme

"Chyroid*al Associations of Plutoniu

Time tkrough the Gastrointestinal Tract of the Eat*
ime*
aplutonium Distribution

Time* cf Plutonium 239 and Americium 241 on Biochemica

Tissue after the Incorporation of Radioactive Pissicn

issue after the Internal ceposition of Some

Tissue after Injury with plutcnium 239* and conten

Fisue after Injury with Plutcniun $239 *$ and content

Iissue in Acute and Sulacute

Tissue Distribution of Monomeric and Polymeric

Tissue Responses to Ionizing Fadiations*

Iissue Samples*

Iissue Storage and Excretion from the Iiving orcanis

Iissue optake and Retention of Polymeric plutonium*
$0 \mathrm{C} 0171$

000334

000060

000264

000133

000174

.

000053

000440

000241

000096

000139

00026

000219

.00183

000402

000461

$0 \mathrm{CO} 410$

000309

000309

000454

000288

.

000452

000479

000092

0 C0090

000091

000088

000449

000275

CC0106

000187

000435

$0 \mathrm{C0148}$

000026

$0 \mathrm{C} 0122$

O 0351

00

000124

00315

00323

000093

CC0076

000100

000321

000423

000169

000111

000190

C 0049

000187

000131

0 C0191

00015

000194

000132

0 0142

0007

00107

000027

000262

000387

000416

OCO310

000225

$0 \mathrm{CO} 223$

000389

000159

000226

000232

000207

0 C0198

000162

C COC77

000075

00135

000128

\# 0C0167

000364

000206

C CO188 
FRR MUTFD INLEX OF TITIE

\#Iymph Node and Intestinal Iymphatic rogen Biosynthesis by Canine Testicular on its Early Retention in Plasma and selected Soft Preparation, Characterization and Distributicn in Mcuse * Sumary of the Distribution of Plutonium in the *The Metabolism of the Content and Benewal of Nucleic Acids in Scme Ratbit a Technical Progress Review by Chronology, Permuted Radium 226 and Radium 228* 4 \#haracterization of Actinide Bearing Soils: Experimenta i A Aproach* Beagle Dogs*

* com fara ti ve \#Chrcnic Dogs. A. Menodisperse 1.5 um Flutonium 238 cioxide Young Adult and Aged Syrian Bamsters. 2 . and Dog* *

Injection of Eadioactive Suspensicns* * Regularities in the Distribution and \#comparati ve

Semiannual Report of Rcrk in Progress on the Chrcnic An Annual keport of Work in Progress on the chrcnic Annual Report of Work in Progress on the Chrcnic Contributicn to Health protection of porkers* *Problems of plutoni un

\#Quantitative Morpholoy of Vertelral the Physico-Chemical Porms of Radionuclides and Stable the Physico-Chemical Porms
Inhalaticn of Al cha Buitters*

$$
\text { "Studies of Flutonium in Human }
$$

Size cn \#asclear\#Structures Accesscry to the Gastrcintestinal in the Atscrftion of plutonium in the Gastrointestinal Pission with Resorption Thereof from the Digestive \#NCte on the Bxchange of Plutoni um 239 Eetween Dogs Burdened with plutonium \#A Ccmparison of $S \in r u$ Dogs Burdened with Plutonium \#A Ccmparisicn of Serum
Plutcniur 239*

* Ser un to the Human Eody in the
\#On the Einding of plutcnium (+4) to

\#Bxcretion and

Feritoneal Fhagocytes of the Rat* \#Phagccytcsis and and Sanitary Dosimetric Mcnitoring when Working with

Morphology of \#Numerical Frediction of the Mescscale \#Te Reaction of plutoni un $(+4)$ with the Ir on Released from Underground Nuclear Detonaticns: Source, Released from Underground Nuclear Detonaticns: Source,
Health PIotecticn of workers*
\#Ioxicology of of the International symposium on Fackaging and Bcosystem: Phase 2, Implications of Differences in
Above-Grcund Retrievable Starage Method for Lon-level \#Chenical, Nuclear, and Biological properties of the \#T he *The Metabolis of \#Remcte Aftereffects Associated with Darage by *rines Containing DTPA* \#The Rapid Determination of the Scils: ToF Sixty Centimeters of $216-2-5$ Enclosed Cycle Industry te the Year 2000* Radion uclides*

\#Principles and \#Removal of Deposited Flutonium ky 239 in the \#pilot Study of the Bffect of Ccrtiscl cn \#The Mcvement of

and High Initial rispersion* * Relative Eiological Effectiveness of \#The Plutonium content in the protein Fraction of Rat Mechicte \#Progress Beport: Flutonium Femoval.

Radioactive Particles*

Radioactive Particles*

Plutcnium Particles*

Injection of Elutonium Nitrate (Plutonium 239)* * Histochemical Fhosphatases and Metachromasia in Murine \#Effect of Internal Bmitters on Liver * Fbcspholicid Disequilitrium in Waters of the Judea Group (CenomanianBxperimental rairy Herd, January 1, 1969-\#Status of the
Tissue*

Tissue* Radionuclides and the Subsequent Alteration Iissue: A Preliminary Analysis of Reported Data

Tissues of Beagles*Physical-Chemical State of Plutoniun Tissues of Graded Polymeric and Monomeric Plutonium. Tissues of Cccupationally Fxposed Horkers*

Iissues of Rats Ireated with plutonium $(+6)$ Nitrate* Tissues* Iitle, and Author vol. 11, No. 1 through vol. 14, No. $6 *$ Tooth Ioss in Beagles In jected with plutoni um 239 ,

ToF Sixty Centimeters of 216-2-9 Enclosed Trench*

Toxicity of Inhaled Alpha-Bmitting Radionuclides--A Toxicity of Inhaled Beta-Bmitting Radion

Toxicity of Inhaled Plutcnium 238 Dioxide in Beagle Toxicity of Inhaled Plutonium 239 Dioxide in Immature, Toxicity of Inhaled Plutonium 239 Dioxide
Toxicity of Inhaled Elutonium 239 Dioxide*

Toxicity of Inhaled Elutonium 239 Dioxide*

Ioxicity of Radioactive Farticles. 1A. Intratracheal Toxicity of Radicelements*

Ioxicity of Strontium 90, Fadium 226, and Plutcnium 239* OCO150

Toxicity Aspects of Internally Leposited Plutoniun 239* 00024

Toxicity Program*

Toxicity Prcgram*

Toxicity Program*

Texicclogy of Californium $252^{*}$

*Research on Radiobiology, Besearch in Radicticlccy. 000071

Toxicology of Transportable vranium : A Critical

Ioxicology*

Ioxicology: Badioactive Metals*

Trabecular Bone*

Irace Flements in seawater in Belation to uftake by the

Irachectronchial Iymph Ncde Involvement Following

Trachectronchial Lymph Nodes*

Track Technique fcr Iow-Ievel plutonium in 0rine

iract of the Rat* \#Bfect of Age and Particle

Iract*

Iract*

Iract*

Iract*

*The Effect of Irradiation

Transaninase Levels and other Serum Constituents in

Iransalnase levels and other Serum Constitutents

Transfer of Heavy Radionuclides to Milk*

Iransfer of Radioactive Nuclides from the Environment

Transferrin and conalbumin*

Iranslccation of Plutonium 239 in Beagle Livers*

Translccation of Plutoni un 239 Dioxide After Inhalaticn*

Translccaticn of Plutonium 230 Pu02 Particles by

Transplutonium Elements* Froblems in Radiaticn safety

Iransplutonium Elemente: A Bitliography*

Transfrt of Atmosphere Fffluents: Philosophy and

Transpcrt System in Human Blocd Serum*

Transert system in human Blocd Serua*

"Radicactivity

Transpcrtable oranium: A Critical Contritution to

ranspcrtation of Radioactive Materials* Proceedings rransuranic Isotopic Ratios* Americium in a Freshwater Transuranic Wastes*

ransuranium $B l \in m e n t s *$

Iransuranium Elements*

Iransuranium Elements*

Iransuranium Blements

ransuranuium Elements by Solid wastes at Savannah aiver 0 047 characterization of Actinide

Irends and projected Shipments in the Nuclear puel

Trends in Therapeutic Removal of Internally Defcsited

Iriethylenetetranine Hexaacetic Acid*

Irisodium Calcium DTPA Enhanced Bxcretion of Plutonium

Tritiul in Fcological systems*

Tritiun Intake in Ney york City*

Iritiun Movement in Soils: The Importance of Exchange Tritiun*

Tubular Bones*

Tuff*

Tumor Incidence Studies*

000258

Tumorigenicity of Intratracheally Administered Earticles 000252 Tumors in Eeagles Injected with Plutonium 239* OCO244

* Iumors in Mice after Pulmonary Deposition of $\quad 00025$

Tumors in Mice After Fulmonary Leposition of

Tumors of the Canine Lung Following Inhalation of

Tumors Developing in Bats after Intraperitoneal

Tumors Induced by Bone Seeking kadionuclides* $\quad 000023$

Tumors Induced by Direthylauincarobeurence*

Turnover in Froduct Foisoned Animals*

Turonian) Aguifer in Galilee, Ncrthern Israel* 238 0c0332

0.S. Atcmic Energy Commission Contractors' Internal 000370

V.S. Environmental Erotection Agency's Nevada Ifst Site C 0210
00064

00376

00129
000356

101
118

0449
0247

00398
0095 145
0170 140 096
267 267
395

0070
0271
00347

00043

00342

00313
$\mathrm{C} 0380$

0362
0293

0207
0185
0177 083 00027
$C 0035$

00225
00223

$C 0221$
00146

. 246
0012

00199

00439 294
419 0347
0440 477
298

000284
00441

00013
00013

0005

309 307 395 , 304
477 298
0281 52
71
84 
from $1963-1968$ and their Ccntalinaticn frcm One-Point Detcnation cf an XW-25 Intraceritcneal Administraticn of Plutoni um 239 \#The Intraperitcneal Administraticn of Plutonium 239 \#The 238 Dioxide in Reagle Rogs. A. Monodisperse 1.5 um Plutoniu 238 Dioxide Particles. E. Monodisperse 3.0 Diffusion, and Deposition* \#Radioactivity Released frcm and Effect of Plutonium 238 in the Petoplacental Internal Bxposure Bxperience, \#A Statistical Summary of Soybean plants* Pactors iffecting Alteration of Phacocytic Activity on Tissue \#Effects of Zirccnium on Early Femur "Effects of Zirconium Citrate on Early Femur is $\mathrm{k} *$

Stable Trace Elements in Seawater in Relation tc by Rats and Man* \#Deposition and Fate of Flutoniug, Sediment s* \#atics of the Average Concentrations of Uranium Cxide-Pentoxide* ${ }^{*}$ \#istribution of \#Studies of plutonium, Americium, and \#A Case of Inhalation of Enriched * Letection and Evaluation of \#Letection and Evaluation of
Eetween Isotopes in a Hixture of Froducts of cn Excretion of Urany 1 Nitrate and Ccurse cf * Health Hazards of the coal and

\#Investigations on the Bacterial leaching of Uranium in the Body After Single and Chrcnic Ertry cf Physics Application of in Vivc Gamma Spectrometry in a Aquifer of South Texas*

Judea Group (Cenomanian-Turonian) Aguifer in Galilee, the Incorporation of Radicactive Fissicn Prcducts cf
\#Uranium 234 and Texas* (Cenomanian-muronian) Aquifer in Galilee, \#Dranium 234 and Bone Retenticn Functions in the Human Metabolism of cf workers* \#Tcxicology of Transfcrtable -Tetracetic 2,21-Diaminodiethylsulfide on Excretion of * Plutoni um \#Fffects of Zirconium on Early Femur Optake an \#Effects of $z$ irconium Citrate on parly Remur optake and of irccnium Citrate on Early remur uptake and Workers* \#Sensitive Method for the Determination of Low \#heoretical 1 xxcreticn of Elutonium in \# A Basis for Boutine

for the Letermination of Alpha-Bmitting Plutonium in * The Analysis of plutonium 241 in \# Determination of Plutonium in Human \# Nuclear-Track Technigue fcr Iow-Level plutonium in
\# Method of Determ in ing Plutcnium 239 in Transuranuiur Elements by Extraction Chromatography in \#Skeletal Dosimetry in Treatment fcr the pemoval of Inhaled Plutonium *T he

\#Effects of Age and Bone-Seeking Radionuclides on the Radicnuclides* \#Preliminary Report: Changes in

\#Bxchange of Iyotropic Series cations by Micaceous Ouantitative Morpholoy cf

\#Chelating sgents in Flutonium Dercsition--A Minority or Plutcnium 239 Dioxide and Subsequent Influenza Autoradiography* 23 Diutonium 239 in Ecnes as Aerosols of Americium 241 Dicxide and Evaluaticn of In of plutcnium 239 Between Tranferrin and Ferritin in Experimental and Calculative Approaches to Predict In "Administration of an In \#healt t Physics Application of in \#Elimination of Inhaled Plutonium oxide Particles by In Radiation*

Blood Constituents*

\#The Measurement of Plutcnium $239^{\# I n}$ of overpack-Constructions Based on Ehenolic Foam of Inhaled flutonium oxide particles by in vivc Iung for Retrieval of Solid Low-Ievel Radioactive Plutoni um isumary of the Study of Disposal cf Nuclear \#Sumary of the Study of Disposal cf Nuclear
Reprocessing Facilities* Reprocessing Facilities* \#Chemical Bngineering Division,
December 1973* December $1973^{*}$ \#Chemical Engineering Division,

\#igh-level \#The Nuclear Fuel cycle and

\# Nev Process for $R \in m$ oving Plutonium frcm

Range Management cf Transuranium-Contaminated Solid of Plutonium and Americium from Al cha-Bearing aqueou Retrievatie Storage yethod for Low-Level Transuran ic of plutcnium and Americium from Alpha-Bearing Aqueous
V.S. Frblic Health Service Pasteurized Milk Network \#Plutonium Cltra High Speed Alpha Autoradiography in the Detection Ultrastructure of Mcncnuclear Phagocytes Following toncalsperse plutoniug 239 um Plutcnium 238 Dioxide Particles. B. Monodisferse 3.0 um Plutonium 238 Dicxide Particles. 1.*Monodisperse Unit cf the Rat* Iistribution Onited States Atcmic Energy Ccmmission Licenses" oniversity of vtah*

optake and Distribution of Plutcnium in Barley and Uptake and Fetention of Polyneric Plutonium* Uptake and Urinary Excretion of Radioisotopes* Cptake and urinary Bxcretion of Radioisotopes*

optake by the Marine Biosphere* Forms of Radicnuclides optake of Plutonium in Bone Marrow: A Fossible leukemic Uraniul and their Fission Products Inhaled as Aerosols oraniun and organic Matter in Fecent sea and ocean

Oraniug in the Eody After Single and Chrcnic Bntry of

Uraniur in Envircnmental Matrices*

Traniuu in En

Dranicr Bxpcsures*

Draniul Fission with pescreticn Thereof from the

Uraniul Intoxication in Bats*2,2\%-Diaminodiethylsulfide Craniua Miner*

Oraniuu Ores*

un oxide-Pentoxide*

Oraniull Processing Plant*

* Uranium 234 and Dranium 238

* Uraniull 234 in the Ccean* Craniug 235 in ICW Doses*

and Fenal $I$ issue after

Oranivg 238 Diseguilibrium South

traniur*

\#Ridney

Oraniü* A critical Contribution to Health Frotection

Eranyl Nitrate and Course of Uranium Intoxicaticn in

Crany 1 Nitrat

Urinanalysis*

Urinary Excretion of Fadioisotopes*

Orinary Bxcretion of Radioisotcpes*

Orinary plutonium Levels in occupationally Exposed

Orinary Plutonium Levels in occupationall

Urine Eased on the New ICRP I ung Model*

Orine Sampling of Workers Exposed to Plutonium 239*
Orine Using a Solid-State Counter*

orine*

trine*

Urine*

trine*

Urines Containing DTPA* \#The Rapid Determinaticn of the Otah Eeagles*

otah*

Varied Solutility in Beagle Degs. 2.* Lavage and DIFA Vascular system"

Vascular Theory of Radiation Injury to Bone*

Vascularity of Bones from Adult Beagles"

Vascularity of Cortical Bones Induced by Bone Seeking

Ventilaticn systems at Mound Laboratory "EP" Building*

vermiculite and Its Weathering Products Determined by

Verterral Tratecular Bone*

Vien*

Virus Infection in Mice and Syrian Hamsters*144 Dioxide Visualized by Photographic and Neutron-Induced

vitro Eissolution*Production of Monodieperse Respiratle Vitro* \#ote on the Exchange Vivo Behavior* by Chelation and Mixed Complexes--Racid Vivo ccunting Program*

Vivo Gamma Spectrometry in a Uranium Processing Plant* Vivo I rng washout*

Vivo Measurements of Nuclides Bmitting Soft Penetrating Vivo Studies on the Interactions of Plutonium(+4) with Vivo, A Progress Feport*

ka.11s*

\#Develcfment and Testing Washout* \#Eliminatic

Kaste at the Nation

Waste Into Space*

Waste Management in Ccmmercial Nuclear Puel

Waste Management Besearch and Development Program at

Waste Frocessing and Disposal, An Annotated

Hast Frocessing and

haste Water--A Frogress Feport*

Wastes at Savannah River*

Wastes. 3.*

Fastes*

Mastes, 2.*
$\mathrm{CCO} 422$

$\mathrm{CCO} \mathrm{Cl}_{2}$

c 00200

000182

政

CCO140

000419

000065

$0 \mathrm{CO} 468$

000233

000274

000188

C0113

.

000313

$\mathrm{C} C 0263$

000204

OCO259

00073

000273

.

c0039

000369

000074

000085

000469

000321

CCO301

000332

C0321

(200332

0,0343

00343
000347

C 00100

000399

000113

000112

$0 \mathrm{C} 0295$

$0 \mathrm{CO} 295$

000345

$0 \mathrm{CO} 291$

000287

000297

000293

000289

000284

000144

OCO233

000183

$0 C 0169$

000115

000115

CCO105

000461

000285

00342

000375

000139
000104

000029

$0 \mathrm{CO035}$

000202
$0 C 0460$

00069

000469
000166

000339

000222

000430

000437

000166

000476

000476

000480

000478

CCO481

000474

000475

.

000473

000471

000279

000477
000280 
Content of Elut onium in River So lubility Changes of Plutcnium 238 oxide in \#Digital Computer Simulation o \#New Erocess for Removing Plutoniull frcil Waste in Galilee, \#Uranium $234 / 0$ ranium 238 Diseguilitrium in \#Airbcrne Elutonium frcm Series Cations by Micaceous Vermiculite and Its $23 \mathrm{c}$ and Strontium $8 \mathrm{c}, 90$ on the Bone Marrow of * Farly Diagnosis and Treatment of Individuals Mcrphclogy of Experimental Models for Predicting the \#Health Physics at the LCs Alamos \# Fesearch on Radiobiclogy, Annual Feport of \#Research in Fadiobiclogy, Semiannual Eeport of \#Research in Radiobiology, An Annual Refort of of plutoniun in the Tissues of occupationally Expcsed A Critical Centribution to Bealth Prctection cf Low Urinary Elutonium levels in Cccupationally Expcsed Safety and Sanitary Dosimetric Monitcring when \#Iyaph Ncde Clearance of Flutoni um from Subcutantous of the Depth and Amcunt of Plutonium 239 in of a Large Area Proportional Counter for Plutcnium 239 of a Large Area Proportional Honitoring of Iow-Bnergy Plutonium Contamination from One-Point Detonation of an Particles* \#Recovery and Refair i * Tritium Intake in $N \in$ of Flutonium 239 Dioxide Particles labeled with of Salts of Zirconium and other Metals on Plutcrium an of Efficiency cf Removal of Plutonium, Calcium and of Plutonium, Calcium and Zinc from sats by Calcium and Distribution and Excretion* \#The Action cf salts c of Radioisotores*

Excretion of Fadioisotopes*
Water in Japan*

later Suspension and Effect on Eiological Behavior ater Tabie*

water--A Prcgress Report*

haters of the Judea Group (Cenomanian-Turonian) AguifeI eapons Accidents*

leathering Froducts Determined by Blectron Micrcscopy

White Fats*

\#The Action of Plutoniu

Who Have Excessive Defositions of Radioisotopes*

nidesfread Dispersion of Plutcnium*Bicassay EXFEriences CC0465

ind and Potential Radiological Fields over the Nevada

Wing cn Hot-cell Pacility*

hork in Progress on the Chronic Toxicity Program*

rork in Progress on the Chronic Toxicity Program*

Forkers Exposed to Plutonium $239 *$

Workers* \#Summary of the Distribution harkers* * Taxicology of Transportatle Uranium \# Sensitive Method for the Determination of crking with Transplutonium Elements* in Radiation Founds in Beagle*

* The Determination

Winds with SI(LI) Detectors* x-ray Letection in Iungs* \#Calikration $x$-Ray Radionuclide Content in Human Body* $\mathrm{XW}-25(0) *$

Yeass Cells After Irradiation with Densely Ionizing York City*

Yttertium 169 in the Rhesus Monkey After a Single Acut ittrium Distribution and Excretion* \#The Actic zinc from Rats by Calcium and zinc DTPA* \#CCmpariso Zinc DIPA* \#Ccmparison of Bfficiency of Remova 2irconium and other Metals on Plutonium and Yttrium Zirconium on Early Pemur Dptake and Urinary Excretion Zirconium Citrate on Early Pemur Uptake and Urinary
000311

000171

$0 \mathrm{CO} 332$

000470

000070

000072

0007

$0 C 0345$

000356

00024

0045

000062

000337

000349

000406

000302

$\mathrm{CC} 0327$

000178

000401

$0 \mathrm{CO} 126$

000266

000213

000213

000266

000113

000112 
PUBLICATION DESCRIPTION INDEX

A/CONP. $15 / 1-P / 2382254$

Act a Medica et Biologica, $20(3-4), 147-161378$

Acta Unio Internationalis contra Cancrum, 20, $1151-1154 \quad 123$

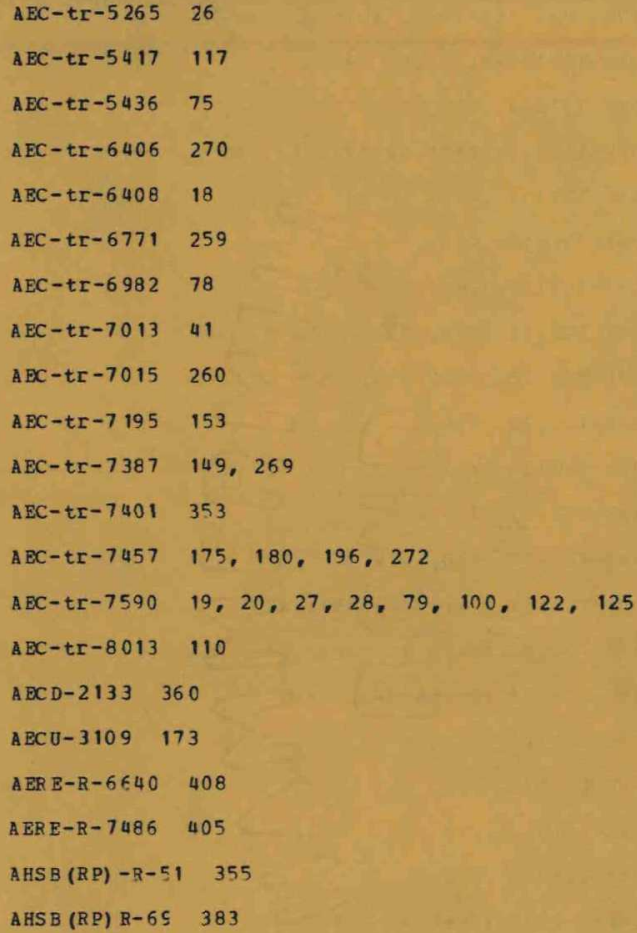

179

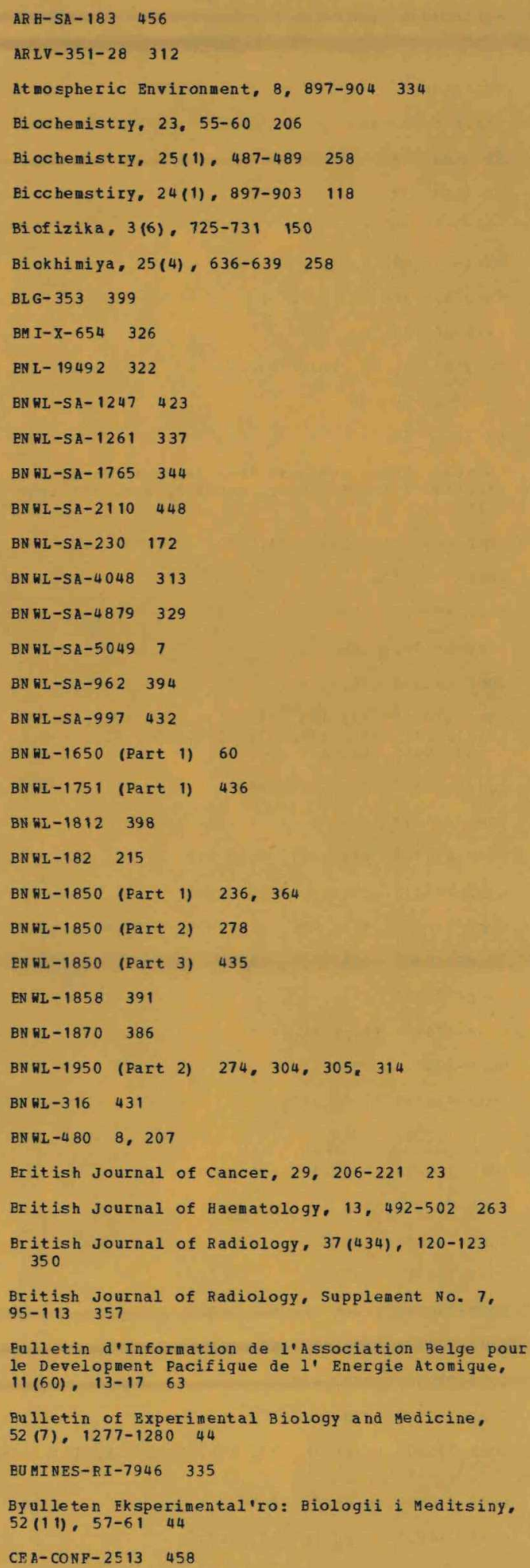


SUBLICATION DESCRIPTION INDEX

$\mathrm{CBA}-\mathrm{R}-3978 \quad 195$

$\mathrm{CEA}-\mathrm{R}-4263 \quad 164$

$\mathrm{CBA}-\mathrm{R}-4488 \quad 316$

CEA-R-4580 349

CH-3589 61

$\mathrm{CH}-3607 \quad 372$

$\mathrm{CN}-1910 \quad 59,92$

$\mathrm{CN}-1990 \quad 58$

$\mathrm{CN}-2740 \quad 158$

$\mathrm{CN}-2905 \quad 91$

$\mathrm{CN}-2992 \quad 1,16,101,102$

$\mathrm{CN}-3190 \quad 56,90$

$\mathrm{CN}-3358 \quad 57$

Comptes Rendus Hebdomadaires des Seances de

'Academie des Sciences, Serie D, 276, 681-684 166

CON P-4 $48 \quad 253,291,373,377,392,393,424$

CON F-556 170

CONF-650624 172

CONP-651102 286

CONF-660212 76, 224

CONF-670521 $82,129,192,194,199,268,303$, $317,319,337,339 ; 370,375,394,423,430$, $317,319,337,339$,
$432,465,468,469$

CONF-680507 277, 327, 452

CONF-681013 344

CONF-690103 $448,451,460,470$

CON P-701112 341

$\operatorname{CONP}-710401438,446,450,455,461,462,464$

CON F-710809 155, 309, 401

CON $P-710 \subseteq 88 \quad 313$

CONF-710991 (Part 2) 408

CONF-7201C8 109

CON P-720519 318, 447

CONF-720562 374

CON P-720823 (Vol. 1) 403

CON P-721030 472

CON F-721C96 376

CON F-721107 445

CONP-730345 (Part 2) 382, 404

CONF-730431 17, 65, 130, 182, 193, 197, 208, 220

CON $F-730503 \quad 330,429$

CONF-730547 338

CONF-730907 (Part 1) 97, 108, 145, 152, 171, 214, 271

CONF-730907 (part 1) 347

CONF-730907 (Part 1) 371, 411
180

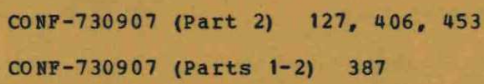

CONF-730907<PART 1) 1 Part of snyder, Proceedings of the $3 \mathrm{rd}$ International congress of the IRPA held in Washington, D.C.., September 9-14, 1973. (p. 141-146), 1475 p. 165

CONF-730907 (PART 2) 99

CONF $-730983 \quad 458$

CONF-731050: IAEA-SM-179/23 178

CONF $-731101 \quad 415$

CONF $-731117 \quad 425$

CONF-740115 288

CONF $-740312321,332$

CONF-740406 402, 414, 454, 473, 476

CONP $-740428 \quad 474$

$\mathrm{CONF}-740434 \quad 477$

CONF $-740702 \quad 7$

CONF-740807 410, 444

CONF-740901 (Part 1) 437, 441

CONF-740901 (Part 2) 442, 443, 457

CONF-740901 (Parts 1-2) 440

CONF-740921 331, 409

CONF $-740930 \quad 362$

CONF-741026 471

CONF $-741210 \quad 322$

CONF-780907 (Part 1) 284

coc-1156-70 323

coc-119-231 34

coc-119-232 5

Coc-119-234 $66,223,246$

COC-119-235 244, 294

Coc-119-236 77, 105, 115, 161, 222, 230, 282

COC-119-237 35

COC-119-240 36

COC-1199-38 328

CoC-1515-56 285

COC $-1731-4 \quad 308$

COC-1787-18 62

$\operatorname{Coc}-218 \quad 86,144,234$

$\mathrm{COC}-220 \quad 71$

coc-222 72

COC-224 247

Coc $-225 \quad 32,70,87,137,242,248,249$

COO-226 106, 283

Coc-3167-28 109

COO-414-18 296 
PUBLICATION DESCRIPTION INDEX

Cornell Energ Project on ational Energy Needs and Bnvironmental Quality 369

CRSSA-1972 368

CS-1907 179

D. Van Ncstrand Company, Inc., Princeton, New Jersey, 3rd Fation 434

Doklady Akadenii Nauk SSSR, 207 (1), 186-189 299

DE-MS $-74-26 \quad 471$

Environmental Letters, 4 (3), 151-185 320

Erzmetal1, $26(10), 484-49074$

BUR $-4712-f \quad 164$

European Journal of Biochemistry, 17, 581-585 50

Federation Proceedings, 20, 206-219 47

Federation Froceedings, 20, 219-220 201

Fourth Edition 340

Gigiena i Sanitariya, 6, 37 40 85

Gigiena i Sanitariya, 8, 69 71 289

Giornale di Fisica Sanitaria e Protezione Contro le Radiazioni, 16 (1), 1-6 295

HASL $-224 \quad 417$

HAS L-286 306,412

Health Physics, 12, 1671-1682 345

Health Physics, 12, 481-500 355

Health Physics, 12, 609-613 55

Health Physics, 12, 895-899 15

Health Physics, 19, 469-485 422

Health Physics, 2, 225-238 73

Health Physics, 2, 379-386 348

Health Physics, 27, 103-108 336

Health Physics, 27, 37-43 307

Health Physics, 28, 29-39 219

Health Physics, 5, 142-148 261

Health Physics, 6, 63-65 287

Health Physics, 8, 725-730 49

Health Physics, 9, 1031-1034 112

Hoken Butsuri, 2, 121-127 361

HW- SA- $3590 \quad 212$

HW- 27688111,265

НW- $41500 \quad 119,264$

HW $-53500333,433$

HW- $5950053,120,252$

HЕ- $65500 \quad 12,121,174,267$

Н

HW- $72500 \quad 14,46,146,147,276$
Hผ $-80500 \quad 52$

Hygiene and Sanitation, 33, 129-132 240

Hygiene and Sanitation, 36, 254-258 143

IA EA-SM-118/45 322

IA FA-SH- $172 / 31 \quad 429$

IA EA-SM- $182 / 34 \quad 332$

IAEA-SM- 182/35 321

IA EA $/ S M-172 / 82 \quad 330$

IDO- $12078 \quad 325$

Indian Journal of Occupational Health, $15(1), 8-14$

International Journal of Applied Radiation and Is ot opes, 19, $422-425138$

International Journal of Radiation Biology, $7(4)$, $405-407 \quad 142$

International Journal of Radiation Biology, 2 (2) $143-156 \quad 250$

International Journal of Radiation Biology, 2(2), $143-156 \quad 251$

Journal of Japan Health Physics Society, 2 (3), $121-127 \quad 361$

Journal of Occupational Medicine, $4(7), 373-382$ 366

Journal of Pharmacology and Experimental Therapeutics, 104, 317-324 266

Journal of the oceanographical Society of Japan, $29(2), 76-82 \quad 416$

Journal of the Reticuloendothelial Society, 6, 123200

JP RS-1132久 151

Ka ga ku, $42(2), 79-85239$

KF K- $1638 \quad 374$

LA -DC-435 297

LA -DC-8433 375

LA $-0 \mathrm{~B}-74-1314 \quad 186$

LA - UR-74-1339 409

LA $-U R-74-1340 \quad 331$

LA $-U R-74-1454 \quad 362$

IA $-4074 \quad 470$

$\mathrm{LA}-5227-\mathrm{PB} \quad 2$

LA -5661273

IA $-5726-P R \quad 413$

LA $-5810-$ MS 384

Laboratory Investigation, 8, 194-204 4

LF-tr-41 43

LF $-4925,29,30,31,95,96,126,139,140,148$, $D C-106188$

MD DC-1221 203

MD DC $-1555 \quad 297$ 
PUE LICATION DESCRIPTION INDEX

Meditsinskaya Radiologiya, 10, 42-46 116

Meditsinskaya Radiologiya, 10, 40-47 154

Meditsinskaya Radiologiya, 15(12), 44-46 80

Meditsinskaya Radiologiya, 16(5), 44-50 168

Meditsinskaya Radiologiya, 17(3), 19-24 176

Meditsinskaya Radiologiya, 2(5), 39-51 235

Meditsinskaya Radiologiya, 4(5), 68-72 135

Meditsinskaya Radiologiya, 4 (6), 75-77 257

Meditsinskaya Radiologiya, 5(11), 49-53 198

Meditsinskaya Radiologiya, 9, 49-52 367

MHS MP-74-12 397

Monographs cn Nuclear Medicine and Biology, No. 2 $82,129,192,194,199,268,303,317,319,337$, $339,370,375,394,423,430$

Monographs on Nuclear Medicine and Biology,., No. 2 432

Monographs on Nuclear Medicine and Biology, No. 2

Monographs on Nuclear Medicine and BIology, No. 2 468

Monographs on Nuclear Medicine and Eiology, No. 2 469

NAS A $-T M-X-68235 \quad 480$

Nature, $180(4587), 651-652 \quad 237$

Nature, $187(4737), 575-576 \quad 133$

Nature, $193(4822), 1301-1304 \quad 13$

Nature, $198(4881), 703-704255$

Nature, 204, 899-900 212

Nature, $206(4987), 945-946 \quad 141$

Nature, $223,642-643211$

Naturwissensc haften, 49, 65-66 418

Naturwissenschaftliche Rundschau, 2695), 191-204 298

NERC-LV V-539-22 210

NOAA-TM-ERL-A RL- $37 \quad 312$

NSJ $-\operatorname{tr}-136 \quad 361$

Nuclear Safety, 15(4), 460-466 479

Nuclear Technology, 24, 383-390 477

Nucleonics, $16(6), 78-81293$

N VO $-1229-173 \quad 300$

NVo -140 (Vol. 1) 315

ORN L-NSIC-115 449

ORN L-TM- $4783 \quad 478$

ORNL-tI- $1463 \quad 63$

ORNL-tr-2823 124

ORNL-3849 22

Paper No. 72-7 369

Papers in Meteorology and Geophysics, 24(1), 75-78 311
182

Part of Air Sampling Instruments for Evaluation of Atmospheric Contaminants, Fourth Edition, (p. G-1 $-6(16), 558$ p. 421

Part of Air Sampling Instruments for Evaluation of Atmospheric Contaminants, Fourth Edition, (p. F-1 - F-11), 558 p. 428

Part of Annual Progress Report: Scientific Works, 1972 , (p. 79-80), 268 p. 368

Part of Barron, E.S.G., et al, Monthly Health Re fort on Froblems Relating to Product for Mont of May, 1945, (p. 37-47), 47 p. 101

Part of Berdjis, C.C. (Ed.), Pathology of Irradiaticn, Chapter 11. Willians and Wilkins

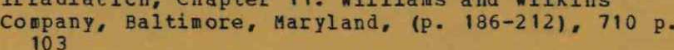

Part of Berdjis, C.C. (Bd.), Pathology of Irradiaticn, Chapter 7. Wiliiams and Hilkins Company. Baitimore, Maryland (f. $(10-119), 710$ p. 243

Part of Biological and Medical Research Division Annual Report, 1966, (p. 132-134), 324 p. 37

Part of Biclogical and Medical Research Division Annual Repcrt, 1965, (p. 154-166), 338 p. 38

Part of Eiclogical and Medical Research Division Annual Repcrt, 1964, (p. 47-48), 223 p. 39

Part of Biological and Medical Research Division Annual Repcrt, 1964, (p. 212-214), 230 p. 132

Part of Biological and Medical Research Division Annual Report, 1965, (p. 194-196), 342 p. 188

Part of Biclogical and Medical Research Division Semiannual Report, January through June, 1961, (p.
$82-8$ 4) 189

Part of Biological and Medical Research Division Annual Repcrt, 1965, (F. 192-193) 342 p. 191

Fart of Blcom, W. (Ed.), Histopathology of Irradiation from Bxternal and Internal Sources, Chapter 8. McGraw Hill Book Company, Inc., New York, New York, (F. 348-445), 808 p. 64

Part of B100m, W. (Ed.), His topathology of Irradiation from External and Internal Sources, Chapter 12. McGraw Hill Book Company. Inc.. Neu Chapter 12. McGraw Hill Book Company, Inc.
York, New York, (p. 550-597), 808 p. 93

Part of Bloom, W. (Ed.), Histopathology of Irradiation from External and Internal Sources, Chapter 5. HCGraw-Hill Bock Company. Inc.. New York, New York, (p. 70-161), 808 p. 94

Part of Blcon, W. (Bd.), His topathology of Irradiation from Bxternal and Internal Sources, Chapter 9. McGraw Hill Book Company, Inc., New York, New York, (p. 446-501),808 p. 159

Part of Blcom, Irradiaticn from External and Internal Sources, Chapter 7. McGraw Hill Book Company, Inc., New York, New York, (p. 243 347), 808 p. 160

Part of Blcon, w. (Ed.), His topathology of Irradiation from External and Internal Sources, Chapter 10. McGraw Hill Book Company, Inc.. Nev York. Ney York, (p. 502-540), 808 p. 177

Part of Blcon, W. (Ed.), His topathology of Irradiation from External and Internal sources, Irradiation from External and Internal Sources, Chapter 16. McGraw Hill Book Company, Inc.
York, New York, (p. 712-735), 808 p. 183

Part of Blcom, W. (Ed.), Histopathology of Irradiation from Bxternal and Internal Sources, Chapter 15. McGraw Hill Book Company. Inc., Ne York, New Ycrk, (F. 704-711), 808 p. 184 
PUBLICAT ION DESCRIPTION INDEX

Part of Bloom, W. (Ed.), His topathology of Irradiation from External and Internal sources, Chapter 11. MCGraw-Hill Bock Company, Inc., Nev York, New York, (p. 541-549), 808 p. 185

Part of $B l o c m$, W. (Ed.). Histopathology of Irradiation from External and Internal Sources, Cha pter 4. McGrav Hill Book Company, Inc., Nev Yor k, New York, (p. 32-69), 808 p. 216

Part of Boecker, B.B. and Rupprecht, P.C. (Eds.), Annual Report of the Inhalaticn Toxicology Research Institute, October 1, 1973 through September 30,1974 (p. $48-52), 384$ p. 25

Part of Boecker, B.B, a nd Rupprecht, P.C. (Eds.) Annual Report of the Inhalaticn Toxicology September 3C, 1974, (p. 1-7), 384 p. 29

Part of Boecker, B.B. and Rupprecht, F.C. (Eds.), Annual Report of the Inhalation Toxicology Research Institute, october 1, 1973 through September 30, 1974, (p. 165-169), 384 p. 30

Part of Boecker, B.B. and Rupprecht, F.C. (Eds.), Annual Report of the Inhalaticn Toxicology Research Institute, October 1, 1973 through
September 30, 1974 (p. 174-178), 384 p. 31

Part of Boecker, B.B. and Rupprecht, F.C. (Eds.), Annual Report of the Inhalaticn Toxicology Research Institute, October 1, 1973 through September 30, 1974; (p. 136-139), 384 p. 95

Part of Boecker, B.B. and Rupprecht, F.C. (Bds.), Annual Report of the Inhalation Toxicology Research Institute, october 1,1973 through
September 30,1974 , (p. 150-155), 384 p. 96

Part of Boecker, B.B. and Rupprecht, P.C. (Eds.), Annual Report of the Inhalaticn Taxicology September 30, 1974, (p. 170-173), 384 p. 126

Part of Boecker, B.B. and Rupprecht, F.C. (Eds.), Annual Report of the Inhalaticn Taxicology Research Institute, October 1, 1973 through September 30, 1974, (p. 211-214), 384 p. 139

Part of Boecker, B. B. and Rupprecht, F.C. (Eds.), Annual Report of the Inhalaticn Toxicology Research Institute, October 1, 1973 through

Part of Boecker, B.B. and Rupprecht, P.C. (Bds.), Annual Report of the Inhalaticn Toxicology September 30,1974 (p. 37-39), 384 p. 148

Part of Eoecker, B.B. and Rupprecht, F.C. (Eds.), Annual Repcrt of the Inhalation Toxicology Research Institute, October 1, 1973 through
September 30, 1974, (p. 274-276), 384 p. 157

Part of Boecker, B.B. and Rupprecht, P.C. (Eds.). Annual Report of the Inhalaticn Toxicology Research Institute, october 1, 1973 through september 30, 1974, (p. 29-36), 384 p. 217

Part of Bourne, G.H. (Ed.), The Biochemistry and Physiology of Bone, Chapter 23. A cademic Press, Inc., New York, New York, (p. 729-765), 875 p. 390

Part of Cherdyntsev, v. V., Uraniun 234 , Chapter 7. Keter press, Jerusaiem, Ísrael, (p. 177-234), 234 p. 301

Part of Crook, M.A. (Bd.), Proceedings of a Symposium cn liquid Scintillation Counting held in Symposium cn Liguid Scintillation Counting held
Brighton, United Kingdom, September 13-16, 1971 . Heydens and Scn, Ltd.., London, Bngland, (p. 155Heydens and
165) $40 \varepsilon$

Part of Davis, J.J. (EA.), Hanford Biology Research Annual Report for 1958, (p. 54-60), 156
Part of Davis, J.J. (Ed.), Hanford Biology Research Annual Report for 1958, (p. 106-108), 156 p. 252

Part of Division of Biological and Medical Research Annual Report, 1972, (p. 121-125), $236 \mathrm{p}$ 131

Part of Dougherty, T.F., Research in RAdiobiology, Annual Repcrt of Progress in the Internal Irradiation program, (p. 188-198), 222 p. 5

Part of Dougherty, T.F., Research in Radiobiology, Annual Report of Work in Progress on the Chronic Toxicity Program, (p. 62-72), 136 p. 32 Part of Dougherty, T.F., Research in Radiobiology,
Annual Repcrt of Work in Progress on the Chronic Toxicity Program, (p. 99-109), 173 p. 34

Part of Dougherty, T.F., Research in Radiobiology, Annual Report of Hork in Progress in the Internal Irradiation Program, (p. 153-157), 168 p. 35

Part of Dougherty, T.F., Research in Radiobiology, Annual Repcrt of work in progress in the Internal Irradiation Program, (p. 139-161), 279 p. 36

Part of Dougherty, T.P., Research in Radiobiology Annual Repcrt of Work in Progress in the Internal Irradiation Program, (p. 218-251), 268 p. 77

Part of Dougherty, T.F., Research in Radiobiology, Annual Repcrt of Work in Progress on the Chronic Toxicity Program, (p. 49-58), 136 p. 87

Part of Dougherty, T.F., Research in Radiobiology, Annual Repcrt of Irradiation Program, (p. 97-125), 268 p. 105

Fart of Dougherty, T.F., Research in Radiobiology, Se mi annual Report of Work in Progress on the Semiannual Report of Work in Progress on the
Chronic Tcxicity Program, (p. 95-127), 135 p. 106

Part of Dougherty, T.P., Research in Radiobiology, Annual Report of Hork in Progress in the Internal Irradiation Program, (p. 126-143), 268 p. 115

Part of Dougherty, T.F., Research in Radiobiology, Annual Repcrt of work in Progress on the Chronic Toxicity Program, (p. 76-83), 136 p. 137

Part of Dougherty, T.F., Research in Radiobiology, Annual Repcrt of work in Progress in the Internal Irradiation Program, (p. 207-217), 268 p. 161

Fart of Dougherty, T.F., Research in Radiobiology. Annual Repcrt of work in Progress in the Internal Irradiaticn Program, (p. 173-190), 268 p. 222

Part of Dougherty, T.F., Research in Radiobiology, Annual Report of work in progress in the Internal Irradiation Program, (p. 94-119), 326 p. 223

Part of Dougherty, T.F., Research in Radiobiology, Annual Report of work in Progress in the Internal Irradiaticn Program, (p. 164-172), 268 p. 230

Fart of Dougherty, T.F., Research in Radiobiology, Annual Repcrt of york in Progress on the Chronic Toxicity Program, (p. 31-42), 136 p. 242

Part of Dougherty, T.F., Research in Radiobiology, Seriannual Report of work in Progress in the Internal Irradiation Program, (p. 71-75), $144 \mathrm{p}$.

244

Part of Dougherty, T.F.. Research in Radiobiology, Annual Repcrt of pork in Progress in the Internal Irradiation Program, (p. 70-84), 326 p. 246

Part of Dougherty, T.F., Research in Radiobiology, Semiannua 1 Report of Work in Progress on the Chronic Toxicity Program, (p. 32-37), 104 p. 247

Part of Dougherty. T.F., Research in Radiobiology, Annual Report of Work in Progress on the Chronic Toxicity Program, (F. 43-47), 136 p. 248 
Part of Dougherty, T.F., Research in Radiobiology, Annual Report of Hork in Progress on the Chronic Toxicity Program, (p. 109-121), 136 p. 249

’art of Dougherty, T. P., Research in Radiobiology, Innual Report of Work in Progress in the Internal Irradiation Program, (p. 191-195), 268 p. 282

Part of Dougherty. T.F., Research in Radiobiology,

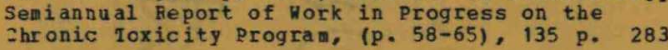

Part of Dougherty. T.F., Research in Radiobiology, Semiannual Feport of Work in Progress in the Internal Irradiation Program, (P 76-95), $144 \mathrm{p}$. 294

Part of Dougherty, T.F., Reserach in Radiobiology, Annual Report of Work in Progress in the Internal Irradiation program, (p. 180-190), 326 p. 66

Part of Enewetak Radiological Survey, (p. 225348). 736 p. 315

Part of Peige, y. (Ed.), Proceedings of the Regional Symposium on Radiat ion protection held in Jerusalen, Is rael. March 5-8, 1973, (p. 743-760) 382

Part of Feige, Y. (Ed.), Proceedings of the Regional Symposium on Radiation Protection held in Jerusalem, Israel, March 5-8, 1973 (p. 805-819) 404

Part of Pirst, M.W. (Ed-), Proceedings of the 12 th AFC Air Cleaning Symposium held in oak Ridge, Tennessee, August 28-31, 1972, (p. 638-645), 899 p. 403

Part of Gus'kova, K. and Baysogolov, G.D. Radiation Sickness in Man, (p. 25-38), 560 p. 353 Part of Haghiri, F., AEC Final Technical Report for Aarch 1971 to August 1972, (p, 58-66), 67 p. 296

Part of Hardy, E.P., Jr., Fallout Program Quarterly Summary Report, June 1, 1974 through September 1, 1974, (p. I-2 - I-10), 169 p. 306

Part of Hardy, E.P.. Jr., Fallout Program Quarterly Sum mary Report, December 1, 1967 through Quarterly Sum mary Report, December 1, 1967
March 1, 1970, (p. I-9-I-13), 144 p. 417 Part of Health Physics Division Annual Progress Report for Fericd Bnding July 31, 1965, (p. 212$213) .257$ p. 22

Part of Hodge, H.C., et al (Eds.), uranium, Plutonium, Transplutonic Elements, Chapter 14. Springer-Verlag, New York, New York, (p. 613-667), 995 p. 466

Part of Jacobson, L.O., et al, Report of Health Activities for Month of Novenber, 1945, (p. 3-7), 7 p. 57

Part of Koelzer, w. (Comp.), Proceedings of the 6 th Annual Scientific symposium of the Association for Radiaticn Protection held in Karlsruhe, Germany, May 17-19, 1972, (p. 253-257), 361 p. 374

Part of Kornberg, H.A. and Norwood, H.D. (Eds.), proceedings of a symposium on the Diagnosis and Treatment of Deposited Radionuclides held in Richland, washington, May 15-17, 1967, (p. 419423). $680^{\circ}$ p. 82

Part of Kornberg, H.A. and Norwood, W.D. (Eds.), proceedings of a symposium on the Diagnosis anc Treatment of Deposited Radionuclides held in Richlanâ, Washington, May 15-17, 1967, (p. 56-64), 680 p. 129
Part of Kornberg, H.A. and Norwood, W.D. (Eds.), Proceedings of a symposium on the Diagnosis and Treatment of Deposited Radionuclides held in Richland, Washington, May 15-17, 1967, (p. 73-80), 680 F. 192

Part of Kornberg, H.A. and Norwood, W.D. (Bds.), Proceedings of a Symposium on the Diagnosis and Treatment of Deposited Radionuclides held in Richland, Nashington, May 15-17, 1967, (p. 403412), 680 F. 194

Part of Kornberg, H.A. and Norwood, W.D. (Bds.), Proceedings of a Symposium on the Diagnosis and Treatment of Deposited Badionuclides held in Richland, Mashington, May 15-17, 1967, (p. 81-90), 680 F. 199

Part of Kornberg, H.A. and Norwood, W.D. (Eds.), Proceedings of a syaposium on the Diagnosis and Treatment of Deposited Radionuclides held in Richland, Washington, May 15-17, 1967, (p. 273$290), 680$ F. 268

Part of Kornberg, H.A. and NCrwood, W.D. (Eds.), Proceedings of a Symposium on the Diagnosis and Treatment cf Deposited Radionuclides held in Richland, Hashington, May 15-17, 1967, (p. 3-18). 680 p. 303

Part of Kornberg, H.A. and Norwood, W.D. (Eds.). Proceedings of a symposium on the biagnosis and Trea tment of Deposited Radionuclides held in Richland, Washington, May 15-17, 1967, (p. 471 48 i), 680 F. 317

Part of Kornberg, H.A. and Norwood, H.D. (Eds.). Proceedings of a Symposium on the Diagnosis and Treatment of Deposited Radionuclides held in Richland, Washington, May 15-17, 1967, (p. 482$486), 680$ F. 319

Part of Kornberg, H.A. and Norwood, H.D. (Eds.). Proceedings of a Symposium on the Diagnosis and Treatment of Deposited Radionuclides held in Richland, Washington, May 15-17, 1967, (p. 164$170), 680$ p. 337

Part of Kornberg, H, A. and Norwood, H.D. (Eds.). Proceedings of a Symposium on the Ciagnosis and Treatment cf Deposited Radionuclides held in Richland, Hashington, May 15-17, 1967, (P. 189$207), 680^{\circ}$ p. 339

Part of Kornberg, H,A, and Ncrwood, W.D. (Eds.), Proceedings of a symposium on the Diagnosis and Ireatment of Deposited Radionuclides held in Richland, Washington, May 15-17, 1967, (p. 427434). 680 F. 370

Part of Kornberg, H. A. and Norwood, H.D. (Eds.). Proceedings of a Symposium on the Diagnosis and Treatment of Deposited Radionuclides held in Rich land, Mashington, May 15-17, 1967, (p. $587-$ 59 2), 680 F. 375

Part of Kornberg, H.A. and NCrwood, H.D. (Eds.), Proceedings of a Symposium on the Diagnosis and Treatment of Deposited Radionuclides held in Richland, Washington, May 15-17, 1967, (p. 593$599), 680$ p. 39

Part of Kornberg, B.A. and Norwood, K.D. (Eds.) Proceedings of a syarosium on the riagnosis and Treatment of Deposited Radionuclides held in Richland, Washington, May 15-17, 1967, (p. 266$278), 680$ F. 423

Part of Kornberg, H.A. and Norwood, W.D. (Eds.), Proceedings of a symposium on the Diagnosis and Ireatment of Deposited Radionuclides held in Richland, Mashington, May 15-17, 1967, (p. 171$188), 680$ F. 430

Part of Kornberg, H.A. and Norwood, K.D. (Eds.) Proceedings of a syaposiun on the Diagnosis and Treatment of Deposited Radionuclides held in Richland, Washington, May 15-17, 1967, (p. 209 $221) .680 \mathrm{~F}-432$ 


\section{PUBL ICATION DESCRIPTION INDEX}

Part of Kornberg, H.A. and Norwood, W.D. (Bds.), Proceedings of a Symposium on the Diagnosis and Treatment of Deposited Padionuclides held in Richland, Washington, May 15-17, 1967, (p. 256265), 680 p. 465

Part of Kornberg, भ.A. and Ncrwood, W.D. (Eds.), proceedings of a symposium on the Diagnosis and Treatment of Ceposited RAdionuclides held in Richland, Washington, May 15-17, 1967, (p. 435$450), 680$ p. 468

Part of Kornberg, H. A. and Ncrwood, W.D. (Eds.), proceedings of a Symposium on the Diagnosis and Treatment of Deposited Radionuclides held in Richland, Washington, May 15-17, 1967, (p. 543552). 680 p. 469 Part of Kornberg, H. A, and Swezea, R.G. (Bds.),
Hanford Biology Research Annual Report for 196i, Han ford Biology Research

part of Kornberg, H.A, and Swezea, B.G. (Bds.), Hanford Biology Pesearch Annual Report for 1961 , (p. $50-51), 180$ p. 45

Part of Kornberg, H.A, and Swezea, E.G. (Bds.), Hanford Biology Research Annual Report for 1963, (p. $42-43), 259$ p. 52

Part of Kornberg, H.A, and Swezea, B.G. (Bds.), Hanford Biology Research annual Peport for 1961 , (p. 44-4s), 180 p. 145

Part of Rornberg, H.A. and Swezea, F.G. (Eds.), (p. $36-40), 180$ p. 147

Part of Kornberg, Н.A., et a 1, Biology Research Annual Report, 1955, (p. 61-72), 188 p. 264

Part of Kornberg, H.A., Hanford Biology Research Annual Report for 1959; (p. $116-121), 208$ p. 12

Part of Kornberg, H.A., Hanford Biology Research Annual peport for 1959, (p. 72-73), 208 p. 174

Part of Kornberg, Н.A.., Hanford Biology Research Ann ual Report for 1959, (p. 122-128), 208 p. 267

Part of Kornberg, Н.A., Hanford Biology Research Annual Report for 1957, (p. 167-171), 226 p. 433

Part of Lebedinskii, A. V. and Moskalev, Yu.I. (Bds.), Biological Bffects of Radiation and Problems of $\mathrm{R}$ adioactive Isotope Distribution, Translated $\mathrm{frcm}$ a publication of the State Publishing House of Literature in the Pield of A tomic Science and Technology, Moscov, USSR, (p. $32-42), 187$ p. 26

Part of Manual on Radiation Eaematology, Chapter 3. (p. 45-69) 218

Part of Manual on Radiation Haematology. Chapter 1, (p. 215-242) 389

Part of McClellan, R.O. and Rupprecht, F.C. (Eds. 1. Inhalation Toxicology Research Institute Annual Report, Octcber 1, 1973 through September 30 , 1974 , (p. 269-273), 342 p. 156

Part of Moghissi, A.A. and Carter, M.W. (Eds.), Proceedings of a Symposium on Tritium held in Las Vegas, Nevada, August 30-September 2, 1971. Messenger Grachics, Publishers, Las Vegas, Nevada, (p. $240-244), 807$ p. 155

Part of Moghissi, A.A. and Carter, M. W. (Bds.), proceedings of a Symposium on Tritium held in Las Vegas, Nevada, August 30-September 2, 1971. Messenger Graphics, Publishers, Las Vegas, Nevada, (p. 430-455). 807 p. 309

Part of Moghissi, A.A. and Carter, M.M. (Eds.), Proceedings of a symposium on Tritium held in Las Veqas, Nevada, August 30-September 2, 1971 . Messenger Gra chics, Publishers, Las Vegas, Nevada, des senger Gra fhics, Publis
(p. 639-646), 807 p. 401
Part of Monthly Health Report on Problens Relating to Product for Month of May. 1945, (p. 12-15), 45 p. 1

Fart of Monthly Health Report on Froblems Relating to Product for Month of May. 1945, (p. 5-11), 45 F. 16

Part of Monthly Health Report on Problems Relating to Product for Month of April, 1945, (p. 21-23), 29 p. 91

Fart of Monthly Health Report on Problems Relating to Product for Period Ending June 30 , 1944, (p. 45) 92

Part of Monthly Health Feport cn Problems Relating to Product for Month of May, 1945, (p. 16-18), 45 p. 102

Part of Monthly Health Report on Problems Relating to Product for Period Ending February 15, 1945, (p. $5-7) \quad 158$

Part of Moskalev Yu.I. and Kalístratova, V.S. (Eds.). Biclogical Effects of Radiation from
External and Internal Sources, (p. 391-397), 515 p. 175

Part of Moskalev, Yu.I. (Ed.), Distribution, Biclcgical Effects, and Accelerated Excretion of Radicactive Isotopes, (p. 356-360), 405 p. 19

Part of Moskalev, Yu.I. (Ed.), Distribution, Eiological Effects, and Accelerated Excretion of Radioactive Isotopes, (p. $361-366), 405$ p. 20

Part of Moskalev, Yu.I. (Bd.), Distribution, Biclcgical Effects, and Accelerated Excretion of Radioactive Isotopes (p. 99-102), 405 p. 27

Part of Moskalev, Yu.I. (Bd.), Distribution, Biclcgical Effects, and Accelerated Excretion of Radicactive Isotopes, (p. 303-311), 405 p. 28

Part of Moskalev, Yu.I. (Ed.), Distribution, Biolcgical Effects, and Accelerated Excretion of Radicactive Isotopes, (p. 42-62), 405 p. 79

Part of Moskalev, Yu.I. (Bd.), Distribution, Biclcgical Effects, and Accelerated Excretion of Radicactive Isotopes, (p. 375-380), 405 p. 100

Part of Moskalev, Yu.I. (Ed.), Distribution, Eiolcgical Effects, and Accelerated Excretion of
Radicactive Isotopes. (p. 25 1-256), 405 p. 122

Part of Moskalev, Yu.I. (Bd.), Distribution, Biclogical Bffects, and Accelerated Bxcretion of Radicactive Isotopes, (p. 230-237), 405 p. 125

Part of Moskalev, Yu.I. (Bd.), Radioactive Isotcpes and the Body, (p. 439-458), 458 p. 153

Part of Moskalev, Yu.I. and Kalistratova, V.S. (Eds.), Biclogical Effects of Radiation from External and Internal Sources, (p. 435-440), 515 p. 180

Part of Moskalev, Yu.I. and Kalistratova, V.S. (Eds.). Biological Effects of Radiation $\mathrm{frcm}$ External and Internal Sources, (p. 486-490), 515 p. 196

Part of Moskalev, Yu.I. and Kalistratova, V.S. (Eds.). Biclogical Effects of Radiation frcm External and Internal Sources, (p. 427-434), 515 p. 272

Part of Nickson, J.J., Health Information Meeting held January 16, 1945, (p. 3-6), 6 p. 179

Part of proceedings of a Symposium cn Research Animals in Medicine held in Washington, D.C., January $28-30,1972,(14$ p.) 109 
PUBL, ICATION DESCRIPTION INDEX

Part of Froceedings of a Symposium on the Bffects of Neutrcn Irradiation opon Cell Punction held in Nuremberg, Germany, October 22, 1973, (p. 177-184) 178

Part of Proceedings of a Symposium on the Assessment of Radioactive Body Burdens in Man held in Heidelberg. Germany, May 11-16, 1964, Vol. 1 , (p. $355-368), 1043$ p. 253

Part of Proceedings of a Symposium on Radiological Protecticn cf the public in a Nuclear Mass Disaster held in Interlaken, Suitzerland, May 26June 1, 1968, (p. 49-64), 688 p. 277

Part of Proceedings of a Symposium on the Assessment of Radioactive Body Burdens in man held in Heidelberg, Germany, May 11-16, 1964, Vol. 1 , (p. $261-274), 1043$ p. 291

Part of Froceedings of a Symposium on marine Radioecclogy held in Hamburg, Germany, September $20-24$, 1571, (p. 21-93), 214 p. 313

Part of Proceedings of a symposium on Isotope

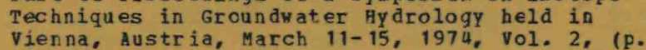
(31-149), 4 $99 \%$. 321

Part of proceedings of a Symposium on the siting of Nuclear Facilities held in vienna, Austria, Decenber 9-13, 1974, (19 p.) 322

Part of Proceedings of a Symposium on Radiological Protection of the Pablic in a Nuclear Mass Disaster held in Interlaken, Switzerland, May 26June 1, 1968, (p. $36-38$ ), 688 p. 327

Part of Froceedings of a syaposium on the Environmental Behavior of Radionuclides Released in the Nuclear Industry held in Aix-en-Provence, France, May 14-18, 1973 , (19 p.) 330

Part of Proceedings of a symposium on Isotope Techniques in Grcundwater Hydrology held in vienna, Austria, March 11-15, 1974, vol. 2, (p. $151-1771,499$ p. 332

Part of proceedings of a symposium on the Dosimetry of Low Energy or Short Range

Irradiations held in Menton, Prance, October 9-11, 1968 , (p. 58-68) 344

Part of Proceedings of a Symposium on the Assessment of Radioactive Body Burdens in Man held in Heidelberg, Germany, May $11-16,1964$, Vo1. 2 , (p. 535-547), 1043 p. 373

Part of proceedings of a symposiun on the Assessment cf Radioactive Body Burdens in Man held in Heidelberg, Germany. May 11-16, 1964, vol. 1. (p. $115-130), 1043$ p. 377

Part of proceedings of a symposium on the Assessment of Badioactive Body Burdens in Man held in Heidelberg, Germany, May 11-16, 1964, Vo1. 1 (p. $15-52), 1043$ p. 392

Part of Froceedings of a symposium on the Assessment cf Radioactive Body Burdens in Man helo in Heidelberg, Germany, May 11-16, 1964, Vol. 2 , (p. 523-533), 1043 p. 393

Part of Proceedings of a Symposium on the Assessment of Radioactive Body Burdens in Man held in Heidelberg, Germany, May 11-16, 1964, Vol. 1 , (p. $245-260), 1043 \mathrm{p}$, 424

Part of proceedings of a symposium on Environmental Behavior of Badionuclides Released in the Nuclear Industry held in Aix-en-Provence. Prance, May 14-18, 1973, (p. 673-700) 429

Part of proceedings of a symposium on the Managenent cf Radioactive Wastes from Puel Reprocessing held in Paris, France, November $27-$ December 1, 1972, (p. 15-36), 1266 p. 445
Part of Proceedings of a symposian on the Radiclogical Prctection of the Public in a Nuclear Mass Disaster held in Interlaken. Suitzerland, May $26-J u n e 1,1968$, (p. 29-31), 688 p. 452

Part of proceedings of a symposiun on the Ma nagement of Plutonium-Contaminated Solid wastes hela in Marcoule, France, October 14-16, 1974, (9 p.) 471

Part of Prcceedings of a sympesium on waste Management held in Tucson, Arizona, April 21-24,
$1974,(8 \mathrm{p})$.477

Part of Prcceedings of the AEC Pcllution Control Symposium held in Oak Ridge, Tennessee, October 25-27, 1972, (p. 153-166), 549 p. 472

Fart of Proceedings of the Atmospheric-Surface Exchange of Particulate and Gaseous Pollutants Sympcsium held in Richland, Pashington, September $4-6,1974,(58$ p.) 331

Fart of Proceedings of the Atmospheric-Surface Exchange of particulate and Gaseous Pollutants Syopcsium held in Richland, Washington, Sectember $4-6,1974,(15 \mathrm{p.}) 409$

Part of Proceedings of the Congress of the Society of Blectric, Blectronic and Radio Engineers Sympcsium held in Vittel, France, September 11-15, 1973 , (18 F.) 458

Part of Prcceedings of the Health Physics Annual Symposium beld in Houston, Texas, July 7-11, 1974,
(10 F.) 7

Part of Prcceedings of the Joint Meeting of the American Nuclear Society and the Atonic Industrial Forum and Nuclear Energy Exhibition held in San Francisco, California, Novem ber 11-15, 1973. Putlished in Transactions of the American Nuclear Society, 17, 541-542 415

Part of Proceedings of the plutonium Information Symposium held in Los Alamos, Hew Mexico, January 4-5, 1974 , (p. 2-7), 96 p. 288

Part of Proceedings of the Rocky Plats Symposiun on Safety in plutonium Handling Facilities held in Golden, Colorado, April 13-16, 1971, (p. 56-67). 457 p. 438

Part of Proceedings of the Rocky Plats Symposium on Safety in plutonium Handing Facilities held in Golden, Colorado, April 13-16, 1971, (p. 4-16), 457 F. $44 \epsilon$

Part of Proceedings of the Rocky Flats Symposiun Golden, Colorado, April 13-1E, 1971, (p. 162-180). $457 \mathrm{~F} \cdot 450$

Part of Proceedings of the Rocky Plats Symposiun on Safety in Plutonium Handing Facilities held in Golden, Coloradc, April 13-16, 1971, (p. 17-25), 457 p. 455

Part of Proceedings of the Rocky Plats Symposium on Safety in Plutonium Handling Facilities held in Golden, Colorado, April 13-16, 1971, (p. 133-148), $457 \mathrm{~F}$. 461

Fart of Proceedings of the Rocky Plats Symposium on Safety in Plutonium Handing Pacilities held in Golden, Colorado, April 13-16, 1971, (p. 83-97), 457 p. 462

Part of proceedings of the Rocky Plats Symposiun on Safety in Plutonium Handling Pacilities held in Golden, Colorade, April 13-16, 1971 (p. 267-279), 457 p. 464

Part of Proceedings of the 10th Space Congress on Technology roday and Tomorrow. held in Cocoa Beach, Plorida, April 11-13, 1973, (p. 7.19-7.26) 480 
PUBL ICATION DESCRIPTION INDEX

Part of Proceedings of the 12 th Annual symposium of the Radiation Research Society held in Miami, Plorida, May 18-20, 1964. Published in Radiation Research, $22(1), 222170$

Part of Proceedings of the 13th $A E C$ Air Cleaning Symposiur held in San Prancisco, California, August $12-15,1974,(10 \mathrm{p.}) 410$

Part of proceedings of the 13 th AEC Air Cleaning Symposium held in San Francisco, California, August $12-15,1974,(13 \mathrm{p}) \quad$.

Part of Proceedings of the 14 th Annual Symposium of the Radiaticn Research Society held in

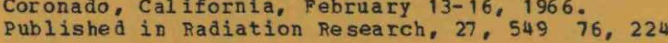

Part of Proceedings of the 14 th Hanford Biology Symposium on Radiation and the Lymphatic System held in Richland, Washington, September 30-0ctober $2,1974,(18 \mathrm{F.})$ 362

Part of Proceedings of the $167 \mathrm{th}$ National Symposium of the American Chemical Society held in Los Angeles, California, April 1-5, 1974 , (14 p.)

474

Part of Proceedings of the 18th Annual Symposium on Bioassay. Environmental, and Analytical

Chemistry held oakbrook Terrace, Illinois, october 10-11, 1972, (7 p.) 376

Part of Froceeaings of the 2 nd International Symposium cn Iung Tumors in Animals held at Penigia, Italy, June $24-29,1965$, (20 p.) 172

Part of Froceedings of the 2 nd United Nations International symposium on the Peaceful Uses of A tomic Bnergy held in Geneva, Switzerland, September 1-13, 1958, Vol. 23, (p. 293-289) 254

Part of Proceedings of the 2 nd United Nations International Symposium on the Peaceful Uses of Atomic Energy held in Geneva, Suitzerland, September 1-13, 1958, Vol. 23, (p. 144-146) 292

Part of Proceedings of the 2 nd International Symposium on Fower from Radioisotopes held in Madrid, Spain, May 29-June 1, 1972, (p. 49-67), $986 \mathrm{p}$. 318

Part of Proceedings of the 2nd AEC Environmental Protecticn Symposium held in A1buquerque, New
Mexico, April $16-19,1974$, vol. 2, (p. 569-576), Mexico, Apri
1151 p. 402

Part of Ercceedings of the 2nd ABC Environmental Protection Symposium held in Albuquerque, New Mexico, April 16-19, 1974, Vol. 2, (p. 705-713), 1151 p. 414

Part of Proceedings of the 2nd International Symposiuu on Power from Radioisotopes held in Madrid, Spain, May 29-June 1, 1972, (p. 827-848), 986 p. 447

Part of Proceedings of the 2nd AFC Environmental Protection Symposium held in Albuquerque, New Mexico, April 16-19, 1974, Vol. 1, (P. 89-147), Mexico, Apri1

Part of Proceedings of the 2nd AEC Environmental Protecticn Symfosium held in Albuquerque, New Mexico, Apri
1151 p. 473

Part of Froceedings of the 2nd Environmental protection Symposium held in Albuquerque, Nev 1151 p. 476 Mexico, April 16-19, 1974, vcl. 2, (p. 1007-1039),

Part of Proceedings of the 21st Annual Symposium of the Radiaticn Research Society held in St. Louis, Missouri, April 29-May 3, 1973. Published in Radiation Research, $55(3), 51617$
187

Part of Proceedings of the 21 st Annual symposiun of the Radiation Research Society held in St. Louis, Missouri, April 29-May 3, 1973. Published in Radiation Research, 55 (3), 51565

Part of Proceedings of the 2 1st Annual Symposiun of the Radiation Research Society held in St. Lovis, Missouri, April 29-May 3, 1973. Published in Radiaticn Research, $55(3), 516130$

Part of Proceedings of the 21 st Annual Symposium of the Radiation Research Society held in St. Louis, Missouri, April 29-May 3, 1973. Published Louis, Missouri, April 29-May 3,1973 .
in Radiation Research, 55(3), 512182

Part of Proceedings of the 21 st Annual Symposium of the Radiation Research Society held in St. Missouri, April 29-May 3, 1973. Published in Radiaticn Research, 55(3), 515-516 193

Part of Proceedings of the 21 st Annual Symposiu of the Radiation Research Society held in St. Louis, Missouri, April 29-May 3, 1973. Published in Radiation Research, 55 (3), 513197

Part of Proceedings of the 2 1st Annual Symposium of the Radiation Research Society held in St. Louis, Missouri, April 29-May 3, 1973. Published in Radiation Research, 55 (3) 514,208

Part of Proceedings of the 2 lst Annual Symposium of the Radiation Research Society held in St. Lovis, Missouri. April 29-May 3, 1973. Published Louis, Missouri, April 29-May $3,{ }^{1973}$.

Fart of Proceedings of the 2 ist American society Symosium cn Mass Spectrcmetry and allied Topics held in San Francisco, California, May 20-25 $1973,(\mathrm{p}, 351-353) 338$

Part of Proceedings of the $4 \mathrm{th}$ International Sympcsium cn Packaging and Transportation of Radioactive Materials held in Miami Beach Flcrida, September 22-27, 1974, (p. 207-216), 1195 p. 437

Part of Proceedings of the $4 \mathrm{th}$ International Symposium on Packaging and Transportation of Radicactive Materials held in Miami Beach, F1 orida, September 22-27, 1974, (F. 349-364), 1195 F. 441

Fart of prcceedings of the $4 \mathrm{th}$ International Symposium on Packaging and Transfortation of Radicactive Materials held in Miami Beach, Flcrida, September 22-27, 1974, (p. 1172-1184),

Part of Proceedings of the 4 th International sympcsium on Packaging and Transportation Radioactive Materials held in Miami Beach, Florida, September 22-27, 1974, (p. $1100-1117$ ).

Part of Proceedings of the $4 \mathrm{th}$ International Sympcsium cn Packaging and Transportation of Radioactive Materials held in Miani Beach, Flcrida, September 22-27, 1974, (13 p.), i195 p. 457

Part of Prcceedings of the 40 th Annual Symposium of the Radiological society cf North America hela in Los Angeles, California, December 5-10, 1954 , (7 p.) 69

Part of Prcceedings of the $7 \mathrm{th}$ Annual Symposium on Bioassay and Analytical Chemistry held in Argonne Illinois, Cctober 12-13, 1961, (p. 5-8), 100 p

Part of Proceedings of the $7 \mathrm{th}$ Annual Symposium on Bicassay and Analytical Chenistry held in Argonne, Illinois, Cetober 12-13, 1961, (p. 9-11), 100 p. 187

Part of Radiobiology, (p. 125-128) 18

Part of Radiobiolcgy, (p. 16 1-171), 232 p. 
PUBLICATION DESCRIPTION INDEX

Part of Radioblology, (p. 19-22) 117

Part of Radiokiology, (p. 204-208), 232 p. 110

Part of Badioblology, (p. 297-315), 453 p. 151

Part of Radioblology, (p. 32-36) 75

Part of Radloblology, (p. 50-57), 211 p. 270

Part of Radioblology, (p. 68-760), 238 p 260

part of Radioblology, (p. 81-87,) 251 p. 259

Part of Fadiological and Environmental Research Division Annual Report, January through December 1973 , (p. $6-17), 187$ p. 290

Part of Remote Aftereffects of Radiation Damage, (p. $344-363), 574$ o. 269

Part of Report of Health Activities for Month of July, 1945, (F. 2-4), 17 p. 56

Part of Refcrt of Health Activities for Month of July, 1945, (p. 10-17), 17 p. 90

Part of Research and Development Activities Quarterly Progress Report for January-March, 1953, (p. 16) 111, 265

Part of Richmond, C.R. and woelz, G.L. (Comps.), Biological and Medical Research Group (H-4) Annual Report, January through December, 1972, (p. 1-3), 144 p. 2

Part of Semiannual Progress Report, (p. 71-73)

Part of Simpson, C.I.; et al (Eds,), Annual Report for 1973 , (F. 223-227), 284 p. 435

Part of Simpscn, C.I., et al, Annual Report for 1972 . (p. $5-15$ ), 152 p. 436

Part of Snyder, W.S. (Ed.), Proceedings of the 3 rd International Congress of the IRPA held in Washingtcn, D.C. September 9-14, 1973, (p. 743-

Part of Snyder, w.S. (Bd.), Proceedings of the 3 ro International Congress of the IRPA held in 175), 1475 F. 108 . September 9-14, 1973, (p. 172-

Part of Snyder, w.S. (Ed.), Proceedings of the 3 ra International congress of the IRPA held in Washington, D.C. S September 9-14, 1973, (p. 1358-

Part of Snyder, w.S. (Bd.), Proceedings of the 3 rd Int ernational congress of the IRPA held in

Washington, D.C.. September 9-14, 1973, (p. 208-

213), 1475 F. 145

Part of Snyder, W.S. (Ed.), Proceedings of the $3 \mathrm{rd}$ International congress of the IRPA held in Washington, D.C.. September 9-14, 1973, (p. 167Washington, D.C., September 9-14, 1973, (p. 167-

Part of Snyder, W.S. (\$d.), Proceedings of the $3 \mathrm{rd}$ International Congress of the IRPA held in lashington, D.C., September 9-14, 1973, (p. $719-$ 124), 1475 F. 171

part of Snyder, W.S. (Bd.), Proceedings of the $3 \mathrm{rd}$ International congress of the IRPA beld in washington, D.C., September 9-14, 1973, (P, 725-

730), 1475 F. 214

Part of Snyder, W.S. (Bd.), Proceedings of the 3rd International congress of the IRPA held in Washington, D.C., September 9-14, 1973, (p. 117128). 1475 F. 271

Part of Snyder, w.S. (Bd.), Proceedings of the 3 ro International Congress of the IRPA held in

washington, D.C.., September 9-14, 1973, (p. 532-

washington, D.C.
537), 1475 F. 284
Part of Snyder, W.S. (Zd.), Proceedings of the 3rd International congress of the IRPA held in Ha shington. D.C., September 9-14, 1973, (p. 736742), 1475 p. 347

Part of snyder, W.S. (Ed.), Proceedings of the 3rd International congress of the IRPA held in ia shington, D.C.. September, $9-14,1973$, (p. 731 735). 1475 p. 371

Part of snyder, W.S. (Ed.), Proceedings of the $3 \mathrm{rd}$ International Congress of the IRPA held in wa shington; D.C. September 9-14, 1973, (p. 957962). 1475 p. 406

Part of Snyder, W.S. (Bd.), Proceedings of the $3 \mathrm{rd}$ International Congress of the IRPa held in Wash ington, D.C.. September 9-14, 1973, (p. 515527), 1475 p. 411

Part of snyder, W.S. (Bd.), Proceedings of the $3 \mathrm{rd}$ International congress of the IRPA held in Hashington, D.C.. September 9-14, 1973, (p. 810813). 1475 p. 453

Part of snyder, W.S. (Bd.),.. Proceedings, of the 3 d International Congress of the IRPA held in Washington, D.c. September 9-14, 1973, (p. 13711376), 1475 p. 9

Part of Stover, B.J. and Jee, W.S.S. (Eds.), Radi cbiology of piutonium. J.'W. Press, Sait Lake City, Utah, (p. 203-212), 552 p. 45

Part of Stover, B.J. and Jee, W.S.S. (Eds.), Radicbiology of plutonium. J.W. Press, Sait Lake City, Utah, (p. 195-202), 552 p. 51

Part of Stcver, B.J. and Jee, W.S.S. (Eds.), Radicbiology of plutonium. J.W. Press, Salt Lake City, Utah, (p. 75-86), 552 F. 68

Part of Stcver, B.J. and Jee, w.S.S. (Eds.), Radicbiology of plutonium. J.W. Press, Salt Lake City, Utah, (p. 171-194), 552 p. 104

Part of Stcver, B.J. and Jee, W.S.S. (Eds.) Radiobiology of plutonium. J.W. Press, Salt Lake Part of Stcver, B.J. and Jee, W.S.S. (Eds.), Radicbiology of Plutonium. J.h. Press, Salt Lake City, Utah, (p. 141-148), 552 p. 136

Part of Stcver, B.J. and Jee, W.S.S. (Eds.). Radicbiology of plutonium. J.W. Press, Salt Lake City, Utah, (p. 87-104), 552 p. 162

Part of Stover, B.J. and Jee, W.S.S. (Eds.), Radicbiology of plutonium, J.W. Press, Salt Lake City, Utah, (p. 243-260), 552 p. 167

Part of Stcver, B.J. and Jee, W.S.S. (Eds.), Radicbiolcgy of plutonium, J.w. press, Salt Lake City, Utah, (p. 305-322), 552 p. 169

Part of Stcrer, B.J. and Jee, W.S.S. (Eds.) Radicbiology of Plutonium. J.W. Press, Salt Lake City, Utah, (p. 47-58), 552 p. 181

Part of Stcver, B.J. and Jee, W.S.S. (Eds.), Radiobiology of plutonium, J,W. Press, Salt Lake Radiobiology of Plutonium. J.W. Press,

Part of Stover, B.J. and Jee, w.S.S. (Eds.), Radicbiology of piutonium. J.W. Press, Sait Lake City, Otah, (p. 1-21), 552 p. 205

Part of Stover, B.J. and Jee, W.S.S. (Eds.), Radicbiolcgy of Plutonium. J.W. Press, Salt Lake City, Utah, (p. 261-272), 552 p. 209

Part of Stover, B.J. and Jee, W.S.S. (Eds.), Radicbiolcgy of Plutonium. J.W. Fress, Salt Lake City, Utah, (p. 129-140), 552 p. 232

Part of Stcver, B.J. and Jee, w.S.S. (Eds.), Radicbiolcgy of plutonium. J.W. Press, Salt Lake City, Otah, (p. 29-46), 552 p. 233 
Part of Stover, B.J. and Jee, M.S.S. (Eds.) Radiobiology of Plutonium. J.W. Press, Salt Lake City, Utah, (p. 59-74), 552 p. 241

Part of Stover, B.J. and Jee, W.S.S. (Eds.) Radiobiology of Piutonium. J. W. Press, Sait Lake

Part of Stover, B.J. and Jee, W.S.s. (Bds.), Radiobiology of plutonium. J.W. Press, Sait Lake City, Utah, (p. 23-27), 552 p. 256

Part of Stover, B.J. and Jee, W.S.S. (Eds.) Radiobiology of Plutonium. J.W. Press, Salt Lake City, Utah, (p. 323-332), 552 p. 262

Part of Stover, B.J. and Jee, W.S.S. (Eds.) Radiobiology of Plutonium. J.W. Press, Salt Lake City, Utah, (F. 333-354), 552 p. 342

Part of Stover, B.J. and Jee, W.S.S. (Eds.). Radiobiology of plutonium. J.W. Press, Salt Lake City, Utah, (p. 431-463), 552 p. 351

Part of Stover, B.J, and Jee, W.S.S. (Bds.) Radiobiology of plutonium. J.w. Press, Sait Lake City, Utah, (F. 293-304), 552 p. 352

Part of Stover, B.J, and Jee, W.S.S. (Bds.). Radiobiology cf plutonium. J.W. Press, Salt Lake City, Utah, (F. 273-280), 552 p. 379

Part of Stover, B.J. and Jee, W.S.S. (Bds.) Radiobiology of plutonium. J.W. Press, Salt Lake City, Utah, (F. 231-242), 552 p. 380

Part of Stover, B.J. and Jee, W.S.S. (Bds.) Radiobiology of plutonium. J.W. Press, Salt Lake City, Utah, (p. 221-230), 552 p. 381

Part of Stover, B.J. and Jee, w.S.S. (Bds.), Radiobiology of plutonium. J.W. Press, Sait Lake City, Utah, (F. 281-292), 552 p. 385

Part of Stover, B.J. and Jee, M.S.S. (Eds.) Radiobiology of plutonium. J.w. Press, Sait Lake City, Utah, (p. 377-408), 552 p. 395

Part of Stover, C.N., Jr. (Bd.), Annual Progress Report, 1959, (p. 72-84), 224 p. 86

Part of Stover, C.N., Jr. (Bd.), Annual 'Progress Report, 1959, (p. 121-145), 224 p. 144

Part of Thcmpson, R.C. (Bd.), Annual Report for Part of Thompson, R.C. and Swezea, E.G. (Bds.), annual Report for 1966, (p. 63-65), 207 p. 8

Part of Thcupson, R.C. and Swezen, E. G. (Bds.). Annual Report for 1966, (P. 93-95), 207 p. 207 Part of Thempson, R.C., et al, Annual Report for
1973 , (p. $112-114), 162$ p. 236 Part of Thempson, R.C., et al, Annual Report for
1973, (p. $100-101), 162$ p. 364

Part of Thompson, R.C.. Summary Technical Report, SNPO and SNAP Biological Studies, (p. 10-14), 16 p. 215

Part of Vaughan, B. B. et al, Annual Report for 1974, (p. 30-36), 238 p. 274

Part of Vaughan, B.E., et al, Annual Report for 1973, (p. 42-44), 200 p. 278

Part of Vaughan, B. E.. et al, Annual Report for 1974 , (p. 99-100), 238 p. 304

Part of Vaughan, B.E., et al, Annual Report for 1974, (p. 96-99), 238 p. 305

Part of Vaughan, B.E., et al, Annual Report for 1974. (p. 134), 238 p. 314
Part of Whicker, F.W., et al, 12th Technical Progress Report on Radioecology of Some Natural Organisms and systems in colorado, (p. $21-40$ ). 69 p. 323

Part of Willis, C.A. and Handloser, J.S. (Eds.) Health Physics operational Mcnitoring, Proceedings of the $3 \mathrm{rd}$ Health Physics Society Midyear Topical Sy mosium held in Los Angeles, California, January $29-31$, 1969, vol. 2. Gordon and Breach, Science Publishers, Inc., New York, Ney York, (p. 12231233), 1848 p. 448

Part of Willis, C.A. and Handloser, J.S. (Eds.), Health Physics operational Monitoring, proceedings of the $3 \mathrm{rd}$ Health Physics Society Midyear Iopical Symposium held in Los Angeles, California, January
$29-31,1969$, vol. 1. Gordon and Breach, Science Publishers, Inc., New York, New York, (p. 349$360), 1848$ p. 451

Part of Willis, C.A. and Handlosev, J.S. (Eds.). Gealth Physics operational Monitoring, Proceedings cf the 3 rd Health Physics Society Midyear Topical Sy mposium held in Los Angeles, California, January $29-31$, 1969, Vol. 1. Gordon and Breach, Science Publishers, Inc. New York, New York, (p. 759$771) .1848$ p. 460

Part of Willis, C.A. and Handloser, J.S. (Eds.) Health Physics operational Monitoring, Proceedings of the $3 \mathrm{rd}$ Health Physics Society Midyear Topical Symposium held in Los angeles, California, January 29-31, 1969, Vol. 1. Gordon and Breach, Science Putlishers, Inc. New York, New Ycrk, (p. 141$164), 1848$ p. 470

$\mathrm{PB}-2$ 12-952 98

Pedotiologia, 12, 374-380 124

Ph.D. Thesis, Colorado State University 62

$\mathrm{Ph} \cdot \mathrm{D}$. Thesis, University of Minnesota 324

$\mathrm{FH}-43-66-9 \varepsilon 2-7 \quad 98$

Fhysics in Medicine and Biology, 13(1), 145-160

Physics in Medicine and Biology, 19(4), 460-471 343

Physics in Medicine and Biology, 13(1), 105-112 346

FOB $-2503 \quad 420$

Problems of Oncology, $5(8), 13-24 \quad 40$

Proceedings of a symposium on New Developments in Physical and Biological Radiation Detectors held in vienna, Austria, November 23-27, 1970,742 p. 341

Proceedings of a symposium on the Environmental Surveillance Around Nuclear Installations held in Warsaw, Poland, November 5-9, 1973, Vols. 1-2, 470 p. 425

Proceedings of the Royal Commonuealth Society $3 \mathrm{r}$ International Symposium on Plutonium held in Lond cn, England, November 22-26, 1965. Chapman and Hall. London, England, 1114 F. 286

Proceedings of the Society for Bxperimental Eiolcgy and Medicine, 84, 576-588 114

Proceedings of the $3 \mathrm{rd}$ International congress of the IRPA held in washington, D.C., September 9-14, $1475 \mathrm{p}$. 387

Proceedings of the 4th International sympcsium on Packaging and Transportation of Radioactive Materials held in Miami Beach, Florida, September $22-27,1974,1195$ p. 440

Progress Report for the Period Bnding August 1, 1971-July 31, $1974 \quad 285$ 
PUBLICAT ICN DESCRIPTION INDEX

Radiation Data and Reports, 14(5), 307-312 427

Radiation Data and Reports, 15(12), 802-817 396

Radiation Research, 12, 41910

Radiation Research, 12, 43167

Radiation Research, $16(4), 583113,238$

Radiation Research, 16,811-821 11

Radiation Research, 23, 420-429 221

Radiation Research, 27, 548-549 228

Radiation Research, 33, 490-500 222

Radiation. Research，39, 201-206 226

Radiation Research, 51,5386

Radiation Research, 51, 53933,231

Radiation Research, 51, 540-541 128, 213

Radiation Research, 51, 541 190, 227

Radiation Research, 60, 525-535 229

Radiation Research, 7, 267-269 83

Radiation Research, 9(1), 11581

Radiobiologiya, $1(2), 250-256 \quad 151$

Radiobiologiya, 3(3), 351-354 75

Radiobiologiya, 3, 501-503 117

Radiobiologiya, 4(3), 370-374 270

Radiobiologiya, $4(5), 760-76318$

Radiobiologiya, 6 (2) 218-223 259

Radiobiologiya, $8(4), 535-541260$

Radiobiologiya, $8(6), 900-907 \quad 41$

Radiobiologiya, $8\{6\}, 925-927,110$

Radiochemical and Radioanalytical Letters, $19(1)$. 33- $42 \quad 279$

Radiochemical and Radioanalytical Letters, 19 (1), 25-32 280

Radiology, 65, 253-259 69

Radioprotecticn, 2(4), 297-312 163

Records of Cceanographic Works in Japan, $9(2)$. 189-195 $31 \mathrm{C}$

RPP-BNV-71B (Brrata) 426

$R P P-1783 \quad 355$

RFP- $2216 \quad 444$

RFP-2218 410

$\mathrm{SC}-4326(\mathrm{TR}) \quad 363$

Science Progress, 52, 65-83 281

Science, 177(4045), 208-210463

Shin Kinzcku, $18(5), 118-123388$

SSI-1973-14 359

$\mathrm{STI} / \mathrm{DOC} / 10 \quad 218,389$

$\mathrm{SPI} / \mathrm{PUB} / 269 \quad 341$

$\mathrm{STI} / \mathrm{PUB} / 345330,429$
190

STI/PUB/353 425

$\mathrm{STI} / 90 \mathrm{~B} / 373 \quad 321,332$

STI/FUB/84 253, 291, 373, 377, 392, 393, 424

Technical Beports Series No. 123218,389

The Ney England Journal of Medicine, 240(22), 86387089

TI D-3311 (Suppl. 2) 475

TID-3317 439

TIE-3535-RE-S8 467

Twelfth Prcgress Report 328

OCID-16377 407

UC BL-50230 (Rev. 1) 419

UCRL-73178 (Rev. 1) 309

UCRL $-74430 \quad 338$

Vopresy onkologii, $5(8), 140-148 \quad 40$

WASH-1332 $402,414,454,473,476$

Williams and Wilkins Company, Baltiaore, Maryland 21

พT $-1510 \quad 302$

WT $-2503 \quad 420$ 


\section{INTERNAL DISTRIBUTION}

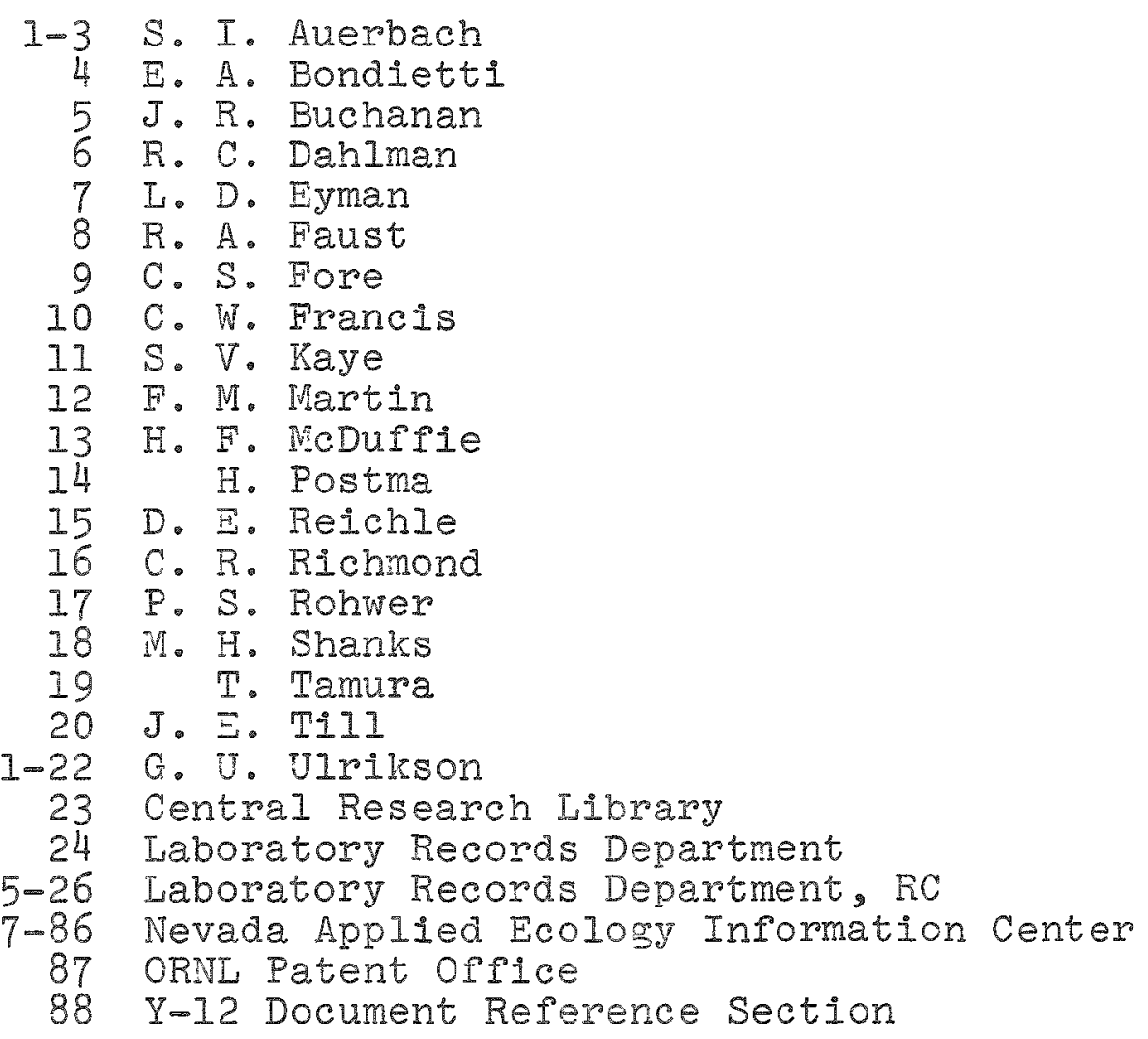




\section{2}

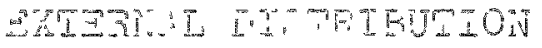

\section{9-90 Albuquerque Opera-ions Office}

J. F. Burke

W. B. Johnston

91 Allied Cremical irupucion

C. E. Nichols

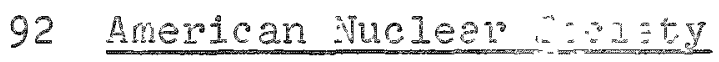

E. Ronne

93-97 Argonine Jational Iseti patory

C. S. Abrams

J. S. Marshall

M. W. Rosenthal

J. Rundo

R. A. Schlenker

98 Atlantic-Richfiela Iariond Company

K. Price

99-101 Battelle Columbn Taboratories

T. Q. Fale

W. Hartin

A. Rudolph

102-114 Battelie-iorthes - jooratories

J. Bair

F. T. Cross

P. J. Dionne

I. L. Eberhardt

R. O. Gilbert

P. O. Jackson

B. RIepper
I. C. Nelson

C. I. Sanders

J. C. Sheppard

i. R. Sikov

B. O. Stuart

R. C. Thompson

115-116 Brookhaven Natione1 Lu Buratory

P. J. Bottino

A. H. Sparrow

117-119 Colorado State J11"isty

J. Johison

T. F. Winsor

W. Whicher 


\section{9?}

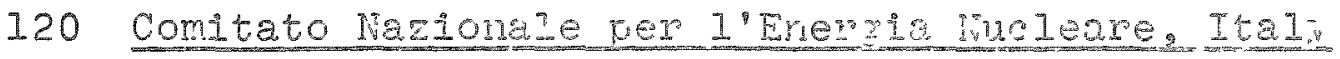

A. AntoneIII

I21 Commissariat a Ir Terrie Atomique, France

A. Grauby

122 Comparative Aninal Eesearch Laboratory

G. R. Eisele

123 Desert Research Institute

T. P. O'FarrelI

124 DRI, Reno

G. B. Maxey

125-129 EG\&G, Inc.

K. C. Humphreys P. Stuart

W. M. Quam T. P. Stuart

W. A. Rhoads

130 Electrical Power Research Institute

C. I. Comar

131-133 Euratom Joint NucIs: Fesearch Center, Italy

P. de Bortoli F. Girardi

P. Gaglione

134-136 Georgia Institute Pechnology

M. W. Carter K. Z. Morgan

A. A. Moghissi

137-140 Health and Safet aborary

E.P. Hardy, Jr. J. Rivera

J. H. Harley H. L. Volchok

141-143 Idaho Operations Prpace

O. D. Markhan C.W.Sill

D. Paabe

144 Institute of Bio:" "Eouth Seas. USSR

G. G. Polikarpor 
145-146 Institute of Biophysies, USSR

Yu. I. Moskalev

D. P. Osanov

147 Institute of Cancer Research, England

D. M. Taylor

148 International Atomic Energy Agency

H. J. Otway

149 Kerr-McGee Corporation

A. Valentine

150 Lawrence Berkeley Laboratory

P. W. Durbin

151-162 Lawrence Livermore Laboratory
I. R. Anspaugh
P. N. Dean
L. S. Germain
V. E. Noshkin
J. I. Olsen
M. L. Mendelsohn
P. I. Phelps
W. T. Nervik
Y. C. $\mathrm{Ng}$
B. W. Shore
J. T. Tinney
G. Tompkins

163-165 LFE/Environmental Analysis Laboratory

L. Leventhal P. Wessman

W. Majors

166-181 Los Alamos Scientific Laboratory

J. E. Dummer

E. H. Essington

H. S. Jordan

E. B. Fowler

J. H. McQueen

I. Gomez

W. D. Moss

J. Nyhan

T. E. Hakonson

J. H. Patterson

W. C. Hanson

J. W. Healy

W. D. Purtymun

L. J. Johnson

D. Rohrer

R. G. Thomas

182 Lovelace Foundation for Medical Education \& Research R. O. McClellan 
183 McClelian Air Force Base

W. A. Myers

184 Mound Laboratory

H. F. Anderson

185 National Oceanographic and Atmospheric Administration, Air Resources Laboratory

N. C. Kennedy

186 National Reactor Testing Station

W. I. Polzer

187-229 Nevada Operations Office

R. C. Amick

E. D. Campbel1

B. W. Church

E. M. Douthett

P. B. Dunaway (5)

M. E. Gates

D. G. Jackson
R. I. Kinnaman

R. R. Loux

R. W. Newman

R. Ray

R. Silverstrom

J. D. Stewart

M. G. White (25)

C. E. Williams

230 Northeastern Radiological Health Laboratory

B. Shleien

231 Pantex Plant, Texas

D. L. Dufek

232-234 Reynolds Electrical and Engineering Company

E. R. Sorom

D. Wireman

A. W. Western

235-241 Rockwell-International/Rocky Flats Plant

E. W. Bean

R. W. Bistiline

F. J. Miner

J. R. Seed
M. A. Thompson

G. J. Werkema

J. F. Willging 


\section{6}

242 Royal Free Hospital arool of Wedicine England

A. C. Tames

243-244 Sandia Laboratories

R. Iuna

M. I. Merritt

245 Southeastem Radiol wor Health Laboratory

R. Iieberman

246-247 Technical Information Center, Oak Ridge

248-252 United Kingdom Atolifg anergy Authority
G. W. Dolphin
H. Smith
D. C. Fraser
3. T. Taylor
D. Ramsden

253-292 U. S. Energy Resear ar and Development Administration. Headquarters
J. P. Abbadessa
J.S. Kirby-Smith
R. E. Allen
A. E. KIuk
H. B. Atkinson
J. I. Iiverman
F. P. Baranowski
T. F。 IncCraw
N. F. Barr
R. D. Maxwe11
M. B. Biles
F. Clark
I. A. Nemzek
F. E. Coffman
J.S. Olson
J. E. Connor
W. S. Osburn, Jr.
G. H. DaIy
I. J. Deal
R. J. Engelman
G. C. Facer
R. Franklin
D. S. Gabriel
E. Graves
J.A. Harris
I. Hoffman
C. I. Osterberg
A. F. Perge
F. K. Pittman
V. H. G. Rickover
W. W. SchroebeI
R. C. Seamans, Jr.
H. E. Soule
J. Swinebroad
J.N. Teem
R. D. Thorne
G. W. Johnson
D. D.W. Thornton
J. S. Kane
R. I. Watters

293 U. S. Energy Resedro. Ind Development Administration, Research and Techricel Supoort Division, Oak Ridge 


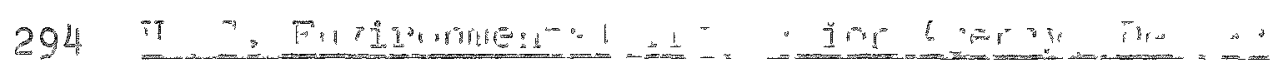

P. Smic.s

- 95-314 I. S. Environment 1 - Eection Agency.

EnvironmentaI Tonj $=$ and Bl,poort Laboratory
F. Au
D. S. Barth
J. Barth
J. MeDride
W. Bliss
C. F. Costa
R. L. Douglas
D. E. Hendricks
F. No. Jakubowski
R. Rinnison
V. D. Leavitt
A. A. Silulien
R. G. Patzer
J. C. Payne, Jr.
G. D. Potter
D. Smith
R. E. Stanley
W. W. Sutton
D. Wickman
D. T. Wruble

315

U. S. Geological E

W. S. Twenhorel

16-317 I. S. Mnolear Rezut Comission

J. J. Davis

G. Hamada

$18-321$ Univeraity of CaI1 tis

J. E. Kinnear

E. M. Romney

A. Morrow

A. Wallace

322 University of Hawas

L. T. Casarett

\$23-325 Tniversity of Jevad- Tas Vegas
W. G. Bradley
W. E. Niles
R. Moor

326-328 University of Nevade, tho
V. Bowman
P. T. Tueller
P. Fenske

329 University of North

B. I. $8 \sin ^{\circ}$ 
330-331 Univelsity of Rochester

P. E. Horrow

J. N. Stannard

332-337 Jniversity of Utah

D. R. Atherton

J. F. Dougherty

I. F. Dcugherty

W. S. S. Jee

C. W. Mays

G. N. Tay Ior

338 University of Washington

W. R. Schell

339-340 Washington State University

L. R. Bustad

T. Schultz

341-342 Westinghouse Environmental Systems

J. Tower

F. C. Woodson

343-345 Woods Hole Oceanographic Inst1tution

V. T. Bowen

J. C. Burke

G. Thompson 